\title{
THE ELUSIVE SEARCH FOR
}

\section{SUSTAINABLE HIGH SEAS FISHERIES}

What Role for an Oceąns Governance Approach?

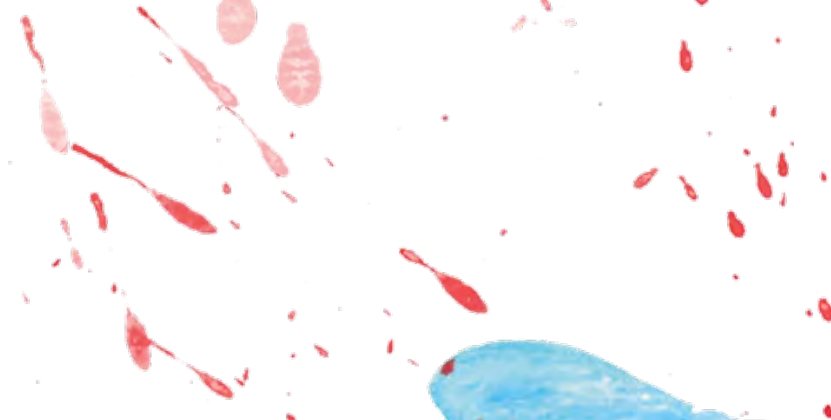

$\therefore$ 

THE ELUSIVE SEARCH FOR SUSTAINABLE HIGH SEAS FISHERIES What Role for an Oceans Governance Approach? 
(C) 2020 Catherine Blanchard

Cover image: Julie Béland

Layout: Klaartje Hoeberechts, vanklaartje.nl

Printing: Ridderprint, the Netherlands

All rights reserved. No part of this book may be reproduced, stored or transmitted in any form, by print, photo copy or any other means without prior written permission from the author. 


\section{THE ELUSIVE SEARCH FOR SUSTAINABLE HIGH SEAS FISHERIES}

\section{What Role for an Oceans Governance Approach?}

De ongrijpbare zoektocht naar duurzame visserij op volle zee Wat is de rol voor een oceaanbeheerbenadering?

(met een samenvatting in het Nederlands)

La recherche insaisissable d'une pêche durable en haute mer

Quel rôle pour une approche de gouvernance des océans?

(avec un résumé en français)

\section{Proefschrift}

ter verkrijging van de graad van doctor aan de Universiteit Utrecht op gezag van de rector magnificus, prof.dr. H.R.B.M. Kummeling, ingevolge het besluit van het college voor promoties in het openbaar te verdedigen op maandag 30 november 2020 des middags te 12.45 uur

door

\section{Catherine Blanchard}

geboren op 6 januari 1988

te Montréal, Québec, Canada 


\section{Promotoren:}

Prof. dr. A.G. Oude Elferink

Prof. dr. S. Trevisanut

This research was supported by the Netherlands Organization for Scientific Research (NWO) under project number 406.16.218, as well as the Social Sciences and Humanities Research Council of Canada (SSHRC) under project number 752-2017-0075. 


\section{ACKNOWLEDGMENTS}

I once heard that starting a research is like facing a blank map. There are no cities, no roads, no borders, no coastlines. It is the task of the researcher to place the cities on the map, connect them with roads, and limit the map with borders and coastlines. Working on this blank map brought me out of my comfort zone. Yet, I was not alone in designing and drawing this map, this thesis. This thesis is not only my thesis; it is also the thesis of the people who have supported me over the years and who have, each in their own way, helped me complete this map.

I first wish to express my gratitude to my supervisors, Professor Alex Oude Elferink and Professor Seline Trevisanut, who guided me throughout this journey. Alex, you believed in me to lead this research, you encouraged me to dare to explore further and to not be afraid of complexity. Seline, you assisted me in facing my uncertainties and helped me refine my analytical skills by challenging me with your conceptual questions. Thank you both for your understanding, your guidance and for helping me overcome obstacles.

I would also like to sincerely thank the members of the Reading Committee, Professor Alfred Soons, Professor Richard Barnes, Professor Suzanne Lalonde, Professor Elisa Morgera, and Professor Judith van Erp. Thank you for your enthusiasm in reading my thesis and for your insightful comments and feedback on my work. I am also grateful to the Netherlands Organization for Scientific Research (NWO), as well as the Social Sciences and Humanities Research Council of Canada (SSHRC) for their generous funding.

The Netherlands Institute for the Law of the Sea (NILOS) has been an enriching working environment to evolve in, and I am extremely lucky to have benefited from the presence of so many inspiring colleagues. A special thank you to Professor Erik Molenaar for sharing your invaluable knowledge and experience, and for always making yourself available to answer my many interrogations about the fascinating yet complex world of fisheries law. Nikolaos Giannopoulos, Chuxiao Yu, Wen Duan, Nina Mileva and Rozemarijn Roland Holst, it was a pleasure to share this academic journey with you. You have, each in your own way, helped me grow, as a teammate and researcher. Nelson Coelho, Arron Honnibal, and Yen Tran, I am grateful for having benefited from your advice and followed your steps. Thank you also to Danae Georgoula, Baine Kerr, Otto Spijkers, Andrea Stefanus, Minh Tran, and Maddalena Visser for your camaraderie in the past years. Finally, a special mention for Lan Nguyen and Solene Guggisberg. Thank you for your patience in answering my endless existential questioning about conducting a $\mathrm{PhD}$, for your support through rough times, and especially for funny stories, movies nights and Skype lunches. You have guided me in so many ways that I can undoubtedly say that Vi and Sybille are lucky daughters. 
The Law School at Utrecht University and the Utrecht Center for Water, Oceans and Sustainability Law (UCWOSL) have also given me the opportunity to work alongside dedicated colleagues. Among them, I wish to thank Leonie Huijbers, Lisa Ansems, Paulien de Morree and Hilke Grotelaar for accompanying me in my very beginnings as a UU employee and for sharing parts of your $\mathrm{PhD}$ journey with me. Further, special thanks to Julie Fraser, Kushtrim Istrefi, Natalie Dobson and Laura Henderson for your support in navigating the meanders of academic life and the academic labour market. I would also like to thank Miranda Walraven and Corrie van Rooijen for answering my numerous administrative questions. My thanks finally go to Saskia Bal for her precious help during the NWO application process.

My PhD adventure would not have been the same without the unique experiences I have had the chance to take part in. First, I am extremely grateful to the Dutch delegation to the intergovernmental negotiations on biodiversity beyond national jurisdiction (BBNJ) for welcoming me as one of their own in New York. Tom Diederen, Wini Broadbelt, Professor René Lefeber, Martijn Peijs and Ton Ijlstra, thank you for sharing so much of your experience as diplomats, negotiators and policy-makers. Second, a heartfelt thank you to the Ocean Governance Team at the Institute for Advanced Sustainability Studies (IASS) in Potsdam for introducing me to the world of policy research and for making my research stay so memorable. I am especially grateful to Carole Durussel and Ben Boteler for so many fruitful discussions and a successful publication together. Finally, my research allowed me to explore the worlds of governance and Earth systems, an exploration that has been truly inspiring. This would not have been possible without the help of Rakhyun Kim, Professor Louis Kotzé, Dona Azizi and the members of the Earth System Law Task Force, and I sincerely thank you all.

The $\mathrm{PhD}$ journey also started way before the $\mathrm{PhD}$ appointment itself. A special thank you goes to Professor France Morrissette. You introduced me to the fascinating world of the law of the sea (as well as to moot court competitions!), you pointed me towards Utrecht University, and you continuously showed interest and support in my professional development throughout the years. To Charlotte Claes, Basant Abdel-Meguid and Nicolas Cordoba, my fellow interns at the International Tribunal for the Law of the Sea, I am very happy to have shared with you the very early developments of this research.

This thesis is also the thesis of friends and family who have accompanied me through this adventure. To my paranymphs, Emilie Conway and Timo Verlaat, in a unique way each of you represents a part of this thesis. Emilie, we crossed the Atlantic together in the quest for new experiences in international law. Timo, together we shared the ups and downs of grant proposals and of $\mathrm{PhD}$ research. I am lucky to have you both by my side, not only on the day of my defence, but also in my life for the past six years. I could not have chosen better Dutch discoveries partners than you two. 
Many friends in the Netherlands, in Québec, in Canada and elsewhere also deserve my huge appreciation. Dankjewel - Merci - Thank you - Gracias Bénédicte LeclercJacques, Sarah Cloutier, Julie Béland (also for the cover image), Sheila Ball, Rodolfo Alvarado, Alex Ziemba, Koen Caris (also for the Dutch summary), Juul Henkens, Fabienne Kannenberg, Amélie Goudreau, Bruno Gélinas-Faucher, Valérie Martin, Charlotte Chicoine-Wilson, Karine Hébert, Laurence Cloutier-Pouliot, Valérie Mercier, Nina Brauchart, Abdulla Abdalla, Amanda Loohuis, Judith Paping, Vincent Nadeau, Anne Gaedeke, Maja Dukic, and « la gang du DI ». Through food feasts, picnics and bike rides, dream interpretations, recipe recommendations, prepared lunches and lama bedsheets, « déisteries », boardgames and BBQs, eccentric Christmas cookies, St-Hubert chicken and new clothing, sweet texts and messages, witchcrafts and wizardry visits, and marzipan cakes, I always feel like you are close by.

I am also appreciative of the support I have received from my aunts, uncles and cousins, who have followed my journey over the years and who have come to visit me in Utrecht (or have planned to do so). My thoughts also go to Grand-Maman, Matante and Mon who are always with me. Moreover, I am very grateful for being welcome into the warm and bighearted family Wakker. Jullie hebben me niet alleen steun en liefde gegeven, maar mij ook laten kennismaken met een gemeenschap waar "vissies" dagelijkse realiteit zijn, naast wetenschappelijk onderzoek. Voor alles ben ik jullie dankbaar.

My most profound gratitude goes to my four parents. Rénald et Louise, merci de suivre mon parcours depuis de si nombreuses années et de toujours m’encourager dans mes aventures personnelles et professionnelles. Maman, Papa, vous avez sans hésitation plongé avec moi dans toutes mes péripéties les plus folles. Malgré la distance, vous êtes là, toujours. Vous m'aidez à avancer, à marrêter, à penser, à agir. Maman, merci pour toutes les heures passées à relire mon travail avec tant d'enthousiasme (et à vérifier les abréviations !). Papa, merci pour tes conseils de vélo et de jardinage qui maident à me changer les idées. Merci à vous deux pour votre ouverture d'esprit, vos pep talks, vos conseils de docteur Wilby et votre confiance absolue. Vous croyez en moi depuis le début, et c'est à vous que je dédie ce travail.

Finally, completing this thesis would not have been possible without the unconditional patience of Jan Willem. JW, I cannot thank you enough for being the ultimate model of adaptability in the face of the complex behavior that I have often displayed in the past years. You have given me support and comfort, space and time when I needed it the most. You kept me going and believed in me. Thank you, for simply being you.

And now, let's see what the map looks like... More importantly, let's already start thinking about the next blank map and road ahead... 



\section{TABLE OF CONTENTS}

Acknowledgments $\quad$ V

List of Tables and Figures $\quad$ xv

List of Abbreviations $\quad$ xvii

\section{CHAPTER 1}

\section{INTRODUCTION}

1. The elusive search for sustainable high seas fisheries

1.1 Seventy years (and counting...) of recognizing overexploitation on the high seas

1.2 Awareness and regulatory successes

1.3 Specific difficulties on the high seas

2. Conceptual framework: revisiting premises to move forward more efficiently

2.1 Interconnectedness, or the need for an integrated, interdisciplinary and intersectoral approach

2.2 A different characterization: high seas fisheries as a complex socio-ecological system

2.3 A different lens of analysis: a dialogue between (oceans) governance and adaptive strategies

3. Research questions and relevance of the study 21

4. Research design 23

4.1 Methodology 24

4.2 Legal research within a multidisciplinary framework 25

4.3 Scope of the study 26

5. Structure of the study 27

\section{CHAPTER 2}

HIGH SEAS FISHERIES AND THE LAW: THE CURRENT STATE OF AFFAIRS

1. Introduction 31

2. International and high seas fisheries: fish, exploitation and the environment 33

2.1 How much fish are we dealing with? The state of fish stocks and captures 34

2.2 Major threats to fish stocks and the marine environment 36

$\begin{array}{ll}2.2 .1 \text { Overfishing } & 38\end{array}$

2.2.2 Illegal, unreported and unregulated (IUU) fishing 40

2.2.3 Impacts on non-target species and marine habitats 41

2.2.4 Environmental changes 43

2.3 The open-access nature of fisheries in ABNJ 44

3. High seas fisheries law: at the crossroads between law of the sea and $\begin{array}{ll}\text { environmental law } & 47\end{array}$

3.1 Legal framework - legally binding instruments 49 
3.1.1 United Nations Convention for the Law of the Sea (UNCLOS) 49

3.1.1.1 Part VII: rights and obligations on the high seas 50

3.1.1.2 Part XII: rights and obligations for the protection and preservation of the marine environment 53

3.1.1.3 How do fisheries and environmental protection interact under UNCLOS?

3.1.1.4 The evolutionary capacity of UNCLOS 58

3.1.2 United Nations Fish Stocks Agreement (UNFSA) 61

3.1.3 Convention on Biological Diversity (CBD) 66

3.1.4 International Convention for the Regulation of Whaling (ICRW) 72

3.1.5 Convention on International Trade in Endangered Species of Wild Fauna and Flora (CITES) 74

3.1.6 Convention on the Conservation of Migratory Species and Wild Animals (CMS) 77

3.1.7 Treaties of the Food and Agriculture Organization (FAO) 79

3.1.7.1 Agreement to Promote Compliance with International

Conservation and Management Measures by Fishing Vessels on the High Seas (Compliance Agreement)

3.1.7.2 Agreement on Port State Measures to Prevent, Deter and Eliminate Illegal, Unreported and Unregulated Fishing (Port State Measures Agreement - PSMA)

3.1.8 World Trade Organization (WTO) measures on fisheries subsidies 81

3.2 Legal framework - soft-law instruments

3.2.1 United Nations General Assembly Resolutions addressing fisheries and the marine environment

3.2.2 Soft-law instruments of the Food and Agriculture Organization (FAO)

3.2.2.1 Code of Conduct for Responsible Fisheries $\quad 89$

3.2.2.2 International Plans of Action $\quad 91$

3.2.2.3 International and voluntary guidelines 93

3.2.2.4 Other relevant initiatives $\quad 95$

3.2.3 Overarching environmental soft-law instruments 95

3.3 Actors operationalizing the legal framework 98

$\begin{array}{llr}\text { 3.3.1 Flag States } & 99\end{array}$

3.3.2 Regional fishery bodies (RFBs) 102

$\begin{array}{ll}\text { 3.3.3 Coastal States and port States } & 109\end{array}$

$\begin{array}{ll}\text { 3.3.4 Regional seas programmes (RSPs) } & 114\end{array}$

4. Conclusion: the co-evolution of frameworks 120 


\section{CHAPTER 3}

PRINCIPLES GOVERNING THE OCEANS: UNIFYING ELEMENTS IN THE FACE OF COMPLEXITY

1. Introduction

2. What are principles?

3. Principles governing the high seas

3.1 The high seas principles of the International Union for the Conservation of Nature (IUCN)

3.1.1 Respect for the law of the sea, in particular UNCLOS and related instruments

3.1.2 Protection and preservation of the marine environment 133

$\begin{array}{ll}3.1 .3 \text { International cooperation } & 136\end{array}$

$\begin{array}{ll}\text { 3.1.4 Science-based approach to management } & 140\end{array}$

$\begin{array}{ll}3.1 .5 \text { Precautionary approach } & 143\end{array}$

3.1.6 Ecosystem approach 146

3.1.7 Sustainable and equitable use 149

3.1.8 Public availability of information, and transparent and open decision-making processes 154

3.1.9 Responsibility of States as stewards of the global marine environment $\quad 157$

3.2 Reflections on the effectiveness of principles governing the high seas 159

4. Fisheries conservation and management: an application of the principles governing the high seas

4.1 Current objectives for fisheries management

4.2 The operationalization of high seas principles through a selection of existing and emerging conservation and management tools

4.2.2 Assessment tools

5. Conclusion: unifying conservation and the use of resources

\section{CHAPTER 4}

\section{BIODIVERSITY BEYOND NATIONAL JURISDICTION: A CATALYST FOR} INTERCONNECTEDNESS?

1. Introduction

2. The different stages of the BBNJ process

2.1 Ad Hoc Open-ended Informal Working Group (2006-2015) 186

$\begin{array}{lll}2.2 & \text { Preparatory Committee (2016-2017) } & 190\end{array}$

2.3 Intergovernmental Conference (2018-?) 194

3. The BBNJ Agreement as a tool for cooperation and coordination in ABNJ 198

$\begin{array}{ll}3.1 \text { Coherence through principles } & 199\end{array}$

3.2 A "rulebook" for the elements of the package deal 202

3.3 A bridge between the law of the sea and international environmental law 205

3.4 Clarifying the relationship between areas beyond national jurisdiction and areas under coastal State jurisdiction 
3.5 Consolidating implementation and compliance through monitoring, control and surveillance (MCS)

4. The relationship between fisheries structures and the BBNJ Agreement

4.1 How could/will the regulatory and management framework for high seas fisheries be influenced by the BBNJ process?

4.2 Institutional structure for the conservation and sustainable use of BBNJ 218

4.3 The "not undermining" clause

5. Conclusion: when uncertainty remains

\section{CHAPTER 5}

THE CHALLENGES TO REACH SUSTAINABILITY: COMBINING VALUES, REGULATION AND BEHAVIOUR

1. Introduction

2. Characteristics of the regime for international fisheries negatively impacting on sustainability performance

2.1 Cognitional task: a shared understanding of the balance between conservation and use

2.1.1 The everlasting concern of balancing interests

2.1.2 The difficulty of obtaining accurate and reliable scientific data

2.2 Regulatory task: translating shared understandings into

legal commitments

247

2.2.1 Geographical and species gaps

248

2.2.2 Difficulties in expanding implementation and enforcement jurisdiction on the high seas

2.2.3 Uncertain scope of application of conservation and management mechanisms

2.3 Behavioural task: implementation, enforcement and compliance weaknesses

2.3.1 General difficulties for monitoring, control and surveillance

2.3.2 Specific implementation and enforcement deficiencies within RFMOs

2.3.3 Lack of participation in key fisheries related instruments and organizations

2.3.4 Uncertainties linked to the scope of dispute settlement procedures

3. The cross-cutting characteristic of fragmentation

3.1 Managing fragmentation: regulation versus implementation and enforcement

3.2 The limits of the BBNJ Agreement in addressing fragmentation 


\section{CHAPTER 6}

THE INTERACTION BETWEEN LAW AND GOVERNANCE: AN AVENUE FOR UNDERSTANDING THE ADAPTIVE CAPACITY OF THE LAW

1. Introduction 285

2. Governance: an all-encompassing concept? 287

2.1 The emergence and analytical conceptions of (global) governance 289

2.2 The programmatic function of governance: what role for the law? 292

2.3 Using the lens of governance for the environment, oceans and fisheries 298

2.3.1 Environmental governance 298

2.3.2 Oceans governance 300

2.3.3 Fisheries governance 303

3. A framework for assessing the law's adaptive capacity in operationalizing $\begin{array}{ll}\text { existing obligations } & 304\end{array}$

3.1 A framework for assessing the adaptive capacity of the law 305

3.2 Selected governance components as building blocks for adaptive
strategies targeting cooperation and coordination

$\begin{array}{ll}3.2 .1 \text { Polycentricity } & 311\end{array}$

$\begin{array}{ll}\text { 3.2.2 Networks } & 314\end{array}$

4. Conclusion: complementing the law as a tool for social change 317

\section{CHAPTER 7}

OPERATIONALIZING THE GOVERNANCE-ADAPTABILITY DIALOGUE FOR

HIGH SEAS FISHERIES LAW: TOWARDS A SYSTEMATIC RELIANCE UPON COOPERATION AND COORDINATION

1. Introduction 321

2. Signs of adaptability within the current regime for high seas fisheries law $\quad 323$

2.1 References to adaptability in the text of selected instruments 323

2.2 Adaptability through existing structures and mechanisms 325

2.2.1 Overarching structure of the regime and actors involved 326

2.2.2 Substance: goals, objectives, and the reliance on science 328

2.2.3 Iteration, feedback loops and review 329

2.2.4 Platforms and networks: sharing science, knowledge and expertise 332

2.2.5 Cross-sectoral collaborations 334

2.3 The BBNJ Agreement and its expected role for the adaptability of the regime 336

2.4 Reflections on adaptability within the current regime for international $\begin{array}{lr}\text { fisheries law } & 340\end{array}$

3. Suggestions for alternative mechanisms 341

3.1 Experimenting with smart mixes 343

3.2 Interplay management: when institutions work together 349

3.3 How would these alternative mechanisms impact the management of fisheries? Reflections on a public-private relationship 356 
4. Pushing operationalization further: re-thinking existing legal structures $\quad 361$

4.1 The high seas fisheries trust 362

4.2 The virtual treaty regime 365

5. Conclusion: giving real meaning to coordination and interactions 367

\section{CHAPTER 8}

CONCLUSION: NEW INSIGHTS TO RESHAPE AND COMPLEMENT THE

LEGAL REGIME FOR THE SUSTAINABLE MANAGEMENT OF HIGH SEAS FISHERIES

1. An overview of the findings

1.1 The interconnectedness between fisheries management and environmental and biodiversity protection in the current legal regime for the high seas

1.2 Behaviours, compliance and lack of coordination as main challenges for sustainability performance

1.3 Relying on the governance-adaptability dialogue as a vector of the key to develop alternative regulatory and policy responses

2. Navigating interconnectedness towards alternative policy suggestions $\quad 389$

3. In closing

Annex - Glossary 393

$\begin{array}{ll}\text { Samenvatting } & 403\end{array}$

Résumé $\quad 413$

List of Primary Legal Sources $\quad 423$

$\begin{array}{ll}\text { List of Cases } & 435\end{array}$

Bibliography $\quad 437$

About the Author $\quad 475$ 


\section{LIST OF TABLES AND FIGURES}

\section{Tables}

Table 1: Main RFMOs and RFMAs with high seas mandate 104

Table 2: Suggestions on the meaning of "not undermining" 227

Table 3: Comparison of features of maladaptive law and adaptive law 307

Table 4: Categories of instruments illustrated with examples from the management of international fisheries $\quad 345$

Table 5: Levels of interplay management among current fisheries structures $\quad 353$

Table 6: Occurrence of terms in selected instruments forming the legal framework for international fisheries $\quad 370$

Table 7: Adaptive capacity of the current regime for high seas fisheries law in light of existing features of adaptability

\section{Figures}

Figure 1: Important dates and points of discussion of the BBNJ process $\quad 185$

Figure 2: Scenarios and characteristics of institutional arrangements for ABNJ 221

Figure 3: Components of governance and their interactions 295

Figure 4: Criteria for analysing resilience and adaptive capacity of legal instruments 308 



\section{LIST OF ABBREVIATIONS}

Aarhus Convention

ABMT

ABNJ

ACCOBAMS

Advisory Opinion on IUU

Fishing

Advisory Opinion on the

Responsibility of

Sponsoring States

Agenda 21

AIS

APEI

ASCOBANS

AWNJ

Barcelona Convention

BBNJ

Brundtland Report

CAOFA

CARICOM

CBD

CBS Convention

CB\&TT
Convention on Access to Information, Public

Participation in Decision-Making and Access to Justice in Environmental Matters

Area-Based Management Tool

Areas Beyond National Jurisdiction

Agreement on the Conservation of Cetaceans of the Black Sea, Mediterranean Sea and Contiguous Atlantic Area

Request for an advisory opinion submitted by the SubRegional Fisheries Commission (SRFC)

Responsibilities and obligations of States sponsoring persons and entities with respect to activities in the Area (Request for Advisory Opinion submitted to the Seabed Disputes Chamber)

Agenda 21 of the United Nations Conference on Environment and Development

Automatic Identification System

Area of Particular Ecological Importance

Agreement on the Conservation of Small Cetaceans of the Baltic, North East Atlantic, Irish and North Seas

Areas Within National Jurisdiction

Convention for the Protection of the Marine

Environment and the Coastal Region of the

Mediterranean

Biodiversity Beyond National Jurisdiction

Final report (Our Common Future) of the World

Commission on Environment and Development, also known as the Brundtland Commission

Agreement to prevent unregulated high seas fisheries in the Central Arctic Ocean (Central Arctic Ocean Fisheries Agreement)

Caribbean Community

Convention in Biological Diversity

Convention on the Conservation and Management of Pollock Resources in the Central Bering Sea

Capacity Building \& Transfer of Technology 


\begin{tabular}{|c|c|}
\hline CAMLR Convention & $\begin{array}{l}\text { Convention on the Conservation of Antarctic Marine } \\
\text { Living Resources }\end{array}$ \\
\hline CCAMLR & $\begin{array}{l}\text { Commission for the Conservation of Antarctic Marine } \\
\text { Living Resources }\end{array}$ \\
\hline CCSBT & $\begin{array}{l}\text { Commission for the Conservation of Southern Bluefin } \\
\text { Tuna }\end{array}$ \\
\hline CCSBT Convention & $\begin{array}{l}\text { Convention for the Conservation of Southern Bluefin } \\
\text { Tuna }\end{array}$ \\
\hline CIA & Cumulative Impact Assessment \\
\hline CITES & $\begin{array}{l}\text { Convention on International Trade in Endangered } \\
\text { Species of Wild Flora and Fauna }\end{array}$ \\
\hline CMS & $\begin{array}{l}\text { Convention on the Conservation of Migratory Species of } \\
\text { Wild Animals (Convention on Migratory Species) }\end{array}$ \\
\hline Code of Conduct & Code of Conduct for Responsible Fisheries \\
\hline COFI & (FAO) Committee on Fisheries \\
\hline Compliance Agreement & $\begin{array}{l}\text { Agreement to Promote Compliance with International } \\
\text { Conservation and Management Measures by Fishing } \\
\text { Vessels on the High Seas }\end{array}$ \\
\hline COP & Conference of the Parties \\
\hline DOALOS & UN Division of Oceans Affairs and the Law of the Sea \\
\hline EAF & Ecosystem Approach to Fisheries \\
\hline EBFM & Ecosystem-Based Fisheries Management \\
\hline EBSA & Ecologically and Biologically Significant Area \\
\hline EEZ & Exclusive Economic Zone \\
\hline EIA & Environmental Impact Assessment \\
\hline Espoo Convention & $\begin{array}{l}\text { Convention on Environmental Impact Assessment in a } \\
\text { Transboundary Context }\end{array}$ \\
\hline EU & European Union \\
\hline FAO & Food and Agriculture Organization \\
\hline G77 & Group of 77 \\
\hline GFCM & General Fisheries Commission for the Mediterranean \\
\hline Guidelines for Flag States & Voluntary Guidelines for Flag State performance \\
\hline Guidelines on By-catch & $\begin{array}{l}\text { International Guidelines on By-catch Management and } \\
\text { Reduction of Discards }\end{array}$ \\
\hline $\begin{array}{l}\text { Guidelines on } \\
\text { Deep-sea Fisheries }\end{array}$ & $\begin{array}{l}\text { International Guidelines for the Management of Deep- } \\
\text { sea Fisheries in the High Seas }\end{array}$ \\
\hline Hamilton Declaration & $\begin{array}{l}\text { Hamilton Declaration on Collaboration for the } \\
\text { Conservation of the Sargasso Sea }\end{array}$ \\
\hline HSA & High Seas Alliance \\
\hline IASS & Institute for Advanced Sustainability Studies \\
\hline
\end{tabular}


IATTC

IATTC Antigua Convention

ICCAT

ICCAT Convention

ICES

ICJ

ICP

ICRW

IDDRI

IGC

IISD

ILO

IMO

IOC

IOTC

IPBES

IPCC

IPOA

IPOA-Capacity

IPOA-IUU

IPOA-Seabirds

IPOA-Sharks

ISA

ITLOS

IUCN

IUU

IWC
Inter-American Tropical Tuna Commission

Convention for the Strengthening of the Inter-American Tropical Tuna Commission Established by the 1949

Convention Between the United States of America and the Republic of Costa Rica

International Commission for the Conservation of Atlantic Tunas

International Convention for the Conservation of Atlantic Tunas

International Council for the Exploration of the Sea

International Court of Justice

United Nations Open-ended Informal Consultative

Process on Oceans and the Law of the Sea

International Convention for the Regulation of Whaling

Institut du développement durable et des relations

internationales

Intergovernmental Conference

International Institute for Sustainable Development

International Labour Organization

International Maritime Organization

Intergovernmental Oceanographic Commission

Indian Ocean Tuna Commission

Intergovernmental Science-Policy Platform on

Biodiversity and Ecosystem Services

Intergovernmental Panel on Climate Change

International Plan of Action

International Plan of Action for the Management of Fishing Capacity

International Plan of Action to Prevent, Deter and Eliminate Illegal, Unreported and Unregulated Fishing International Plan of Action for reducing incidental catch of seabirds in longline fisheries

International Plan of Action for Conservation and Management of Sharks

International Seabed Authority

International Tribunal for the Law of the Sea

International Union for the Conservation of Nature

Illegal, Unreported and Unregulated (fishing)

International Whaling Commission 
Jakarta mandate

JNRFC

Lima Convention

MCS

MDG

MGR

MOP

$\mathrm{MoU}$

MPA

MSC

MSP

MSY

NAFO

NAFO Convention

NASCO

Nauru Agreement

NEAFC

NEAFC Convention

NGO

Noumea Convention

NPAFC

NPFC

NPFC Convention

NPOA

OECD

OSPAR

OSPAR Convention

PNA

PSIDS
Jakarta Mandate on the Conservation and Sustainable Use of Marine and Coastal Biodiversity

Joint Norwegian-Russian Fisheries Commission

Convention for the Protection of the Marine

Environment and Coastal Area of the South-East Pacific

Monitoring, Control and Surveillance

Millennium Development Goal

Marine Genetic Resource

Meeting of the Parties

Memorandum of Understanding

Marine Protected Area

Marine Stewardship Council

Marine Spatial Planning

Maximum Sustainable Yield

North Atlantic Fisheries Organization

Convention on Cooperation in the Northwest Atlantic Fisheries

North Atlantic Salmon Conservation Organization

Agreement concerning Cooperation in the Management of Fisheries of Common Interest

North-East Atlantic Fisheries Commission

Convention on Future Multilateral Cooperation in the North-East Atlantic Fisheries

Non-Governmental Organization

Convention for the Protection of the Natural Resources and Environment of the South Pacific Region

North Pacific Anadromous Fish Commission

North Pacific Fisheries Commission

Convention on the Conservation and Management of High Seas Fisheries Resources in the North Pacific Ocean

National Plan of Action

Organisation for Economic Co-operation and Development

Refers to the Commission created under the OSPAR Convention

Convention for the Protection of the Marine Environment of the North-East Atlantic

Parties to the Nauru Agreement

Pacific Small Island Developing State 
PSMA

PSSA

Regular Process

Reykjavik Declaration

RFB

RFMA

RFMO

Rio+20 Conference

Rio Conference

Rio Declaration

RSP

SCM Agreement

SDG

SEA

SEAFO

SEAFO Convention

SIOFA

SPA

SPA/BD Protocol

SPAMI

SPREP

SPRFMO

SPRFMO Convention

Stockholm Conference

Stockholm Declaration

TAC

TIA

TMG

UN
Agreement on Port State Measures to Prevent, Deter and Eliminate Illegal, Unreported and Unregulated Fishing (Port State Measures Agreement)

Particularly Sensitive Sea Area

The Regular Process for Global Reporting and Assessment of the State of the Marine Environment, including Socioeconomic Aspects

Reykjavik Declaration on Responsible Fisheries in the Marine Ecosystem

Regional Fishery Body

Regional Fisheries Management Arrangement

Regional Fisheries Management Organization

United Nations Conference on Sustainable Development

United Nations Conference on Environment and

Development

Rio Declaration on Environment and Development

Regional Seas Programme

Agreement on Subsidies and Countervailing Measures

Sustainable Development Goal

Strategic Environmental Assessment

South East Atlantic Fisheries Organization

Conservation and Management of Fishery Resources in the South East Atlantic Ocean

Southern Indian Ocean Fisheries Agreement

Specially Protected Area

Specially Protected Areas and Biological Diversity

Protocol

Specially Protected Area of Mediterranean Importance

Secretariat of the Pacific Regional Environment

Programme

South Pacific Regional Fisheries Management

Organization

Convention on the Conservation and Management of High Seas Fishery Resources in the South Pacific Ocean

United Nations Conference on the Human Environment

United Nations Declaration on the Human Environment

Total Allowable Catch

Transboundary Impact Assessment

ThinkTank for Sustainability

United Nations 
UNCLOS

UNECE

UNEP

UNESCAP

UNESCO

UNFCCC

UNFSA

UNGA

USD

UVI

VCLT

VME

VMS

WCPFC

WCPFC Convention

Wellington Convention

Working Group

WTO

WWF
United Nations Convention on the Law of the Sea

United Nations Economic Commission for Europe

United Nations Environment Programme

United Nations Economic and Social Commission for Asia and the Pacific

United Nations Educational, Scientific and Cultural Organization

United Nations Framework Convention on Climate Change

Agreement for the Implementation of the Provisions of the United Nations Convention on the Law of the Sea of 10 December 1982 relating to the Conservation and Management of Straddling Fish Stocks and Highly Migratory Fish Stocks (Fish Stocks Agreement)

United Nations General Assembly

US dollars

Unique Vessel Identifier

Vienna Convention on the Law of Treaties

Vulnerable Marine Ecosystem

Vessel Monitoring System

Western and Central Pacific Fisheries Commission

Conservation and Management of Highly Migratory Fish Stocks in the Western and Central Pacific Ocean

Convention for the prohibition of fishing with long driftnets in the South Pacific

Ad Hoc Open-ended Informal Working Group to study issues relating to the conservation and sustainable use of BBNJ

World Trade Organization

World Wildlife Fund 


\section{INTRODUCTION}

\section{THE ELUSIVE SEARCH FOR SUSTAINABLE HIGH SEAS FISHERIES}

The high seas have been the terrain of an ever-growing exploitation of marine living resources. In fact, the Olympic Games motto Citius, Altius, Fortius - faster, higher, stronger - might well apply to high seas fisheries: with technological advances, fish is being caught at unprecedented rate and in farther and deeper waters. ${ }^{1}$ The idea of the high seas as "the ultimate frontier" will soon be pertaining to the past.

To address this changing picture of international fisheries, high seas fishing activities are the object of a continuously growing body of State-driven regulatory instruments and cooperation measures undertaken by States directly or through regional fisheries management organizations (RFMOs). However, difficulties linked to the remoteness of high seas areas as well as political and economic considerations have left many gaps and grey areas in fisheries regulation and management, therefore contributing to making the story of high seas fisheries "one of rich harvests followed by overfishing followed by stock decline and collapse."2

In fact, overexploitation of fish stocks is not a new phenomenon. Overfishing was described as early as $1854,{ }^{3}$ and the general overexploitation of stocks was identified by the Food and Agriculture Organization (FAO) in 1945, the very year of its creation. ${ }^{4}$ Yet, "as recently as 1969 it was still acceptable to consider as alarmist

1 See David Tickler et al, "Far from home: Distance patterns of global fishing fleets" (2018) 4:8 Sciences Advances 1-6 at 2-3, where the authors mention that "offshore and high seas waters have also become increasingly exploited in the past 65 years, with essentially no waters other than those at extreme high latitudes presently unfished to some degree". See also William Cheung, Vicky Lan \& Collette Wabnitz, "Future scenarios and projections for fisheries on the high seas under changing climate" (2019) IIED Working Paper at 7; Olav Schram Stokke, "Introduction" in Olav Schram Stokke (ed), Governing High Seas Fisheries. The Interplay of Global and Regional Regimes (Oxford: Oxford University Press, 2001) 1-19 at 5 [Stokke, "Introduction"].

2 Rosemary Rayfuse, Non-flag State enforcement in high seas fisheries (Leiden: Martinus Nijhoff, 2004) at 3 [Rayfuse, Non-flag State enforcement].

3 Serge Garcia, Jake Rice \& Anthony Charles, "Governance of marine fisheries and biodiversity conservation: A history" in Serge Garcia, Jake Rice \& Anthony Charles (eds), Governance of marine fisheries and biodiversity conservation: Interaction and Coevolution (Hoboken: Wiley, 2014) 3-17 at 5.

4 FAO, "The State of World Fisheries and Aquaculture 1996. Contributing to food security and nutrition for all” (1996) at 6, online: <http://www.fao.org/3/w3265e/W3265E.htm> [FAO Report 1996], cited in Rayfuse, Non-flag State enforcement, supra note 2 at 4. 
that collapse of fish stocks was due to overfishing". ${ }^{5}$ Now, in 2020 , with increased knowledge about the impact of fishing operations on the wider marine environment, it is better understood that the overexploitation of marine living resources combined with weak conservation measures targeting the high seas are main threats to marine biodiversity in these areas. ${ }^{6}$ The story of high seas fisheries has therefore become not only one of stock decline and collapse, but also one of elusive marine sustainability more broadly, making us wonder whether the current legal framework is leaving high seas fisheries management short of adequate concrete solutions.

What if, then, the sustainability of high seas fish stocks resided in alternative and complementary approaches to fisheries management and regulation? This question inevitably arises when overfishing and unsustainable fishing practices continue to occur despite various legal attempts at tackling such practices, ${ }^{7}$ and despite initiatives to raise awareness about the state of fish stocks in the high seas and the impact of high seas fisheries on the marine environment. ${ }^{8}$

Of course, environmental changes create new realities for high seas fisheries, which remain difficult to monitor and assess. But problems with the sustainability of high seas fisheries pre-date new environmental concerns, and it could be asked whether they are caused by how the regime is built. How, then, is overexploitation of marine living resources perceived by State and non-State actors, and how has it influenced their behaviour? The answer to these questions is shaped through an evolution of events, which are dotted with successes and difficulties.

5 Richard Barnes, Property Rights and Natural Resources (Oxford: Hart, 2009) at 4, citing Harry N. Scheiber, "Ocean Governance and the Marine Fisheries Crisis. Two Decades of Innovation - And Frustration" (2001) 20 Virginia Environmental Law Journal 119-138 at 120, who refers to W.S. Chapman, "Seafood and World Famine - A positive Approach" (Address to the Symposium on Food from the Sea, 23 September 1969).

6 See, e.g., FAO, “The State of World Fisheries and Aquaculture 2020. Sustainability in action” (2020) at vi-vii, online: <http://www.fao.org/state-of-fisheries-aquaculture> [FAO Report 2020]. See also Summary of the first global integrated marine assessment, UNGAOR, 70th Sess, UN Doc A/70/112 (2015) at paras 33 and 92 .

7 E.g. the recent adoption (2009) and entry into force (2016) of the Agreement on Port State Measures to prevent, deter and eliminate illegal, unreported and unregulated fishing, infra note 50, and the recent adoption (2019) of the Agreement to prevent unregulated high seas fisheries in the Central Arctic Ocean, infra note 53. These instruments are also mentioned in section 1.2 below.

8 E.g. SDG 14.4 on ending overfishing and 14.6 on banning certain forms of fisheries subsidies, see Transforming our world: the 2030 Agenda for Sustainable Development, GA Res 70 (I), UNGAOR, 70th Sess, UN Doc A/RES/70/1 (2015) [UNGA Res 70/1]; and the UN Ocean Conference which strengthened the dialogue among all relevant stakeholders on the state of the oceans and the marine environment, see United Nations Ocean Conference (New York, USA, 5-9 June 2017), online: <https://oceanconference. un.org/about>. These examples are discussed in section 1.1 below. 


\subsection{Seventy years (and counting...) of recognizing overexploitation on the high seas}

The exploitation of marine living resources and its impact on biodiversity and the marine environment has been widely addressed by the international community and the scholarly literature. A historical recap is in order. ${ }^{9}$

1958. Upon the conclusion of the first United Nations (UN) Conference on the Law of the Sea, States adopt four international agreements, one being the Convention on Fishing and Conservation of the Living Resources of the High Seas. This Convention acknowledges that "the development of modern techniques for the exploitation of the living resources of the sea, [and] increasing man's ability to meet the need of the world's expanding population for food, has exposed some of these resources to the danger of being over-exploited". ${ }^{10}$ The text of the Convention therefore provides a framework for regulating fishing activities and conservation measures on the high seas.

1958 also marks the beginning of the "Cod Wars". Iceland, concerned that British vessels would overfish the living resources in the fertile waters beyond its fishing zone, unilaterally extends its zone, an extension that the United Kingdom ignores. This leads the Icelandic coast guard to cut British fishing nets, and the British Royal Navy to respond by sending ships to protect British fishing vessels. Two other incidents will follow in 1972-1973 and 1975. ${ }^{11}$ The confrontations illustrated by the Cod Wars show how far States can go to protect their fishing rights, often intrinsically linked with national interests and identity.

1960s. Following the failed attempt of the Second UN Conference on the Law of the Sea to address fishery limits, State practice develops rapidly regarding the unilateral claims to fishing zones. While most European States, following Iceland, claim exclusive fishing zones up to 12 nautical miles, Asian, African and Latin American States declare much more extensive zones, sometimes up to 400 nautical miles. ${ }^{12}$ Claims to exclusive fishing zones consequently affect the characterization of - as well as rights and duties over - fish stocks within and beyond national jurisdiction.

9 The historical recap is based on Serge Garcia, "Annex I - History of Fisheries and biodiversity conservation: A timeline of key events (1850-2012)" in Serge Garcia, Jake Rice \& Anthony Charles (eds), Governance of marine fisheries and biodiversity conservation: Interaction and Coevolution (Hoboken: Wiley, 2014) 429-460. The timeline by Garcia is very relevant to the understanding of the evolution of nature and biodiversity conservation presented in parallel with the development of fisheries management. The present study, however, focuses on a selection of important events characterizing fisheries on the high seas more specifically.

10 Convention on Fishing and Conservation of the Living Resources of the High Seas (29 April 1958, entered into force 20 March 1966) 559 UNTS 285 at preamble.

11 British Sea Fishing, "The Cod Wars", online: <http://britishseafishing.co.uk/the-cod-wars/>; Stokke, "Introduction", supra note 1 at 4

12 Donald Rothwell \& Tim Stephens, The International Law of the Sea (Oxford: Hart, 2016) at 10-11. 
1968. In his seminal work "The Tragedy of the Commons", Garrett Hardin criticizes the continuous reliance of maritime nations on the freedom of the high seas, and warns that believing "in the 'inexhaustible resources of the oceans', [...] bring[s] species after species of fish and whales closer to extinction". ${ }^{13}$

1972. States adopt the Declaration of the United Nations Conference on the Human Environment (Stockholm Declaration). ${ }^{14}$ The text underlines the important relationship between humans and their environment. More specifically, Principle 7 recognizes the necessity "to prevent pollution of the seas [and] harm to living resources and marine life". ${ }^{15}$ This constitutes an acknowledgement of the environmental impact of human activities, including fishing, on marine living resources and, more generally, on the oceans, and brings forward the need to address these concerns.

1982. Twenty-four years after the adoption of the Convention on Fishing and Conservation of the Living Resources of the High Seas, most of its provisions are included in the new United Nations Convention on the Law of the Sea (UNCLOS), ${ }^{16}$ adopted after nine years of negotiations. While Section 2 of Part VII addresses the conservation and management of the living resources of the high seas, Part XII deals with the protection and preservation of the marine environment, which adopts an overarching approach to marine environmental protection. UNCLOS also formally crystalizes the possibility to extend fisheries zones through the establishment of exclusive economic zones (EEZ). Time has shown, however, that the expansion of coastal State jurisdiction over the oceans through the EEZ has failed to achieve more effective environmental protection; in fact, States have not taken the newly extended duty to protect the marine environment (a corollary to the extended jurisdiction over the EEZ) seriously. ${ }^{17}$ In addition, stocks straddling the high seas and the EEZ remain available for fishing by other States on the high seas, and the development of fishing techniques allows for more distant fishing. ${ }^{18}$

1987. The work of the World Commission on Environment and Development, also known as the Brundtland Commission, culminates in the adoption of its final report, Our Common Future (Brundtland Report). ${ }^{19}$ This Report highlights several

13 Garrett Hardin, "The Tragedy of the Commons" (1968) 3859 Science 1243-1248 at 1245.

14 "United Nations Conference on the Human Environment: Final Documents" (1972) 11:6 International Legal Materials 1416-1469 [Stockholm Declaration].

15 Ibid at 1417.

16 United Nations Convention on the Law of the Sea (10 December 1982, entered into force 16 November 1994), 1833 UNTS 3 [UNCLOS].

17 Stokke, "Introduction", supra note 1 at 1-2.

18 These three reasons are discussed in Olav Schram Stokke, "International fisheries politics: from sustainability to precaution" in Steina Andresen, Elin Lerum Boasson \& Geir Honneland (eds), International Environmental Agreements: An Introduction (Abingdon, Oxon: Routledge, 2011) 97-116 at 107-108.

19 World Commission on Environment and Development, Our Common Future (Oxford: Oxford University Press, 1987). 
threats affecting high seas fisheries and the oceans, and suggests potential solutions that need to be undertaken at the national, regional and global levels. The Report also defines the term "sustainable development".

1990. In her ground-breaking book, Governing the Commons, Nobel Prize winner Elinor Ostrom explains that although everyone agrees on the problem - overfishing - how to address the problem, however, is still affected by divergences of views. She also mentions that "neither the state nor the market is uniformly successful in enabling individuals to sustain long-term, productive use of natural resource systems". ${ }^{20}$ To address such concerns, she dedicates her book to analysing other solutions for the governance and management of common pool resources in order to "develop better intellectual tools to understand the capabilities and limitations of self-governing institutions for regulating many types of resources". ${ }^{21}$

1992. The UN Conference on Environment and Development (Rio Conference) ${ }^{22}$ results in the adoption of the Rio Declaration on Environment and Development (Rio Declaration), containing a list of principles in which the ecosystem and precautionary approaches are enshrined. ${ }^{23}$ The Conference also adopts Agenda $21,{ }^{24}$ a plan of action for the 21 st century. Its chapter 17 , dedicated to the protection of the oceans and the use of their living resources, recognizes that integration, cooperation and coordination are necessary for marine management and development. ${ }^{25}$

The Rio Conference is also marked by the opening for signatures of the Convention on Biological Diversity (CBD), ${ }^{26}$ a multilateral environmental treaty developed as a response to the biodiversity loss triggered by certain human activities. The CBD aims for the conservation of biodiversity, the sustainable use of its components, and the fair and equitable sharing of benefits from the use of genetic resources. ${ }^{27}$

1995. On 9 March, Canada arrests and detains the Estai, a Spanish vessel fishing just outside the Canadian EEZ, on the basis of alleged overfishing and of violation of fishing regulations such as fishing gear sizes. Spain, supported by the European Union (EU), files proceedings in the International Court of Justice (ICJ), claiming a violation of international law and the freedom of the high seas. The ICJ will however

20 Elinor Ostrom, Governing the Commons. The Evolution of Institutions for Collective Action (Cambridge: Cambridge University Press, 1990) at 1.

21 Ibid at 2.

22 United Nations Conference on Environment and Development (Rio de Janeiro, Brazil, 3-14 June 1992) [Rio Conference], see Garcia, Rice \& Charles, supra note 3 at 7.

23 "United Nations Conference on Environment and Development: Rio Declaration on Environment and Development" (1992) 31:4 International Legal Materials 874-880 at 887 (principle 7) and 889 (principle 15) respectively [Rio Declaration].

24 Agenda 21 of the United Nations Conference on Environment and Development, UNCED Report A/CONF.151/26/Rev.1 (1993).

25 Ibid at chapter 17, para 17.1.

26 Convention on Biological Diversity (5 June 1992, entered into force 29 December 1993) 1760 UNTS 79 [CBD].

27 Ibid at art. 1. 
find that it had no jurisdiction over the matter. Later characterized as the "Turbot War", these events, which put the need for further regulation of straddling stocks in the limelight, become an incentive for the adoption of the Agreement for the Implementation of the Provisions of the United Nations Convention on the Law of the Sea of 10 December 1982 relating to the Conservation and Management of Straddling Fish Stocks and Highly Migratory Fish Stocks (Fish Stocks Agreement - UNFSA). ${ }^{28}$ Complementing the UNCLOS regime on the protection and preservation of living resources by focusing on "the long-term conservation and sustainable use of straddling fish stocks and highly migratory fish stocks", the UNFSA also addresses issues of preservation of biodiversity and integrity of ecosystems. ${ }^{29}$

That same year, the Code of Conduct for Responsible Fisheries (Code of Conduct), a voluntary set of "principles and standards applicable to the conservation, management and development of all fisheries" ${ }^{\prime 3}$ is adopted by the FAO. It also warns about the dangers of an exploitation-oriented fishing industry, and underlines the urgent need for "new approaches to fisheries management embracing conservation and environmental considerations". ${ }^{31}$

2007. An independent panel mandated to develop a model for improved fisheries governance publishes its Recommended Best Practices for RFMOs. The document, known as the Chatham Report, recognizes the problem of overfishing and the need for more cooperation. ${ }^{32}$

2015. The UN General Assembly (UNGA) adopts the 2030 Agenda for Sustainable Development, which contains the Sustainable Development Goals (SDGs). ${ }^{33}$ This set of goals focuses on the three dimensions of the concept of sustainability - social, economic and environmental. Goal 14, "Conserve and sustainably use the oceans, seas and marine resources", outlines the need to sustainably manage and protect ecosystems, to fight illegal, unregulated and unreported (IUU) fishing and other destructive fishing practices, and to prohibit certain forms of fisheries subsidies. ${ }^{34}$

28 See, e.g., Jamison Colburn, “Turbot Wars: Straddling Stocks, Regime Theory, and a New UN Agreement" (1996-1997) 6:2 Transnational Law and Policy 323-366 at 323-326.

29 Agreement for the Implementation of the Provisions of the United Nations Convention on the Law of the Sea of 10 December 1982 relating to the Conservation and Management of Straddling Fish Stocks and Highly Migratory Fish Stocks (4 August 1995, entered into force 11 December 2001) 2167 UNTS 3 at preamble [UNFSA].

30 Code of Conduct for Responsible Fisheries, FAO, 28th Sess, FAO Doc 95/20/Rev/1 (1995).

31 Ibid at preface (emphasis added).

32 Michael Lodge et al, Recommended Best Practices For Regional Fisheries Management Organizations. Report of an Independent Panel to Develop a Model for Improved Governance by Regional Fisheries Management Organizations (London: The Royal Institute of International Affairs Chatham House, 2007) at 1 and ix-xi.

33 UNGA Res 70/1, supra note 8.

34 Ibid at 23-24. 
That same year, the Regular Process for Global Reporting and Assessment of the State of the Marine Environment, including Socioeconomic Aspects (Regular Process) ${ }^{35}$ publishes its First Global Integrated Marine Assessment, ${ }^{36}$ which highlights the major pressures affecting the ocean and indicates that "the limits of its carrying capacity are being, or in some cases have been, reached" ${ }^{37}$

2017. The First UN Ocean Conference ${ }^{38}$ gathers together State actors, scientists, civil society, academics and the private sector in order to raise awareness of the conservation and sustainable use of oceans and their resources. The aim of the Conference is also to mobilize action for the implementation of SDG 14. Various fisheries related topics are addressed, such as fisheries subsidies, overfishing, IUU fishing, and the importance of cross-sectoral dialogues between RFMOs and regional seas programmes (RSPs).

2018. After more than a decade of intergovernmental discussions and preparatory work, the Intergovernmental Conference on an international legally binding instrument on the conservation and sustainable use of marine biological diversity beyond national jurisdiction (BBNJ) starts its work. This instrument should aim to address needs and gaps in terms of cooperation and coordination in areas beyond national jurisdiction $(\mathrm{ABNJ})$. While it seems at present that the instrument's scope of application will exclude the management of high seas fish stocks, ${ }^{39}$ it is however expected to affect these stocks indirectly, mainly through provisions on cooperation between instruments and structures. ${ }^{40}$

2019. Two alarming reports are published. First, the Intergovernmental SciencePolicy Platform on Biodiversity and Ecosystem Services (IPBES) publishes its first global assessment report on biodiversity and ecosystems services, highlighting, among others things, that in "marine ecosystems, direct exploitation of organisms (mainly fishing) has had the largest relative impact", ${ }^{41}$ and that economic incentives

35 The Regular Process was established through Oceans and the law of the sea, GA Res 57(CXLI), UNGAOR, 57th Sess, UN Doc A/RES/57/141 (2003) at para 45. It is an intergovernmental process that aims "to contribute to the strengthening of the regular scientific assessment of the state of the marine environment in order to enhance the scientific basis for policymaking", see Regular Process, online: <https://www. un.org/regularprocess/>.

36 Summary of the first global integrated marine assessment, supra note 6.

37 Background information on the Regular Process, online: <https://www.un.org/depts/los/global_reporting/ Background_to_the_Regular_Process.pdf $>$.

38 United Nations Ocean Conference, supra note 8.

39 Revised draft text of an agreement under the United Nations Convention on the Law of the Sea on the conservation and sustainable use of marine biological diversity of areas beyond national jurisdiction, Intergovernmental conference on an international legally binding instrument under the United Nations Convention on the Law of the Sea on the conservation and sustainable use of marine biological diversity of areas beyond national jurisdiction, 4th Sess, UN Doc A/CONF.232/2020/3 (2019) at art. 8(2)(a).

40 Ibid at arts. 4 and 6.

41 IPBES, "Summary for Policymakers of the IPBES Global Assessment Report on Biodiversity and Ecosystem Services” (2019) at 12, para B1: online: <https://ipbes.net/sites/default/files/inline/files/ipbes_ global_assessment_report_summary_for_policymakers.pdf $>$. 
such as fisheries subsidies have contributed to environmental harm. ${ }^{42}$ Second, the special report on the Ocean and Cryosphere of the Intergovernmental Panel on Climate Change (IPCC) highlights, among other issues, the importance of the impact of climate change on fisheries which, for example, decreases the maximum catch potential and consequently results in the overfishing of certain stocks. ${ }^{43}$

Looking at the different statements above about overfishing, protection of biodiversity on the high seas and preservation of the broader marine environment, it becomes evident that the world is facing perennial problems. And seeing that overfishing is one of the main problems for biodiversity in ABNJ, it would be an understatement to say that the need for solution is pressing.

\subsection{Awareness and regulatory successes}

It would be erroneous, however, not to acknowledge the progress achieved regarding the regulation and management of fishing activities, and the protection of the marine environment, both on the high seas and within national jurisdiction. For example, UNCLOS includes provisions for the conservation and management of marine living resources. ${ }^{44}$ The UNFSA complemented the UNCLOS regime on straddling and highly migratory fish stocks. The UNGA, through various resolutions, has also shown its concern for fishing-related issues, such as sustainable fisheries, deep-sea fish stocks, fisheries by-catch and discards, and large-scale pelagic driftnet fishing. ${ }^{45}$ A UNGA resolution on the last-mentioned issue in fact led to the 1989 Convention for the Prohibition of Fishing with Long Driftnets in the South Pacific (Wellington Convention), ${ }^{46}$ showing "the power of UN General Assembly resolutions to promote goals which might have been unattainable [directly] through treaty-based mechanisms". ${ }^{47}$

42 Ibid at 14 , para B5.

43 IPCC, "Special Report on the Ocean and Cryosphere in a Changing Climate - Summary for Policymakers" (2019) at para A.5.4, online: <https://www.ipcc.ch/site/assets/uploads/sites/3/2019/11/03_SROCC_ SPM_FINAL.pdf>.

44 UNCLOS at arts. 61-64 and 116-119.

45 See, e.g. Large-scale pelagic drift-net fishing and its impact on the living marine resources of the world's oceans and seas, GA Res 46(CCXV), UNGAOR, 46th Sess, UN Doc A/RES/46/215 (1991); Sustainable fisheries, including through the 1995 Agreement for the Implementation of the Provisions of the United Nations Convention on the Law of the Sea of 10 December 1982 relating to the Conservation and Management of Straddling Fish Stocks and Highly Migratory Fish Stocks, and related instruments, GA Res 61(CV), UNGAOR, 61th Sess, UN Doc A/RES/61/105 (2006). Both resolutions are discussed in Glen Wright et al, "High seas fisheries: what role for a new international instrument?" (2016) IDDRI Paper $3 / 2016$ at 8 .

46 Convention for the prohibition of fishing with long driftnets in the South Pacific (24 November 1989, entered into force 17 May 1991) 1899 UNTS 3 [Wellington Convention].

47 Jenny Grote Stoutenburg, "Implementing a New Regime of Stable Maritime Zones to Ensure the (Economic) Survival of Small Island States Threatened by Sea-Level Rise" (2011) 26:2 International Journal of Marine and Coastal Law 263-312 at 304. For more information on how the UNGA Resolution led first to the adoption of the Tarawa Declaration on Driftnet Fishing (10 July 1989, entry into force 6 March 2008) PITSE 17, and then to the Wellington Convention, see Stoutenburg at 304-307. 
Moreover, concrete measures to reduce overfishing have been established, e.g. gear restrictions, catch limits and closure of fishing areas. ${ }^{48}$ The fight against IUU fishing has become a real priority at the global level, as shown by the $2001 \mathrm{FAO}$ International Plan of Action to Prevent, Deter and Eliminate Illegal, Unreported and Unregulated Fishing (IPOA-IUU) ${ }^{49}$ and the 2009 FAO Agreement on Port State Measures to prevent, deter and eliminate illegal, unreported and unregulated fishing (PSMA), ${ }^{50}$ as well as the recurring mention of the problem in UNGA Resolutions. ${ }^{51}$ Regional action against IUU fishing has also been taken, e.g., by the EU..$^{52}$ Another concrete measure to prevent overfishing can be seen in the recent adoption of the Agreement to prevent unregulated high seas fisheries in the Central Arctic Ocean (CAOFA), which relies on a precautionary approach to address the particularities of fisheries in the Arctic, by creating a moratorium on commercial fishing in the Arctic for at least 16 years following its entry into force ${ }^{53}$ Interest is further shown in better understanding States' obligations in countering unsustainable practices, as can be seen from the Advisory Opinion of the International Tribunal for the Law of the Sea (ITLOS) requested by the Western African Sub-regional Fisheries Commission (hereafter Advisory Opinion on IUU Fishing). ${ }^{54}$ Civil society also participates in the common effort, as can be seen from the continuous actions of various nongovernmental organizations. ${ }^{55}$ The awareness of the inclusion of environmental

48 Rayfuse, Non-flag State enforcement, supra note 2 at 5.

49 International Plan of Action to Prevent, Deter and Eliminate Illegal, Unreported and Unregulated Fishing, FAO COFI, 24th Sess (2001), online: <http://www.fao.org/3/a-y1224e.pdf >.

50 Agreement on Port State Measures to prevent, deter and eliminate illegal, unreported and unregulated fishing (22 November 2009, entered into force 5 June 2016) UNTS No 541333 [PSMA].

51 See, generally, Sustainable fisheries, including through the 1995 Agreement for the Implementation of the Provisions of the United Nations Convention on the Law of the Sea of 10 December 1982 relating to the Conservation and Management of Straddling Fish Stocks and Highly Migratory Fish Stocks, and related instruments, GA Res 73(CXXV), UNGAOR, 73rd Sess, UN Doc A/RES/73/125 (2018); Sustainable fisheries, including through the 1995 Agreement for the Implementation of the Provisions of the United Nations Convention on the Law of the Sea of 10 December 1982 relating to the Conservation and Management of Straddling Fish Stocks and Highly Migratory Fish Stocks, and related instruments, GA Res 74(XVIII), UNGAOR, 74th Sess, UN Doc A/RES/74/18 (2019).

52 See, e.g., Council Regulation (EC) No 1005/2008 establishing a Community system to prevent, deter and eliminate illegal, unreported and unregulated fishing, amending Regulations (EEC) No 2847/93, (EC) No 1936/2001 and (EC) No 601/2004 and repealing Regulations (EC) No 1093/94 and (EC) No 1447/1999, (2008) OJ, L 286/1.

53 Agreement to prevent unregulated high seas fisheries in the Central Arctic Ocean, (2019) OJ, L 73/3 at art. 13(1) [CAOFA].

54 Request for an advisory opinion submitted by the Sub-Regional Fisheries Commission (SRFC), Advisory opinion, (2015) ITLOS case 21. The Sub-Regional Fisheries Commission is composed of seven States: Guinea, Cape Verde, The Gambia, Guinea Bissau, Mauritania, Senegal and Sierra Leone. Although ITLOS limited its opinion to the EEZ, it did bring clarification to flag States' obligations, which are also important on the high seas considering the exclusive flag State jurisdiction as per art. 92 UNCLOS.

55 See, e.g. Global Fishing Watch, online: <http://globalfishingwatch.org/>; "Sea Shepherd Helps Arrest Two Illegal Fishing Vessels" (17 July 2017) The Marine Executive, online: <http://maritime-executive.com/ article/sea-shepherd-aids-in-arrest-of-illegal-fishing-vessels $>$. NGOs have also been allowed to openly take part in the BBNJ negotiations and make interventions, see, e.g. interventions made by Greenpeace, WWF and the High Seas Alliance in IISD, "Summary of the Third Session of the Intergovernmental Conference (IGC) on the Conservation and Sustainable Use of Marine Biodiversity of Areas Beyond National Jurisdiction" (2019) 25:118 Earth Negotiation Bulletin. The BBNJ negotiations are discussed in further detail in chapter 4 below. 
protection in fisheries management has also been incremental. A recent study shows that the continuous mainstreaming of biodiversity and sustainability in fisheries has "led to significant expansions in legal frameworks, policies and practices in terms of biodiversity conservation" and cross-sectoral cooperation. ${ }^{56}$

Hope for the oceans has also been reflected in a study published in Nature on 1 April 2020 , showing that oceans can be restored by 2050, therefore bringing optimism to the scientific and policy making communities alike. The study demonstrates that oceans have shown resilience to anthropogenic activities and climate change, but that the window for action is small and that governments must seize the opportunity to act quickly to ensure durable results. ${ }^{57}$

\subsection{Specific difficulties on the high seas}

A large proportion of fishing activities takes place in the EEZ of coastal States rather than on the high seas. Yet, the focus on ABNJ is necessary: the weaknesses in the interactions between instruments and institutions, as well as the sustainability challenges faced by fisheries management on the high seas, show that there is a need for alternatives to how the regime is currently organized and implemented.

Notwithstanding all that has been accomplished at the legal, regulatory and policy levels, problems of effective enforcement and compliance stand out as key issues when considering the specific conservation and management of living resources in $\mathrm{ABNJ}$. This is due, among other things, to difficulties in monitoring and to the remoteness of the areas. Specific data about fish stocks on the high seas is also difficult to obtain and process. The legal status of ABNJ, as well as the limited number of actors having enforcement jurisdiction, are also limitations. In fact, the principles of freedom of fishing and of exclusive flag-State jurisdiction on the high seas are central to implementation and enforcement in ABNJ. ${ }^{58}$ Yet, control exercised by flag States has clearly been insufficient to ensure the conservation and preservation of marine biodiversity, including fish, on the high seas. ${ }^{59}$ Therefore, not only should the regulatory scheme of $\mathrm{ABNJ}$ be developed; the focus should also be on the enforcement of and compliance with already existing features.

56 Kim Friedman, Serge Garcia \& Jake Rice, "Mainstreaming Biodiversity in Fisheries" (2018) 95 Marine Policy 209-220 at 209.

57 Carlos Duarte et al, "Rebuilding Marine Life" (2020) 580 Nature 39-51. See also Matt McGrath, "Oceans can be successfully restored by 2050, say scientists" (1 April 2020) BBC News, online: <https://www.bbc. com/news/science-environment-52122447>.

58 Rayfuse, Non-flag State enforcement, supra note 2 at 5-6.

59 Dire Tladi, “The Proposed Implementing Agreement: Options for Coherence and Consistency in the Establishment of Protected Areas Beyond National Jurisdiction” (2015) 30:4 International Journal of Marine and Coastal Law 654-673 at 657-658. 
The legal framework in $\mathrm{ABNJ}$ is also prone to fragmentation, i.e. characterized by "fragments of normative and institutional activity", ${ }^{60}$ namely that rules are found in various instruments and applied by different institutions. This is particularly true with international fisheries law: it is formed by a plethora of instruments, is sectororiented and remains decentralized. For example, regarding fisheries, besides the UNFSA, which implements the general provisions of UNCLOS on the conservation of straddling and highly migratory fish stocks, binding and non-binding instruments are also adopted by the FAO. ${ }^{61}$ These instruments are subsequently implemented by individual State actions, as well as collectively through the work of RFMOs. ${ }^{62}$ This fragmentation is accentuated by the presence of geographical and species gaps within fisheries management. Uncertainty arises from the difficulty in navigating through these various layers of obligations, and this influences actors' behaviours.

In order to ensure coherence, i.e. connectedness of rules, institutions, etc., in a way that supports "each other's effectiveness", ${ }^{3}$ efforts would need to target cooperation and coordination, which, this study submits, are currently weak in ABNJ, especially when it comes to reconciling fisheries management and environmental protection. In fact, the necessity of developing and operationalizing the protection of the marine environment in ABNJ is one of the issues with which UNCLOS has been having difficulties. ${ }^{64}$ The current negotiations for the development of an instrument for the conservation and sustainable use of biodiversity in ABNJ show an interest in looking into "up to date" cooperation and coordination beyond national jurisdiction; however, the exact content and impact of this instrument remain to be seen.

High seas fisheries, thus, are subject to specific difficulties embedded in their remoteness and in actors' capacity - and willingness - to implement and enforce. Yet, considering the continuous efforts to develop new regulations aiming for a more sustainable management of high seas fisheries and the numerous mobilization actions described above, it could be thought - rightly for that matter - that significant improvements should have been observed by now. ${ }^{65}$ But that is not the case. What

60 Margaret Young, "Introduction: The Productive Friction between Regimes" in Margaret Young (ed), Regime Interaction in International Law. Facing Fragmentation (Cambridge: Cambridge University Press, 2012) $1-20$ at 2 .

61 See, generally, Jean-François Pulvenis, "FAO, Ocean Governance and the Law of the Sea" in Harry N. Scheiber \& Jin-Hyun Paik (eds), Regions, Institutions, and Law of the Sea: Studies in Ocean Governance (Leiden: Brill Nijhoff, 2013) 111-128.

62 Jeff Ardron et al, "Advancing governance of the High Seas" (2013) IASS Policy Brief 1/2103 at 6; Cassandra Brooks et al, "Challenging the 'Right to Fish' in a Fast-Changing Ocean" (2014) 33:3 Stanford Environmental Law Journal 289-324 at 316-320.

63 Olav Schram Stokke, "Management Options for High Seas Fisheries: Making Regime Complexes More Effective" in Richard Caddell \& Erik Molenaar (eds), Strengthening International Fisheries Law in an Era of Changing Oceans (Oxford: Hart, 2019) 51-77 at 55.

64 Jill Barrett, "The UN Convention on the Law of the Sea: A 'Living' Treaty?" in Jill Barrett \& Richard Barnes (eds), Law of the Sea: UNCLOS as a Living Treaty (British Institute of International and Comparative Law, 2016) 3-37 at 35.

65 This observation is also at the heart of the analysis in Marcus Haward, Governing Oceans in a Time of Change. Fishing for the Future (Cheltenham: Edward Elgar, 2020) at 4. 
is wrong, then? What is it that we are failing to understand? Why is this search for sustainable high seas fisheries so elusive?

\section{CONCEPTUAL FRAMEWORK: REVISITING PREMISES TO MOVE FORWARD MORE EFFICIENTLY}

A famous saying often attributed to Albert Einstein suggests that insanity means doing the same thing over and over again and expecting different results. Following that reasoning, this study suggests that the absence of significant change towards an increased sustainable management of high seas fisheries is linked to the fact that most recent developments in high seas fisheries management have been rooted in the same types of instruments, the same actors and institutions, and the same processes. This approach is strongly enshrined in traditional considerations of international law and of the law of the sea as, first and foremost, a regime for the regulation of oceans uses and not for the preservation of the environment. It therefore raises the question of whether the law as it currently stands is the appropriate avenue to tackle recurring problems that are not linear ${ }^{66}$ nor unidimensional but, above all, whether it is able to tackle State behaviour in enforcement and compliance for the sustainable management of fisheries. ${ }^{67}$

This study therefore takes a step back and focuses on the necessity to understand the interconnectedness within the regime (2.1). As part of this focus, it looks at high seas fisheries as a complex socio-ecological system (2.2). It also suggests assessing the law from a different lens of analysis: as one of multiple components of governance (2.3). It is by beginning with a different starting point that we can consider new ways of doing things, and contemplate why alternative models are necessary if we are to expect different results.

\subsection{Interconnectedness, or the need for an integrated, interdisciplinary and intersectoral approach}

In 1982, the need to characterize the oceans as one ecological and biological unit, and the acknowledgement of the transboundary nature of the challenges impacting on ocean space, had already been enshrined in the preamble to UNCLOS, through a short, yet meaningful, sentence: Conscious that the problems of ocean space are closely interrelated and need to be considered as a whole.

66 Non-linear means that they do not follow a linear response, i.e. identifying the problem, assessing the problem, planning the response, making a decision as to this response, and implementing it, see, generally, Rakhyun E. Kim \& Brendan Mackay, "International Environmental Law as a Complex Adaptive System" (2014) 14 International Environmental Agreements 5-24.

67 This relies on a similar reasoning conducted in relation to climate change in Seline Trevisanut, "Unsustainable International Law" (Inaugural lecture delivered at Utrecht University, 4 April 2019). 
Until $2000,{ }^{68}$ the annual UNGA resolution on Oceans and the law of the sea had reiterated the necessity to consider the oceans as a unit by referring to the language of UNCLOS' preamble. However, in its 2001 resolution, the General Assembly altered the phrasing for the first time and added a reference to "an integrated, interdisciplinary and intersectoral approach". ${ }^{69}$ In 2005, the phrasing changed once again, directly linking this new approach to "the need to improve cooperation, coordination and management at national, regional and global levels" ${ }^{70}$

This change in terminology coincided with the creation of UN-Oceans, ${ }^{71}$ an "interagency coordination mechanism on ocean and coastal issues established within the UN"72 to ensure cooperation between UN structures involved in ocean affairs. UN-Oceans now includes financial institutions, the secretariat of environmental conventions, as well as other UN specialized agencies and other organizations. ${ }^{73} \mathrm{Ad}$ hoc task forces have been developed to further enhance collaboration in respect of specific issues. ${ }^{74} \mathrm{~A}$ Task Force on marine biodiversity beyond national jurisdiction was established in 2005, working on the global distribution of biodiversity and the available tools for its conservation and sustainable use. ${ }^{75}$ The Task Force also focuses on the improvement of intersectoriality in the face of fragmentation among instruments, bodies and structures.

More recently, in 2012, when launching the Oceans Compact, "an initiative to strengthen [UN] system-wide coherence to deliver on its oceans-related mandates", ${ }^{76}$

68 The last time the same phrasing as the one found under the preamble to UNCLOS was used was in Oceans and the law of the sea, GA Res 55(VII), UNGAOR, 55th Sess, UN Doc A/RES/55/7 (2000).

69 The whole phrasing reads as follows: "Conscious also that the problems of ocean space are closely interrelated and need to be considered as a whole through an integrated, interdisciplinary and intersectoral approach", see Oceans and the law of the sea, GA Res 56(XII), UNGAOR, 56th Sess, UN Doc A/RES/56/12 (2001).

70 See Oceans and the law of the sea, GA Res 60(XXX), UNGAOR, 60th Sess, UN Doc A/RES/60/30 (2005). A reference to cooperation and coordination was also found in previous resolutions, however it was never directly linked to integration, interdisciplinarity and intersectorality.

71 UN-Oceans, online: <http://www.unoceans.org/home/en/>. For a discussion on the development and role of UN-Oceans, see also Yoshinobu Takei, "Demystifying Ocean Governance" in Seline Trevisanut, Nikolaos Giannopoulos \& Rozemarijn Roland Holst (eds), Regime Interaction in Ocean Governance. Problems, Theories and Methods (Leiden: Brill Nijhoff, 2020) 22-51 at 37.

72 Rosemary Rayfuse \& Robin Warner, "Securing a Sustainable Future for the Oceans Beyond National Jurisdiction: The Legal Basis for an Integrated Cross-Sectoral Regime for High Seas Governance for the 21st Century" (2008) 23:3 International Journal of Marine and Coastal Law 399-421 at 413.

73 Georgia Nogueira de Souza Patu, Scope and evolution of ocean governance: improving cross-sectoral management by the adoption of principles of international law (Doctor of Philosophy thesis, Australian National Center for Ocean Resources and Security, University of Wollongong, 2011) at 351-352.

74 Ibid at 353.

75 For a list of bodies involved in the Task force, see DOALOS, "Marine biological diversity beyond areas of national jurisdiction. Cooperation and coordination within the United Nations system", online: <http:// www.un.org/depts/los/biodiversityworkinggroup/webpage_cooperation\%20and\%20coordination.pdf>. See also James Harrison, "Actors and Institutions for the Protection of the Marine Environment" in Rosemary Rayfuse (ed), Research Handbook on International Marine Environmental Law (Cheltenham: Edward Elgar, 2017) 57-78 at 76-77.

76 Oceans Compact. Healthy Oceans for Prosperity, UNEP, 14th Global Meeting of the Regional Seas Convention and Action Plans, UNEP (DEPI)/RS.14/WP.9.RS (2012), online: <https://wedocs.unep.org/ bitstream/handle/20.500.11822/12476/RS.14_WP.9.RS.pdf? sequence=1\&isAllowed=>. 
in connection the thirtieth anniversary of the opening for signature of UNCLOS, the then UN Secretary-General Ban Ki-moon used the concept of interconnectedness to illustrate the importance of the links between seas and oceans, as well as between the marine-related sectors, nations and people. In his address, he mentioned that

The world's oceans are key to sustaining life on the planet. The ocean constitutes a conduit for ninety per cent of the world trade, and for connecting people, markets and livelihoods. In light of the ocean's interconnectedness, all nations of the world should strive to make the oceans places of safety and sustainability of maritime activities for all humankind. ${ }^{77}$

These ideas were reiterated in the First Global Integrated Marine Assessment, which "examined the state of knowledge of the world's oceans and the ways in which humans benefit from and affect them" ${ }^{78}$

The sustainable use of the ocean cannot be achieved unless the management of all sectors of human activities affecting the ocean is coherent. [...] This requires taking into account the effects on ecosystems of each of the many pressures, what is being done in other sectors and the way that they interact. ${ }^{79}$

The concepts of integration, interdisciplinarity and intersectoriality, as well as the overarching concept of interconnectedness, were not found in the legal literature until approximately the last twenty years, and their appearance is closely linked to the growing use of the concept of oceans governance. These terms refer to transversal concepts and appear to take form within the legal system through the notions of cooperation or regime interaction, among others. Nevertheless, these concepts are not legal in nature, and this is why translating them into legal obligations or operationalizing them through actors' behaviours represents a challenge.

In the absence of a legal definition of the concept of interconnectedness, its understanding within the present study stems from general system theory, which defines a system as a combination of interdependent elements that are interconnected through meaningful relationships. ${ }^{80}$ These elements interact, influencing each other, sometimes even reaching the level of integration, which amounts to an alteration and merger of elements. ${ }^{81}$ This choice of definition from system theory is also

77 Ibid at 2.

78 UN Regular process, "World Ocean Assessment I", online: <https://www.un.org/regularprocess/content/ first-world-ocean-assessment>.

79 Summary of the first global integrated marine assessment, supra note 6 at para 40, discussed in Kristina M. Gjerde, Nichola A. Clark \& Harriet R. Harden-Davies, "Building a Platform for the Future: the Relationship of the Expected New Agreement for Marine Biodiversity in Areas beyond National Jurisdiction and the UN Convention on the Law of the Sea" (2019) 33 Ocean Yearbook 3-44 at 5.

80 Kim \& Mackay, supra note 66 at 10-11.

81 Jens Heidingsfelder \& Markus Beckmann, "A governance puzzle to be solved? A systematic literature review of fragmented sustainability governance" (2019) Management Quarterly Review at section 5.2.2. 
justified by the characterization of fisheries as a socio-ecological system, which is discussed further below.

Interconnectedness acts as a guiding concept throughout this study. It raises the intertwined nature of interests and activities in the oceans, the intertwined nature of marine ecosystems, as well as the way human interests and activities affect these ecosystems ${ }^{82}$ It is now uncontested that human activities have an impact on the marine environment, ${ }^{83}$ even on the most remote areas and habitats of the oceans, ${ }^{84}$ as scientific explorations in ABNJ have expanded over the past decades. ${ }^{85}$ These have shown not only a link between human activities and the oceans, but also the "intrinsic linkages between the deep sea and surface waters". ${ }^{86}$ The recognition of human activities being the primary impact factor affecting the Earth's climate and ecosystem ${ }^{87}$ is characterized as a new era, the Anthropocene, which has developed a literature of its own. ${ }^{88}$ Basically, the environment and the activities conducted therein are, by nature, interconnected, and this should urge us to approach the subject accordingly; as Kotzé puts it, "the environment as a holistic, integrated and interrelated whole requires us to part with our current fragmented, 'silo-based', and

82 See, e.g., generally, Natalie Ban et al, "Better integration of sectoral planning and management approaches for the interlinked ecology of the open oceans" (2014) 49 Marine Policy 127-136. See also Kristina Gjerde, "High Seas Fisheries Governance: Prospects and Challenges in the 21st Century" in Peter Johan Schei \& Davor Vidas (eds), The World Ocean in Globalisation: Climate Change, Sustainable Fisheries, Biodiversity, Shipping, Regional Issues (Leiden: Brill, 2011) 221-232 at 223; James Harrison, Saving the Oceans Through Law. The International Legal Framework for the Protection of the Marine Environment (Oxford: Oxford University Press, 2017) at 43 and 301 [Harrison, Saving the Oceans].

83 See, e.g., Natalie Samarasinghe \& Fred Carver (eds), "Sustainable development goals: from promise to practice" (2017) United Nations Association UK Report at 50-55, online: <https://www.una.org.uk/ sustainable-development-goals-promise-practice>.

84 Kristina Gjerde, "Enhancing integrated management beyond national jurisdiction under the environmental provisions of the UN Convention on the Law of the Sea" in Marta Chantal Ribeiro (ed), 30 Years After the Signature of the United Nations Convention on the Law of the Sea: The Protection of the Environment and the Future of the Law of the Sea. Proceedings of the International Conference (Coimbra: Coimbra Editora, 2014) 441-452 at 443 [Gjerde, "Enhancing integrated management"]; Harrison, Saving the Oceans, supra note 82 at 43.

85 See, e.g., David Freestone, "Problems of High Seas Governance" in Peter Johan Schei \& Davor Vidas (eds), The World Ocean in Globalisation. Climate Change, Sustainable Fisheries, Biodiversity, Shipping, Regional Issues (Leiden: Brill, 2011) 99-130 at 100.

86 See, e.g. Alan Jamieson et al, "Bioaccumulation of persistent organic pollutants in the deepest ocean fauna” (2017) 1 Nature Ecology and Evolution article number 0051.

87 See, e.g., Rosemary Rayfuse, "The Anthropocene, Autopoiesis And The Disingenuousness Of The Genuine Link: Addressing Enforcement Gaps In The Legal Regime For Areas Beyond National Jurisdiction" in Alex Oude Elferink \& Erik Molenaar (eds), The International Legal Regime of Areas beyond National Jurisdiction: Current and Future Developments (Leiden: Brill, 2010) 163-190 at 165 [Rayfuse, "The Anthropocene"].

88 The present study does not intend to discuss further the literature regarding the Anthropocene and the law, but for more on the topic, see, e.g., Davor Vidas, Jan Zalasiewicz \& Mark Williams, "What Is the Anthropocene-and Why Is It Relevant for International Law?" (2014) 25:1 Yearbook of International Environmental Law 3-23; Peter Johan Schei \& Davor Vidas, The World Ocean in Globalisation. Climate Change, Sustainable Fisheries, Biodiversity, Shipping, Regional Issues (Leiden: Brill, 2011); Rayfuse, “The Anthropocene", supra note 87; Ronan Long, "Commentary: The Anthropocene, Autopoiesis And The Disingenuousness Of The Genuine Link: Addressing Enforcement Gaps In The Legal Regime For Areas Beyond National Jurisdiction" in Alex Oude Elferink \& Erik Molenaar (eds), The International Legal Regime of Areas beyond National Jurisdiction Current and Future Developments (Leiden: Brill, 2010) 191-204 at 192. See also, Trevisanut, supra note 67. 
reductionist approach to the way we perceive and purport to regulate the effects of our activities in an on the environment". 89

Fisheries, one anthropogenic activity, are no exception to such interconnectedness. The present study raises first the interconnectedness between international fisheries and the marine environment, and the impacts that the former have had, and are still having, on the latter. ${ }^{90}$ It must also not be forgotten that the interconnectedness can also be seen the other way around: changes in the marine environment, such as acidification of the oceans or rise in ocean temperature, can have and are already having an impact on international fisheries. ${ }^{91}$ Environmental conferences ${ }^{92}$ show that States have agreed to align the exploitation of living resources, including fisheries, with core environmental principles; in practice, however, the focus remains on fisheries as an economic activity, with their impact on associated species and on the wider marine environment still remaining a secondary preoccupation. ${ }^{93}$ This is due, among other things, to international environmental law being embedded in neoliberalism, where the environment is seen as a source of resources for exploitation and less as an entity to be protected. ${ }^{94}$ Yet, as Wakefield observes, the "failure to integrate environmental and fisheries policy [... prevents the] regeneration and sustainability of both fish stocks and wider ecosystems" ${ }^{95}$

Second, this study considers that international fisheries are one of the activities that particularly give rise to the intertwinement of disciplines, where decision-making

89 Louis Kotzé, "A Juridical-Conceptual Perspective on Environmental Governance" in Tuomas Kuokkanen et al (eds), International Environmental Law-Making and Diplomacy. Insights and Overview (Abingdon, Oxon: Routledge, 2016) 48-67 at 58-59.

90 Robin Churchill, "Fisheries and their impact on the marine environment: UNCLOS and beyond" in Marta Chantal Ribeiro (ed), 30 Years After the Signature of the United Nations Convention on the Law of the Sea: The Protection of the Environment and the Future of the Law of the Sea. Proceedings of the International Conference (Coimbra: Coimbra Editora, 2014) 23-52 at 23-27; Gjerde, "Enhancing integrated management", supra note 84 at 441; Maribus, "The Future of Fish - The Fisheries of the Future" (2013) World Ocean Review at 12-13.

91 See, e.g., Kieran Kelleher, "Ocean acidification impacts on fisheries and aquaculture" in Nathalie Hilm et al (eds), Bridging the Gap Between Ocean Acidification Impacts and Economic Valuation: Regional Impacts of Ocean Acidification on Fisheries and Aquaculture (Gland, Switzerland: IUCN, 2015).

92 Rio Conference, supra note 22; World Summit on Sustainable Development (Johannesburg, South Africa, 26 August - 4 September 2002); United Nations Conference on Sustainable Development (Rio de Janeiro, Brazil, 20-22 June 2012) [Rio+20 Conference].

93 Kristina Gjerde et al, "Ocean in Peril: Reforming the Management of Global Ocean Living Resources in Areas Beyond National Jurisdiction” (2013) 74:2 Marine Pollution Bulletin 540-551 at 545-546. See also, generally, Churchill, supra note 90.

94 See, e.g., Helene Mayrand, "Déconstruire et repenser les fondements du droit international de l'environnement" (2018) Hors-série Revue québécoise de droit international 35-59. See also the principles put forward by the Green Legal Theory, e.g. Michael M'Gonigle \& Paula Ramsay “Greening Environmental Law: From Sectoral Reform to Systemic Re-Formation” (2004) 17 Journal of Environmental Law and Policy 333-356; Michael M'Gonigle \& Louise Takeda, "The Liberal Limits of Environmental Law: A Green Legal Critique” (2013) 30:3 Pace Environmental Law Review 1005-1115.

95 Jill Wakefield, "The Ecosystem Approach and the Common Fisheries Policy" in David Langlet \& Rosemary Rayfuse (eds) The Ecosystem Approach in Ocean Planning and Governance (Leiden: Brill Nijhoff, 2019) 288-316 at 293, referred to by the editors of the book in the concluding chapter, see David Langlet \& Rosemary Rayfuse, "Challenges in Implementing the Ecosystem Approach: Lessons Learned" $445-461$ at 453 . 
in terms of management is dependent upon considerations from other disciplines. Scientific engagement is necessary to increase knowledge of the oceans and of the consequences of exploiting the oceans, so as to better address coordination of actions later on.$^{96}$ In the legal sphere, the current framework, developed to provide stability, certainty and predictability, now faces the challenge of being applied to a reality it is not yet ready to tackle. ${ }^{97}$ The law can benefit from interactions with other disciplines, as each actor and each discipline advances its own arguments, for its own interests, and it is this dynamism between arguments and interests that "allows for meaning to adapt and adjust to different societal needs".98

Finally, interconnectedness exists between different regimes that include measures and instruments impacting international fisheries and the marine environment. International fisheries are obviously addressed in the law of the sea and environmental law, ${ }^{99}$ but relevant provisions and concepts for their conservation and exploitation can also be found in, e.g., trade $\operatorname{law}^{100}$ or the specific regime for climate change law. ${ }^{101} \mathrm{~A}$ similar reasoning applies to organizations and bodies directly covering fisheries or indirectly impacting them. Some have primarily a fisheries management mandate, such as RFMOs, while others, such as RSPs, have conservation as their primary objective. In $\mathrm{ABNJ}$ most particularly, the mandate of relevant organizations must be seen as interrelated, since none of them has a comprehensive cross-sectoral mandate. ${ }^{102}$ This also triggers the importance of an intersectoral approach, where all relevant sectors (potentially) interacting with

96 See, e.g., IASS, IDDRI \& TMG, "Marine Regions Forum 2019: Achieving a healthy ocean - regional ocean governance beyond 2020. Conference Report" (2019), online: <http://publications.iass-potsdam. de/pubman/item/escidoc:5041891:8/component/escidoc:5054888/5041891.pdf>.

97 Davor Vidas \& Peter Johan Schei, “The World Ocean in Globalisation: Challenges and Responses for the Anthropocene Epoch" in Peter Johan Schei \& Davor Vidas (eds), The World Ocean in Globalisation. Climate Change, Sustainable Fisheries, Biodiversity, Shipping, Regional Issues (Leiden: Brill, 2011) 3-15 at 3.

98 Richard Barnes, "The Continuing Vitality of UNCLOS" in Jill Barrett \& Richard Barnes (eds), Law of the Sea: UNCLOS as a Living Treaty (British Institute of International and Comparative Law, 2016) 459-489 at 470 .

99 For example, fisheries on the high seas are addressed under arts. 117-119 UNCLOS (and complemented by the UNFSA), and the protection of the marine environment is the subject of Part XII of UNCLOS. Similarly, the CBD covers all marine biodiversity, including marine biodiversity. This is elaborated further in chapter 2 sections 3.1 and 3.2.

100 For example, the General Agreement on Tariffs and Trade (30 October 1947, entered into force 1 January 1948) 55 UNTS 187 at art. XX(b) provides exceptions for measures which are necessary to protect animal and plant life.

101 For an overview of the state of affairs concerning the relationship between UNCLOS and the United Nations Framework Convention on Climate Change (9 May 1992, entered into force 21 March 1994) 1771 UNTS 107 [UNFCCC], as well as how to address climate change within the framework of oceans, see, e.g., Alan Boyle, "Climate change and oceans governance" in Marta Chantal Ribeiro (ed), 30 Years After the Signature of the United Nations Convention on the Law of the Sea: The Protection of the Environment and the Future of the Law of the Sea. Proceedings of the International Conference (Coimbra: Coimbra Editora, 2014) 357-382; Alan Boyle, "Climate change, Ocean governance and UNCLOS" in Jill Barrett \& Richard Barnes (eds), Law of the Sea UNCLOS as a Living Treaty (British Institute of International and Comparative Law, 2016) 211-230. The diversity of regimes also illustrates the issue of fragmentation through the proliferation of specialized regimes. The question of fragmentation is discussed in further detail in chapter 5 section 3.1 below.

102 PEW Charitable Trusts, "Mapping governance gaps on the high seas" (2017), online: <https://www. pewtrusts.org/-/media/assets/2017/04/highseas_mapping_governance_gaps_on_the_high_seas.pdf $>$. 
fisheries on the high seas (environmental protection as already mentioned, but also shipping and deep seabed exploitation, to name only a few) must also be taken into consideration.

Interconnectedness therefore acts as an overarching concept, shaping this study's objectives. It is sought in the object of regulation (i.e. what is being regulated), and also in the methods of regulation (i.e. the different tools used to regulate). By understanding how interconnectedness manifests itself and, consequently, how it can be addressed (i.e. how solutions can be found in accordance with interconnectedness), we seek to modify our perspective towards what needs to be achieved.

\subsection{A different characterization: high seas fisheries as a complex socio-ecological system}

In order for high seas fisheries law to reflect interconnectedness that could in turn contribute to intrinsically reconcile fisheries management and environmental protection, it is not sufficient to approach fisheries as a traditional, linear interest, merely concerned with full access to and utilization of living resources. Not only must they be seen as one component of an ever-growing web of activities and interests on the high seas, but they must also be seen as interacting with and impacting on these other activities and interests. The sustainable management of high seas fisheries also includes concerns of biodiversity conservation, concerns characterized as common to humankind, ${ }^{103}$ which supports the inherent interconnectedness of the subject matter. This is why contemplating the regulation of an intrinsically interconnected reality from the point of view of a legal regime that was conceived around a sectoral and inter-State balance of interests does not lead to a good regulatory fit. As Kim and Bosselmann observe, "any control system needs to be as advanced as the system being controlled" ${ }^{104}$ which does not seem to be the case at the moment.

This study therefore suggests starting from the premise that, to reconcile fisheries management with biodiversity and environmental considerations, high seas fisheries must be characterized and considered as a complex socio-ecological system. By approaching high seas fisheries as a system, one focuses on the interactions and interconnectedness between its different components. While ecological systems (ecosystems) focus on the interaction between organisms, and between organisms and their environment, social-economic systems represent the network of relationships between individuals, groups and institutions. ${ }^{105}$ A socio-

103 CBD at preamble.

104 Rakhyun E. Kim \& Klaus Bosselman, "International Environmental Law in the Anthropocene: Towards a Purposive System of Multilateral Environmental Agreements" (2013) 2:2 Transnational Environmental Law 285-309 at 288 .

105 Stockholm Resilience Center, "Resilience dictionary", online: <https://www.stockholmresilience.org/ research/resilience-dictionary.html>. See also Carl Folke, "Resilience: the emergence of a perspective for social-ecological systems analyses" (2006) 16 Global Environmental Change 253-267 at 255. 
ecological system thus exists when both systems influence one another. ${ }^{106}$ High seas fisheries are formed by socio-ecological components since they raise issues of food security, biodiversity conservation, labour conditions, economic activity, means of subsistence, and even cultural value, components that do interact. Systems also develop their own behaviours, i.e. different from the behaviours of their different components. For example, high seas fisheries are formed by social, economic and environmental components, as well as political ones. How the system evolves therefore depends on all components, and it would probably evolve differently if one or more of these components were absent. ${ }^{107}$

High seas fisheries are also complex because they are non-linear, multiscalar (i.e. involving local, regional and global actors) and uncertain (e.g. from data gaps, from impacts of environmental changes). ${ }^{108}$ Approaching high seas fisheries as a complex system therefore offers an alternative focus that takes into consideration their non-linear and uncertain nature, and that emphasizes interconnectedness. ${ }^{109}$ Consequently, the need for cooperation and coordination in their management, triggered by the remoteness of high seas fisheries and the fragmentation characterizing their legal and institutional framework, should be more adequately addressed.

\subsection{A different lens of analysis: a dialogue between (oceans) governance and adaptive strategies}

From a new starting point, which suggests a different characterization of the subject matter as a complex socio-ecological system, the question that ensues is how to approach this complexity. This study submits that "[o] ur conventional legal picture of the patterns of power is no longer adequate", ${ }^{110}$ and that the law is only one of the necessary components to address complexity.

In fact, the study questions whether UNCLOS and the current law of the sea in general have the capacity to accommodate the necessity for a different focus in a traditional use of the ocean, i.e. fisheries, a use strongly embedded in the "conventional legal

106 On the intertwinement of components in the Earth system, see Louis Kotzé \& Rakhuyn Kim, "Earth system law: The juridical dimensions of earth system governance" (2019) 1 Earth System Governance article 100003 at 5: "the Earth system does not only include 'natural' or ecological aspects such as climatic, oceanic and biodiversity systems. The Earth's is an adaptive and multifaceted system comprising human- social and ecological elements [...]. These elements are deeply intertwined. The stability of the ecological element is required for the human-social element to flourish, while the human-social element is determinative of the overall stability and integrity of the Earth system, including its ecological element".

107 See Kim \& Mackay, supra note 66 at 7.

108 Ibid in general but in particular at 6.

109 Haward in fact mentions that using the perspective of complexity "provides a wider and more nuances lens", see Haward, supra note 65 at 5, see also 142.

110 David Kennedy, “The Mystery of Global Governance" (2008) 34 Ohio Northern University Law Review $827-860$ at 835 . 
patterns of power". ${ }^{111}$ As the adage says, "old habits die hard", and quitting a habit is infinitely more difficult than creating a new one. Therefore, the capacity of the law of the sea to adapt to the necessary re-design of already existing interests faces different challenges from the tracing of a path for the inclusion of new interests. And the continuing development of new legal instruments for sustainable fisheries management without significant improvement supports the need to revisit the approach to high seas fisheries regulation and management.

This is why the particular alternative considered in this study is rooted in oceans governance. The concept is commonly defined as "those formal and informal rules, arrangements, institutions and concepts which structure the ways in which sea space is used, how ocean problems are monitored and assessed, what activities are permitted or prohibited, and how sanctions and other responses are applied", ${ }^{112}$ showing that law is only one of many components of governance. Because of its overarching lens of analysis, this approach "encourages us to find imperfect answers to big questions about changing conditions for ordered rule rather than perfect answers to small questions about the precise impact of different policies, services and regulations", 113 an interesting focus to adopt when looking at the high seas fisheries regime from a structural perspective.

The understanding of governance in the context of this study differs from what is normally referred to as governance in policy and legal literature. Governance prima facie refers to the way activities are conducted, to governance structures such as institutions and their performance, in the sense of good versus bad governance. The study looks into these various elements, but focuses on a broader understanding of the concept, one that uses governance as an approach in itself. It is employed as a toolbox which suggests alternative ways to develop management and policy, regulation, and compliance. ${ }^{114}$ It is suggested that this toolbox builds on the usual set of formal rules and institutions, but also goes beyond it, by providing a wider variety of actors, fora and concepts to rely upon. This, in turn, provides more flexibility to the regime, therefore leading to a stronger capacity to adapt.

Relying on the perspective offered by governance thus understood broadens the path for the law to be more flexible and adaptive. Adaptability finds its roots in resilience research, which first appeared in the field of ecology in the 1960s and, following the growing understanding of the intertwinement between social, economic and ecological systems, permeated social sciences. ${ }^{115}$ Originally understood as "the persistence of relationships within a system and [...] a measure of the ability of

111 Ibid.

112 Rothwell \& Stephens, supra note 12 at 507.

113 Christopher Ansell \& Jacob Torfing, "Introduction: Theories of Governance" in Christopher Ansell \& Jacob Torfing (eds), Handbook on Theories of Governance (Cheltenham: Edward Elgar, 2016) 1-17 at 13.

114 Blaise Kuemlangan, "FAO and SDG 14" (Presentation delivered at the BBNJ PrepCom 4 side event "Monitor and Review SDG 14 by DOALOS”, UN Headquarters, New York, 10 July 2017).

115 Folke, supra note 105 at 255. 
these systems to absorb changes [...] and still persist","116 resilience also includes the "capacity [of a system] for renewal, re-organization and development". ${ }^{117}$ Adaptability therefore amounts to a sine qua non condition to ensure that a socioecological system, as well as the legal framework that regulates it, is resilient.

As the legal dimension of resilience research is emerging, ${ }^{118}$ the dialogue between governance and adaptability comes as a useful perspective to grasp the role that the law can play to contribute to a system's resilience and capacity for renewal. In short, governance can help the law be more adaptive, while a legal system that is more adaptive will ensure that the legal commitments are translated into actions that will effectively influence oceans management. Consequently, this study intends to explore how an oceans governance approach could make us address the behavioural challenges and the fragmentation affecting international fisheries differently, by approaching the high seas fisheries regime not as a static set of rules but as an adaptive process, that would render it more flexible and resilient to ongoing changes and challenges, and above all to sustainability.

Undoubtedly, the definitions of oceans governance and adaptability, ${ }^{119}$ upon which this study is based, represent the most complete achievement of the concepts. The present study relies on the assumption that the full application of the concepts in high seas fisheries has not yet been reached, but would be the way to go to ensure the flexibility and adaptability needed for the regime of high seas fisheries to face the challenges linked to biodiversity conservation. The analysis of the governance approach and its applicability to high seas fisheries law therefore indirectly includes an assessment on how to come as close as possible to the model definition of oceans governance in practice.

\section{RESEARCH QUESTIONS AND RELEVANCE OF THE STUDY}

Considering the conceptual framework discussed in the previous section, the central and overarching research question of this study is:

How can governance reshape and complement high seas fisheries law in order to reach a more sustainable management of the oceans and its living resources on the high seas?

116 Crawford Stanley Holling, "Resilience and stability of ecological systems" (1973) 4 Annual Review of Ecological Systems 1-23 at 17.

117 Folke, supra note 105 at 256 and 259.

118 See, e.g., Jonas Ebbesson \& Ellen Hey, “Introduction: Where in law is social-ecological resilience?” (2013) 18:3 Ecology and Society article 25.

119 These definitions are further developed in chapter 6 . 
In testing high seas fisheries law against governance mechanisms for reaching better sustainability performance in the management of fisheries, the study further looks into the following sub-questions:

- How is the current legal framework designed to address the interconnectedness between fisheries management and environmental and biodiversity protection on the high seas?

- What role do principles governing the high seas play in systematizing the interconnectedness between fisheries management and environmental and biodiversity protection on the high seas, in general within the legal framework, and more specifically in relation to fisheries management tools?

- What role do the current negotiations on the conservation and sustainable use of marine biodiversity beyond national jurisdiction (BBNJ process) play in fostering this interconnectedness?

- What are the challenges currently impacting the need for cooperation, coordination and coherence in the legal and regulatory regime for the management of fisheries on the high seas?

- What is (oceans) governance and what is its added value for improving the law's adaptability in facing uncertainty and complexity?

- How could an approach rooted in the dialogue between (oceans) governance and adaptability impact the behavioural and fragmentation challenges characterizing the regime for high seas fisheries?

These questions are embedded in broader discussions on the purpose and added value of (oceans) governance for the adaptability of the law. This is what makes this study "not yet another book about high seas fisheries management". In fact, the present study participates in building the body of knowledge which posits the necessity of looking into alternatives for the implementation of high seas fisheries law and its intertwinement with biodiversity protection in ABNJ. ${ }^{120}$

120 See, e.g., Markos Karavias, “Mixing Regional Fisheries Management and Private Certification” in Judith van Erp et al (eds), Smart Mixes for Transboundary Environmental Harm (Cambridge: Cambridge University Press, 2019) 126-145 at 127; Elisa Techera \& Natalie Klein, International Law of Sharks. Obstacles, Options and Opportunities (Leiden: Brill Nijhoff, 2017) at 87 and 238; Richard Barnes \& Carmino Massarella, "High Seas Fisheries" in Elisa Morgera \& Kati Kulovesi (eds), Research Handbook on International Law and Natural Resources (Cheltenham: Edward Elgar, 2016) 369-389 at 388; FAO Report 2020, supra note 6 at vi. 
While high seas fisheries regulation and management have been analysed from the angle of specific species, ${ }^{121}$ regions, ${ }^{122}$ or challenges, ${ }^{123}$ the present study tackles the issue from a structural perspective. It invites the reader "to step back from the detail and to examine the underlying structures, the basic pillars on which environmental law, regulation and governance are built, and to show how those pillars are often connected in such a way that the whole is far more than the sum of the parts". ${ }^{124}$ Further, such structural perspective allows "international fisheries law [to be strengthen] through its interconnections with alternative domains of international law", which "has generally been little explored". ${ }^{125}$

In brief, this study aims to apply new knowledge stemming from governance (i.e. new to the legal field) to an existing reality. ${ }^{126}$ There already exists a great body of literature on fisheries, and the literature, both legal and non-legal, on governance is expanding. Yet, the link between both topics is underexplored. This research therefore contributes to the discussion that looks at the topic of fisheries through the lens of governance.

\section{RESEARCH DESIGN}

In order to address these questions, the present study is designed around different elements that shape its contours and content. First, the study is conducted on the basis of the research methods employed (4.1), as well as the multidisciplinary aspects it encompasses (4.2). Finally, as fisheries operations can comprise a large number of activities, located in several geographical areas, the focus of the present study is clarified through a brief description of its scope (4.3).

121 See, e.g. Yoshinobu Takei, Filling Regulatory Gaps in High Seas Fisheries: Discrete High Seas Fish Stocks, Deep-Sea Fisheries, and Vulnerable Marine Ecosystems (Leiden: Martinus Nijhoff, 2013).

122 See, e.g., Gerard van Bohemen, "High Seas Fisheries Management: reflections on Experience with Regional Fisheries management Organisations in the South Pacific" in Peter Johan Schei \& Davor Vidas (eds), The World Ocean in Globalisation: Climate Change, Sustainable Fisheries, Biodiversity, Shipping, Regional Issues (Leiden: Brill, 2011) 233-245; Olav Schram Stokke (ed), Governing High Seas Fisheries. The Interplay of Global and Regional Regimes (Oxford: Oxford University Press, 2001); Erik Molenaar, "International Regulation of Central Arctic Ocean Fisheries" in Myron Nordquist, John Norton Moore \& Ronan Long (eds), Challenges of the Changing Arctic. Continental Shelf, Navigation, and Fisheries (Leiden, Boston: Brill Nijhoff, 2016) 429-463; Rosemary Rayfuse, "The Role of Law in the Regulation of Fishing Activities in the Central Arctic Ocean" (2019) 110 Marine Policy article 103562.

123 See, e.g., Rayfuse, Non-flag State enforcement, supra note 2; Haward, supra note 65.

124 Neil Gunningham, "Environment Law, Regulation and Governance: Shifting Architectures" (2009) 21:2 Journal of Environmental Law 179-212 at 180.

125 Erik Molenaar \& Richard Caddell, "Options and Pathways to Strengthen International Fisheries Law in an Era of Changing Oceans" in Richard Caddell \& Erik Molenaar (eds) Strengthening International Fisheries Law in an Era of Changing Oceans (Oxford: Hart, 2019) 423-429 at 425.

126 Sanne Taekema \& Bart van Klink, "On the Border. Limits and Possibilities of Interdisciplinary Research" in Sanne Taekema \& Bart van Klink (eds), Law and Method, Interdisciplinary Research into Law (Tübingen, Germany: Mohr Siebeck, 2010) 7-32 at 29, a contrario. 


\subsection{Methodology}

To understand the role of the law as a control system "to achieve and maintain ecological sustainability", ${ }^{127}$ the study performs both a descriptive and a normative function. As law is a hermeneutical discipline, the present study is primarily rooted in the interpretation and understanding of the substantial and conceptual components of relevant rules and principles that characterize the legal regime for high seas fisheries. It first maps out and assesses the way rules and principles are currently organized, implemented and complied with. ${ }^{128}$ It then studies how these rules and principles interrelate between themselves, and also with other branches of the law of the sea, environmental law and, more generally, of international law. ${ }^{129}$ The study further looks into the reasons underlying the adoption of a specific rule or principle, ${ }^{130}$ which sometimes reveals that these reasons are no longer in line with current realities; ${ }^{131}$ consequently, the rules and principles - or the way they are applied - are rendered ill-equipped to address present-day challenges. Then, drawing on ideas from governance, international relations and policy literature, the study makes normative claims on the way a new perspective on how to evaluate, use and apply the present regime could be more effective in the face of complexity. ${ }^{132}$ The study also gives insights on both the desirability and, to some extent, the feasibility of such alternatives. ${ }^{133}$

The present study therefore aims at conducting the descriptive and normative analyses consecutively, ${ }^{134}$ by starting to explain the current state of affairs of the regime (i.e. how things are), and then assessing possible solutions to fight its weaknesses (i.e. how things should be). By conducting both a factual and an evaluative assessment of the high seas fisheries regime, this study also adheres to a more flexible approach to the fact-value separation, suggesting that these assessments are mixed as the knowledge of facts and the knowledge of values influence one another. The present author also argues that not only do these two types of knowledge influence each other, but they complement each other. Facts are not necessarily sufficient to fully explain a phenomenon, as underlying values might also come into play. ${ }^{135}$ This is relevant for the present study on fisheries. For example, inefficiency in the system does not necessarily come only from gaps in the legal framework (i.e. the rules themselves),

127 Kim \& Bosselman, supra note 104 at 287-288.

128 See chapters 2,3 and 5 .

129 See chapters 2,3 and 4 .

130 See chapters 2,3 and 4 .

131 See chapter 5 .

132 See chapters 6 and 7.

133 See chapter 7.

134 Taekema \& van Klink, supra note 126 at 18, where it is specified that "it is possible and legitimate to study law from both perspectives, but not at the same time".

$135 \mathrm{Ibid}$ at 17-19. They use the following example at 18: "it does not necessarily follow from the fact that a certain legal procedure is not efficient that the procedure has to be changed; there can be other reasons to keep it as it is, reasons of fairness for example". 
but may also come from a lack of implementation or a lack of cooperation and coordination, triggered by certain political motivations - or a lack thereof.

To carry out such analysis, the research generally follows a qualitative legal methodology. The research first analyses the relevant primary legal sources, i.e. provisions of existing global and regional instruments (legally and non-legally binding), within both the law of the sea and international environmental law, and secondary sources, i.e. existing legal literature in these fields. Regional initiatives (such as practical measures adopted by RFMOs) and existing projects are also considered. ${ }^{136}$ The study of governance, its meaning, scope and components, is mostly done through the analysis of the existing literature in the field, combined with the analysis of policy studies and reports conducted by scholars, research institutions and non-governmental organizations.

\subsection{Legal research within a multidisciplinary framework}

Looking into alternatives rooted in governance implies that the study is multidisciplinary in nature. Indeed, governance studies stem from political and social sciences, and it is here being transposed to international legal studies. However, the use of the non-legal concept - governance - does not lead to fully interdisciplinary research, where international law and governance would be combined. Governance is used in an auxiliary manner; as the aim of this study is to find solutions that cannot be found with legal methods only, governance fulfils this "need for input from another discipline". ${ }^{137}$ Governance is also used heuristically, as it provides "a source of argument or inspiration" for the legal research. ${ }^{138}$ Based on these heuristic and auxiliary approaches, one can conclude that governance is used here as a "device for generating new insights from which the target domain - the legal science - may profit". ${ }^{139}$ And, as discussed above, considering the fact that the current legal framework and its implementation do not prevent overexploitation and the negative impact of fisheries on the marine environment, such new input stemming from governance is necessary to explore solutions that could bring us closer to sustainability. ${ }^{140}$

Conducting multidisciplinary research however triggers theoretical and practical issues. The main issue rests in the fact that concepts used by one discipline might mean something completely different in another discipline, or might not even exist in that second discipline. One must therefore be careful in importing concepts from other disciplines. ${ }^{141}$ This is why the present study approaches concepts

136 See, e.g., Sargasso Sea Commission, online: <http://www.sargassoseacommission.org>.

137 Taekema \& van Klink, supra note 126 at 11.

$138 \mathrm{Ibid}$ at 10-11. For all types of multi- and interdisciplinary research, see ibid at 10-13.

$139 \mathrm{Ibid}$ at 29.

$140 \mathrm{Ibid}$ at 26.

141 Ibid at 19-20. 
from a nominalist point of view, i.e. as "mere constructions, [as] conventional and convenient ways of expression" and not as connected to particular objects or ideas. ${ }^{142}$ This allows for more flexibility in using terms and concepts from one discipline in another. Yet, many terms and concepts used in this study stem from different disciplines and may have different meanings depending on the context in which they are being used. To avoid confusion for the readers, who might come from different fields of research and practice, the most frequently recurring terms used in this study are briefly described in the Glossary found in an Annex at the end of this study. Where relevant, the Glossary also makes a reference to the chapter of the study where a particular term or concept is further analysed.

\subsection{Scope of the study}

It is important to state the scope of the analysis conducted in this chapter. Fisheries on the high seas amount to approximately $15 \%$ of marine fishing activities, representing a large-scale activity that is growing because of the continuing development of increasingly accurate, detailed and precise technology. Yet, information related to fishing activities within national jurisdiction (e.g. data, instruments, actors) is sometimes cited in this study in order to provide examples or points of comparison, but it is not systematically analysed. These references to examples from within national jurisdiction are, once again, justified by interconnectedness: everything in the oceans is connected, and information on certain aspects of the oceans is important for the understanding of other areas and of the oceans as a whole. As observed by Étienne, "[w]hat happens in the high seas will affect the [EEZs] and coastal regions that are in proximity. If the high seas ecosystems are in danger $[\ldots]$ this can result in a lack of resources for neighboring countries. So understanding and managing the high seas becomes crucial for the food security and stability of $[\ldots]$ countries". ${ }^{143}$ The opposite also applies: the impacts of activities conducted within national jurisdiction are also felt in $\mathrm{ABNJ}$.

Furthermore, although this study is conducted within the realm of international law and its findings are justified "according to the standards accepted in the science of law", ${ }^{144}$ it is exploratory in nature. This is why it deviates from a positivist, blackletter law and structured analytical approach, and it also dares to wander on the border where law meets policy. The analysis of governance is primarily conducted at the conceptual level, and the discussions on possible complementary developments and/or reinterpretations based on governance are still at a preliminary stage. Consequently, the reader must keep in mind that an approach rooted in governance remains, for now, somewhat speculative, and that the results of using such an approach have yet to come to fruition. Additionally, as the issues at the core of this

143 Interview of Janique Étienne in IUCN, “Beyond the Last Frontier” (2018), online: <https://www.youtube. com/watch?v=F7x6pDVWSEg $>$.

144 Taekema \& van Klink, supra note 126 at 25. 
study are entrenched in complex socio-ecological systems, uncertainty as to their development and evolution is unavoidable. ${ }^{145}$ Therefore, this study does not aim to solve the problem, but aims to highlight patterns, to raise questions and to suggest possible alternatives for the discussion process to remain dynamic. ${ }^{146}$ This is why the research does not pretend to be exhaustive or definitive; it wishes to make a useful contribution to the growing body of knowledge on oceans governance.

As the state of international fisheries, as well as the regime for their regulation and management are in a constant state of flux, keeping up with all recent development constitutes a continuous task. This is why, for the purpose of this study, developments have been taken into consideration until early August 2020; it is hoped that developments taking place after that date will form the basis for further work on the sustainability of high seas fisheries and on the interconnectedness between traditional and alternative mechanisms for their regulation and management.

\section{STRUCTURE OF THE STUDY}

In order to answer the research question, the study is divided into six substantive chapters, which can be categorized in two overarching research themes. The first four chapters form an analysis of how things currently stand, and ask whether the current framework is sufficiently stable and/or effective to achieve more sustainability in the interconnected world of high seas fisheries. Taking a descriptive, and to some extent evaluative, approach, the study assesses the current legal framework for the regulation and management fisheries on the high seas, as well as the principles governing the oceans. Attention is also dedicated to the BBNJ process, as an important current development in the law of the sea and biodiversity law. This first part of the study ends with an overview of the challenges currently affecting the effectiveness of the legal regime for high seas fisheries in achieving sustainable management. Through its last two substantive chapters, the study delves into a normative analysis of how things could be, by exploring potential alternative and complementary avenues towards sustainability and a more flexible approach to fisheries management in $\mathrm{ABNJ}$. This is done first by looking at the concept of governance and how this broader approach can help to develop a theoretical framework for understanding the adaptive capacity of the law. The study ends with an operationalization of this adaptability through alternative mechanisms, with the aim of finding complementary ways for the regime to improve its role for the sustainable management of fisheries on the high seas.

More specifically, each chapter attempts at answering one of the research subquestions listed above. The chapters can be summarized as follows: 
Chapter 2, "International Fisheries and the Law: The Current State of Affairs"

How is the current legal framework designed to address the interconnectedness between fisheries management and environmental and biodiversity protection on the high seas?

This chapter portrays the "state of affairs" concerning the functioning of the regime for international and high seas fisheries. This requires looking first at current environmental, social and economic challenges affecting high seas fisheries themselves. It then illustrates the complexity of the legal framework by looking into the way the interconnectedness between high seas fisheries and environmental protection is found under numerous global and regional, legally and non-legally binding instruments. It finally looks at the way in which different actors operationalize these instruments to implement and enforce the various relevant obligations.

Chapter 3, "Principles Governing the Oceans: Unifying Elements in the Face of Complexity"

What role do principles governing the high seas play in systematizing the interconnectedness between fisheries management and environmental and biodiversity protection on the high seas, in general within the legal framework, and more specifically in relation to fisheries management tools?

This chapter identifies the principles currently applicable to the oceans, as common elements within the complexity characterizing the legal framework for high seas fisheries. A particular focus is dedicated to those principles operationalized through fisheries management and conservation objectives, as well as through area-based tools and assessment tools in high seas fisheries.

\section{Chapter 4, "Biodiversity Beyond National Jurisdiction: A Catalyst for Interconnectedness?"}

What role does the BBNJ process play in fostering the interconnectedness between fisheries management and environmental and biodiversity protection on the high seas? This chapter embarks on a discussion on the recent developments targeting ABNJ: the $\mathrm{BBNJ}$ process. It first draws a portrait of the evolution of the current negotiations and the main issues raised therein. As it remains uncertain to what extent the scope of application of the instrument will encompass fisheries, the chapter looks into certain issues discussed within the BBNJ process that could still impact the regime for high seas fisheries. It also underlines the importance of the interrelatedness of activities and concerns in ABNJ. 
Chapter 5, “The Challenges to Reach Sustainability: Combining Values, Regulation and Behaviour”

What are the challenges currently impacting the need for cooperation, coordination and coherence in the legal and regulatory regime for the management of fisheries on the high seas?

This chapter identifies a number of challenges currently impacting the ability of the regime to effectively address sustainability concerns in the management of high seas fisheries. It looks into challenges in reaching shared understandings of the goals to be achieved, in translating these understandings into legal commitments, and in actors' compliance with the commitments undertaken. The chapter also dedicate some attention to the overarching challenge of fragmentation and how it affects cooperation and coordination initiatives.

Chapter 6, "The Interaction Between Law and Governance: An Avenue for Understanding the Adaptive Capacity of the Law"

What is (oceans) governance and what is its added value for improving the law's adaptability facing uncertainty and complexity?

This chapter delves into an exploration of the concept of governance and its applicability to the oceans. A closer look at the broader theoretical approach that the concept offers allows us to grasp better the relationship that exists between law and governance, the former being one of many components of the latter. By letting the law be permeated by other components of governance, this chapter looks into analytical frameworks for assessing the adaptability of the regime, suggesting that adaptive strategies and flexibility are necessary in the face of complexity. The purpose of this analysis is therefore to better understand the governance-adaptability dialogue in which the suggested alternatives are subsequently rooted.

Chapter 7, "Operationalizing the Governance-Adaptability Dialogue for High Seas Fisheries Law: Towards a Systematic Reliance upon Cooperation and Coordination"

How could an approach rooted in the dialogue between (oceans) governance and adaptability impact the behavioural and fragmentation challenges characterizing the regime for high seas fisheries?

The last substantive chapter tests the theoretical frameworks on adaptability by assessing adaptive elements within the current regulatory and management framework for high seas fisheries, as well as the adaptive potential of the upcoming BBNJ legally binding Agreement. The core of the chapter then embarks on the analysis of two mechanisms rooted in adaptability components, namely smart mixes and interplay management. These mechanisms could catalyse cooperation and coordination within the legal framework for high seas fisheries and, consequently, 
trigger improved sustainable performance in the complex management of high seas fisheries.

The study concludes with reflections on the two research themes. On one hand, the interconnectedness between fisheries management and environmental and biodiversity protection is assessed within the current regime for high seas fisheries regulation and management. The assessment further highlights some shortcomings in reaching the objectives which this regime is set to safeguard. It shows that "the way the world is governed is striking for its blind spots and biases. The pieces don't fit together or add up. But it remains worth understanding why not and how they could have seemed so coherent for so long" ${ }^{147}$ Only then can an assessment be made as to what alternatives are needed for the different components of the regime (e.g., instruments, institutions, actors) to interact more efficiently with one another, and for the behaviour of the various stakeholders (State and non-State) to be effectively aligned with contributing to an improved sustainable management of high seas stocks.

The second theme addresses the necessity to find alternatives that shed light on the linkages between social, political, economic and ecological processes that form the system of high seas fisheries. Bridging all knowledge, all interests, represents a clear and relevant challenge, and this is why there is a need for the development of complementary insights and conceptualizations for regulating and managing complex social-ecological systems through the lens of adaptability.

147 Kennedy, supra note 110 at 836. 


\title{
HIGH SEAS FISHERIES AND THE LAW
}

\author{
The Current State of Affairs
}

\section{INTRODUCTION}

The problems affecting the sustainability of fish stocks on the high seas, and the instruments already available to address these issues, are not only numerous, but also varied in terms of what sector or areas they target, what sort of obligations they create, and who is mandated to perform such obligations. These instruments and the different objectives found therein mirror the scientific knowledge, and the political and economic situations of the time during which they were developed. ${ }^{1}$ To get a better grasp of the problems we are facing and the tool box that is currently available, it is therefore necessary to conduct "a clear analysis of the legislative landscape in order to [later on] fully understand the impacts of [alternative] legislation and policies on the viability of measures intended to implement" ${ }^{2}$ sustainability oriented approaches.

Through the lens of interconnectedness, this chapter presents the international legal framework applicable to fisheries. It aims at looking at the way legal instruments and structures have been used to address the regulation of high seas fisheries and the marine environment, as well as the connections between them. It intends to depict fisheries not only as an activity for the exploitation of resources that needs to be regulated, but also as a component of the oceans' use that characterizes and impacts their current state. This is why fisheries are addressed through the perspective of management, but can further be seen from the perspective of wider marine environmental protection and species conservation. Although it has been said that fisheries and marine environmental protection/biodiversity law have "coevolved in the right direction within a common legal framework", their "parallel implementation frameworks and processes [are] not sufficiently conducive to the

1 Francisco Orrego Vicuña, “The International Law of High Seas Fisheries: From Freedom of Fishing to Sustainable Use" in Olav Schram Stokke (ed), Governing High Seas Fisheries. The Interplay of Global and Regional Regimes (Oxford: Oxford University Press, 2001) 23-52 at 23.

2 David Langlet \& Rosemary Rayfuse, "Challenges in Implementing the Ecosystem Approach: Lessons Learned” in David Langlet \& Rosemary Rayfuse (eds), The Ecosystem Approach in Ocean Planning and Governance (Leiden: Brill Nijhoff, 2019) 445-461 at 449. In the chapter, Langlet \& Rayfuse refer to the specific implementation of the ecosystem-based approach, but it is believed that the reasoning can extend to other sustainability-oriented approaches of a more overarching nature. 
level of coherence needed". ${ }^{3}$ The present chapter highlights aspects where this coevolution is marked, and also where there could be improvements. ${ }^{4}$

This chapter starts with a brief overview of the state of international fisheries, by presenting the state of fish stocks, the threats to these stocks occurring naturally or those created by the activities undertaken to pursue their exploitation, and finally explores the concepts of common goods and the tragedy of the commons that characterize fisheries in $\mathrm{ABNJ}$ (section 2). This is done in order to understand better the different components of the complex socio-ecological system that is high seas fisheries, and to be aware of the economic, social and political realities that can impact on the development and implementation of legal obligations.

The heart of this chapter then resides in the presentation of the legal framework covering international and high seas fisheries (section 3). As a starting point, it analyses the role played by UNCLOS within that framework. Building on identified weaknesses of the "Constitution for the oceans" in the coverage of fisheries and the interconnectedness of the oceans, it presents instruments that can be used to complete and complement the framework, or that have been developed specifically for that purpose. It does so first by assessing the legal framework of global application through a selection of legally binding instruments and of non-legally binding instruments. It then moves on to looking into the actors who operationalize those norms. Section 4 finally concludes with reflections on the way different frameworks have co-evolved to shape high sea fisheries law.

Through this portrait of the current state of international and high seas fisheries, the present chapter further intends to elaborate on the way of approaching fisheries from the perspectives of both the law of the sea and international environment law. ${ }^{6}$ As observed by Barnes and Massarella, "[i]nternational fisheries law cannot be viewed in isolation from other areas of international law. [...] Beyond the UNCLOS, international trade law and area-based fisheries management regimes now shape fisheries regulation, either directly or indirectly". International fisheries law is also influenced by the work of the International Labour Organization (ILO), and by navigation and shipping under the umbrella of the International Maritime

3 Serge Garcia, Jake Rice \& Anthony Charles, "Governance of marine fisheries and biodiversity conservation: The integration challenge” in Serge Garcia, Jake Rice \& Anthony Charles (eds), Governance of marine fisheries and biodiversity conservation: Interaction and Coevolution (Hoboken: Wiley, 2014) 37-52 at 40.

4 The present chapter does not focus on the improvements needed at the level of implementation. A more detailed analysis of implementation challenges is conducted in chapter 5 below.

5 Tommy T.B. Koh, "A Constitution for the Oceans" (Remarks by Tommy T.B. Koh, of Singapore, President of the Third United Nations Conference on the Law of the Sea), online <https://www.un.org/Depts/los/ convention_agreements/texts/koh_english.pdf>.

6 Alexander Proelss \& Katherine Houghton, "Protecting Marine Species" in Rosemary Rayfuse (ed), Research Handbook on International Marine Environmental Law (Cheltenham: Edward Elgar, 2015) 229258 at 257.

7 Richard Barnes \& Carmino Massarella, "High Seas Fisheries” in Elisa Morgera \& Kati Kulovesi (eds), Research Handbook on International Law and Natural Resources (Cheltenham: Edward Elgar, 2016) $369-389$ at 379. 
Organization (IMO), which deal with operational aspects of international fisheries law, such as labour conditions, safety of navigation and standards for fishing vessels. ${ }^{8}$ Yet, the main focus of the analysis conducted in the present chapter remains on the two selected regimes of the law of the sea and international environmental law. It is submitted that these regimes are the ones that need to be bridged for strengthening a core body of regulatory instruments and structures in order for them to be adapted to the interconnected context of sustainable fisheries management.

\section{INTERNATIONAL AND HIGH SEAS FISHERIES: FISH, EXPLOITATION AND THE ENVIRONMENT}

Interconnectedness is first and foremost seen through the relationship that humans have with fisheries and the marine environment. Indeed, "[t]wo-thirds of humanity inhabit coastal areas and depend on coastal and marine environments for their livelihood". 'This illustrates the importance of fish as a source of food and income, as well as the historical and cultural significance of fishing activities and, more generally, the marine environment for several populations. ${ }^{10}$ For example, the economic and cultural importance of sharks is recognized in recent yearly UNGA resolutions on sustainable fisheries, ${ }^{11}$ which also called attention to the importance of sustainable fisheries for the subsistence, livelihood and development of small island developing States and other developing coastal States. Small island developing States have also continuously reiterated this importance in the discussions and negotiations on the conservation and sustainable use of marine biodiversity in ABNJ, ${ }^{12}$ along with the necessity to include traditional knowledge within scientific practices when conducting environmental impact assessments. ${ }^{13}$

8 Richard Caddell, "International Fisheries Law and Interactions with Global Regimes and Processes" in Richard Caddell \& Erik Molenaar (eds), Strengthening International Fisheries Law in an Era of Changing Oceans (Oxford: Hart, 2019) 133-163 at 157-162.

9 Benjamin K. Sovacool, "A Game of Cat and Fish: How to Restore the Balance in Sustainable Fisheries Management" (2009) 40 Ocean Development and International Law 97-125 at 98, cited in Solène Guggisberg, The Use of CITES for Commercially-Exploited Fish Species: A Solution to Overexploitation and Illegal, Unreported and Unregulated Fishing? (Cham: Springer, 2016) at 1 [Guggisberg, The Use of CITES].

10 See, e.g. Maribus, "The future of Fish - The Fisheries of the Future" (2013) World Ocean Review at 32; James Harrison, Saving the Oceans Through Law. The International Legal Framework for the Protection of the Marine Environment (Oxford: Oxford University Press, 2017) at 166 [Harrison, Saving the Oceans].

11 Sustainable fisheries, including through the 1995 Agreement for the Implementation of the Provisions of the United Nations Convention on the Law of the Sea of 10 December 1982 relating to the Conservation and Management of Straddling Fish Stocks and Highly Migratory Fish Stocks, and related instruments, GA Res 73 (CXXV), UNGAOR, 73rd Sess, UN Doc A/RES/73/125 (2018) at 7; Sustainable fisheries, including through the 1995 Agreement for the Implementation of the Provisions of the United Nations Convention on the Law of the Sea of 10 December 1982 relating to the Conservation and Management of Straddling Fish Stocks and Highly Migratory Fish Stocks, and related instruments, GA Res 74 (XVIII), UNGAOR, 74th Sess, UN Doc A/RES/74/18 (2019) at 8.

12 Small island developing States are very active in the negotiation of the upcoming international legally binding agreement on biological diversity beyond national jurisdiction (BBNJ). The BBNJ process is discussed in further detail in chapter 4 below.

13 See e.g. IISD, "Summary of the Third Session of the Intergovernmental Conference (IGC) on the Conservation and Sustainable Use of Marine Biodiversity of Areas Beyond National Jurisdiction" (2019) 25:118 Earth Negotiation Bulletin at 1. On the question of including traditional knowledge in 
This is why, before looking into the legal framework covering international and high seas fisheries, it is worth addressing the object of this coverage: international fisheries themselves. First, this section presents an overview of the state of fishery resources and fishing activities (2.1). It then conducts a discussion on the major threats impacting fish stocks and the marine environment (2.2). This section concludes by exploring the concepts of common goods and the tragedy of the commons as elements of relevance for understanding the particular status of fisheries - and consequently their exploitation and conservation - in ABNJ (2.3). All of the above serve as a basis for the following section, which looks at the way these threats, and fishing activities in general, are addressed by the existing normative/ legal framework.

\subsection{How much fish are we dealing with? The state of fish stocks and captures}

To grasp the scope of fishing activities worldwide, some general figures can be considered. Around 1,500 fish stocks are commercially exploited worldwide, ${ }^{14}$ and the global total captures ${ }^{15}$ in 2018 amounted to 96.6 million tonnes, ${ }^{16}$ of which 84.4 million tonnes were taken in marine waters. ${ }^{17}$ This represents a slight reduction from previous years. ${ }^{18}$ This global average of around 90 million tonnes per year has been relatively stable since the $1990 \mathrm{~s} ;^{19}$ the stability of numbers, however, needs to be seen in light of the decimation of stocks in previous years. ${ }^{20}$ The stability in

environmental impact assessments, see Akwé: Kon Voluntary guidelines for the conduct of cultural, environmental and social impact assessments regarding developments proposed to take place on, or which are likely to impact on, sacred sites and on lands and waters traditionally occupied or used by indigenous and local communities, which can be found in an annex to Article $8(j)$ and related provisions, CBD COP Dec VII/16, COP 7, UNEP/CBD/COP/7/16 (2004).

14 Maribus, supra note 10 at 43.

15 Captures refer to wild fish stocks, as opposed to aquaculture (farmed fish).

16 FAO, "The State of World Fisheries and Aquaculture 2020. Sustainability in action" (2020) at 2-4, online: <http://www.fao.org/state-of-fisheries-aquaculture> [FAO Report 2020]. As a familiar point of comparison, an average African elephant is estimated by the World Wildlife Fund to have a mass of 6 tonnes (see WWF, "African Elephants", online: <https://wwf.panda.org/knowledge_hub/endangered_ species/elephants/african_elephants/>). 96.6 million tonnes of fish would therefore represent approximately 16 million elephants.

17 FAO report 2020, supra note 16 at 2-4. The rest of captures are taken in inland waters.

18 Marine captures amounted to 81.2 million tonnes in 2017, 78.3 million tonnes in 2016, and 79.3 million tonnes in 2015, see FAO report 2020, supra note 16 at 3.

19 Although the present study focuses on fish captures, and more specifically on marine captures, a word must be said on the contribution of the aquaculture sector to fish supply. While the world capture fisheries have seen no major rise since the 1990s, aquaculture production has increased considerably, reaching 82.1 million tonnes in 2018 , compared with an average of 14.9 million tonnes per year in the late $1980 \mathrm{~s} /$ early 1990 s, see FAO report 2020 , supra note 16 at 3 . In 2014 , for the first time, the contribution of the aquaculture sector to the supply of fish for human consumption overtook the contribution from wildcaught fish, see FAO, "The State of World Fisheries and Aquaculture 2016. Contributing to food security and nutrition for all” (2016) at 2, online: <http://www.fao.org/3/a-i5555e.pdf> [FAO Report 2016]. Aquaculture therefore plays a major role when addressing fish as a commodity and fishing activities.

20 Olav Schram Stokke, "International fisheries politics: from sustainability to precaution" in Steina Andresen, Elin Lerum Boasson \& Geir Hønneland (eds), International Environmental Agreements: An introduction (Abingdon, Oxon: Routledge, 2011) 97-116 at 99. The collapse of cod in Eastern Canada in the early 1990s and the fishing ban that ensued are often cited as an accurate example of depleted stocks, 
the number of vessels can also be observed, although their harvesting capacity is continuously growing. ${ }^{21}$ Moreover, approximately $20 \%$ of wild captures come from straddling stocks, i.e. stocks that migrate between the EEZ of one or more States and the high seas..$^{22}$ In 2016 , the catches in marine waters from the 25 major producers ${ }^{23}$ amounted to 67.83 million tonnes, representing $80 \%$ of all marine captures. ${ }^{24}$ The Pacific Ocean is the major fishing area with approximately 49.16 million tonnes (of these, almost 20.06 million tonnes in the northwest area, almost 13.54 million tonnes in the western-central region, and approximately 10.27 million tonnes in the southeast region). The North-East Atlantic and the Eastern Indian Ocean were also major fishing areas, with 9.32 and 6.77 million tonnes respectively. ${ }^{25} \mathrm{~A}$ scientific report from early 2018 observes that "[m]ore than half of the world's oceans are subject to industrial-scale harvest, spanning an area four times that covered by terrestrial agriculture". ${ }^{26}$

The difficulty of gathering data on the high seas represents a sizeable challenge to developing an accurate and reliable picture on the state of fish stocks in these areas. ${ }^{27}$ As observed by Wright $e t$ al, " $[\mathrm{t}]$ he [FAO] report does not provide precise figures on fisheries in $\mathrm{ABNJ}$, but notes that the 'situation seems more critical for some highly migratory, straddling and other fishery resources that are fished solely or partially in the high seas"'. ${ }^{28}$ Some average numbers can, however, be cited: between 2000 and 2010, "an average of 10 million [tonnes] of fish was caught annually in the high seas $[\ldots]$. This represents [approximately] $12 \%$ of the global average annual marine

see, e.g. Ransom A. Myers, Jeffrey A. Hutchings \& Nicholas J. Barrowman, "Why do Fish Stocks Collapse? The Example of Cod in Atlantic Canada" (1997) 7:1 Ecological Applications 91-106.

21 Stokke, supra note 20 at 98.

22 Pedro Pintassilgo et al, "Stability and Success of Regional Fisheries Management Organizations" (2010) 46:3 Environmental and Resource Economics 377-402 at 378. The present author acknowledges that the data used in this article is from 2004; although not very recent, the data is simply used in the present study as an illustration of the scope of wild capture from straddling stocks. Further, to the present author's knowledge, the limited specific data regarding high seas capture does not allow a conclusion to be made on the proportion of those wild captures being taken specifically on the high seas. The only data specifically referring to high seas captures is discussed below in the current section.

23 China, the major producer, had catches of 12.68 million tonnes in marine waters in 2018, almost double the catches of the second major producer state, Peru, with 7.12 million tonnes. The other major producers are: Indonesia, Russia, the United States, India, Vietnam, Japan, Norway, Chile, Philippines, Thailand, Mexico, Malaysia, Morocco, South Korea, Iceland, Myanmar, Mauritania, Spain, Argentina, Taiwan, Denmark, Canada and Iran, see FAO report 2020, supra note 16 at 13. It is to be noted that this list is based on national reports, and therefore does not include the EU as a fishing entity. In 2016, the EU catches amounted to 5 million tonnes, see Eurostat, "Fisheries statistics", online <http://ec.europa.eu/ eurostat/statistics-explained/index.php/Fishery_statistics\#Catches $>$. This would rank the EU within the top 5 of major producers.

24 FAO report 2020, supra note 16 at 13.

25 Ibid at 16.

26 David A. Kroodsma et al, "Tracking the global footprint of fisheries" (2018) 359:6378 Science 904-908, cited in Owen Gaffney, "Should nations close the high seas to fishing?" (3 May 2018) Re.Think, online: $<$ https://rethink.earth/should-nations-close-the-high-seas-to-fishing/>.

27 The difficulty of collecting data on the high seas is discussed in further details in chapter 5 section 2.1.2 below.

28 Glen Wright et al, "High seas fisheries: what role for a new international instrument" (2016) IDDRI Paper 3/2016 at 5, citing FAO Report 2016, supra note 19 at 44 . 
fisheries catch" ${ }^{29}$ This data is also reiterated by Warner, who mentions that "[a]n estimated 10 to 20 per cent of the world's commercial fish catch is now derived from high seas areas" ${ }^{30}$ In fact, between 2000 and 2010, 10 nations were leading fishing activities on the high seas: Japan, South Korea, Taiwan, Spain, the United States, Chile, China, the Philippines, France and Indonesia. ${ }^{31}$ Their total high seas captures amounted to $62 \%$ of all catches on the high seas, and equalled $71 \%$ of the high seas landed value in USD. ${ }^{32}$

One must, however, keep in mind that these average and global numbers have the potential of masking regional realities: the often alarming regional data is spread out and the reality of a particular region is then diluted. ${ }^{33}$ Yet, although imprecise, this picture of the status of fish stocks globally illustrates the magnitude of fishing activities and their potential impact on the marine environment. Some of these impacts represent major threats, to which we now turn.

\subsection{Major threats to fish stocks and the marine environment}

Fishing activities are the main cause of biological diversity loss and weakening of ecosystem services and resilience on the high seas. ${ }^{34}$ Not only do fishing activities have destructive impacts on the stocks themselves, but some of them also threaten non-

29 U. Rashid Sumaila et al, "Winners and losers in a world where the high seas is closed to fishing" (2015) 5 Scientific Reports article number 8481.

30 Robin Warner, "Conservation and Management of Marine Living Resources Beyond National Jurisdiction: Filling the Gaps" in Robert Beckman et al (eds), High Seas Governance: Gaps and Challenges (Leiden: Brill, 2018) 179-194 at 181.

31 Sumalia et al, supra note 29. This list is based on the average high-seas landed value ("Fish landings are defined as the catches of marine fish landed in foreign or domestics ports", see OECD, "Fish landings (indicator)" (2018), online: <https://data.oecd.org/fish/fish-landings.htm>). Although not focusing on high seas captures per se, a 2018 study has shown the fishing patterns of distant fishing fleets, i.e. fishing in areas outside from a State's own maritime zones, which has revealed that "[f]or the top 20 fishing countries, catches caught on the high seas or in the EEZs of other countries grew by more than $600 \%$ between 1950 and 2014, increasing their contribution to global catches from 16 to $23 \%$ over this period". The top 20 industrial fishing nations include (the first 10 are in descending order of the distance travelled to fish in 2014, while the last 10 are in no particular order as the distance travelled is relatively similar): Taiwan, South Korea, Spain, China, Japan, Thailand, Former USSR, Indonesia, India, Norway, Argentina, Chile, Iceland, Malaysia, Mexico, Mororcco, Peru, Philippines and the United States, see David Tickler et al, "Far from home: Distance patterns of global fishing fleets" (2018) 4:8 Science Advances 1-6 at 2. This data does not allow us to conclude on the exact amount of catches taken on the high seas, but this study however illustrates that high seas fishing has increased over the past decades.

32 Sumaila et al, supra note 29, referring to Alex D. Rogers et al, "The High Seas and Us: Understanding the Value of High-Seas Ecosystems” (2014) Global Ocean Commission, online: <http://www.oceanunite.org/ wp-content/uploads/2016/03/High-Seas-and-Us.FINAL_.FINAL_high_.spreads.pdf>.

33 Fikret Berkes et al, "Globalization, Roving Bandits, and Marine Resources" (2006) 311 Science 1557-1558 at 1558 .

34 See, e.g., Warner, supra note 30 at 182-183; Guillermo Ortuño Crespo et al, "High-seas fish biodiversity is slipping through the governance net" (2019) 3 Nature Ecology \& Evolution 1273-1276 at 1273; Rafael LealArcas, "Sustainability, Common Concern and Public Goods" (2017) 49 George Washington International Law Review 801-877 at 801; Tulio Treves, "Principles and Objectives of the Legal Regime Governing Areas Beyond National Jurisdiction" in Alex Oude Elferink \& Erik Molenaar (eds), The International Regime of Areas Beyond National Jurisdiction: Current and Future Developments (Leiden: Martinus Nijhoff, 2010) 5-25 at 13; Richard Barnes, "The Proposed LOSC Implementation Agreement On Areas Beyond National 
target species, the habitat of various marine species, ${ }^{35}$ and the marine environment as a whole. Such impacts are caused by, ${ }^{36}$ among other factors, the development of fishing technology, ${ }^{37}$ as well as subsidies, ${ }^{38}$ that make fishing, but also the location of fish, more accessible; non-selective fishing gear leading to increased by-catch; ${ }^{39}$ inadequate management caused by a lack of knowledge, resources, political will (triggered by demands from the industry), cooperation, and enforcement; ${ }^{40}$ and problems with flags of convenience and re-flagging, which makes it more difficult to track down and sanction wrong-doers. ${ }^{41}$ Ignoring fishing practices when addressing the broader conservation of marine biodiversity would therefore be illogical. ${ }^{42}$

\begin{abstract}
Although these activities have a direct impact on stocks and the marine environment, other anthropogenic activities also have had - and are still having - environmental impacts, which, in turn, affect fish stocks and their habitats. Consequently, environmental changes also represent threats to fish stocks. ${ }^{43}$
\end{abstract}

Jurisdiction and Its Impact on International Fisheries Law" (2016) 31:4 International Journal of Marine and Coastal Law at 583-619 at 593-594.

35 Robin Churchill, "Fisheries and their impact on the marine environment: UNCLOS and beyond" in Marta Chantal Ribeiro (ed), 30 Years After the Signature of the United Nations Convention on the Law of the Sea: The Protection of the Environment and the Future of the Law of the Sea. Proceedings of the International Conference (Coimbra: Coimbra Editora, 2014) 23-52 at 24; Kristina Gjerde, "High Seas Fisheries Governance: Prospects and Challenges in the 21st Century" in Peter Johan Schei \& Davor Vidas (eds), The World Ocean in Globalisation: Climate Change, Sustainable Fisheries, Biodiversity, Shipping, Regional Issues (Leiden: Brill, 2011) 221-232 at 221-222 [Gjerde, "High Seas Fisheries Governance"].

36 These factors are discussed generally in Churchill, supra note 35 at 27-29; and in Seokwoo Lee, Anastasia Telesetsky \& Clive Schofield, "Slipping the Net: Why Is It So Difficult to Crack Down on IUU Fishing?" in Myron Nordquist et al (eds), Freedom of Navigation and Globalization (Leiden: Brill Nijhoff, 2015) 89-119 at $89-92$.

37 See e.g. Lawrence Juda, "Changing Perspectives on the Oceans: Implications for International Fisheries and Oceans Governance" in David Caron \& Harry Scheiber (eds), Bringing New Law to Ocean Waters (Leiden: Brill Nijhoff, 2004) 17-28 at 20-21; Kristina Gjerde, "High Seas Fisheries Management under the Convention on the Law of the Sea" in David Freestone, Richard Barnes, \& David Ong (eds), The Law of the Sea: Progress and Prospects (Oxford: Oxford University Press, 2006) 281-307 at 281 [Gjerde, "High Seas Fisheries Management"]; Rosemary Rayfuse, Non-flag State enforcement in high seas fisheries (Leiden: Martinus Nijhoff, 2004) at 5 [Rayfuse, Non-flag State enforcement].

38 See, e.g., Margaret Young, "Fragmentation or Interaction: the WTO, Fisheries Subsidies and International Law" (2009) 8:4 World Trade Review 477-515.

39 Warner, supra note 30 in at 183.

40 See, e.g. WWF, "Fishing Problems: Poor Fisheries Management", online: <https://wwf.panda.org/ our_work/oceans/problems/fisheries_management/>. More specifically, the weaknesses of RFMOs are discussed in further detail in chapter 5 section 2.3.2 below.

41 See, e.g., Matthew Gianni \& Walt Simpson, "The Changing Nature of High Seas Fishing: how flags of convenience provide cover for illegal, unreported and unregulated fishing" (2005), online: <http://assets. wwf.org.uk/downloads/flagsofconvenience.pdf $>$. The issue of flags of convenience is discussed in further detail in chapter 5 section 2.3 .1 below.

42 Dire Tladi, "The Proposed Implementing Agreement: Options for Coherence and Consistency in the Establishment of Protected Areas Beyond National Jurisdiction" (2015) 30:4 International Journal of Marine and Coastal Law 654-673 at 661; Wright et al, supra note 28 at 1 and 5-7.

43 See, e.g., Rosemary Rayfuse \& Robin Warner, "Securing a Sustainable Future for the Oceans Beyond National Jurisdiction: The Legal Basis for an Integrated Cross-Sectoral Regime for High Seas Governance for the 21st Century" (2008) 23:3 International Journal of Marine and Coastal Law 399-421 at 407; Richard Kenchington \& Robin Warner, "Uncertain Seas Ahead: Legal and Policy Approaches to Conserving Marine Biodiversity in the Face of Changing Climate" in Robin Warner \& Clive Schofield (eds) Climate Change and the Oceans: Gauging the Legal and Policy Currents in the Asia Pacific and Beyond (Cheltenham: Edward Elgar, 2012) 51-73 at 52; Gjerde, "High Seas Fisheries Governance", supra note 35 at 221-222. 
The present section discusses some of the major threats to the sustainability of fish stocks and the marine environment, ${ }^{44}$ including overfishing (2.2.1), IUU fishing (2.2.2), the impacts of fishing operations on non-target species and the marine environment (2.2.3), and environmental changes (2.2.4). These threats are described in an attempt to illustrate the socio-ecological problems that, to some extent, support the need to regulate. A more extensive discussion on the regulatory, structural and behavioural challenges underlying these threats to sustainability is conducted in chapter 5 below.

\subsubsection{Overfishing}

Often characterized as the most damaging practice on the oceans, ${ }^{45}$ overfishing, or overexploitation, is simply defined as fishing above the maximum sustainable yield (MSY). This means that fishing is done above the reproduction rate, which does not allow the fish population to replenish. This is caused mainly by ineffective management and non-compliance with existing regulations, but also by the capacity of modern fishing fleets to conduct fishing activities. Indeed, as indicated above, the development of technology and modern equipment has rendered fish stocks, even in remote regions, accessible for fishing, which leads to overcapacity, i.e. a fishing capacity that exceeds the availability of fish stocks. ${ }^{46}$ Fisheries subsidies, understood as "any government intervention [...] that [...] is interpreted as something having an impact on the profitability of the fisheries industry", ${ }^{47}$ accentuate this phenomenon, by reducing costs to conduct fishing operations. ${ }^{48}$

In 2017, approximately $34 \%$ of stocks were reported as being fished at unsustainable levels, i.e. overexploited. ${ }^{49}$ On the high seas, $66 \%$ of the stocks are overexploited, ${ }^{50}$

44 This section builds on the discussion on the major threats to fish stocks conducted by Guggisberg, The Use of CITES, supra note 9 at 9-22.

45 See, e.g., Harrison, Saving the Oceans, supra note 10 at 166; Theodore Okonkwo, "Managing the Ocean Commons Beyond National Jurisdiction" (2016) 2 China Oceans Law Review 56-82 at 75-76; David Freestone, "Problems of High Seas Governance" in Peter Johan Schei \& Davor Vidas (eds), The World Ocean in Globalisation. Climate Change, Sustainable Fisheries, Biodiversity, Shipping, Regional Issues (Leiden: Brill, 2011) 99-130 at 110; Klaus Bosselmann, Earth Governance. Trusteeship of the Global Commons (Cheltenham: Edward Elgar, 2015) at 82-83.

46 Stefaan Depypere, “Ocean Governance for Sustainable Fisheries” in Myron Nordquist, John Norton Moore \& Ronan Long (eds) Legal Order in the World's Oceans. UN Convention on the Law of the Sea (Leiden, Boston: Brill Nijhoff, 2018) 370-378 at 374

47 FAO, "What is fisheries subsidies?", online: <http://www.fao.org/3/y4446e/y4446e0k.htm>.

48 In fact, "[a] recent analysis of the economics of high seas fishing found that profits from these activities for the major distant-water fishing countries would be greatly reduced, or even disappear completely, if fleets were not subsidized", see Tickler et al, supra note 31 at 3, referring to Enric Sala et al, "The economics of fishing the high seas" (2018) 4:8 Science Advances.

49 FAO report 2020, supra note 19 at 47-48. See also Robin Churchill, "The LOSC Regime for Protection of the Marine Environment - Fit for the Twenty-First Century?” in Rosemary Rayfuse (ed), Research Handbook on International Marine Environmental Law (Cheltenham: Edward Elgar, 2017) 3-30 at 19-20; Harrison, Saving the Oceans, supra note 10 at 166.

50 Global Ocean Commission, "Improving accountability and performance in international fisheries management" (2013) Policy Options Paper \#9 at 1, cited in Harrison, Saving the Oceans, supra note 10 at 166. 
much more than overexploited stocks within national jurisdiction. ${ }^{51}$ The numbers are themselves alarming, but even more so when compared with the ones from 1974 , when stocks fished at unsustainable levels represented only $10 \%$ of all marine captures. ${ }^{52}$ This is explained primarily by the booming of industrial fisheries, severe weaknesses in management in the second half of the twentieth century, and growing fishing activities on the high seas due to the collapse of coastal fisheries, that forced fishing activities to be conducted further from the coast, ${ }^{53}$ and into deeper waters. ${ }^{54}$ Moreover, deep-sea fishing has become possible due, among other things, to deep-sea bottom trawling. However, its impact has been shown to be disastrous, especially with seamount fisheries, ${ }^{55}$ characterized by rapid depletion of stocks and slow recovery. ${ }^{56}$ While the precise extent of overexploitation remains uncertain, the threat of overexploitation, for its part, is unchallenged..$^{57}$

Although overfishing is undoubtedly a scourge for the sustainability of fish stocks, it does not automatically mean that the act of overfishing is illegal. Indeed, the legality of catches is determined in accordance with the total allowable catch (TAC), which is then divided among actors most often through catch quotas. ${ }^{58}$ If an entity catches the amount of fish that it has been assigned, these catches are legal. However, if that TAC was initially set higher than the recommendations from scientific bodies, or despite the lack of scientific information, ${ }^{59}$ legal catches could still be unsustainable. This is also due to the fact that these recommendations do not necessarily take into

51 Warner, supra note 30 at 182-183.

52 FAO report 2020, supra note 19 at 47-48.

53 See, e.g., Wright et al, supra note 28 at 6; Crow White \& Christopher Costello, "Close the High Seas to Fishing?" (2014) 12:3 PLOS Biology; Freestone, supra note 45 at 100.

54 Warner, supra note 30 at 181.

55 Seamount fisheries refer to the capture of stocks occurring around seamounts, defined as "under-sea mountains whose summits lie beneath the ocean waves", see Serge Garcia, "Glossary" in Kevern Cochrane \& Serge Garcia (eds), A fishery manager's guidebook (Rome and Hoboken: FAO and Wiley, 2009) 473-505 at 494.

56 Gjerde, "High Seas Fisheries Management", supra note 37 at 284-285.

57 The threat of overfishing has been reiterated as a main concern by the FAO in its biennial Report on the State of World Fisheries and Aquaculture, at least since 1994, see Rayfuse, Non-flag State enforcement, supra note 37 at 4 .

58 To understand how the TAC is allocated in the EU, see European Commission, "Managing Fisheries Fishing quotas", online: <https://ec.europa.eu/fisheries/cfp/fishing_rules/tacs_en>.

59 See, e.g. Harrison, Saving the Oceans, supra note 10 at 186. A TAC set without taking scientific recommendations into consideration or in the absence of scientific information could prima facie raise issues about the legality of such TAC. In fact art. 119 UNCLOS provides that "[i]n determining the allowable catch and establishing other conservation measures for the living resources in the high seas, States shall: (a) take measures which are designed, on the best scientific evidence available" (emphasis added), an obligation reiterated under art. 5(b) UNFSA, which provides that "[i]n order to conserve and manage straddling fish stocks and highly migratory fish stocks, coastal States and States fishing on the high seas shall [...] (b) ensure that such measures are based on the best scientific evidence available" (emphasis added). A similar wording is used in the constitutive instruments of most RFMOs. Practice however shows that these obligations are often interpreted as only implying to "take into consideration" scientific advice/information. Further, States and organizations have been relying on the necessity to follow the available science, somehow justifying to go ahead in establishing TACs despite a lack of scientific information. For a more detailed discussion on the reliance on scientific information to set TACs, see Guggisberg, The Use of CITES, supra note 9 at 144-146. 
consideration other sources of depletion and damageable practices, such as IUU fishing. ${ }^{60}$

\subsubsection{Illegal, unreported and unregulated (IUU) fishing}

IUU fishing, although generally addressed together, is in fact composed of three distinct phenomena that all present different violations of distinct obligations. Article 3 of the FAO IPOA-IUU ${ }^{61}$ explains these distinctions. Illegal fishing represents fishing activities conducted in national waters of another State in contravention of the laws and regulations of that State, or conducted by a member of a RFMO or a cooperative State in the waters under the RFMO's jurisdiction in contravention of the conservation measures adopted by such RFMO. ${ }^{62}$ Unreported fishing, for its part, refers to fishing activities which have not been reported, or have been misreported, to the relevant national authority or to the relevant RFMO. Finally, unregulated fishing consists of activities conducted in the waters under the jurisdiction of an RFMO by vessels without nationality or flying the flag of a nonparty in contravention of conservation measures adopted by such RFMO or, more generally, in areas where no particular conservation measure exists, in contravention of the generally applicable rules of State responsibilities for the conservation of living marine resources under international law. A common element to these definitions is that the main cause of IUU fishing lies in a lack of effective flag State control. ${ }^{63}$

IUU fishing and overexploitation are correlated, the former being both a cause and a consequence of overfishing. IUU fishing does contribute to fish catches, but comes on top of the TACs, therefore contributing to overfishing. Conversely, measures to avoid overfishing might encourage actors, which fall outside the scheme of such measures, to by-pass them and engage in IUU activities. For example, an actor that has not been attributed fishing opportunities might still engage in fishing activities, rendering them illegal or unregulated. IUU fishing undoubtedly also contributes to other major threats to stocks and the marine environment, such as the destruction of habitats, as such fishing is conducted in violation of conservation measures.

The consequences of IUU fishing go beyond environmental damage and the violation of legal obligations. Representing between 11 to 26 million tonnes of fish catches, which amounts to 10 to 23.5 billion USD annually, ${ }^{64}$ IUU fishing also has

60 Guggisberg, The Use of CITES, supra note 9 at 17.

61 International Plan of Action to Prevent, Deter and Eliminate Illegal, Unreported and Unregulated Fishing, FAO COFI, 24th Sess (2001), online: <http://www.fao.org/3/a-y1224e.pdf> [IUU-IPOA]. See also Gjerde, "High Seas Fisheries Management", supra note 37 at 289-290.

62 Only the last part of the definition would therefore be relevant for high seas fisheries.

63 Holly Matley, "Developments in International Fisheries Law and Their Contribution to Improving Effectiveness of RFMOs and Other Environmental Regimes" in Neil Craik et al (eds), Global Environmental Change and Innovation in International Law (Cambridge: Cambridge University Press, 2018) 102-122 at 116.

64 David J. Agnew et al, "Estimating the Worldwide Extent of Illegal Fishing" (2009) 4:2 PLoS ONE 1-8. See also Maribus, supra note 10 at 70 . 
economic impacts, through loss of licensing and tax income, adverse impact to the fishing industry, and social impacts, triggering the displacement of legitimate fishers and creating unemployment. ${ }^{65}$ IUU fishing is also considered, beyond just a fisheries management and environmental protection problem, as an issue related to transnational organized crime. ${ }^{66}$

Finding solutions to the expansion of this phenomenon is therefore rooted in the necessary participation of a wide variety of actors and entities. Suggestions made include "tightening up controls on ship registration and flagging, improving port state control measures, increasing satellite monitoring, improving catch documentation, blacklisting vessels, and a range of market-based controls, including taxation" ${ }^{67}$ This would trigger different obligations for different actors, whether flag States, coastal States or port States individually, as well as through collective actions. ${ }^{68}$ This is why combatting IUU fishing requires a comprehensive and integrated approach, which must involve all actors, in all jurisdictions, including ABNJ, in accordance with international law. It must also address all economic, social and environmental impacts of IUU fishing, ${ }^{69}$ illustrating the cross-sectoral nature of the consequences stemming from IUU fishing. ${ }^{70}$

\subsubsection{Impacts on non-target species and marine habitats}

Fishing activities do not only impact target fish stocks, but can also be a threat for non-target species, also known as by-catch. ${ }^{71}$ Various species, including turtles and marine mammals, get easily caught in nets, or in discarded and lost fishing gear, a

65 Kristina Gjerde et al, "Ocean in Peril: Reforming the Management of Global Ocean Living Resources in Areas Beyond National Jurisdiction” (2013) 74:2 Marine Pollution Bulletin 540-551 at 544-545. For an overview of the impact of IUU fishing, see Lee, Telesetsky \& Schofield, supra note 36 at 89-92.

66 See, e.g. Sustainable fisheries, including through the 1995 Agreement for the Implementation of the Provisions of the United Nations Convention on the Law of the Sea of 10 December 1982 relating to the Conservation and Management of Straddling Fish Stocks and Highly Migratory Fish Stocks, and related instruments, GA Res 72(LXXII), UNGAOR, 72nd Sess, UN Doc A/RES/72/72 (2017) at para 98; Combating illegal fishing at the global level European Parliament resolution of 17 November 2011 on combating illegal fishing at the global level - the role of the EU (2010/2210(INI)), (2011) OJ, C 153E/148 at para 62; Report of the 24th Session of the Commission on Crime Prevention and Criminal Justice, ECOSOCOR, 24th Sess, Un Doc E/CN.15/2015/19 (2015) at para 210.

67 Barnes \& Massarella, supra note 7 at 371-372.

68 See, e.g. High Seas Task Force, "Closing the Net: Stopping Illegal Fishing on the High Seas. Final Report of the Ministerially led Task Force on IUU Fishing on the High Seas" (2006), at recommendations 3-6, online: <https://www.oecd.org/sd-roundtable/papersandpublications/39375276.pdf>, summarized in Freestone, supra note 45 at 111-113. See also Moritaka Hayashi, "Illegal, Unreported, and Unregulated (IUU) Fishing: Global and Regional Responses" in David Caron \& Harry Scheiber (eds), Bringing New Law to Ocean Waters (Leiden: Brill Nijhoff, 2004) 95-124 at 116-121, which discusses some measures related to flag State responsibility, port State control and market/trade related measures.

69 IPOA-IUU, supra note 61 at art. 9.3.

70 For an overview of the impact of IUU fishing, see Lee, Telesetsky \& Schofield, supra note 36 at 88-90. For a specific reference to the interconnectedness of issues in IUU fishing, see 113-118.

71 Gjerde, "High Seas Fisheries Management", supra note 37 at 286-287. 
phenomenon also referred to as "ghost fishing".72 Birds are also subject to by-catch, especially in longline fishing. ${ }^{73}$ This problem has been addressed directly through the adoption by the FAO of the International Plan of Action for reducing incidental catch of seabirds in longline fisheries (IPOA-Seabirds). ${ }^{74}$

Marine habitats are also highly affected by certain fishing techniques, most particularly beam trawling and bottom trawling. ${ }^{75}$ With such techniques, the net and/or the beam disturbs or even destroys features found on the sea floor, such as coral reefs, hydrothermal vents, around which nutrients and mineral deposits create the necessary habitat for deep-sea organisms, and seamounts which, because of their elevated position and underwater currents, create ideal habitat for some species. ${ }^{76}$ Consequently, "[b]ottom-trawling for stocks that spawn on seamount ecosystems can eliminate whole year groups as well as destroy the very seabed ecosystems that attract them". ${ }^{77}$ Marine habitats can also be the casualty of fishing techniques using explosives, as well as discarded and lost fishing gear.

The recent debate within the EU on the use of electric pulse fishing has also raised questions as to the advantages and disadvantages of new fishing techniques on marine habitats and non-target species. ${ }^{78}$ Although not conducted on the high seas, pulse fishing is a fairly new fishing technique that uses small electric "shocks to drive fish from the bottom of the sea into nets floating above" ${ }^{79}$ Compared with beam trawling, which is known to have severe adverse impacts on seabed habitats as well as high by-catch, pulse fishing allegedly lowers the trawl footprint and fuel consumption. ${ }^{80}$ Yet, "[f]ishing trials and laboratory experiments reported

72 Churchill, supra note 35 at 26; Harrison, Saving the Oceans, supra note 10 at 166; Code of Conduct for Responsible Fisheries, FAO, 28th Sess, FAO Doc 95/20/Rev/1 (1995) at arts. 7.6 .9 and 8.5 [Code of Conduct].

73 See, generally, Euan Duun, "Reducing Seabird Bycatch: From Identifying Problems to Implementing Policy" in Peter Johan Schei \& Davor Vidas (eds), The World Ocean in Globalisation. Climate Change, Sustainable Fisheries, Biodiversity, Shipping, Regional Issues (Leiden: Brill, 2011) 247-261.

74 International Plan of Action for Reducing Incidental Catch of Seabirds in Longline Fisheries, FAO COFI, 23rd Sess (1999), online: <http://www.fao.org/tempref/docrep/fao/006/x3170e/X3170E00.pdf> [IPOASeabirds].

75 Trawling consists of cone-shaped nets dragged either in the water column (pelagic trawls) or on the seabed (bottom trawls). Beam trawling is a form of bottom trawling, but the net is fixed to a metal beam, which is dragged along the seabed. While pelagic trawls have minimal impacts on the marine environment, bottom trawls, and especially beam trawls, have major impacts on underwater habitats, even leading to their complete destruction. For more on fishing techniques, see Maribus, supra note 10 at 112.

76 Churchill, supra note 35 at 26-27; Gjerde, "High Seas Fisheries Management", supra note 37 at 287-288.

77 Freestone, supra note 45 at 100.

78 See, e.g. Wageningen University \& Research, "Pulse fishing”, online: <https://www.wur.nl/en/Dossiers/ file/Pulse-fishing.htm>; Pulse Fishing, "What is pulse fishing", online: $<$ https://www.pulsefishing.eu $>$.

79 Kait Bolongaro, "The Franco-Dutch fish fight over electric pulse trawling" (14 February 2018) Politico, online: <https://www.politico.eu/article/the-franco-dutch-fish-fight-over-electric-pulse-trawling/>.

80 Adriaan Rijnsdorp et al, "Pulse fishing and its effects on the marine ecosystem and fisheries. An update of the scientific knowledge" (2016) Wageningen University \& Research Report C117/16 at 4-6, online: $<$ https://edepot.wur.nl/405708>; Ministry of Economic Affairs of the Netherlands, "Pulse Fishing. Pulse trawling as a promising alternative to beam trawling" (2017), online: <https://g8fip1kplyr33r3krz5b97d1wpengine.netdna-ssl.com/wp-content/uploads/2018/02/Infographic-Pulse-Fishing-DEF-PRINT.pdf>. 
spinal fractures in cod". ${ }^{81}$ Further, uncertainties related to "the ecological effects of electrical pulses on the marine ecosystem and [...] the risk of an increase in catch efficiency and the consequences for other fisheries"82 have led to serious concerns among various stakeholders from the fishing industry and non-governmental organizations (NGOs). After an EU-wide ban by the European Commission in $1998,{ }^{83}$ and then a scheme for derogations established in $2006,{ }^{84}$ the European Parliament officially banned the practice in 2019, to be fully effective in $2021 .^{85}$ This debate illustrates the many issues triggered by the use of new fishing techniques, both at the environmental level, and because of economic and political concerns.

\subsubsection{Environmental changes}

The environment has undergone changes for millennia, and the oceans have also felt their consequences: changing currents, variations in salinity and oxygen levels, etc. But it is well known that these changes are now taking place at an unprecedented rapidity and to an unprecedented extent, due to anthropogenic activities. ${ }^{86}$ Pollution, not only from shipping, fishing, seabed exploitation and other activities at sea, but also from land-based sources and climate change, ${ }^{87}$ which is itself the result of pollution and human activities, are the main causes of the growing rapidity and scope of the changes to the marine environment and marine species.

Fish stocks suffer from these changes. Referring to the particular consequences of climate change, Gjerde observes that "[p]rojected scenarios [...] include the betterknown impacts of warming oceans, acidification, coral bleaching and rising sea levels. These all have direct implications for fisheries" ${ }^{88}$ Indeed, higher concentration

81 Rijnsdorp et al, supra note 80 at 6, citing B van Marlen et al, "The effect of pulse stimulation on biotaResearch in relation to ICES advice-Progress report with preliminary results" (2007) IMARES Report C098/07, and D. de Haan et al, "The effect of pulse stimulation on biota-Research in relation to ICES advice-Progress report on the effects on cod" (2008) IMARES Report C098/08.

82 Rijnsdorp et al, supra note 81 at 6.

83 Council Regulation (EC) No 850/98 of 30 March 1998 for the conservation of fishery resources through technical measures for the protection of juveniles of marine organisms, (1998) OJ, L 125/1.

84 Council Regulation (EC) No 1967/2006 of 21 December 2006 concerning management measures for the sustainable exploitation of fishery resources in the Mediterranean Sea, amending Regulation (EEC) No $2847 / 93$ and repealing Regulation (EC) No 1626/94, (2006) OJ, L 409/11.

85 See, e.g. Laura Schrerer \& Jan Boersema, "Was the EU's ban on electric fishing the right decision?" (14 February 2019), online: <https:/www.universiteitleiden.nl/en/news/2019/02/was-the-eu-ban-onelectric-fishing-the-right-decision $>$. The debate on pulse fishing involves many economic and political components, including questions regarding fishing subsidies, which go beyond the scope of this study. This example is simply used as an illustration of the questions that can arise from the use of a new fishing technique.

86 The new geological era triggered by the impact of human activities on the earth system is called the Anthropocene. The capacity of international law to address issues from the perspective of this new era has also been discussed by legal scholars, see chapter 1 section 2.1 above.

87 See, generally, IPCC, "Special Report on the Ocean and Cryosphere in a Changing Climate - Summary for Policymakers” (2019), online: <https://www.ipcc.ch/site/assets/uploads/sites/3/2019/11/03_SROCC_ SPM_FINAL.pdf>.; IUCN, “The ocean and climate change” (2017), online: <https://www.iucn.org/sites/ dev/files/the_ocean_and_climate_change_issues_brief-v2.pdf $>$.

88 Gjerde, "High Seas Fisheries Governance", supra note 35 at 226. 
of $\mathrm{CO}_{2}$ in the oceans leads to their acidification and/or warming, and creates disturbance for species, which simply do not survive, or are forced to migrate in the quest for healthier waters which allow them to survive and reproduce. Acidification of the oceans and their rising temperature also affects the algae which provide the necessary nutrients for corals to survive. Without these nutrients, the corals become bleached and slowly die, also affecting the other species living among such corals. ${ }^{89}$

Migration of marine living resources consequently forces the activities for their exploitation to adapt and move to other regions, ${ }^{90}$ where exploitation mechanisms and fishing techniques might affect habitats that had so far been untouched. In fact, "[s]hifts in species distributions are leading to the redistribution of fisheries resources, resulting in substantial reduction in potential catches in tropical oceans [...], but increased catches - particularly of warmer-water species - in high-latitude regions". ${ }^{11}$ This is only one example of the potential impacts of environmental changes on fish stocks and fishing activities. These impacts once again illustrate the interconnectedness of species and their habitats, and the interconnectedness of human activities and the marine environment.

\subsection{The open-access nature of fisheries in $\mathrm{ABNJ}$}

As observed by Lodge et al, "[u]ntil comparatively recently, the legal regime for high seas fisheries was based on two fundamental premises: (a) the impossibility of the high seas being subject to effective occupation and (b) the inexhaustible nature of marine fishery resources". ${ }^{92}$ The latter premise has since clearly been refuted, the depletion of fish stocks being an obvious reality. The former premise, however, still stands, but requires some nuanced discussion.

89 On the impact of climate change on fisheries, see, generally, Rosemary Rayfuse, "Addressing Climate Change Impacts in Regional Fisheries Management Organizations" in Richard Caddell \& Erik Molenaar (eds), Strengthening International Fisheries Law in an Era of Changing Oceans (Oxford: Hart, 2019) $247-$ 267; Solene Guggisberg, "Funding coastal and marine fisheries projects under the climate change regime" (2019) 107 Marine Policy article 103352; and Tim Stephens, "Warming Waters and Souring Seas: Climate Change and Ocean Acidification" in Donald Rothwell et al (eds), Oxford Handbook on the Law of the Sea (Oxford: Oxford University Press, 2015) 777-798.

90 See e.g. Berkes et al, supra note 33 at 1557; Richard Caddell, "Precautionary management and the development of future fishing opportunities: The international regulation of new and exploratory fisheries" (2018) 33 International Journal of Marine and Coastal Law 199-260 at 200.

91 William Cheung, Vicky Lan \& Collette Wabnitz, "Future scenarios and projections for fisheries on the high seas under changing climate" (2019) IIED Working Paper at 9. See also William Cheung, Reg Watson \& Daniel Pauly, "Signature of ocean warming in global fisheries catch" (2013) 497 Nature 365-368.

92 Michael Lodge et al, Recommended Best Practices For Regional Fisheries Management Organizations. Report of an Independent Panel to Develop a Model for Improved Governance by Regional Fisheries Management Organizations (London: The Royal Institute of International Affairs Chatham House, 2007) at 2, citing Francisco Orrego Vicuna, The changing international law of high seas fisheries (Cambridge: Cambridge University Press, 1999) at 4-5, and Michael Lodge, "Review of Factors of Unsustainability in Fisheries: Relationship to International Fisheries Instruments" (Paper prepared for the FAO Workshop on Factors of Unsustainability and Overexploitation in Fisheries, Bangkok, Thailand, 4-8 February 2002). 
In fact, the impossibility of the high seas being subject to effective occupation leads back to qualifying the high seas as res communis, belonging to everyone and being a potential source of benefit for all. Indeed, as stated by Judge De Castro in his separate opinion in the Fisheries Jurisdiction Case (UKv Iceland), the use of the high seas is common, including fishing activities. ${ }^{93}$ The open access to high seas resources therefore flows from the area being a global common, i.e. a resource domain or area that contains resource units to which all have, theoretically, equal access. ${ }^{94}$

From the reality of open access can ensue (over)exploitation; this is an illustration of Hardin's concept of the "tragedy of the commons", 95 where individual actors, if acting in their own self-interest in the exploitation of a common resource, will deplete or damage such a resource. ${ }^{96}$ The open access concept is the basis of the current regime for high seas fisheries, ${ }^{97}$ rooted in the freedom of fishing. ${ }^{98}$ This is "[o]ne of the main reasons for [the regime's] inability to sufficiently address the degradation of the marine environment", 99 including fish stocks. Consequently, more stocks available in open access would lead to less sustainability. ${ }^{100}$ However, the tragedy plaguing fisheries not only comes from the actions of actors exploiting them, but also from the nature of fisheries themselves: "harvests are rivalrous, fish are fugitive (sic) and thus are difficult to 'own' and manage, and fisheries are subject to irreducible uncertainties". ${ }^{101}$

There are two "traditional" ways of confronting negative impacts stemming from this open access: privatization and State control through regulation. ${ }^{102}$ Under the former, property rights are created over the resource and/or over the area they are in. The owner, theoretically wanting to ensure the benefits that stem from the resource, will protect his share. ${ }^{103}$ In the realm of fisheries, the creation of the EEZ was a way of giving "ownership" to coastal States of what used to be high seas areas, coastal States which now have the right to exclude vessels from fishing in their

93 Fisheries Jurisdiction Case (UK v Iceland), Separate Opinion of Judge de Castro, (1974) ICJ Rep 72 at 81, cited in Valérie Wyssbrod, Lexploitation des ressources génétiques marines hors juridiction nationale (Leiden: Brill Nijhoff, 2018) at 49.

94 Bosselman, supra note 45 at 71,73 .

95 Garrett Hardin, "The Tragedy of the Commons" (1968) 3859 Science 1243-1248 at 1244. See also Donald Rothwell \& Tim Stephens, The International Law of the Sea (Oxford: Hart, 2016) at 315.

96 See, e.g. Okonkwo, supra note 45 at 74.

97 See, e.g. Robin Churchill \& Vaughan Lowe, The law of the sea, 3rd ed (Manchester: Manchester University Press, 1999) at 281; Otto Spijkers \& Natalia Jevglevskaja, "Sustainable Development and High Seas Fisheries" (2013) 9:1 Utrecht Law Review 24-37 at 28; Wyssbrod, supra note 93 at 53.

98 UNCLOS at arts. 87(1)(e) and 116.

99 Tladi, supra note 42 at 659.

100 See, e.g. White \& Costello, supra note 53; Okonkwo, supra note 45 at 75; Klaus Bosselman, “Conclusion: Governing the Commons - Can States Be Trustees?” in Laura Westra, Janice Gray \& Antonio D’Aloia (eds), The Common Good and Ecological Integrity Human Rights and the Support of Life, (Abingdon, Oxon: Routledge, 2016) 267-283 at 270; Lodge et al, supra note 92 at 1.

101 R. Quentin Grafton, James Kirkley \& Dale Squires, Economics for Fisheries Management (Abingdon, Oxon: Routledge, 2006) at 2, discussed in Rothwell \& Stephens, supra note 95 at 315.

102 Elinor Ostrom, Governing the Commons. The Evolution of Institutions for Collective Action (Cambridge: Cambridge University Press, 1990) at 1 . See also Berkes et al, supra note 33 at 1557-1558.

103 Ostrom, supra note 102 at 12-13. 
"property" and take other prevention measures. ${ }^{104}$ This has, however, had adverse effects on areas beyond those covered under this "ownership"; in fact, the expansion of domestic efforts in the EEZ has pushed third States further on to the high seas. ${ }^{105}$

The second way to approach the open-access nature of the high seas is through State regulation. ${ }^{106}$ The legal framework described below illustrates this form of State-control: a set of rules and principles aiming to avoid, or at least limit, the overexploitation of the resources found in a part of the commons and other damage that can ensure from this exploitation. ${ }^{107}$ This regulation can take different forms, for example a complete ban on the exploitation of the resource (e.g. the moratorium on whaling) or a limitation on the extent to which the commons are used (e.g. rules on access to water such as when and where fishing activities can take place, fishing quotas in certain areas)..$^{108}$

The current "regulated yet open access" fisheries in ABNJ can be seen as the coexistence of two commonalities: the common interest in resource exploitation, and the common concern for the well-being of the environment. ${ }^{109}$ The goal sought by the principle of common concern is to tackle global and interdependent issues where international cooperative action is needed, ${ }^{110}$ triggering the common responsibility of taking appropriate measures to protect and preserve the marine environment. ${ }^{111}$ These ideas of commonality often raise tensions with traditional concepts of international law rooted in national interests, such as sovereignty or borders, which are now constantly challenged because of (emerging) global environmental issues. ${ }^{112}$ Yet, the principle of common concern has found its way into some treaties, especially in environmental treaties, ${ }^{113}$ and can be considered

104 This has, however, led to problems of overexploitation of fish stocks in the EEZ, creating a tragedy of the commons under national jurisdiction, see Richard Barnes, Property Rights and Natural Resources (Oxford: Hart, 2009) at 5 [Barnes, Property Rights].

105 Ibid at 1-2.

106 Ostrom, supra note 102 at 9-11; Okonkwo, supra note 45 at 74; Churchill \& Lowe, supra note 97 at 283. States can also regulate their own "property", i.e. their EEZ, but the regulations discussed in this paragraph refer to high seas areas.

107 From regulations also flow fisheries management measures, such as rules on access to water or technical measures, which can limit the exploitation or assist in the allocation of resources.

108 Bosselman, supra note 45 at 82; Barnes, Property Rights, supra note 104 at 6.

109 Atsuko Kanehara, "What Does a New International Legally Binding Instrument on Marine Biological Diversity of Areas Beyond National Jurisdiction 'under the UNCLOS’ Mean?” (2016) 59:4 Sophia Law Journal 53-73 at 65-71.

110 Konrad Marciniak, “The notion of 'the commons' in the current negotiations concerning the New Implementing Agreement under UNCLOS” (Presentation delivered at the Interest group on the Law of the Sea of the Annual Conference of the European Society of International Law, Naples, 6 September 2017); Bosselman, supra note 45 at 79-81.

111 Rayfuse \& Warner, supra note 43 at 410. See also Alex Oude Elferink, "Governance Principles for Areas Beyond National Jurisdiction” (2012) 27 International Journal of Marine and Coastal Law 205-259 at 243-244.

112 Seline Trevisanut, "Unsustainable International Law" (Inaugural lecture delivered at Utrecht University, 4 April 2019); Sustainable Ocean Project, "Sovereignty, a shape-shifting concept in ocean governance? Report on the Expert Workshop" (2019) 2 NILOS Paper Series at 5-6.

113 UNFCCC at preamble, which states that "climate change is a common concern of human kind"; CBD at preamble. 
as being accommodated under others, e.g. the obligations to protect the marine environment or the concept of common heritage of mankind under UNCLOS. ${ }^{114}$

It is this balance between common interest and common concern that we must tackle to find the most effective regulatory alternatives to open access. This chapter now turns to assessing the coexistence between exploitation and environmental protection that has shaped and is still shaping the legal framework of international and high seas fisheries law.

\section{HIGH SEAS FISHERIES LAW: AT THE CROSSROADS BETWEEN LAW OF THE SEA AND ENVIRONMENTAL LAW}

The law of the sea was initially developed to regulate spaces and activities, and is the result of a delicate balance between various national interests. ${ }^{115}$ Within its central instrument, UNCLOS, constructed around zonal and sectoral approaches, fisheries are first and foremost seen as an activity for the exploitation of resources, and fisheries law as the way to regulate that activity, according to the maritime zone in which the activity takes place. ${ }^{116}$ Although fisheries are also addressed under UNCLOS from the perspective of their conservation, Proelss and Houghton have observed that " $\mathrm{t}]$ raditonally, marine species protection has merely constituted a side-effect of exploitation-oriented instruments". ${ }^{117}$

The regulation of high sea fisheries has undergone changes which "occurred simultaneously with corresponding changes in circumstances and interests". ${ }^{118}$ From an unconditional freedom of fishing, to reasonable use, to improved conservation based on the expansion of national claims to maritime zones, and to the need to balance common and individual interests in exploitation, ${ }^{119}$ this evolution has also influenced the development of regulatory instruments targeting high seas fisheries.

114 Sustainable Ocean Project, supra note 112 at 5-6. The common heritage of humankind confronts the open-access nature of the deep seabed as global commons, see e.g. Wyssbrod, supra note 93 at 53 . The objective of the common heritage is one of distributive justice regarding the benefits obtained from the exploitation of resources beyond national jurisdiction, see Marciniak, supra note 110; Bosselman, supra note 45 at 75-79. Under UNCLOS, the common heritage is applicable to resources of the Area, see UNCLOS at art. 136. Yet, it is not applicable to fisheries in the context of commercially exploitable fish stocks. It is, however, raised within the question of exploiting fish as a marine genetic resource and how this activity fits within the debate setting freedom of the high seas against the common heritage of humankind principle. This has been the subject of lively debates within the BBNJ process. This question is addressed in the chapter 4 below, but an extensive discussion on fish as a source of MGRs falls outside the scope of this study.

115 Richard Barnes, "The Convention on the Law of the Sea: An Effective Framework for Domestic Fisheries Conservation?" in David Freestone, Richard Barnes \& David Ong (eds), The Law of the Sea. Progress and Prospects (Oxford: Oxford University Press, 2006) 233-260 at 237 [Barnes, "Domestic Fisheries Conservation"].

116 Proelss \& Houghton, supra note 6 at 231; Pascale Ricard, La conservation de la biodiversité dans les espaces maritimes internationaux. Un défi pour le droit international (Paris: Pedone, 2019) at 27 and 150.

117 Proelss \& Houghton, supra note 6 at 229.

118 Orrego Vicuña, supra note 1 at 24.

119 Ibid. 
In fact, the regulation of fisheries management on the high seas is not limited to UNCLOS, or to law of the sea instruments. Following the approach defended in this study that species exploitation is interconnected with the wider marine environment and biodiversity related concerns, it is submitted that international fisheries law also comprises instruments of international environmental law as well as biodiversity law instruments. ${ }^{120}$

To understand better this connection between the law of the sea and environmental law, how they have evolved, on their own and together, in shaping international fisheries law, ${ }^{121}$ and what lacunae remain, this section revisits the extensive and complex framework covering international and high seas fisheries. ${ }^{122}$ Although this portrait is only illustrative and not exhaustive, it starts by describing instruments, both binding (3.1) and non-binding (3.2), of relevance for regulatory purposes. ${ }^{123}$ It then moves on to presenting the main actors operationalizing such instruments (3.3). It is to be noted that this portrait focuses on instruments and structures that present an intergovernmental component (e.g. binding treaties adopted between States, or instruments adopted under the auspices of the UN or intergovernmental conferences). ${ }^{124}$

However, the assessment of the legal framework for the management of fisheries on the high seas must be seen in the context of the nature of the issue regulated, "the availability of instruments and institutions, [the] regulatory culture and [the] governance discourse". ${ }^{25}$ This is why

[f] isheries regulation is in part the product of the physical nature of the resource base and the ocean environment, in part the product of historical factors that

120 On the links between the law of the sea and environmental/biodiversity law, see Ricard, supra note 116 at 3-4.

121 See Kanehara, supra note 109 at 54, who talks about the role of treaties and organizations in the development of regulations and their implementation on the high seas.

122 For a comprehensive account of how fisheries are addressed by different structures and agency within the UN system, see Lori Ridgeway, "Key global institutions, bodies and processes: Roles, participation and main focus" in Serge Garcia, Jake Rice \& Anthony Charles (eds), Governance of marine fisheries and biodiversity conservation: Interaction and Coevolution (Hoboken: Wiley, 2014) 462-495. For a brief overview of legal and policy frameworks regarding marine biodiversity in areas ABNJ, see DOALOS, "Marine biological diversity of areas beyond national jurisdiction. Legal and policy framework" online: $<$ https://www.un.org/depts/los/biodiversityworkinggroup/webpage_legal_and_policy.pdf>.

123 Many of the fisheries and environment-related instruments and institutions discussed below are also addressed in Yoshinobu Takei, "Demystifying Ocean Governance" in Seline Trevisanut, Nikolaos Giannopoulos \& Rozemarijn Roland Holst (eds), Regime Interaction in Ocean Governance. Problems, Theories and Methods (Leiden: Brill Nijhoff, 2020) 22-51 at 26-38, who attempts to "illustrate the diversity of instruments and institutions and the interaction of these institutions for the governance of oceanrelated activities", see at 27. Further, although the present chapter categorizes the instruments discussed according to their legally binding or non-legally binding nature, such a typology might overlook subtle differences, as instruments might present elements of both a legally and a non-legally binding nature, see Takei at 30 .

124 This focus is justified by the fact that the current regulation and management of fisheries on the high seas rest mostly under the purview of State-based instruments and organizations.

125 Richard Barnes, “The Pursuit of Good Regulatory Design Principles in International Fisheries Law. What Possibility of Smarter International Regulation?" in Judith van Erp et al (eds), Smart Mixes for Transboundary Environmental Harm (Cambridge: Cambridge University Press, 2019) 97-125 at 100. 
have emerged from an iterative process of regulation and reaction (bricolage), and in part the product of un-orchestrated or diffusely orchestrated social and political processes. Cumulatively, these have generated a complex picture of fisheries regulation. ${ }^{126}$

These context-embedded elements need to be kept in mind when reflecting on how the instruments or entities addressed below relate to and/or influence the interaction between the law of the sea and international environmental law, and how they address the threats discussed in section 2.2 above.

\subsection{Legal framework - legally binding instruments}

This first section focuses on legally binding instruments that shape the legal framework of international and high seas fisheries. It starts by looking at the provisions for fisheries management and protection of the marine environment under UNCLOS, with a focus on ABNJ (3.1.1). However, as discussed above, "[g] iven the inability of UNCLOS to prevent the adverse impacts of fisheries on the marine environment, action has had to be taken in other fora to try to mitigate such impacts". ${ }^{127}$ This is why this section takes into consideration two other central instruments for the regulation of fisheries, biodiversity and the marine environment: the 1995 UNFSA, which implements UNCLOS provisions on straddling and migratory fish stocks (3.1.2), and the $1992 \mathrm{CBD}$, the first convention to comprehensively address the question of the conservation of biodiversity and the sustainable use of its components (3.1.3). The section then moves on to addressing other legally binding instruments that "are either directly meant to regulate fisheries or which can be used to do so" (3.1.4 to 3.1.8). ${ }^{128}$ These subsequent instruments are addressed in chronological order of adoption.

\subsubsection{United Nations Convention for the Law of the Sea (UNCLOS)}

UNCLOS is often characterized as "[ $\mathrm{t}]$ he most important instrument in the modern law of the sea". ${ }^{29}$ Understanding its framework is therefore fundamental in grasping the role it plays in addressing fisheries and the protection of the marine environment. ${ }^{130}$ However, regarding the regulation of fisheries, the framework developed in UNCLOS targets mainly fisheries in the EEZ, something that "is quite understandable bearing in mind that about 90 per cent of the commercially exploited fish stocks" are found in that maritime zone, which seems to relegate the

126 Ibid at 100-101.

127 Churchill, supra note 35 at 34.

128 Guggisberg, The Use of CITES, supra note 9 at 29.

129 Harrison, Saving the Oceans, supra note 10 at 17.

$130 \mathrm{Ibid}$ at 18 . 
coverage of high seas fisheries to a vaguer, less developed status. ${ }^{131}$ The framework for high seas fisheries is also less developed simply because the EEZ was the main interest during UNCLOS negotiations, due to the remoteness of high seas areas. ${ }^{132}$ This does not mean, however, that high seas fisheries are completely absent from UNCLOS, as demonstrated through Part VII of UNCLOS. Part VII addresses the conservation and management of living resources of the high seas (3.1.1.1). Part XII, on the protection of the marine environment, also contains provisions that are of interest for the purpose of the present analysis (3.1.1.2). ${ }^{133}$ This section then looks into the interaction between fisheries and marine environmental protection under UNCLOS (3.1.1.3), as well as the evolutionary capacity of the Convention with regard to this interaction (3.1.1.4).

\subsubsection{Part VII: rights and obligations on the high seas}

Part VII, presenting the framework applicable to the high seas, is relevant for fisheries as it establishes the general rights and duties of States in conducting fishing activities and in regulating them. Article 87(1)(e) first provides the general rule that fishing is one of the freedoms of the high seas. This freedom, however, is conditional ${ }^{134}$ on two main elements: first, the duty to exercise this freedom with due regard for the interests of other States in their exercise of the freedom of the high seas, ${ }^{135}$ and, second, the provisions laid down in Section 2 of Part VII, ${ }^{136}$ addressing the conservation and management of the living resources of the high seas.

Under Section 2 of Part VII, article 116 elaborates on the general right of all States to fish on the high seas, ${ }^{137}$ subject to their treaty obligations, including the other obligations found in Section 2 of Part VII. The right to fish is also subject to the rights, duties and interests of the coastal States. These rights, duties and interests of coastal States target first the taking of conservation measures, directly by the

131 Erik Franckx, “The Protection of Biodiversity and Fisheries Management: Issues Raised by the Relationship between Cites and LOSC" in David Freestone, Richard Barnes \& David Ong (eds), The Law of the Sea: Progress and Prospects (Oxford: Oxford University Press, 2006) 210-232 at 210; Matley, supra note 63 at 104, also refers to Barbara Kwiatkowska, "The high seas fisheries regime: at a point of no return?” (1993) 8:3 International Journal of Marine and Coastal Law 327-358 at 327, who defines the high seas fisheries regime under UNCLOS as an "unfinished business".

132 Are Sydnes, "Regional Fishery Organizations: How and Why Organizational Diversity Matters" (2001) 32:4 Ocean Development and international law 349-372 at 352.

133 See, e.g. Gjerde, "High Seas Fisheries Management", supra note 37 at 291.

134 The notion of conditional freedom of the high seas is also discussed in chapter 3 section 3.1.1 below, also referred to as the principle of the "respect for the law of the sea".

135 The content of due regard in the context of art. 87 "is, at best, unclear", see Douglas Guilfoyle, "Article 87. Freedom of the high seas" in Alexander Proelss (ed), United Nations Convention on the Law of the Sea. A Commentary (Munich: Verlag C. H. Beck, 2017) 678-682 at 681. It would, however, refer to a balancing of interests in the uses of the seas, equivalent to the balancing of rights and interests in the EEZ provided by the due regard obligation under arts. 56(2) and 58(3) UNCLOS. The notion of due regard is also discussed in chapter 3 section 3.1 .1 below.

136 UNCLOS at arts. 116-120.

137 See, e.g. Wyssbrod, supra note 93 at 136; Harrison, Saving the Oceans, supra note 10 at 173; Proelss \& Houghton, supra note 6 at 238. 
coastal State or through regional organizations, for stocks migrating between its EEZ and the high seas, ${ }^{138}$ and, second, for certain species, i.e. highly migratory species, marine mammals, as well as anadromous and catadromous stocks. ${ }^{139}$ The framework for the conservation of marine mammals in the EEZ found under article 65 is equally applicable to the high seas, as stated under article 120.

Article 117 is the first of three articles explaining how to fulfil the obligation to conserve living resources. ${ }^{140}$ It refers to the duty of all States to take measures to control the activities of their nationals "as may be necessary for the conservation of living resources". This duty refers to both the adoption and enforcement of measures, as mentioned by the ICJ in the Fisheries Jurisdiction Case (Spain v Canada). ${ }^{141}$ This duty also includes a component of cooperation, where States are called upon to "cooperate with other States in taking" the necessary measures for conservation.

Article 118 elaborates on this duty of cooperation. While the first part provides a general duty for States to cooperate with each other, it is subsequently refined, by mentioning that States "exploiting identical living resources, or different living resources in the same area, shall enter into negotiations with the view to taking the measures necessary for the conservation" and that, as appropriate, they must "cooperate to establish subregional or regional fisheries organizations to this end". This last element therefore provides for the creation of the institutional framework for fisheries management, i.e. RFMOs. ${ }^{142}$ The importance of cooperation in the management of fisheries was recognized by the ICJ in the Fisheries Jurisdiction Case (UK $v$ Iceland) as including "a recognition of a duty to have due regard to the rights of other States and the needs of conservation for the benefit of all". ${ }^{143}$ The duty of cooperation was later on reiterated and relied upon by ITLOS in the Southern Bluefin Tuna Cases, highlighting the necessity of the parties to cooperate in the management of the resource. ${ }^{144}$ This obligation of cooperation, further strengthened under the UNFSA, ${ }^{145}$ remains vague however, and is thus hardly enforceable. ${ }^{146}$

138 UNCLOS at art. 63(2).

139 Ibid at arts. 64-67. This shows the species approach adopted by UNCLOS, see Orrego Vicuña, supra note 1 at 27.

140 Rosemary Rayfuse, "Article 117. Duty of States to adopt with respect to their national measures for the conservation of the living resources of the high seas" in Alexander Proelss (ed), United Nations Convention on the Law of the Sea. A Commentary (Munich: Verlag C. H. Beck, 2017) 803-817 at 805 [Rayfuse, "Article 117 "].

141 Fisheries Jurisdiction (Spain v Canada), Jurisdiction of the Court, (1998) ICJ Rep 432 at para 84.

142 Rayfuse, "Article 117", supra note 140 at 819; Wyssbrod, supra note 93 at 136.

143 Fisheries Jurisdiction Case (UK v Iceland), supra note 93 at 31 (and cited again in Fisheries Jurisdiction Case (Spain v Canada), supra note 141 at para 93), discussed in Lodge et al, supra note 92 at 5-6.

144 Southern Bluefin Tuna Cases (New Zealand v. Japan; Australia v. Japan), Provisional Measures, (1999) ITLOS cases $3 \& 4$ at paras 48,72 and 78.

145 A discussion on the obligations under the UNFSA is conducted under section 3.1.2 below.

146 Guggisberg, The Use of CITES, supra note 9 at 119. 
Article 119, for its part, represents the core of the duty of conservation, as it is the provision limiting the freedom of fishing for the purpose of conservation. ${ }^{147}$ It underlines elements to be taken into consideration when undertaking conservation measures. As observed by Rayfuse:

[s] everal key elements of Art. 119 are found essentially verbatim in Art. 61 on the conservation of living resources within the [EEZ], namely: the determination of the allowable catch on the basis of the best scientific evidence available; the designation of measures to maintain or restore populations of harvested species at levels that can produce the MSY, as qualified by relevant environmental and economic factors including the special requirements of developing States; the need to take into account fishing patterns; the interdependence of stocks and any generally recommended international minimum standards; and the obligation to contribute and exchange available scientific information on a regular basis through international organisations. ${ }^{148}$

Non-discriminatory and transparent measures can also be added to this list. ${ }^{149}$ It has also been suggested that article 119 could be complemented by provisions found under non-legally binding instruments, as they would fall under the international minimum standards provided for in the wording of the article. ${ }^{150}$

This brief overview of the rights and obligations found under Section 2 of Part VII underlines that the duty of cooperation for the conservation of marine living resources is enshrined in UNCLOS. However, its formulation remains vague, without imposing the adoption of specific measures. ${ }^{151}$ Furthermore, there is uncertainty as to the existence of an obligation to prevent overexploitation on the high seas. In fact, article 119 refrains from directly referring to the need to prevent overexploitation. ${ }^{152}$ This represents a stark contrast with article 61, the equivalent provision for the EEZ. Paragraph 3 of article 61 deals with the necessity to restore populations at levels which can produce MSY, by relying on economic and environmental factors. This obligation is reproduced in article 119(1)(a). A similar equivalence regarding the maintenance and restoration of populations of non-target species (article 61(4)) is found under article 119(1)(b). However, the equivalent of paragraph 2 of article 61, which refers to overexploitation, is not found under article 119. The question that therefore arises is whether the duty to avoid overexploitation can be considered as being included in the duty to restore populations, or whether, as under article

147 Churchill, supra note 35 at 30; Harrison, Saving the Oceans, supra note 10 at 173.

148 Rosemary Rayfuse, "Article 119. Conservation of the living resources of the high seas" in Alexander Proelss (ed), United Nations Convention on the Law of the Sea. A Commentary (Munich: Verlag C.H. Beck, 2017) 830-850 at 832-833 [Rayfuse, "Article 119"].

149 Orrego Vicuña, supra note 1 at 29.

150 UNCLOS at art. 119(1)(a), discussed in Harrison, Saving the Oceans, supra note 10 at 180.

151 Wyssbrod, supra note 93 at 137. On the absence of mandatory measures, see also Rayfuse, "Article 119", supra note 148 at 833 .

152 Proelss \& Houghton, supra note 6 at 238, relying on Patricia Birnie, Alan Boyle \& Catherine Redgwell, International Law of the Environment, 3rd ed (Oxford: Oxford University Press, 2009) at 720-721. 
61 , the two obligations must be dealt with separately. While it could reasonably be concluded that the implementation of the duty to restore populations should also be understood as resulting in the absence of overexploitation or in the adoption of additional measures if overexploitation still were to occur, there is currently no clear answer regarding the impact of the absence of a direct reference to overexploitation under article $119 .^{153}$

\subsubsection{Part XII: rights and obligations for the protection and preservation of the marine environment}

The relevance of UNCLOS for the marine environment can also be seen through its Part XII, addressing the protection and preservation of the marine environment. Part XII is considered to be a comprehensive framework, addressing all sources of pollution, ${ }^{154}$ applying to the entirety of the marine environment, ${ }^{155}$ and formulating different types of obligations. ${ }^{156}$ The obligations under Part XII are now considered to refect customary obligations. ${ }^{157}$ The duty to fulfil such obligations "appl[ies] to States irrespective of where the alleged harmful activities took place" 158 and "[is] not in any way dependent upon, which State is sovereign over" 159 a feature or an area.

Part XII presents a strong protection framework in many respects. It has been said that UNCLOS "effectue donc une rationalisation de l'obligation [de conservation], dans le sens où elle regroupe les différentes composantes jusqu'alors éparses de cette obligation dans un même instrument, permettant une appréhension cohérente de

153 The different wording between arts. 61 and 119 could also simply be the result of a different interest in and understanding of the different zones at the time of negotiating UNCLOS, and not of a difference in the legal obligations stemming from the provisions. In fact, in the 1970s, less high seas fisheries activities were conducted due to technical and physical limitations in accessing high seas stocks. The EEZ, for its part, was recognized as a new, extended exclusive fishing zone. The express reference to the duty to avoid overexploitation under art. 61 could therefore be seen as a counter-balance to the extension of fishing rights: if coastal States are given a larger exclusive fishing zone and, consequently, extended exclusive fishing rights, such rights should come with a specific obligation to avoid overexploitation. The express reference to overexploitation under art. 61 could also be seen as a counter-balance to the duty of optimum utilization in the EEZ found under art. 62(1) UNCLOS.

154 UNCLOS at art. 194(3).

155 Kristina Gjerde, "Enhancing integrated management beyond national jurisdiction under the environmental provisions of the UN Convention on the Law of the Sea" in Marta Chantal Ribeiro (ed) 30 Years After the Signature of the United Nations Convention on the Law of the Sea: The Protection of the Environment and the Future of the Law of the Sea. Proceedings of the International Conference (Coimbra: Coimbra Editora, 2014) 441-452 at 445-446 [Gjerde, "Enhancing integrated management"].

156 See Harrison, Saving the Oceans, supra note 10 at 17-42, who presents UNCLOS as a jurisdictional framework, as a source of general principles, of substantial obligations, and of procedural obligations, as a framework for future normative development, and as a dispute settlement regime.

157 See, e.g., Philippe Sands \& Jacqueline Peel, with Adriana Fabra \& Ruth MacKenzie, Principles of International Environmental Law, 4th ed (Cambridge: Cambridge University Press, 2018) at 462, who also mention that this customary status is referred to in the preamble to the OSPAR Convention, infra note 594, which reads "recalling the relevant provisions of customary international law reflected in Part XII of [UNCLOS]". OSPAR is discussed in further detail in section 3.3.4 below.

158 The South China Sea Arbitration (The Republic of the Philippines $v$ The People's Republic of China), Award, (2016) PCA case 2013-19 at para 927.

159 Ibid at para 940, see also at para 927. 
ces différentes obligations ainsi que leur consécration". ${ }^{160}$ First, article 192 states the general obligation to protect and preserve the marine environment. Second, article 194, for its part, specifies the measures that States must take, individually or jointly, to prevent, reduce and control pollution in the marine environment. ${ }^{161}$ Paragraph 5 of that article is of particular interest for the present study, as it provides the protection of rare and fragile ecosystems, as well as certain habitats. This therefore offers a direct protection to certain marine habitats that could be threatened by fishing activities. ${ }^{162}$ While the title of article 194, referring to protection from pollution, could lead to the understanding that ecosystems and habitats referred to under paragraph 5 would be protected only from interference stemming from pollution, the arbitral tribunal in the Chagos Arbitration specified that all forms of interference are targeted by the provision, not only pollution. ${ }^{163}$ In the South China Sea Arbitration, the tribunal further mentioned that the general obligation of article 192 not only includes an obligation to protect the marine environment, but also to take active steps to "improv[e] its present condition" ${ }^{164}$ Read together with article 194(5) and other obligations under the $\mathrm{CBD},{ }^{165}$ this statement of the tribunal could even trigger the possibility of the emergence of an obligation of restoration. ${ }^{166}$ Third, the general obligations found under articles 192 and 194 are complemented by article 193, which is often seen as a predecessor to the concept of sustainable use, since its text links the exploitation of natural resources to the "duty to protect and preserve the marine environment".

In terms of the specific obligations of Part XII, a selected number can be considered of particular importance in relations to high seas fisheries. First, article 197 presents a clear duty to cooperate, ${ }^{167}$ which, in the context of fisheries, is to be read in conjunction with article 118. States are called upon to cooperate on a global and regional basis, directly among themselves or through competent international organizations. This express reference to international organizations makes it clear that fisheries management bodies, such as RFMOs, and organizations whose

160 "therefore effectuates a rationalisation of the obligation of conservation, in the sense that it contains the different components of the obligation, until then scattered, in one instrument, allowing a coherent understanding of these different obligations as well as their enshrinement in the law" (free translation), Ricard, supra note 116 at 269.

161 For an overview of measures with a particular application to ABNJ, see Katharina Rogalla von Bieberstein et al, "Governance of areas beyond national jurisdiction for biodiversity conservation and sustainable use. Institutional arrangements and cross-sectoral cooperation in the Western Indian Ocean and the South East Pacific" (2017) UNEP-WCMC at 28.

162 Churchill, supra note 35 at 30-31; Harrison, Saving the Oceans, supra note 10 at 173.

163 Chagos Marine Protected Area Arbitration (Mauritius v. United Kingdom), Award, (2015) PCA case 2011-03 at para 320, discussed in Churchill, supra note 49 at 21.

164 South China Sea Arbitration, supra note 158 at para 941.

165 The CBD is discussed in section 3.1.3 below.

166 See, generally, James Harrison, "The Protection of Species, Ecosystems and Biodiversity Under UNCLOS in Light of the South China Sea Arbitration: An Emergent Duty of Marine Ecosystem Restoration?" (2019) Edinburgh School of Law Research Paper No. 2019/20, online: <https://papers.ssrn.com/sol3/ papers.cfm?abstract_id=3388657>.

167 The MOX Plant Case (Ireland v United Kingdom), Provisional Measures, (2001) ITLOS case 10 at para 82; Gjerde, "Enhancing integrated management", supra note 155 at 446. 
mandate primarily focuses on marine conservation, e.g. RSPs, fall under the scope of the provision, and are therefore part of the broader framework for marine environmental protection.

Article 206, for its part, refers to the procedural obligation of conducting an impact assessment before engaging in a new activity that may cause a harmful change to the marine environment. ${ }^{168}$ For already existing activities, a duty of monitoring such activities normally applies, as per article 204(2), the wording of which does not suggest any limitation as to what sorts of activities it applies to. This more specific obligation targeting activities complements the general obligation of monitoring "the risks or effects of pollution of the marine environment" under the first paragraph of article 204. The requirement to conduct an impact assessment for fisheries activities is normally requested for new or exploratory fisheries, as detailed in subsequent instruments building on the general duty of article 206. ${ }^{169}$ For existing established fisheries, assessments are done mostly for data collection and monitoring purposes, building on the general duty of monitoring under article $204 .{ }^{170}$

Section 5 of Part XII addresses, one by one, sources of pollution: from land-based sources (article 207), from seabed activities within national jurisdiction (article 208), from activities in the Area (article 209), from dumping (article 210), from vessels (article 211), and from/through the atmosphere (article 212) ${ }^{171}$ Each provision calls upon States to prevent pollution from the listed sources by adopting laws and regulations, by taking other measures of prevention, and by harmonizing policies. They also call upon States to act through the appropriate international organizations or diplomatic conferences covering the issue. Section 6 of Part XII, for its part, ensures that States must enforce the laws, regulations and other measures undertaken under Section 5. ${ }^{172}$ The pollution framework found under UNCLOS remains a residual one, because obligations to prevent pollution are found under many other specialized instruments. ${ }^{173}$

\subsubsection{How do fisheries and environmental protection interact under UNCLOS?}

The above discussion on the regimes for fisheries management and conservation on the high seas, coupled with the understanding of the most relevant provisions for environmental protection applicable in ABNJ found under UNCLOS, shows

168 Gjerde, "Enhancing integrated management", supra note 155 at 447.

169 See, e.g., UNFSA at art. 6(6). The UNFSA is discussed in further detail in section 3.1.2 below.

170 The different mechanisms for impact assessment, both for new/exploratory and ongoing/existing fisheries, are discussed in further detail in chapter 3 section 4.2 .2 below.

171 Gjerde, "Enhancing integrated management", supra note 155 at 446.

172 Ibid at 447.

173 See, e.g. International Convention for the control and management of ship's ballast water and sediments (13 February 2004, entered into force 8 September 2017) UNTS No. 55544; Annex IV to the Protocol on Environmental Protection to the Antarctic Treaty, Marine Pollution (4 October 1991, 14 entered into force January 1998) 2941 UNTS 3. This last protocol falls under the mandate of CCAMLR, which is the only RFMO to have such a scheme regarding marine pollution. 
that the Convention contains various strongly established obligations. However, understanding how the exploitation of marine living resources can be seen in the broader context of its impact on the marine environment varies. The obligations found under Part XII apply to fishing activities in two different ways. On the one hand, fish stocks and other marine living resources form marine life, which in turn forms part of the marine environment. The general obligations of Part XII would consequently be applicable to fish stocks as part of the marine environment, ${ }^{174}$ and impose a duty to protect them. Similarly, the marine environment also includes non-target species and marine habitats. Impacts on these features through fishing activities would therefore constitute a violation of the duty to protect and preserve. The provision found under article 194(5), which provides for the protection and preservation of "rare or fragile ecosystems as well as the habitat of depleted, threatened or endangered species" is also of direct application to most fish stocks. ${ }^{175}$

On the other hand, however, it is more difficult to find legal grounds for the application of the obligations of Sections 5 and 6 (sources of pollution) to fisheries related activities. Fishing activities could potentially trigger the application of obligations related to pollution from vessels, ${ }^{176}$ for example through pollution stemming from the operation of fishing vessels. Fishing gear purposely thrown overboard could also fall under pollution by dumping, ${ }^{177}$ defined as the "deliberate disposal of wastes or other matter from vessels [...] at sea". ${ }^{178}$ Further, environmental changes that could stem from pollution created by the other above listed sources (e.g. pollution through the atmosphere ${ }^{179}$ ) have the potential to trigger modifications to fish stocks patterns and fishing activities which, in turn, could impact the marine environment.

Emerging trends also suggest that other forms of fishing techniques could be considered as falling under the definition of "pollution of the marine environment" because they amount to "the introduction by man, directly or indirectly, of substances or energy into the marine environment", and such practices "[result] or [are] likely to result in such deleterious effects as harm to living resources and marine life". ${ }^{180}$ Consequently, these practices would then trigger the application of the general obligations found under Section 1 of Part XII. For example, the use of chemicals for dynamite fishing could be considered as such an introduction of energy or substance. Similarly, the noise created by the dragging of nets or other fishing gear along the sea floor, or created by fishing vessels themselves, could also

174 Southern Bluefin Tuna Cases, supra note 144 at para 70. See also Rayfuse, “Article 119”, supra note 148 at 833.

175 For a recent analysis of the way Part XII, and more specifically arts. 192 and 194 UNCLOS, are applicable to the regulation of fishing, see Yoshifumi Tanaka, "Reflections on the Implications of Environmental Norms for Fishing: The Link between the Regulation of Fishing and the Protection of Marine Biological Diversity" (2020) 22 International Community Law Review 389-409.

176 UNCLOS at art. 211.

177 Ibid at art. 210.

178 Ibid at art. 1(1)(4)(a)(i). However, dumping would not include incidental disposal of waste, which means that a deliberate intent is required for the application of dumping related provisions.

179 Ibid at art. 212.

$180 \mathrm{Ibid}$ at art. 1(1)(4). 
amount to the introduction of a form of energy; however, pollution by noise in the fisheries context remains controversial. ${ }^{181}$

Orrego Vicuña further underlines that several obligations under Part XII do demonstrate the inclusion of an ecosystem approach within UNCLOS, for example through its preventive approach to marine pollution, the introduction of the notion of precaution (although not necessarily under these terms), and environmental impact assessments, to name but a few. However, these developments have not been sufficient to counter problems caused by fisheries on the high seas. ${ }^{182}$ In fact, despite this potential applicability of the obligations of Part XII to fishing activities, the regime for environmental protection under UNCLOS lacks specificity in light of the interconnectedness between fishing activities and the marine environment. To that end, the Convention has even been considered by Churchill as "almost completely useless to prevent the adverse impacts that fisheries have had on the marine environment". ${ }^{183}$ This is initially explained by the fact that UNCLOS is a framework convention, intended to be complemented by more specific obligations under separate instruments, while leaving discretion to States in terms of implementation. The vagueness of provisions, especially in terms of operationalization, ${ }^{184}$ might be one of the reasons for this alleged "uselessness" of UNCLOS.

It sometimes even seems that the two regimes are studied in parallel to one another, as witnessed by the "perceived fisheries-versus-environment debate", an issue that is dominating "the various global processes relating to fisheries". ${ }^{185}$ It is submitted that this is due to two main factors. First, it resides in the perspective of "conservation for exploitation" that is found throughout UNCLOS, i.e. stocks are to be conserved so that they can be further exploited. This is probably a relic of the 1958 Convention on Fishing and Conservation of the Living Resources of the High Seas, which defines "conservation of living resources on the high seas" as "the aggregate of the measures rendering possible the optimum sustainable yield from those resources so as to secure a maximum supply of food and other marine products. ${ }^{186}$ Indeed, the management and conservation of stocks is seen under UNCLOS in the sense of MSY, i.e. the largest average catch that can be captured without affecting the replacement rate of

181 On noise, see e.g. Alexander Gillepsie, "Noise Pollution, the Oceans, and the Limits of International Law" (2010) 21:1 Yearbook of International Environmental Law 114-139 at 125; Rob Williams et al, "Impacts of Anthropogenic Noise on Marine Life: Publication Patterns, New Discoveries, and Future Directions in Research and Management" (2015) 115 Ocean and Coastal Management 17-24, cited in Carole Durussel et al, "Strengthening Regional Ocean Governance for the High Seas: Opportunities and Challenges to Improve the Legal and Institutional Framework of the Southeast Atlantic and Southeast Pacific" (2018) STRONG High Seas Project at 51.

182 Orrego Vicuña, supra note 1 at 29.

183 Churchill, supra note 35 at 31.

184 Ricard, supra note 116 at 50-51. See also Churchill supra note 35 at 31-34.

185 Karsten Hoydal, David Johnson \& Alf Håkon Hoel, "Regional governance: The case of NEAFC and OSPAR" in Serge Garcia, Jake Rice \& Anthony Charles (eds), Governance of marine fisheries and biodiversity conservation: Interaction and Coevolution (Hoboken: Wiley, 2014) at 225-238 at 237.

186 Convention on Fishing and Conservation of the Living Resources of the High Seas $(29$ April 1958, entered into force 20 March 1966) 559 UNTS 285 at art. 2, discussed in Ricard, supra note 116 at 22. 
a stock, which is to be established relying on both environmental and also economic factors. This focus on optimal use does not necessarily include the consideration of the impacts of such use on the wider marine environment. ${ }^{187}$ Such an approach to fisheries management also depicts the dominant role played by economic norms. ${ }^{188}$

Second, UNCLOS, the primary instrument of the law of the sea regime, fails to directly include references to several concepts now considered to be pillars of environmental law, primarily because these concepts did not exist at the time of negotiating the Convention. ${ }^{89}$ The Convention was also set up as a framework of general, overarching guiding norms, not to provide a comprehensive set of detailed rules. ${ }^{190}$ Most environmental instruments, for their part, were developed in the 1990s, following the Rio Conference, and were constructed around these very concepts, which recognize the prime impacts incurred by the environment because of human activities. While UNCLOS presents a general framework for marine environmental protection, it is in these subsequent environmental instruments that more precise answers can be found for the application of fundamental environmental concepts to international and high seas fisheries law.

\subsubsection{The evolutionary capacity of UNCLOS}

Different mechanisms allowing for the adaptation and evolution of UNCLOS, and facilitating its connection with environmental law instruments ${ }^{191}$ are found in the text of the Convention, e.g. through the adoption of laws and regulations at the national level ${ }^{192}$ or of subsequent agreements within the scope of UNCLOS. ${ }^{193}$ The text of the Convention also accommodates obligations found under other instruments through various rules of reference. ${ }^{194}$ For example, article 237 refers to other conventions on the protection and preservation of the marine environment. This article creates a bridge with previous agreements, so as to maintain a respect for them. The article also encourages States to adopt and implement further measures on the basis of the obligations and principles found under UNCLOS, ensuring an

187 Churchill, supra note 35 at 31-32; Bosselman, supra note 45 at 86; Anastasia Telesetsky, “'Good Faith' Obligations to Protect and Preserve the Marine Environment: A Proposal on Uniform High Seas Fisheries Management" in Clive Schofield, Seokwoo Lee \& Moon-Sang Kwon (eds), The Limits of Maritime Jurisdiction (Leiden: Brill, 2013) 449-471 at 459.

188 Peter Jaques \& Rafaella Lobo, “The Shifting Context of Sustainability: Growth and The World Ocean Regime" (2018) 18:4 Global Environmental Politics 85-106 at 85; Elizabeth A. Kirk, "Marine Governance, Adaptation, and Legitimacy" (2011) 22:1 Yearbook of international environmental law 110-139 at 129.

189 See, e.g. Barnes, "Domestic Fisheries Conservation", supra note 115 at 244.

190 Ibid at 237.

191 These mechanisms are discussed in Seline Trevisanut, "La Convention des Nations Unies sur le droit de la mer et le droit de l'environnement : développement intrasystémique et renvoi intersystémique" in Hélène Ruiz Fabri \& Lorenzo Gradoni (eds), La circulation des concepts juridiques : le droit international de lenvironnement entre mondialisation et fragmentation (Société de législation comparée: Paris, 2009) 397-426.

$192 \mathrm{Ibid}$ at art. 211(2) and (5).

193 Ibid at art. 237(1).

194 UNCLOS at arts. 237, 293 and 311. 
evolution of the Convention. ${ }^{195}$ Further, UNCLOS also contains, under article 311, a general rule of reference to other conventions and agreements, which is not limited to the context of protection and preservation of the marine environment. More particularly, provisions on the conservation and management of living resources of the high seas (in Part VII) could fall under the scope of article $311^{196}$ and benefit from the respect which this provision provides for other agreements dealing with similar subject-matters. ${ }^{197}$ UNCLOS can thus be looked at through the lens of other instruments and obligations, allowing its interpretation and implementation to evolve accordingly. ${ }^{198}$ It must however be noted that the relevance of rules of reference on fisheries regulation and management might be more limited than their relevance in other sectors, most particularly shipping. In fact, as mentioned by Guggisberg,

Shipping rules are further detailed in widely ratified global treaties, which bind all states through the relevant rules of reference. Many UNCLOS provisions related to shipping indeed require states to conform to generally accepted international regulations; these rules, mostly found in IMO instruments, thus become binding on all UNCLOS parties. In comparison, the fisheries regime involves fewer global treaties, and hence general obligations remain vaguer. It is also more fragmented due to lower ratification levels of existing treaties and the absence of similar rules of reference in UNCLOS. ${ }^{199}$

Furthermore, the interpretation of UNCLOS by courts and tribunals has also provided insight into the evolution and development of certain concepts of environmental law and their application in the context of the law of the sea, ${ }^{200}$ and, more particularly, regarding the management of fish stocks. ${ }^{201}$ The cases addressing questions related

195 Detlef Czybulka, "Article 237. Obligations under other conventions on the protection and preservation of the marine environment" in Alexander Proelss (ed), United Nations Convention on the Law of the Sea. A Commentary (Munich: Verlag C. H. Beck, 2017) 1596-1604 at 1597-1598; Harrison, Saving the Oceans Harrison, Saving the Oceans, supra note 10 at 37; Gjerde, "Enhancing integrated management”, supra note 155 at 446.

196 More specifically its paragraphs 2 and 5, see UNCLOS at art. 311(2): "This Convention shall not alter the rights and obligations of States Parties which arise from other agreements compatible with this Convention and which do not affect the enjoyment by other States Parties of their rights or the performance of their obligations under this Convention", and at art. 311(5): "This article does not affect international agreements expressly permitted or preserved by other articles of this Convention".

197 For a brief analysis of this rule of reference in the context of commercially exploited aquatic species, see Franckx, supra note 131 at 219-222.

198 Proelss \& Houghton, supra note 6 at 233. The authors criticize the scholarship arguing that there is a strong disconnect between protection of the marine environment and management of species, and reiterate that UNCLOS provides for the possibility of references to other instruments. They, however, acknowledge the shortcomings of UNCLOS.

199 Solène Guggisberg, "Independent, Compulsory, and Centralized verification of States' Obligations in Fisheries: Can the IMO Audit Scheme for Shipping Law Be Used as an Example to Follow?" (2020) 22 International Community Law Review 513-531 at 529 [Guggisberg, "IMO Audit Scheme"].

200 See, e.g., Lan Ngoc Nguyen, The development of the law of the sea by UNCLOS tribunals (Cambridge: Cambridge University Press, forthcoming).

201 See, e.g., Southern Bluefin Tuna Cases, supra note 144 at paras 77 and 80, which have implicitly recognized the precautionary approach for the management of stocks. See also Request for an advisory opinion submitted by the Sub-Regional Fisheries Commission (SRFC), Advisory opinion, (2015) ITLOS case 21 at 
to the conservation and management of marine living resources, including the cooperation for such management and conservation, have allowed courts and tribunals to interpret and elaborate on the state of the law concerning these matters. ${ }^{202}$ They have discussed: obligations of flag States in the fight against IUU fishing; ${ }^{203}$ cooperation in management ${ }^{204}$ as well as in the conservation of transboundary fish stocks, including the applicability of the precautionary approach; ${ }^{205}$ due regard for other States fishing in adjacent waters; ${ }^{206}$ and the protection of marine biodiversity more broadly, ${ }^{207}$ to name just a few. Although not a dispute settlement body per se, the decisions of the review panels of the South Pacific Regional Fisheries Management Organization (SPRFMO) can also be relevant as they apply to high seas stocks. The review panels have made two decisions on objections by member States, shedding light on the question of discrimination in the exclusion from quota allocation, as well as more specific questions related to equity, historical catches, jurisdiction of the SPRFMO Commission in the assessment of scientific data, and consideration of special requirements of developing coastal States. ${ }^{208}$

The jurisdiction of dispute settlement bodies to adjudicate is, however, limited by the complex nature of the provisions on the settlement of disputes under UNCLOS (Part XV), which often creates uncertainty in terms of the stocks covered and issues discussed. ${ }^{209}$ Further, a dispute regarding fisheries on the high seas that is dealt with bilaterally has been seen as denaturing the commonality/public interest component linked to high seas resources and marine environmental protection. ${ }^{210}$

para 191 [Advisory Opinion on IUU Fishing], where sustainable management is equated to conservation and development, as well as the separate opinion of Judge Paik at para 34, who highlights the importance of cooperation for sustainable management. Although these understandings refer to the wording of art. 63(1) UNCLOS, applicable to the EEZ, it is submitted that, considering the similar wording of arts. 63(1) and 118 UNCLOS ("measures necessary to coordinate and ensure the conservation and development of such stocks" in art. 63(1) and "measures necessary for the conservation of the living resources" in art. 118, and they both refer to the possibility of fulfilling such obligation through cooperation and/or regional organizations), the interpretation of conservation as forming part of sustainable management is also applicable to the conservation of high seas fish stocks.

202 Guggisberg, The Use of CITES, supra note 9 at 166-173. See also, generally, Nguyen, supra note 200.

203 Advisory Opinion on IUU Fishing, supra note 201, although the opinion is limited to the EEZ.

204 Fisheries Jurisdiction Case (UK v Iceland), supra note 93.

205 Southern Bluefin Tuna Cases, supra note 144.

206 Chagos Arbitration, supra note 163; South China Sea Arbitration, supra note 158.

207 Whaling in the Antarctic (Australia v Japan: New Zealand intervening), Merits, (2014) ICJ Rep 226.

208 Objection by the Russian Federation, (2013) SPRFMO, Findings and Recommendations of the Review Panel; Objection by the Republic of Ecuador, (2018) SPRFMO, Findings and Recommendations of the Review Panel. On the second case, see Solène Guggisberg, "Best Practices for Regional Fisheries Conservation and Management" (2 November 2018) Nereus Programme Blog, online: <https:// nereusprogram.org/works/best-practices-for-regional-fisheries-conservation-and-management/>, and Maddalena Visser, "Assessing the role of equity in fisheries allocation decisions" (31 August 2018) JCLOS blog, online: <https://site.uit.no/nclos/2018/08/31/assessing-the-role-of-equity-in-fisheries-allocationdecisions/>.

209 The framework for dispute settlement is discussed in further detail in chapter 5 section 2.3.4 below.

210 Guggisberg, The Use of CITES, supra note 9 at 174-175, referring to Birnie, Boyle \& Redgwell, supra note 152 at 212, Michael Bothe, "Compliance" (2010) Max Planck Encyclopedias of Public International Law at para 45, Phoebe Okowa, "Environmental Dispute Settlement: Some Reflections on Recent Developments" in Malcolm D. Evans (ed), Remedies in International Law: The Institutional Dilemma (Oxford: Hart, 1998) 157-172 at 166-167, and Robin Churchill \& Geir Ulfstein, "Autonomous Institutional Arrangements in 
Despite the central place of UNCLOS within the legal framework for the law of the sea and its capability for adaptation, it does not cover all aspects of international fisheries law. As observed by Harrison, it "only offers a basic layer of regulation, founded upon an abstract standard of due diligence and further elementary procedural guarantees. At the same time, it foresees the negotiation of rules and standards that are more specific, to give direction to States with regard to what they must do to $[\ldots]$ protect the marine environment more generally". ${ }^{211}$ The most relevant instruments addressing these more specific rules and standards are described below.

\subsubsection{United Nations Fish Stocks Agreement (UNFSA)}

The negotiations for the development of an instrument complementing the provisions of UNCLOS to ensure the long-term conservation and sustainable use of straddling and highly migratory stocks were triggered by the concerns for the sustainability of these stocks raised during the 1992 Rio Conference and addressed in its action plan, Agenda 21. ${ }^{212}$ The necessity for such an instrument also arose following different interpretations of the obligations in UNCLOS. For example, "[d] istant water fishing nations held the view that the Convention had only provided for two basic situations: coastal state jurisdiction in the [EEZ] and freedom of fishing beyond". ${ }^{213}$ Coastal States, for their part, interpreted the Convention as giving them a default role of management and conservation of fish resources on the high seas if cooperation on the high seas were to fail. There was therefore a need to accommodate this difference in views.

The UNFSA, adopted in 1995, builds upon the general obligations of UNCLOS in terms of conservation of marine living resources, providing a detailed regulatory framework for the targeted stocks: ${ }^{214}$ straddling stocks, which migrate between the EEZ of one or several States and the high seas, and highly migratory species, also crossing international boundaries, which do so by travelling very long distances,

Multilateral Environmental Agreements: A Little-Noticed Phenomenon in International Law" (2000) 94:5 American Journal of International Law 623-659 at 644-645. The bilateral character of fisheries dispute is discussed further in chapter 5 section 2.3.4 below.

211 Harrison, Saving the Oceans, supra note 10 at 301. See also Proelss \& Houghton, supra note 6 at 230, who mention that the protection of marine species is mostly found outside the law of the sea regime.

212 "Seeking to address in particular the problems identified in chapter 17, programme area C, of Agenda 21 adopted by the United Nations Conference on Environment and Development, namely, that the management of high seas fisheries is inadequate in many areas and that some resources are overutilized; noting that there are problems of unregulated fishing, over-capitalization, excessive fleet size, vessel reflagging to escape controls, insufficiently selective gear, unreliable databases and lack of sufficient cooperation between States", see UNFSA at preamble. See also Guggisberg, The Use of CITES, supra note 9 at 38. The Rio Conference and Agenda 21 are further discussed in section 3.2.3 below.

213 Orrego Vicuña, supra note 1 at 31.

214 It must be specified that it "does not elaborate substantive measures for the conduct of fishing; rather it lays down the jurisdictional framework for the regulation of such stocks", see Caddell, supra note 8 at 147. See also Tore Henriksen, Geir Hønneland \& Are Sydnes, Law and Politics in Ocean Governance. The UN Fish Stocks Agreement and Regional Fisheries Management Regimes (Leiden: Martinus Nijhoff, 2006) at 56. 
e.g. tuna and sharks. ${ }^{215}$ Consequently, the obligations found under the UNFSA apply in relation to stocks that travel between EEZs and ABNJ. Therefore, although it does create obligations applicable on the high seas, the Agreement does not impose obligations on parties to take measures applicable to discrete high seas stocks, i.e. occurring only on the high seas. ${ }^{216}$

The UNFSA is often seen as "an example of innovation", as "an early attempt in international fisheries law to create new ideas to address a problem". ${ }^{217}$ It makes several contributions to the development of the legal regime for the sustainable management of straddling and highly migratory stocks, by strengthening the relationship between the management of fishing activities and their impact on the marine environment. The main contribution of the UNFSA resides in the important steps it makes towards the introduction of principles of environmental law into the regime for the conservation and management of international fisheries, ${ }^{218}$ and of a focus on protection objectives. ${ }^{219}$ This focus on protection is visible through clear references to the precautionary approach ${ }^{220}$ (the application of which is detailed in the guidelines found under Annex II), the ecosystem-based approach, ${ }^{221}$ sustainable development, ${ }^{222}$ prevention ${ }^{223}$ and a reaffirmed reliance on best available science. ${ }^{224}$ Its focus on core environmental law principles, which are at the heart of the Agreement, makes the UNFSA "a missing link between the law of the sea and international environmental law". ${ }^{225}$ A clear reference to the protection of marine biodiversity ${ }^{226}$ also links the UNFSA to the CBD, "giving [the latter] effect to international fisheries law" and making fisheries management holistic. ${ }^{227}$ It has also been noted that the MSY, so central to UNCLOS, has taken a different role under the UNFSA, acting mostly as a guideline or a reference rather than a goal in itself. ${ }^{228}$ This therefore implies that other factors and methods of measurement should be taken into consideration to establish catch levels.

215 UNCLOS at annex I. See Evelyne Meltzer, “Global Overview of Straddling and Highly Migratory Fish Stocks: Maps and Charts Detailing RFMO Coverage and Implementation” (2005) 20:3-4 International Journal of Marine and Coastal Law 571-604 at 573.

216 Henriksen, Hønneland \& Sydnes, supra note 214 at 14.

217 Matley, supra note 63 at 105.

218 Orrego Vicuña, supra note 1 at 32-34. See also Henriksen, Hønneland \& Sydnes, supra note 214 at 28.

219 The elements addressed in this paragraph are based on the discussions conducted in Guggisberg, The Use of CITES, supra note 9 at 39-41; von Bieberstein et al, supra note 161 at 37; Churchill, supra note 35 at 35-36; and Proelss \& Houghton, supra note 6 at 240-241. More particularly on the precautionary approach, see Trevisanut, supra note 191 at 412.

220 UNFSA at arts. 5(c) and 6, and at annex II. See also Lodge et al, supra note 92 at 19-20.

221 UNFSA at preamble and art. 5(d)-(e).

222 Ibid at art. 2.

223 Ibid at art. 5(h).

224 Ibid at arts. 5(b) and 6.

225 Proelss \& Houghton, supra note 6 at 240. See also Harrison, Saving the Oceans, supra note 10 at 176; Lodge et al, supra note 92 at 4-5.

226 UNFSA at art. 5(g).

227 Henriksen, Hønneland \& Sydnes, supra note 214 at 28.

$228 \mathrm{Ibid}$ at 214 at 26. 
A second contribution is the central importance given to the duty of cooperation, which also forms a strong pillar of the UNFSA. ${ }^{229}$ While article 8 mentions that this duty is to be fulfilled by direct cooperation between States or through RFMOs, the latter approach is privileged. ${ }^{230}$ Henriksen, Hønneland and Sydnes even argue that the possibility for States to choose between direct cooperation or cooperation through RFMOs is radically limited by article 8(3) UNFSA, which states that when an RFMO has been established in a determined region, States fishing in that region shall become members of the organization. If they choose not to, they must still comply with the conservation and management measures adopted by that organization. Similarly, if a stock is not regulated by a regional organization, States must establish such an organization and participate in its work, by becoming members and/or by complying with its measures. ${ }^{231}$ The broad scope of the duty to cooperate has even led to the suggestion that "a State will forfeit the right for its nationals to participate in the freedom of fishing on the high seas where it refuses or fails in its duty to cooperate in conservation and management measures". 232 This suggestion is based on the wording of article 8(4), which states that "[o]nly those States which are members of such an organization [...], or which agree to apply the conservation and management measures established by such organization [...], shall have access to the fishery resources to which those measures apply".

A third contribution is to be found in the introduction of novel measures for enforcement. First, it includes a procedure for boarding and inspection to be conducted by States, individually or through the relevant RFMO, on the high seas. When there are clear grounds for believing that a vessel from a State, whether or not a party to the regional organization having competence in the region, has engaged in any activity contrary to the conservation and management measures adopted by the regional organization, the inspecting State, after notifying the flag State of the vessel to be inspected and receiving its approval, can proceed to boarding and inspection. ${ }^{233}$ Article 23, for its part, lays down measures that can be taken by port States, including the prohibition of landing and transhipment of products that are suspected of having been obtained in violation of conservation and management measures, including through IUU fishing. Increased jurisdiction to States other than the flag State on the high seas is therefore a step forward in extending the

229 Orrego Vicuña, supra note 1 at 40-41.

230 Art. 8 is entirely dedicated to cooperation for conservation and management measures. The duty of cooperation is also found in the preamble, and in art. 7, see Proelss \& Houghton, supra note 6 at 241. For a short overview of the main measures introduced by the UNFSA, see Gjerde, "High Seas Fisheries Management", supra note 37 at 293.

231 Henriksen, Hønneland \& Sydnes, supra note 214 at 15-16.

232 Warwick Gullett \& Quentin Hanich, "Rethinking High Seas Fishing Freedoms: How High Seas Duties Are Catching Up" in Keyuan Zou (ed), Global Commons and the Law of the Sea (Leiden, Boston: Brill Nijhoff, 2018) 112-123 at 116, citing Rosemary Rayfuse, "Countermeasures and high seas fisheries enforcement” (2004) 51:1 Netherlands International Law Review 41-76 at 54.

233 UNFSA at art. 21. The boarding and inspection then needs to be conducted in accordance with the basic procedures established under art. 22. 
possibilities of enforcement on the high seas or over activities conducted on the high seas. Enforcement per se, however, still remains weak. ${ }^{234}$

The recognition of new mechanisms or the strengthening of existing ones raises questions regarding the nature of the UNFSA as an implementing agreement under UNCLOS, as well as its scope of application. ${ }^{235}$ Theoretically, the UNFSA and UNCLOS are two separate treaties, with different ratifications; this creates different legal regimes for high seas fisheries, one under the UNFSA and one under UNCLOS. ${ }^{236}$ Yet, the way the UNFSA acts as an implementing agreement to UNCLOS depends on the way in which the two treaties interact: is the UNFSA merely interpreting UNCLOS obligations (i.e. bringing clarification to already existing obligations to facilitate their implementation), or does it amend UNCLOS or even create new law?237 A role of interpretation is not contested, as the two instruments are seen as informing one another. ${ }^{238}$ It also does not seem to be denied that the UNFSA implements UNCLOS obligations through the creation of new law. This observation is, however, crucial to understanding the applicability of the UNFSA's provisions when facing the fact that not all parties to UNCLOS are parties to the UNFSA (only 90 States have ratified the UNFSA, a significantly lower ratification number than UNCLOS, which has 168 parties $^{239}$ ).

It is in fact a basic rule of treaty law that third States cannot be bound by a treaty without their consent, ${ }^{240}$ and non-parties to the UNFSA would therefore not be bound by its obligations. Yet, it has been argued that most of its provisions have reached the status of customary law and would consequently be applicable to all; the fact that the treaty was negotiated by the entire international community and was adopted by consensus supports this view. ${ }^{241}$ State and non-State parties have shown

234 This question is generally addressed in chapter 5 below.

235 For a more detailed discussion on the applicability of the UNFSA, see Guggisberg, The Use of CITES, supra note 9 at 43-49. See also Proelss \& Houghton, supra note 6 at 240.

236 Henriksen, Hønneland \& Sydnes, supra note 214 at 14.

237 Guggisberg, The Use of CITES, supra note 9 at 121; Caddell, supra note 8 at 147. A similar debate could also be relevant in the context of the development of the new BBNJ agreement.

238 Harrison, Saving the Oceans, supra note 10 at 175; Henriksen, Hønneland \& Sydnes, supra note 214 at 15; Robert Blasiak \& Nobuyuki Yagi, "Shaping an International Agreement on Marine Biodiversity Beyond Areas of National Jurisdiction: Lessons from High Seas Fisheries" (2016) 71 Marine Policy 210-216 at 214.

239 As of 27 July 2019, see DOALOS, "Status of the United Nations Convention on the Law of the Sea, of the Agreement relating to the Implementation of Part XI of the Convention and of the Agreement for the Implementation of the Provisions of the Convention relating to the Conservation and Management of Straddling Fish Stocks and Highly Migratory Fish Stocks as at 27 June 2019", online: <https://www.un.org/ Depts/los/reference_files/status2019.pdf $>$. From the 10 leading high seas fishing nations listed in section 2.1 above, only the United States are not a party to UNCLOS and have only signed (and not ratified) the UNFSA. Taiwan is also not a party to the UNFSA, but this results from the controversial status of Taiwan's sovereignty and ability to conclude international agreements, which falls beyond the scope of the present study. Art. 1(3) UNFSA however indicates that the "Agreement applies mutatis mutandis to other fishing entities whose vessels fish on the high seas" therefore covering the particular legal situation of Taiwan, see Orrego Vicuña, supra note 1 at 43.

240 Vienna Convention on the Law of Treaties (23 May 1969, entered into force 27 January 1980) 1155 UNTS 331 at art. 34 [VCLT].

241 Guggisberg, The Use of CITES, supra note 9 at 45-46. 
efforts in carrying out its implementation, ${ }^{242}$ directly or through their participation in RFMOs. In fact, those organizations created after the adoption of the UNFSA have mirrored the UNFSA's provisions in their constitutive instruments, while older RFMOs have made amendments to their instruments in order to align them with the UNFSA's provisions. ${ }^{243}$ This is why, although the specific issue of the UNFSA's scope of application remains unsettled, the recognition of the UNFSA as a central element of the framework for the conservation and management of straddling and highly migratory fish stocks is for its part undisputed.

Despite such a central role, the UNFSA could benefit from a strengthened implementation and enforcement of its provisions, ${ }^{244}$ a recurring concern raised by the UNFSA Review Conference. Established under article 36 UNFSA, the Review Conference aims at "assessing the effectiveness of this Agreement in securing the conservation and management of straddling fish stocks and highly migratory fish stocks", and is open to parties and non-parties to the UNFSA. This Review Conference does not, however, amount to a review of State compliance. ${ }^{245}$ The Review Conference, which started in 2006, was resumed over the course of two subsequent meetings, in 2010 and 2016 respectively, ${ }^{246}$ and is scheduled to be resumed in $2021{ }^{247}$ During each meeting, the Conference adopted recommendations, which have been reviewed and built upon by the subsequent meetings.

The 2016 Review Conference presented various recommendations ${ }^{248}$ linked to management and conservation measures, ${ }^{249}$ cooperation by members and nonmembers of RFMOs, compliance and enforcement, ${ }^{250}$ the special case of developing States through capacity-building and enhanced participation in RFMOs, and the need for encouraging more general participation, i.e. increasing the number of State parties of the UNFSA. Regarding conservation measures, the Review Conference recommended that the ecosystem approach would benefit from being more detailed in terms of implementation, as is the case for the precautionary approach with the guidelines for implementation found under Annex II. In terms of compliance

242 Ibid, citing Giselle Vigneron, 'The Most Recent Efforts in the International Community to Implement the 1995 United Nations Straddling Fish Stocks Agreement' (1999) 10 Colorado Journal of International Environmental Law and Policy 225-245 at 231-233.

243 See, e.g. IISD, "Summary of the Resumed Review Conference on the Agreement for the Implementation of the Provisions of the UN Convention on the Law of the Sea (UNCLOS) 1982 Relating to the Conservation and Management of Straddling Fish Stocks and Highly Migratory Fish Stocks: 23-27 May 2016" (2016) 7:71 Earth Negotiations Bulletin at 11. See also Warner, supra note 30 at 186.

244 Barnes, "Domestic Fisheries Conservation", supra note 115 at 247-248.

245 Guggisberg, "IMO Audit Scheme", supra note 199 at 517.

246 A further session should take place in 2021, see Caddell supra note 8 at 148.

247 UNGA Res 74/18, supra note 11 at para 58, cited in Takei, supra note 123 at 34.

248 The recommendations can be found in IISD, supra note 243 at 4-7.

249 E.g. solidifying measures for new and exploratory fisheries in line with art. 6(6) UNFSA, developing area-based management tools, ensuring a better sharing of data, and developing recovery strategies for overexploited stocks.

250 E.g. establishing best practice guidelines for all RFMOs following the model of the Kobe-process for tuna RFMOs, ensuring that the opt-out procedures are constrained, and strengthening the capacity to take action regarding IUU fishing. 
and enforcement, concerns have been raised in terms of the role of RFMOs in the implementation of the UNFSA, underlining the disparate successes of the different organizations. ${ }^{251}$ Although useful as an assessment exercise, the powers of the Review Conference are limited to coordination, and it can merely make recommendations; it is not mandated to make and enforce decisions, and does not constitute a global review mechanism of RFMOs' actions and performance. ${ }^{252}$

Notwithstanding these elements in need of strengthening, especially in terms of implementation and enforcement, the UNFSA is undoubtedly an instrument that has contributed to the evolution of UNCLOS' provisions. The text of the UNFSA itself allows for the evolution of the Agreement, through its reference to the possibility for States to "adopt and apply any generally recommended international minimum standards for the responsible conduct of fishing operations.". 253 According to Harrison, this "[establishes] other international instruments as a benchmark for action", 254 and seems to refer to an even broader range of instruments, including soft-law instruments, than the strict reference to "conventions and agreements" found under article 237 UNCLOS. Nevertheless, the UNFSA remains an instrument that is very much management and conservation oriented, but that, through the various environmental law principles it puts forward, has the potential of bringing some focus on the relationship between fish stocks, fisheries and the wider marine environment.

\subsubsection{Convention on Biological Diversity $(C B D)^{255}$}

Just like UNCLOS, the CBD is often considered as an umbrella treaty, complementing other biodiversity related instruments by providing an overarching and coherent framework for the conservation and sustainable use of biodiversity. ${ }^{256}$ Its overarching approach does not target specific species, but addresses spatial considerations from the perspective of ecosystems and biodiversity. ${ }^{257}$ This is why the CBD is seen as

251 IISD, supra note 243 at 11. See also, generally, Blasiak \& Yagi, supra note 238 at 213 . These deficiencies are also addressed in chapter 5 section 2.3.2 below.

252 Guggisberg, The Use of CITES, supra note 9 at 128. The limited powers of the Review Conference are also addressed in chapter 4 section 3.3, and in chapter 7 section 2.2 .3 below.

253 UNFSA at art. 10(c).

254 Harrison, Saving the Oceans Harrison, Saving the Oceans, supra note 10 at 176.

255 The discussion conducted in this section is based on the contribution of the present author to Catherine Blanchard, Otto Spijkers \& Wen Duan, "Three Structural Pillars of the Future Internationally Legally Binding Instrument for the Conservation and Sustainable Use of Marine Biodiversity in Areas Beyond National Jurisdiction" in Marta Chantal Ribeiro, Fernando Loureiro Bastos \& Tore Henriksen (eds), Global Challenges and the Law of the Sea (Cham: Springer, 2020) 351-378 at 360-366. For an overview of the CBD regime and its role for marine environmental protection, see Harrison, Saving the Oceans, supra note 10 at 45-51.

256 Marine Yzquierdo, "The 1992 Convention on Biological Diversity” in Malgosia Fitzmaurice, Attila Tanzi \& Angeliki Papantoniou (eds), Multilateral Environmental Treaties (Cheltenham: Edward Elgar, 2017) 9-24 at 10. For a short overview of the main principles brought by the CBD, see Gjerde, "High Seas Fisheries Management", supra note 37 at 293.

257 Proelss \& Houghton, supra note 6 at 252 . 
a source of protection not only for specific components of biodiversity, but also for marine habitats more broadly, ${ }^{258}$ which are only addressed in a limited way under UNCLOS. ${ }^{259}$ The CBD can therefore potentially enlighten us further on the sustainable management of high seas fish stocks.

Developed as a response to the biodiversity loss triggered by certain human activities, the $\mathrm{CBD}^{260}$ was opened for signature at the 1992 Rio Conference. ${ }^{261}$ It puts forward three main objectives: the conservation of biodiversity, the sustainable use of its components, and the fair and equitable sharing of benefits from the use of genetic resources. ${ }^{262}$ The CBD further establishes the overarching goal of conservation of biological diversity as a common concern of humankind, ${ }^{263}$ while reiterating the sovereign right of States parties to exploit their own resources. ${ }^{264}$ While these main objectives are obviously intertwined with the environmental aspects of biodiversity, they also target its social, economic, scientific, cultural and educational components. ${ }^{265}$

The CBD creates obligations targeting the components of biodiversity found within the limits of national jurisdiction of States parties, and the processes and activities under the control of State parties carried out beyond national jurisdiction. ${ }^{266}$ It also covers the conservation of the components of biodiversity inside and outside their natural habitat. ${ }^{267}$ In order to work towards the conservation and sustainable use of biodiversity, States are urged to develop national strategies, plans or programmes, ${ }^{268}$ undertake identification and monitoring of components of biodiversity, ${ }^{269}$ and adopt economic and social incentives. ${ }^{270}$ Conservation and sustainable use must also be reached through research and training, ${ }^{271}$ public education and awareness, ${ }^{272}$ the conducting of environmental impact assessments, ${ }^{273}$ exchange of information, ${ }^{274}$ as well as general technical and scientific cooperation. ${ }^{275}$ Some of the wording used under the $\mathrm{CBD}$, where obligations must apply "as far as possible and as

258 Churchill, supra note 49 at 21-22.

259 A specific reference to the protection of habitats is only found under art. 194(5) UNCLOS.

$260 \mathrm{CBD}$ at preamble.

261 CBD, "History of the Convention", online: <https://www.cbd.int/history/>.

262 CBD at art. 1.

$263 \mathrm{Ibid}$ at preamble. The question of common concern of humankind is addressed briefly in section 2.3 above.

264 Ibid at art. 3

265 Ibid at preamble.

$266 \mathrm{Ibid}$ at art. 4. For a brief and recent overview of the relevant provisions of the CBD in relation to ABNJ, see Kristina M. Gjerde, Nichola A. Clark \& Harriet R. Harden-Davies, "Building a Platform for the Future: the Relationship of the Expected New Agreement for Marine Biodiversity in Areas beyond National Jurisdiction and the UN Convention on the Law of the Sea" (2019) 33 Ocean Yearbook 3-44 at 17-21.

267 CBD at arts. 8-9.

$268 \mathrm{Ibid}$ art. 6.

269 Ibid at art. 7

270 Ibid at art. 11

271 Ibid at art. 12.

272 Ibid at art. 13.

273 Ibid at art. 14

274 Ibid at art. 17

275 Ibid at art. 18, see also at art. 5. 
appropriate" ${ }^{276}$ gives the impression, however, that they are merely objectives or guidelines, therefore amounting to provisions that are legally weaker. ${ }^{277}$

Subsequent practice of the parties reflected in decisions of the Conference of the Parties (COP) show the specific role that the CBD can play for the marine environment. ${ }^{278}$ Six examples can be mentioned. First, the importance of the CBD provisions for the protection of coastal and marine environment was expanded upon in the Jakarta Mandate on the Conservation and Sustainable Use of Marine and Coastal Biodiversity (Jakarta Mandate), adopted at the COP in $1995,{ }^{279}$ and which aims to strengthen the implementation of the $\mathrm{CBD}$ to marine and coastal areas. ${ }^{280} \mathrm{~A}$ group of experts on coastal and marine biodiversity was subsequently established, and this group devised a work programme, that was adopted by the COP in $1998,{ }^{281}$ to better implement the Jakarta mandate. Three elements of the work programme are of relevance for the study of international fisheries law, namely 1) integrated marine and coastal area management, which promotes a cross-sectoral and holistic approach to management, 2) marine and coastal living resources, which acknowledges the problem of overexploitation and the need for an ecosystem-based management, and 3) marine and coastal protected areas, as a management tool for environmental protection. ${ }^{282}$ Second, in 2010, the $\mathrm{COP}^{283}$ adopted a Strategic Plan for Biodiversity 2011-2020, providing an overarching framework on biodiversity for all stakeholders involved in biodiversity management. ${ }^{284}$ The Aichi Biodiversity Targets have been developed under the Strategic Plan, and targets $3,{ }^{285} 6,{ }^{286} 10^{287}$ and

276 See, e.g., ibid at art 5 regarding cooperation, and at art. 6(b) regarding the inclusion of measures for conservation and sustainable use in relevant plans, programmes, and policies.

277 Harrison, Saving the Oceans, supra note 10 at 47.

$278 \mathrm{Ibid}$ at 48 .

279 Conservation and Sustainable Use of Marine and Coastal Biological Diversity, CBD COP decision II/10, COP 2, UNEP/CBD/COP/DEC/II/10 (1995). See also CBD, “The Jakarta Mandate - from global consensus to global work" (2000) at 6-7, online: <https://www.cbd.int/doc/publications/jm-brochure-en.pdf >.

280 Barnes, "Domestic Fisheries Conservation", supra note 115 at 250-251.

281 Conservation and sustainable use of marine and coastal biological diversity, including a programme of work, CBD COP decision IV/5, COP 4, UNEP/CBD/COP/DEC/IV/5 (1998).

282 CDB, "Jakarta Mandate", supra note 279 at 8-13.

283 The Strategic Plan for Biodiversity 2011-2020 and the Aichi Biodiversity Targets, CBD COP decision X/2, COP 10, UNEP/CBD/COP/DEC/X/2 (2010).

284 CBD, “Strategic Plan for Biodiversity 2011-2020, including Aichi Biodiversity Targets”, online: <https:// www.cbd.int/sp/default.shtml>.

285 "By 2020, at the latest, incentives, including subsidies, harmful to biodiversity are eliminated, phased out or reformed in order to minimize or avoid negative impacts, and positive incentives for the conservation and sustainable use of biodiversity are developed and applied, consistent and in harmony with the Convention and other relevant international obligations, taking into account national socio economic conditions", see CBD, "Aichi Biodiversity Targets", online: <https://www.cbd.int/sp/targets/default. shtml $>$. This could include fisheries subsidies, which is discussed in section 3.1.8 below.

286 "By 2020 all fish and invertebrate stocks and aquatic plants are managed and harvested sustainably, legally and applying ecosystem based approaches, so that overfishing is avoided, recovery plans and measures are in place for all depleted species, fisheries have no significant adverse impacts on threatened species and vulnerable ecosystems and the impacts of fisheries on stocks, species and ecosystems are within safe ecological limits", see CBD, "Aichi Biodiversity Targets", supra note 285. See also Kim Friedman, Serge Garcia \& Jake Rice, "Mainstreaming Biodiversity in Fisheries" (2018) 95 Marine Policy 209-220 at 212-213.

287 "By 2015, the multiple anthropogenic pressures on coral reefs, and other vulnerable ecosystems impacted by climate change or ocean acidification are minimized, so as to maintain their integrity and functioning", 
$11^{288}$ relate to marine and coastal biodiversity by addressing the threats impacting fish stocks and/or stemming from fishing activities. A post-2020 Global Biodiversity Framework, which also makes reference to the protection of marine ecosystems, is currently being negotiated ${ }^{289}$ and is expected to be adopted at the CBD COP 15 in mid-2021. Third, the overarching role of the CBD is also furthered by the conclusion of different types of partnership agreements (e.g. Memorandum of Understanding $(\mathrm{MoU})$ ) with collaborative partners in the marine sector, such as the Secretariat of the Pacific Regional Environment Programme (SPREP). ${ }^{290}$ As observed by Caddell, however, no such agreements have so far been concluded with RFMOs. ${ }^{291}$ Fourth, a process developed under the CBD framework and specifically relevant for the marine environment in $\mathrm{ABNJ}$ is the process of establishing ecologically or biologically significant marine areas (EBSAs), ${ }^{292}$ which designates areas, including marine areas, based on a series of scientific criteria. ${ }^{293}$ The EBSA process is, for now, only a scientific process which has no legal value, but it could potentially be seen as broadening the scope of application of the $\mathrm{CBD}$ to $\mathrm{ABNJ}$. Fifth, the recently adopted concept of "other effective area-based conservation measures" by the CBD COP, which are measures aiming to complement existing protected areas and associated $\mathrm{ABMTs},{ }^{294}$ could also potentially be used for marine areas. Finally, in practice, the role of the $\mathrm{CBD}$ in providing scientific and technical assistance and advice with respect to marine protected areas (MPAs) in ABNJ has been clearly expressed by the COP. ${ }^{295}$ However, the CBD remains an instrument of support only, as the UNGA

see CBD, "Aichi Biodiversity Targets", supra note 285.

288 "By 2020, at least 17 per cent of terrestrial and inland water, and 10 per cent of coastal and marine areas, especially areas of particular importance for biodiversity and ecosystem services, are conserved through effectively and equitably managed, ecologically representative and well connected systems of protected areas and other effective area-based conservation measures, and integrated into the wider landscapes and seascapes", see see CBD, "Aichi Biodiversity Targets", supra note 285.

289 Zero Draft of the Post-2020 Global Biodiversity Framework, Open-Ended Working Group on the Post2020 Global Biodiversity Framework, 2nd Meeting, CBD/WG2020/2/3 (2020). See also Basile de Havre, "Plateforme Biodiversité 2020 - Quatrième rencontre" (Webinar hosted by IDDRI, 19 March 2020).

290 CBD, "Partnership Agreements", online: <https://www.cbd.int/agreements/>.

291 Caddell, supra note 8 at 151.

292 Marine and coastal biodiversity, CBD COP 9 decision IX/20, COP 9, UNEP/CBD/COP/DEC/IX/20 (2008). ABMTs and the EBSA process are discussed in further detail in chapter 3 section 4.2.1 below.

293 The criteria are: uniqueness or rarity; special importance for life history stages of species; importance for threatened, endangered or declining species and/or habitats; vulnerability, fragility, sensitivity, or slow recovery; biological productivity; biological diversity; and naturalness, see CBD COP decision IX/20, supra note 292 at annex.

294 Protected Areas and Other Effective Area-Based Conservation Measures, CBD COP Decision, COP 14, UNEP/CBD/COP/DEC/14/8 (2018) at para 2: “Other effective area-based conservation measure' means 'a geographically defined area other than a Protected Area, which is governed and managed in ways that achieve positive and sustained long-term outcomes for the in situ conservation of biodiversity, with associated ecosystem functions and services and, where applicable, cultural, spiritual, socioeconomic, and other locally relevant values"'.

295 Marine and coastal biodiversity, CBD COP decision X/29, COP 10, UNEP/CBD/COP/DEC/X/29 (2010) at para 24; Marine and coastal biodiversity: ecologically or biologically significant marine areas, CBD COP decision XI/17, COP 11, UNEP/CBD/COP/DEC/XI/17 (2012) at preamble; Kristina Gjerde \& Anna Rulska-Domino, "Marine Protected Areas Beyond National Jurisdiction: some Practical Perspectives for Moving Ahead" (2012) 27 International Journal of Marine and Coastal Law 351-373 at 360-361; Wright et al, supra note 28 at 23 . 
retains the main role in addressing issues relating to conservation and sustainable use of BBNJ. ${ }^{296}$

In fact, the applicability of the CBD's provisions to $\mathrm{ABNJ}$ is influenced by certain distinctions in its jurisdictional scope. Under article 4(a), the CBD covers the components of biodiversity, but it does so only in areas within national jurisdiction (AWNJ). ${ }^{297}$ In ABNJ, article 4(b) states that the CBD applies only to processes and activities carried out, ${ }^{298}$ and not to the components of biodiversity themselves. ${ }^{299}$ Since fisheries can undoubtedly be considered as activities, the applicability of the $\mathrm{CBD}$ to fishing activities in $\mathrm{ABNJ}$ can hardly be denied. However, such a distinction implies that, while all obligations of the CBD are applicable in AWNJ, only the obligations covering activities and processes are applicable in ABNJ. These obligations, which include cooperation, the responsibility not to cause environmental damage, and the identification of activities which have or are likely to have significant adverse impacts on biodiversity, ${ }^{300}$ are however broadly phrased and lack specificity. It is therefore to be asked whether these obligations trigger anything additional or complementary for the protection of the marine environment and fish stocks to what already exists under Parts VII and XII of UNCLOS. Similarly, this distinction in the scope of application of the CBD means that ABNJ, in terms of protection of biodiversity per se, are therefore currently covered only by the general provisions on the protection of the marine environment and cooperation under UNCLOS. ${ }^{301}$ Another interpretation however suggests that this distinction in the scope of application of the CBD does not lead to any difference in practice; indeed "these distinctions are in some way arbitrary since the components of biological diversity are necessarily affected by human processes and activities" ${ }^{302}$ Under such interpretation, components of biodiversity in $\mathrm{ABNJ}$ would consequently be covered through the obligations targeting activities and processes.

When raising the question of the relationship between the CBD and UNCLOS and, more generally, the CBD and other instruments, article 22(2) CBD pays particular

296 Marine and coastal biodiversity: ecologically or biologically significant marine areas, CBD COP decision $\mathrm{XIII} / 12$, COP 12, UNEP/CBD/COP/DEC/XIII/12 (2016) at preamble; Marine and coastal biodiversity: ecologically or biologically significant marine areas (EBSAS), CBD COP decision XII/22, COP 12, UNEP/ $\mathrm{CBD} / \mathrm{COP} / \mathrm{DEC} / \mathrm{XII} / 22$ (2014) at preamble.

297 CBD at art. $4(\mathrm{a})$.

$298 \mathrm{Ibid}$ at art. 4(b).

299 It is probably because of divergences of views regarding (marine) genetic resources that the components of biodiversity were not included in the text of the CBD, because of the controversies it triggers between the application of the freedom of the high seas and the common heritage of mankind. This issue is also central to the current BBNJ process, discussed further in chapter 4 below, see Fernanda Millicay, "Marine Biodiversity of Areas Beyond National Jurisdiction Securing a Sound Law of the Sea Instrument" in David Joseph Attard, David Ong \& Dino Kritsiotis (eds), The IMLI Treatise on Global Ocean Governance, vol I: UN and Global Ocean Governance (Oxford: Oxford University Press, 2018) 167-177 at 172-173.

300 CBD at arts. 3, 5, 7(c) and 8(1). See also Nicholas A. Robinson \& Lal Kurukulasuriya, "Training Manual on International Environmental Law" (2006) Pace Law Faculty Publications at 226-227.

301 See, e.g., UNCLOS at arts. 192 and 197.

302 Lyle Glowka et al, "A Guide to the Convention on Biological Diversity" (1994) IUCN Environmental Policy and Law Paper No 30 at 27. 
respect to the law of the sea. Indeed, paragraph 1 of this article prima facie gives a priority status to the conservation of biodiversity over rights and obligations found under other instruments; ${ }^{303}$ however, this direct reference to biodiversity is not found under the second paragraph, which provides that "Contracting Parties shall implement this Convention with respect to the marine environment consistently with the rights and obligations of States under the law of the sea", including UNCLOS. Although a literal interpretation of the wording of paragraph 2 would give priority to the balance between rights and obligations in the law of the sea provisions over CBD related obligations, this has been characterised as illogical for two reasons. First, the drafters would most probably have used more explicit vocabulary if they had wanted to give priority to law of the sea rules over biodiversity related ones. Second, the law of the sea framework and biodiversity law do not have the same scope of application as to substance; consequently, always giving priority to law of the sea would leave some issues partially or completely uncovered. ${ }^{304}$ This is why, as pointed out by Wolfrum and Matz, "[a]rticle 22 paragraph 2 of the [CBD] instead means that the two regimes exist in parallel and supplement and reinforce each other. Only if the application of the [CBD] does infringe upon the rights or obligations of States, the law of the sea rules prevail". ${ }^{305}$

This necessity for the the law of the sea and biodiversity law to supplement and reinforce each other is also found in the nature of the two regimes. As a matter of fact, the law of the sea and biodiversity law have different aims. The former focuses mostly on regulating the use of resources, while the latter puts the emphasis on preservation. Moreover, the two regimes are not completely coherent, as they come from two different "generations". ${ }^{306}$ In fact, looking at marine life from the perspective of biodiversity has shone a different light on the exploitation of marine living resources. This can clash with the traditional approach to the law of the sea, which, although focusing more on an environmental management of resources and activities, ${ }^{307}$ sees the regime as regulating oceans uses. In any case, facing the different nature of the two instruments, the watchwords remain compatibility and collaboration.

The CBD clearly acts as a promoter for approaching the marine environment in a comprehensive and cross-sectoral manner, and it recognizes the importance

303 "The provisions of this Convention shall not affect the rights and obligations of any Contracting Party deriving from any existing international agreement, except where the exercise of those rights and obligations would cause a serious damage or threat to biological diversity." (emphasis added). See also Robinson \& Kurukulasuriya, supra note 300 at 226 (para 41); Wyssbrod, supra note 93 at 91-92.

304 Rudiger Wolfrum \& Nele Matz, “The Interplay between UNCLOS and CBD” (2000) 4 Max Planck United Nations Yearbook 445-480 at 476; Robinson \& Kurukulasuriya, supra note 300 at 226.

305 Wolfrum \& Matz, supra note 304 at 476.

306 Ibid at 464, 473-474 and 477.

307 "progressively comes back as part of the core concerns of the contemporary law of the sea" (free translation), Florence Galletti, “Les transformations du droit international de la mer: Entre gouvernance de 'l'espace' et gouvernance de la 'ressource' en mer" in André Monaco \& Patrick Prouzet (eds), Gouvernance des mers et des océans (London: ISTE Editions, 2015) 21-53 at 38. 
of cooperation with other instruments and bodies. ${ }^{308}$ However, the vagueness of the obligations applicable to $\mathrm{ABNJ}$ puts into question the CBD's added-value for high seas fisheries management. Nevertheless, as fish stocks are an intrinsic part of biodiversity, the framework of the CBD is still informative to further our understanding of obligations related to conservation and sustainable use.

\subsubsection{International Convention for the Regulation of Whaling (ICRW)}

Marine mammals, including whales, are obviously not fish. Yet, as they are marine living resources and form part of marine biodiversity, the regime for their protection and management, as well as the political and economic reality surrounding such management, can inform us about the different regulatory and management mechanisms - and their effectiveness - available for the conservation of resources.

The International Convention for the Regulation of Whaling (ICRW) ${ }^{309}$ established the International Whaling Commission (IWC), originally mandated with the regulation of whaling activities through restrictions on whaling methods and the designation of protected species. ${ }^{310}$ These regulations are contained in a Schedule to the ICRW, which allows the Commission to amend them through a simplified procedure. ${ }^{311}$ Indeed, the amendments to the Schedule undertaken over the years show that the ICRW is an instrument that has radically changed over the course of its evolution. Initially set to regulate whaling, it has then been used for more protection-oriented measures, eventually leading to a moratorium on commercial whaling activities, ${ }^{312}$ adopted in 1982 and entering into force four years later, ${ }^{313}$ which in practice banned almost all whaling activities. Two exceptions exist, which allow for whaling activities to take place: for aboriginal subsistence, ${ }^{314}$ and for the purpose of scientific research. ${ }^{315}$

This second exception has been at the core of the Whaling Case in front of the ICJ where Australia (with New Zealand intervening) claimed that the Japanese scientific programme, JARPA II, was whaling on such a large scale that it could not be considered as conducted for the purpose of scientific research. The ICJ considered whether the elements of the programme's design and implementation

$308 \mathrm{CBD}$ at art. 23(4)(h), discussed in Proelss \& Houghton, supra note 6 at 255. See also Harrison, Saving the Oceans, supra note 10 at 55.

309 International Convention for the Regulation of Whaling (2 December 1946, entered into force 10 November 1948) 161 UNTS 72 [ICRW].

310 For an overview of the historical developments of the IWC, see Laura Hoey, "The Battle over Scientific Whaling: A New Proposal to Stop Japan's Lethal Research and Reform the International Whaling Commission" (2017) 41 William \& Mary Environmental Law \& Policy Review 435-470 at 436-445.

311 Harrison, Saving the Oceans, supra note 10 at 197.

312 ICRW at Schedule, rule 10(e). See also Bosselman, supra note 45 at 90-91.

313 Proelss \& Houghton, supra note 6 at 229 and 243; Harrison, Saving the Oceans, supra note 10 at 197-198. 314 ICRW at Schedule, para 13.

315 Ibid at art. VIII. Both exceptions are discussed in Harrison, Saving the Oceans Harrison, Saving the Oceans, supra note 10 at 199-200. 
were reasonable in relation to its stated scientific objectives. ${ }^{316}$ It found that, considering the open-ended time frame of the programme, the large scale of the whaling activities and the limited research output, the activities conducted by Japan under the JARPA II programme could not be considered as being conducted for the purpose of scientific research. ${ }^{317}$ The ICJ also noted the "lack of cooperation between JARPA II and other domestic and international research programmes in the Antarctic Ocean". ${ }^{318}$ It therefore ordered Japan to revoke all authorizations and permits in relation to JARPA II and to refrain from granting further authorizations. ${ }^{319}$ The ICJ also concluded that Japan had violated its obligations in relation to the whale sanctuary in the Southern Ocean and the moratorium on taking certain whale species. ${ }^{320}$ Japan resumed its whaling activities under a new programme in 2015, one year after the ICJ's ruling. ${ }^{321}$ Frustrations as to the necessity of maintaining the ban eventually led Japan to formally withdraw from the IWC in December 2018, a withdrawal which became effective on 1 July 2019.322

The nature of the moratorium is contested. Some States argue that its original purpose was to allow stocks to replenish in order to eventually resume whaling activities; an improvement in the state of many whale stocks therefore does not justify maintaining the moratorium. Japan, Norway and Iceland have also persistently objected to the moratorium and have continued undertaking whaling activities. ${ }^{323}$ In an attempt to find alternative methods (i.e. alternative to the moratorium) for the conservation and management of whales, it has been suggested that "[d]eveloping a mechanism that combines a species-specific approach based on precaution and scientific evidence with a strict enforcement and control scheme must surely be an adequate alternative", 324 but this has so far not led to any concrete result. Following the entry into force of the moratorium, the Scientific Committee of the IWC was mandated to develop a procedure that would establish a scientifically based method to provide advice on catch limits. In 1994, the Revised Management Procedure was

316 Whaling Case, supra note 207 at para 127. The ICJ for example looked at the use of lethal methods, the scale of the programme, the methodology used to select samples, the size of the samples and the time frame of the programme, see at para 88.

317 Ibid at paras 223-227.

318 UN News, "UN court rules against Japan's whaling activities in the Antarctic" (31 March 2014), online: $<$ https://news.un.org/en/story/2014/03/465062-un-court-rules-against-japans-whaling-activitiesantarctic $>$. See also Whaling Case, supra note 207 at para 222.

319 Whaling Case, supra note 207 at para 245.

320 Respectively under arts. 7(b) and 10(d)-(e) of the Schedule to the ICRW, see Whaling Case, supra note 207 at para 247.

321 "Japan to resume whaling in Antarctic despite court ruling" (25 November 2015) BBC News, online: $<$ https://www.bbc.com/news/world-asia-34952538>.

322 "Statement on Government of Japan withdrawal from the IWC" (14 January 2019), online: <https://iwc.int/ statement-on-government-of-japan-withdrawal-from- $t>$. See also Solène Guggisberg, "Legal Considerations Around Japan's Announcement That it Will Leave the International Whaling Commission (IWC)" (5 February 2019) Nereus Programme Blog, online: <https://nereusprogram.org/works/legal-considerations-aroundjapans-announcement-that-it-will-leave-the-international-whaling-commission-iwc/>. For an overview of Japan's response to the moratorium over the years, see Hoey, supra note 310 at 445-450.

323 Bosselman, supra note 45 at 91; Elisa Techera \& Natalie Klein, International Law of Sharks. Obstacles, Options and Opportunities (Leiden: Brill Nijhoff, 2017) at 234-235.

324 Proelss \& Houghton, supra note 6 at 244-245. 
adopted, consisting of a strong, conservation oriented management mechanism "to estimate sustainable catch limits for commercial whaling of baleen whales". ${ }^{325}$ This procedure was, however, to be implemented only with the Revised Management Scheme, a scheme which emphasised the development of enforcement mechanisms. However, no compromise on the content of the Revised Management Scheme was reached, and the Commission had to face the fact that the moratorium was to remain. ${ }^{326}$

Despite the political difficulties in finding a compromise as regards the ban, this moratorium shows, from an environmental protection perspective, that it is beneficial for the replenishment of stocks. Other processes aimed at the conservation of species could rely on such a mechanism to develop their own measures, while also learning from the negative effect of political tensions on the regime's effectiveness. In addition, the IWC has over the years adopted other conservation measures, pointing towards a protectionist shift. It has designated two whale sanctuaries, where commercial whaling is prohibited. ${ }^{327}$ It has also established, in 2003, a conservation committee, focusing on the development of conservation measures, and has extended its conservation interest to other sources of interference with whales and their environment, such as by-catch and habitat destruction. ${ }^{328}$ The characterization of the IWC as a fisheries body ${ }^{329}$ has also led the Commission to collaborate within the network of fisheries organisations. For these reasons, the ICRW and the Commission remain examples of structures that have tackled both the protection of species and their interaction with the marine environment.

\subsubsection{Convention on International Trade in Endangered Species of Wild Fauna and Flora (CITES)}

International fisheries law also includes measures from international trade law. ${ }^{330}$ The Convention on International Trade in Endangered Species of Wild Fauna and Flora $(\mathrm{CITES})^{331}$ is one of the instruments dealing with the protection of marine

325 IWC, online: $<$ https://iwc.int/rmp $>$.

326 Ibid; Proelss \& Houghton, supra note 6 at 244-245.

327 One in the Indian Ocean established in 1979, and one in the Southern Ocean established in 1994, discussed in Proelss \& Houghton, supra note 6 at 243. See also Harrison, Saving the Oceans, supra note 10 at 197-198.

328 Harrison, Saving the Oceans, supra note 10 at 198.

329 The IWC is sometimes seen as a specialised RFMO, as it deals with the regulation and conservation of one particular species. The difficulty with this characterization, however, is that the species regulated is a mammal, not a fish, see Stefan Asmundsson, "Regional Fisheries Management Organisations (RFMOs): Who are they, what is their geographic coverage on the high seas and which ones should be considered as General RFMOs, Tuna RFMOs and Specialised RFMOs?” (2016) CBD Meeting Documents, Sustainable Ocean Initiative (SOI) Global Dialogue with Regional Seas Organizations and Regional Fisheries Bodies on Accelerating Progress Towards the Aichi Biodiversity Targets at 6, online: <https://www.cbd.int/doc/ meetings/mar/soiom-2016-01/other/soiom-2016-01-fao-19-en.pdf >.

330 See generally Barnes \& Massarella, supra note 7.

331 Convention on international trade in endangered species of wild fauna and flora (3 March 1973, entered into force 1 July 1975) 993 UNTS 243 [CITES]. 
living resources, including certain fish species, from the perspective of trade. Based on the premise that endangered species should not be threatened by trade, ${ }^{332}$ CITES protects them through controls on trade activities, i.e. import, export, re-export and introduction from the sea. ${ }^{33}$

CITES works through the designation of species and their listing under one of the three appendices. ${ }^{334}$ Appendix I includes "species threatened with extinction which are or may be affected by trade" and should be subject to strict regulations. ${ }^{335} \mathrm{~A}$ permit is necessary for any trade transaction, requiring the species not to be used primarily for commercial purposes. ${ }^{336} \mathrm{COP}$ Resolution 5.10 has even recommended State parties to define "commercial purposes" as broadly as possible to ensure a maximum effectiveness of the measures under the Convention. ${ }^{337}$ Appendix II covers species that, although not currently endangered, might become so if strict regulation of their trade is not undertaken. ${ }^{338}$ Appendix III, for its part, applies to species "which any Party identifies as being subject to regulation within its jurisdiction for the purpose of preventing or restricting exploitation, and as needing the co-operation of other Parties in the control of trade" ${ }^{339}$ Following sufficient scientific evidence, a species can be downlisted (e.g. from Appendix I to Appendix II), uplisted or de-listed.

CITES is directly applicable to species of the high seas through the concept of introduction from the sea, defined as the "transportation into a State of specimens of any species which were taken in the marine environment not under the jurisdiction of any State". ${ }^{340}$ Although many marine mammals, such as whales, dolphins, walruses and seals, and some species of sharks are protected under the appendices (acting in a complementary role to the ICRW in the case of whales), marine species in general are underrepresented in the listing of CITES. ${ }^{341}$ This is particularly the case for fish, especially commercially exploited fish such as tuna, which are not designated on the list.

The low designation rate of (commercially exploited) fish is explained by political, social and commercial pressures. Indeed, although the listing process is largely based on scientific data, the decision as to whether or not to list a species is often

332 Ibid at art. II(1). See also, generally, Franckx, supra note 131 at 213-214.

333 CITES at art. II(4). Trade is defined in art. I(c) as being composed of these 4 components.

334 For general overview of the three appendices, see Annecoos Wiersema, "Uncertainty, Precaution, and Adaptive Management in Wildlife Trade" (2015) 36 Michigan Journal of International Law 375-424 at 396-398.

335 CITES at art. II(1).

$336 \mathrm{Ibid}$ at art. III.

337 Definition of 'primarily commercial purposes', CITES COP Resolution 5.10 (Rev. COP 15), COP 5 (1985) at para 3. See also Harrison, Saving the Oceans, supra note 10 at 203-204.

338 CITES at art. II(2).

339 Ibid at art. II(3).

$340 \mathrm{Ibid}$ at art. I(e).

341 Proelss \& Houghton, supra note 6 at 247. 
the result of political debate rather than being taken from a biological conservation perspective. ${ }^{342}$ This is illustrated by the proposition of Monaco at COP 15 in 2010 to list the bluefin tuna, a species widely known to be under threat, under Appendix $1 .{ }^{343}$ The proposition obtained very little support, Japan being its fiercest opponent because it was concerned for its fishing industry. This failure by Monaco is explained by two main factors: commercial interests trump conservation interests, and the argument that the management and conservation of fish is already dealt with under other instruments, mostly RFMOs. ${ }^{344}$ Monaco's attempts have, however, had the impact of raising awareness of the issue of marine species protection in the context of CITES.

Despite the argument that CITES is not the right forum for addressing commercially exploited fish, and that RFMOs are the bodies mandated to do so, it has nonetheless been suggested that CITES provides a legal basis for dealing with the management of such species. ${ }^{345}$ Indeed, Guggisberg observes that nothing in the text of CITES excludes this possibility. Further, nothing prima facie indicates that RFMOs' mandate would be affected or that relying on CITES would result in a duplication of work; it all depends on how member States approach the interaction of both instruments. In fact, collaborations with RFMOs could be worthwhile as CITES, mostly geared towards preservation, could complement the management mandate of fisheries organizations. ${ }^{346}$ Moreover, nothing prevents CITES from developing its expertise in marine species. For example, the adoption of a MoU between CITES

342 Ibid.

343 Proposal to include Atlantic Bluefin Tuna (Thunnus thynnus (Linnaeus, 1758)) on Appendix I of CITES in accordance with Article II 1 of the Convention, CITES COP 15 Prop.19 (2010).

344 The issue of sufficient regulation through existing mechanisms is also a recurring theme in the BBNJ negotiations, see chapter 4 below.

345 See generally Guggisberg, The Use of CITES, supra note 9 at chapter 7.

346 Since listing a species normally reflects problems in the conservation of that species, a listing could support the fact that the parties to an RFMO have an obligation of conduct to take a CITES' decision into consideration as part of the RFMO's conservation and management mandate. However, the underlying cause of the problems of conservation inform us on the potential complementarity of a CITES listing for RFMOs' actions. If the main threat to conservation is IUU fishing, a CITES listing could indeed complement the actions needed from RFMOs to preserve the species; a CITES listing could therefore support RFMOs' fight against IUU fishing. However, if the threat to conservation comes from TACs that are set to high or in contradiction to the precautionary approach (i.e. stemming from an economic/ political decision within the RFMO), the impact of a CITES listing would most likely be limited, or such a listing would actually be improbable due to a lack of political support (see the example of the bluefin tuna discussed above). Two current examples of CITES-RFMOs interactions are the Cooperation between CITES and the Commission for the Conservation of Antarctic Marine Living Resources regarding trade in toothfish, CITES COP Resolution 12.4 (Rev. COP18), COP 12 (2002), and the Guidelines for Cooperation Between the International Commission for the Conservation of Atlantic Tunas (ICCAT) and the Conference of the Parties to the Convention on International Trade in Endangered Species of Wild Fauna and Flora (CITES), Annex to CITES Standing Committee Document 14.6, SC 62 (2012). However, such initiatives remain limited to exchange of information and mutual understandings, and they do not amount to a close form of cooperation. 
and the FAO in $2006^{347}$ has contributed to strengthening this marine expertise of CITES. ${ }^{348}$

Although some uncertainties remain in terms of the enforcement of CITES provisions for marine species (e.g. the vast amount of commercial fish entering the market might prove difficult for the handling and verification of trade certificates), this instrument is a well-established source of protection for various marine species. It remains a promising instrument for the protection of fish stocks, including potentially countering overexploitation.

\subsubsection{Convention on the Conservation of Migratory Species and Wild Animals (CMS)}

Building on the approach taken by the ICRW and CITES, which provide a speciesbased approach to protection, the Convention on the Conservation of Migratory Species and Wild Animals (CMS) ${ }^{349}$ requires States, individually or through cooperative action, to take measures for the conservation of species that "cyclically and predictably cross one or more national jurisdictional boundaries", 350 and for the conservation of their habitat. ${ }^{351}$ Most obligations are borne by range States, defined as States which exercise jurisdiction over part of the area of land or water which the species inhabits, stays in temporarily or crosses, and also includes States whose vessels take species beyond national jurisdiction. ${ }^{352}$ These definitions therefore expressly cover marine species and ABNJ.

In a similar way to CITES, the CMS works with a designation procedure, where species are listed in different appendices. There is a prohibition on taking the endangered species ${ }^{353}$ listed under Appendix I. ${ }^{354}$ Species which have an unfavourable conservation status are for their part included in Appendix II, ${ }^{355}$ and range States are required to conclude agreements to restore those species to a favourable conservation status or to maintain such status. ${ }^{356}$ This agreement procedure illustrates the importance of cooperation between range States. Several marine species, such as cetaceans and other marine mammals, sharks, and some species

347 CITES Issues with Respect to International Fish Trade and the CITES/FAO MOU, COFI Sub-Committee on Fish Trade, 10th Sess, Doc COFI:FT/X/2006/3 (2006).

348 FAO, "FAO and CITES - FAO activities in relation to CITES", online: <http://www.fao.org/fishery/ topic/18145/en>.

349 Convention on the conservation of migratory species of wild animals (23 June 1979, entered into force 1 November 1983) 1651 UNTS 333 [CMS].

$350 \mathrm{Ibid}$ at art. I (1) (a).

351 Ibid art. II (1).

352 Ibid art. I(1)(f) and (h).

353 Ibid at art. III(5). "Taking" is defined in art. I(1)(i). For a brief overview of the CMS as an instrument for marine environmental protection, see Harrison, Saving the Oceans, supra note 10 at 51-53.

354 CMS at art. III.

$355 \mathrm{Ibid}$ at art. IV.

356 Ibid at art. IV and V(1). 
of fish, are protected under different appendices, ${ }^{357}$ but major commercial species are not, which raises questions as to the ability of the CMS to combat overfishing. ${ }^{358}$ Furthermore, as decisions for amending an appendix are made by the COP, which meets only every three years, ${ }^{359}$ it might already be too late for some species which can easily be depleted in months. ${ }^{360}$

However, the CMS contains strengths in terms of broader conservation concerns. First, as well as targeting the species to be conserved, the agreements to be taken by range States should also ensure the conservation, maintenance and restoration of habitats. ${ }^{361}$ Second, some instruments adopted under the CMS address adverse impacts on non-target species. For example, some provisions on by-catch can be found in memoranda of understanding, concluded as agreements under article IV of the CMS ${ }^{362}$ These provisions are, however, often imprecise, but have been further refined in subsequent measures adopted by the COP, such as COP resolution 12.22 on by-catch. ${ }^{363}$ This resolution reaffirms States' obligation to protect migratory species against by-catch and to collaborate on that matter. It also makes a reference to other instruments targeting the adverse impacts of by-catch, such as the $1999 \mathrm{FAO}$ IPOA-Seabirds, and the role of RFMOs in combatting by-catch. ${ }^{364}$ Finally, legally binding instruments for the conservation of some migratory species in particular regions have been adopted under the auspices of the CMS. ${ }^{365}$ These instruments address, among other provisions, the impact of fishing activities on these species and the damage done to their habitat. ${ }^{366}$ This ability of the CMS to create a global framework that encourages the development of regional initiatives is therefore seen as highly positive for the establishment of interactions between instruments, actors, and levels of implementation, i.e. regional and global. ${ }^{367}$ The focus on regional initiatives and cooperation is highly relevant for fisheries management.

357 CMS Appendix I and II, online: <https://www.cms.int/sites/default/files/basic_page_documents/cms_ cop12_appendices_e_0.pdf>.

358 A similar concern was raised when discussing the scope of application of CITES, see section 3.1.5 above. 359 Unless the procedure for an extraordinary meeting is triggered, see CMS at art. VII(3).

360 Berkes et al, supra note 33 at 1558.

$361 \mathrm{CMS}$ at art. $\mathrm{V}(5)$.

362 See, e.g. Memorandum of understanding on the conservation of migratory sharks (2018), online: <https:// www.cms.int/sharks/sites/default/files/basic_page_documents/Sharks_MOU_Text_annexes_2018_e. pdf $>$ at preamble, objective B point 4.2 and 5. See also Churchill, supra note 35 at 45.

363 By-Catch, CMS COP Res 12.22, COP 12 (2017).

364 CMS COP Res 12.22 , supra note 363 at paras 2, 7 and 8.

365 See, e.g., Agreement on the Conservation of Small Cetaceans of the Baltic, North East Atlantic, Irish and North Seas (17 March 1992, entered into force 29 March 1994) 1772 UNTS 217 [ASCOBANS], and Agreement on the conservation of cetaceans of the Black Sea, Mediterranean Sea and contiguous Atlantic area (24 November 1996, entered into force 1 June 2001) 2183 UNTS 303 [ACCOBAMS], discussed in Churchill, supra note 35 at 45 .

366 See, e.g., ASCOBANS at preamble and annex, and ACCOBAMS at preamble, art. II(3) and annex.

367 Harrison, Saving the Oceans, supra note 10 at 53; Proelss \& Houghton, supra note 6 at 250. 


\subsubsection{Treaties of the Food and Agriculture Organization (FAO)}

The FAO plays an important role in the framework for the regulation of fisheries. As it is the UN specialized agency dealing with food security, the management of fisheries falls within its mandate, most particularly under the mandate of the Committee on Fisheries (COFI), a subsidiary body of the FAO Council. Furthermore, many RFMOs, were established under the FAO and still benefit from its administrative and technical support. ${ }^{368}$

In terms of legally binding instruments, two treaties were adopted under the auspices of the FAO to help complement the legal framework mapped out in UNCLOS in terms of the impacts of fishing activities on the marine environment: the 1993 Agreement to Promote Compliance with International Conservation and Management Measures by Fishing Vessels on the High Seas (Compliance Agreement) ${ }^{369}$ (3.1.7.1) and the 2009 PSMA (3.1.7.2). These treaties attempt to tackle the issue of adverse impacts through two main actors involved in fishing operations: flag States and port States.

\subsubsection{Agreement to Promote Compliance with International Conservation and Management Measures by Fishing Vessels on the High Seas (Compliance Agreement)}

The growing concern regarding the use of flags of convenience for fishing activities on the high seas and the phenomenon of reflagging as a mean to avoid compliance was acknowledged at the 1992 Rio Conference and in its Agenda 21. ${ }^{370}$ This led to the adoption, in 1993, of the Compliance Agreement, which elaborates the duties of flag States. ${ }^{371}$ These duties include ensuring that fishing vessels flying their flag are authorized to do so and are not engaging in activities that violate conservation and management measures, that vessels are entered in the record and provide information on their operations, and that the flag States takes enforcement measures against non-complying vessels. ${ }^{372}$

One could question the relevance of the Compliance Agreement considering that flag States' duties were elaborated even further in the UNFSA, adopted shortly afterwards, and which takes a more comprehensive approach to the regulation of fishing activities of straddling and highly migratory stocks. Franckx still underlines that, although the two instruments overlap in terms of their goal, their approach

368 von Bieberstein, supra note 161 at 37-31; Guggisberg, The Use of CITES, supra note 9 at 51. RFMOs are discussed in section 3.3 .2 below.

369 Agreement to Promote Compliance with International Conservation and Management Measures by Fishing Vessels on the High Seas (24 November 1993, entered into force 24 April 2003) 2221 UNTS 91 [Compliance Agreement].

370 Agenda 21 at chapter 17 at paras 17.45 and $17.50-17.52$.

371 See generally Churchill, supra note 35 at 37-38; Guggisberg, The Use of CITES, supra note 9 at 52-53.

372 Compliance Agreement at art. III. 
is different, which safeguards the relevance of the Compliance Agreement. ${ }^{373}$ For example, the Compliance Agreement is not limited in term of species, but allows a party to exclude small vessels, while the UNFSA focuses solely on straddling and highly migratory stocks, but does not contain any vessel size restrictions. Further, record keeping is more developed under the Compliance Agreement, while boarding and inspection, a central aspect of the UNFSA, is not addressed. Finally, while the Compliance Agreement focuses on flag States, the UNFSA includes a broader range of actors. ${ }^{374}$ Both agreements, taken together, can be considered as giving legal force to the non-legally binding 1995 Code of Conduct, ${ }^{375}$ as many of their provisions on flag State duties overlap.

\subsubsection{Agreement on Port State Measures to Prevent, Deter and Eliminate Illegal, Unreported and Unregulated Fishing (Port State Measures Agreement - PSMA)}

The second FAO treaty, the 2009 PSMA, uses article 23 UNFSA as a starting point. This provision, allowing port States to take measures to promote the conservation and management of straddling and highly migratory fish stocks, was considered innovative as it, among other measures, prohibits the landing and transhipment of products deemed to have been taken in contravention of conservation measures. However, article 23 UNFSA was also considered insufficient to specifically target IUU fishing on a global scale. ${ }^{376}$ This is why the PSMA was developed as a promising tool for combatting IUU fishing, as it creates a "consistent international standard of port state inspection of vessels and their catch", complementing and enhancing "the current ad hoc system of regional approaches with disparate standards that simply shift IUU fishing activities to regions and ports with the weakest inspection system". ${ }^{377}$

Under the PSMA, in addition to restrictions on the use of ports ${ }^{378}$ and inspectionrelated duties, ${ }^{379}$ a port State is also allowed "to authorize or deny the access to its port of vessels known or suspected to be engaged in IUU fishing" activities. ${ }^{380}$ The PSMA also promotes the need for cooperation, through the integration and coordination of port measures among State parties, ${ }^{381}$ and through the cooperation between flag States and port States. ${ }^{382}$ The PSMA contains an obligation for States to undergo a regular review of their performance in implementing the Agreement. ${ }^{383}$

373 Franckx, supra note 131 at 211.

374 Ibid at footnote 8.

375 The Code of conduct, supra note 72 is discussed in further detail in section 3.2.2.1 below.

376 Freestone, supra note 45 at116; Churchill, supra note 35 at 38; Lee, Teletesky \& Schofield, supra note 36 at 101-103.

377 Gjerde et al, supra note 65 at 544 .

378 PSMA at art. 11.

379 Ibid at arts. 12-18.

$380 \mathrm{Ibid}$ at arts. 9 and 18.

$381 \mathrm{Ibid}$ at arts. 5, 6 .

$382 \mathrm{Ibid}$ at art. 20.

383 Ibid at art. 24(1). 
A questionnaire was adopted at the meeting of the parties in 2019, which will serve as a basis for States to report on their own implementation of the Agreement. ${ }^{384}$

The success of both the 1993 Compliance Agreement and the 2009 PSMA in terms of number and relevance of ratification has so far been limited. ${ }^{385}$ Nevertheless, both instruments illustrate the development of measures that address activities and practices contributing to the adverse impacts of fishing activities on the marine environment, and that target the role of actors implementing such measures.

\subsubsection{World Trade Organization (WTO) measures on fisheries subsidies}

Alast set oflegallybinding instruments relevant to the current portrait of international fisheries law stems from the trade regime. In fact, the WTO regime addresses the issue of subsidies more generally, ${ }^{386}$ one of the main causes of overexploitation, and the WTO is currently developing a new legally binding instrument specifically targeting fisheries subsidies. This shows once again the potential of the trade regime for tackling threats from and to fisheries.

The main WTO instrument currently covering subsidies is the Agreement on Subsidies and Countervailing Measures (SCM Agreement), adopted in 1994. ${ }^{387}$ This SCM Agreement includes rules on the provision of subsidies (i.e. "rules regarding whether or not a subsidy may be provided by a Member" 388 ), and on the use of countervailing measures to offset detriment caused by subsidized imports. ${ }^{389}$ This regime, however, lacks effectiveness primarily because States do not want to challenge others, either because they are themselves in the wrong with the subsidies they grant, or because they lack understanding of how the regime works. ${ }^{390}$ In fact, the difficulty of quantifying subsidies, or differentiating good subsidies from bad subsidies, creates an obstacle for the implementation of appropriate regulatory responses. ${ }^{391}$ More specifically in terms of subsidies in the fisheries sector, a lack of expertise, coupled with a lack of compliance (no notification or surveillance, and subsidies are underreported) explain the poor performances in the implementation and enforcement of this SCM Agreement. ${ }^{392}$

384 Guggisberg, "IMO Audit Scheme", supra note 199 at 519.

385 Major fishing nations on the high seas, such as China, have not become parties to either agreement. As of 2 July 2018 (last available update), there were 42 parties to the Compliance Agreement, see FAO, "Parties to the Agreement", online: <http://www.fao.org/fileadmin/user_upload/legal/docs/012s-e.pdf>. As of December 2019 (last available update), 63 States and the EU were parties to the PSMA, with 5 additional States having signed the Agreement, see FAO, "Parties to the Agreement", online: <http://www.fao.org/ fileadmin/user_upload/legal/docs/037s-e.pdf $>$.

386 Young, supra note 38 at 486.

387 Agreement on Subsidies and Countervailing Measures, (1994) OJ, L326/156.

388 WTO, "Subsidies and Countervailing Measures: Overview", online: <https://www.wto.org/english/ tratop_e/scm_e/subs_e.htm>.

389 Young, supra note 38 at 487.

390 Barnes \& Massarella, supra note 7 at 383; Young, supra note 38 at 487.

391 Barnes \& Massarella, supra note 7 at 382.

392 Young, supra note 38 at 488. 
This is why a ministerial declaration made at the beginning of the Doha Round of Negotiations ${ }^{393}$ in 2001 underlined the need to establish a clear fisheries subsidies mandate. This mandate was clarified in 2005 to include the prohibition of subsidies that contribute to overcapacity and overfishing. In 2007, the Chair of the Rules Negotiating Group ${ }^{394}$ distributed a draft text of a potential Annex VIII to the SCM Agreement to address fisheries subsidies, but divergences led to a deadlock, and this annex was never adopted. In fact, two groups of States had opposing views: the 'Friends of Fish' ${ }^{395}$ underlined the connection between trade, environment and development, and proposed a general prohibition on fisheries subsidies; and others, ${ }^{396}$ who "contest[ed] the link between subsidies and environmental damage, and instead assert[ed] that inadequate fisheries management is the main cause of unsustainable fishing" ${ }^{397}$ The negotiations resumed in 2017, as a response to the adoption of the SDGs, ${ }^{398}$ where SDG 14.6 reiterated the importance of addressing fisheries subsidies. ${ }^{399}$ The mandate for the development of a new agreement was restated, and the ministerial conference established the deadline for the adoption of a fisheries subsidies agreement by the end of 2019. As of 21 July 2020, negotiators aim to conclude the agreement by the end of $2020 .^{400}$

The current working document for this fisheries subsidies agreement includes definitions of fishing activities, overfished stocks and IUU fishing; the scope of the agreement, ranging from subsidies for aquaculture, inland and recreational fisheries, to subsidies related to equipment, research and development, and work for the sustainability of stocks; prohibited subsidies, with a specific reference to IUU fishing; subsidies for overfished stocks; subsidies leading to overcapacity and

393 Launched in 2001, this is the latest round of negotiations within the WTO to "achieve major reform of the international trading system through the introduction of lower trade barriers and revised trade rules", see WTO, “The Doha Round”, online: <https://www.wto.org/english/tratop_e/dda_e/dda_e.htm>.

394 This group is where the negotiations on the development and reforms of WTO rules take place, see WTO, “The Rules Negotiations", online: <https://www.wto.org/english/tratop_e/rulesneg_e/rulesneg_e.htm>.

395 Membership of this group varies, but has included Australia, Chile, Ecuador, Iceland, New Zealand, Peru, Philippines, and the United States.

396 Japan, Korea and Taiwan among others.

397 Young, supra note 38 at 490.

398 The SDGs are discussed in further detail in section 3.2.3 below.

399 "By 2020, prohibit certain forms of fisheries subsidies which contribute to overcapacity and overfishing, and eliminate subsidies that contribute to IUU fishing, and refrain from introducing new such subsidies, recognizing that appropriate and effective special and differential treatment for developing and least developed countries should be an integral part of the WTO fisheries subsidies negotiation", see Transforming our world: the 2030 Agenda for Sustainable Development, GA Res 70 (I), UNGAOR, 70th Sess, UN Doc A/RES/70/1 (2015) at 24 [UNGA Res 70/1].

400 "WTO members set work programme for text-based phase of fisheries subsidies talks" (21 July 2020), online: <https://www.wto.org/english/news_e/news20_e/fish_21jul20_e.htm>. For the most recent updates on the negotiations for the fisheries subsidies agreement, see WTO, "Negotiations on fisheries subsidies", online: <https://www.wto.org/english/tratop_e/rulesneg_e/fish_e/fish_e.htm>. A full timeline of the different stages of the fisheries subsidies negotiations was discussed by Leonila Guglya, "Could the WTO Save the Oceans? An inquiry into the [accessory] role of the Organization in the future of fisheries policies" (Presentation delivered at the conference The Rule of Law for Oceans, Oslo, 4 November 2019). 
overfishing; notification/transparency/surveillance; and the special situation of least developed countries. ${ }^{401}$

However, several issues prevent the negotiators from arriving at a convergence of views: a lack of real consensus on the effect of subsidies on stocks; ${ }^{402}$ weaknesses at the institutional level of the WTO (e.g. weak rule-making capacity and consensus); ${ }^{403}$ and the fact that the agreement might be too "all-inclusive, for all fisheries of the world, domestic or international, small or large scale, etc". ${ }^{404}$ Sumaila indeed deplores the fact that "[t]his approach, has limited the ability of the negotiations to make progress by confounding the issues". ${ }^{05} \mathrm{He}$ also highlights that the incentives, the institutional framework and the actual methods to reduce harmful fisheries might depend on whether we are dealing with a domestic or a high seas fishery. ${ }^{406}$ For international fisheries for example, the incentive for a single State to reduce subsidies might be less prominent than for domestic fisheries, because the impacts of overfishing are not directly felt. Considering the weak current governance and management framework, the WTO would have a strong role to play. These interests need to be addressed separately from domestic ones, which, for now, does not seem to be the case in the draft documents. Another main difficulty stems from the technical and cross-cutting nature of the subject matter. ${ }^{407} \mathrm{In}$ fact, it is the first time that the WTO is addressing an issue which main focus goes beyond trade, the focus of the negotiations being on sustainability, ${ }^{408}$ therefore pushing the negotiators "out of their comfort zone".

It remains to be seen what impact this new agreement will have on the management of fisheries on the high seas. Although subsidies contribute to the problem of overexploitation from an economic perspective, the problem remains a cross-cutting one, and all relevant sectors and regimes should be reflected in the negotiations for the new agreement to be meaningful and effective. ${ }^{409}$

401 The latest draft found by the present author is dated 26 July 2018, see Fisheries Subsidies. Working Documents on: Definitions; Scope; Prohibited Subsidies Relating to IUU Fishing, Overfished Stocks, Overcapacity, Capacity-Enhancing Subsidies, and Overfishing; Notifications and Transparency; Special and Differential Treatment; Transitional Provisions; and Institutional Arrangements, WTO Negotiation Group on Rule, Doc TN/RL/W/274/Rev.5 (2018).

402 Barnes \& Massarella, supra note 7 at 382.

403 Ibid.

404 U. Rashid Sumaila, "How to make progress in disciplining overfishing subsidies" (2013) 70:2 ICES Journal of Marine Science 251-258 at 253.

405 Ibid.

406 Ibid at 253-254.

407 Guglya, supra note 400.

408 Santiago Wills, Chair of the WTO negotiating group on rules, "Reflections on the ongoing WTO fisheries subsidies negotiations" (Presentation given at the Session "Subsidies and IUU fishing" of the 12th International Forum on Illegal, Unreported and Unregulated Fishing, 20 May 2020).

409 Young, supra note 38 at 514-515. 


\subsection{Legal framework - soft-law instruments}

Soft-law instruments have grown with the multiplication of international institutions and structures, ${ }^{410}$ and, although the principles and measures they develop do not have a legally binding nature, their influence on political processes and on legally binding instruments themselves is not questioned. ${ }^{411}$ Indeed, soft-law instruments can serve as a basis upon which legally binding instruments - hard law - will subsequently be developed; they can clarify legally binding norms; and they can fill gaps, when legally binding rules are absent or inefficient. ${ }^{412}$ Soft law in an environmental context also represents the compromise between the awareness of States that the protection of the environment is a common concern that needs to be addressed, and the reluctance of these same States to be legally bound by international obligations. Soft law therefore contributes to the dynamic development of international law, with States not being afraid to see their sovereignty affected. ${ }^{413}$

It is through these functions that soft-law instruments have been contributing to bridging the gap between international fisheries law and international environmental law. Although this is a generally perceived development, the bridging role of soft-law instruments has been particularly visible in three situations. First, they have supported the inclusion of environmental law principles into international fisheries law, as demonstrated by the inclusion in the UNFSA of the environmental principles crystallized in the Rio Declaration, among others. Second, soft law assists in the implementation of binding instrument by often providing more details on the way in which obligations under legally binding instruments can be fulfilled and behaviours modelled. For example, some of the instruments discussed below have informed actors on specific actions to be taken against the adverse impacts of bottom fisheries, or on conducting assessments and developing plans of action. Third, soft-law instruments tend to be more inclusive in terms of the actors (e.g. non-State actors, individuals) and levels of operation (i.e. not only international or regional, but also national or local) they target. Not only is this desirable in a situation of complexity, but it is necessary. ${ }^{414}$

Hence, the present section continues mapping out the legal framework for international and high seas fisheries law by looking into the main non-legally

410 Wyssbrod, supra note 93 at 97.

411 Ibid at 93-94.

412 Ibid at 95-96; Jill Barrett, “The UN Convention on the Law of the Sea: A 'Living' Treaty?" in Jill Barrett \& Richard Barnes (eds) Law of the Sea. UNCLOS as a Living Treaty (British Institute of International and Comparative Law, 2016) 3-37 at 14; James Harrison, "Actors and Institutions for the Protection of the Marine Environment" in Rosemary Rayfuse (eds), Research Handbook on International Marine Environmental Law (Cheltenham: Edward Elgar, 2017) 57-78 at 67-68 [Harrison, "Actors and Institutions"].

413 Ulrich Beyerlin, "Different types of norms in international environmental law: Policies, principles, and rules" in Daniel Bodansky, Jutta Brunée \& Ellen Hey (eds), The Oxford Handbook on International Environmental Law (Oxford: Oxford University Press, 2007) 425-448 at 427-428.

414 A detailed discussion on the benefits of a multi-level and multi-actors approach in the face of complexity is conducted in chapter 6 section 3 below. 
binding instruments that have influenced the regime. First, it reviews several relevant measures stemming from UNGA resolutions, with a particular focus on the yearly resolutions on Oceans and the law of the sea and Sustainable fisheries, but also resolutions that have led to well-known processes in terms of environmental protection and sustainability, processes that have also left their mark on fisheries and the marine environment (3.2.1). Second, it moves on to discussing selected FAO instruments, including the Code of conduct, four International Plans of Action, and three sets of guidelines (3.2.2). Finally, this section concludes with a brief overview of other processes, mostly from international environmental law, that have pinpointed concerns about the marine environment (3.2.3).

\subsubsection{United Nations General Assembly Resolutions addressing fisheries and the marine environment}

The UNGA "is the competent global institution to undertake the annual consideration, review and evaluation of the implementation of UNCLOS and other related developments". ${ }^{415}$ It performs many of the tasks that "under most treaties would be fulfilled by a conference of the parties". ${ }^{416}$ It has shown - and continues to show - a particular interest in oceans affairs. ${ }^{417}$ This leads to the yearly adoption of two resolutions addressing marine questions, one directly targeting sustainable fisheries, ${ }^{418}$ and the other being the Oceans and the law of the sea resolution, which addresses broader questions related to the law of the sea, including fisheries and the marine environment. ${ }^{419}$ The Sustainable fisheries resolution normally covers issues faced by fisheries and stemming from fishing activities, such as the implementation of the UNFSA and other related instruments, IUU fishing, monitoring, control, surveillance, compliance and enforcement, fishing overcapacity, large-scale pelagic drift-net fishing, by-catch and discards, regional cooperation, capacity-building in fishing activities, and the question of responsible fisheries in the marine ecosystem. ${ }^{420}$ For its part, the Oceans and the law of the sea resolution covers, in terms of fisheries, the overarching themes of marine environment and marine resources, as well as marine biodiversity, therefore addressing the link between fisheries and the marine environment. These themes target most specifically questions of destructive fishing

415 von Bieberstein, supra note 161 at 29.

416 Alex Oude Elferink, "Reviewing the Implementation of the LOSC Convention: The Role of the United Nations General Assembly and the Meeting of States Parties" in Alex Oude Elferink \& Donald Rothwell (eds), Oceans Management in the $21^{\text {st }}$ century: Institutional Frameworks and Responses (Leiden: Martinus Nijhoff, 2004) 295-312 at 304, cited in Caddell, supra note 8 at 135.

417 David Freestone, "An Unfinished Agenda: Governance of Areas beyond National Jurisdiction" in Keyuan Zou (ed), Global Commons and the Law of the Sea (Leiden, Boston: Brill Nijhoff, 2018) 209-225 at 224-225.

418 The yearly resolution on Sustainable fisheries has only been adopted since the $58^{\text {th }}$ session of the UNGA (2003). Before this inception, fisheries were addressed periodically in thematic resolutions, e.g. Largescale pelagic drift-net fishing, unauthorized fishing in zones of national jurisdiction and on the high seas/ illegal, unreported and unregulated fishing, fisheries by-catch and discards, and other developments, GA Res 57(CXLII), UNGAOR, 57th Sess, UN Doc A/RES/57/142 (2002).

419 Guggisberg, The Use of CITES, supra note 9 at 34-35.

420 See, e.g., UNGA Res 72/72, supra note 66; UNGA Res 73/125, supra note 11; UNGA Res 74/18, supra note 11. 
practices, collaboration at the regional level, and the importance of sustainable fishing practices for the marine environment. States are therefore called upon to improve implementation and enforcement of the existing framework, accede to relevant instruments and organizations, and enhance cooperation. ${ }^{421}$

Despite the fact that UNGA resolutions do not have legally binding force, the adoption of the law of the sea and fisheries resolutions on a yearly basis and by consensus, or with a high number of votes in favour, show the influence of the recommendations found therein. ${ }^{422}$ Some resolutions adopted over the years have become key references in addressing marine biodiversity issues or the specific impact of fisheries on marine habitats and the broader marine environment. Resolutions dealing with bottom fishing and large-scale pelagic drift-net fishing are probably the more obvious examples of this relationship. ${ }^{423}$ Regarding the former, in 2004, the concerns about the impacts of the exploitation of deep-seas stocks on vulnerable ecosystems, by the use inter alia of bottom trawling, led the UNGA, through Resolution 59/25, ${ }^{424}$ to call upon States, individually or through regional organizations, to act urgently on that matter. It is, however, Resolution 61/105 of 2006 that developed the actions to be undertaken by all relevant actors, detailing what is expected from them. ${ }^{425}$ RFMOs are called upon to identify vulnerable marine ecosystems and assess the impact of bottom fishing activities on them, to close areas to bottom fishing where necessary, and to require their member States to prohibit their vessels from engaging in bottom fishing activities. ${ }^{426}$ Flag States are required to implement and respect the measures set by the RFMOs, ${ }^{427}$ and all States are asked to make publicly available the list of vessels authorized to conduct bottom fishing activities. ${ }^{428}$ The FAO is also requested, for the management of deep-sea fisheries,

421 Harrison, Saving the Oceans, supra note 10 at 292-293. See, e.g., Oceans and the law of the sea, GA Res 74(XIX), UNGAOR, 74th Sess, UN Doc A/RES/74/19 (2019) at paras 3, 228, 262 and 274.

422 The Oceans and the law of the sea resolution is normally adopted with a vote, with a very high number of votes in favour. For example, the 2019 UNGA Res 74/18, supra note 11, was adopted with 135 votes in favour, 1 against and 3 abstentions, these 4 votes being from States which are not party to UNCLOS. The Sustainable fisheries resolution has always been adopted without a vote, with the exception of UNGA Res $72 / 72$ in 2017, supra note 66 . That year, the resolution was for the first (and only) time adopted with a vote (126 in favour, 1 against (United States), and 3 abstentions). The vote was called for by the United States, which strongly opposed the inclusion of the reference to the WTO's discussion on fisheries subsidies, but otherwise supported the rest of the text, see UN, "Adopting Two Texts on Oceans, Seas, General Assembly Also Tackles Sustainable Management, Conservation of Marine Life beyond National Jurisdiction" (5 December 2017), online: <https://www.un.org/press/en/2017/ga11985.doc.htm>.

423 Churchill, supra note 35 at 46; Churchill, supra note 49 at 21; Freestone, supra note 45 at 106-108; Gjerde, "High Seas Fisheries Governance", supra note 35 at 225; Caddell, supra note 8 at 137.

424 Sustainable fisheries, including through the 1995 Agreement for the Implementation of the Provisions of the United Nations Convention on the Law of the Sea of 10 December 1982 relating to the Conservation and Management of Straddling Fish Stocks and Highly Migratory Fish Stocks, and related instruments, GA Res 59(XXV), UNGAOR, 59th Sess, UN Doc A/RES/59/25 (2004) at paras 66-67.

425 Sustainable fisheries, including through the 1995 Agreement for the Implementation of the Provisions of the United Nations Convention on the Law of the Sea of 10 December 1982 relating to the Conservation and Management of Straddling Fish Stocks and Highly Migratory Fish Stocks, and related instruments, GA Res 61(CV), UNGAOR, 61th Sess, UN Doc A/RES/61/105 (2006) at paras 80 and 83-90.

$426 \mathrm{Ibid}$ at para 83.

427 Ibid at para 86.

$428 \mathrm{Ibid}$ at para 87. 
to "enhanc[e] data collection and dissemination, promot[e] information exchange and increased knowledge on deep sea fishing activities, [...] [develop] standards and criteria for [...] identifying vulnerable marine ecosystems and the impacts of fishing on such ecosystems, and [establish] standards for the management of deep sea fisheries, such as through the development of an international plan of action". ${ }^{229}$

The elaboration of specific duties through Resolution 61/105 has led to progress in the sustainable management of bottom fishing. The resolution has, however, been unevenly implemented, some actors being more successful than others in undertaking significant measures. This is why some of its obligations have been clarified in further resolutions. For example, Resolution 64/72 clarified the conducting of environmental impact assessments, ${ }^{430}$ and Resolution 66/68 called for the strengthening of assessment and compliance measures. ${ }^{431}$ Notwithstanding these weaknesses, Resolution 61/105 became a key reference when talking about measures undertaken to counter the adverse impacts of fisheries. It is also used as an example of progress for the protection of the marine environment against fishing practices and for its elaboration of specific duties targeting different actors. The importance of Resolution 61/105 for the protection of marine habitats is also reiterated in the yearly sustainable fisheries resolutions. ${ }^{432}$

Another example of successful measures for the protection of the marine environment from fishing practices through UNGA resolutions can be seen in the case of largescale pelagic drift-net fishing. These nets, hanging in the water column to catch pelagic species, cause extremely high numbers of by-catch, including endangered species. States of the South Pacific, which rely heavily on fishing activities for their economic survival, were concerned by the effects of long driftnet fishing techniques on non-target species and the marine environment in their respective EEZ and in high seas areas beyond their EEZs. They adopted the 1989 Wellington Convention to restrict and prohibit the use of driftnets in the South Pacific region in order to conserve marine living resources. ${ }^{433}$ The Wellington Convention led the UNGA, in

429 Ibid at paras 89-90.

430 Sustainable fisheries, including through the 1995 Agreement for the Implementation of the Provisions of the United Nations Convention on the Law of the Sea of 10 December 1982 relating to the Conservation and Management of Straddling Fish Stocks and Highly Migratory Fish Stocks, and related instruments, GA Res 64(LXXII), UNGAOR, 64th Sess, UN Doc A/RES/64/72 (2009) at para 119(a) and (c).

431 Sustainable fisheries, including through the 1995 Agreement for the Implementation of the Provisions

of the United Nations Convention on the Law of the Sea of 10 December 1982 relating to the Conservation and Management of Straddling Fish Stocks and Highly Migratory Fish Stocks, and related instruments, GA Res 66(LXVI), UNGAOR, 66th Sess, UN Doc A/RES/66/68 (2011) at para 129.

432 See, e.g. UNGA Res 74/18, supra note 11 at paras 26, 194-196, 199, 207 and 241, and UNGA Res 73/125, supra note 11 at paras 25, 187-189, 192, 200 and 234.

433 On the Wellington Convention, see Ellen Hey et al, "The regulation of driftnet fishing on the high seas: legal issues" (1991) FAO legislative study 47 at 41-42. The following year, two protocols supplemented the Wellington Convention. Protocol I, ratified by the United States in 1992, indicates that States without territory in the Convention area can still forbid their nationals from using drift-nets in the Convention area, see Protocol No. I to the Convention for the prohibition of fishing with long driftnets in the South Pacific (20 October 1990, entered into force 28 February 1992) 1899 UNTS 37. Protocol II, ratified by Chile in 1993 and Canada in 1998, provides that States with adjacent waters to the Convention area can still forbid 
1991, to call for a worldwide moratorium on large driftnet fishing on the high seas through Resolution 46/215. ${ }^{434}$ Following that resolution, nearly all States prohibited large-scale pelagic driftnets, ${ }^{435}$ and some RFMOs have also expressly prohibited the use of driftnets in their area of jurisdiction, as demonstrated by the 2013 SPRFMO Conservation and management measure for Gillnets in the SPRFMO Convention Area. ${ }^{436}$

Oceans and the Law of the Sea resolutions have also contributed to the evolution of marine biodiversity protection. For example, the 2004 Resolution 59/24 outlined the importance of developing medium- and long-term solutions in combatting the adverse impacts of destructive practices on marine ecosystems and biodiversity. It led to the establishment of an Ad-Hoc Open-Ended Informal Working group to study issues related to the conservation and sustainable use of marine biodiversity beyond national jurisdiction. ${ }^{437}$ This marked the start of the institutionalisation of the BBNJ process, which has now entered the phase of the intergovernmental conference, negotiating the text of an internationally legally binding instrument on the matter. ${ }^{438}$ The 2005 Resolution 56/12 for its part brought further specifications to the notion of "interrelated" found under the preamble to UNCLOS. It in fact referred to the need to use "an integrated, interdisciplinary and intersectoral approach" to address the problems of ocean space. ${ }^{439}$ This shows the evolution of the understanding of some basic concepts guiding the application of UNCLOS in light of new developments and principles.

\subsubsection{Soft-law instruments of the Food and Agriculture Organization (FAO)}

In addition to the two legally binding treaties adopted under the auspices of the FAO, ${ }^{440}$ the Organization has developed a series of non-legally binding instruments: a code of conduct (3.2.2.1) set to complement the UNFSA, four international plans of action (3.2.2.2), and various guidelines, three of which are discussed below (3.2.2.3). All these instruments have one common goal: to assist in the implementation of

their nationals from using drift-nets in the Convention area, see Protocol No. II to the Convention for the prohibition of fishing with long driftnets in the South Pacific (20 October 1990, entered into force 5 October 1993) 1899 UNTS 47.

434 Large-scale pelagic drift-net fishing and its impact on the living marine resources of the world's oceans and seas, GA Res 46(CCXV), UNGAOR, 46th Sess, UN Doc A/RES/46/215 (1991) at para 3.

435 Jenny Grote Stoutenburg, "Implementing a New Regime of Stable Maritime Zones to Ensure the (Economic) Survival of Small Island States threatened by Sea-Level Rise" (2011) 26 International Journal of Marine and Coastal Law 263-312 at 306.

436 Conservation and Management Measure for Gillnets in the SPRFMO Convention Area, SPRFMO CMM 08-2013 (2013) at para 1.

437 Oceans and the law of the sea, GA Res 59(XXIV), UNGAOR, 59th Sess, UN Doc A/RES/59/24 (2004) at paras 68 and 76, discussed in Gjerde, "High Seas Fisheries Management", supra note 37 at 296.

438 The BBNJ process is discussed in more detail in chapter 4 below.

439 Oceans and the law of the sea, GA Res 56 (XII), UNGAOR, 56th Sess, UN Doc A/RES/56/12 (2001). These concepts are discussed in the chapter 1 above.

440 See section 3.1.7 above. 
the legally binding instruments discussed above. ${ }^{411}$ Further, these non-binding instruments tend to have a broader scope of application, targeting all actors involved in fishing operations at all levels, and often expressly underlining the importance of the interconnectedness between fishing operations and the marine environment. This section finally addresses briefly some relevant initiatives undertaken under the auspices of the FAO (3.2.2.4).

\subsubsection{Code of Conduct for Responsible Fisheries}

Adopted in 1995, the Code of Conduct"42 "sets out principles and international standards of behaviour for responsible practices with a view to ensuring the effective conservation, management and development of living aquatic resources, with due respect for the ecosystem and biodiversity". ${ }^{43}$ Although the Code of Conduct's aim overlaps with that of the UNFSA, the former has a broader scope of application than the latter. It covers all fisheries, not only straddling and highly migratory stocks, and applies to all aspects of fisheries, including capture and trade, as well as the consideration of fisheries in broader environmental management and research activities. ${ }^{444}$ Its scope of application also extends to all actors in fisheries. ${ }^{445}$

In terms of the relationship of the Code of Conduct with other instruments, article 3 reaffirms the importance of interpreting and applying the Code of Conduct in a manner consistent with UNCLOS, the UNFSA, and "other applicable rules of international law, including the respective obligations of States pursuant to international agreements to which they are party", which would also include the obligations contained in the constitutive instruments of RFMOs. This supports the role of the Code of Conduct as an instrument guiding the implementation of the relevant binding treaties. Article 3 also provides that the Code should be interpreted and applied in light of the major environmental law declarations (e.g. Rio Declaration and Agenda 21). This last reference strengthens the role of the Code of Conduct as an instrument bridging the gap between fisheries operations and environmental law principles.

441 For a more detailed selection of FAO-based initiatives and guidelines on fisheries that support the Code of conduct, supra note 72, and highlight the consideration of biodiversity across fisheries, see Friedman, Garcia \& Rice, supra note 286 at 211 . The instruments discussed in the present section have, however, been chosen because of their relevance for high seas fisheries and because of their scope of application, which targets a wide variety of actors.

442 For an overview of the Code of conduct's framework, see Harrison, Saving the Oceans, supra note 10 at 178 ; Guggisberg, The Use of CITES, supra note 9 at 55; Churchill, supra note 35 at 38-40; Wyssbrod, supra note 93 at 108.

443 Code of conduct, supra note 72 at introduction.

$444 \mathrm{Ibid}$ at art. 1.3.

445 Ibid at art. 1.2. 
The most relevant provisions related to high seas fisheries can be found in articles 6, 7 and 8 of the Code of Conduct. ${ }^{446}$ Article 6 lists the general principles that should govern actors' behaviour in fisheries activities. These principles can subsequently be found in the management of fisheries (objectives, framework, measures and implementation) dealt with under article 7, including details as to the economic and environmental factors qualifying the $\mathrm{MSY}^{447}$ and in fishing operations, covered under article 8. Articles 6 to 8 ensure that long-term conservation measures, of fish stocks and their habitats, should be determined by sustainable practice, the best available science and the precautionary approach. Activities should be directed towards avoiding overfishing and unsafe fishing gear, and reducing adverse impacts on the marine environment. Actors should ensure compliance and enforcement, by imposing appropriate sanctions when necessary, and by being transparent in making decisions and undertaking measures. They are also required to cooperate, among themselves and through regional organizations.

The application of the Code of Conduct is complemented by a series of Technical Guidelines for Responsible Fisheries, adopted by the FAO over the years. ${ }^{448}$ These Guidelines remain indicative only, although they are detailed and diverse in terms of coverage and emphasize various aspects of the relationship between fisheries and the marine environment. ${ }^{449}$ The Guidelines aim to further develop the understanding of certain concepts referred to in the Code of Conduct. For example, general guidelines addressing the precautionary approach, as well as fishing operations and fishing management were adopted shortly after the Code of conduct in order to support its articles 7 and $8{ }^{450}$ Further, a series of guidelines were adopted on the ecosystem approach to fisheries, covering its human dimensions and the best practices in ecosystem modelling. ${ }^{451}$ More recently, guidelines have addressed questions that have gained importance over the last decade, such as responsible fish trade, and the use of MPAs in the context of fisheries as a measure to include fisheries management into biodiversity conservation. ${ }^{452}$

Under article 4 of the Code of Conduct, all actors "should collaborate in the fulfilment and implementation of the objectives and principles contained in this

446 For an overview of the main measures under the Code of conduct, see Gjerde, "High Seas Fisheries Management", supra note 37 at 293-294.

447 Code of conduct, supra note 72 at art. 7.2.2, addressed in Barnes, "Domestic Fisheries Conservation", supra note 115 at 253

448 All guidelines can be found at FAO, online: <www.fao.org/fishery/code/publications/guidelines/en>.

449 Churchill, supra note 35 at 39.

450 FAO, "Precautionary approach to capture fisheries and species introductions" (1996) FAO Technical Guidelines for Responsible Fisheries, online: <http://www.fao.org/3/a-w3592e.pdf>; FAO, "Fishing operations" (1996) FAO Technical Guidelines for Responsible Fisheries, online: <http://www.fao.org/3/aw3591e.pdf>.

451 See, e.g., FAO, "Fisheries Management. 2. The Ecosystem Approach to Fisheries" (2003) FAO Technical Guidelines for Responsible Fisheries No. 4 Suppl. 2, online: <http://www.fao.org/3/a-y4470e.pdf >.

452 FAO, "Responsible fish trade" (2009) FAO Technical Guidelines for Responsible Fisheries, online: <http:// www.fao.org/3/a-i0590e.pdf>; FAO, "Fisheries Management. 4. Marine Protected Areas and Fisheries" (2011) FAO Technical Guidelines for Responsible Fisheries, online: <http://www.fao.org/3/a-i2090e.pdf>. 
Code", and this is why implementation and monitoring measures play a key role. The FAO COFI is responsible for monitoring the implementation of the Code of Conduct, which is done mostly through questionnaires filled in voluntarily by States, RFMOs and NGOs. For the report of the $33^{\text {rd }}$ session of the COFI in $2018,{ }^{453}$ 128 States, ${ }^{454} 33$ regional fishery bodies (RFBs) and 11 NGOs responded. ${ }^{455}$ The report showed that most members had implemented fisheries policies and that, from those which had marine fisheries activities, "most reported to have developed and implemented fisheries management plans." ${ }^{356}$ Three quarters of the members had started implementing an ecosystem approach to fisheries, ${ }^{457}$ while more than half had monitored by-catch and discards ${ }^{458}$ Nearly all States have also reported to have been conducting control operations outside their EEZ through mandatory authorization schemes. ${ }^{459}$ States have also reported "medium to high" in the level of implementation of all major legally binding fisheries instruments (e.g. UNCLOS, UNFSA, Compliance Agreement and PSMA). ${ }^{460}$ At the level of RFBs, between half and two thirds have taken steps to ensure that fishing operations follow the management plans, that the precautionary approach is applied in their respective area of competence, that requirements for the implementation of vessel monitoring systems (VMS) are established, and that they assist in the implementation of IPOAs. ${ }^{461}$ Yet, despite these promising numbers, it has to be remembered that these data are collected on a voluntary basis and that, although they are a good indication of progress achieved, they can be incomplete. Member States have also mentioned that their difficulties in implementing the Code of Conduct come mostly from insufficient financial and human resources, incomplete policy and legal frameworks, and lack of scientific research and information about the Code of Conduct. ${ }^{462}$

\subsubsection{International Plans of Action}

The four International Plans of Action (IPOAs) are voluntary instruments which elaborate on practical measures to help actors fulfil the commitments they are

453 Progress in the Implementation of the Code of Conduct for Responsible Fisheries and Related Instruments, FAO COFI, 33rd Sess, Doc COFI/2018/3 (2018) [COFI Report 2018]. The $34^{\text {th }}$ session of the COFI was supposed to take place in July 2020 but was postponed due to the COVID-19 pandemic.

$454 \mathrm{Ibid}$ at 2, para 5. 128 States represent 65\% of all FAO member States (194 in total, which includes North Korea which is not a UN member State). Out of the 193 UN member States, 151 are coastal States. Consequently, 128 States participating in the voluntary reporting is rather promising. It is important to underline that, as the Code of conduct applies to all types of fisheries, including inland fisheries, these numbers do not necessarily differentiate the types of fisheries conducted by the States. The numbers are therefore used for illustrative purposes only and caution should be exercised when analysing them for the understanding of high seas catches. Data on high seas fisheries only are hardly available, see section 2.1 above, and chapter 5 section 2.1 .2 below.

45533 RFBs out of 52, see COFI Report 2018, supra note 453 at 3, para 6.

456 Ibid at 3, para 9.

457 Ibid at 3, para 10.

458 Ibid at 4 , para 12

459 Ibid at 3-4, para 11.

460 Ibid at 5, para 21.

$461 \mathrm{Ibid}$ at 7, paras 32-35.

$462 \mathrm{Ibid}$ at 6, para 29. 
called to make under the Code of Conduct. The IPOA-Seabirds, the International Plan of Action for the Management of Fishing Capacity (IPOA-Capacity) and the International Plan of Action for Conservation and Management of Sharks (IPOASharks) were adopted in 1999, while the IPOA-IUU was adopted two years later. ${ }^{463}$

The IPOA-Seabirds intends "to reduce the incidental catch of seabirds in longline fisheries where this occurs" ${ }^{464}$ through the use of safe gear and fishing methods. ${ }^{465}$ On the high seas, the IPOA targets "States that conduct longline fisheries" in that area. ${ }^{466}$ Similarly, the IPOA-Sharks works generally to "ensure the conservation and management of sharks and their long-term sustainable use", ${ }^{467}$ addressing both target and non-target catches ${ }^{468}$ by ensuring that mortality rates of target catches are within sustainable levels, ${ }^{469}$ while reducing incidental catches. The IPOA-Capacity, for its part, aims for the "efficient, equitable and transparent management of fishing capacity.".70 In all three IPOAs, States are required to conduct an assessment of whether fisheries create adverse impacts on the other species (for IPOA-Seabirds and Sharks), and an assessment of capacity (for IPOA-Capacity). If adverse impacts exist, States must adopt a National Plan of Action (NPOA), mirroring the IPOA. ${ }^{471}$ Lastly, the IPOA-IUU supports the fight against IUU fishing "by providing all States with comprehensive, effective and transparent measures by which to act, including through appropriate" RFMOs. ${ }^{472}$ In a similar way to the other IPOAs, the IPOAIUU includes general measures for all States, including the requirement to adopt NPOAs, ${ }^{473}$ complemented by measures specifically for flag States, coastal States, port States, RFMOs and the FAO. ${ }^{474}$

Overall, the IPOAs must be seen as providing guidance for the implementation of the obligations contained in other instruments. The IPOA-Sharks for example, could be of relevance for bringing clarification to obligations held by RFMOs mandated with the conservation and management of these species, or to the obligation of cooperation held by range States under the CMS. Nevertheless, the relationship of the IPOAs to other instruments is the same as the one provided for under the Code of conduct ${ }^{475}$ meaning that they must be interpreted and applied in accordance with

463 International Plan of Action for the conservation and management of sharks and International Plan of Action for the management of fishing capacity, FAO COFI, 23rd Sess (1999), online: <http://www.fao. org/tempref/docrep/fao/006/x3170e/X3170E00.pdf> [IPOA-Sharks \& IPOA-Capacity]; IPOA-Seabirds, supra note 74; IPOA-IUU, supra note 61.

464 IPOA-Seabirds, supra note 74 at para 10.

465 Referring to the Code of conduct, supra note 72 at arts. 7.6.9 and 8.5.

466 IPOA-Seabirds, supra note 74 at para 9.

467 IPOA-Sharks, supra note 463 at para 16.

468 Ibid at para 12.

$469 \mathrm{Ibid}$ at para 14.

470 IPOA-Capacity, supra note 463 at para 7

471 IPOA-Seabirds, supra note 74 at para 12; IPOA-Sharks, supra note 463 at para 18; IPOA-Capacity, supra note 463 at paras 8 and 19-24.

472 IPOA-IUU, supra note 61 at para 8.

$473 \mathrm{Ibid}$ at paras 25-27.

474 Ibid at paras $34-50,51,52-64,78-84$ and 88-93 respectively.

475 Code of conduct, supra note 72 at art. 3 . 
other relevant international instruments. IPOAs are therefore meant to inform the implementation of obligations, but cannot broaden their scope.

\subsubsection{International and voluntary guidelines}

Alongside the IPOAs, international guidelines have been adopted to assist actors in implementing certain aspects of fisheries management and fishing operations. ${ }^{476}$ Three of these guidelines are relevant for the present study.

First, the FAO was urged by the UNGA in Resolution 61/105 to adopt guidelines to assist States and RFMOs in their sustainable management of deep-sea fisheries. ${ }^{477}$ The International Guidelines for the Management of Deep-sea Fisheries in the High Seas (Guidelines on Deep-sea Fisheries) were therefore adopted in 2008, targeting "fisheries exploiting deep-sea fish stocks, in a targeted or incidental manner, in areas beyond national jurisdiction, including fisheries with the potential to have significant adverse impacts on vulnerable marine ecosystems (VMEs)". ${ }^{478}$ The Guidelines on Deep-sea Fisheries first include descriptions of key concepts, such as VMEs and significant adverse impacts, i.e. that compromise ecosystem integrity. ${ }^{479}$ They then address general management considerations (respect other fisheries related instruments, rely on best scientific information available, ensure effective monitoring, control and surveillance, etc.), ${ }^{40}$ and further elaborate on management and conservation steps, notably data collection and reporting, the assessment of VMEs, and the adoption of measures to ensure enforcement and compliance. ${ }^{481}$ The Guidelines on Deep-sea Fisheries' main objectives are the long-term conservation and sustainable use of marine living resources in the deep seas, the prevention of significant adverse impacts on VMEs and the protection of marine biodiversity; ${ }^{482}$ they thus represent a good example of instruments directly targeting the impact of fishing on the marine environment. ${ }^{483}$

Secondly, in 2011, following a call for action in several UNGA resolutions on sustainable fisheries, ${ }^{484}$ the International Guidelines on By-catch Management and

\footnotetext{
476 See generally, FAO, "International guidelines", online: <http://www.fao.org/fishery/code/guidelines/en>.

477 UNGA Res 61/105, supra note 425 at para 53. See also Freestone, supra note 45 at 108 . Deep-sea fisheries are defined as fisheries "that take place at great depths (up to 1600 metres)" and most of which take place in ABNJ, see FAO, "Deep-sea Fisheries in the High Seas. Ensuring sustainable use of marine resources and the protection of vulnerable marine ecosystems" (2009) at 2, online: <http://www.fao.org/3/i1064e/ i1064e00.pdf>.

478 International Guidelines for the Management of Deep-sea Fisheries in the High Seas (2009) at para 5, online: $<$ http://www.fao.org/3/i0816t/i0816t00.htm>.

$479 \mathrm{Ibid}$ at para 17.

480 Ibid at para 21.

$481 \mathrm{Ibid}$ at paras $30-83$.

482 Ibid at paras 6, 11 and 12 .

483 Churchill, supra note 35 at 46-47.

484 See, e.g., UNGA Res 64/72, supra note 430 at preamble and paras 80-86.
} 
Reduction of Discards (Guidelines on By-catch) ${ }^{485}$ were adopted to complement the provisions of the Code of conduct dealing with by-catch and non-target species, as well as the IPOA-Seabirds and the IPOA-Sharks. ${ }^{486}$ The Guidelines on By-catch, of global application, including the high seas, ${ }^{487}$ promote responsible fisheries by minimizing catches not consistent with the Code of Conduct, more effective management of by-catch, and the improvement of the reporting of by-catch and discards. ${ }^{488}$ In a similar way to the Guidelines on Deep-sea Fisheries, the Guidelines on By-catch provide a definition of by-catch, ${ }^{489}$ and then elaborate on measures that all actors ${ }^{490}$ should undertake to improve management planning, data collection and by-catch assessments. ${ }^{491}$ They also present a list of specific measures and tools to manage by-catch and reduce discards, including the combatting of ghost-fishing. ${ }^{492}$

The final set of guidelines of relevance for understanding the existing measures addressing the adverse impacts of fisheries on the marine environment, targets the problem of IUU fishing. In 2015, the Voluntary Guidelines for Flag State performance (Guidelines for Flag States) were adopted, seeking "to prevent, deter and eliminate illegal, unreported and unregulated (IUU) fishing [...] through the effective implementation of flag State responsibilities" for the flagging and control of fishing vessels. ${ }^{493}$ Seemingly reaffirming already existing principles and measures, the Guidelines for Flag States were, however, acknowledged for harmonizing all the relevant criteria for the assessment of flag State performance and for the interpretation of their obligations regarding conservation measures. ${ }^{494}$ They also encourage States to have their performance assessed regularly, either through self-assessment or through an external assessment. This procedure is, however, voluntary. ${ }^{495}$

The Guidelines for Flag States further underline some recent concerns. These include the reference not only to fishing, but also fishing related activities, which could potentially include pre- and post-capture activities. It also cross-references the IPOA-IUU by expecting States to adopt national frameworks to combat IUU fishing, and to establish a licensing regime, which would allocate licences to vessels complying with measures protecting marine ecosystems. ${ }^{496}$ The obligations of flag

485 International Guidelines on By-catch Management and Reduction of Discards (2011) at para 1.2, online: $<$ http://www.fao.org/3/a-ba0022t.pdf>.

486 Ibid at para 1.3 .

487 Ibid at para 2.1 .

$488 \mathrm{Ibid}$ at para 2.3 .

$489 \mathrm{Ibid}$ at para 2.4 .

490 Ibid at para 3.

491 Ibid at paras 4-5.

492 Ibid at paras 7-8, and most particularly at para 7.3.

493 Voluntary Guidelines for Flag State Performance (2015) at para 1, online: <http://www.fao.org/3/a-i4577t. pdf> [Guidelines for Flag State Performance].

494 Guggisberg, The Use of CITES, supra note 9 at 149.

495 Guidelines for Flag State Performance, supra note 493 at paras 44-46. See also Guggisberg, "IMO Audit Scheme", supra note 199 at 517-519.

496 Lee, Teletesky \& Schofield, supra note 36 at 103-104. 
States in cases of IUU fishing were developed further by ITLOS in its 2015 Advisory Opinion on IUU Fishing, which is discussed in further detail below. ${ }^{497}$

\subsubsection{Other relevant initiatives}

From 2014 to 2019, the FAO coordinated the Global Sustainable Fisheries Management and Biodiversity Conservation in the Areas Beyond National Jurisdiction Programme. The programme promoted the "efficient and sustainable management of fisheries resources and biodiversity conservation in $\mathrm{ABNJ}$ to achieve the global targets agreed in international fora" ${ }^{498}$ In order to do so, the programme focused on the promotion of the ecosystem approach and crosssectoral coordination for the sustainable exploitation of tuna and deep-sea fisheries, and worked towards the development of ocean partnerships.

The FAO also oversees the Global Record of Fishing Vessels, Refrigerated Transport Vessels and Supply Vessels, a global initiative aiming to deter IUU fishing by keeping a comprehensive and updated repository of fishing vessels. This is achieved by, among other means, assigning "a Unique Vessel Identifier (UVI) to each vessel worldwide, which remains constant throughout the vessel's lifetime regardless of change of name, ownership or flag". ${ }^{499}$

\subsubsection{Overarching environmental soft-law instruments}

The description of the main soft-law instruments shaping international fisheries law would not be complete without having a look at different environmental law instruments addressing questions of sustainability, biodiversity and environmental protection. These instruments in fact outline several principles of general application to the marine environment and the activities conducted therein, principles which have also found their way into the legally and non-legally binding instruments discussed above.

The first time that the impact of human activities on the environment, including the marine environment, was specifically addressed in a global instrument dates back to the 1972 Stockholm Declaration, which recognized the need to safeguard ecosystems through careful appropriate management and to maintain sustainable productivity of resources. ${ }^{500}$ The recognition of the dependence of humans on

497 Advisory Opinion on IUU Fishing, supra note 201, discussed in further detail in section 3.3.1 below.

498 FAO, "Common Oceans - A partnership for sustainability in the ABNJ", online: <http://www.fao.org/ in-action/commonoceans/en/>.

499 FAO, "Global Record of Fishing Vessels, Refrigerated Transport Vessels and Supply Vessels", online: $<$ http://www.fao.org/global-record/en/>.

500 See in particular principle 2 ("The natural resources of the earth, including the air, water, land, flora and fauna and especially representative samples of natural ecosystems, must be safeguarded for the benefit of present and future generations through careful planning or management, as appropriate"), principle 3 ("The capacity of the earth to produce vital renewable resources must be maintained and, wherever 
nature, and therefore the need to protect the environment from human activities, especially those leading to excessive exploitation and destruction of natural habitats, was reiterated 10 years later in the 1982 World Charter for Nature, adopted through UNGA Resolution 37/7..$^{501}$ In 1992, the international community went a step further and adopted the Rio Declaration, which focused on the relationship between the environment and development, with a specific interest in the concepts of sustainability and precaution in the use of resources. ${ }^{502}$ The Rio Declaration was complemented by Agenda 21, of which Chapter 17 addresses the protection of the oceans and their living resources. The 1992 Rio Conference also established the Global Environment Facility, ${ }^{503}$ a fund created to support projects aimed at finding solutions to severe environmental problems, operating in seven fields, including biodiversity and international waters. Fisheries also fall under its domains of interests.

The start of the 21st century also saw the adoption of overarching soft-law instruments aimed at protecting and preserving the (marine) environment. With the new millennium, the Millennium Development Goals (MDGs) were adopted. ${ }^{504}$ In particular, Goal 7 ensures environmental sustainability through, among other things, the reduction of biodiversity loss and the protection of ecosystems, on land and also in marine areas. ${ }^{505}$ Most of the targets established under the MDGs have, however, not been achieved within the agreed deadlines.

Furthermore, the 2002 World Summit on Sustainable Development ${ }^{506}$ was convened to discuss the questions of sustainable development which had been addressed 10 years before in Rio. The Plan of Implementation of the World Summit on Sustainable Development, as part of the commitment to protect and manage the natural resource base of economic and social development, dedicates a section to the importance of oceans for the earth's ecosystem and for food security, and identifies many actions

practicable, restored or improved") and principle 5 ("The non-renewable resources of the earth must be employed in such a way as to guard against the danger of their future exhaustion and to ensure that benefits from such employment are shared by all mankind").

501 World Charter for Nature, GA Res 37(VII), UNGAOR, 37th Sess, UN Doc A/RES/37/7 (1982).

502 Rio Declaration at principle 3 ("The right to development must be fulfilled so as to equitably meet developmental and environmental needs of present and future generations"), principle 4 ("In order to achieve sustainable development, environmental protection shall constitute an integral part of the development process and cannot be considered in isolation from it"), principle 7 ("States shall cooperate in a spirit of global partnership to conserve, protect and restore the health and integrity of the Earth's ecosystem. In view of the different contributions to global environmental degradation, States have common but differentiated responsibilities") and principle 15 ("In order to protect the environment, the precautionary approach shall be widely applied by States according to their capabilities. Where there are threats of serious or irreversible damage, lack of full scientific certainty shall not be used as a reason for postponing cost-effective measures to prevent environmental degradation").

503 Global Environmental Facility, online: <https://www.thegef.org/>.

504 The MDGs emanate from United Nations Millennium Declaration, GA Res 52(II), UNGAOR, 52nd Sess, UN Doc A/RES/52/2 (2000).

505 See, generally, UN, “Millennium Development Goals and beyond 2015”, online: <http://www.un.org/ millenniumgoals/environ.shtml $>$.

506 World Summit on Sustainable Development (Johannesburg, South Africa, 26 August-4 September 2002). 
to protect fisheries and the oceans more broadly. ${ }^{507}$ It also calls upon States to ratify or accede to the main law of the sea related instruments, and promotes their implementation, including that of Chapter 17 of Agenda 21. Ten years later, the 2012 United Nations Conference on Sustainable Development (Rio+20 Conference) saw the adoption of "clear and practical measures for implementing sustainable development" ${ }^{508}$ Contained in a political outcome document, The Future We Want ${ }^{509}$ these measures aim to "promote policy coherence at all relevant levels, improve efficiency, reduce unnecessary overlap and duplication, and enhance coordination and cooperation among the multilateral environmental agreements". ${ }^{510}$

Building upon The Future We Want, in 2015 the UNGA adopted Resolution 70/1, Transforming our World: the 2030 Agenda for Sustainable Development ${ }^{511}$ which establishes the 17 SDGs to be accomplished through 169 targets. These goals and targets "seek to build on the [MDGs] and complete what they did not achieve". 512 Among those 17 goals, SDG 14 "Life below water" is entirely dedicated to the conservation and sustainable use of the oceans, seas and marine resources for sustainable development, addressing, among other matters, issues of climate change, ocean acidification, overfishing and marine pollution. In June 2017, the UN Oceans Conference, which gathered stakeholders from all sectors, including NGOs, academia, the industry, and the public sector, was held to discuss the implementation of SDG $14 .{ }^{513} \mathrm{~A}$ second conference is expected to be held in $2021 .{ }^{514}$

Finally, 2017 saw the presentation of the Global Pact for the Environment to the UN. The original project aimed to become an international treaty of legally binding force containing "the major principles that guide environmental actions", 515 gathering all main principles under the banner of one single document, and approaching them all in an interconnected and complementary manner. An ad hoc open-ended working group, created in May 2018, ${ }^{516}$ considered a technical and evidence-based report that identified and assessed possible gaps in international environmental law and environment-related instruments with a view to strengthening their implementation. ${ }^{517}$ It also addressed the feasibility of developing an international

507 Plan of Implementation of the World Summit on Sustainable Development (2002) at para 30, online: $<$ https://www.un.org/esa/sustdev/documents/WSSD_POI_PD/English/WSSD_PlanImpl.pdf>. See also Gjerde, "High Seas Fisheries Management", supra note 37 at 295.

508 UN, "United Nations Conference on Sustainable Development, Rio+20", online: <https://sustainable development.un.org/rio20.html>.

509 The Future We Want, GA Res 66(CCLXXXVIII), UNGAOR, 66th Sess, UN Doc A/RES/66/288 (2012).

$510 \mathrm{Ibid}$ at para 89.

511 UNGA Res 70/1, supra note 398.

512 Ibid at preamble.

513 United Nations Ocean Conference (New York, 5-9 June 2017), online: <https://oceanconference.un.org/about>.

514 UN, “UN Ocean Conference", online: <https://www.un.org/en/conferences/ocean2020>. The second UN Conference was initially planned for June 2020, but was postponed due to the COVID-19 pandemic.

515 "Global Pact for the Environment", online: < https://globalpactenvironment.org/en/>.

516 Towards a Global Pact for the Environment, GA Res 72(CCLXXVII), UNGAOR, 72nd Sess, UN Doc A/RES/72/277 (2018).

517 Ibid at paras 1-2. 
instrument. The working group met on three occasions between January and May 2019, and the recommendations finally adopted by the States merely suggested the adoption of a simple political declaration in 2022. This result was considered to be disappointing and was said to be a "setback in terms of ambition: a simple Declaration, the content of which remains vague, and not an international, legally binding treaty that enshrines the general principles of environmental law". ${ }^{18}$ As the initiative is said to have been blocked by a minority of States, ${ }^{519}$ the expected document remains indicative of the will of a majority of States.

Although mainly providing general principles, especially for instruments predating 2000, these overarching instruments and the provisions contained therein have formed the basis for the development of many of the instruments discussed in previous sections. Just to name a few, the 1992 Rio Declaration strongly influenced the text of the CBD as well as some provisions of the UNFSA, while, more recently, SDG14 acts as a catalyst for the BBNJ process, which is expected to interact with the regime for international fisheries. ${ }^{520}$ The importance of these overarching environmental soft-law instruments for the development of the regime for international fisheries law must therefore be acknowledged.

\subsection{Actors operationalizing the legal framework}

The above sections have examined instruments which map the main rules to be followed in the conducting of fishing activities. It also maps how obligations have been framed to ensure the conformity of these fishing activities with the conservation and sustainable use of the resources and, more broadly, of the marine environment. The interconnectedness that characterizes the oceans is also visible in the array of actors sharing interests in its components, and undertaking actions to achieve compliance with the obligations and duties to which they or others are bound. A portrait of the current state of international fisheries law would therefore be incomplete without having a look at the actors involved in the operationalization of its legal framework.

Questions of implementation, enforcement and compliance have been addressed sporadically above, whereas the present section looks more closely at the actors charged with operationalizing the framework. It does not assess the implementation of different actors or give examples of implementation, but looks at the nature of these actors and the obligations which they hold. Although the instruments presented in this chapter have, on some occasions, briefly addressed non-State

518 Global Pact for the Environment, "Third and last session of the working group on the Pact in Nairobi", online: <https://globalpactenvironment.org/en/third-session-of-the-working-group-on-the-pact-innairobi/>.

519 Ibid.

520 The BBNJ process, and the issue of fisheries within the process, are both discussed further in chapter 4 below. 
actors as emerging actors in the implementation and enforcement of fisheries regulations, these instruments mostly create rights and obligations for State actors and target their behaviour. ${ }^{521}$ As stated by Harrison, "[S]tates retain control over international law-making, despite the increased involvement of non-[State] actors in this process", ${ }^{22}$ and it is submitted that the implementation also remains Statecentred. This is why the present section focuses on the role of State-based structures for the operationalization of the legal regime for international fisheries.

This section starts by looking into the actors recognized in the institutional structure of the law of the sea. ${ }^{523}$ Flag States have a primary enforcement role of fisheries regulations in $\mathrm{ABNJ}$ and standard setting to their nationals (3.3.1). International and regional organizations, mostly RFMOs (3.3.2) in the case of high seas fisheries, are the vehicles through which States are encouraged to undertake measures for management, conservation and cooperation. ${ }^{524}$ Coastal States and port States (3.3.3), although not being "traditional" actors on the high seas, have contributed to the development of the regime as well as its operationalization, coastal States through the regulation of activities within maritime zones under their jurisdiction (and potentially beyond), and port States mostly through fisheries related measures such as access to ports and landings. The section finally describes the role of RSPs in the operationalization of the regime (3.3.4). Although not mandated to address fisheries management and conservation, and despite the fact that they do not hold an implementation and enforcement role per se, RSPs remain relevant for the present analysis because of the role they play in the operationalization of marine environmental protection, which is, this study claims, interconnected with (high seas) fisheries management.

\subsubsection{Flag States}

Flag States are the main actors on the high seas, having in principles exclusive jurisdiction over the vessels flying their flag. ${ }^{525}$ This exclusive jurisdiction and control must be exercised effectively "in administrative, technical and social matters" ${ }^{26}$ In the framework of fisheries, this exclusive jurisdiction translates into the "exclusive authority for the enforcement of conservation and management measures on the high seas". ${ }^{527}$ It is submitted that this must be read complementarily with the duty

\footnotetext{
521 One exception is probably the Code of conduct which is intended to have a broader scope of application and also includes non-State actors.

522 Harrison, "Actors and Institutions", supra note 412 at 73.

523 Richard Barnes, "The Continuing Vitality of UNCLOS” in Jill Barrett \& Richard Barnes (eds), Law of the Sea UNCLOS as a Living Treaty (British Institute of International and Comparative Law, 2016) 459-489 at 472. See also Depypere, supra note 46 at 372.

524 See, e.g. UNCLOS at arts. 118 and 197.

525 UNCLOS at art. 92. See also Robin Geiß \& Christian J. Tams, "Non-Flag States as Guardians of the Maritime Order: Creeping Jurisdiction of a Different Kind?” in Henrik Ringbom (ed), Jurisdiction over Ships. Post-UNCLOS Developments in the Law of the Sea (Leiden: Brill Nijhoff, 2015) 19-49 at 21-23.

526 UNCLOS at art. 94(1). See also Gjerde, "High Seas Fisheries Management", supra note 37 at 292.

527 Harrison, Saving the Oceans, supra note 10 at 173.
} 
of enforcement by flag States in terms of marine pollution, which provides that flag States must ensure compliance with measures for the "prevention, reduction and control of pollution of the marine environment". ${ }^{28}$ It must further be specified that such measures apply to all fishing related activities, not only the fishing itself. Hence, transshipment or fuelling of shipping vessels would also fall under these conservation measures. ${ }^{529}$

Nevertheless, there is no clear list of flag State fisheries-related obligations on the high seas. The UNGA has, however, provided some clarification in its annual resolutions, ${ }^{530}$ and so have the Guidelines for Flag States. ${ }^{531}$ Flag States' obligations of conservation and management of marine living resources were also discussed by ITLOS in the 2015 Advisory Opinion on IUU Fishing. This Advisory Opinion dealt, among other matters, with the obligations of flag States regarding IUU fishing conducted in the EEZ of third parties (i.e. non-members of an RFMO). Although the Tribunal expressly limited its analysis of the relevant applicable IUU-related obligations to the EEZ ${ }^{532}$ it still embarked on an overview analysis of the general obligations of States under UNCLOS with regard to conservation and management. ${ }^{533}$ On that matter, it reiterated article 194 and confirmed the necessity for flag States to adopt conservation measures applicable to its nationals engaged in fishing activities on the high seas, ${ }^{534}$ which was characterized as a due diligence obligation. ${ }^{535}$

The duty to implement and enforce conservation measures can be fulfilled by three categories of actions. First, flag States must adopt conservation measures, which should be in line with generally accepted international rules and standards. Second, they must apply these conservation measures, by controlling the vessels flying their flags to ensure that they respect such measures. This control can take place, for example, through the issuance of authorization or licences, and through sanctions for the violation of established rules. Third, flag States must cooperate with other actors in the implementation of measures safeguarding the marine environment. ${ }^{536}$ Cooperation can take several forms, for example through participation in RFMOs or similar structures with conservation aims (e.g. RSPs), or through direct interstate actions. ${ }^{537}$ In the latter case, cooperation might take the form of technical and

528 UNCLOS at art. 217.

529 Harrison, Saving the Oceans, supra note 10 at 174.

530 On relevant UNGA Resolutions, see section 3.2.1 above.

531 Guidelines for Flag State Performance, supra note 493. See also Guggisberg, The Use of CITES, supra note 9 at 152.

532 Advisory Opinion on IUU Fishing, supra note 201 at para 89.

533 Ibid at para 109.

$534 \mathrm{Ibid}$ at para 119, discussed in Harrison, Saving the Oceans, supra note 10 at 174.

535 Advisory Opinion on IUU Fishing, supra note 201 at paras 125-139. On due diligence, see generally Timo Koivurova, "Due diligence" (2010) Max Planck Encyclopedia of International Law.

536 These categories of actions are also discussed in William Burke, "Unregulated High Seas Fishing and Ocean Governance" in Jon M. Van Dyke, Durwood Zaelke \& Grant Hewison (eds), Freedom for the Seas in the 21st Century: Ocean Governance and Environmental Harmony (Washington: Island Press, 1993) 235-271 at 244.

537 Harrison, Saving the Oceans, supra note 10 at 173; Guggisberg, The Use of CITES, supra note 9 at 149. 
technological assistance, such as assistance in providing and operating satellite surveillance and monitoring systems. ${ }^{538}$ Cooperation can also take place through other roles carried out by States, e.g. the fight against IUU fishing is also conducted through port State measures. ${ }^{539}$ Finally, if measures are undertaken over a vessel on the high seas by a State other than the flag State, such as inspection and boarding under article 21 UNFSA, the authorization of the flag State will be necessary for such intervention to take place, reaffirming the "supremacy" of flag State jurisdiction on the high seas, and leading to a need for collaboration between the flag State and the intervening State. ${ }^{540}$

The lack of ability and/or will of flag States to undertake these actions and measures or to respect them are the major obstacles to effective implementation of existing regulations. ${ }^{541}$ Different mechanisms have been developed to assist States in identifying and sanctioning non-complying actors. One mechanism that has proved to be fairly successful relies on blacklisting and whitelisting certain States or vessels. The EU has been a leader in using such measures. ${ }^{542}$ Adopted in 2008, and entering into force in $2010,{ }^{543}$ the EU blacklisting and cards system provides that a third State (i.e. non-EU State) that wishes to export fish to the EU must meet strict standards, showing that mechanisms are in place to prevent IUU fishing. If the authorities of that third State engage in a cooperative dialogue with the European Commission, show sufficient compliance with anti-IUU mechanisms, or demonstrate a will to improve such mechanisms, catches from that State will be allowed into the EU. On the other hand, if the State does not cooperate, or if there is evidence of shortcomings within that State's system to fight IUU fishing, the Commission sends a warning to that State, i.e. a yellow card, notifying it that it might be listed. If the State does not take action to improve its system, the Commission notifies that State that it has been listed, i.e. that it is receiving a red card. Upon the recommendations of the Commission, the Council then blacklists that State, and sanctions apply: fish and fish products from that State will not be allowed into the EU. Red cards and yellow cards can always be lifted if the sanctioned State provides evidence that measures have been undertaken to remedy the situation. ${ }^{544}$

538 Harrison, Saving the Oceans, supra note 10 at 174.

539 Ibid at 175.

540 This issue was at the heart of The M/V "SAIGA" (No. 2) Case (Saint Vincent and the Grenadines v. Guinea), (1999) ITLOS case 2, discussed in Harrison, Saving the Oceans, supra note 10 at 174 . See also Geiß \& Tams, supra note 525 at 32-33.

541 Harrison, Saving the Oceans, supra note 10 at 17; Freestone, supra note 45 at 117-118; FAO, "Report of the Expert Consultation on Flag State Performance" (2009) FAO Fisheries and Aquaculture Report No. 918 at 1, online: <http://www.fao.org/tempref/docrep/fao/012/i1249e/i1249e00.pdf>. Challenges of implementation are discussed generally in chapter 5 below.

542 For a visual overview of the cards and blacklisting system, see The Environmental Justice Foundation et al, "EU Regulation to combat illegal fishing. Third country carding process" (2015) Case Study \#1, online: <http://www.iuuwatch.eu/wp-content/uploads/2015/06/Case-Study1.2pp.FIN_1.pdf>.

543 Council Regulation (EC) No. 1005/2008 of 29 September 2008 establishing a Community system to prevent, deter and eliminate illegal, unreported and unregulated fishing, (2008) OJ, L 286/1.

544 For a general overview of the EU's blacklisting and cards procedure, see generally Eva Romée van der Marel, "Problems and Progress in Combatting IUU Fishing" in Richard Caddell \& Erik Molenaar (eds), Strengthening International Fisheries Law in an Era of Changing Oceans (Oxford: Hart, 2019) 291-318, 
The performance of flag States is further subject to assessment procedures under the Guidelines for Flag States. ${ }^{545}$ The real impact of such a procedure, however, remains to be seen, because assessments are voluntary and have for now not been conducted extensively. This is why, in the present author's opinion, the last two cooperation measures outlined above, i.e. measures taken by port States and by other States on the high seas, could be seen as complementing flag States' actions. It is submitted that, while the interventions by non-flag States on the high seas are sometimes raised as potentially encroaching on a flag State exclusive jurisdiction, ${ }^{546}$ this collaboration should be seen as "enrich[ing] the arsenal" for implementation and enforcement of fisheries related measures on the high seas, ${ }^{547}$ as they operate from different geographical areas and through different measures.

\subsubsection{Regional fishery bodies (RFBs)}

The obligation to engage in cooperation and collaboration for the management and conservation of fisheries ${ }^{548}$ is illustrated through the participation of States in RFBs. ${ }^{549}$ The mandate of these bodies varies: conducting scientific research, engaging in policy coordination and development, playing a purely advisory role, or adopting legally binding conservation and management measures (e.g. allocating fishing quotas and catches). ${ }^{550}$ The geographical coverage of RFBs is also diverse, e.g. inland fisheries, coastal fisheries, high seas fisheries, ${ }^{551}$ as are the types of species they cover. ${ }^{52}$

Within conservation and management bodies, two categories have the competence to adopt legally binding measures for the management and conservation of marine species: RFMOs and regional fisheries management arrangements (RFMAs). There is no generally accepted definition of RFMOs or RFMAs. ${ }^{53}$ RFMOs are

and Eva Romée van der Marel, "An Opaque Blacklist: the Lack of Transparency in Identifying Non Cooperating Countries under the EU IUU Regulation" in Lawrence Martin, Constantinos Salonidis \& Christina Hioureas (eds), Natural Resources and the Law of the Sea. Exploration, Allocation, Exploitation of Natural Resources in Areas under National Jurisdiction and Beyond (New York: JurisNet, 2017) 237-256.

545 Guidelines for Flag State Performance, supra note 493 at paras 44-46.

546 Geiß \& Tams, supra note 525 at 33-34. For example, one could think of the intervention of NGOs in enforcement actions on the high seas. For more on the involvement of NGOs in implementation and enforcement, see chapter 5 section 2.3 .1 below.

547 Geiß \& Tams, supra note 525 at at 48 .

548 UNCLOS at art. 118.

549 Lodge et al, supra note 92 at 1.

550 Sydnes, supra note 132 at 354; Wyssbrod, supra note 93 at 126-128.

551 Asmundsson, supra note 329 at 2; Tladi, supra note 42 at 662-663.

552 For a comprehensive overview of the major RFMOs and RFMAs covering straddling and highly migratory stocks, see Meltzer, supra note 215 at 571-604. See also Tladi, supra note 42 at 663.

553 Erik Molenaar, "International Regulation of Central Arctic Ocean Fisheries" in Myron Nordquist, John Norton Moore \& Ronan Long (eds), Challenges of the Changing Arctic. Continental Shelf, Navigations, and Fisheries (Leiden: Brill Nijhoff, 2016) 429-463 at 442-443 [Molenaar, "Central Arctic Ocean Fisheries"]; Henriksen, Hønneland \& Sydnes, supra note 214 at 17, further argue that if RFMOs and direct cooperation between States were to be placed on two opposing ends of a spectrum, RFMAs would fall somewhere in the middle. For a distinction between RFMO and RFMA, see also Marcus Haward, Governing Oceans in a Time of Change. Fishing for the Future? (Cheltenham: Edward Elgar, 2020) at 42. For a recent publication on the origins of RFMOs and RFMAs, the different types and key functions of 
normally considered as intergovernmental organizations with a distinct personality from their member States. They normally function through a more or less clear institutional structure, ${ }^{554}$ with a permanent organ mandated with decision-making powers (a Commission), ${ }^{555}$ a compliance/technical committee, a scientific body, ${ }^{556}$ and a secretariat to organise daily administrative duties. RFMAs are defined in the UNFSA as "a cooperative mechanism established [...] by two or more States for the purpose, inter alia, of establishing conservation and management measures". ${ }^{557}$ They differ from RFMOs as they do not present a formal structure but rely on flexible cooperative mechanisms. ${ }^{558}$ Although RFBs in general play an important role in the development and management of fisheries worldwide, the present section focuses on RFMOs and RFMAs, because they are the bodies with a clear high seas management and conservation mandate. The use of the term RFMO throughout this study also refers to RFMA.

Generally speaking, there are three types of RFMOs. First, general RFMOs normally have the mandate to regulate all fisheries resources in a defined area, unless specified otherwise. Their competence also applies to deep-sea fisheries. Second, specialised RFMOs are the organizations that have species specifically included in their mandate (as opposed to general RFMOs, which deal with all species unless excluded). Specialised RFMOs are normally created to deal with management situations that arise on an ad hoc basis. ${ }^{59}$ Third, tuna RFMOs, which can also be considered as specialised organizations, are normally categorized separately. In fact, tuna have specific characteristics, such as the fact that they are highly migratory, and this requires specific management knowledge and abilities. Tuna RFMOs in general deal with many species of tuna, except for the Commission for the Conservation of Southern Bluefin Tuna (CCSBT), which deals with bluefin tuna only. ${ }^{560}$ The main RFMOs and RFMAs with a high seas mandate are listed in Table 1 below. ${ }^{561}$

organizations and arrangements, and whether or not a body qualifies as an RFMO or an RFMA., see Erik J. Molenaar, "Regional Fisheries Management Organizations" in Marta Chantal Ribeiro, Fernando Loureiro Bastos \& Tore Henriksen (eds), Global Challenges and the Law of the Sea (Cham: Springer, 2020) 81-109.

554 On the structure of RFMOs and RFMAs, see James Harrison, "Key Challenges Relating to the Governance of Regional Fisheries" in Richard Caddell \& Erik Molenaar (eds), Strengthening International Fisheries Law in an Era of Changing Oceans (Oxford: Hart, 2019) 79-102 at 84 [Harrison, "Key Challenges"].

555 On the decision-making structure, see ibid at 86-92.

556 For more on the role of scientific bodies, see Stokke, supra note 20 at 102.

557 UNFSA at art. 1(1)(d).

558 Harrison, "Key Challenges", supra note 554 at 85; Meltzer, supra note 215 at 56.

559 Asmundsson, supra note 329 at 6-7.

560 Ibid at 4-6.

561 Based mostly on Erik Molenaar, "Participation in Regional Fisheries Management Organizations" in Richard Caddell \& Erik Molenaar (eds), Strengthening International Fisheries Law in an Era of Changing Oceans (Oxford: Hart, 2019) 103-129 at 108-109, and Erik Molenaar, "Participation in the Central Arctic Ocean Fisheries Agreement" in Akiho Shibata et al (eds), Emerging Legal Orders in the Arctic. The Role of Non-Arctic Actors (Abingdon, Oxon: Routledge, 2019) 132-170 at 150 [Molenaar, "Participation in the CAOFA"], completed by Asmundsson, supra note 329, and Meltzer, supra note 215. The classification between authors differs, and Table 1 is therefore indicative only. The variation among authors also supports the difficulty in classifying organizations and arrangements. 


\section{CHAPTER 2}

Table 1: Main RFMOs and RFMAs with high seas mandate

\section{General RFMOs}

Commission for the Conservation of Antarctic Marine Living Resources (CCAMLR) ${ }^{562}$

General Fisheries Commission for the Mediterranean (GFCM) ${ }^{563}$

North-East Atlantic Fisheries Commission (NEAFC) ${ }^{564}$

North Pacific Fisheries Commission (NPFC) ${ }^{565}$

Northwest Atlantic Fisheries Organization (NAFO) $)^{566}$

South East Atlantic Fisheries Organization (SEAFO) $)^{567}$

South Pacific Regional Fisheries Management Organization (SPRFMO) ${ }^{568}$

\section{Tuna RFMOs}

Commission for the Conservation of Southern Bluefin Tuna (CCSBT) ${ }^{569}$

Indian Ocean Tuna Commission (IOTC) $)^{570}$

International Commission for the Conservation of Atlantic Tunas (ICCAT) ${ }^{571}$

562 CCAMLR was established by the Convention on the Conservation of Antarctic Marine Living Resources (20 May 1980, entered into force 7 April 1982) 1329 UNTS 47 [CAMLR Convention]. See, generally, CCAMLR, online: <https://www.ccamlr.org>. See also D.G. Webster, "International Fisheries: Assessing the Potential for Ecosystem Management" (2013) 3:2 Journal of Environmental Studies and Sciences 169183 at 175; Tladi, supra note 42 at 664. CCAMLR was developed under the Antarctic Treaty System, while most RFMOs were similarly developed under UNCLOS. CCAMLR is often referred to as a hybrid organization, as its mandate goes beyond fisheries management and also encompasses competences of a purely conservationist nature, such as the actions undertaken by RSPs, described further in section 3.3.4 below.

563 GFCM was established by the Agreement for the Establishment of the General Fisheries Commission for the Mediterranean (24 September 1949, entered into force 20 February 1952) 2275 UNTS 157. It was last amended in 2014, see FAO, "General Fisheries Commission for the Mediterranean", online: <http://www. fao.org/gfcm/about/legal-framework/en/>.

564 NEAFC was established by the Convention on Future Multilateral Cooperation in the North-East Atlantic Fisheries (18 November 1980, entered into force 17 March 1982) 1285 UNTS 129. The most recent amendements entered into force in 2013, see NEAFC, "Convention on Future Multilateral Cooperation in North-East Atlantic Fisheries”, online: <https://www.neafc.org/system/files/Text-of-NEAFCConvention-04.pdf> [NEAFC Convention].

565 NPFC was established by the Convention on the Conservation and Management of High Seas Fisheries Resources in the North Pacific Ocean (24 February 2012, entered into force 19 July 2015) [NPFC Convention].

566 NAFO was established by the Convention on Cooperation in the Northwest Atlantic Fisheries, originally Convention on Future Multilateral Cooperation in the Northwest Atlantic Fisheries (24 October 1978, entered into force 1 January 1979) 1135 UNTS 369. It was last amended in 2017, see NAFO, "Northwest Atlantic Fisheries Organization, online: <https:/www.nafo.int/Portals/0/PDFs/key-publications/ NAFOConvention-2017.pdf $>$ [NAFO Convention].

567 SEAFO was established by the Convention on the Conservation and Management of Fishery Resources in the South East Atlantic Ocean (10 April 2001, entered into force 13 April 2003) 2221 UNTS 189 [SEAFO Convention].

568 SPRFMO was established by the Convention on the Conservation and Management of High Seas Fishery Resources in the South Pacific Ocean (14 November 2009, entered into force 24 August 2012) 2899 UNTS 211 [SPRFMO Convention].

569 CCSBT was established by the Convention for the Conservation of Southern Bluefin Tuna (10 May 1993, entered into force 20 May 1994) 1819 UNTS 360 [CCSBT Convention].

570 IOTC was established by the Agreement for the Establishment of the Indian Ocean Tuna Commission (25 November 1993, entered into force 27 March 1996) 1925 UNTS 329.

571 ICCAT was established by the International Convention for the Conservation of Atlantic Tunas (14 May 1966, entered into force 21 March 1969) 673 UNTS 63. It was last amended in 2019, see ICCAT, "International Commission for the Conservation of Atlantic Tunas. Basic Texts", online: <https://www. iccat.int/Documents/Commission/BasicTexts.pdf> [ICCAT Convention]. 
Inter-American Tropical Tuna Commission (IATTC) ${ }^{572}$

Western and Central Pacific Fisheries Commission (WCPFC) $)^{573}$

\section{Specialised non-tuna RFMOs}

North Atlantic Salmon Conservation Organization (NASCO) $)^{574}$

North Pacific Anadromous Fish Commission (NPAFC) ${ }^{575}$

\section{RFMAs}

Agreement to Prevent Unregulated High Seas Fisheries in the Central Arctic Ocean (CAOFA) ${ }^{576}$

Conservation and Management of Pollock Resources in the Central Bering Sea (CBS Convention) ${ }^{577}$

Joint Norwegian-Russian Fisheries Commission (JNRFC) ${ }^{578}$

South Indian Ocean Fisheries Agreement (SIOFA) ${ }^{579}$

Loop Hole Agreement among Iceland, Norway and Russia ${ }^{580}$

The membership of RFMOs and RFMAs is normally limited to States, and in some cases the EU, which conduct fishing activities in a determined region or have a real, i.e. factual and concrete, fishing interest in such a region. ${ }^{581}$ Difficulties can

572 IATTC was established by the Convention for the Establishment of an Inter-American Tropical Tuna Commission (31 May 1949, entered into force 3 March 1950) 80 UNTS 3. This convention has now been replaced by the Convention for the Strengthening of the Inter-American Tropical Tuna Commission Established by the 1949 Convention Between the United States of America and the Republic of Costa Rica (14 November 2003, entered into force 27 August 2010), (2006) OJ, L 224/24, also known as the Antigua Convention [IATTC Antigua Convention].

573 WCPFC was established by the Convention on the Conservation and Management of Highly Migratory Fish Stocks in the Western and Central Pacific Ocean (5 September 2000, entered into force 19 June 2004) 2275 UNTS 43 [WCPFC Convention].

574 NASCO was established by the Convention for the Conservation of Salmon in the North Atlantic Ocean (2 March 1982, entered into force 1 October 1983) 1338 UNTS 33.

575 NPAFC was established by the Convention for the Conservation of Anadromous Stocks in the North Pacific Ocean (11 February 1992, entered into force 16 February 1993) (1993) 22 Law of the Sea Bulletin 21.

576 Agreement to prevent unregulated high seas fisheries in the Central Arctic Ocean, (2019) OJ, L 73/3 [CAOFA].

577 Convention on the Conservation and Management of Pollock Resources in the Central Bering Sea (16 June 1994, entered into force 8 December 1995) (1995) 34:1 International Legal Materials 67-77 [CBS Convention].

578 The JNRFC was established by the Agreement between the Government of the Kingdom of Norway and the Government of the Union of Soviet Socialist Republics on Co-operation in the Fishing Industry (11 April 1975) 983 UNTS 7. The JNRFC is normally not classified as a "formal" RFMO even if its area of competence extends to some portion of the high seas, mostly because its institutional structure, although including several subsidiary bodies, does not have a Secretariat. On the characterization of the JNRFC as an RFMO/RFMA, see Molenaar, "Central Arctic Ocean Fisheries", supra note 553 at 442-444.

579 Southern Indian Ocean Fisheries Agreement (7 July 2006, entered into force 21 June 2012) 2835 UNTS 409 [SIOFA]. Asmundson, supra note 329, classifies SIOFA as a general RFMO.

580 Agreement between the Government of Iceland, the Government of Norway and the Government of the Russian Federation concerning certain aspects of cooperation in the area of fisheries (15 May 1999) (1999) 41 Law of the Sea Bulletin 53.

581 UNFSA at art. 8(3), discussed in Henriksen, Hønneland \& Sydnes, supra note 214 at 19-22. It is noted that the notion of "real interest" is not defined anywhere. Orrego Vicuña, supra note 1 at 41-42, although recognizing the different views on the matter, indicates that a real interest "can only mean the conduct of actual fishing operations of significance in the region concerned" or "a legitimate stake in the fisheries concerned", and that "having fished in the past or the intention to do so in the future is not enough to qualify". 
arise when prospective members, also called "new entrants", wish to join an RFMO, as the same amount of resources might have to be allocated amongst more members. ${ }^{582}$ Further, other stakeholders, including fishing companies, NGOs, and consumers, just to name a few, are not members per se but can have an influence in the decision-making process of RFMOs and RFMAs. In point of fact, they have their position represented by States, or they directly intervene with the organization or arrangement, for example by sharing information to improve management and conservation. ${ }^{583}$

The regulation of fishing activities is mostly done through the adoption of conservation and management measures, including the determination of the TAC. These measures are normally based on recommendations made by the scientific committee of the RFMO or RFMA concerned. ${ }^{54}$ The functions of RFMOs and RFMAs also vary, but should include, along with the conservation and management measures, the allocation of the TAC, the collection, verification and exchange of data, the promotion of scientific assessments, and cooperation for control, surveillance and enforcement. ${ }^{585}$

Conservation measures ${ }^{586}$ include restrictions on catch (e.g. sort and size of species that can be caught, limitations on by-catch) and effort (e.g. restrictions on the type of gear that can be used, designated times/seasons for fishing, spatial measures such as the partial or total closure of some areas). ${ }^{587}$ For example, the designation of VMEs, areas particularly vulnerable to the impacts of fishing activities, ${ }^{588}$ lead RFMOs to limit some types of fishing or all fishing, and for a certain period of time, in these areas. ${ }^{589}$ The decisions made through conservation measures are normally binding, although most treaties constituting RFMOs allow for member States to opt out, even when a measure is adopted by consensus. ${ }^{590}$ In some cases, the treaty

582 See, generally, Andrew Serdy, The New Entrants Problem in International Fisheries Law (Cambridge: Cambridge University Press, 2016). What often occurs is that the TAC is increased to accommodate the new members. In other cases, new entrants are told that there are no current fishing opportunities available, and that only new stocks can be exploited, which could encourage these new entrants to engage in illegal fishing. This is why the UNFSA reiterates that RFMOs must accommodate prospective new members, supporting the argument that not only is there an obligation to cooperate through RFMOs, but also a right to become a member, see Lodge et al, supra note 92 at 12 and 16-17, and Henriksen, Hønneland \& Sydnes, supra note 214 at 18-19. The question of the participation in RFMOs and the difficulties triggered by new entrants are also discussed in chapter 5 section 2.3 .3 below.

583 Depypere, supra note 46 at 371.

584 Guggisberg, The Use of CITES, supra note 9 at 61.

585 UNFSA at art. 10.

586 Conservation measures from the point of view of fisheries management principles are discussed in further detail in chapter 3 section 4.2 below.

587 von Bieberstein, supra note 161 at 38.

588 FAO, "Vulnerable Marine Ecosystems", online: <http://www.fao.org/in-action/vulnerable-marineecosystems/en/>.

589 See, e.g. NEAFC, "VMEs and Closures Maps and Coordinates", online: <https://www.neafc.org/ managing_fisheries/vmec $>$.

590 Harrison, Saving the Oceans, supra note 10 at 183-184; Solene Guggisberg, "Recent developments to improve compliance with international fisheries law" (2017) 42 L'Observateur des Nations Unies 145-175 at 148 . 
limits the opt-out procedure by imposing conditions on its application. For example, article 23(1)(d) SEAFO Convention states that the notification of objection must be accompanied by a written explanation for making such notification and proposals for alternative measures when appropriate. ${ }^{591}$ SPRFMO and the NPFC both allow objections only if the objected measure goes against UNCLOS and the UNFSA or unjustifiably discriminates against the objecting member. ${ }^{592}$

Conservation also triggers the need for cooperation cross-sectorally and also among RFMOs and RFMAs. ${ }^{593}$ First, to achieve cross-sectoral cooperation, RFMOs and RFMAs are encouraged to collaborate with RSPs, which, being primarily oriented towards the protection of the marine environment, complement the management mandate of RFMOs and RFMAs. The collaboration between NEAFC and the Commission of the Convention for the Protection of the Marine Environment of the North-East Atlantic (OSPAR) ${ }^{594}$ can be cited as a successful precedent, where the two organizations signed a Collective Arrangement to coordinate their modes of operation and practices. ${ }^{595}$ Second, to achieve cooperation among the wide variety of RFMOs and RFMAs, a Regional Fishery Body Secretariats Network has been created under the auspices of the FAO. It aims at facilitating the exchange of information among the different bodies, the harmonization of practices, and the strengthening of cooperation. ${ }^{596}$ The Network also discusses "ways to integrate ecosystem-related aspects into management, overcapacity, methods to combat IUU, aquaculture or performance reviews".597 Tuna RFMOs specifically collaborate in a similar way through the Kobe process, a forum which is intended to assist the harmonization of knowledge and practices across all tuna-RFMOs. ${ }^{598}$ The effectiveness of these mechanisms has, however, been criticized. ${ }^{599}$

Cooperation is also needed between RFMOs and RFMAs, flag States and coastal States regarding the compatibility of conservation measures in a State's EEZ and on the high seas. ${ }^{600}$ Distant waters fishing nations (flag States) interpreted the duty of compatibility as the necessity for coastal States to implement in their EEZ compatible measures to the ones applied by RFMOs in their area of competence. Coastal States replied that compatibility had to be seen the other way around: since

591 Harrison, Saving the Oceans, supra note 10 at 183-184.

592 See SPRFMO Convention at art. 17(2)(c), and NPFC Convention at art. 9(1)(d).

593 von Bieberstein, supra note 161 at 38-39.

594 Convention for the Protection of the Marine Environment of the North-East Atlantic (22 September 1992, entered into force 25 March 1998) 2354 UNTS 67 [OSPAR Convention].

595 Collective arrangement between competent international organisations on cooperation and coordination regarding selected areas in areas beyond national jurisdiction in the North-East Atlantic, OSPAR Agreement 2014-09, online: <https://www.ospar.org/documents?v=33030>. The Collective Arrangement is discussed in further detail in section 3.3.4 below, and in chapter 7 section 3.2 below.

596 FAO, "Regional Fishery Body Secretariats Network", online: <http://www.fao.org/fishery/rsn/en>.

597 Guggisberg, The Use of CITES, supra note 9 at 73.

598 Asmundsson, supra note 329 at 5; von Bieberstein, supra note 161 at 38.

599 These criticisms are discussed further in chapter 5 section 2.3.2, and in chapter 7 section 2.2.3 below.

600 UNCLOS at arts. 63(2), 64(1) and 118; UNFSA at art. 7. 
coastal State rights are protected under the UNFSA ${ }^{601}$ and the regional organizations' instruments, ${ }^{602}$ it is RFMOs and RFMAs which need to ensure that their conservation measures are compatible with the ones applied by the coastal State in its EEZ. ${ }^{603}$ The solution in terms of compatibility of measures is two-fold: first, if a coastal State has adopted measures for its EEZ, measures on the high seas cannot be less stringent; and second, a coastal State that has not adopted adequate measures cannot require stricter measures on the high seas, and will have to improve its own measures if it wishes the adjacent high seas area to be equally protected. ${ }^{604}$ The need to reach compatibility among conservation measures therefore requires a high degree of cooperation between RFMOs and RFMAs and the coastal States whose waters are adjacent to the organization's or arrangement's area of competence.

To ensure compliance with the various measures which they adopt, RFMOs and RFMAs resort to several monitoring, control and surveillance mechanisms. ${ }^{605}$ This is done, for example, by setting up vessel registers, imposing the use of mandatory VMS, or even conducting inspections at sea. RFMOs and RFMAs also engage in the regulation of transhipment, in trade- and market-related measures, and in the establishment of port State measures, such as port inspection schemes, which is discussed below. Additional actions against non-complying members include the blacklisting of vessels, also used against non-members, and quota reduction. ${ }^{606}$

Most of the RFMOs and RFMAs listed above have undergone a performance review. ${ }^{607}$ This consists of the assessment, by an independent expert panel, of the RFMOs or RFMAs' performance. The performance is measured based on the effectiveness of conservation and management measures on the state of fish stocks, the compliance with and enforcement of international obligations, the legal framework of the organization, and the status of cooperation with other international organizations and non-member States. ${ }^{608}$ The results of the reviews conducted so far vary considerably (e.g. mostly positive for CCAMLR, ${ }^{609}$ while mostly negative for ICCAT $^{610}$ ) as does the implementation of the recommendations given following the

601 Ibid at art. 7(1).

602 See, e.g., SPRFMO Convention at art. 4.

603 Gullett \& Hanich, supra note 232 at 122.

604 The question of compatibility of measures on the high seas and in a State's EEZ is discussed in Orrego Vicuña, supra note 1 at 37-40.

605 See, generally, Klaudija Cremers, Glen Wright \& Julien Rochette, "Strengthening Monitoring, Control and Surveillance in Areas Beyond National Jurisdiction" (2020) STRONG High Seas Project. MCS mechanisms are discussed in further detail in chapter 4 section 3.5 , and chapter 5 section 2.3.1 below.

606 Lodge et al, supra note 92 at 44-66.

607 Péter D. Szigeti \& Gail L. Lugten, “The implementation of performance review reports by regional fishery bodies, 2004-2014" (2015) FAO Fisheries and Aquaculture Circular No. 1108. This, however, does not take into consideration more recent reviews of tuna RFMOs. In fact, the latest reviews took place in 2012 (WCPFC), 2014 (CCSBT), 2015 (IOTC) and 2016 (IATTC and ICCAT), see Tuna-org, online: <http:// www.tuna-org.org >. See also Haward, supra note 553 at 51.

608 Szigeti \& Lugten, supra note 607 at 5.

609 Ibid at 9-11.

610 Ibid at $27-30$. 
reviews. However, a slow implementation of recommendations, ${ }^{611}$ or in some cases a complete lack of follow-up on these recommendations, as well as the voluntary nature of these performance reviews, ${ }^{612}$ are often cited as the two main weaknesses of the effectiveness of these review procedures. ${ }^{613}$

Despite the measures taken by RFMOs and RFMAs, overall problems remain for the management of fish stocks on the high seas. ${ }^{614}$ As stated by Churchill, "during the 30 or more years that many RFMOs have been in existence, there has been no improvement in the status of high seas fish stocks". ${ }^{615}$ The main problem resides in the fact that, generally, RFMOs and RFMAs tend to put more emphasis on allocation than on conservation. ${ }^{616}$ This could be explained by the nature of RFMOs and RFMAs themselves: they are organizations first established for the management of fisheries as a resource to be exploited. ${ }^{617}$ Yet, RFMOs and RFMAs remain an important vehicle through which conservation measures can be strengthened, ${ }^{618}$ but their actions can only go as far as those matters on which their members agree, ${ }^{619}$ which might well be the real core problem: the will and ability of States to act.

\subsubsection{Coastal States and port States}

States, in their capacity as port State and/or coastal State, do not prima facie come across as "traditional" actors having an influence on the high seas, primarily because such influence could easily be linked to a potential (unlawful) extension of a State's jurisdiction on the high seas. However, coastal States and port States have contributed to the development of the regime as well as its operationalization, and they can also implement measures to achieve compliance with international obligations. ${ }^{620}$

In their capacity as coastal States, States' obligations in terms of implementation and enforcement are normally confined to existing obligations found under

611 Ibid.

612 Only SPRFMO makes the review mandatory every five years, see SPRFMO Convention at art. 30, and Guggisberg, "IMO Audit Scheme", supra note 199 at 520.

613 The weaknesses of these review procedures, as well as the lack of impact which they have on RFMOs' practices are discussed in further detail in chapter 5 section 2.3 .2 below.

614 Marika Ceo et al, "Performance Reviews by Regional Fishery Bodies: Introduction, summaries, synthesis and best practices, Volume I: CCAMLR, CCSBT, ICCAT, IOTC, NAFO, NASCO, NEAFC” (2012) FAO Fisheries and Aquaculture Circular No.1072 at 2, online: <http://www.fao.org/docrep/015/i2637e/ i2637e00.pdf>. See also Gjerde, "High Seas Fisheries Governance", supra note 35 at 227; Harrison, Saving the Oceans, supra note 10 at 207; Ricard, supra note 116 at 148-149.

615 Churchill, supra note 35 at 37. See also Gjerde et al, supra note 65 at 541; Lodge et al, supra note 92 at ix.

616 Webster, supra note 562 at 170, indicates that "most RFMOs are allocation focused while a few are conservation focused".

617 See, generally, Jennifer E. Telesca, Red Gold. The Managed Extinction of the Giant Bluefin Tuna (Minneapolis: University of Minnesota Press, 2020).

618 Webster, supra note 562 at 175.

619 Gjerde et al, supra note 65 at 543.

620 Erik Molenaar, "Port and Coastal States" in Donald Rothwell et al (eds), Oxford Handbook on the Law of the Sea (Oxford: Oxford University Press, 2015) 280-303 at 280 [Molenaar, "Port and Coastal States"]. 
UNCLOS, mainly the obligation of cooperation. ${ }^{621}$ However, some coastal States have, over the years, taken the liberty to go beyond simple cooperation and have directly intervened on the high seas. ${ }^{622}$ Such national practices, undoubtedly raising concerns with regard to creeping jurisdiction, have in any case had an impact on the regime for the conservation and management of fisheries in $\mathrm{ABNJ}$.

A first example of such a national practice occurred at the end of the 1980s, when the United States and the Soviet Union considered extending their jurisdiction to the high seas pocket in the Central Bering Sea (the "doughnut hole") as a measure to address the extensive fishing of pollock in the Bering Sea, as well as to fight illegal fishing of vessels coming from the high seas pocket and into their EEZ. ${ }^{623}$ The two States, however, never acted upon their intentions; the two superpowers did not want to undermine their fishing and navigation interests in other regions of the world, where other States could have relied on Soviet and American actions in the Bering Sea as a precedent to extend their own coastal State jurisdiction. ${ }^{62}$ The situation finally led to the adoption, in 1994, of the CBS Convention, and the subsequent creation of the RFMA, where both coastal States, as well as fishing States in the region, are members.

Second, in the 1990s, Chile, in order to justify actions on the high seas against vessels engaged in illegal fishing, started putting forward the concept of mar presencial. This concept, which does not pretend to claim sovereignty over an area of the high seas or to abolish the freedoms of the high seas, relied on the coastal State's influence or effective occupation over an $\mathrm{ABNJ}$ area, invoking its interest in regulating activities for preservation purposes. ${ }^{625}$ The concept has been included in Chile's national legislation, ${ }^{626}$ and has influenced the development of fisheries management in the region. In fact, when ratifying UNCLOS in 1997, Chile made several declarations; faced with the absence of a regime on the management of living resources on the high seas in the region, Chile announced it would rely on article 116 UNCLOS to justify its interests and actions in the area. In 2000, the members of the Permanent

621 UNCLOS at arts. 118 and 197 and, to some extent, art. 63(2) which refers to stocks in adjacent areas to the EEZ, i.e. the high seas: "same stock or stocks [...] occur both within the exclusive economic zone and in an area beyond and adjacent to the zone, the coastal State and the States fishing for such stocks in the adjacent area shall seek, either directly or through appropriate subregional or regional organizations, to agree upon the measures necessary for the conservation of these stocks in the adjacent area".

622 Examples discussed in Rayfuse \& Warner, supra note 43 at 408.

623 Molenaar, "Participation in the CAOFA", supra note 561 at 142.

624 David Balton, “The Bering Sea Doughnut Hole Convention: Regional Solution, Global Implications” in Olav Schramm Stokke (ed), Governing High Seas Fisheries: The Interplay of Global and Regional Regimes (Oxford University Press: Oxford, 2001) 143-177 at 150-151.

625 See, generally, Luis Kohler Gary, "El mar presencial de Chile, su desafiao actual" (2001) 118:862 Revista de Marina 251-257. See also Erik Molenaar, "New Maritime Zones and the Law of the Sea" in Henrik Ringbom (ed), Jurisdiction over Ships. Post-UNCLOS Developments in the Law of the Sea (Leiden: Brill Nijhoff, 2015) 249-277 at 267-271 [Molenaar, "New Maritime Zones"].

626 Ley no 18.892 general de pesca y acuicultura (1989). Other inclusions in national legislation are Ley No. 19.300 Sobre Bases Generales Del Medio Ambiente (1 March 1994), and Ley No. 18.302 de Seguridad Nuclear (16 April 1984), discussed in Molenaar, "New Maritime Zones", supra note 625 at 268. 
Commission for the South Pacific ${ }^{627}$ adopted the Framework Agreement for the Conservation of the Living Marine Resources of the High Seas of the South Pacific (Galapagos Agreement), ${ }^{628}$ giving a preferential role to its members in high seas fisheries adjacent to their EEZ, which has been considered as a regional application of the mar presencial. The concept has however not been seen as contradictory to international law, as it does not unilaterally modify any rights or obligations of third parties in ABNJ. ${ }^{629}$ The Galapagos Agreement, however, never entered into force, and in 2005, SPRFMO, to which Chile is a party, became the regime applicable to high seas fisheries management in the region. ${ }^{630}$

A third example took place in 1995, when Canada arrested the Spanish vessel Estai on the high seas, justifying its action under the need to preserve straddling stocks within its EEZ. This event, referred to as the "Turbot War", triggered an application at the ICJ, which subsequently refused to hear the case for lack of jurisdiction. ${ }^{631}$ The situation, however, enhanced the necessity of adopting the UNFSA, and most specifically its articles 21 and $22,{ }^{632}$ which address the question of inspection and boarding as a measure for enforcement on the high seas. Canada has further raised claims of "custodial management", on some occasions in the late 1980s, when fishing vessels from the EU were very active in the Northwest Atlantic, but more particularly since the beginning of the 21st century. Custodial management refers to "a system providing for Canadian management of fish stocks outside 200 nautical miles to ensure the sustainability of the stocks and prevent overfishing, while maintaining the traditional proportionate catch shares of distant water fishing states".633 The pendulum of political opinion on this practice has swung back and forth over the years in Canada, often showing diverging views between the federal government, the provincial government of Newfoundland, one of the Canadian Atlantic provinces greatly affected by overfishing, and the fishing industry. ${ }^{634}$ The advocates of "custodial management" raised the ineffective measures of NAFO as the reason for the need to Canada to step in, while others preferred to focus their efforts on amendments to the NAFO Convention, which finally became the favoured option. ${ }^{635}$ Custodial management is considered by scholars to be inconsistent with

627 This Commission is composed of four members: Chile, Colombia, Ecuador and Peru, see FAO, "Permanent Commission for the South Pacific", online: <http://www.fao.org/fishery/rfb/cpps/en\#OrgOrgsInvolved $>$.

628 Framework Agreement for the Conservation of the Living Marine Resources of the High Seas of the South Pacific (14 August 2000) [Galapagos Agreement].

629 Molenaar, "New Maritime Zones", supra note 625 at 271; Molenaar, "Port and Coastal States", supra note 620 at 299, 302-303.

630 Molenaar, "New Maritime Zones", supra note 625 at 269-270.

631 Fisheries Jurisdiction (Spain v Canada), supra note 141.

632 See, e.g., Jamison Colburn, “Turbot Wars: Straddling Stocks, Regime Theory, and a New UN Agreement" (1996-1997) 6:2 Transnational Law and Policy 323-366 at 323-326.

633 Donald Barry, Bob Applebaum \& Earl Wiseman, Fishing for a Solution: Canada's Fisheries Relations with the European Union, 1977-2013 (Calgary: University of Calgary Press, 2014) at 5.

634 See, generally, ibid.

635 Molenaar, "Participation in the CAOFA", supra note 561 at 142-143. 
UNCLOS, on the basis that it encroaches on the interests of the international community on the high seas. ${ }^{636}$

Fourth, the adoption in 2018 of the new CAOFA has also raised questions about the potential of the Agreement for opening the door to creeping coastal State jurisdiction over high seas areas. The CAOFA was signed by the five coastal States of the Central Arctic Ocean (Canada, Denmark (on behalf of Greenland), Norway, Russia and the US are the coastal States of the Central Arctic Ocean), as well as five other States having a fishing interest in the region (China, the EU (on behalf of Sweden and Finland), Iceland, Japan and South Korea). ${ }^{67}$ The CAOFA establishes under what conditions high seas fisheries in the Central Arctic Ocean can start, and basically creates a moratorium on commercial fishing in the Arctic for at least 16 years following its entry into force. ${ }^{638}$ This allows for scientific research to be conducted, in order to gain more knowledge on marine species and their environment in the Arctic, as well as impacts of climate change in the region. Article 6 CAOFA addresses the decision-making procedure, which works on the basis of consensus of all parties to the Agreement. This necessity for consensus could be seen as a disguised form of coastal State creeping jurisdiction over high seas area, since a measure would not be adopted without the approval of the coastal States of the Central Arctic Ocean. Since the participants' interests in the commencement of commercial fishing activities vary, ${ }^{639}$ the necessity for the coastal States to also agree to a measure in order for consensus to be reached gives these States a power of veto.

More generally, the question of creeping coastal State jurisdiction in ABNJ also arises in the context of the establishment of MPAs on the high seas. The situation, often referred to as adjacency, raises the question of whether coastal States should be given a say in the establishment of area-based tools on high seas areas adjacent to their national waters, because of the potential impact it could have on the access to and exploitation of resources in its EEZ or on its continental shelf beyond 200 nautical miles. It has been suggested that adjacent States could become leading conservation actors for $\mathrm{ABNJ}$ areas adjacent to their waters. Indeed, a prioritization of interests of adjacent coastal States in ABNJ could amount to "duties and responsibilities of [these] States in designing management plans [...], inter alia, implementing Area Based Management approaches" in ABNJ. ${ }^{640}$ Opposing views submit that due regard, which is embedded in the current law of the sea regime, remains the basic principle for balancing the rights, interests and obligations of coastal states and third States. ${ }^{641}$

636 Rayfuse \& Warner, supra note 43 at 408.

637 See, e.g. Molenaar, "Participation in the CAOFA", supra note 561 at 132-134.

638 CAOFA at art. $13(1)$.

639 Non-coastal States are normally more inclined to commence fishing activities, while the Arctic Five, for their part, support fishing only if they can engage in fishing themselves or if fishing activities by others would not impede their interests, see Molenaar, "Participation in the CAOFA", supra note 561 at 140-141.

640 Daniel Dunn et al, "Adjacency: How legal precedent, ecological connectivity, and traditional knowledge inform our understanding of proximity" (2017) Nereus Scientific \& Technical Briefs on ABNJ series at 9.

641 Alex Oude Elferink, "Coastal States and MPAs in ABNJ: Ensuring Consistency with the LOSC" (2018) 33 International Journal of Marine and Coastal Law 437-466 at 465-466; Joanna Mossop \& Clive Schofield, 
The impact of adjacency is also discussed in the context of the BBNJ process, which is addressed in greater detail in chapter 4 below.

In their capacity as port States, States can also have some influence over high seas activities. ${ }^{642}$ The role of port States in particular has so far been growing mostly within the legal framework for the prevention and deterrence of IUU fishing, as demonstrated by the adoption of the IUU-IPOA and the 2009 PSMA. The framework has however the potential of being further developed in relation to questions regarding the marine environment, marine biodiversity and sustainable fisheries more generally. ${ }^{643}$

While article 218 UNCLOS allows a port State to take measures against a vessel in its port, under article 23(1) UNFSA the application of its jurisdiction is no longer optional. ${ }^{644}$ In fact, taking measures "to promote the effectiveness of subregional, regional and global conservation and management measures" has now reached the threshold of duty. ${ }^{645}$ Similar provisions are adopted in various instruments, including within RFMOs, ${ }^{646}$ making port State measures more global and more mandatory. Port State measures can therefore complement flag State jurisdiction: if non-complying parties get away with some actions on the high seas, they can still lose the benefits or advantages gained by free riding once they reach a port. This works only if port States measure are harmonized, otherwise there is the potential for "port States of convenience", ${ }^{647}$ where vessels will visit ports with less stringent measures to avoid regulations. This is particularly the case with port State practices developed through RFMOs, since not all RFMOs have adopted them, and they can be implemented with different levels of rigour. ${ }^{648}$

Concerns have been raised, however, that port State measures could be interpreted as applying to activities conducted on the high seas and consequently be considered as an extraterritorial application of jurisdiction. The legality of such measures depends on "two aspects, namely a sufficient jurisdictional basis and the type of enforcement measure taken". ${ }^{69}$ The question of jurisdictional basis is nowadays covered, as port States can find the jurisdiction to act under several instruments, including the UNFSA, the PSMA or the IUU-IPOA. To avoid any misunderstanding in terms of enforcement, port States should target actions that occur in ports and not at sea, for

"Adjacency and due regard: The role of coastal States in the BBNJ treaty" (2020) Marine Policy article 103877.

642 Molenaar, "Participation in the CAOFA", supra note 561 at 143.

643 Molenaar, "Port and Coastal States", supra note 620 at 302; Bevan Marten, "Port State Jurisdiction, International Conventions, and Extraterritoriality: An Expansive Interpretation” in Henrik Ringbom (ed), Jurisdiction over Ships. Post-UNCLOS Developments in the Law of the Sea (Leiden: Brill Nijhoff, 2015) 105-139 at 106.

644 Erik Molenaar, "Port State Jurisdiction: Toward Comprehensive, Mandatory and Global Coverage" (2007) 38:1-2 Ocean Development \& International Law 225-257 at 234 [Molenaar, "Port State Jurisdiction"]. 645 Lodge et al, supra note 92 at 54. See also Henriksen, Hønneland \& Sydnes, supra note 214 at 49-51. 646 Guggisberg, The Use of CITES, supra note 9 at 69-70.

647 See, e.g. Molenaar, "Port State Jurisdiction”, supra note 644 at 226.

648 Molenaar, "Port and Coastal States", supra note 620 at 283 and 294.

649 Ibid at 289. 
example non-collaboration with inspections, or providing false information about vessel activities. ${ }^{650}$

The actions described above undertaken by coastal States/port States within their jurisdiction but having effect on high seas areas do not seem to have raised legal issues, however. One way to ensure the legality of actions is for States to make the "[a]ccess to their ports and fishing access to their maritime zones [...] conditional on not fishing in adjacent areas of high seas". ${ }^{651}$ For example, to limit unregulated fishing, mostly conducted by Icelandic vessels, in the high seas pocket of the Barents Sea (the "loophole"), Russia and Norway have given access to their respective EEZ and have relaxed the measures to access their ports to third States which do not engage in fishing activities in the high seas pocket. Fishing in the loophole also has consequences for Norway and Russia because of the straddling and transboundary nature of stocks in the area. This practice finally led to the adoption of the Loophole Agreement between the two nations and Iceland. ${ }^{652}$ Similarly, in the Western and Central Pacific, the parties to the Agreement concerning Cooperation in the Management of Fisheries of Common Interest (Nauru Agreement) ${ }^{653}$ have set conditions on the granting of fishing licences in their respective EEZ to third States which agree to refrain from fishing in the high seas pockets in the region. ${ }^{654}$ Neither case alters the right of third States to fish on the high seas in accordance with article 116 UNCLOS. These examples show the role that coastal and port States can indirectly play for the regulation and management of fisheries on the high seas.

\subsubsection{Regional seas programmes (RSPs)}

In 1974, the United Nations Environment Programme (UNEP) ${ }^{655}$ established the Regional Seas Programme, aimed at addressing "the accelerating degradation of the world's oceans and coastal areas through a 'shared seas' approach - namely, by engaging neighbouring countries in comprehensive and specific actions to protect their common marine environment". ${ }^{656}$ Although initially covering issues related to pollution, over recent years its mandate has evolved to cover issues of biodiversity,

$650 \mathrm{Ibid}$ at 287-288; Marten, supra note 643 at 108.

651 Molenaar, "Participation in the CAOFA", supra note 561 at 143.

652 Molenaar, "Central Arctic Ocean Fisheries", supra note 553 at 439.

653 Agreement concerning Cooperation in the Management of Fisheries of Common Interest (11 February 1982, entered into force 2 December 1982), online: <http://www.pnatuna.com/sites/default/files/Nauru\%20 Agreement_0.pdf >. It was last amended in April 2010.

654 Discussed in Molenaar, "Participation in the CAOFA", supra note 561 at 136-138.

655 UNEP, online: <https://www.unenvironment.org/>. See also, generally, Nilufer Oral, "Forty years of the UNEP Regional Seas Programme: from past to future" in Rosemary Rayfuse (ed), Research Handbook on International Marine Environmental Law (Cheltenham: Edward Elgar, 2017) 339-362.

656 UNEP, "Why does working with regional seas matter?", online: <https://www.unenvironment.org/exploretopics/oceans-seas/what-we-do/working-regional-seas/why-does-working-regional-seas-matter $>$. 
protected areas and coastal habitat management. ${ }^{657}$ Under such initiative, 18 RSPs are currently established in different marine regions. ${ }^{658}$

This study acknowledges that RSPs' mandate does not cover fisheries management and conservation. They also do not have the same implementation and enforcement role that flag States, RFMOs, and to some extent coastal States and port States, have, nor do they have the same institutional structure as RFMOs. However, RSPs remain relevant for the present analysis for two main reasons. First, participating in RSPs can be seen as a way for States to operationalize their obligations under UNCLOS in terms of protection of the marine environment and overall cooperation. ${ }^{659}$ Second, RSPs have competence over the marine environment, which in turn might impact fisheries management and conservation. Having a look at the role of RSPs in the operationalization of marine environmental protection therefore takes part in the analysis of the interconnectedness between fisheries management and environmental protection conducted in this study.

Most RSPs work through action plans creating a framework for the protection of the marine environment in the designated regional area, and 14 programmes have also adopted legally binding conventions, sometimes supplemented by protocols or other legally binding instruments. ${ }^{660}$ To fulfil their mandate, RSPs adopt various types of measures, such as sustainable development strategies, which aim to develop collaborative frameworks targeting all ecosystems and to achieve the implementation of the SDGs, ${ }^{661}$ or ecosystem-based integrated ocean policy, which involves cross-sectoral cooperation and the integrated management of resources and marine space ${ }^{662}$ They also engage in several kinds of joint actions, including multi-stakeholder engagement and public-private partnerships, to enhance crosssectoral dialogue. ${ }^{663}$ An element of core importance for the purpose of this study is the cooperation that exists between RSPs and regional fisheries bodies, mainly RFMOs ${ }^{664}$ In fact the two kinds of organizations complement one another: while RFMOs' main function is to manage specific fishing activities, RSPs primarily adopt conservation measures but do not have regulatory powers over the allocation of stocks and their management. These collaborations range from information and knowledge sharing to joint measures across sectors and levels. ${ }^{665}$

657 UNEP, "Realizing Integrated Regional Oceans Governance - Summary of case studies on regional crosssectoral institutional cooperation and policy coherence" (2017) UNEP Regional Seas Reports and Studies No. 199 at 8.

658 There are seven UN Environment-administered RSPs, seven non-UN Environment-administered RSPs, and four independent RSPs, see UNEP, "Why does working with regional seas matter?", supra note 656.

659 See, e.g. UNCLOS at arts. 192 and 197.

660 UNEP, "Regional seas programmes", online: <https://www.unenvironment.org/explore-topics/oceans-seas/ what-we-do/working-regional-seas/regional-seas-programmes >; Freestone, supra note 45 at 105-106.

661 UNEP, supra note 657 at 12.

$662 \mathrm{Ibid}$ at 15.

$663 \mathrm{Ibid}$ at $23-24$.

664 Ibid at 8, 17-18; Harrison, Saving the Oceans, supra note 10 at 281-289.

665 UNEP, supra note 657 at 18. 
Despite the variety of existing RSPs, there remain coverage gaps in ABNJ, because only five RSPs cover high seas areas. ${ }^{666}$ Firstly, OSPAR addresses the protection of the marine environment of the North-East Atlantic. Its mandate includes measures for the assessment of the quality of the marine environment ${ }^{667}$ and the protection and conservation of ecosystems and marine biodiversity, ${ }^{668}$ a feature illustrating an integrated process of protection that is not found under all RSPs. ${ }^{69}$ OSPAR's main achievement in terms of conservation measures that target the protection of marine species or the adverse impacts of fishing activities is its legal framework for the designation of MPAs, which has led to the establishment of seven MPAs. ${ }^{670}$ It has also adopted recommendations on threatened and declining species and habitats. ${ }^{671}$ OSPAR has further entered into collaboration with NEAFC for the management of selected areas in the North-East Atlantic. ${ }^{672}$ In fact, following a MoU signed in 2008, the organizations adopted a Collective Arrangement in $2014 .{ }^{673}$ Often cited as a success story of cross-sectoral collaboration, the Collective Arrangement aims to coordinate measures for the conservation and management of the selected areas through, inter alia, the sharing of relevant scientific information, environmental assessments and monitoring data, the notification of existing and proposed human uses of the selected areas, cooperation in conducting environmental impact assessments, and the obtention of better knowledge of the areas concerned. ${ }^{674}$

A second RSP covering a high seas area is CCAMLR in the Antarctic. ${ }^{675}$ To fulfil its main objective of conservation of marine living resources ${ }^{676} \mathrm{CCAMLR}$ has adopted, among other measures, MPAs and gear regulations. ${ }^{677}$ The most recent MPA, the Ross Sea MPA, which came into force on 1 December $2017,{ }^{678}$ is the largest MPA in the world, and $72 \%$ of its area of coverage will be completely closed to fishing activities. ${ }^{679}$ More recent attempts at designating MPAs under CCAMLR have,

666 Darius Campbell et al, "Regional Seas programmes covering Areas Beyond National Jurisdictions" (2017) UNEP Regional Seas Reports and Studies No.202 at 1. Two other conventions, the Abidjan Convention for Cooperation in the Protection, Management and Development of Marine and Coastal Environment of the Atlantic Coast of the West, Central and Southern Africa Region (23 March 1981, entered into force 5 August 1984), and the Nairobi Convention for the Protection, Management and Development of the Marine and Coastal Environment of the Western Indian Ocean (21 June 1985, entered into force 30 May 1996), are currently examining issues related to BBNJ.

667 OSPAR Convention at annex IV.

668 Ibid at annex V.

669 Campbell et al, supra note 666 at 8 .

670 Ibid at 3-5 and 7.

$671 \mathrm{Ibid}$ at 6. On measures from OSPAR, see, generally, Harrison, Saving the Oceans, supra note 10 at 59-61.

672 UNEP, supra note 657 at 18 and 28.

673 Collective arrangement, supra note 595.

674 Ibid at para 6.

675 See Campbell et al, supra note 666 at 10. As mentioned in section 3.3.2 above, CCAMLR is often characterized as a hybrid RFMO-RSP.

676 CAMLR Convention at art. II(1).

677 Campbell et al, supra note 666 at 10-11.

678 Ross Sea region marine protected area, CCAMLR CMM 91-05 (2016).

679 CCAMLR, "CCAMLR to create world's largest Marine Protected Area" (28 October 2016), online: $<$ https://www.ccamlr.org/en/organisation/ccamlr-create-worlds-largest-marine-protected-area $>$. See 
however, failed because of persistent objections by some members. ${ }^{680}$ CCAMLR is also often cited as a pioneer in the adoption of conservation measures for new and exploratory fisheries. ${ }^{681}$ The objectives of CCAMLR also refer to the principles of conservation in harvesting activities. ${ }^{62}$ This reference to exploitation activities illustrates that CCAMLR also has functions of fisheries management and quota allocation, which also qualifies it as an RFMO.

A third RSP covering a high seas area is found in the Mediterranean and was established under the Convention for the Protection of the Marine Environment and the Coastal Region of the Mediterranean (Barcelona Convention). ${ }^{683}$ It is under its auspices that the Mediterranean Action Plan was adopted. This Action Plan was the first initiative to be undertaken under the Regional Seas Programme. Following the 1992 Rio Conference, the Action Plan was extended to include biodiversity and sustainable development related objectives. ${ }^{64}$ Six Protocols were adopted under the Barcelona Convention ${ }^{685}$ but the most relevant for the purposes of this study is the Specially Protected Areas and Biological Diversity Protocol (SPA/BD Protocol), the main legal instrument to implement the CBD in the Mediterranean. Under the SPA/ $\mathrm{BD}$ Protocol, three main tools are developed to protect biodiversity in the region: the establishment of specially protected areas (SPAs), ${ }^{686}$ the establishment of Specially Protected Areas of Mediterranean importance (SPAMIs), ${ }^{687}$ and the protection and conservation of species. ${ }^{688}$ While the SPAs are established in AWNJ, ${ }^{689}$ SPAMIs can also be established on the high seas, ${ }^{690}$ and they create obligations for States to collaborate in the management and conservation of natural areas, threatened species and their habitats. ${ }^{691}$ The implementation of the Protocol has been supported by several COP decisions. ${ }^{692}$ There have also been collaborations with the

also CCAMLR, "Marine Protected Areas (MPAs)", online: <https://www.ccamlr.org/en/science/marineprotected-areas-mpas $>$.

680 See, e.g. "Talks on Antarctic marine sanctuary fail for eighth straight year" (2 November 2019) The Japan Times, online: <https://www.japantimes.co.jp/news/2019/11/02/asia-pacific/science-health-asia-pacific/ talks-antarctic-marine-sanctuary-fail/\#.Xcbwyi17SL8>.

681 See, generally, Richard Caddell, "Precautionary Management and the Development of Future Fishing Opportunities: The International Regulation of New and Exploratory Fisheries" (2018) 33 International Journal of Marine and Coastal Law 199-260. New and exploratory fisheries are also addressed in chapter 3 section 4.2 .2 below.

682 CAMLR Convention at art. $\mathrm{II}(3)$.

683 Convention for the protection of the Mediterranean Sea against pollution (16 February 1976, entered into force 12 February 1978) 1102 UNTS 27, renamed Convention for the Protection of the Marine Environment and the Coastal Region of the Mediterranean (10 June 1995, entered into force on 9 July 2004) [Barcelona Convention].

684 Campbell et al, supra note 666 at 12.

685 See, e.g. European Commission, “The Barcelona Convention”, online: <http://ec.europa.eu/environment/ marine/international-cooperation/regional-sea-conventions/barcelona-convention/index_en.htm>.

686 Protocol concerning Specially Protected Areas and Biological Diversity in the Mediterranean (10 June 1995, entered into force 12 December 1999), (1999) OJ, L 322/3 at arts. 3(1)(a) and 4-7.

687 Ibid at arts. 3(1)(a), 8-10, and annex I.

$688 \mathrm{Ibid}$ at arts. 3(1)(b), and 11-13.

689 Ibid at art. 5(1).

$690 \mathrm{Ibid}$ at art. 9(1). See also Campbell et al, supra note 666 at 14.

691 Ibid at art. 8(1).

692 Campbell et al, supra note 666 at 15. 
CBD secretariat to establish EBSAs in the Mediterranean. ${ }^{693}$ Furthermore, in 2005, the Mediterranean Commission on Sustainable Development, established under the Barcelona Convention and the Action Plan, also adopted the Mediterranean Sustainable Development Strategy (initially from 2006-2015, but renewed from 2016-2025), intended to bring together various stakeholders in a collaborative work underlining the interconnectedness between the environment and development. ${ }^{694}$ Finally, in terms of collaboration between the RSP and RFBs, the Action Plan and the GMFC signed a MoU in 2012, which covers different areas of cooperation including the promotion of an ecosystem-based approach, the mitigation of the impact of fisheries on marine habitats and species, the designation of EBSAs, the establishment of an integrated maritime policy, and other legal, institutional and policy related cooperative actions. This aims, inter alia, to create collaboration for the implementation of SDG $14 .{ }^{695}$

The fourth RSP covering a high seas area is in the South Pacific and was established under the Convention for the Protection of the Natural Resources and Environment of the South Pacific Region (Noumea Convention) ${ }^{696}$ It is the main multilateral environmental agreement for the protection of natural resources and the environment in the region, and it is managed by the SPREP. ${ }^{697}$ The SPREP fulfils an important role in capacity-building with the member States, mostly regarding the implementation of area-based and environmental assessment tools. Although these activities target mostly EEZ areas, they have impacts on "the capacity to manage biodiversity in areas beyond national jurisdiction" ${ }^{698}$ Similarly, although the SPREP has signed a MoU with WCPFC, ${ }^{699}$ it covers mostly tuna stocks in the EEZ. The SPREP has, however, used its observer status at WCPFC to advocate for the conservation of threatened and migratory species, as well as to deal with marine pollution from fishing vessels, measures that could, once again, have positive repercussions for a sustainable management of $\mathrm{ABNJ}{ }^{700}$

Finally, the fifth RSP covering high seas areas is located in the South-East Pacific and was established under the Convention for the Protection of the Marine Environment and Coastal Area of the South-East Pacific (Lima Convention). ${ }^{701}$ It, however, covers the high seas indirectly; in fact, its article 1 indicates that the convention covers areas

$693 \mathrm{Ibid}$ at 17-18. EBSAs are also discussed in section 3.1.3 above.

694 UN Environment, supra note 657 at 13.

695 Ibid at 18-21.

696 Convention for the Protection of the Natural Resources and Environment of the South Pacific Region (24 November 1986, entered into force 22 August 1990) (1987) 26:1 International Legal Materials 38 [Noumea Convention].

697 SPREP, “Noumea Convention", online: <https://www.sprep.org/convention-secretariat/noumea-convention>. 698 Campbell et al, supra note 666 at 20-21.

699 Memorandum of Understanding between the Western and Central Pacific Fisheries Commission and the Secretariat of the Pacific Regional Environment Programme, online: <https://www.wcpfc.int/doc/wcpfcsprep-memorandum-understanding $>$.

700 Campbell et al, supra note 666 at 21 .

701 Convention for the Protection of the Marine Environment and Coastal Area of the South-East Pacific (12 November 1981, entered into force 19 May 1986) 1648 UNTS 3 [Lima Convention]. 
within 200 nautical miles of the States parties' coasts, as well as "the high seas up to a distance within which pollution of the high seas may affect that area". Its article 2(a), which mirrors the definition of pollution found under UNCLOS, ${ }^{702}$ could therefore be intended to cover pollution created, for example, by lost fishing gear on the high seas that has an impact within national jurisdiction. It has also entered into an agreement with the SPREP, "to cooperate in the protection of a more extensive area of the Pacific" ${ }^{703}$ which illustrates possible collaborations among RSPs.

Although not a RSP per se, the Hamilton Declaration on Collaboration for the Conservation of the Sargasso Sea (Hamilton Declaration) ${ }^{704}$ is a recent initiative that also relies on collaboration between different entities for the protection of ecosystems and biodiversity in the Sargasso Sea. Located in the North Central Atlantic, off the eastern coast of the United States and north of the Antilles, the Sargasso Sea is recognized for being a hub of marine biodiversity, which unfortunately is threatened by several activities including fishing. Although the area falls under the mandate of ICCAT and NAFO, several species are being overfished, and stocks are recovering slowly. ${ }^{705}$ The Sargasso Sea is also prone to the impacts of shipping, pollution, and the extraction of the sargassum algae, and might, in the near future, be subject to the extraction of minerals on the seabed. In 2010, the government of Bermuda brought together governments and collaborative partners from the academic and scientific community to create the Sargasso Sea Alliance, aiming to build a partnership for the recognition and protection of the ecosystems of the Sargasso Sea. This recognition was further underlined in 2012 when the region was described as an EBSA by the parties of the CBD. ${ }^{706}$ In March 2014, following a two-year negotiation process between States located in the area or that have an interest in the conservation of ecosystems in the region, the governments of the Azores, Bermuda, Monaco, the UK and the US signed the Hamilton Declaration. The British Virgin Islands, the Bahamas, Canada, the Cayman Islands and the Dominican Republic subsequently joined. This declaration is a non-legally binding political statement aiming for collaboration in the protection of the Sargasso Sea. The Sargasso Sea Commission, established following the adoption of the Hamilton Declaration, consists of a partnership under the leadership of the Government of Bermuda, in collaboration with scientists, international marine conservation groups

702 UNCLOS at art. 1(1)(4), which reads "the introduction by man, directly or indirectly, of substances or energy into the marine environment $[\ldots]$ which results or is likely to result in such deleterious effects as harm to living resources and marine life, [...], hindrance to marine activities, including fishing".

703 UNEP, "South East Pacific", online: <https://www.unenvironment.org/explore-topics/oceans-seas/whatwe-do/working-regional-seas/regional-seas-programmes/south-east $>$.

704 Hamilton Declaration on Collaboration for the Conservation of the Sargasso Sea (11 March 2014), online: $<$ http://www.sargassoseacommission.org/storage/Hamilton_Declaration_with_signatures_April_2018. pdf $>$ [Hamilton Declaration].

705 Sargasso Sea Commission, "Threats to the Sargasso Sea”, online: <http://www.sargassoseacommission. org/about-the-sargasso-sea/threats-to-the-sargasso-sea>. See also David Freestone, "Governance of Areas Beyond National Jurisdiction: And Unfinished Agenda?” in Jill Barrett \& Richard Barnes (eds), Law of the Sea UNCLOS as a Living Treaty (British Institute of International and Comparative Law, 2016) $231-265$ at 245.

706 CBD COP Decision XI/17, supra note 295 at annex. 
and private donors, working towards the application of the Hamilton Declaration and the protection of the unique ecosystem of the Sargasso Sea. ${ }^{707}$ However, the Hamilton Declaration remains a political initiative. In fact, the Commission has no management authority, and the relevant sectoral organizations in the region (e.g. IMO, ICCAT and NAFO) remain the main actors for management purposes, but the Commission works closely with these organizations. ${ }^{708}$ The Commission further serves as a platform for information and data gathering, ${ }^{709}$ and aims to stimulate strong cooperation between the governments, national, regional and international actors. ${ }^{710}$ The Commission, as a steward for the Sargasso Sea, ${ }^{711}$ works at ensuring "its health, productivity and resilience [is] under continual review". ${ }^{712}$

This portrait of the RSPs and similar initiatives covering high seas areas shows the role of the organizations for the development and implementation of measures for marine environmental protection. It also shows the collaboration of these organizations with cross-sectoral structures, most particularly RFMOs, thereby contributing to an integrated and interrelated coverage of the high seas.

\section{CONCLUSION: THE CO-EVOLUTION OF FRAMEWORKS}

International fisheries are characterized by an interconnectedness of activities and concerns, ranging from the state of fish stocks and the impacts of unsustainable fishing practices on the marine environment and marine biodiversity, to the position of fisheries among other activities taking place in ABNJ. ${ }^{713}$ Actors involved are not limited to individual States, but also include structures and entities created by States for cooperation. The role of non-State actors, such as NGOs, the scientific community and the private sector, is also growing, these actors putting forward interests of their own.

707 See, generally, Freestone, supra note 705.

708 For example, by attending meetings of the ICCAT to promote conservation measures for the Sargasso Sea and by "work[ing] with the ICCAT Ecosystem Subcommittee to use the Sargasso Sea as a pilot ecosystem for EBFM proposals", Sargasso Sea Commission, Work Programme Priorities (2016-2018), Doc SSC/2017/3/Doc.1 at 2-3, online: <http://www.sargassoseacommission.org/storage/NEW_Horta_ Updated_Work_Plan_2016-18.pdf >.

709 Hamilton Declaration, supra note 704 at annex II, para e).

710 Ibid at annex II, paras i), j) and $\mathrm{k}$ ).

711 The role of steward is listed in the mandate of the Commission, see ibid at annex II, para a).

712 Ibid at annex II, para a).

713 See Harrison, "Actors and Institutions", supra note 412 at 61-63. Apart from fishing, the two main activities on the high seas are navigation/shipping and seabed exploitation, regulated and managed by the IMO and the ISA respectively. The IMO, the UN specialized agency for the safety and security of shipping, addresses questions of navigation as well as of pollution by ships, having adopted several instruments to regulate that matter. The ISA, for its part, is the body established under UNCLOS to oversee the regime of deep seabed mining under Part XI of the Convention. It is mandated to organize and control activities in the Area as well as managing its resources. To do so, it has been developing the Mining Code, a "comprehensive set of rules, regulations and procedures issued by the International Seabed Authority to regulate prospecting, exploration and exploitation of marine minerals in the international seabed Area". The ISA also has a duty to take the protection of the marine environment into consideration with respect to activities in the Area, see UNCLOS at art. 145. 
The portrait of international fisheries law drawn in this chapter aimed to illustrate the state of its current legal framework and the different actors operationalizing this framework, so as "to gain a thorough understanding of what is included, the current state of international law applicable to these environmental domains and resources, and the state of their governance". ${ }^{714}$ The current legal framework is far reaching, as it covers an array of issues, activities and actors involved. Despite the "normative weaknesses" of UNCLOS, ${ }^{715}$ its provisions on international fisheries have been supplemented by several instruments addressing sustainable fisheries management and the adverse impacts of fishing on the marine environment. It can indeed be said that fisheries law and biodiversity conservation "co-evolved in the right direction within a common legal framework", ${ }^{716}$ and that the frameworks have been "broadening and better specifying States' responsibilities". ${ }^{717}$ The current framework therefore offers a fairly good tool box.

Nonetheless, we remain in a context where specific regimes regulate specific resources, ${ }^{718}$ and the framework does not fully make clear the complexity and interconnectedness present "in the field". This is due to the fact that the framework has been shaped by concerns evolving over time. The state of scientific knowledge, the political context and general public awareness influenced not only the understanding of the interconnectedness characterizing the regulated subject matter, but also the will to act upon this interconnectedness. The evolution of the framework shifted over the years, originally addressing the management of fisheries as an individual activity, and then slowly including concepts of cross-sectoral application. However, "while broadening and better specifying States' responsibilities, these debates left fisheries policy-making and management practices largely unaltered in most countries"719 These cross-sectoral concepts remain mostly within the realm of soft-law instruments, and, even when successfully included within legally binding instruments, are often weakly implemented. ${ }^{720}$

This variety of instruments, coming from different legal regimes and of different legal natures, tends to create "tensions between frameworks focused on conservation versus utilisation, regional divisions and differences, and a variety of institutionled initiatives have created a complex landscape that requires harmonisation. The way forward, though, is not clear and $[\ldots]$ an exploration of alternative theoretical frames may hold value" ${ }^{721}$ How to find the best regulatory options for addressing overexploitation is an open question. ${ }^{722}$ Considering that addressing

714 Bosselmann, supra note 45 at 71.

715 Harrison, Saving the Oceans, supra note 10 at 206.

716 Garcia, Rice \& Charles, supra note 3 at 40. See also, Friedman, Garcia \& Rice, supra note 286 at 216.

717 Garcia, Rice \& Charles, supra note 3 at 41 .

718 Bosselmann, supra note 45 at 71-72.

719 Garcia, Rice \& Charles, supra note 3 at 41.

720 Franckx, supra note 131 at 212.

721 Techera \& Klein, supra note 323 at 67-68.

722 Orrego Vicuña, supra note 1 at 44. 
interconnectedness is a main challenge for international fisheries law, we submit that there is a need for enhanced global coordination, as well as the recognition and understanding of the growing pressure of human activities on resources, inter alia, through the use of technology. ${ }^{723}$ It is against this reality that complementing and/ or alternative structures/options have to be tested. 


\title{
PRINCIPLES GOVERNING THE OCEANS
}

\author{
Unifying Elements in the Face of Complexity
}

\section{INTRODUCTION}

The complexity of the conservation and management of high seas fisheries resides in the nature of the subject, at the crossroads between social, economic, political and environmental interests, and in the interconnectedness of issues shaping this socio-ecological system. The framework regulating such system is just as complex, from legally binding to non-legally binding instruments, from the law of the sea to environmental law and even, to some extent, trade law regimes, with a variety of actors operationalizing different obligations, at different levels.

Among this myriad of instruments, institutions, actors and interests, it might a priori seem difficult to find a global thread, elements that could systematize obligations, guide behaviours, and contribute to coherence. Yet, these unifying elements are often present in a legal framework in the form of principles. Such principles play an integrative function, often illustrating the core values behind legal obligations. In the face of the complexity characterizing the regulatory regime for high seas fisheries, these principles also have the potential to act as catalysts for interconnectedness, and thus bridge the gap between the law of the sea and international environmental law.

What exactly are the "principles" governing the oceans? What are their legal value and their place in the hierarchy of norms? More particularly, what are the principles governing high seas fisheries and how have they shaped the framework for high seas fisheries law described in the previous chapter? In an attempt to answer these questions, this chapter identifies the principles currently applicable to the oceans, as common elements within the complexity characterizing the legal framework for high seas fisheries. While the previous chapter lists and describes the instruments and obligations found therein, the present chapter gives examples of how these obligations are categorized, to help in the understanding of their scope and applicability.

First of all, section 2 delves into the notion of principles. It first reflects on the nature of principles, and on understanding this nature from a legal perspective. 
The section further describes the different roles which principles (can) play within a legal framework. This section also serves as an introduction to the overarching discussion on the relationship between law and governance conducted in this study. ${ }^{1}$

Then, section 3 lays out the principles applicable to the regulation and management of the oceans in ABNJ. It examines the way in which these principles have been included in existing instruments (binding and non-binding) and customary law, discussed in the literature, and interpreted by international tribunals. This assessment of the high seas principles pays particular attention to the way in which these principles influence the regulation and management of high seas fisheries.

Section 4 looks at how some of the principles are operationalized through fisheries conservation and management. A particular focus is first given to those principles applicable to fisheries management and conservation objectives. Then, the study assesses the relevance of principles for informing area-based and assessment tools for high seas fisheries is then assessed. This chapter finally concludes with a short reflection on the role which these principles hold in connecting and bringing coherence to the creation, application and interpretation of rules and norms applicable to the oceans (section 5).

The principles discussed in this chapter are not per se new; they have shaped the development of the law of the sea and environmental law, ${ }^{2}$ and they are guiding the regulation of various sectoral activities. Yet, their role as catalysts of interconnectedness, as unifying elements in the face of complexity, is underrepresented in the legal literature. This is why this chapter embarks on the exploration of the contribution which principles can make to the coherence of high seas fisheries management and conservation.

\section{WHAT ARE PRINCIPLES?}

A principle is generally defined as a statement or proposition underlying a particular system. It is a postulate, a concept upon which behaviour and theories are developed; ${ }^{3}$ principles are "guides to proper conduct". ${ }^{4}$ When applied to the legal sphere, a principle refers to a "legal statement which describes obligations of conduct or obligations to achieve an objective". ${ }^{5}$ Legal principles are either inherent to a legal

1 The discussion on the relationship between law and governance is conducted in chapter 6 below.

2 Philippe Sands \& Jacqueline Peel, with Adriana Fabra \& Ruth MacKenzie, Principles of International Environmental Law, 4th ed (Cambridge: Cambridge University Press, 2018) at 197-240.

3 The Oxford English Dictionary, 2d ed, sub verbo "principle".

4 Oran Young, Governing Complex Systems. Social Capital for the Anthropocene (Cambridge, MA: MIT Press, 2017) at 162.

5 Rudiger Wolfrum, "General International Law (Principles, Rules, and Standards)" (2010) Max Planck Encyclopedia of Public International Law at para 6. 
system or developed from broader philosophical precepts and then introduced into a legal system. ${ }^{6}$

The open-textured ${ }^{7}$ nature of principles often makes it difficult to differentiate them from other related concepts. For example, principles differ from values, as the latter are broader, even more abstract, representing moral beliefs considered to be important. The present author suggests that values underlie principles. For example, the specific duty of cooperation embodied in article 118 UNCLOS (cooperation of States in the conservation and management of living resources) relies on the principle of international and regional cooperation, which, in turn, relies on the values of tolerance and unification of strength, as embodied in the preamble to the Charter of the United Nations. ${ }^{8}$

Principles must also be distinguished from norms. A norm is based on an expectation of a certain collective behaviour, "defined in terms of rights and obligations". As described by Krieger and Liese, norms "can be of a social nature (embodied in nonlegally binding declarations and moral-political norms)" or they "can be of legal nature". ${ }^{10}$ The latter are normally embedded in legally binding instruments such as treaties or customs, or in principles. In that sense, principles become vehicles of a certain norm or norms.

For their part, rules are distinguished from principles because they are specific instructions on how to perform actions, ${ }^{11}$ while the latter are "described in abstract rather than concrete terms ready for direct application". ${ }^{12}$ In the words of Beyerlin, "rules and principles may roughly be distinguished from each other by saying that the former are norms immediately aimed at making the addressees take action, refrain from action, or achieve a fixed result, while the latter only aim at influencing the states' decision-making, $[\ldots]$ as well as their interpretation of rules." ${ }^{13}$

Although this characterization helps understanding the nature of principles, differences are, in practice, quite blurred, especially when addressing the legal nature

6 Ibid.

7 See, e.g., Yoshifumi Tanaka, "Principles of international marine environmental law" in Rosemary Rayfuse (ed), Research Handbook on International Marine Environmental Law (Cheltenham: Edward Elgar, 2015) 31-56 at 31 [Tanaka, "Principles"]; Jonas Ebbesson, "The rule of law in governance of complex socioecological changes" (2010) 20 Global Environmental Change 414-422 at 414.

8 "to practice tolerance and live together in peace with one another as good neighbors, and to unite our strength to maintain international peace and security".

9 Stephen D. Krasner, "Structural causes and regime consequences: regimes as intervening variables" (1982) 36:2 International Organization 185-205 at 186.

10 Heike Krieger \& Andrea Liese, "A Metamorphosis of International Law? Value changes in the international legal order from the perspectives of legal and political science" (2019) KFG Working Paper Series No. 27 at 7.

11 Krasner, supra note 9 at 186.

12 Wolfrum, supra note 5 at para 6. See also Tanaka, "Principles", supra note 7 at 31.

13 Ulrich Beyerlin, "Different Types of Norms in International Environmental Law: Policies, Principles, and Rules" in Daniel Bodansky, Jutta Brunnée \& Ellen Hey (eds) The Oxford Handbook of International Environmental Law (Oxford: Oxford University Press, 2007) 425-448 at 437. 
of principles. From the outset, it is worth stating that the principles discussed in this study do not refer to "the general principles of law recognized by civilized nations" mentioned under article 38 of the Statute of the International Court of Justice. ${ }^{14}$ Nonetheless, some principles are not excluded from being sources of international law, because they "can be considered as a rule of customary international law or an emerging rule of the law". ${ }^{15}$ Other principles, for their part, act mostly as policy guidelines. ${ }^{16}$ For now, however, only principles embodying legal obligations are susceptible to trigger international responsibility and, consequently, form the basis of a cause of action before a dispute settlement body. ${ }^{17}$ Such an approach remains embedded in a traditional positivism regarding the legal nature and impact of principles.

Different views on the legal status of principles do not, however, affect the fact that principles do have an impact on the rules and obligations found within a legal instrument or more generally within a legal regime, nor do those different views affect the political-moral impact of principles on actors' behaviours. ${ }^{18}$ In fact, the open-textured nature of principles allows the variety of functions they can play. ${ }^{19}$ Principles first play a role of coherence and systematization. They provide a basis upon which one can organize "relevant rules within the legal system". ${ }^{20}$ In fact, by considering facets of a non-legal nature, such as political, social, economic or environmental elements, principles provide a context for the development of specific rules and for their organization. This is particularly relevant in studies where diverse disciplines come into play, as with high seas fisheries. Principles further act as a common thread within an instrument, and also ensure coherence and consistency across instruments dealing with the same subject matter or with different aspects of the same subject matter. ${ }^{21}$ Systematizing the rules and obligations helps in the understanding of how they relate to each other and how they have to be applied.

14 Statute of the International Court of Justice (26 June 1945, entered into force 24 October 1945) 3 Bevans 1179 at art. $38(1)(c)$.

15 Tanaka, "Principles", supra note 7 at 33. For example, the no harm principle or the principle of (international) cooperation are recognized as principles of customary international law, see sections 3.1.2 and 3.1.3 below. In comparison, because of the debate surrounding their legal nature, the precautionary principle/approach, as well as the principle for sustainable development could be considered as being emerging rules of law, see sections 3.1.5 and 3.1.7 below.

16 Tanaka, "Principles", supra note 7 at 33. For example, the principle linked to the responsibility of States as stewards of the marine environment, if not translated into specific legal obligations, could be considered as a policy guideline, see section 3.1.9 below.

17 Views of Philippe Sands, Principles of International Environmental Law, 2nd ed (Cambridge: Cambridge University Press, 2003) at 231, discussed in Beyerlin, supra note 13 at 430.

18 Beyerlin, supra note 13 at 447.

19 The main functions of principles are discussed in Tanaka, "Principles", supra note 7 at 31-32 (in relation to marine environmental protection more specifically), and in Beyerlin, supra note 13 at 437 (in relation to environmental protection more generally).

20 Tanaka, "Principles", supra note 7 at 31-32. See also Beyerlin, supra note 13 at 429, where he explains the role of principles according to the UNEP.

21 Richard Barnes, "Consolidating Governance Principles for Areas beyond National Jurisdiction Biological Diversity and Governance of Areas beyond National Jurisdiction” (2012) 27:2 International Journal of Marine and Coastal Law 261-290 at 272-273 and 288-289; Young, supra note 4 at 166-167. 
Following a second, yet related, function, principles play a role of guidance in the interpretation and application of relevant rules. ${ }^{22}$ As explained by Henriksen, Honneland and Sydnes, "principles do not point to a specific solution for problems but indicate the directions states should take in fulfilling the over-arching objective". ${ }^{23}$ Such flexibility is needed when facing the complexity of high seas fisheries. This guidance role is, for example, illustrated through the principles found in the preamble to a treaty or in a "general principles" provision: ${ }^{24}$ principles create a conceptual framework for interpreting and applying the treaty. ${ }^{25}$ Principles underlying a rule can also guide a court or tribunal in determining the meaning of that rule. ${ }^{26}$

A third function of principles is that they provide parameters for the development of the law. Principles can participate in the progressive development of international law, ${ }^{27}$ either by interpreting and applying a rule in accordance with current concepts that were not necessarily present at the time the norm was adopted, ${ }^{28}$ or by applying the rule to a situation that, although similar in nature, lies outside a given legal regime. ${ }^{29}$ With principles, one can give direction but without overprescribing, which could affect the evolutive capacity of an instrument or a regime. When dealing with biodiversity, which is not static, we must be even more aware of this need for malleability.

Within the present study, principles are therefore seen as instruments for developing clusters of obligations, a "check list" to manage the high seas in a way that connects ocean uses with marine environmental protection considerations. They act as a method of shaping different constructions of ocean space around the same set

22 Barnes, supra note 21 at 272-273; Astrid Epiney \& Martin Scheyli, Unweltvölkkerrecht (Baden-Baden: Stämpfli-Verlag, 2000) at 76, discussed in Beyerlin, supra note 13 at 431; Young, supra note 4 at 164.

23 Tore Henriksen, Geir Hønneland \& Are Sydnes, Law and Politics in Ocean Governance. The UN Fish Stocks Agreement and Regional Fisheries Management Regimes (Leiden: Martinus Nijhoff, 2006) at 22-23.

24 See, e.g. UNFSA at art. 5.

25 It is to be noted that "[p]rinciples contained in international agreements which were originally designed to guide interpretation and application of that particular instrument but which have, through the mechanisms described above, developed into independent principles do not lose their function as tools for interpretation", see Wolfrum, supra note 5 at paras 56-57.

26 Barnes, supra note 21 at 272.

27 Wolfrum, supra note 5 at paras 7-8.

28 E.g. in the Gabčikovo-Nagymaros Case (Gabčíkovo-Nagymaros Project (Hungary v Slovakia), Judgment, (1997) ICJ Rep 7 at para 140), the concept/principle of sustainable development did not formally exist when the treaty discussed in this case (Treaty of 16 September 1977 concerning the construction and operation of the Gabcrikovo-Nagymaros Systems of Locks) was adopted. Yet, the ICJ refers to the concept of sustainable development, and so does Vice-President Weeramantry in his Separate Opinion (Gabčikovo-Nagymaros Case (Gabčíkovo-Nagymaros Project (Hungary v Slovakia), Separate Opinion of Vice-President Weeramantry, (1997) ICJ Rep 7 at 88), where he considers sustainable development as "more than a mere concept, but as a principle with normative value which is crucial to the determination of this case. Without the benefits of its insights, the issues involved in this case would have been difficult to resolve".

29 E.g. principles of environmental protection are involved in the reasoning of the WTO in United States Import Prohibition of Certain Shrimp and Shrimp Products (India, Malaysia, Pakistan, Thailand $v$ United States), Report of the Appellate Body, (2001) WTO AB-2001-4, so trade is consequently interpreted in line with environmental protection. 
of tools. They bring coherence and coordination to the way a legal framework characterized by complexity is organized, applied, interpreted and evolves.

\section{PRINCIPLES GOVERNING THE HIGH SEAS}

There is no definitive list of principles governing the high seas or applicable to the management of its resources. ${ }^{30}$ The principles used in the context of marine environmental exploitation and protection tend to rely on existing principles of general international environmental law. ${ }^{31}$ They are therefore generally accepted by the international community, as can be seen from their inclusion in a wide variety of global and regional instruments (including UNCLOS and other instruments discussed in the previous chapter), as well as from their consideration by dispute settlement bodies. ${ }^{32}$ What has received less attention, however, is a uniform consideration of their application to $\mathrm{ABNJ}$ and fisheries. ${ }^{33}$

In order to provide this missing uniform set of tools for a coherent and coordinated management of the high seas and its resources, the International Union for the Conservation of Nature (IUCN) suggested a list of principles governing the high seas. These principles were identified and listed for the first time in a 2007 IUCN workshop entitled "Workshop on High Seas Governance for the 21st Century". ${ }^{44}$ The principles were then reiterated by the Netherlands in written comments to the draft EU position for the 2010 meeting of the Ad Hoc Open-ended Informal Working Group to study issues relating to the conservation and sustainable use of BBNJ (Working Group). Spain, on behalf of the EU and its Member States, then submitted analogous principles to the Working Group that same year. ${ }^{35}$ Since then, these principles have been reiterated and addressed in the legal and policy literature. ${ }^{36}$

30 Tanaka, "Principles", supra note 7 at 32. David Freestone, "Problems of High Seas Governance" in Peter Johan Schei \& Davor Vidas (eds), The World Ocean in Globalisation. Climate Change, Sustainable Fisheries, Biodiversity, Shipping, Regional Issues (Leiden: Brill, 2011) 99-130 at 108-109 and 121 [Freestone, "Problems of High Seas Governance"] suggests that a list could eventually be formally recognized, e.g. in a UNGA resolution.

31 Tanaka, "Principles", supra note 7 at 32.

32 Freestone, "Problems of High Seas Governance", supra note 30 at 121. See also Thomas Greiber, with comments from Kristina Gjerde \& Elisabeth Druel, "Paper IV: Governance Principles. An International Instrument on Conservation and Sustainable Use of Biodiversity in Marine Areas beyond National Jurisdiction. Exploring Different Elements to Consider" (2008) IUCN Policy Briefs at 1.

33 Freestone, "Problems of High Seas Governance", supra note 30 at 121.

34 Rosemary Rayfuse et al, "Co-Chair's Report of Workshop on High Seas Governance for the 21st Century" (2007) at 24-25, online: <https://www.iucn.org/sites/dev/files/import/downloads/iucn_workshop_co_ chairs_summary_new_iucn_format.pdf $>$.

35 "Draft EU position on the outcome of the third meeting of the BBNJ Working group, Written comments by the Netherlands" (2010), cited in Alex Oude Elferink, "Governance Principles for Areas beyond National Jurisdiction" (2012) 27:2 International Journal of Marine and Coastal Law 205-259 at 206-207 [Oude Elferink, "Governance Principles"]. The BBNJ process is discussed in further details in chapter 4 below.

36 See, e.g. David Freestone, "Principles Applicable to Modern Ocean Governance" (2008) 23 International Journal of Marine and Coastal Law 385-391 [Freestone, "Modern Ocean Governance"]; David Freestone, 
This section explores the way in which these principles act as standards of good practice on the high seas, as guidelines towards which stakeholders should turn to ensure that their behaviour is in line with good management of the oceans. It first studies the content of the main high seas principles identified by the IUCN and later reiterated by various $\mathrm{ABNJ}$-related actors and literature, and underlines, where relevant, the specific application of these principles to high seas living resources (3.1). The section ends with a short reflection on the effectiveness of these principles, as well as further actions necessary for strengthening and improving not only their implementation but also their particular applicability to $\mathrm{ABNJ}$ (3.2).

\subsection{The high seas principles of the International Union for the Conservation of Nature (IUCN)}

Most of the principles discussed below might not be new to a reader familiar with general environmental law or the protection of the marine environment. What this study suggests, however, is looking at these principles in light of their inclusion in - or absence from - the regime for the high seas which could eventually inform us of the role they have played for the effective operationalization of the conservation and management of fisheries resources. Building on these observations, the specific role that these principles could play in the development of the upcoming legally binding instrument on the conservation and sustainable use of BBNJ is discussed in the chapter 4 below. ${ }^{37}$

Although discussed separately for ease of presentation, and although having varying impacts on actors' behaviours, these high seas principles must be seen as building blocks that "reaffirm each other, sometimes providing different dimensions as to how to go about achieving the central goal of" 38 balancing use with conservation. This list of principles is not exhaustive, and the literature has been open to identifying further principles relevant for ABNJ. ${ }^{39}$ From time to time, the listed principles are, in the present study, also assessed in relation to other principles of environmental

"Modern Principles of High Seas Governance - The Legal Underpinnings" (2009) 39-1 Environmental Policy and Law 44-49 [Freestone, "Legal Underpinnings"]; Freestone, "Problems of High Seas Governance", supra note 30; Georgia Nogueira de Souza Patu, Scope and evolution of ocean governance: improving cross-sectoral management by the adoption of principles of international law (Doctor of Philosophy thesis, Australian National Center for Ocean Resources and Security, University of Wollongong, 2011); Oude Elferink, "Governance Principles", supra note 35; Barnes, supra note 21.

37 The analysis of the principles conducted in Oude Elferink, "Governance Principles", supra note 35 also discusses their potential inclusion in the BBNJ instrument.

38 Elisa Techera \& Natalie Klein, International Law of Sharks. Obstacles, Options and Opportunities (Leiden: Brill Nijhoff, 2017) at 220.

39 Oude Elferink, "Governance Principles", supra note 35; de Souza Patu, supra note 36; Tanaka, "Principles", supra note 7. These include, e.g., the polluter-pays principle ("National authorities should endeavour to promote the internalization of environmental costs and the use of economic instruments, taking into account the approach that the polluter should, in principle, bear the cost of pollution, with due regard to the public interest and without distorting international trade and investment", see Rio Declaration at principle 16), and the principle of common but differentiated responsibility ("In view of the different contributions to global environmental degradation, States have common but differentiated responsibilities. The developed countries acknowledge the responsibility that they bear in the international pursuit of 
law that are of further relevance for the conservation and management of the high seas and its resources.

Some of the principles discussed below have reached the status of customary international law, whilst others can so far only be characterized as agreed international minimum standards, or as policy goals. ${ }^{40}$ However, whatever the legal nature or status of these principles, they are understood as guiding "actors in adopting and implementing specific rules or approaches in respect of activities in ABNJ" ${ }^{41}$

\subsubsection{Respect for the law of the sea, in particular UNCLOS and related instruments}

As discussed in the previous chapter, the open access to fish stocks stemming from the freedom of fishing on the high seas has led to the tragedy of the commons and an overexploitation of resources. ${ }^{42}$ However, it would be wrong to claim that the freedoms of the high seas are applied without restrictions. In fact, the law of the sea's main role for the high seas is to provide regulations for limiting the damages triggered by open-access. Yet, an excessive reliance on this open nature of ABNJ, combined with the failure of regulations to impact sufficiently on States' behaviour, have led to unsustainable practices and an inadequate protection of the wider marine environment. Reiterating the importance of the legal framework applicable to the oceans through an overarching guiding principle is therefore necessary.

The principle calling for the respect for the law of the sea is two-fold. First, the principle, also referred to as "conditional freedom of activity on the seas", ${ }^{43}$ looks into some of the conditions or limitations imposed on the freedom of the high seas through regulation. A particular emphasis is put on the need to balance different interests on the high seas and some mechanisms/notions impacting on this balancing exercise. Second, the respect for the law of the sea can be found in references to the law of the sea regime in other relevant instruments.

sustainable development in view of the pressures their societies place on the global environment and of the technologies and financial resources they command", see Rio Declaration at principle 7).

40 Freestone, "Problems of High Seas Governance", supra note 30 at 121.

41 Barnes, supra note 21 at 273, referring to Oude Elferink, "Governance Principles", supra note 35.

42 Dire Tladi, "The Proposed Implementing Agreement: Options for Coherence and Consistency in the Establishment of Protected Areas Beyond National Jurisdiction" (2015) 30:4 International Journal of Marine and Coastal Law 654-673 at 659. For the full discussion on open access and the tragedy of the commons, see chapter 2 section 2.3 above.

43 Freestone, "Modern Ocean Governance", supra note 36 at 45. See also Michaela Young, "Then and Now: Reappraising Freedom of the Seas in Modern Law of the Sea" (2016) 47:2 Ocean Development and International Law 165-185 at 165. On the fact that freedoms are conditional due to the fisheries management mandate given to RFMOs on the high seas, see, e.g. Pascale Ricard, La conservation de la biodiversité dans les espaces maritimes internationaux. Un défi pour le droit international (Paris: Pedone, 2019) at 139-142; and Warwick Gullett \& Quentin Hanich, "Rethinking High Seas Fishing Freedoms: How High Seas Duties Are Catching Up" in Keyuan Zou (ed), Global Commons and the Law of the Sea (Leiden, Boston: Brill Nijhoff, 2018) 112-123 at 112. 
With regard to the first aspect of this principle, freedoms of the high seas are firstly conditional on limitations stemming from UNCLOS as well as other obligations contained in international law in general. ${ }^{44}$ These limitations are to be found inter alia in generally formulated conditions such as the duty of good faith under article $300 \mathrm{UNCLOS},{ }^{45}$ or the responsibility towards the protection and preservation of the marine environment under article 235(1) UNCLOS. ${ }^{46}$ These limitations are also meant to vary according to each freedom concerned. ${ }^{47}$ For example, when looking more specifically at limitations related to the use of living resources, article 116 UNCLOS indicates that the freedom of fishing is subject to treaty obligations and "other provisions of this section on the conservation and management of living resources of the high seas", referring to articles 117-120 on the conservation of the living resources on the high seas, including the duty of States to co-operate for such conservation obligations. Further, Part XII of UNCLOS also makes the freedoms of the high seas conditional on the various obligations aimed at the protection and preservation of the marine environment. All these obligations are also complemented by other instruments of international law, such as the UNFSA and the constitutive instruments of RFMOs, which contain additional limitations on the freedom of fishing. In fact, the reference to limitations from other instruments ensures a continuous development in the exercise of the freedom of the high seas, through the interaction between existing and new rules of international law found elsewhere. $^{48}$

The freedoms are further conditional on the rights, duties and interests of other States. This applies to interests on the high seas and in relation to the Area, ${ }^{49}$ as well as particular rights and interests of coastal States in the zones under their respective jurisdiction. ${ }^{50}$ These conditions call for the exercising of due regard for the interests of States on the high seas. There should in fact be consideration for the various uses

44 UNCLOS at art. 87(1), first sentence.

45 "States Parties shall fulfil in good faith the obligations assumed under this Convention and shall exercise the rights, jurisdiction and freedoms recognized in this Convention in a manner which would not constitute an abuse of right." This provision is also considered as being a specific application of the even more general obligation of pacta sunt servanda found under VCLT at art. 26, which reads "Every treaty in force is binding upon the parties to it and must be performed in good faith", discussed in Oude Elferink, "Governance Principles", supra note 35 at 211.

46 "States are responsible for the fulfilment of their international obligations concerning the protection and preservation of the marine environment. They shall be liable in accordance with international law", see Oude Elferink, "Governance Principles", supra note 35 at 213-214.

47 Douglas Guilfoyle, "Article 87. Freedom of the high seas" in Alexander Proelss (ed), United Nations Convention on the Law of the Sea. A Commentary (Munich: Verlag C. H. Beck, 2017) 678-682 at 681.

48 Oude Elferink, "Governance Principles", supra note 35 at 212.

49 UNCLOS at art. 87(2).

50 See, e.g. ibid at art. 116(b), which refers to the rights, duties and interests of coastal States within their EEZ. Respect for the rights and interests of coastal States in their EEZ has raised the question of the balancing of these rights and interests with the ones of other States conducting activities in ABNJ and this is addressed generally in chapter 2 section 3.3.3 above. The specific application of the issue in the context of the BBNJ process is addressed in chapter 4 section 3.4 below. 
of ocean space, to ensure as little interference as possible with activities undertaken by other actors. ${ }^{51}$

The duty of due regard amounts to a balancing exercise between the interests of different States conducting activities on the high seas. The content of this duty on the high seas is unclear, $^{52}$ and no dispute settlement body has so far had the chance to interpret its extent and application on the high seas. Some guidance on how to implement the duty can, however, be found in recent decisions ${ }^{53}$ dealing with the application of the duty in the EEZ, as found under articles 56(2) and 58(3) UNCLOS. ${ }^{54}$ In the Chagos Arbitration, the Tribunal refused "to find [...] any universal rule of conduct" or any "uniform obligation to avoid any impairment of [...] rights". ${ }^{55}$ It nevertheless mentioned some requirements, including the importance of the circumstances, the nature and importance of the rights to which to have due regard, the nature, extent and importance of the activities that might lead to an impairment, and the availability of alternative approaches. ${ }^{56}$ It also underlined that due regard included "some consultation with the rights-holding State", 57 as well as a balancing of the rights and duties of all parties involved. ${ }^{58}$ In the South China Sea Arbitration, the tribunal further relied on ITLOS' 2015 Advisory Opinion on IUU Fishing to define the obligation of due regard "[i]n the context of the duties of a flag State with respect to fishing by its nationals". ${ }^{59}$ In such a case, due regard would also include the duty to take "the necessary measures to ensure that [its] nationals and vessels flying [its] flag are not engaged in IUU fishing activities", ${ }^{60}$ which amounts to an obligation of due diligence. ${ }^{61}$ Consequently, in such a situation, due regard would also include the duty of due diligence.

51 H. Gary Knight, The Future of International Fisheries Management (St. Paul, Minnesota: West Publishing Co., 1975) at 21-22.

52 Guilfoyle, supra note 47 at 681.

53 Proelss in fact observes that, prior to the Chagos Marine Protected Area Arbitration (Mauritius v. United Kingdom), Award, (2015) PCA case 2011-03, little guidance regarding the meaning and implementation of the duty could be found, see Alexander Proelss, "Article 56. Rights, jurisdiction and duties of the coastal State in the exclusive economic zone" in Alexander Proelss (ed), United Nations Convention on the Law of the Sea. A Commentary (Munich: Verlag C. H. Beck, 2017) 418-437 at 431.

54 The application of both articles creates a mutual obligation of due regard, where the coastal State must respect the rights and duties of other States (art. 56(2)), and vice versa (art. 58(3)). It has been argued that the application of due regard triggers a different balance of interests depending on whether it is applied in a State's EEZ or on the high seas. In the EEZ, the interests of a coastal State would weigh more in the balance considering their sovereign rights in that zone, see Proelss, supra note 53 at 432, citing David J. Attard, The Exclusive Economic Zone in International Law (Oxford: Clarendon Press, 1987) at 75.

55 Chagos Arbitration, supra note 53 at para 519.

56 Ibid.

57 Ibid at paras 519 and 534-535; The South China Sea Arbitration (The Republic of Philippines v The People's Republic of China), Award, (2016) PCA case 2013-19 at para 742.

58 Chagos Arbitration, supra note 53 at paras 534-535. This interpretation was subsequently referred to in the South China Sea Arbitration, supra note 57 at para 742.

59 South China Sea Arbitration, supra note 57 at para 743.

60 Request for an advisory opinion submitted by the Sub-Regional Fisheries Commission (SRFC), Advisory Opinion, (2015) ITLOS case 21 at para 124 [Advisory Opinion on IUU Fishing], cited in South China Sea Arbitration, supra note 57 at para 743.

61 Advisory Opinion on IUU Fishing, supra note 60 at para 129, cited in South China Sea Arbitration, supra note 57 at para 743 . 
However, no other reference to due regard can be found under Part VII of UNCLOS. The only functionally equivalent obligation to the one found under article 56(2) UNCLOS applicable to the high seas is found in Part XII, under article 194(4) UNCLOS, which indicates that "States shall refrain from unjustifiable interference with activities carried out by other States". The tribunal in the Chagos Arbitration, however, mentioned that article 194(4) "facially applies only to the 'activities carried out by other States' pursuant to their rights, rather than to the rights themselves". ${ }^{62}$ An activity would therefore need to be already taking place to be subject to the obligation of due regard from another party, and not be only prospective. ${ }^{63}$ Nonetheless, it remains instructive about the way in which the freedom of the high seas must be exercised and how rights and interests must be respected. In any case, article 194(4) interconnects the duty of good faith to the protection and preservation of the marine environment. ${ }^{64}$

Besides referring to the conditions limiting high seas freedoms, the principle calling for the respect for the law of the sea can also be seen through the references made to the law of the sea in other international instruments. For example, article 22(2) CBD specifically mentions the necessity to consistently implement the CBD with the law of the sea. Article XIV(6) CITES establishes a similar requirement for consistency. These compatibility clauses specifically call for the concerned instrument to be applied in accordance with the law of the sea, UNCLOS and related agreements.

\subsubsection{Protection and preservation of the marine environment}

The general principle of environmental protection has evolved significantly since the Trail Smelter Arbitration, ${ }^{65}$ which established the prevention of transboundary harm as a legally binding duty. The obligation has since been strengthened through a substantial body of environmental law instruments and rules, where the obligation not only includes a negative duty to refrain from affecting the environment, but also a positive duty to take active measures for protection. For example, the general duty of protection, preservation and conservation is found in many environmental law agreements. For instance, the $\mathrm{CBD}$ directly addresses the conservation of biological diversity, ${ }^{66}$ while the CMS provides for the conservation ${ }^{67}$ and the immediate protection of species, ${ }^{68}$ as well as "the need to take action to avoid any [of these] species becoming endangered".69 Soft law instruments have also embodied the

62 Chagos Arbitration, supra note 53 at para 540.

63 For example, due regard would only be owed to an already ongoing fishing activity, and not a prospective fishing activity pursuant to the right to fish on the high seas.

64 Detlef Czybulka, "Article 194. Measures to prevent, reduce and control pollution of the marine environment" in Alexander Proelss (ed), United Nations Convention on the Law of the Sea. A Commentary (Munich: Verlag C. H. Beck, 2017) 1295-1315 at 1308.

65 Trail Smelter Arbitration (United States $v$ Canada), (1938 and 1941) 3 RIAA 1905.

$66 \mathrm{CBD}$ at preamble and art. 1.

67 CMS at art. II(1).

68 Ibid at art. II(3)(b).

69 Ibid at art. II(2). 
duty, as can be seen from principle 4 of the 1972 Stockholm Declaration, ${ }^{70}$ from the UNGA Resolution The Future we Want ${ }^{71}$ adopted following the 2012 Rio+20 Conference, and from the 2015 SDGs. ${ }^{72}$ At the national level, some States have given specific rights to nature in order to ensure its protection, rights in certain cases even enshrined in constitutional texts. ${ }^{73}$

This general environmental duty has also been reflected in the specific protection of the marine environment. A guiding principle of UNCLOS, embedded in its preamble and generally in Part XII, the protection and preservation of the marine environment has reached the level of a general obligation for States parties under article 192, also considered as a rule of customary international law. This obligation is complemented by a general obligation to take measures to prevent pollution (article 194(1) UNCLOS) as well as ensuring that activities under States' control or jurisdiction do not cause damage by pollution beyond their areas of jurisdiction (article 194(2) UNCLOS), therefore targeting potential impacts on ABNJ. Further supplemented by the obligation to protect rare and fragile ecosystems under article 194(5), and by the obligation to cooperate under article 197, the duty of protection and preservation is also necessarily linked to the ecosystem and precautionary

70 "responsibility to safeguard [...] the heritage of wildlife and its habitat", see Stockholm Declaration at principle 4.

71 The future we want, GA Res 66(CCLXXXVIII), UNGAOR, 66th Sess, UN Doc A/RES66/288 (2012) at paras 40, 158 and 162, the last-mentioned specifically referring to ABNJ.

72 Transforming our world: the 2030 Agenda for Sustainable Development, GA Res 70/1, UNGAOR, 70th Sess, UN Doc A/RES/70/1 (2015) at goal 14. The goal's title is "Conserve and sustainably use the oceans, seas and marine resources", substantiated by the goal's targets, which include some concrete actions such as the reduction of pollution, the protection of marine ecosystems, and the fight against IUU fishing and overexploitation.

73 See, e.g. Duncan Currie \& Mischa Davis, "Governance Principles Relevant to Marine Biodiversity in Areas Beyond National Jurisdiction. Submission to the Chair of the Third Session of the BBNJ Preparatory Committee" (25 February 2016), online: <https://www.un.org/depts/los/biodiversity/ prepcom_files/greenpeace.pdf $>$, referring to national legislations, e.g., Te Awa Tupua (Whanganui River Claims Settlement) Act (NZ), 2017, where a river was given the same rights as human beings; Constitución Política de la República de Colombia (1991) at art. 79, online: <https://www.funcionpublica. gov.co/eva/gestornormativo/norma_pdf.php?i=4125>, which reads "All persons have the right to enjoy a healthful environment. The law shall guarantee communitarian participation in decisions that may affect the environment. It is the duty of the state to protect the diversity and integrity of the environment, preserve areas of special ecological importance and promote education for the attainment of those ends"; Constitución de la República del Ecuador (2008) at arts. 3 and 4, online: <https://www. ministeriodegobierno.gob.ec/wp-content/uploads/2015/04/constitucion-de-la-republica-del-ecuador1. pdf $>$, which reads "Art. 3. The State will motivate natural and juridical persons as well as collectives to protect nature; it will promote respect towards all the elements that form an ecosystem. Art. 4. The State will apply precaution and restriction measures in all the activities that can lead to the extinction of species, the destruction of the ecosystems or the permanent alteration of the natural cycles"; and The Constitution of the Republic of the Philippines (1987) at art. II, section 16, online: <https://www.officialgazette.gov. $\mathrm{ph} /$ constitutions/1987-constitution/>, which reads "The State shall protect and advance the right of the people to a balanced and healthful ecology in accord with the rhythm and harmony of nature". For more examples of laws related to the rights of nature, i.e. where nature is a right-bearing subject, as well as an overview of the characteristics of those laws, see Harriet Harden-Davies et al, "Rights of Nature: Perspectives for Global Ocean Stewardship" (2020) Marine Policy. See also M.C. Mehta v. Kamal Nath, (1997) 1 SCC 388 (India), where the Supreme Court of India recognized that the State as a trustee has a duty to protect natural resources. 
approaches, and to sustainability. ${ }^{74}$ In the framework of high seas fisheries, the duty to preserve and protect the marine environment is also embodied through the duty of conservation of marine living resources on the high seas (articles 116-120 UNCLOS). ${ }^{75}$

The principle also forms an intrinsic part of the mandate of the RSPs, through their role as leading institutions for protection and preservation in the marine environment. ${ }^{76}$ In particular, CCAMLR, whose mandate covers "conservation and rational use", is often cited as a "role model institution" in matters of environmental protection and marine living resources. ${ }^{78}$ Furthermore, RFMOs and RFMAs give effect to the principle through the adoption of conservation measures. Conservation ${ }^{79}$ as such is in fact also part of most RFMOs' mandate and objectives.$^{80}$ In particular, the more recent RFMOs, especially the ones created after the adoption of the UNFSA, tend to be more detailed on their conservation objectives, by balancing them expressly with other objectives of a social and economic nature. The NPFC, for example, established in 2012, lists some concrete actions to be taken to fulfil the duty of conservation, such as eliminating overexploitation, adopting and implementing measures in accordance with the precautionary and ecosystem approaches, and assessing the impact of fishing activities. ${ }^{81}$

The principle for the protection and preservation of the marine environment has reached the status of legally binding obligation. Despite this clear legal status, this principle is necessary as a framework which guides the application of some of the other principles listed below. ${ }^{82}$ It in fact informs the application of other principles, which, in turn, brings clarification to its implementation.

74 Greiber et al, supra note 32 at 2-3.

75 The duty of conservation of marine living resources on the high seas was raised by Chile in Case concerning the Conservation and Sustainable Exploitation of Swordfish Stocks in the South-Eastern Pacific Ocean (Chile/European Union), Order, (2000) ITLOS case 7. No judgment was delivered, because the case was withdrawn from the case list of the Tribunal at the request of the parties in 2009, see Case concerning the Conservation and Sustainable Exploitation of Swordfish Stocks in the South-Eastern Pacific Ocean (Chile/European Union), Order, (2009) ITLOS case 7. On conservation see also, e.g. Knight, supra note 51 at 16-17.

76 See, e.g., Barcelona Convention at preamble and art. 4(1), and OSPAR Convention at art. 2, both discussed in Freestone, "Legal Underpinnings", supra note 36 at 45-46, and Currie \& Davis, supra note 73. See also Noumea Convention at art. 5(1), and Lima Convention at art. 3(1).

77 CAMLR Convention at art. II.

78 As discussed in chapter 2 sections 3.3.2 and 3.3.4 above, CCAMLR is often referred to as a "hybrid" entity between an RSP and an RFMO.

79 A discussion on the meaning of the notion of conservation in comparison with the notions of preservation and protection is conducted in chapter 2 section 3.1.1.3 above and in the Gloassy in Annex below. Conservation tends to involve an underlying subsequent interest in exploitation (i.e. conserve a resource to ensure its exploitation can still continue), while protection and preservation tend to refer to purely preservationist interests. It is, however, submitted in this study that conservation can be understood as giving effect to the principle of protection and preservation of the marine environment, as it acts as a corollary of protection and preservation in the context of use.

80 See e.g., NEAFC Convention at art. 2; ICCAT Convention at preamble; NPFC Convention at art. 2; WCPFC Convention at art. 2.

81 NPFC Convention at art. 3.

82 Oude Elferink, "Governance Principles”, supra note 35 at 216. 


\subsubsection{International cooperation}

Reaffirmed in contexts going far beyond the law of the sea and enshrined in key UNGA resolutions, ${ }^{83}$ cooperation is a duty of conduct rather than a duty of result, ${ }^{84}$ calling upon States to cooperate in the conduct of their international affairs. Cooperation "is an implied formal declaration between States of their interdependency" ${ }^{85}$ It in fact recognizes that multiplicity and interconnectedness (e.g. of ecosystems components, of treaties, rules and institutions) ${ }^{86}$ triggers the need for actors to intervene collectively rather than unilaterally. The positive component of cooperation requires actors to reach agreements amongst themselves, while the negative component entails that these actors should refrain from taking unilateral measures that would, for example in international fisheries law, impede the adoption and implementation of conservation measures undertaken by bodies, such as RFMOs. ${ }^{87}$ Cooperation can further be horizontal, (i.e. between sectors on the same level, be it local, regional or international) or vertical (i.e. between levels) ${ }^{88}$

The duty of cooperation remains the main mechanism for the management of common resources (fisheries) and common interests (protection of the marine environment) in ABNJ. This is why the duty is found under several provisions addressing such resources and interests. In UNCLOS, cooperation is implicitly found in article 87, where States are requested to exercise due regard for the interests of other States. The implementation of due regard in this context has been interpreted by Oude Elferink as necessitating cooperation between States' actions. Articles 117-118 further provide that States must cooperate in the conservation and management of the living resources of the high seas, ${ }^{89}$ including in the adoption of national measures to reach that goal and in the establishment of RFMOs. Under Part XII, article 194(1) requires States to take measures to prevent, reduce and control pollution of the marine environment. Article 197, ${ }^{90}$ which specifies the general obligation to take measures for the prevention of pollution of the marine environment, ${ }^{91}$ calls upon States to cooperate for the protection and preservation of the marine environment at both the global and regional levels. This element is

83 See e.g. Declaration on Principles of International Law concerning Friendly Relations and Co-operation among States in accordance with the Charter of the United Nations, GA Res 2625(XXV), UNGAOR, 25th Sess, UN Doc A/RES/2625 (1970), and Charter of Economic Rights and Duties of States, GA Res 29(MMMCCLXXXI), UNGAOR, 29th Sess, UN Doc A/RES/29/3281 (1974).

84 Young, supra note 43 at 169-170.

85 de Souza Patu, supra note 36 at p. 51

86 These elements, discussed in de Souza Patu, supra note 36 at 55-62, are the three rationales (ecological, legal and institutional) of cooperation.

87 Michael Lodge et al, Recommended Best Practices For Regional Fisheries Management Organizations. Report of an Independent Panel to Develop a Model for Improved Governance by Regional Fisheries Management Organizations (London: The Royal Institute of International Affairs Chatham House, 2007) at 70-71.

88 de Souza Patu, supra note 36 at 62.

89 Freestone, "Modern Ocean Governance", supra note 36 at 46.

90 See also UNCLOS at arts. 198-201.

91 Ibid at art. 194(1). 
interesting as regards the geographical scope of the duty, which not only applies globally, but also on a regional basis. ${ }^{92}$ Cooperation is also implicitly found in other provisions of Sections 3, 4 and 5 of Part XII, for example in measures concerning technical assistance, exchange of information or environmental impact assessment. ${ }^{93}$

Cooperation is also enshrined in other legally binding instruments. Obligations on the exchange of information and cooperation with developing countries can also be found under the 1993 Compliance Agreement ${ }^{94}$ as well as under the 2009 PSMA. ${ }^{95}$ An overarching obligation of cooperation is also found in article $5 \mathrm{CBD}$. It has, however, already been mentioned ${ }^{96}$ that the obligation under the CBD does not seem to reach the same mandatory level as under UNCLOS. In fact, the former makes it a condition that the duty to cooperate is to be exercised only "as far as possible and as appropriate", a limitation not found under UNCLOS provisions.

Although all these obligations reiterate the need for cooperation, they do not provide specifications as to the content or meaning of the duty, which remains loosely formulated. The broad phrasing of the duty of cooperation under several provisions of UNCLOS and related agreements has led Oude Elferink et al to suggest that States are given a large margin of appreciation in the way in which they interpret and fulfil the duty; it can either refer to the framework for cooperation, or to the content of a rule in a specific regime. ${ }^{97}$ The appropriate framework for cooperation will depend on the subject matter discussed (e.g. certain issues can be effectively regulated at the regional level, but others can only be dealt with globally), on the resources that are already available (e.g. what is the role of existing international organizations), and on who is entitled to implement the rules in a specific context. ${ }^{98}$ The framework for cooperation can also be influenced by the content of a specific rule, especially in fragmented regimes such as the law of the sea and environmental law; in fact, if rules in a specific regulatory regime only cover that particular regime, cooperation will be needed, especially in cases where issues are intertwined. This is the case with the protection of the marine environment, which can involve rules from the fisheries, the shipping and the seabed regimes. ${ }^{99}$

In the case of articles 117-118 UNCLOS, this large margin of appreciation was reduced with the adoption of the UNFSA which has provided elaboration on the content of

92 It is worth mentioning that regional cooperation does not necessarily refer to States of the same region only, but can also encompass States which have an interest in that region.

93 This implicit reference is discussed in Oude Elferink, "Governance Principles", supra note 35 at 220.

94 Compliance Agreement at art. V.

95 PSMA at arts. 6 and 21.

96 Oude Elferink, "Governance Principles”, supra note 35 at 221.

97 Alex Oude Elferink, Erik Molenaar \& Donald Rothwell, “The Regional Implementation of the Law of the Sea and the Polar Regions" in Erik Molenaar, Alex Oude Elferink \& Donald Rothwell (eds), Law of the Sea and the Polar Regions. Interactions Between Global and Regional Regimes (Leiden: Brill Nijhoff, 2013) 1-16 at 3 .

98 Ibid at 3-5.

99 Ibid at 5-6. 
the duty of cooperation found under these provisions. ${ }^{100}$ Part III of the UNFSA (articles 8-16) specifically addresses the duty of international cooperation, a duty to be honoured directly or through States' participation in regional organizations. By underlining this distinction and expressly referring to regional entities, these instruments put forward the necessity for States to cooperate regionally. The duty to cooperate can also be found in other parts of the UNFSA, including in article 17, which stipulates that non-members of regional organizations are still bound by the duty to cooperate, and articles 20-21, which focus on cooperation in enforcement. Some regional organizations have also directly enshrined the duty in their constitutive instruments. That is the case with CCAMLR ${ }^{101}$ and SPRFMO, ${ }^{102}$ to name but two.

Moreover, the discussion on the content of the duty triggers the question about whether, in the context of high seas fisheries, the duty forms part of customary international law. In fact, debate continues in the literature as to the fulfilment of the necessary elements (State practice and opinio juris) for the duty to be considered as customary law. ${ }^{103}$ It is the inclusion of the duty in RFMOs' constitutive instruments, as well as the presence of the duty in many soft-law instruments that have led some authors to conclude in favour of a customary nature for the obligation. ${ }^{104}$ For example, Principle 7 of the Rio Declaration states that "States shall cooperate in a spirit of global partnership to conserve, protect and restore the health and integrity of the Earth's ecosystem",105 thereby focusing on cooperation in the conservation

100 This is also the case for other obligations of cooperation regarding marine living resources occurring in several maritime zones (e.g. articles 63-67 UNCLOS). Elaboration on the content and scope of the duty of cooperation is not, however, found for other issues, see Oude Elferink, "Governance Principles", supra note 35 at 221.

101 CAMLR Convention at preamble, which reads "international co-operation with due regard for the provisions of the Antarctic Treaty".

102 SPRFMO Convention at art. 3(1)(a)(vi), which reads "cooperation and coordination among Contracting Parties shall be promoted".

103 Hayasi believes that there is insufficient evidence of opinio juris to conclude that the duty to cooperate has become a customary rule, see Moritaka Hayasi, "Regional Fisheries Management Organizations and Non-Members" in Tafsir Malick Ndiaye \& Ruidiger Wolfrum (eds), Law of the Sea, Environmental Law and Settlement of Disputes - Liber Amicorum Judge Thomas A. Mensah (Martinus Nijhoff Publishers, Leiden, 2007) 751-765 at 761. His opinion is opposed to that of Rayfuse, who argues that there is sufficient State practice, through the participation of States in RFMOs, to characterize the duty as customary rule, see, generally, Rosemary Rayfuse, Non-Flag State Enforcement in High Seas Fisheries (Leiden: Martinus Nijhoff, 2004) at 373; and Rosemary Rayfuse, "To Our Children's Children's Children: From Promoting to Achieving Compliance in High Seas Fisheries" (2005) 20 International Journal of Marine \& Coastal Law 509-532 at 525. This debate is also discussed in Elise Anne Clark, "Strengthening Regional Fisheries Management - An analysis of the duty to cooperate" (2011) 9 New Zealand Journal of Public International Law 223-246 at 233-234. For his part, Freestone mentions that the general duty of cooperation among States has reached the status of customary law through UNGA Res 2625, supra note 83, which reads "States have the duty to cooperate with one another [...] in the various spheres of international relations", see Freestone, "Legal Underpinnings", supra note 36 at 46. The Chatham report also acknowledges the customary nature of the duty in the context of international fisheries, see Lodge et al, supra note 87 at 71.

104 Alan E. Boyle, "The Principle of Co-operation: the Environment" in Vaughan Lowe \& Colin Warbrick (eds), The United Nations and the Principles of International Law: Essays in Memory of Michael Akehurst (Abingdon, Oxon: Routledge, 1994) 120-136 at 121, cited in de Souza Patu, supra note 36 at 55.

105 Rio Declaration at principle 7. See also, Freestone, "Modern Ocean Governance", supra note 36 at 46. 
and protection of the environment. UNGA Resolutions have also put forward the principle in the marine context, e.g. Resolution $61 / 105$ on the necessity of cooperation for the regulation of bottom fisheries, ${ }^{106}$ and Resolution 61/222 on regional and global cooperation regarding the sustainability of the oceans. ${ }^{107}$

Conclusions reached by dispute settlement bodies are also used by authors who argue in favour of the customary nature of cooperation in the context of high seas fisheries. Dispute settlement bodies have in fact to some extent contributed to interpreting the scope and content of the duty. In the Bluefin Tuna Cases, New Zealand and Australia requested ITLOS to order Japan to immediately cease the unilateral experimental fishing of the southern bluefin tuna, claiming that Japan was failing to conserve and to cooperate in the conservation of the southern bluefin tuna stock. ${ }^{108}$ In its order of 27 August 1999, ITLOS reiterated the existence of the obligation to cooperate for the conservation and optimum utilization of resources, applicable directly or through the relevant international organizations, and the duty of the parties to respect this obligation. ${ }^{109}$ Two years later, in the MOX Plant Case, Ireland submitted a request for provisional measures following the authorisation by the United Kingdom for the opening of a facility that would have had, according to Ireland, a potential pollutant effect on the Irish Sea. In its order of 3 December 2001, ITLOS underlined the importance of the necessity of cooperation of parties in the prevention of pollution of the marine environment. ${ }^{110}$

More recently, in its 2015 Advisory Opinion on IUU Fishing, ITLOS focused on the obligations of flag States regarding IUU fishing in the EEZ of a third party and to the rights and obligations of the coastal State in ensuring the sustainable management of shared stocks. ITLOS reiterated the obligation of cooperation stated in the MOX Plant Case, and affirmed the extension of its application to the fight against IUU fishing. ${ }^{111}$ It also reaffirmed that cooperation for the "conservation and management of shared fisheries resources [...] is a well-established principle in [UNCLOS]", ${ }^{112}$ and that member States of a regional organization should seek the cooperation of non-members sharing the exploited stocks. ${ }^{113}$ Although focusing its

106 Sustainable fisheries, including through the 1995 Agreement for the Implementation of the Provisions of the United Nations Convention on the Law of the Sea of 10 December 1982 relating to the Conservation and Management of Straddling Fish Stocks and Highly Migratory Fish Stocks, and related instruments, GA Res 61(CV), UNGAOR, 61st Sess, UN Doc A/RES/61/105 (2006).

107 Oceans and the Law of the Sea, GA Res 61(CCXXII), UNGAOR, 61st Sess, UN Doc A/RES/61/222 (2006) at paras 119-120.

108 Southern Bluefin Tuna Cases (New Zealand v Japan; Australia v Japan), Provisional Measures, (1999) ITLOS cases $3 \& 4$ at paras 28-29 and 31-32.

$109 \mathrm{Ibid}$ at paras 48 and 78 .

110 "the duty to cooperate is a fundamental principle in the prevention of pollution of the marine environment under Part XII of the Convention and general international law and that rights arise therefrom which the Tribunal may consider appropriate to preserve under article 290 of the Convention", see The MOX Plant Case (Ireland v United Kingdom), Provisional Measures, (2001) ITLOS case 10 at para 82.

111 Advisory Opinion on IUU Fishing, supra note 60 at para 140.

112 Ibid at para 213.

113 Ibid at para 215. 
analysis on obligations arising in the EEZ, as per the scope of the request for the Advisory Opinion, ITLOS' reasoning does include references to shared fisheries resources, stocks straddling between EEZs and high seas areas, as well as highly migratory species. Since such references also cover stocks occurring on the high seas, the present author submits that the statements of ITLOS inform a general understanding of the principle of cooperation in the context of fisheries resources, including its applicability to areas other than the EEZ, including ABNJ.

As can be seen from the examples given above, the duty to cooperate most often arises among States. However, the duty is not limited to a "State-to-State" cooperation. There is, for example, a duty for international organizations to cooperate for the development and transfer of marine technology under article 278 UNCLOS. The Collective Arrangement between NEAFC and OSPAR illustrates another form of regional cooperation, one between actors with different mandates; ${ }^{114}$ in fact, NEAFC, being an RFMO, fulfils its main mandate of fisheries management, while the OSPAR, a RSP, focuses on conservation objectives. ${ }^{115}$ Furthermore, one could reasonably conclude that there must also be cooperation between instruments. ${ }^{116}$ This can be deduced from the compatibility provisions contained in most instruments, ${ }^{117}$ or from the attempts at developing "synergies" amongst biodiversity related conventions to combat fragmentation and treaty congestion in the sector. ${ }^{118}$

The above discussion illustrates that the principle of cooperation is reflected through well-established legal obligations. It remains necessary, however, to reiterate this principle to underline the necessity to elaborate on its scope and content, as cooperation is currently the main mechanism for the management of common resources (fisheries) and common interests (protection of the marine environment) on the high seas.

\subsubsection{Science-based approach to management}

Also referred to as "the use of best available science", "best scientific evidence" or "best scientific information", the principle of a science-based approach to management is

114 Collective arrangement between competent international organisations on cooperation and coordination regarding selected areas in areas beyond national jurisdiction in the North-East Atlantic, OSPAR Agreement 2014-09, online: <https://www.ospar.org/documents?v=33030>.

115 Daniel Owen, "Principles and Objectives of the Legal Regime Governing Areas Beyond National Jurisdiction - Commentary on Tullio Treves" in Alex G Oude Elferink \& Erik J Molenaar (eds), The International Legal Regime of Areas Beyond National Jurisdiction: Current and Future Development (Leiden: Martinus Nijhoff, 2010) 27-37 at 30-31.

116 Jill Barrett, “The UN Convention on the Law of the Sea: A 'Living' Treaty?” in Jill Barrett \& Richard Barnes (eds) Law of the Sea. UNCLOS as a Living Treaty (British Institute of International and Comparative Law, 2016) 3-38 at 23.

117 See the discussion on compatibility clauses in chapter 2 section 3.1.1.4 above.

118 See, generally, Richard Caddell, “'Only Connect'? Regime Interaction and Global Biodiversity Conservation" in Michael Bowman, Peter Davies \& Edward Goodwin (eds), Handbook on Biodiversity and Law (Cheltenham: Edward Elgar, 2016). 
embedded in the conservation of high seas living resources through article 119(1) UNCLOS, which requires measures for the conservation of these living resources to be "designed, on the best scientific evidence available". In point of fact, conservation tools must be rooted in scientific information. ${ }^{119} \mathrm{~A}$ science-based approach is further listed as a general principle in article 5(b) UNFSA. It is also intrinsically linked with the precautionary approach, as shown by its use under article 6 UNFSA, which expressly mentions that the approach must be implemented according to "the best scientific information available" 120 and that emergency measures for conservation and management must also "be based on the best scientific evidence available". ${ }^{21}$ The principle also appears in soft-law instruments, as can be seen, for example, from article 6.4 of the Code of conduct, ${ }^{122}$ or in paragraph 17.25 of Chapter 17 of Agenda 21. ${ }^{123}$

Regional organizations have also incorporated the principle. ${ }^{124}$ For example, the preamble to the CAMLR Convention establishes that decisions on exploitation of resources must be based "on sound scientific information", while its article IX (1) (f) dictates that the Commission must "formulate, adopt and revise conservation measures on the basis of the best scientific evidence available". Similarly, the SPRFMO Convention mentions that measures and decisions related to the conservation and management must "be based on the best scientific information available", ${ }^{125}$ while under the WCPFC Convention, these measures must be based on the best scientific evidence available. ${ }^{126}$ The NEAFC Convention establishes that it is the recommendations given by the Commission that must be "based on the best scientific evidence available". ${ }^{127}$ Under article VII IATTC Antigua Convention, measures to ensure the long-term conservation and sustainable use of stocks must be based on the best scientific evidence available, ${ }^{128}$ while the determination of whether a particular species is fully fished or overfished must be decided according to the best scientific information available. ${ }^{129}$

119 See, e.g., Monica Stankiewicz, "The role of Regional Seas Conventions in MSP: Presenting HELCOM" (Maritime Spatial Planning Conference series: The marine environment, delivered at the Albert Borschette Conference Centre, 7 December 2015).

120 UNFSA at art. 6(3)(a)-(b).

$121 \mathrm{Ibid}$ at art. 6(7).

122 Code of Conduct for Responsible Fisheries, FAO, 28th Sess, FAO Doc 95/20/Rev/1 (1995) at art. 6.4 [Code of Conduct], discussed in Barnes, supra note 21 at 280.

123 Agenda 21 of the United Nations Conference on Environment and Development, UNCED Report A/CONF.151/26/Rev.1 (1993) at chapter 17 at para 17.25 [Agenda 21], discussed in Barnes, supra note 21 at 280 .

124 Freestone, "Legal Underpinnings" supra note 36 at 46.

125 SPRFMO Convention at preamble and art. 3(1)(v).

126 WCPFC Convention at art. 5(b).

127 NEAFC Convention at art. 4(2)(a).

128 IATTC Antigua Convention at art. VII (c).

$129 \mathrm{Ibid}$ at art. VII (d). It appears from the examples cited in this paragraph that two different terms, "best scientific information" and "best scientific evidence", are used. This would suggest that a distinction must be made between both terms. However, other instruments seem to use them without such distinction. For example, in an attempt at defining the term, CCAMLR uses both terms:

"Building on the deliberations and conclusions of the Working Group for the Development of Approaches to Conservation of Antarctic Marine Living Resources (WG-DAC) in 1990 (CCAMLR-IX, Annex 7, 
A science-based approach can also be inferred from provisions containing obligations that can only be effectively implemented with scientific knowledge. This is, for example, the case in article 194(5), where science would be necessary to identify the vulnerable ecosystems and the appropriate measures to be undertaken. ${ }^{130}$

Read in conjunction with the principle of cooperation, a science-based approach could further include the duty of data sharing, which underlines the need to rely on the most recent available scientific data. In the context of high seas fisheries, the sharing of scientific information can, for example, be of great relevance for the establishment of management tools on the high seas, or for the requirement of an environmental impact assessment in the case of new and exploratory fisheries. ${ }^{131}$ The duty of data-sharing is furthermore intrinsically linked to general issues of development of knowledge and technology, ${ }^{132}$ and more specifically to technology transfer and capacity-building of developing countries. ${ }^{133}$

However, none of the provisions discussed above refers to the acceptable standard of science required; this therefore gives leeway to States to rely on criteria of lower quality if "they deem it appropriate, for example, on the basis of a cost-benefit analysis". ${ }^{134}$ It is, furthermore, important to underline that the principle of a sciencebased approach refers to the need to base decisions and regulations on science, but does not seem to include an obligation to gather data. This latter duty is dealt with under the precautionary approach, defined below. ${ }^{135}$

The principle for a science-based approach is necessary to ensure the adaptability of legal instruments, and the rules found therein, to a changing body of scientific knowledge. In the face of the highly complex subject-matter of high seas fisheries,

Appendix 2) regarding the ways in which scientific evidence is used by the Commission to aid its decisionmaking, and the Commission's conclusion that the Commission should regard the Scientific Committee as the source of the best scientific evidence available (CCAMLR-IX, paragraph 7.6)" (CAMLR Convention at preamble, emphasis added).

"Take full account of the best scientific information available from the Scientific Committee in the formulation, adoption and revision of conservation measures." (Best available science, CCAMLR Resolution 31/XXVIII (2009) at para 1 (emphasis added), resolution discussed in Rosemary Rayfuse, "Article 119. Conservation of the living resources of the high seas" in Alexander Proelss (eds), United Nations Convention on the Law of the Sea. A Commentary (Munich: Verlag C. H. Beck, 2017) 830-850 at 842).

Based on this seemingly interchangeable use in practice, the present study uses the terms as leading to the same requirements and obligations.

130 Oude Elferink, "Governance Principles", supra note 35 at 224.

131 Area-based management tools and assessment tools in the context of fisheries are discussed in further details in section 4.2 below.

132 Knight, supra note 51 at p. 21. See also Draft Global Pact for the Environment at art. 13, online <https:// globalpactenvironment.org/uploads/EN.pdf>, which promotes "exchanges of scientific and technological knowledge and [the enhancement of] the development, adaptation, dissemination and transfer of technologies respectful of the environment, including innovative technologies".

133 See, e.g. UNGA Res 66/288, supra note 71 at para 160.

134 Barnes, supra note 21 at 280-281.

135 Oude Elferink, “Governance Principles", supra note 35 at 224. 
the principle ensures that the law remains dynamic to inform the conducting of all activities accordingly.

\subsubsection{Precautionary approach}

Normally referred to as a "tool to allow regulatory action in the face of uncertainty", 136 the precautionary approach is now well established under international law and is central to the fisheries' regulatory framework. ${ }^{137}$ Precaution started to appear in international law in the mid-1980s, and it "aims to provide guidance in the development and application of international environmental law where there is scientific uncertainty". ${ }^{138}$ There is normally agreement on the fact that, while the approach is still evolving, its core meaning stems from Principle 15 of the Rio Declaration. ${ }^{139}$ Simply put, one could equate the approach to the well-known proverb "better safe than sorry".

To better understand the nature of the approach, Schröder compares it with the preventive or protective principle. ${ }^{140}$ Precaution is a more developed form of prevention, because it ensures the use of prevention measures even in the face of scientific uncertainty as to the impact of an activity. ${ }^{141}$ The precautionary approach therefore comes before the fact of the actual presence of harm or risk. The effects triggered by the approach have, however, been criticized. Its opponents generally rely on a risk of over-regulation and on the potential imposition of a disproportionate burden on actors wanting to undertake a specific activity, consequently limiting human activity. ${ }^{142}$

136 Annecoos Wiersema, "Uncertainty, Precaution, and Adaptive Management in Wildlife Trade" (2015) 36 Michigan Journal of International Law 375-424 at 388.

137 Solène Guggisberg, The Use of CITES for Commercially-Exploited Fish Species: A Solution to Overexploitation and Illegal, Unreported and Unregulated Fishing? (Cham: Springer, 2016) at 195-196.

138 Sands et al, supra note 2 at 230.

139 Ibid. Rio Declaration at principle 15 reads as follows: "In order to protect the environment, the precautionary approach shall be widely applied by States according to their capabilities. Where there are threats of serious or irreversible damage, lack of full scientific certainty [as to the impact of the measure on the environment] shall not be used as a reason for postponing cost-effective measures to prevent environmental degradation".

140 Meinhard Schröder, "Precautionary Approach/Principle" (2014) Max Planck Encyclopedia of Public International Law at para 4. The preventive or protection principle, which is now well-established under international law (Legality of the Threat or Use of Nuclear Weapons, Advisory Opinion, (1996) ICJ Rep 226 at para 29), finds its origins in the general obligation that States should not allow their territory to be used for activities to affect the rights of other States (Corfu Channel Case (United Kingdom v Albania), Merits, (1949) ICJ Rep 4 at 22). In the particular context of environmental protection, the prevention principle stems from the Trail Smelter Arbitration, supra note 65, and provides that a State should avoid activities conducted on its territory or under its jurisdiction affecting the environment of another State (Pulp Mills on the River Uruguay (Argentina v Uruguay), Merits, (2010) ICJ Rep 14 at para 101). For discussion on the application of the principle to the protection and preservation of the marine environment, see section 3.2.1 above.

141 de Souza Patu, supra note 36 at 23.

142 Sands et al, supra note 2 at 230; Schröder, supra note 140 at para 5. 
Nevertheless, despite a now strong recognition under international (environmental) law, the terminology related to the approach, as well as its legal status and scope, remain widely debated. Both "precautionary approach" and "precautionary principle" are found in international instruments and in the literature. There does not seem to be a unified view as to what precise formulation should be used, ${ }^{143}$ as well as no clear distinction between the legal effects stemming from these different wordings. Commentators who underline a distinction suggest that "approach" refers to a looser meaning of precaution where uncertainty should not be an obstacle to action, while "principle", of stricter application, implies that precaution must be taken in the face of scientific uncertainty. ${ }^{144}$ Regardless of this dictinction, Oude Elferink however underlines that the use of "precautionary approach" is to be preferred because it follows the trend in recent practice, ${ }^{145}$ including the wording of the Rio Declaration.

The law of the sea and international fisheries instruments in which the precautionary approach has been included can shed further light on the scope of application of the principles in the context of these regimes. Although the precautionary approach cannot be found in UNCLOS, simply because the principle appeared after the Convention was adopted in 1982, it is still relevant in the context of the law of the sea. ${ }^{146}$ For example, the precautionary approach forms an integral part of the UNFSA. Its article 6 in fact lists measures that States should be undertaking in their implementation of the approach, such as relying on the best scientific information available; applying the guideline set out in Annex II of the Agreement regarding precautionary reference points; paying particular attention to uncertainties regarding the size, productivity and condition of stocks; developing data collection and research programmes assessing the impact of fishing on non-target species; ${ }^{147}$ monitoring more closely the status of stocks under concern, ${ }^{148}$ and dedicating specific attention to new and exploratory fisheries. ${ }^{149}$ Precaution is further found in

143 Tanaka, "Principles", supra note 7 at 40, underlines the non-unified nature of the terminology and uses it interchangeably.

144 Guggisberg, supra note 137 at 194, who refers to the following authors:

For "approach": Serge Garcia, "The Precautionary Principle: its Implications in Capture Fisheries Management” (1994) 22 Ocean and Coastal Management 99-125 at 103-104; Simon Marr, The Precautionary Principle in the Law of the Sea: Modern Decision Making in International Law (Leiden: Martinus Nijhoff, 2003) at 1718; David VanderZwaag, “The Precautionary Principle and Marine Environmental Protection: Slippery Shores, Rough Seas, and Rising Normative Tides” (2002) 33:2 Ocean Development \& International Law $165-188$ at 166.

For "principle": Jonathan B. Wiener, "Precaution" in Daniel Bodansky, Jutta Brunnee \& Ellen Hey (eds), Oxford Handbook of International Environmental Law (Oxford: Oxford University Press 2008) 597-612 at 604-606.

145 Oude Elferink, "Governance Principles", supra note 35 at 225, referring to Oceans and the Law of the Sea; GA Res 64(LXXI), UNGAOR, 64th Sess, UN Doc A/RES/64/71 (2009) at paras 133 and 150, which refers to the precautionary approach.

146 Oude Elferink, "Governance Principles", supra note 35 at 225; Richard Barnes, "The Continuing Vitality of UNCLOS" in Jill Barrett \& Richard Barnes (eds), Law of the Sea UNCLOS as a Living Treaty (British Institute of International and Comparative Law, 2016) 459-489 at 472-473.

147 UNFSA at art. 6(3).

$148 \mathrm{Ibid}$ at art. 6(5).

$149 \mathrm{Ibid}$ at art. 6(6). 
the preamble to the $\mathrm{CBD} .{ }^{150}$ At the regional level, the application of the precautionary approach to the conservation and use of fish stocks is included in the mandate of some RFMOs. ${ }^{151}$ As regards soft law instruments, several references to precaution can be found in Chapter 17 of Agenda 21, as well as articles 6.5 and 7.5 of the Code of Conduct, mirroring the formulation used in the UNFSA.

Judicial decisions in law of the sea related cases have provided a limited interpretation of the approach. In the Bluefin Tuna Cases, ITLOS referred to notions of prudence, caution and scientific uncertainty, ${ }^{152}$ but did not refer directly to the precautionary approach. ${ }^{153}$ The Seabed Disputes Chamber of ITLOS elaborated more on the approach in its Advisory Opinion on the Responsibilities and obligations of sponsoring States with respect to activities in the Area (hereafter Advisory Opinion on the Responsibility of Sponsoring States), where it characterized the precautionary approach as being one of the direct obligations incumbent on sponsoring States. ${ }^{154}$ It also underlined the "trend towards making this approach part of customary international law" ${ }^{155}$ thereby confirming discussions as to its legal status. ${ }^{156}$ Similarly, in its Advisory Opinion on IUU Fishing, the Tribunal indicated that the sustainable management of shared stocks in EEZ must be based on precaution in the absence of sufficient scientific evidence. ${ }^{157}$

Although the meaning of the approach is clear, and although there is growing consensus regarding its status as a rule of customary law, specifications as to the modalities for its implementation are lacking. ${ }^{158}$ In fact, the specific measures that need to be adopted and implemented in order to apply the approach will be determined by the States according to their capabilities, resources and interests. States have also been more active in engaging in such determination in matters

$150 \mathrm{CBD}$ at preamble, which reads "where there is a threat of significant reduction or loss of biological diversity, lack of full scientific certainty should not be used as a reason for postponing measures to avoid or minimize such a threat".

151 See, e.g. WCPFC Convention at art. 6; IATTC Antigua Convention at art. IV. See also, generally, Paul de Bruyn, Hilario Murua \& Martin Aranda, “The Precautionary Approach to Fisheries Management: How This Is Taken Into Account by Tuna Regional Fisheries Management Organisations (RFMOs)” (2013) 38 Marine Policy 397-406.

152 Southern Bluefin Tuna Cases, supra note 108 at paras 77, 79 and 80.

153 Only Judge Treves made a direct reference to the approach, see Southern Bluefin Tuna Cases (New Zealand v Japan; Australia v Japan), Separate Opinion of Judge Treves, (1999) ITLOS cases $3 \& 4$ at paras 9-11, discussed in Guggisberg, supra note 137 at 195.

154 Responsibilities and obligations of States sponsoring persons and entities with respect to activities in the Area (Request for Advisory Opinion submitted to the Seabed Disputes Chamber), Advisory Opinion, (2011) ITLOS case 17 at paras 122, 125-136, 161 and 236 [Advisory Opinion on the Responsibility of Sponsoring States].

155 Ibid at para 135. See also Oude Elferink, "Governance Principles”, supra note 35 at 226.

156 See, generally, David Freestone, "Satya Nandan's Contribution to the Development of the Precautionary Approach in International Law" in Michael Lodge \& Myron Nordquist (eds), Peaceful Order in the World's Oceans. Essays in Honor of Satya N. Nandan (Leiden: Brill Nijhoff, 2014) 308-324. See also Oude Elferink, "Governance Principles", supra note 35 at 226.

157 Advisory Opinion on IUU Fishing, supra note 60 at para 208.

158 Barnes, supra note 21 at 282. 
related to ozone protection or whaling than with fishing activities. ${ }^{159}$ This is probably explained by the fact that stakes are higher when balancing environmental concerns and economic development ${ }^{160}$ in the context of fisheries, which is highly politically and economically charged.

The reaffirmation of the principle in the context of high seas fisheries draws particular attention to the necessity to clarify its application and implementation in ABNJ. The complexity and limited knowledge about high seas stocks reinforces the need for precaution in the face of insufficient scientific knowledge. It also reiterates the importance of considering precaution in relation to other principles. In fact, in the context of the conservation of marine living resources, the precautionary and ecosystem approaches work in an integrated manner. ${ }^{161}$ Fish stocks form part of ecosystems, equally circumscribed by complexity and uncertainty, ${ }^{162}$ especially in remote areas, therefore triggering the need to approach them with caution.

\subsubsection{Ecosystem approach}

The ecosystem approach strives for the "best understanding of the ecological interactions and processes necessary to sustain ecosystem structure and function". ${ }^{163}$ It suggests looking at oceans through the lens of ecosystems rather than managing them according to political and/or jurisdictional boundaries. It relies on ecological connectivity, "a complex natural phenomenon linking various components of marine ecosystems in time and space", where connections rely on the circulation of ocean currents and of migration of species. ${ }^{164}$ The ecosystem approach is therefore a transboundary approach, as ecosystems often extend across zones (e.g., across the territorial sea and the EEZ of a State) or across jurisdictions (e.g., across the EEZ of a State and the high seas, or across the EEZ of two States). It deals with the management of all activities and stakeholders towards the environment as a whole, ${ }^{165}$ and aims at developing and implementing management plans cross-

159 Patricia Birnie, Alan Boyle \& Catherine Redgwell, International Law and the Environment, 3rd ed (Oxford: Oxford University Press, 2009) at 163, cited in Oude Elferink, "Governance Principles", supra note 35 at $226-227$

160 Guggisberg, supra note 137 at 197.

161 Tanaka, "Principles", supra note 7 at 41.

162 Guggisberg, supra note 137 at 196-197.

163 Oceans and the Law of the Sea: Report of the Secretary-General, UNGAOR, 61st Sess, UN Doc A/61/63 (2006) at para 107, cited in Vladimir Golitsyn, "Major Challenges of Globalisation for Seas and Oceans: Legal Aspects" in Davor Vidas (ed) Law, Technology and Science for Oceans Globalisation. IUU Fishing, Oil Pollution, Bioprospecting, Outer Continental Shelf (Leiden: Brill Nijhoff, 2010) 59-73 at 64.

164 Daniel Dunn et al, "Adjacency: How legal precedent, ecological connectivity, and traditional knowledge inform our understanding of proximity" (2017) Nereus Scientific \& Technical Briefs on ABNJ series at 2 and 6.

165 For example, the CBD COP has defined the ecosystem approach as "a strategy for integrated management of land, water and living resources that promotes conservation and sustainable use in an equitable way", see Ecosystem Approach, CBD COP decision V/6, COP 5, UNEP/CBD/COP/DEC/V/6 (2000) at section A. It is also important to underline that, as mentioned by Ricard, supra note 43 at 154 , the ecosystem approach refers to the management of activities while taking ecosystems into consideration; it does not refer to the management of ecosystems. 
sectorally. ${ }^{166}$ In the context of fisheries, this focus on management is more in line with the current understanding of the approach as a management method, ${ }^{167}$ rather than simply a question of conservation values. ${ }^{168}$

Similar to the precautionary approach, the ecosystem approach is enshrined in a variety of legal instruments. Although not expressly mentioned in UNCLOS, considerations of ecosystems can be implied from measures embedded in some of its provisions. The importance of ecosystems is first found in the consideration of non-target and dependent species when determining the TAC, and conservation measures under article 119(1)(b) underline the necessity to consider that all species "together are key parts of marine biodiversity". ${ }^{169}$ Second, article 194(5) affirms the need to ensure the protection of fragile ecosystems, habitats and endangered species. ${ }^{170}$

The ecosystem approach is further implied in some provisions of the UNFSA, which refer to the long-term maintenance of marine ecosystems, ${ }^{171}$ the importance of assessing the impact of human activities on ecosystems, ${ }^{172}$ and the protection of marine biodiversity. ${ }^{173}$ The approach is also found in the constitutive instruments of several RFMOs. For example, the CAMLR Convention, which underlines, as part of the duty of conservation, the "maintenance of the ecological relationships between [...] populations of Antarctic marine living resources", ${ }^{174}$ is also considered as a pioneer document in including the approach. The impact of fisheries on wider ecosystems when making recommendations or undertaking actions is also taken into consideration under the NEAFC Convention, ${ }^{175}$ and the SIOFA reaffirms the need to adopt measures based "on the best scientific evidence available to

166 Cross-sectorally is understood here as meaning both across fields and across zones, within and beyond national jurisdiction, see, e.g., Richard Kenchington \& Robin Warner, "Uncertain Seas Ahead: Legal and Policy Approaches to Conserving Marine Biodiversity in the Face of Changing Climate" in Robin Warner \& Clive Schofield (eds), Climate Change and the Oceans: Gauging the Legal and Policy Currents in the Asia Pacific and Beyond (Cheltenham: Edward Elgar, 2012) 51-73 at 57; Ichiro Nomura, "Sustainable World Fisheries: Elements of Success" in Michael Lodge \& Myron Nordquist (eds), Peaceful Order in the World's Oceans. Essays in Honor of Satya N. Nandan (Leiden: Brill Nijhoff, 2014) 325-337 at 328; Golitsyn, supra note 163 at 68 .

167 The particular issue of the ecosystem approach to fisheries, as an objective and method for the management of marine living resources, is discussed in further detail in section 4.1 below.

168 Vito De Lucia, “The Ecosystem Approach for Areas Beyond National Jurisdiction: Reflections on the Chair's non-paper ahead of 'PREPCOM III"' (20 March 2017) JCLOS Blog, online: <http://site.uit.no/ nclos/2017/03/20/the-ecosystem-approach-for-areas-beyond-national-jurisdiction-reflections-on-thechairs-non-paper-ahead-of-prepcom-iii/>.

169 Kim Friedman, Serge Garcia \& Jake Rice, “Mainstreaming Biodiversity in Fisheries" (2018) 95 Marine Policy 209-220 at 210.

170 Oude Elferink, "Governance Principles”, supra note 35 at 228.

171 UNFSA at preamble.

172 Ibid at art. 5 d)-e).

$173 \mathrm{Ibid}$ at preamble, art. $5 \mathrm{~d}$ )-e) and art. $5 \mathrm{~g}$ ) respectively.

174 CAMLR Convention at art. II(3)b).

175 NEAFC Convention at art. 4 
ensure [...] an ecosystem approach to their management". ${ }^{176}$ Within non-legally binding instruments, the Code of Conduct recognizes the transboundary nature of ecosystems, the necessity to assess the relationship between fisheries and broader ecosystems, as well as the importance of ecosystems in fisheries-related research. ${ }^{177}$ The Reykjavik Declaration on Responsible Fisheries in the Marine Ecosystem (Reykjavik Declaration), the outcome of the Conference of the same name held in 2011 by the FAO in collaboration with Iceland, also recognizes the particular importance of the consideration of ecosystems in conducting fisheries activities. ${ }^{178}$

All these instruments strongly establish the ecosystem approach as part of the regulatory framework for fisheries management in ABNJ, and link it to a sciencebased approach to management, and also, especially in ABNJ, to the duty to cooperate. Yet, similar to the precautionary approach, uncertainty persists as to the legal status of the ecosystem approach. ${ }^{179}$

The ecosystem approach is also intrinsically linked to the notion of integration. ${ }^{180}$ Facing the growing importance of interrelatedness of ecosystems and activities, and the interdependence of stakeholders, an integrated management represents a better understanding of interactivity, i.e. how "the operation of each affects the performance of the others". ${ }^{181}$ It also triggers a cross-disciplinary and multi-level assessment. ${ }^{182}$ Although not explicitly mentioned in UNCLOS, the integrated approach is implied in the preamble to the Convention. ${ }^{183}$ Oude Elferink argues that the integrated approach can also be interpreted as being included in Part XII. Indeed, while the various sources of pollution are addressed separately under Section 5 of Part XII, which could be read as triggering a sectoral approach towards the protection and preservation of the marine environment, the general obligation of protection and preservation under article 192 implies that the whole part must be read together and its obligations fulfilled in an integrated manner. Integration can also be seen in

176 SIOFA at art. 4(a), discussed in Yoshifumi Tanaka, "The Changing Approaches to Conservation of Marine Living Resources in International Law" (2011) 71 Zeitschrift fuer Auslaendisches Oeffentliches Recht und Voelkerrecht 291-330 at 304 [Tanaka, "The Changing Approaches"].

177 See, e.g. Code of conduct, supra note 122 at arts. 6.4, 7.2.3 and 12.

178 The Reykjavik Declaration on Responsible Fisheries in the Marine Ecosystem in Food and Agriculture Organization, "Report of the Reykjavik Conference on Responsible Fisheries in the Marine Ecosystem" (2001) FAO Fisheries Report No. 658, online: <http://www.fao.org/fishery/docs/DOCUMENT/reykjavik/ y2198t00_dec.pdf> [Reykjavik Declaration]. This instrument does not apply exclusively to high seas fisheries, but it is "intended to underscore the necessity of incorporating ecosystem considerations into existing fisheries management", see Otto Spijkers \& Natalia Jevglevskaja, "Sustainable Development and High Seas Fisheries" (2013) 9:1 Utrecht Law Review 24-37 at 31.

179 Guggisberg, supra note 137 at 205, referring to Tanaka, “The Changing Approaches", supra note 176 at 305-306.

180 For a historical overview of the principle of integration in international documents and instruments, see de Souza Patu, supra note 36 at 37-40.

181 Oran Young, "Building an international regime complex for the Arctic: current status and next steps" (2012) 2:2 The Polar Journal 391-407 at 394.

182 de Souza Patu, supra note 36 at 40.

183 UNCLOS at preamble, which reads "conscious that the problems of ocean space are closely interrelated and need to be considered as a whole". 
article 204, which requires States to monitor the risks or effects of pollution; as this obligation does not specify what sources of pollution are covered, one may infer that the risks of pollution must be taken as a whole. ${ }^{184}$ In parallel to this integrated control of pollution, Barnes further underlines the seeming integration of AWNJ and $\mathrm{ABNJ}$ through measures such as article 195, which imposes a duty to prevent the transfer of damage or hazards from one area to another. ${ }^{185}$ A similar spatial integrated perspective is also implied in article 7 UNFSA, which works at ensuring the compatibility of management and conservation measures undertaken by a coastal State in its EEZ with the ones from an RFMO in ABNJ. ${ }^{186}$

The ecosystem approach forms an intrinsic part of the management framework of $\mathrm{ABNJ}$ and high seas fisheries, and it underlies the necessity for all institutions and bodies to coordinate their actions to ensure that its very nature, i.e. taking the wider marine environment as a whole, is respected. ${ }^{187}$ This is why integration must form part of the ecosystem approach; without it, the approach would not be able to fulfil its holistic function and be effectively implemented. Reiterating the principle of an ecosystem approach is therefore necessary to realign behaviours towards ecological connectivity and the cross-sectoral nature of (resource) management on the high seas.

\subsubsection{Sustainable and equitable use}

Although two independent principles, sustainable use and equitable use are present together in this study because they are closely linked and complement one another. First they both find their roots in the concept of sustainable development itself. Sustainable development entails a "development that meets the needs of the present without compromising the ability of future generations to meet their own needs". ${ }^{188}$ It includes two concepts: the concept of needs (ensure the fulfilment of essential needs of people), and the concept of imposed limitations (limit exploitation so that the environment can meet present and future needs). ${ }^{189}$ The fulfilment of needs for both present and future generations is an illustration of equity, which triggers a

184 Oude Elferink, “Governance Principles”, supra note 35 at 231-233.

185 Barnes, supra note 21 at 284. A similar provision for integration can be found under UNCLOS at art. 194(2), which states that activities under the control or jurisdiction of a State should not cause damage by pollution beyond their areas of jurisdiction, therefore targeting potential impacts on ABNJ.

186 Barnes, supra note 21 at 284.

187 De Lucia, supra note 168.

188 This now well-known definition of the concept was formulated for the first time in the 1987 Brundtland Report, see Report of the World Commission on Environment and Development: Our Common Future, UNGAOR, 42nd Sess, UN Doc A/42/427 (1987) at chapter 2, para 1. Beyerlin, for his part, suggests that "the composite term 'sustainable development' describes a political value that deserves respect in today's international relations. As indicated by the term 'development', it does not set a clear target to be finally achieved but instead points to a process of interaction that should be set in motion, without saying by whom", see Beyerlin, supra note 13 et 443.

189 Our Common Future, supra note 188 at chapter 2, para 1, discussed in Sands et al, supra note 2 at 218. 
sustainable use of the environment. This shows that sustainable use and equitable use act together for sustainable development to be achieved.

Further, based on the use of sustainable development in various international agreements, Sands et al have identified four components in its legal meaning: ${ }^{190}$ intergenerational equity (consider current use in light of future generations), ${ }^{191}$ sustainable use (use in a way that is rational and appropriate), equitable use or intragenerational equity (consider the needs of other actors), and integration (balance between the various spheres of sustainability: environmental, social, economic, also including development ${ }^{192}$ ). Within this understanding of the concept, sustainable use and equitable use are once again linked, as they refer to the second and third elements of sustainable development.

In fact, equitable use more specifically entails that "[e]quitable considerations can be taken into account in designing regimes on access to resources", ${ }^{193}$ or, as entrenched in the preamble to UNCLOS, that States should ensure an "equitable and efficient utilization of [the oceans'] resources". In other words, this means that measures by one actor should consider the needs of others. For example, in the field of fisheries, the use by developed States of "subsidies in the fisheries sector [...] decreases the ability of developing countries, as new entrants, to benefit from fisheries". ${ }^{194}$ Equitable use would therefore dictate that developed countries, when establishing and implementing fisheries-related measures, should take into consideration the needs of developing countries for the exploitation of fish. ${ }^{195}$ Equitable use entails that the differences in needs must be acknowledged and balanced, ${ }^{196}$ as also should the differences in means and resources of the different actors involved. This is why the principle of equitable use should also be read in conjunction with the principle of common but differentiated responsibilities. This entails the common and shared

190 Sands et al, supra note 2 at 219.

191 On intergenerational equity, see also Draft Global Pact for the Environment, supra note 132 at art. 4.

192 Greiber et al, supra note 32 at 5. Frank Biermann, Olwen Davies \& Nicolien van der Grijp, "Environmental policy integration and the architecture of global environmental governance" (2009) 9:4 International Environmental Agreement 351-369 at 353, also characterized sustainable development as an integrationist principle, i.e. that sustainable development plays a role in integration. Integration also refers to the idea of interrelatedness and interconnectedness discussed under the ecosystem approach above, see section 3.1.6. It is also linked to the connectivity between the different components of complex socio-ecological systems, see chapter 1 section 2.1 .

193 Oude Elferink, "Governance Principles", supra note 35 at 236. See also Knight, supra note 51 at 20-21.

194 Freestone, "Legal Underpinnings", supra note 36 at 47.

195 Although the principle of equitable use arises more naturally in ABNJ in the context of access and benefit sharing and is enshrined in the regime for the exploitation of the Area (Part XI UNCLOS) through the principle of the common heritage of humankind, equitable use is also found, to a more limited extent, under provisions for the conservation and management of living resources. This is enshrined in UNCLOS at art. 119(1)(a), where the special interests and needs of developing countries are factors to consider when establishing conservation measures for high seas living resources. These requirements of developing States are also recognized under UNFSA at arts. 24-25. This is discussed in Oude Elferink, "Governance Principles", supra note 35 at 235.

196 Barnes, supra note 21 at 285, referring to Birnie, Boyle \& Redgwell, supra note 159 at 402, underlines that the balancing exercise is always more challenging when conducted in ABNJ; in fact individual interests are also balanced against community interests, which are more difficult to define and ascertain. 
responsibility of all States for the protection of the environment, while considering the special needs and ability of some States to participate in the prevention and control of pollution. ${ }^{197}$

Despite sustainable and equitable use being clearly established as components of sustainable development, and despite the recognition of the importance of sustainable development, which ensures a balance between use and protection, the scope and exact nature of sustainable development remain difficult subjects to tackle. Indeed, the concepts and components described above are often used interchangeably, or are used in themselves to describe sustainable development. As underlined by Techera and Klein, "it is not entirely clear whether sustainability and sustainable development are concepts or principles themselves". ${ }^{198}$

Taking a look at the historical evolution of the concept of sustainable development helps towards a better understanding of the commitments which the principle of sustainable and equitable use wishes to trigger. This historical evolution in turn informs the application of the principle to the marine context and, more specifically, to the regulation and management of high seas living resources. ${ }^{199}$ Prior to the first express formulation of the concept in the Brundtland Report in 1987, ${ }^{200}$ the idea of the protection of renewable resources and the maintenance of sustainable productivity were found in the 1972 Stockholm Declaration ${ }^{201}$ and the 1982 World Charter for Nature. ${ }^{202}$ The applicability of the concept, as defined by the Brundtland Report, became clearer with the 1992 Rio Declaration, which linked sustainability to development. ${ }^{203}$ Sustainable development is also at the core of Agenda 21, where the concept is presented in light of its social and economic dimensions, the conservation and management of resources, and the participation of all relevant actors. ${ }^{204}$ The reconciliation of economic and environmental objectives for purposes of sustainability was once again at the heart of the negotiations of the 2002 World Summit on Sustainable Development and the 2012 Rio+20 Conference. The link between all spheres of sustainability can also be seen from the MDGs, which included a specific goal on environmental sustainability as part of the overarching goal of ending poverty, ${ }^{205}$ and the interrelatedness between these spheres was reiterated in the 2015 SDGs. ${ }^{206}$

197 Rio Declaration at principle 7. See also Sands et al, supra note 2 at 225-227.

198 Techera \& Klein, supra note 38 at 58.

199 For the historical overview of the use of the concept of sustainability in a general sense, as well as its applicability to the oceans and, more specifically, to high seas fisheries, see, generally, Spijkers \& Jevglevskaja, supra note 178. See also, Tanaka, "Principles", supra note 7 at 46-49.

200 Our Common Future, supra note 188.

201 Stockholm Declaration at principles 2, 3 and 5.

202 World Charter for Nature, GA Res 37(VII), UNGAOR, 37th Sess, UN Doc A/RES/37/7 (1982) at art. I(4).

203 Rio Declaration at principles 4, 5, 8, 9 and 12.

204 Agenda 21, supra note 123.

205 The Millennium Development Goals emanate from United Nations Millennium Declaration, GA Res 52(II), UNGAOR, 52nd Sess, UN Doc A/RES/52/2 (2000), see goal 7 "ensure environmental sustainability".

206 The Sustainable Development Goals emanate from Transforming our world: the 2030 Agenda for Sustainable Development, GA Res 70/1, UNGAOR, 70th Sess, UN Doc A/RES/70/1 (2015). 
The meaning of the concept has also evolved through judicial decisions. In the Gabčikovo-Nagymaros Case decided in 1997, the ICJ recognized the balance between economic development and environmental protection within the concept of sustainable development. ${ }^{207}$ In his separate opinion, then Vice-President Weeramantry went even further and defined sustainable development as being of customary nature. ${ }^{208}$ Although not endorsed by the ICJ, this interpretation remains indicative as to the evolution of the concept. In 2010, in the Pulp Mills Case, the ICJ observed the "interconnectedness between equitable and reasonable utilization of a shared resource and the balance between economic development and environmental protection [as] essence of sustainable development", 209 recognizing that the two principles - sustainable and equitable use - form an intrinsic part of the broader concept of sustainability.

In the marine context, although UNCLOS does not directly refer to sustainability, its article 193 is often referred to as sustainability avant la lettre, as it refers to the right of States to exploit their natural resources while ensuring their duty to protect and preserve the marine environment. Sustainability is also enshrined in the CBD, which has put forward the importance of sustainability when assessing the use of biological resources. ${ }^{210}$ More specifically regarding marine living resources, the need for management based on the sustainable use of stocks appears on many occasions in, inter alia, the UNFSA, ${ }^{211}$ the Code of conduct, ${ }^{212}$ the Reykjavik Declaration, ${ }^{213}$ the FAO IPOA-IUU, ${ }^{214}$ the FAO Guidelines on Deep-sea Fisheries, ${ }^{215}$ and the PSMA. ${ }^{216}$ Sustainable use of fisheries is also a commitment made as part of the Plan of Implementation of the World Summit on Sustainable Development, ${ }^{217}$ as it is part of SDG 14, focusing on the conservation and sustainable use of the oceans, seas and marine resources. ${ }^{218}$

Sustainable use is also found in the constitutive instruments of RFMOs. Older organizations tend to have a narrow focus on sustainable catches, exploitation or conservation of catches, as can be seen in the ICRW, ${ }^{219}$ the IATTC Antigua

207 Gabčikovo-Nagymaros Case, supra note 28 at para 140.

208 Separate Opinion of Vice-President Weeramantry, supra note 28 at 104.

209 Pulp Mills Case, supra note 140 at para 177.

$210 \mathrm{CBD}$ at preamble and art. 10.

211 UNFSA at preamble, arts. 2, 5, 6 and 10.

212 Code of conduct, supra note 122 at arts. 7.2.1 and 7.2.2.

213 Reykjavik Declaration, supra note 178 at preamble, paras 2, 5(a),(f), and 8.

214 International Plan of Action to Prevent, Deter and Eliminate Illegal, Unreported and Unregulated Fishing, FAO COFI, 24th Sess (2001) at paras 1, 9.4 and 83, online: <http://www.fao.org/3/Y1224E/y1224e.pdf $>$.

215 International Guidelines for the Management of Deep-sea Fisheries in the High Seas (2009) at paras 1, 6, 11, 13, 22, 28, 63, 66, 70, 76, 77 and 78 [Guidelines on Deep-sea Fisheries].

216 PSMA at preamble and art. 2.

217 Plan of Implementation of the World Summit on Sustainable Development (2002) at para 30, online: $<$ https://www.un.org/esa/sustdev/documents/WSSD_POI_PD/English/WSSD_PlanImpl.pdf >. See also Freestone, "Legal Underpinnings", supra note 36 at 47.

218 SDGs, supra note 206 at goal 14.

219 ICRW at preamble. 
Convention, ${ }^{220}$ the ICCAT Convention, ${ }^{221}$ and the CAMLR Convention. ${ }^{222}$ Other RFMOs, however, envisage a more global application of the concept of sustainability. For example, article II NEAFC Convention states that the conservation and utilization of resources should "provid[e] sustainable economic, environmental and social benefits", encompassing all three spheres of sustainability. The WCPFC Convention focuses on the sustainability of stocks, ${ }^{223}$ while the SPRFMO Convention refers to sustainable use and development, and sustainability of fisheries resources. ${ }^{224}$ Both of these conventions refer to sustainability in conjunction with other concepts such as long-term conservation, ecosystems, effective management, and precaution, demonstrating a broader understanding of the concept.

In its 2015 Advisory Opinion on IUU Fishing, ITLOS provided further clarification on the expression "sustainable management" in the context of the exploitation of living resources. ${ }^{225}$ Observing that the expression is not defined as such under the Convention, ITLOS still relied on the general framework of UNCLOS on the conservation and management of living resources, and stated "that the ultimate goal of sustainable management of fish stocks is to conserve and develop them as a viable and sustainable resource". ${ }^{226}$ It concluded that, in this context, "sustainable management" could be equated with "conservation and development". Although the legal question under which the analysis of sustainable management is embedded is linked in this Advisory Opinion to the exploitation of fish stocks in the EEZ, the present author is of the view that the interpretation of "sustainable management" conducted by ITLOS can be of general application and is not necessarily limited to conservation purposes in the EEZ.

The principle of sustainable and equitable use acts as a complementary mechanism to the principle of the protection and preservation of the marine environment, ensuring that the exploitation of marine living resources is conducted in a manner that ensures the preservation of the stocks themselves. It also brings together several components of the complex socio-ecological system that represent high seas fisheries, guiding the balance between social, economic and ecological considerations of use. Despite the uncertain legal status of the principle, it is used to interpret States' commitments in other instruments, and it has the "effect of legitimizing and encouraging legal developments based on the new perspectives of the sustainable usage". ${ }^{27}$ As such, this principle underlies the development of legally binding obligations and aims at colouring their implementation, as a reminder

220 IATTC Antigua Convention at arts. II, IV(1), VII(1)(c)\&(h) and XXIII(1).

221 ICCAT Convention at preamble, arts. IV, VII and VIII.

222 CAMLR Convention at art. II.

223 WCPFC Convention at preamble, arts. 2, 5(a), (g), 6(5)-(6) and 10(1)(a).

224 SPRFMO Convention at preamble, arts. 2, 3(1)(a)(ii)-(b), 20(1)(a)-(b) and (5)(a).

225 Advisory Opinion on IUU Fishing, supra note 60 at paras 187-191.

226 Ibid at para 190.

227 Spijkers \& Jevglevskaja, supra note 178 at 26. 
that the exploitation of resources must always follow sustainable and equitable considerations.

\subsubsection{Public availability of information, and transparent and open decision-making processes}

Although these principles are described separately in most academic literature, the present author believes that they must be dealt with together because the two are rooted in the same rationale: accessibility to the information by all stakeholders, and by the public in general. Moreover, most instruments addressing one of these principles analyses it - directly or not - in conjunction with the other.

Rooted in principle 10 of the Rio Declaration, ${ }^{228}$ the availability of information, transparency and open decision-making became three pillars of the 1998 Aarhus Convention on Access to Information, Public Participation in Decision-Making and Access to Justice in Environmental Matters (Aarhus Convention). ${ }^{229}$ Central to the Aarhus Convention is the creation of an obligation for States to make environmental information available to the public. "Environmental information" is meant as encompassing information regarding the state of the environment, factors ranging from substances to policies, legislation and programmes likely to affect the environment, as well as the state of human health, cultural sites and built structures. ${ }^{230}$ Since these obligations primarily refer to measures to be undertaken at the national level, the Aarhus Convention was complemented in 2005 by the Almaty Guidelines on Promoting the Application of the Principles of the Aarhus Convention in International Forums, ${ }^{231}$ which promote the application of the principles contained in the Convention in international decision-making processes. These guidelines are in fact meant to assist in the implementation of article 3(7) Aarhus Convention, which states that States parties "shall promote the application of the principles of this Convention in international environmental decision-making processes and

228 "Environmental issues are best handled with the participation of all concerned citizens, at the relevant level. [...] States shall facilitate and encourage public awareness and participation by making information widely available. Effective access to judicial and administrative proceedings, including redress and remedy, shall be provided", see Rio Declaration at principle 10.

229 Convention on Access to Information, Public Participation in Decision-Making and Access to Justice in Environmental Matters, 25 June 1998, 2161 UNTS 447 at art 1 [Aarhus Convention]. Although the Aarhus Convention is a regional instrument, "concluded under the auspices of the UN Economic Commission for Europe (ECE), [...] it is open for accession by any other UN Member state", see Freestone, "Legal Underpinnings", supra note 36 at 47 . It is indicative of the standard to be achieved, and its "global significance [...] has been recognized by the then Secretary-General of the United Nations, Kofi Annan, in 2000", see Oude Elferink, "Governance Principles", supra note 35 at 240, referring to "Foreword by the Secretary-General of the United Nations" in Stephen Stec and Susan Casey-Lefkowitz in collaboration with Jerzy Jendroska (eds), The Aarhus Convention: An Implementation Guide (United Nations, New York and Geneva, 2000) at v, online: <https://www.unece.org/fileadmin/DAM/env/pp/acig.pdf>.

230 Aarhus Convention at art. 2(3). See also, generally, Sands et al, supra note 2 at 710-712.

231 Promoting the Application of the Principles of the Aarhus Convention in International Forums (the Almaty Guidelines), Meeting of the Parties Aarhus Convention Dec II/4, 2nd Sess, ECE/MP.PP/2005/2/Add.5 (2005). 
within the framework of international organizations in matters relating to the environment".

This application of the principles to international decision-making and within the framework of international organizations is interesting in the context of ABNJ. In fact, it is through international organizations that many activities are managed in $\mathrm{ABNJ}$. This is especially the case for high seas fisheries, most of which are under the management of RFMOs. ${ }^{232}$ Article 3(7) Aarhus Convention could thus complement related provisions found under fisheries-related instruments that target the role and mandate of RFMOs. For example, the UNFSA contains a duty for States to "provide for transparency in the decision-making process and other activities of subregional and regional fisheries management organizations and arrangements" ${ }^{233}$ It also refers to the possibility for other organizations having an interest in straddling fish stocks and highly migratory fish stocks to take part in meetings of RFMOs and access their reports. ${ }^{234}$ This is complemented by the Code of Conduct, which includes the need for transparency in its general principles, ${ }^{235}$ and in its "mechanisms for fisheries management and in the related decision-making process" ${ }^{236}$ Some RFMOs also contain similar transparency duties, ${ }^{237}$ or other obligations in relations to the dissemination of information. ${ }^{238}$

Nevertheless, despite efforts to strengthen openness, impartiality and inclusiveness, transparency and availability of information within the functioning of RFMOs remain the subjects of criticism in fisheries management. ${ }^{239}$ Uncertainty remains with regard to RFMOs' practices which are intended to ensure transparency in, for example, decision-making regarding conservation and management measures, conducting monitoring, control and surveillance activities, as well as sharing the results of those measures, such as effective sanctioning. ${ }^{240}$ Access to information,

232 Fishing vessels are the main "actors" performing fishing activities on the high seas, and this is why the reference to transparency in the preamble to the Compliance Agreement as a means to achieve the objective of the agreement ("the objective of this Agreement can be achieved through [...] strengthened international cooperation and increased transparency through the exchange of information on high seas fishing") is of great importance for our assessment of the use of the principle. Relevant management frameworks, however, rest with RFMOs.

233 UNFSA at art. 12(1).

234 Ibid at art. 12(2).

235 Code of conduct, supra note 122 at art. 6.13.

236 Ibid at art. 7.1.9.

237 See, e.g. SEAFO Convention at art 8; WCPFC Convention at art. 21; NPFC Convention at art. 3(1); SPRFMO Convention at arts. 3(1)(a)(i) and 18.

238 See e.g., CAMLR Convention at art. IX(1)(d); NEAFC Convention at art. 11; NAFO Convention at arts. VI(6)(b) and VII(8)(d); SPRFMO Convention, supra note 102 at art. 18.

239 For a portrait of different aspects of transparency and what it entails within RFMOs' functioning, see Johanne Fischer, "How transparent are RFMOs? Achievements and challenges" (2020) Marine Policy article 104106. See also, generally, Jeff Ardron et al, "Tracking twenty-four years of discussions about transparency in international marine governance: where do we stand?" (2014) 33 Stanford Environmental Law Journal 167-190; and Nichola A. Clark, Jeff A. Ardon \& Linwood H. Pendleton, "Evaluating the basic elements of transparency of regional fisheries management organizations" (2015) 57 Marine Policy 158166.

240 Ibid. 
transparency and open decision-making ensure a balance in information sharing, and this is why they need to be solidified through mechanisms such as more regular reviews of RFMOs' performances, or platforms for information sharing between States and/or organizations, such as clearing-house mechanisms. ${ }^{241}$ This could further contribute to fulfilling obligations of information sharing in the fisheries context found under other instruments, such as UNCLOS ${ }^{242}$ and the 1993 Compliance Agreement. ${ }^{243}$

Transparency and availability of information are also embodied through the actors present during RFMO meetings. A recent study on the participation of non-State actors in the meetings of tuna RFMOs has shown that, although there seems to have been a continuous participation of non-State actors, most of those actors represent the interests of industries from developed countries. ${ }^{24}$ Nevertheless, ensuring the openness of decision-making processes brings the possibility for more input from different stakeholders, ${ }^{245}$ which can in turn contribute to the adaptability of measures and procedures to changes in interests and needs. ${ }^{246}$

Since the principles of access to information, transparency and open decision making are more strongly established in environmental law, ${ }^{247}$ assessing them in the context of the sustainable management of the oceans solidifies the bridge between the law of the sea and environmental law. Transposing these principles into the management of $\mathrm{ABNJ}$ therefore reiterates the importance of the environmental legal regime in informing the implementation of the high seas fisheries regime. The principles also link fisheries management to broader issues of trust and confidence among actors. ${ }^{248}$ Not only do they reiterate the valuable results that can stem from international cooperation, but they increase States' responsibility towards third parties concerning the measures undertaken for the preservation and conservation of marine biodiversity.

241 The weaknesses of RFMOs are discussed in further detail in chapter 5 section 2.3.2 below.

242 See e.g. UNCLOS at art. 119(2), where the Convention provides that information on catch and fishing efforts should be exchanged and shared on a regular basis, discussed in Barnes, supra note 21 at 285.

243 "strengthened international cooperation and increased transparency through the exchange of information on high seas fishing", see Compliance Agreement at preamble.

244 See, generally, Matilda Petersson et al, "Patterns and trends in non-state actor participation in regional fisheries management organizations” (2019) 104 Marine Policy 146-156.

245 Open decision-making process includes the participation of all States, as well as of all non-state stakeholders, see Owen, supra note 115 at 32-36.

246 The benefits stemming from a multiplicity of actors for the adaptability of legal frameworks are discussed in chapter 6 below.

247 "Expert Workshop on Transparency in Fisheries Governance" (Organized by the University of Sydney and Utrecht University, Utrecht, 20-21 May 2019).

248 James Harrison, "International Transparency Obligations in Fisheries Conservation and Management: Inter-State and Intra-State Dimensions" (2020) Marine Policy article 104105. 


\subsubsection{Responsibility of States as stewards of the global marine environment}

The principle of stewardship dictates that States act as guardians of the marine environment. This role is two-pronged. States must first guarantee that activities under their jurisdiction or control will not have an adverse impact on the marine environment, which amounts to a duty of due diligence. This includes the duty of flag States to monitor the activities of vessels flying their flag, ${ }^{249}$ as well as the duty of States to control the activities undertaken by all other nationals, including private investors, to ensure the protection of the environment. ${ }^{250}$ Second, in ABNJ, where open access prevails, this responsibility of stewardship is also a shared one, ${ }^{251}$ among States and the relevant international organizations, to work together and collaborate to create, implement and enforce relevant regulations. ${ }^{252}$

Stewardship, however, goes beyond the undertaking of diligent efforts to prevent or minimize damage to the marine environment: the concrete achievement of stewardship can onlybe reached if one condition is fulfilled: a feeling of accountability. States will be willing to act only if they feel accountable and responsible for acting as stewards. ${ }^{253}$ This can be stimulated by the necessary balancing exercise to be undertaken between the common interest in resource exploitation and the common concern for the well-being of the environment. ${ }^{254}$ This triggers the common responsibility of protecting and preserving the marine environment ${ }^{255}$ and must result in a responsible use of resources. The Sargasso Sea Commission ${ }^{256}$ illustrates the success that comes from accountability and awareness, by raising the various stakeholders' interest in protecting the high seas areas of the region. Although the management of activities in the ABNJ of the Sargasso Sea will remain under the control of existing organizations, and although the Hamilton Declaration is not binding, it shows the will of actors to work together and the role of the Commission as steward for the protection of the marine environment of the region. ${ }^{257}$

249 See, e.g., Compliance agreement at art. 3; Code of conduct, supra note 122 at art. 8.2.

250 Freestone, "Legal Underpinnings", supra note 36 at 48.

251 Curries \& Davis, supra note 73 at 5.

252 Atsuko Kanehara, "What Does a New International Legally Binding Instrument on Marine Biological Diversity of Areas Beyond National Jurisdiction 'under the UNCLOS’ Mean?” (2016) 59:4 Sophia Law Journal 53-73 at 64 .

253 See, e.g., Knight, supra note 51 at 22-23, who refers to "political acceptability", which means that "any international fisheries regime must, in order to be effectuated, be acceptable to a substantial majority of nations". See also, on the necessity of the role of other non-State actors, Draft Global Pact for the Environment, supra note 132 at arts. 2 and 14.

254 This is discussed in chapter 2 section 2.3 above.

255 Rosemary Rayfuse \& Robin Warner, "Securing a Sustainable Future for the Oceans Beyond National Jurisdiction: The Legal Basis for an Integrated Cross-Sectoral Regime for High Seas Governance for the 21st Century" (2008) 23:3 International Journal of Marine and Coastal Law 399-421 at 410. See also Oude Elferink, "Governance Principles", supra note 35 at 243-244, referring to Birnie, Boyle \& Redgewell, supra note 159 at 130 . A discussion on the common concern for the protection of the marine environment is conducted in chapter 2 section 2.3 above.

256 See chapter 2 section 3.3.3.

257 David Freestone, “Governance of Areas Beyond National Jurisdiction: An Unfinished Agenda?” in Jill Barrett \& Richard Barnes (eds), Law of the Sea UNCLOS as a Living Treaty (British Institute of International 
Nonetheless, it remains difficult to define what can be done to implement stewardship duties, and how to hold a State accountable for stewardship duties. ${ }^{258}$ Some suggestions have been made to solidify the applicability and operationalization of the principle when discussed in the context of ABNJ. In terms of institutions, Okonkwo for example suggests creating a World Oceans Organization, which would act as a global steward for the marine environment while regulating the access to resources, or transforming the mandate of RFMOs into regional oceans management organizations that would manage all activities having an impact on the conservation of living resources. ${ }^{259}$ Rayfuse and Warner for their part suggest putting the ocean under public trusteeship, managed by the international community. ${ }^{260}$

The link between stewardship and universal participation further underlines the importance of including all ocean actors - not only States - in the stewardship of the oceans. The act of bringing together all stakeholders, including States that are not parties to UNCLOS and non-State entities, illustrates the interconnectedness of activities and challenges in ABNJ. Furthermore, universal participation also entails the consideration of the particular status of local and indigenous communities and their special relationship with the oceans. This includes the strong connection of these communities to fishing activities, and States fishing on the high seas should "take into account the interests of artisanal and subsistence fishers". ${ }^{261}$

Contrary to the principles previously assessed, stewardship does not amount to a category or cluster of obligations. It encompasses them all, and it is through stewardship that other principles can be achieved. Stewardship reinforces the obligation to cooperate and the need for States to not frustrate the measures that others take to implement their stewardship duties. In that sense, stewardship acts as an overarching guideline for a general behaviour that States should adopt. Although the principle aims for universal participation of all actors, States remain the main vehicles through which the effective application of the principles for the sustainable management of $\mathrm{ABNJ}$ can be achieved. ${ }^{262}$

and Comparative Law, 2016) 231-265 at 243-247 and 263. See also Sargasso Sea Commission, online: $<$ http://www.sargassoseacommission.org/index.php $>$.

258 Barnes, supra note 21 at 287-288.

259 Theodore Okonkwo, "Managing the Ocean Commons Beyond National Jurisdiction" (2016) 2 China Oceans Law Review 56-82 at 66.

260 See, generally, Rayfuse \& Warner, supra note 255. The question of public trusteeship is discussed in chapter 7 section 4.1 below.

261 UNFSA at art. 5(i).

262 Young, supra note 4 at 171. 


\subsection{Reflections on the effectiveness of principles governing the high seas}

After analysing the content and scope of the principles governing the high seas, one could ask how to measure their effectiveness. In a way of comparison, the effectiveness of rules is normally assessed through three questions: ${ }^{263}$

1. Have the rules been operationalized through some process of promulgating detailed regulations?

2. What is the level of compliance with the rules on the part of members of the relevant groups of subjects?

3. Is there some procedure available to generate authoritative interpretations of individual rules in cases where the relevant parties disagree about their operational meaning?

To some extent, these questions - especially the first and third - are also relevant to the understanding of how principles governing the high seas have been included and interpreted in the legal framework. Yet, transposing the second question to principles (i.e. the question of whether principles have been complied with) does not completely match their functions. Principles are used as a vocabulary to frame questions, to "provide a coherent ensemble of terms and concepts that [actors] can use" ${ }^{264}$ and provide standards for guiding and evaluating behaviours. ${ }^{265}$ As Young puts it, using the example of the polluter pays principle, another core principle of international environmental law: ${ }^{266}$

No one expects the polluter pays principle to lead [...] to an established practice in which states routinely comply with clear-cut and legally binding liability rules [...]. Yet the emergence of the polluter pays principle has provided a basis for talking about the environmental responsibilities of states, and [...] the obligation to make good faith efforts. ${ }^{267}$

The effectiveness of principles cannot therefore be measured in terms of whether they directly lead to compliance.

This is why it would therefore be more appropriate to assess the effectiveness of principles through five "fits": physical fit, legal fit, intellectual fit, moral fit and

\footnotetext{
263 Ibid at 166.

264 Ibid at $166-167$.

265 Ibid at 168-169.

266 See Rio Declaration at principle 16: "National authorities should endeavour to promote the internalization of environmental costs and the use of economic instruments, taking into account the approach that the polluter should, in principle, bear the cost of pollution, with due regard to the public interest and without distorting international trade and investment". The polluter pays principle was not discussed in detail in section 3.1 above because it does not figure on the IUCN list of principles governing the high seas. However, as it constitutes an important principle of environmental law (see, e.g. Sands et al, supra note 2 at 229-240) it remains relevant to use it as an example as part of the present reflection on the effectiveness of principles.
}

267 Young, supra note 4 at 167. 
political fit. ${ }^{268}$ It is suggested that the principles governing the high seas do fulfil these fits. First, the transposability and applicability of the principles to the interconnected nature of the marine environment and its resources satisfies the physical fit, therefore fulfilling the necessity for principles to "be properly aligned with the physical nature of the subject matter to which they apply". ${ }^{269}$ Second, the legal fit prescribes that principles "ought to be sensitive to limits inherent in current legal processes" ${ }^{\text {"270 }}$ by, for example, respecting limits of legal authority and being consistent with other rules in the system. The fact that most of the principles governing the high seas relate, in one way or another, to legal obligations or recognized approaches found in the law of the sea and/or international environmental law supports such a fit. This is the case despite the fact that the zonal legal structures are themselves not always aligned with the interconnected physical nature of oceans. This shows the ability of principles to potentially bridge the gap in the incongruities between the object regulated and many aspects of the framework regulating it. Third, the intellectual fit submits that principles, especially in a matter that is as interdisciplinary as high seas fisheries, must be defended by many disciplines. Most principles described above are also rooted, for example, in science (e.g. science-based, precautionary and ecosystem approaches), management (e.g., sustainable use, public availability of information, open decision-making) and/or development studies (e.g. equitable use). This intellectual fit is of primary importance when facing a complex system such as high seas fisheries. Fourth, the moral fit, which provides that principles will find legitimacy if they relate to fundamental values, is also fulfilled since most principles are rooted in the fundamental values of international law, such as the respect for the rule of law, cooperation and the role of States. Finally, the analysis of principles conducted has shown a political fit: these principles generally receive broad political support since they have been included in a wide variety of legally and non-legally binding instruments, and legal mechanisms have been developed to ensure their practical application.

The effectiveness of principles finally resides in the "valuable role [they] play in adapting the existing rules of international law [...] to new circumstances". 271 The flexibility and adaptability that principles offer can be beneficial in the context of complexity, by using a reasoning that approaches States' behaviour differently. As part of our exploration of high seas fisheries from the perspectives of both the law of the sea and international environment law, principles act as unifying elements in the face of complexity. They contribute to reconciling tensions between frameworks focused on conservation versus utilisation, and then form an interconnected basis upon which to build mechanisms that, in turn, will allow States to guide their behaviors in accordance to commitments undertaken.

271 Tanaka, "Principles", supra note 7 at 56. 


\section{FISHERIES CONSERVATION AND MANAGEMENT: AN APPLICATION OF THE PRINCIPLES GOVERNING THE HIGH SEAS}

The previous section has observed the role that principles play in systematizing obligations, and has also offered reflections on their potential for steering actors' behaviours. The present section builds on this analysis, and elaborates on the way these principles have informed fisheries conservation and management which, in turn, contribute to States fulfilling their obligations in that respect. The present section in fact observes how principles are operationalized through management and conservation measures for international and high seas fisheries. It first looks at the way principles have underlain the evolution of the objectives guiding fisheries management (4.1). Then, it assesses the particular relevance of principles for existing and emerging area-based and assessment tools in high seas fisheries (4.2). The present section therefore analyses how, through their nature and/or functioning, these existing and emerging area-based and assessment tools embody some of the principles governing the oceans and apply them in practice.

\subsection{Current objectives for fisheries management}

The underlying objectives of fisheries management have evolved over time. ${ }^{272}$ In 1975 , Knight wrote that the main objectives of fisheries management were maximization of food production, conservation and allocation, which are normally reflected through securing MSY. ${ }^{273}$ The rationale behind fisheries management remains the same nowadays $s^{274}$ - namely to achieve sustainable fisheries $-{ }^{275}$ and MSY is still seen as the "dominant" approach to fisheries management. ${ }^{276}$ Yet, other objectives are advanced through approaches in which environmental considerations are

272 Olav Schram Stokke, "International fisheries politics: from sustainability to precaution" in Steina Andresen, Elin Lerum Boasson \& Geir Hønneland (eds), International Environmental Agreements: An introduction (Abingdon, Oxon: Routledge, 2011) 97-116 at 103.

273 Knight, supra note 51 at 15-17.

274 Maribus, "The future of Fish - The Fisheries of the Future" (2013) World Ocean Review at 108: "The primary task of modern fisheries management is therefore to limit catch volumes to a biologically and economically sustainable level and ensure equitable access to fish as a living resource".

275 Kristina Gjerde et al, "Ocean in Peril: Reforming the Management of Global Ocean Living Resources in Areas Beyond National Jurisdiction" (2013) 74:2 Marine Pollution Bulletin 540-551 at 541 define sustainable fisheries as follows: "fisheries whose fishing practices can, in theory, be maintained indefinitely without reducing the targeted species' ability to maintain its population at levels, which can be sustained over the long-term, and without causing unsustainable impacts on other species within the ecosystem".

276 D.G. Webster, "International Fisheries: Assessing the Potential for Ecosystem Management" (2013) 3:2 Journal of Environmental Studies and Sciences 169-183 at 169 explains that RFMOs tend to rely mostly on MSY, and even set quotas that are higher than MSY, instead of following the ecosystem or precautionary approaches. This is also discussed in chapter 5 section 2.1 .2 below. 
more central. ${ }^{277}$ This section therefore addresses MSY, as well as the precautionary approach to fisheries and the ecosystem approach to fisheries (EAF). ${ }^{278}$

MSY is defined as "the highest theoretical equilibrium yield that can be continuously taken (on average) from a stock under existing (average) environmental conditions without affecting significantly the reproduction process", ${ }^{279}$ which means that stocks can be fished up to the point where the fishing activities are not sustainable anymore. This definition obviously builds on the principle of sustainable use, which relies on a rational and appropriate use of the resources, one that will fulfil the needs of present generations while not compromising the needs of future generations. ${ }^{280}$ MSY lies at the heart of the current regime for fisheries management, as it is the only objective developed in UNCLOS for the establishment of conservation measures for the living resources on the high seas. ${ }^{281}$ In UNCLOS, MSY acts as a target that decision-makers should aim for when establishing fisheries measures, although environmental and economic factors (e.g. a lack of food supplies that would trigger higher catch quotas) could justify derogating from it.

Better knowledge of the intertwinement of concerns that characterize fisheries has brought forward the consideration of caution, societal objectives and interactions of species. In fact, although MSY persists as the preferred approach to objectives of fisheries management by RFMOs, ${ }^{282}$ it remains a single species approach. ${ }^{283}$ Objectives rooted in the precautionary and ecosystem approaches to fisheries management, which are cross-sectoral and not limited to one species, are, increasingly, the cornerstones of recent instruments and fisheries management initiatives. For example, the inclusion of the precautionary approach as a central

277 de Bruyn, Murua \& Aranda, supra note 151 at 397; Gjerde et al, supra note 275 at 545; James Harrison, Saving the Oceans Through Law. The International Legal Framework for the Protection of the Marine Environment (Oxford: Oxford University Press, 2017) at 169.

278 In terms of definitions and terminology, some studies also refer to "ecosystem-based fisheries management" (EBFM), see, e.g. Erik Molenaar, "Ecosystem-Based Fisheries Management, Commercial Fisheries, Marine Mammals and the 2001 Reykjavik Declaration in the Context of International Law" (2001) 17:4 International Journal of Marine and Coastal Law 561-595 at 572-575 [Molenaar, "EcosystemBased Fisheries Management"]. Since a generally accepted definition and/or distinction between EAF and EBFM is not available, the present study uses the two terms interchangeably.

279 FAO Term Portal, "Maximum Sustainable Yield", online: <http://www.fao.org/faoterm/en/>.

280 See section 3.1 .7 above.

281 UNCLOS at art. 119(1)(a): "take measures which are designed [...] to maintain or restore populations of harvested species at levels which can produce the maximum sustainable yield, as qualified by relevant environmental and economic factors [...] and taking into account fishing patterns, the interdependence of stocks and any generally recommended international minimum standards, whether subregional, regional or global" (emphasis added). A very similar wording is used in art. 61(3) for the conservation of living resources in EEZ.

282 See, e.g., Gjerde et al, supra note 275 at 541; Webster, supra note 276 at 169. Although most RFMOs do apply general precautionary measures (e.g. management based on scientific advice, by-catch monitoring and reduction, input and output control of fishing operations), not all of them refer directly to the approach in their constitutive instrument, either because they were created before the adoption of the UNFSA and the Code of Conduct, or because their member States are not parties to these instruments, see de Bruyn, Murua \& Aranda, supra note 151 at 397 and 402. This is also discussed under section 3.1.5 above.

283 Webster, supra note 276 at 169. 
principle within the UNFSA ${ }^{284}$ and the Code of conduct ${ }^{285}$ changes the role of the different objectives: while MSY is a threshold that cannot be crossed, ${ }^{286}$ precaution is the guiding standard for decision-making. ${ }^{287}$ Precaution in fisheries management, which is indubitably linked to a science-based approach to management, should also be seen as applying "in all steps of the management process including data collection, assessment, decision-making, monitoring, control and surveillance". ${ }^{28}$

The ecosystem-based objective for fisheries management, for its part, aims to balance "diverse societal objectives, by taking account of the knowledge and uncertainties about biotic, abiotic and human components of ecosystems and their interactions and boundaries". ${ }^{289}$ The European Common Fisheries Policy adds to these concepts the need "to safeguard the composition, structure and functioning of the habitats of the ecosystem affected". ${ }^{290}$ The EAF also focuses on the need to "plan, develop and manage fisheries" according to the potential impact it could have on future generations, bringing the approach in line with the principles of sustainable use and development. ${ }^{291}$ In fact, human concerns are central to this approach, ${ }^{292}$ and it includes all stakeholders and their respective activities. In practice, it also assesses different elements, such as the state of the resource (e.g. overfishing), the impact of fishing operations on non-target species (e.g. by-catch), potential habitat destruction (e.g. destructive fishing practices), and, conversely, the impact of changes to the marine environment (e.g. climate change, pollution, etc.) on fish stocks which act as indicators for measuring the "ecosystem friendliness" level of a measure or practice. ${ }^{293}$

284 UNFSA at art. 6.

285 Code of conduct, supra note 122 at arts. 6.5 and 7.5.

286 UNFSA at art. 5 b) and c).

287 For guidelines on how to apply the precautionary approach to fisheries in the context of highly migratory and straddling stocks, see UNFSA at annex II, with a specific reference to MSY at para 7.

288 de Bruyn, Murua \& Aranda, supra note 151 at 398.

289 Serge Garcia et al, "The ecosystem approach to fisheries. Issues, terminology, principles, institutional foundations, implementation and outlook" (2003) FAO Fisheries Technical Paper No 443 at 2. On the definition of and the rationale behind EAF, see also, Daniela Diz Pereira Pinto, Fisheries Management in Areas beyond National Jurisdiction, The Impact of Ecosystem-Based Law-Making (Leiden: Martinus Nijhoff, 2013) at 8.

290 Regulation (EU) No 1380/2013 of the European Parliament and of the Council of 11 December 2013 on the Common Fisheries Policy, amending Council Regulations (EC) No 1954/2003 and (EC) No 1224/2009 and repealing Council Regulations (EC) No 2371/2002 and (EC) No 639/2004 and Council Decision 2004/585/EC (Common Fisheries Policy), (2003) OJ, L 354/222 at art. 4, cited in Luc van Hoof, "Fisheries management, the ecosystem approach, regionalisation and the elephants in the room" (2015) 60 Marine Policy 20-26 at 22 .

291 FAO, "Fisheries Management. 2. The Ecosystem Approach to Fisheries" (2003) FAO Technical Guidelines for Responsible Fisheries No. 4 Suppl. 2 at xi-xii, online: <http://www.fao.org/3/a-y4470e.pdf $>$.

292 See, generally, FAO, "Fisheries Management. 2. The ecosystem approach to fisheries. 2.2 Human dimensions of the ecosystem approach to fisheries" (2009) FAO Technical Guidelines for Responsible Fisheries No. 4 Suppl. 2 Add. 2, online: <http://www.fao.org/docrep/012/i1146e/i1146e00.pdf> [FAO, "Human dimensions"].

293 Serge Garcia, "The Ecosystem Approach to Fisheries: On the Way to Implementation" in Myron Nordquist et al (eds) Law, Science and Ocean Management (Leiden: Martinus Nijhof, 2007) 171-216 at 193. 
While the EAF can be operationalized through, for example, environmental assessments or area-based tools ${ }^{294}$ it remains very difficult to implement the EAF in practice. ${ }^{295}$ According to Van Hoof it is even delusional to aspire to the EAF because fisheries management remains species-based. ${ }^{296}$ It would be more accurate to talk about "fisheries management in an ecosystem context" rather than "ecosystem management in a fisheries context". 297 Therefore, when elaborating measures to implement this approach, one must keep in mind that the EAF remains a sectoral approach to fisheries management, although one that is rooted in a broader, more holistic perspective than single- or multi-species management. ${ }^{298}$

While recognizing the difficulties linked to the practical implementation of the EAF, the rationale behind the approach, i.e. one of integration of concerns, contributes to finding a solution to the problems stemming from fragmentation, especially in ABNJ. ${ }^{299}$ The EAF considers socio-ecological systems, and looks "at the big picture, beyond traditional management agency boundaries, ${ }^{300}$ by promoting a close working relationship with other resource managers, both public and private"."301 The EAF also brings forward a new way of thinking, one that sees interrelated components rather than ones that are managed separately. This would support the principle of international cooperation, and, consequently, the need for cooperation among bodies, instruments and structures.

\subsection{The operationalization of high seas principles through a selection of existing and emerging conservation and management tools}

Fisheries management measures are generally understood as "a broad set of rules which govern how, [how much,] where and when fishermen may fish". ${ }^{302}$ Such measures can range from input control, targeting the fishing effort, ${ }^{303}$ to

294 See section 4.2 below.

295 See e.g. van Hoof, supra note 290 at 21 and 24, who focuses on EAF in an EU context, whilst still listing some practical difficulties of implementing the EAF.

$296 \mathrm{Ibid}$ at 24; Molenaar, "Ecosystem-Based Fisheries Management", supra note 278 at 571 and 573.

297 van Hoof, supra note 290 at 24 . This is also linked to the terminology and definition difficulties signalled above.

298 Molenaar, "Ecosystem-Based Fisheries Management", supra note 278 at 574.

299 Okonkwo, supra note 259 at 78.

300 FAO, "Human dimensions", supra note 292 at 3.

301 van Hoof, supra note 290 at 22.

302 This definition refers to "technical measures", but this study uses it as a general illustration of fisheries management measures, see European Commission, “Technical measures”, online: <https://ec.europa. eu/fisheries/cfp/fishing_rules/technical_measures>. See also Richard Barnes, “The Pursuit of Good Regulatory Design Principles in International Fisheries Law. What Possibility of Smarter International Regulation?" in Judith van Erp et al (eds), Smart Mixes for Transboundary Environmental Harm (Cambridge: Cambridge University Press, 2019) 97-125 at 115-116.

303 Examples of input control include rules on access to water (e.g. issuance of licences; limitations on the number of fishing days or the season during which fishing activities can take place; spatial measures and specific designated zones for fishing; limitations on the fleet capacity), the imposition of fees on other aspects of the fishing operations (e.g. taxation on fuel, landing fees), or restrictions on the type of gear that can be used or the fishing techniques that can be employed, see, e.g. European Commission, "Access 
output control, targeting the fishing volume, ${ }^{304}$ or be a combination of both. ${ }^{305}$ Such measures need to be differentiated from legally binding conservation and management measures adopted by RFMOs and which bind its member States. Conservation and management measures, as understood under the present section, refer to the broader array of measures for the conservation and management of marine living resources, which target States and also non-State actors. These can subsequently form the basis of a legally binding measure adopted by an RFMO, although this is not always the case.

Although some fishing techniques do get banned because of their adverse impact on ecosystems (e.g. bottom trawling), specific technical restrictions are not sufficient to ensure the recognition of the EAF as a main driver for management. Additional tools, that consider the management of fisheries within broader ecosystems and which rely on a more holistic reach, need to be considered further. This is why the present section looks into area-based tools (4.2.1) and assessment tools (4.2.2). These two types of tools are chosen because they have undergone recent developments within RFMOs; for example, VMEs, bans and closed areas, bottom fishing management regimes, exploratory fishing measures, as well as by-catch measures have been identified as successful measures conducted by RFMOs. ${ }^{306}$ These tools also form an intrinsic part of the more recent developments in the law of the sea through the negotiations of the upcoming legally binding instrument on the conservation and sustainable use of BBNJ. ${ }^{307}$

Area-based and assessment tools "promote [a] coherent and integrated management and [are] not simply [used] as a device to provide for allocation of resources and space" ${ }^{308}$ Indeed, they have an impact on - if not even a role in - management of the oceans and their activities. They also address conservation and management together, as two sides of the same coin. It is in that conservation and management perspective that these tools are seen as advancing not only the ecosystem and precautionary approaches within fisheries management in ABNJ, but also, more generally, the protection and preservation of the marine environment, as well as

to Waters", online: <https://ec.europa.eu/fisheries/cfp/fishing_rules/access-to-waters>, and European Commission, "Fishing Effort", online: $<$ https://ec.europa.eu/fisheries/cfp/fishing_rules/fishing_effort $>$.

304 Examples of output control include the establishment of the TAC and the allocation of catch quotas (based on, e.g. historical catch or zonal attachment, special dependencies of certain States, especially developing States and/or fishing communities), or the selectivity criterion of fish by imposing restrictions on the size or age of the fish caught, or by imposing a by-catch limit, see European Commission, "Managing fisheries", online: <https://ec.europa.eu/fisheries/cfp/fishing_rules_en>.

305 See, e.g., Maribus, supra note 274 at 108; European Commission, supra note 304. It is to be noted that different sources classify different measures under different categories. The classification used in the present chapter is for illustration purposes only and does not constitute an exhaustive list of measures.

306 Zoey Scanlon, “The art of 'not undermining': possibilities within existing architecture to improve environmental protections in areas beyond national jurisdiction" (2018) 75:1 ICES Journal of Marine Science $405-416$ at 411-412.

307 ABMTs and EIAs in the framework of the BBNJ Agreement are discussed further in chapter 4 below.

308 Lawrence Juda, "Changing Perspectives on the Oceans: Implications for International Fisheries and Oceans Governance” in David Caron \& Harry Scheiber (eds), Bringing New Law to Ocean Waters (Leiden: Brill Nijhoff, 2004) 17-28 at 26. 
the sustainable use of its resources. These tools also reiterate the importance of a science-based approach to management, as well as the necessity of the availability and sharing of information. The present section therefore analyses how, through their nature and/or functioning, these existing and emerging area-based and assessment tools embody some of the principles governing the oceans and apply them in practice.

\subsubsection{Area-based tools}

Described as spatial or non-spatial tools granting special protection by regulating human activities, ${ }^{309}$ area-based tools (or area-based management tools - ABMTs) have great significance for conservation and protection objectives. ${ }^{310}$ While States commonly use ABMTs within their maritime zones, the unilateral designation and establishment of such tools in $\mathrm{ABNJ}$ could amount to creeping jurisdiction or the appropriation of maritime territory; ${ }^{311}$ this is why ABMTs on the high seas must fall under multilateral authority and oversight. ${ }^{312}$

Area-based tools can be divided into two categories: sectoral tools and cross-sectoral tools. ${ }^{313}$ Sectoral tools address resource management in a particular sector. ${ }^{314}$ For

309 Greiber et al, supra note 32 at 1 . The regulation of activities can lead to the complete closure of specific areas, although the designation of MPAs or other ABMTs does not always lead to that result. Other regulation measures include partial closure (e.g. closure to a particular activity) or limitations on the extent of certain activities without a complete prohibition.

$310 \mathrm{Ibid}$ at 2, although they are not necessarily always aimed at conservation (i.e. an area can be designated for recreational or scientific research purposes).

311 Such appropriation could be seen as violating art. 89 UNCLOS, which reads: "No State may validly purport to subject any part of the high seas to its sovereignty".

312 Daniel Dunn, Guillermo Ortuño Crespo \& Richard Caddell, "Area-based fisheries management" in Richard Caddell \& Erik Molenaar (eds), Strengthening International Fisheries Law in an Era of Changing Oceans (Oxford: Hart, 2019) 189-217 at 190 and 194.

313 Greiber et al, supra note 32 at 2; Guillermo Ortuño Crespo et al, "Beyond static spatial management: Scientific and legal considerations for dynamic management in the high seas" (2020) Marine Policy article 104102 at 2; IUCN, "Suggestions for elements of a draft text of an internationally legally binding instrument under UNCLOS for the conservation and sustainable use of marine biological diversity beyond areas of national jurisdiction" (2015) at 14-16 (on file with author). For a short explanation of cross-sectoral or integrated perspectives, see Kanehara, supra note 252 at 67-68. Although his explanation is developed in the context of cross-sectoral/integrated regulation on the high seas, it illustrates the sectoral and crosssectoral concepts more generally. For a detailed account of the policy and legal framework of different sectoral and cross-sectoral tools in ABNJ, see Tullio Scovazzi, "Negotiating conservation and sustainable use of marine biological diversity in areas beyond national jurisdiction: prospects and challenges" (2014) 24 The Italian Yearbook of International Law 63-93 at 73-86. For a general reference to the different ABMTs used under sectoral and cross-sectoral regimes, see David Freestone, "An Unfinished Agenda: Governance of Areas beyond National Jurisdiction" in Keyuan Zou (ed), Global Commons and the Law of the Sea (Leiden, Boston: Brill Nijhoff, 2018) 209-225 at 215-217 [Freestone, "An Unfinished Agenda"].

314 Examples of well-established sectoral ABMTs include, first, Areas of Particular Environmental Interest (APEIs) established by the ISA. These areas, also called preference reference zones, are similar to the ones where mining is to take place, but are closed to mining for comparison purposes, for assessing possible changes in the marine environment caused by mining (see, e.g., ISA, "Biodiversity", online: $<$ https://www.isa.org.jm/biodiversity-0>; ISA, "Preservation Reference Zone", online: <https://www. isa.org.jm/preservation-reference-zone $>$ ). Second, in the field of shipping, the IMO has established a designation process of Particularly Sensitive Sea Area (PSSA). These areas of particular ecological, socio- 
high seas fisheries, two main types of ABMTs can be identified: tools for the deep sea and pelagic tools. In the deep sea, as a response to a series of UNGA resolutions drawing attention to the adverse impacts of bottom fishing activities, ${ }^{315}$ a regime for the protection of VMEs, areas potentially vulnerable to fishing activities because of their physical and functional fragility, ${ }^{316}$ was created and is meant to be implemented by RFMOs. The main responses for the protection of VMEs rely on designating restricted areas fully or partially closed to fishing, and asking State parties to identify their existing fishing footprint. ${ }^{317}$ Eight RFMOs have developed different policies and measures to regulate deep-sea fisheries. ${ }^{318}$ For example, CCAMLR has imposed restrictions on the use of bottom-trawling gear in high seas areas of the Convention area, allowing the use of such gear only where conservation measures are in place. ${ }^{319}$ Similarly, NEAFC, in its Recommendation 19:2014 on the protection of VMEs in the NEAFC Regulatory Area, ${ }^{320}$ temporarily ${ }^{321}$ closed certain areas for the protection of VMEs, where bottom-fishing was prohibited. ${ }^{322}$ Although the FAO has established guidelines to assist RFMOs in the designation of VMEs, ${ }^{323}$ the capacity of these RFMOs to monitor the state of these areas varies. Precaution therefore acts as an important approach in the face of a lack of data regarding the state of ecosystems, and also because of varying capacity and measures undertaken. ${ }^{324}$

economic or scientific importance are vulnerable and need special protection by the IMO from shipping related activities, such as navigational routes or specific rules for discharge (see, e.g., IMO, "Particularly Sensitive Sea Areas", online: <http://www.imo.org/en/OurWork/Environment/PSSAs/Pages/Default. aspx $>$; Revised Guidelines For The Identification And Designation Of Particularly Sensitive Sea Areas, IMO Resolution A.982(24) (2005); Scovazzi, supra note 313 at 73-74; Richard Barnes \& Carmino Massarella, "High Seas Fisheries" in Elisa Morgera \& Kati Kulovesi (eds), Research Handbook on International Law and Natural Resources (Cheltenham: Edward Elgar, 2016) 369-389 at 386. For an overview of the main sectoral ABMTs in ABNJ, see Kristina Gjerde, "Underpinning a Strong Global High Seas Agreement on BBNJ through Regional and Sectoral Governance: Possible Options" (Presentation delivered at the High Level Expert Meeting "Building a Strong High Seas Treaty: What is the Role for Regional Ocean Governance?", New York, 8 September 2018); David Freestone, “The Limits of Sectoral and Regional Efforts to Designate High Seas Marine Protected Areas” (2018) 112 AJIL Unbound 129-133 at 131-132.

315 See chapter 2 section 3.2.1 above. For example, the 2006 UNGA Res 61/105 remains a leading global instrument, urging RFMOs to close areas to bottom-fishing until appropriate measures have been taken to protect VMEs (see UNGA Res 61/105, supra note 106 at para 83(c)). The 2009 UNGA Res 64/72 also calls upon States and RFMOs to take action to protect deep-sea fish stocks and VMEs from destructive fishing practices (see Sustainable fisheries, including through the 1995 Agreement for the Implementation of the Provisions of the United Nations Convention on the Law of the Sea of 10 December 1982 relating to the Conservation and Management of Straddling Fish Stocks and Highly Migratory Fish Stocks, and related instruments, GA Res 64(LXXII), UNGAOR, 64th Sess, UN Doc A/RES/64/72 (2009) at para 113).

316 Guidelines on Deep-sea Fisheries, supra note 215 at paras 42-43; FAO, "Vulnerable Marine Ecosystems", online: <http://www.fao.org/in-action/vulnerable-marine-ecosystems/en/>.

317 Dunn, Ortuño Crespo \& Caddell, supra note 312 at 197-198.

318 NEAFC, NAFO, SEAFO, SIOFA, NPFC, GFCM, SPRFMO, and CCAMLR, see Dunn, Ortuño Crespo \& Caddell, supra note 312 at 195.

319 Restrictions on the use of bottom trawling gear in high-seas areas of the Convention Area, CCAMLR CMM 22-05 (2008).

320 Recommendation on the protection of vulnerable marine ecosystems in the NEAFC Regulatory Area as Amended by Recommendation 09:2015, NEAFC Recommendation 19-2014 (2014).

$321 \mathrm{Ibid}$ at art. 10.

322 Ibid at art. 5.

323 Guidelines on Deep-sea Fisheries, supra note 215, discussed in Dunn, Ortuño Crespo \& Caddell, supra note 312 at $195-196$.

324 Dunn, Ortuño Crespo \& Caddell, supra note 312 at 196. 
Pelagic tools are for their part more difficult to establish because of the dynamic character of species, the changing conditions of ecosystems, and the lack of data regarding these features. ${ }^{325}$ Consequently, they require a more dynamic and adaptive approach because things change more easily. ${ }^{326}$ The pelagic tools that do exist, however, are mostly implemented by tuna RFMOs and take the form of speciesspecific or gear-specific closures. ${ }^{327}$ Other pelagic tools include ABMTs established by CCAMLR in the form of MPAs which completely or partially close the area to fishing (among other activities). In fact, although MPAs are considered to be crosssectoral tools when they target several sectors (see below), the status of CCAMLR as a hybrid RFMO/RSP entity ${ }^{328}$ allows it to adopt ABMTs that go beyond the fisheries sector.

Cross-sectoral tools in fact address the impacts coming from diverse sectors and therefore trigger the need for cooperation and collaboration among various organizations and activities. MPAs, as the most commonly used cross-sectoral tool, ${ }^{329}$ aim for the preservation of an ecosystem, achieved through the complete or partial closure of a specific geographical area to some or all activities. While

325 Ortuño Crespo et al, supra note 313 at 2.

326 Ibid at 199.

$327 \mathrm{Ibid}$ at 200-201 where the authors refer to a yellowfin and big eye tuna closure by the WCPFC, a purse seiner closure by the IOTC, a long-line fishing closure by the IATTC, and a fish aggregation device closure by the ICCAT.

328 See chapter 2 sections 3.3.2 and 3.3.4 above.

329 For a study on MPAs as tools for the conservation of biodiversity, see Ricard, supra note 43 at 159-206. Another important cross-sectoral tool in the marine context is marine spatial planning (MSP). MSP seeks to reconcile the multiple uses of the marine environment in a defined geographical area, and to reach a balance between economic, social, developmental and conservation concerns. It also analyses and integrates the spatial and temporal components of management. It is a process-based tool, in the sense that it is not an end in itself, but rather offers a framework that aims at covering all activities included in a specific area. Consequently, MSP will be looked at and applied differently according to the particularities and needs of a specific region. For example, in 2014, the European Parliament and Council adopted a Directive creating a framework for MSP (Directive 2014/89/EU of the European Parliament and of the Council of 23 July 2014 establishing a framework for maritime spatial planning, (2014) OJ, L 257/135). This complemented the Marine Strategic Framework Directive of 2008 (Directive 2008/56/EC of the European Parliament and of the Council of 17 June 2008 establishing a framework for community action in the field of marine environmental policy, (2008) OJ, L 164/19), the objective of which was to establish a framework for community action in the field of marine environmental policy, and which is considered as the environmental pillar of the Integrated Maritime Policy for the European Union. Although MSP has been used in AWNJ (as shown by the EU example), their use in ABNJ has been very limited (or MSP-like planning has been conflated with other ABMTs) because it poses difficulties (e.g. "logistically and politically challenging" because there is a "lack of comprehensive data, a diverse and diffuse group of stakeholders, and no legal framework or body with the authority to coordinate the development and implementation of plans and activities", see Glen Wright et al, "Marine spatial planning in areas beyond national jurisdiction" (2018) IDDRI Issue Brief No 08/18). Similarly, while MSP can also be relevant for fisheries, it has not yet been broadly used for high seas fisheries management. An exhaustive analysis of MSP therefore falls outside the scope of the present study, but their relevance within the BBNJ process is briefly addressed in chapter 4 below. On MSP, generally, see, e.g. Charles Ehler \& Fanny Douvere, "Marine spatial planning: a step-by-step approach toward ecosystem-based management" (2009) Intergovernmental Oceanographic Commission Manual and Guides No 53; Greiber et al, supra note 32 at 4. On MSP in ABNJ, see Glen Wright et al, "Marine spatial planning in areas beyond national jurisdiction" (2019) Marine Policy; and Susanne Altvater, Ruth Fletcher \& Cristian Passarello, "The Need for Marine Spatial Planning in Areas Beyond National Jurisdiction" in Jacek Zaucha \& Kira Gee (eds), Maritime Spatial Planning: past, present, future (Cham: Springer, 2019) 397-415. 
there is no generally accepted definition of MPAs, ${ }^{330}$ there is consensus on what characterizes MPAs: the priority put on conservation objectives. More specifically, the main goal of MPAs is to work towards coordination of actions to achieve sustainability. ${ }^{331}$

MPAs partially or entirely located in ABNJ have been established under the auspices of three RSPs: ${ }^{332}$ by OSPAR in the North-East Atlantic, by the Barcelona Convention in the Mediterranean, and by CCAMLR in the Antarctic region. Although this study acknowledges, as discussed in the previous chapter, ${ }^{333}$ that RSPs are not mandated to address fisheries management and conservation, they remain relevant for the present analysis because of the interconnectedness that can arise between cross-sectoral MPAs and fisheries ABMTs. For example, OSPAR, although having established a network of MPAs, does not have the mandate to expressly regulate fisheries, even if multiple VMEs designated by NEAFC, the competent RFMO in the region, overlap with OSPAR MPAs. This is one of the reasons why OSPAR and NEAFC have developed the Collective Arrangement to strengthen cooperation and coordination of activities in ABNJ of the North-East Atlantic. ${ }^{334}$ MPAs under the Barcelona Convention similarly do not cover fisheries, but its Secretariat has signed a MoU with the GFCM.

It is probably under CCAMLR that the most relevant MPAs for the management and conservation of fishing activities in ABNJ have been developed. For example, the most recent and biggest high seas MPA, the Ross Sea MPA, established under the auspices of CCAMLR in 2016, "limit[s], or entirely prohibit[s], certain activities in order to meet specific conservation, habitat protection, ecosystem monitoring and fisheries management objectives. Seventy-two percent of the MPA [is] a 'no-take' zone, which forbids all fishing, while other sections [permits] some harvesting of fish and krill for scientific research". ${ }^{335}$ It is also under the auspices of CCAMLR that

330 See, e.g., Scovazzi, supra note 313 at 69-70. The definitions of MPA used by the IUCN and OSPAR are most widely followed:

IUCN: "A clearly defined geographical space, recognised, dedicated and managed, through legal or other effective means, to achieve the long-term conservation of nature with associated ecosystem services and cultural values." (IUCN, "When is a Marine Protected Area really a Marine Protected Area", online: $<$ http://www.iucn.org/?uNewsID=10904>).

OSPAR: "an area within the [OSPAR] maritime area for which protective, conservation, restorative or precautionary measures, consistent with international law have been instituted for the purpose of protecting and conserving species, habitats, ecosystems or ecological processes of the marine environment." (Network of Marine Protected Areas, OSPAR Recommendation 2003/3 (2003) at para 1.1.).

331 Greiber et al, supra note 32 at 2-3.

332 The designation and establishment of ABNJ MPAs by RSPs is also discussed in chapter 2 section 3.3.4 above.

333 See chapter 2 section 3.3.4 above.

334 Dunn, Ortuño Crespo \& Caddell, supra note 312 at 205. The Collective Arrangement between OSPAR and NEAFC, see Collective arrangement, supra note 114, is discussed in further detail in chapter 2 section 3.3.4 above, and chapter 7 section 3.2 below.

335 CCAMLR, "CCAMLR to create world's largest Marine Protected Area", online: <https://www.ccamlr.org/ en/news/2016/ccamlr-create-worlds-largest-marine-protected-area>. 
the first high seas only MPA was established in 2009 in the South Orkney Region (South West Atlantic) and where commercial fishing is prohibited. ${ }^{336}$

By granting special protection to certain areas from fishing activities, ABMTs undoubtedly operationalize most of the principles governing the high seas. ABMTs aim for preservation and protection; they call for the cooperation of all relevant actors in establishing and respecting the appropriate tools; they further the ecosystem approach, especially through cross-sectoral ABMTs, by aiming for an integrated approach and by considering impacts stemming from different sectors; $; 37$ and they rely on designation criteria established in accordance with scientific information.

Despite the potential of the above described area-based tools for embedding the conservation and management of fisheries in the ecosystem and precautionary approaches, ABMTs also raise concerns. First, among the fishing sector, fisheries closures and limitations impact on national revenues brought in by fishing operations and on the employment of the labour force in the fishing sector. A second concern, raised this time by coastal States, is the question of the rights, interests and obligations of coastal States, also known as "adjacency". As discussed above, ${ }^{338}$ some States claim that the establishment of an ABMT on the high seas adjacent to national waters could limit the rights of a coastal State, especially in relation to the access to and exploitation of resources in its EEZ and on its continental shelf beyond 200 nautical miles. ${ }^{339}$ Finally, concerns persist regarding the sufficient enforcement of and compliance with ABMTs; this is why to be truly effective, "ABMTs must therefore be targeted, scientifically-robust measures embedded in a wider governance framework that generates the necessary capacity to provide effective monitoring, control and surveillance of the site and to adapt to changing conditions or objectives" ${ }^{340}$

\subsubsection{Assessment tools}

Environmental assessments are decision-aiding tools, ${ }^{341}$ which guarantee that potential environmental impacts are taken into consideration before a decision

336 CCAMLR, "Marine Protected Areas (MPAs)", online: <https://www.ccamlr.org/en/science/marineprotected-areas-mpas $>$. Some of the MPAs established by OSPAR and CCAMLR are discussed by Freestone, "An Unfinished Agenda", supra note 313 at 218.

337 Oude Elferink, "Governance Principles”, supra note 35 at 250.

338 See chapter 2 section 3.3.4 above.

339 It is hoped that this question will be clarified during the BBNJ negotiations, discussed in greater detail in chapter 4 below. On adjacency and the BBNJ process, see Joanna Mossop \& Clive Schofield, "Adjacency and due regard: The role of coastal States in the BBNJ treaty" (2020) Marine Policy article 103877; "Utrecht informal meeting on rights and interests of coastal States (including issues relating to adjacent or subjacent maritime areas) and other States in the BBNJ Implementing Agreement - exploring scenarios and approaches" (Organized by the Netherlands Institute for the Law of the Sea (NILOS), Utrecht University, and the Netherlands Ministry of Foreign Affairs, Utrecht, 10-11 February 2020).

340 Dunn, Ortuño Crespo \& Caddell, supra note 312 at 193.

341 Simon Marsden, "Environmental Assessment and International Fisheries Law” in Richard Caddell \& Erik Molenaar (eds), Strengthening International Fisheries Law in an Era of Changing Oceans (Oxford: Hart, 
regarding an activity, project or programme is made. ${ }^{32}$ The necessity to "assess the potential effects" of activities that "may cause [...] significant and harmful changes to the marine environment" is recognized under UNCLOS. ${ }^{343}$ Conducting an environmental assessment in the context of fisheries is also required under the UNFSA to assess the impact of fishing on target or associated stocks. ${ }^{344}$

The main type of environmental assessment takes the form of an environmental impact assessment (EIA). ${ }^{345}$ It is an integrated decision-making procedure, which takes "into account interrelated socioeconomic, cultural and human health impacts, both beneficial and adverse" ${ }^{346}$ EIAs are made for a specific project or planned activity, before that project or activity starts, to assess if it should be undertaken or not. EIAs are also conducted after a project has started, to assess the appropriateness of its continuation. The judiciary has recognized a customary obligation to conduct an EIA, ${ }^{347}$ and this customary status has been interpreted as extending to ABNJ. ${ }^{348}$

2019) $219-246$ at 219.

342 Convention on Environmental Impact Assessment in a Transboundary Context (25 February 1991, entered into force 10 September 1997) 1989 UNTS 309 at art. 1(vi) [Espoo Convention].

343 UNCLOS at art. 206.

344 UNFSA at art. 5(d). See also, Marsden, supra note 341 at 223. It is, however, not unusual to see, in EAs for other activities, the impact of those activities on fishing activities and fish stocks.

345 Another type of EA is a strategic environmental assessment (SEA). Contrary to an EIA, which targets a specific activity, SEAs are undertaken at an earlier stage, targeting overarching policies and exploring broader alternatives and impacts, see OECD, "Strategic Environmental Assessment and Environmental Impact Assessment", online: <http://www.oecd.org/env/outreach/eapgreen-sea-and-eia.htm>. Associated types of EAs also include transboundary impact assessments (TIAs), which include the assessment of the impacts of an activity, conducted within or beyond national jurisdiction, on the maritime zone of another State, or in ABNJ. This triggers the question of whether an EA should be conducted in relation to an activity or the impacts of an activity. This impact based versus activity based approach is at the heart of the scope of application of EIAs within the current BBNJ negotiations, see chapter 4 section 3.4 below. Cumulative impact assessments (CIAs), for their part, assess the cumulative impact of different activities. It can also be argued that CIAs are already taken into consideration within SEAs, which normally have a more holistic approach than EIAs, see Marsden, supra note 341 at 225. Although SEAs, TIAs and CIAs can also be relevant for fisheries, they are not yet broadly used for high seas fisheries management; an exhaustive analysis of these types of EAs therefore falls outside the scope of the present chapter, but their relevance within the BBNJ process is briefly addressed in the chapter 4 below.

346 Chair's streamlined non-paper on elements of a draft text of an international legally-binding instrument under the United Nations Convention on the Law of the Sea on the conservation and sustainable use of marine biological diversity of areas beyond national jurisdiction (June 2017) at 6, online: <https://www. un.org/Depts/los/biodiversity/prepcom_files/Chairs_streamlined_non-paper_to_delegations.pdf $>$.

347 The separate opinion of Judge Weeramantry in the Gabčikovo-Nagymaros Case (Separate Opinion of Vice-President Weeramantry, supra note 28 at 88) expresses the need for continuing EIAs, while the MOX Plant Case raised the necessity to conduct EIAs (this was raised by Ireland in its submissions, see MOX Plant Case, supra note 110 at para 26). It is however in the Pulp Mills Case, supra note 140 at para 204, and reiterated in Certain Activities Carried Out by Nicaragua in the Border Area (Costa Rica v Nicaragua) and Construction of a Road in Costa Rica along the San Juan River (Nicaragua v Costa Rica), Judgment, (2015) ICJ Rep 665 at para 104, that the customary nature of the obligation to conduct an EIA was recognized. All cases are considered in Marsden, supra note 341 at 231-234.

348 ITLOS in Advisory Opinion on the Responsibility of Sponsoring States, supra note 154 at para 148, has interpreted the ICJ's reasoning in a transboundary context in the Pulp Mills Case (supra note 140 at para 204) as also applying "to activities with an impact on the environment in an area beyond national jurisdiction". ITLOS further said that the ICJ's "reference to 'shared resources' may also apply to resources that are the common heritage of mankind." It has not been discussed by the judiciary, however, if high seas fish stocks could also be considered as shared resources falling under the same EIA customary requirement. 
This recognized customary status of EIAs by the judiciary, however, does not give indication as to what the assessments should contain or how they should be conducted, ${ }^{349}$ nor can such indications be found in UNCLOS or the UNFSA. This limited guidance for conducting environmental assessments triggers the necessity to rely on other sources of international law, ${ }^{350}$ including the 1991 Convention on Environmental Impact Assessment in a Transboundary Context (Espoo Convention) which defines EIAs and establishes the different steps of the EIA process (notification, preparation of the EIA documentation, final decision making and post-project analysis). ${ }^{351}$ Nonetheless, the utility of the Espoo Convention in the marine context is limited. ${ }^{352}$ First, its Appendix I, which lists the activities requiring an EIA, does not include fisheries. Second, although the Espoo Convention does apply in a transboundary context, it is unclear whether the transboundary nature also extends to $A B N J$, because the language of article 1(viii) seems to limit the scope of application to States. ${ }^{353}$ Third, because the content of the Espoo Convention is not of a customary nature, ${ }^{354}$ its use to interpret obligations found under other instruments (e.g. UNCLOS) is limited. Finally, the focus of application of the Espoo Convention is on terrestrial contexts.

349 The ICJ mentioned that each State should determine "the specific content of the environmental impact assessment required in each case, having regard to the nature and magnitude of the proposed development and its likely adverse impact on the environment as well as to the need to exercise due diligence in conducting such an assessment", see Pulp Mills Case, supra note 140 at para 205; Certain Activities Case, supra note 347 at para 104. A broad discretion is indeed left to States to determine what the EAs should contain. See also Marsden, supra note 341 at 225 and 233.

350 Other non-legally binding instruments also provide some guidance in terms of EAs' content. The 1987 Goals and Principles of Environmental Impact Assessment from the UNEP, although not specific on the components of an assessment, offer a general framework that can later be complemented by international, regional and national measures, see UNEP, "Goals and principles of environmental impact assessment: decision 14/25 of the Governing Council of UNEP, of 17 June 1987”, online: <https://www.elaw.org/ system/files/unep.EIA_.guidelines.and_.principles.pdf $>$. For their part, the CBD Voluntary Guidelines on Biodiversity-Inclusive Environmental Impact Assessment Contents provide detailed specifications for, e.g., the different stages and content of the assessment, the identification of specific areas, the participation of stakeholders, see Voluntary Guidelines on Biodiversity-Inclusive Environmental Impact Assessment Contents, Annex to Impact assessment: Voluntary guidelines on biodiversity-inclusive impact assessment, CBD COP decision VIII/28, COP 8, UNEP/CBD/COP/8/28 (2006).

351 Espoo Convention at arts. 1, 3, 4, 6 and 7 respectively. Its appendixes also expand on this process, for example through Appendixes II (Content of the environmental impact assessment documentation), IV (Inquiry procedure), and V (Post-project analysis). Appendix I, listing activities requiring EIAs, complemented by Appendix III establishing general criteria to assist in the determination of the environmental significance of activities not listed in Appendix I, are also relevant for establishing the scope of application of EIAs. Although the Espoo Convention was adopted by the United Nations Economic Commission for Europe (UNECE) and was therefore intended to apply to the European region, the Convention has since become open to ratification by all UN member States, see UNECE, "Espoo Convention", online: <https://www. unece.org/environmental-policy/conventions/environmental-assessment/about-us/espoo-convention/ enveiaeia/more.html>. In 2003, the Espoo Convention was further complemented by a Protocol on SEAs, which was adopted by an Extraordinary meeting of the Parties, see UNECE, “The SEA Protocol”, online: $<$ https://www.unece.org/env/eia/sea_protocol.html>.

352 Marsden, supra note 341 at 238 and 245.

353 “ 'Transboundary impact' means any impact, not exclusively of a global nature, within an area under the jurisdiction of a Party caused by a proposed activity the physical origin of which is situated wholly or in part within the area under the jurisdiction of another Party."

354 Pulp Mills Case, supra note 140 at paras 204-205. 
This is one of the reasons why the use of EIAs, as understood under international environmental law, remains uneven and difficult to categorize with respect to (high seas) fisheries. This was highlighted by the 2010 UNFSA Review Conference, where it was suggested that applying EIAs to fisheries should be considered; 355 however only a reference to article 5(d) UNFSA on the assessment of the impacts of fishing appeared in the outcome of the Review Conference. ${ }^{356}$ No mention of EIAs is made in the report of the 2016 UNFSA Review Conference. ${ }^{357}$ In fact, as mentioned by Caddell, "with the exception of [CCAMLR and the SPRFMO, discussed below], the environmental assessments called for under the UNGA resolutions have left much to be desired, especially with regards to consideration of cumulative impacts". ${ }^{358}$

The scarce references to EIAs with respect to (high seas) fisheries are explained by three elements. First, as observed by Oude Elferink:

This seems to be mostly explained by the fact that international fisheries law has developed in parallel with environmental law. Whereas the instrument of EIA has been developed in the context of environmental law, fisheries has not taken this broad perspective in assessing the impacts of fishing activities. Fisheries management focuses on the assessment of the impact of activities on an ongoing basis and does not require the prior assessment of impacts. ${ }^{359}$

EIAs indeed differ from the general assessments that seem to be conducted in the field of fisheries. As mentioned above, EIAs are conducted before an activity takes place, to assess the impact from prospective human activities on the environment, while general assessments are more often conducted for data collection and monitoring (e.g. on the status of stocks and/or ecosystems, and environmental baselines). ${ }^{360}$ While the need for data collection, which reiterates the importance of the principles of a science-based approach and the availability of information, is fundamental to help us understand the potential human impacts on stocks and ecosystems, general

355 Report of the resumed Review Conference on the Agreement for the Implementation of the Provisions of the United Nations Convention on the Law of the Sea of 10 December 1982 relating to the Conservation and Management of Straddling Fish Stocks and Highly Migratory Fish Stocks, UNGAOR, UN Doc A/ CONF.210/2010/7 (2010) at paras 3158 and 135 [Report Review Conference 2010], discussed in Alex Oude Elferink, "Environmental Impact Assessments in Areas beyond National Jurisdiction" (2012) 27:2 International Journal of Marine and Coastal Law 449-480 at 467 [Oude Elferink, "EIAs"].

356 Report Review Conference 2010, supra note 355 at para 42.

357 Report of the resumed Review Conference on the Agreement for the Implementation of the Provisions of the United Nations Convention on the Law of the Sea of 10 December 1982 relating to the Conservation and Management of Straddling Fish Stocks and Highly Migratory Fish Stocks, UNGAOR, UN Doc A/ CONF.210/2016/5 (2016) [Report Review Conference 2016].

358 Richard Caddell, "International Fisheries Law and Interactions with Global Regimes and Processes" in Richard Caddell \& Erik Molenaar (eds), Strengthening International Fisheries Law in an Era of Changing Oceans (Oxford: Hart, 2019) 133-163 at 144.

359 Oude Elferink, "EIAs", supra note 355 at 469.

360 For example, stocks and biological assessment are the main necessary assessments referred to in the Report of the 2016 UNFSA Review Conference, see Report Review Conference 2016, supra note 357 at paras 67,68 and 77. 
assessments are not EIAs per se. ${ }^{361}$ For existing established fisheries, assessments are done for data collection and monitoring purposes.

Second, based on the language of article 119(1)(b) UNCLOS, which refers to "the effects on species associated with or dependent upon harvested species", the assessments of the impact of fishing activities seem to be focused on dependent and associated species, and not necessarily on the impact on the environment as a whole. This focus has, however, been modified with the UNFSA, which now includes the necessity to look at impacts on the broader marine environment. ${ }^{362}$

The third and probably main element explaining the infrequent application of EIAs to (high seas) fisheries is the concept of new and exploratory fisheries, a fisheriesspecific assessment tool. There is no specific definition of new and exploratory fisheries, but they are normally understood as fisheries of a species that has never been commercially exploited, or fisheries of an already commercially fished species but in a new fishing area, or fisheries which use new fishing methods within an existing fishery. ${ }^{363}$ They are distinguished from established fisheries because they are characterized by an important lack of scientific data, and are subject to more stringent management conditions. ${ }^{364}$ Yet, assessing what amounts to a new and exploratory fishery in practice can be difficult, ${ }^{365}$ except maybe for fisheries that would take place in areas not previously accessible, e.g. polar regions.

It is in the framework of CCAMLR that the concept of new and exploratory fisheries was first established, ${ }^{366}$ and it subsequently influenced the drafting of article 6(6) UNFSA, the only global instrument referring directly to such fisheries. In turn, many RFMOs have subsequently imported the concept into their own constitutive instruments. ${ }^{367}$ The most notable example is found in the SPRFMO Convention, where its article 22(1) mentions that "[a] fishery that has not been subject to fishing or has not been subject to fishing with a particular gear type or technique for ten years or more shall be opened as a fishery or opened to fishing with such gear

361 Marsden, supra note 341 at 228-230.

362 Oude Elferink, "EIAs", supra note 355 at 469-470, referring to, e.g., UNFSA at arts. 5(g) and 6(3)(d).

363 Richard Caddell, "Precautionary management and the development of future fishing opportunities: The international regulation of new and exploratory fisheries" (2018) 33 International Journal of Marine and Coastal Law 199-260 at 205 [Caddell, "New and exploratory fisheries"].

364 Ibid.

365 This difficulty stems from the fact that a number of considerations can be relevant in defining a fishery as new or exploratory, such as using a new gear, targeting new species, opening new areas for an existing fishery, significantly increasing fishing efforts, etc.

366 For the definition of new fisheries, see Notification that Members are Considering Initiating a New Fishery, CCAMLR CMM 21-01 (2010). For the definition of exploratory fisheries, see Exploratory fisheries, CCAMLR CMM 21-02 (2017). Although these measures are not currently active, they remain the main reference for the definition of the two concepts.

367 Examples from RFMOs include WCPFC Convention at art. 6(5); NPFC Convention at arts. 3(h) and 7(3) (d); SIOFA at art. 6(3)(b); NAFO Convention at art. I(h); CAOFA at art. 3(3), all discussed in Caddell, "New and exploratory fisheries", supra note 363 at 203 and 243-247. 
type or technique only when the Commission has adopted cautious preliminary conservation and management measures in respect of that fishery".

In order to comply with the more stringent regulations associated with new and exploratory fisheries, certain procedures must be followed by States wanting to engage in such fisheries. Under CCAMLR, when a member proposes a new fishery, it must submit a Fishery Operation Plan (nature of fishery, location, gear, etc.), together with information on the targeted stock and possible impacts on ecosystems. The proposal will then be contingent on a data collection plan established by the Scientific Committee. ${ }^{368}$ Similar requirements apply to exploratory fisheries. ${ }^{369}$ In some contexts, "[a]ccess to new and exploratory fishing opportunities in the CCAMLR Area is contingent upon a record of good conduct, with rights of participation denied to any vessel that has been listed as having participated in [IUU] fishing." ${ }^{30}$ The behaviour of actors in the responsible conducting of new and exploratory fisheries can also influence their future participation in commercial fisheries. ${ }^{371}$ While the designation of a fishing activity as a new fishery can have beneficial environmental impacts, because it really implements the precautionary approach, the designation of a fishery as "new" can also be used as a political and/ or economic tool to block a fishery or the use of new fishing techniques that could otherwise have gone ahead. ${ }^{372}$

The new CAOFA further illustrates an implementation of the framework for new and exploratory fisheries found under article 6(6) UNFSA. ${ }^{373}$ While creating a ban on commercial fishing, ${ }^{374}$ it still allows parties to engage in exploratory fishing in the central Arctic Ocean. ${ }^{375}$ The conducting of such fisheries, however, must be done "pursuant to conservation and management measures established by the [Meeting of the Parties (MOP)] on the basis of Article 5, paragraph 1(d)". ${ }^{376}$ Fisheries must then meet conditions in terms of duration, scope, scale, scientific knowledge and monitoring, and can be authorized only after the requesting party "has notified the other Parties of its plans for such fishing and it has provided other Parties an opportunity to comment on those plans" ${ }^{377}$ As observed by Molenaar, "[m]aking the commencement of commercial and exploratory fishing on the high seas portion of the central Arctic Ocean conditional on obtaining prior approval by the MOP

\footnotetext{
368 Caddell, "New and exploratory fisheries", supra note 363 at 215.

369 Ibid at 216.

370 Ibid at 222.

371 Ibid at 225.

372 Examples in the context of CCAMLR are discussed in ibid. The example of pulse fishing, discussed in chapter 2 section 2.2 .3 above, also illustrates this reality.

373 Erik Molenaar, "Participation in the Central Arctic Ocean Fisheries Agreement" in Akiho Shibata et al (eds), Emerging Legal Orders in the Arctic. The Role of Non-Arctic Actors (Abingdon, Oxon: Routledge, 2019) $132-170$ at 162 [Molenaar, "Participation in the CAOFA"].

374 CAOFA at art. 3(1).

375 Ibid at art. 3(3).

376 Ibid.

377 Ibid at art. 5(1)(d)(iv), and art. 5(1)(d) more generally. Also discussed in Molenaar, "Participation in the CAOFA", supra note 373 at 157-158.
} 
[...] can be regarded as an important step in [...] the gradual transformation of the freedom of the high seas $[. .$.$] into an increasingly conditional freedom.378$

Although article 6(6) UNFSA and similar provisions under RFMO instruments enshrine new and exploratory fisheries in the precautionary approach, this has not triggered significant regulatory responses. Even in the context of CCAMLR, the regulatory design for new and exploratory fisheries might be clear under the conservation and management measures CMM 21-01 and CMM 21-02, but the implementation of such design has proved more difficult. In fact, the difference, in practice, between what amounts to new and exploratory fisheries and, for example, fishing activities linked to scientific research, can be unclear. There is also uncertainty as to the procedure to follow to transition from a new and exploratory fishery to an established commercial fishery. ${ }^{379}$

In addition to this regime established under CCAMLR and which has subsequently permeated the UNFSA and RFMOs, "a second and more specific basis for the elaboration of overarching standards for [new and exploratory fisheries] has emerged comparatively recently in the context of international efforts to protect the deep-sea environment" ${ }^{380}$ The conducting of EIAs for deep-sea fisheries has been established as a necessary conservation measure by the UNGA. EIAs in fact became part of the list of measures to be taken to protect deep-sea VMEs, ${ }^{381}$ as called upon by several UNGA resolutions on the impact of fishing activities on deep-sea habitats and ecosystems (and discussed under the area-based tools above). ${ }^{382}$ This also includes exploratory deep-sea fishing activities. ${ }^{383}$ In essence, the FAO Guidelines on Deep-Sea Fisheries also recognizes the high level of coverage necessary for such fisheries. ${ }^{384}$ What the EIA procedure triggers in the case of deep-sea fishing is, in essence, a reversal of the burden of proof, where the entity wanting to engage in a fishing activity needs to provide sufficient evidence that such an activity will not be damaging to the marine environment. The particular situation of deep-sea fishing could even be said to amount to a lex specialis regime, or at least the recognition that special rules apply to marine areas with specific ecological characteristics.

RFMOs have also established specific procedures for exploratory fisheries in the context of deep-sea fishing. For example, Annex 4 of the NEAFC Recommendation 19:2014 on the protection of VMEs in the NEAFC Regulatory Area (amended by Recommendation 09:2015) lists them as elements to look at when conducting an assessment of exploratory bottom fishing activities. This annex builds on the

378 Molenaar, "Participation in the CAOFA", supra note 373 at 169.

379 Caddell, "New and exploratory fisheries", supra note 363 at 216-220 and 259.

380 Ibid at 247.

381 UNGA res 61/105, supra note 106, also discussed in Oude Elferink, "EIAs", supra note 355 at 468.

382 See section 4.2.1 above. See also chapter 2 section 3.2.1 above.

383 See UNGA Res 61/105, supra note 106 at para 83, discussed in Caddell, "New and exploratory fisheries", supra note 363 at 251.

384 Guidelines on Deep-sea Fisheries, supra note 215 at paras 42-53. 
obligation found under article 7 of the Recommendation, which requires States parties to conduct such an assessment. ${ }^{385} \mathrm{~A}$ similar obligation and list of elements can also be found in the Conservation Measure 30/15 Bottom Fishing Activities and Vulnerable Marine Ecosystems in the Convention Area of SEAFO. ${ }^{386}$ In 2012, a Scientific Working Group of the Scientific Committee of SPRFMO developed the Bottom Fishery Impact Assessment Standard, ${ }^{387}$ which aims "to constitute the standardised approach to be taken by all participants when preparing risk and impact assessments for high seas bottom fishing activities in the SPRFMO area" and "to guide the [Scientific Working Group] when reviewing these assessments". The content of these impact assessments standards follows the elements suggested in the FAO Guidelines on Deep-sea Fisheries. ${ }^{388}$

Despite this somewhat uneven portrait of environmental assessments in the context of (high seas) fisheries, the existence of assessment tools for fishing activities reflects the fisheries management objectives of precautionary and ecosystem approaches. As can be seen from article 6(6) UNFSA cited above and other conservation measures enacted by various RFMOs, not only do these measures raise the need to conduct impact assessments for various activities, but they directly link the assessments with the precautionary approach, as they present caution and assessment as two components of the development of conservation and management measures. Assessment tools also require the application of an ecosystem approach as the goal of the assessment is to foresee the impact of a particular activity or programme on some aspects of the marine environment, or on the marine environment as a whole.

Assessment tools further reiterate the importance of other principles governing the high seas for the management and conservation of high seas fish stocks. First, one cannot forget the importance of a science-based approach, as environmental assessments are based on scientific and technical information on the state of fish stocks and surrounding species, the state of the marine environment, the scope of the methods and activities undertaken, etc. Second, the principle of cooperation is brought forward by the need for multiple actors to participate in the development and implementation of assessments. For example, a flag State wanting to conduct a fishing activity on the high seas will have to notify the RFMO of its intended activity and provide specific information on such an activity, and then the Scientific Committee of the RFMO will have to set out a data collection plan, etc. Cooperation here takes the form of the sharing of information. It is through such procedures of general environmental assessments, of new and exploratory fisheries, and of

385 NEAFC Recommendation 19-2014, supra note 320 at art. 7 and annex 4.

386 Bottom Fishing Activities and Vulnerable Marine Ecosystems in the SEAFO Convention Area, SEAFO Conservation Measure 30/15 (2016) at art. 7 and annex 3.

387 South Pacific Regional Fisheries Management Organization, "Bottom Fishery Impact Assessment Standard", online: <https://www.sprfmo.int/assets/Meetings/Meetings-before-2013/Scientific-WorkingGroup/SWG-06-2008/a-Miscellaneous-Documents/SPRFMO-Bottom-Fishing-Impact-AssessmentStandardagreed-Vanuatu-Fri23Sep2011-1140am.pdf>.

$388 \mathrm{Ibid}$ at $15-21$, and more specifically at 22 about new and exploratory fisheries. 
monitoring, review and data collection that flexibility and reactivity in fisheries conservation and management will be achieved.

\section{CONCLUSION: UNIFYING CONSERVATION AND THE USE OF RESOURCES}

The principles currently underlying the regulation and governance of the oceans are not new; they have shaped the development and consolidation of the framework for the management of the oceans, by contributing to the coherence and systematization of the law; acting as guiding and interpretative tools; and creating parameters for the development of the law. These principles have found their way into environmental law, biodiversity law, and the law of sea and also, more specifically, into international and high seas fisheries law. The principles can be found in a variety of different instruments, ranging from legally binding texts to declarations, guidelines and soft-law instruments, and some have been discussed and analysed by the judiciary. Certain principles have reached the status of customary law, while the exact nature of others is still under discussion. Be that as it may, the instruments in which principles can be found are of relevance for shedding light on the way in which certain principles have evolved and are evolving within a regime.

An analysis of how principles are operationalized through the management and conservation of international fisheries further informs the understanding of the concrete application of these principles. The assessment of fisheries management objectives, as well as an overview of various conservation and management tools, constitutes another component of the analysis of the concrete application of principles to the regime.

The management of fisheries is concerned with the way in which resources are being used, with some of its aims being rooted in conservation objectives. Conservation and the use of resources are, in fact, two sides of the same coin that is fisheries management. Yet, the different interests they represent sometimes clash: are conservation and use to be balanced as competing interests, or should they be balanced as contemplated in light of one another? ${ }^{389}$ The different elements of the debate show that the shift needed for strengthened interconnectedness is actually one that is moving from a "use versus conservation" state of mind towards a "use and conservation" state of mind, where concepts are integrated rather than opposed. The possibility to develop this paradigm further depends on the ability of actors to change their perception of high seas freedoms, and on the way the interaction of conservation and use presents itself as the unavoidable evolution. ${ }^{390}$

389 The principle of sustainable use probably illustrates best this attempt at considering conservation and use in a complementary manner.

390 Young, supra note 43 at 171, 176 and 180. 
The present chapter has followed the approach of contemplating conservation in light of exploitation, and has presented management, use and conservation in an integrated manner. This representation is possible through the principles governing the high seas, which, in turn, inform the development of tools that bring together conservation and use within management. Nonetheless, the principles governing the high seas are not a panacea, and their implementation and operationalization remains somewhat challenging. ${ }^{391}$ However, the assessment of their effectiveness should always be conducted in light of the role they fulfil: they are tools for coherence, guidance and interpretation.

In the face of a legal framework characterized by fragmentation, complexity, and a lack of coordination and cooperation between structures, instruments and actors, principles governing the high seas act as reminders of the objectives which we want to achieve. They play a role in systematizing the interconnectedness between fisheries management and environmental and biodiversity protection on the high seas, and act as reference points around which the framework for oceans, $\mathrm{ABNJ}$ and international fisheries management can be built, developed and consolidated. 



\title{
BIODIVERSITY BEYOND NATIONAL JURISDICTION
}

\author{
A Catalyst for Interconnectedness?
}

\section{INTRODUCTION}

The legal framework presented previously described the main instruments found within two legal regimes applicable to $\mathrm{ABNJ}$ and international fisheries: the law of the sea regime, and environmental law, including questions of biodiversity. ${ }^{1}$ This framework was then complemented by a description of the main principles governing the high seas, and examples of how these principles influence and/or are operationalized in international and high seas fisheries law. However, the portrait of the legal framework for ABNJ and its impact on (high seas) fisheries law would be incomplete without addressing the ongoing developments on the conservation and sustainable use of marine biodiversity in ABNJ.

The international community is currently negotiating the text of an international legally binding instrument on the conservation and sustainable use of marine biodiversity of areas beyond national jurisdiction (hereafter the Agreement), which will become an implementing agreement under UNCLOS. In order to do so, the Agreement covers four issue-areas: 1) marine genetic resources (MGRs), including questions on the sharing of benefits; 2) measures such as ABMTs, including MPAs; 3) EIAs; and 4) capacity-building and the transfer of marine technology (CB\&TT). ${ }^{2}$ The Intergovernmental Conference (IGC) negotiating the text of the Agreement started its work in September 2018. At the time of writing, the IGC had concluded three of the four sessions planned in its initial mandate, ${ }^{3}$ and an extension of its programme of work is also pending, as the Conference has not yet reached a text

1 On the links between the law of the sea and international environmental and biodiversity law, see Pascale Ricard, La conservation de la biodiversité dans les espaces maritimes internationaux. Un défi pour le droit international (Paris: Pedone, 2019) in general, but most particularly at 3.

2 International legally binding instrument under the United Nations Convention on the Law of the Sea on the conservation and sustainable use of marine biological diversity of areas beyond national jurisdiction, GA Res 72(CCXLIX), UNGAOR, 72nd Sess, UN Doc A/RES/72/249 (2017) at para 2.

3 Ibid at para 3. It is to be noted that the fourth session, originally planned to take place in March 2020, had to be postponed due to the COVID-19 pandemic, see Draft decision submitted by the President of the General Assembly. Intergovernmental conference on an international legally binding instrument under the United Nations Convention on the Law of the Sea on the conservation and sustainable use of marine biological diversity of areas beyond national jurisdiction, GA Res 74(DXLIII), UNGAOR, 74th Sess, UN Doc A/74/L.41 (2020). The meeting has yet to be rescheduled. 
ready for adoption. The core of the analysis conducted in the present chapter, as well as references to the Agreement's text are done on the basis of the latest available draft text for the Agreement (the Revised draft text from November 2019), ${ }^{4}$ unless specified otherwise.

This instrument is expected to become the third implementing agreement under UNCLOS, ${ }^{5}$ one that aims to implement the (limited) provisions of the Convention addressing the conservation and sustainable use of marine biodiversity in ABNJ. The Agreement would develop further the regime for $\mathrm{ABNJ},{ }^{6}$ building on the general obligations related to the two zones forming part of ABNJ, the high seas (Part VII) and the Area (Part XI), and to the protection and preservation of the marine environment (Part XII). The instrument would further help strengthen, mostly through CB\&TT, the provisions on marine scientific research (Part XIII) and the development and transfer of marine technology (Part XIV). Through its implementing role, the Agreement must also ensure the fulfilment of three underlying components of the delicate balance reached by UNCLOS: the "intensified use of the high seas, [the] protection of its ecological integrity, and [the] consideration of social needs"?

However, the overarching objective of the Agreement, the conservation and sustainable use of BBNJ, as well as the four issue-areas it covers, do not directly address the different activities taking place in ABNJ. Indeed, fisheries, like any other sector operating in ABNJ (e.g. shipping, exploration and exploitation of the deep seabed, cable laying), are not directly covered by the Agreement, as these activities do not form the essential core of the four issue-areas; but fisheries have triggered a particularly passionate debate. On the one hand, some delegations have urged the international community to include fisheries in the Agreement because of their major impact on biodiversity and the marine environment in ABNJ. Completely setting fisheries aside, they argue, would deny the importance of the ecosystemic approach needed in $\mathrm{ABNJ}$ and the interconnectedness of the activities taking place in these areas. ${ }^{8}$ On the other hand, others have firmly opposed that idea, claiming

4 Revised draft text of an agreement under the United Nations Convention on the Law of the Sea on the conservation and sustainable use of marine biological diversity of areas beyond national jurisdiction, Intergovernmental conference on an international legally binding instrument under the United Nations Convention on the Law of the Sea on the conservation and sustainable use of marine biological diversity of areas beyond national jurisdiction, 4th Sess, UN Doc A/CONF.232/2020/3 (2019) [Revised draft text].

5 The first two implementing agreements being the Agreement relating to the implementation of Part XI of the United Nations Convention on the Law of the Sea of 10 December 1982 (28 July1994, entered into force 28 July 1996) 1836 UNTS 3 [Part XI implementing agreement], and the UNFSA.

6 On the development of a general regime for ABNJ through a new implementing agreement and its link with UNCLOS, see Tullio Treves, "Principles and objectives of the legal regime governing areas beyond national jurisdiction" in Alex G. Oude Elferink \& Erik J. Molenaar (eds), The International Legal Regime of Areas Beyond National Jurisdiction: Current and Future Development (Leiden: Martinus Nijhoff, 2010) 9-25 at 20-25.

7 Cymie Payne, "Introduction to the Symposium on Governing High Seas Biodiversity" (2018) 112 AJIL Unbound 118-122 at 120 .

8 See, e.g. Glen Wright et al, "High seas fisheries: what role for a new international instrument?" (2016) IDDRI Paper 3/2016 at 9 [Wright et al, "High seas fisheries"]. 
that the current framework is sufficient and that new structures and measures would overburden or undermine the current mechanisms. ${ }^{9}$

Therefore, to assess the relevance of this new Agreement for the legal framework of $\mathrm{ABNJ}$, and more specifically the implications it might have for fisheries management, one must understand what triggered the process in the first place: the recognition of the interconnectedness between the components of the oceans, as well as the necessity for an integrated approach to their management. While interconnectedness and integrated management of the oceans appeared in Agenda 21 (and more specifically its chapter 17) ${ }^{10}$ following the 1992 Rio Conference, it is in the framework of the United Nations Open-ended Informal Consultative Process on Oceans and the Law of the Sea (ICP) that such necessities were identified with regard to the conservation and sustainable use of marine biodiversity in ABNJ more specifically. ${ }^{11}$ Created in 1999 to provide input and suggestions to the UNGA regarding affairs related to oceans and the law of the sea, ${ }^{12}$ the ICP started focusing on BBNJ during its fifth meeting in 2004, where delegations concluded that " $[\mathrm{g}]$ iven the existing legal framework, [...] the international community should at this point consider specific ocean governance options". ${ }^{13}$ It was then suggested that "a working group with a mandate to begin the preparation of a legal instrument" should be established. ${ }^{14}$ The BBNJ process was therefore launched because of a need for cooperation and coordination for the management of biodiversity in ABNJ. The Agreement is therefore expected to act as a creator of interlinkages and interconnectedness between existing regimes, processes, institutions and actors operating in $\mathrm{ABNJ}$.

9 See, e.g. Fernanda Millicay, "Marine Biodiversity of Areas Beyond National Jurisdiction. Securing a Sound Law of the Sea Instrument" in David Joseph Attard, David Ong \& Dino Kritsiotis (eds), The IMLI Treatise on Global Ocean Governance, vol I: UN and Global Ocean Governance (Oxford: Oxford University Press, 2018) 167-177 at 168 .

10 Agenda 21 of the United Nations Conference on Environment and Development, UNCED Report A/CONF.151/26/Rev. 1 (1993) at chapter 17.

11 Discussions on ABNJ were initially targeting biodiversity in the seabed more specifically, see generally Report on the work of the United Nations Open-ended Informal Consultative Process on Oceans and the Law of the Sea at its fifth meeting, UNGAOR, 59th Sess, UN Doc A/59/122 (2004) at para 1 [Report ICP $5^{\text {th }}$ meeting].

12 The ICP was established "in order to facilitate the annual review by the General Assembly, in an effective and constructive manner, of developments in ocean affairs by considering the Secretary-General's report on oceans and the law of the sea and by suggesting particular issues to be considered by it, with an emphasis on identifying areas where coordination and cooperation at the intergovernmental and inter-agency levels should be enhanced", see Results of the review by the Commission on Sustainable Development of the sectoral theme of "Oceans and seas": international coordination and cooperation, GA Res 54(XXXIII), UNGAOR, 54th Sess, UN Doc A/RES/54/33 (1999) at para 2. This was done on the basis of the recommendations of the Commission on Sustainable Development, established by the UNGA in Institutional arrangement to follow up the United Nations Conference on Environment and Development, GA Res 47(XXCI), UNGAOR, 47th Sess, UN DocA/RES/47/191 (1992) to provide a follow up to the United Nations Conference on Environment and Development (Rio de Janeiro, Brazil, 3-14 June 1992), see Commission on Sustainable Development, online: <https://sustainabledevelopment.un.org/ intergovernmental/csd $>$.

13 Report ICP $5^{\text {th }}$ meeting, supra note 11 at para 89.

14 Ibid. 
To understand the role of the BBNJ Agreement as a major (upcoming) component of the legal regime for $\mathrm{ABNJ}$, this chapter first presents a historical overview of the developments of the BBNJ process, starting with the creation of the Ad Hoc Open-ended Informal Working Group to study issues relating to the conservation and sustainable use of BBNJ (Working Group), up to the ongoing IGC for the development of an internationally legally binding instrument on the matter (section 2). The chapter then looks at different ways in which the Agreement could improve cooperation and coordination, with a particular emphasis on the role it plays in bridging the law of the sea and international environmental law (section 3). Then, as it remains uncertain to what extent the scope of application of the Agreement will encompass fisheries,$^{15}$ the chapter explores different elements that could shape the relationship between fisheries management structures and the BBNJ Agreement (section 4). Finally, section 5 concludes with observations on the implications of the Agreement for coordination in ABNJ, including for the current management and regulation of (high seas) fisheries.

\section{THE DIFFERENT STAGES OF THE BBNJ PROCESS}

The formal discussions on the conservation and sustainable use of BBNJ started with the creation of the Working Group. ${ }^{16}$ In order to understand the evolution of the discussions, the present section underscores the issues that have gained importance over the different phases of the process, what events have influenced the focus put on certain issues, how concerns were addressed, and what were the positions of some States regarding selected topics. It also gives some indication as to how fisheries were addressed throughout the process. Each stage of the process is discussed in chronological order, starting with the Working Group (2.1), continuing with the Preparatory Committee for the development of an international legally binding instrument on BBNJ (PrepCom) (2.2), and finally with the IGC (2.3). The important dates and points discussed during the process are summarized in Figure 1.

15 Art. 8(2)(a) of the Revised draft text, supra note 4, currently states that "The provisions of this [Part II of the Agreement, Part covering MGRs] shall not apply to: (a) The use of fish and other biological resources as a commodity". While there seems to be a convergence of views towards the exclusion of fish as a commodity in relation to MGRs, it remains uncertain whether this exclusion will apply to the Agreement in its entirety.

16 Oceans and the law of the sea, GA Res 59(XXIV), UNGAOR, 59th Sess, UN Doc A/RES/59/24 (2004) at para 73. 
Figure 1: Important dates and points of discussion of the BBNJ process

\begin{tabular}{|c|c|}
\hline Working ( & $\begin{array}{l}\text { - Creation of the WG in UNGA Res 59/24 (2004) } \\
\text { - 1st meeting (2006): exchange of views on the mandate, role of the } \\
\text { UNGA and sectoral organizations. } \\
\text { - 2nd meeting (2008): effectiveness of implementation and } \\
\text { enforcement, cooperation and coordination. } \\
\text { - 3rd meeting (2010): exchange on measures to reach the goals } \\
\text { identified in previous meetings. } \\
\text { - 4th meeting (2011): package deal elements (MGR, ABMT, ELA, CBTT). } \\
\text { - 5th meeting (2012): unfolding of the elements of the package deal, } \\
\text { divergences and convergences take shape. } \\
\text { - 6th meeting (2013): scope, parameters and feasibility of developing } \\
\text { an international instrument under UNCLOS. } \\
\text { - 7th and 8th meetings (2014): elements of the package deal in light of } \\
\text { the potential development of an international instrument. } \\
\text { - 9th meeting (2015): the WG makes the recommendations to hold an } \\
\text { IGC, which would be preceded by a PrepCom. }\end{array}$ \\
\hline & $\begin{array}{l}\text { - Creation of the PrepCom in UNGA Res 69/292 (2015) } \\
\text { PrepCom } 1 \text { (March 2016): unpacking and defragmenting; MGR: } \\
\text { freedom of high seas vs common heritage and work towards } \\
\text { complementarity; ABMT: risk of interfering with RFMOs; EIA: need } \\
\text { for clearing-house mechanism. } \\
\text { - PrepCom } 2 \text { (Sept. 2016): MGR: link between genetic resources and } \\
\text { intellectual property; ABMT: modalities, processes, institutional } \\
\text { arrangements, and adjacency; EIA: other types of assessments, i.e. } \\
\text { TEIA and SEA; CBTT: importance of stakeholders' involvement. } \\
\text { - PrepCom } 3 \text { (March 2017): regional/global/hybrid institutional } \\
\text { structure; continuation of the discussion on the package deal elements. } \\
\text { - PrepCom } 4 \text { (July 2017): convergences and divergences; MGR: } \\
\text { freedom vs common heritage, and monetary vs non-monetary } \\
\text { benefit sharing; ABMT: decision-making process; EIA: other types of } \\
\text { assessments, and possible internationalization of the process; CBTT: } \\
\text { terms and conditions for the transfer of marine technology; cross- } \\
\text { cutting: relation between institutions and instruments. The PrepCom } \\
\text { makes the recommendations on some elements of the draft text, and } \\
\text { recommends holding an IGC. }\end{array}$ \\
\hline $\begin{array}{l}\text { Inter- } \\
\text { ernmental } \\
\text { onference }\end{array}$ & $\begin{array}{l}\text { - Creation of the IGC in UNGA Res } 72 / 249 \text { (2017) } \\
\text { - IGC1 (Sept. 2018): President's aid to discussions; reiteration of } \\
\text { positions; persisting divergences. } \\
\text { - IGC2 (March 2019): President's aid to negotiations, list of options } \\
\text { for treaty language; persisting divergences, yet more additional points } \\
\text { necessitating discussion (e.g. mandatory or discretionary nature of } \\
\text { components of EIAs, implementation, monitoring and review of } \\
\text { ABMTs). } \\
\text { - IGC3 (Aug. 2019): Draft text; change of discussion format (i.e. } \\
\text { "informal informals"), persisting divergences and progress; more } \\
\text { attention dedicated to cross-cutting issues, e.g. institutional } \\
\text { arrangements. } \\
\text { - IGC4 (March 2020 - postponed): Revised draft text; Compilation of } \\
\text { textual proposals. } \\
\text { - IGC5 ??? }\end{array}$ \\
\hline
\end{tabular}




\subsection{Ad Hoc Open-ended Informal Working Group (2006-2015)}

The Working Group started its work in 2006, slightly over a year after its establishment, and met on nine occasions. It was mandated to survey the activities of the UN and other international organizations on BBNJ, to examine the scientific, technical, legal, environmental and socio-economic aspects of BBNJ, and to indicate possible options for the promotion of cooperation and coordination regarding BBNJ. ${ }^{17}$

The first three meetings (February 2006, April-May 2008 and February 2010) were dedicated to exchanging views on the mandate. Already, at this early stage, the Working Group raised elements that eventually became central to the process. For example, it underlined the central role of the UNGA, complemented by the relevant sectoral organizations; the need for more efficient implementation through capacitybuilding in developing States; the importance of the precautionary and ecosystems approaches, as well as best available science; the environmental impacts of human activities on BBNJ; coordination and cooperation among States; and whether there are governance or regulatory gaps, and if so, how it should be addressed (i.e. possible institutional arrangements). ${ }^{18}$

The fourth meeting (May-June 2011) was of crucial importance for the BBNJ process; this is when the idea of developing an agreement under UNCLOS was formalized. ${ }^{19}$ The recommendations also mentioned that the

process would address the conservation and sustainable use of marine biodiversity in areas beyond national jurisdiction, in particular, together and as a whole, marine genetic resources, including questions on the sharing of benefits, measures such as area-based management tools, including marine protected areas, and environmental impact assessments, capacity-building and the transfer of marine technology. ${ }^{20}$

17 Ibid.

18 See, generally, the reports of the first three meetings: Report of the Ad Hoc Open-ended Informal Working Group to study issues relating to the conservation and sustainable use of marine biological diversity beyond areas of national jurisdiction, UNGAOR, 61st Sess, UN Doc A/61/65 (2006) [Report $1^{\text {st }}$ meeting]; Letter dated 15 May 2008 from the Co-Chairpersons of the Ad Hoc Open-ended Informal Working Group to study issues relating to the conservation and sustainable use of marine biological diversity beyond areas of national jurisdiction addressed to the President of the General Assembly, UNGAOR, 63rd Sess, UN Doc A/63/79 (2008) [Report $2^{\text {nd }}$ meeting]; Letter dated 16 March 2010 from the Co-Chairpersons of the Ad Hoc Openended Informal Working Group to the President of the General Assembly, UNGAOR, 65th Sess, UN Doc $\mathrm{A} / 65 / 68$ (2010) [Report $3^{\text {rd }}$ meeting].

19 Letter dated 30 June 2011 from the Co-Chairs of the Ad Hoc Open-ended Informal Working Group to the President of the General Assembly, UNGAOR, 66th Sess, UN Doc A/66/119 (2011) at para 1(a) [Report $4^{\text {th }}$ meeting].

20 Ibid at para 1(b) (emphasis added). 
These elements, from then on referred to as "the package" or "the package deal", structured the issues to be addressed. The necessity to consider them together and as a whole also calls for cross-cutting considerations.

The fifth meeting of the Working Group (May 2012) was the first to be conducted on the basis of the new process established in the package. ${ }^{22}$ The discussions on the four elements of the package unfolded and shed light on convergences and divergences that still remain at the time of writing. ${ }^{23}$ The sixth (August 2013), seventh (April 2014) and eight (June 2014) meetings, for their part, benefited from a renewed momentum because of the Rio+20 Conference, held in June 2012. ${ }^{24}$ The meetings focused on developing recommendations on the scope, parameters and feasibility of an international instrument under UNCLOS. ${ }^{25}$ More specifically on the question of feasibility, some delegations raised concerns as to whether the instrument was really necessary or not, and on the fact that other options should be considered. ${ }^{26}$ There

21 See, e.g. Chair's streamlined non-paper on elements of a draft text of an international legally binding instrument under the United Nations Convention on the Law of the Sea on the conservation and sustainable use of marine biodiversity of areas beyond national jurisdiction (June 2017) at 9, online: <https://www. un.org/Depts/los/biodiversity/prepcom.htm>; Zoey Scanlon, “The art of 'not undermining': possibilities within existing architecture to improve environmental protections in areas beyond national jurisdiction" (2018) 75:1 ICES Journal of Marine Science 405-416 at 406; Jeff Ardron et al, "Advancing governance of the High Seas" (2013) IASS Policy Brief 1/2103 at 2.

22 Letter dated 8 June 2012 from the Co-Chairs of the Ad Hoc Open-ended Informal Working Group to the President of the General Assembly, UNGAOR, 67th Sess, UN Doc A/67/95 (2012) [Report $5^{\text {th }}$ meeting].

23 These convergences and divergences are discussed further in sections 3 and 4 below.

24 For a more detailed discussion on the impact of the Rio+20 Conference on the BBNJ, see Sunil Kr. Agarwal, "Legal Issues in the Protection of Marine Biological Diversity Beyond National Jurisdiction" (2015) 11:1 Maritime Affairs: Journal of the National Maritime Foundation of India 84-98 at 92-94. For a discussion on the Rio+20 Conference and the oceans more generally, see Otto Spijkers \& Natalia Jevglevskaja, "Sustainable Development and High Seas Fisheries" (2013) 9:1 Utrecht Law Review 24-37 at 32-36.

25 See, generally, the reports of the sixth, seventh and eighth meetings: Letter dated 23 September 2013 from the Co-Chairs of the Ad Hoc Open-ended Informal Working Group to the President of the General Assembly, UNGAOR, 68th Sess, UN Doc A/68/399 (2013) [Report $6^{\text {th }}$ meeting]; Letter dated 5 May 2014 from the Co-Chairs of the Ad Hoc Open-ended Informal Working Group to the President of the General Assembly, UNGAOR, 69th Sess, UN Doc A/69/82 (2014) [Report $7^{\text {th }}$ meeting]; Letter dated 25 July 2014 from the Co-Chairs of the Ad Hoc Open-ended Informal Working Group to the President of the General Assembly, UNGAOR, 69th Sess, UN Doc A/69/177 (2014) [Report $8^{\text {th }}$ meeting]. For example, the following issues were identified: the need to find a common understanding of key terms (Report $7^{\text {th }}$ meeting at para 29), to rely on modern principles of governance as guiding principles (Report $6^{\text {th }}$ meeting at para 49; Report $7^{\text {th }}$ meeting at para 39; Report $8^{\text {th }}$ meeting at para 39), to reach universal participation (Report $7^{\text {th }}$ meeting at para 44; Report $8^{\text {th }}$ meeting at para 41$)$, and to find a balance between interests, rights and obligations (Report $7^{\text {th }}$ meeting at para 40; Report $8^{\text {th }}$ meeting at para 18 ); to determine what activities should be regulated (Report $6^{\text {th }}$ meeting at para 49 ; Report $7^{\text {th }}$ meeting at para 35 ), what zones and resources should be covered (Report $7^{\text {th }}$ meeting at paras 45-46; Report $8^{\text {th }}$ meeting at paras $42-43$ ), what should be the relationship between the new instrument and existing instruments (Report $7^{\text {th }}$ meeting at para 41; Report $8^{\text {th }}$ meeting at paras 19-20 and 31-33), and whether the instrument should take a global or a regional approach (Report $8^{\text {th }}$ meeting at paras 35-36). There were also suggestions on how to include means of implementation and settlement of disputes (Report $7^{\text {th }}$ meeting at para 43), and how to address fisheries (Report $6^{\text {th }}$ meeting at para 22; Report $7^{\text {th }}$ meeting at para 47 ).

26 See, e.g. Report $7^{\text {th }}$ meeting, supra note 25 at paras $68-74$, more specifically at para 73 ; Report $8^{\text {th }}$ meeting, supra note 25 at paras 76-81, more specifically at para 81 . 
were also diverging views on what constitutes legal, regulatory and implementation gaps, and whether they should all be addressed. ${ }^{27}$

At the ninth meeting (January 2015), the Working Group concluded its work by recommending that the UNGA, in the face of the need for a comprehensive global regime, ${ }^{28}$ should develop an international legally binding instrument under UNCLOS on the conservation and sustainable use of marine biological diversity of $\mathrm{ABNJ}$. To that end, the Working Group recommended the holding of an intergovernmental conference, which would be preceded by a preparatory committee "to make substantive recommendations to the General Assembly on the elements of a draft text of an international legally binding instrument under the Convention". ${ }^{29}$ The recommendations further specified that the negotiations should be conducted on the basis of the elements of the package, and that the process should not undermine existing relevant legal instruments and frameworks and relevant global, regional and sectoral bodies. ${ }^{30}$ These final recommendations of the Working Group were adopted by the UNGA in Resolution 69/292, ${ }^{31}$ resulting in the creation of the Preparatory Committee.

The current structure of the BBNJ process was shaped by the attention given to different issues that were put forward throughout the nine meetings of the Working Group. Two are of most relevance for the present study. First, concerns were frequently expressed on whether there was really a need to develop a new instrument. Indeed, according to these views, the problems affecting biodiversity in $\mathrm{ABNJ}$ stem from a lack of implementation and political will, not from a lack of instruments and mechanisms. ${ }^{32}$ Consequently, efforts should be put towards using already existing mechanisms and building upon them. ${ }^{33}$

Tladi recalls that, in the beginning, many delegations did not support the creation of a new instrument. It is mainly the EU which was pushing forward the idea of an instrument, mostly for conservation purposes, in order to "further specify and implement" the conservation measures found under UNCLOS. ${ }^{34}$ But the Group

27 Report $7^{\text {th }}$ meeting, supra note 25 at paras 28,34 and 70 ; Report $8^{\text {th }}$ meeting, supra note 25 paras $17,25-26$, 40,77 and 81 .

28 Letter dated 13 February 2015 from the Co-Chairs of the Ad Hoc Open-ended Informal Working Group to the President of the General Assembly, UNGAOR, 69th Sess, UN Doc A/69/780 (2015) at para 1(d).

29 Ibid at para $1(\mathrm{e})$.

30 Ibid at para $1(\mathrm{f})$ and $(\mathrm{g})$.

31 Development of an international legally binding instrument under UNCLOS on the conservation and sustainable use of marine biological diversity of areas beyond national jurisdiction, GA Res 69(CCXCII), UNGAOR, 69th Sess, UN Doc A/RES/69/292 (2015).

32 The question of implementation and compliance is discussed generally in chapter 5 below.

33 Report $4^{\text {th }}$ meeting, supra note 19 at para $42-43$; Report $7^{\text {th }}$ meeting, supra note 25 at para 70 ; Report $8^{\text {th }}$ meeting, supra note 25 at para 17.

34 Dire Tladi, "Conservation and sustainable use of marine biodiversity in areas beyond national jurisdiction: towards an implementing agreement" in Rosemary Rayfuse (ed), Research Handbook on International Marine Environmental Law (Chentenham: Edward Elgar, 2017) 259-271 at 266 [Tladi, "Conservation and sustainable use"]. See also Tullio Scovazzi, "Negotiating conservation and sustainable use of marine 
of 77 (G77) and China made the "progress on the conservation and preservation issues [dependent] on the progress on the marine genetic resources question". ${ }^{35}$ The support of most delegations was finally secured thanks to the creation of the package deal: although States did not share the same views on the importance of the substantive elements (i.e. MGRs, ABMTs, EIAs, and CB\&TT), the process - an international instrument - finally gathered a majority of delegations. ${ }^{36}$ It is often informally said that the package is a compromise, MGRs and capacity-building being the priority of developing countries, and ABMTs and EIAs being pushed forward by developed countries. ${ }^{37}$

Second, fisheries-related concerns were underscored throughout the nine meetings of the Working Group. There was a general recognition of the importance of fish for biodiversity, ${ }^{38}$ the damaging impact of destructive fishing practices (including IUU fishing) on biodiversity and the wider marine environment ${ }^{39}$ and the need to work towards better collection and exchange of data on the state of fish stocks. ${ }^{40} \mathrm{In}$ addition, there was a general acknowledgement of the important role of the FAO and the UNFSA for BBNJ. ${ }^{41}$ Some delegations submitted that coastal States, having full entitlement over their continental shelf for the purpose of adopting conservation measures, should also be entitled to impose restriction on fishing activities in the high seas above the continental shelf, thereby raising the question of adjacency. ${ }^{42}$

Yet the basic - but more difficult - question on how to deal with fisheries ${ }^{43}$ is whether fisheries should be included at all in the BBNJ process, some claiming that existing instruments were sufficient to cover fishing activities; ${ }^{44}$ consequently, coordination

biological diversity in areas beyond national jurisdiction: prospects and challenges" (2014) 24 The Italian Yearbook of International Law 63-93 at 65-67.

35 Tladi, "Conservation and sustainable use", supra note 34 at 268. At that stage, only the United States, Russia, Iceland, Norway, Canada and Japan opposed the creation of an instrument, see Tladi at 269. These States expressed concern as to the instrument's scope and complexities, and also called for the consideration of other options. However, all States finally agreed to the creation of an instrument, as the final recommendations of the Working Group were adopted by consensus. See also Scovazzi, supra note 34 at 66.

36 Tladi, "Conservation and sustainable use", supra note 34 at 269.

37 Thembile Joyini, "The Role of Equity in the Governance of Biological Diversity in Areas beyond National Jurisdiction" (Presentation given at the workshop "Negotiating an Agreement on the Conservation and sustainable use of marine biological diversity of areas beyond national jurisdiction", Utrecht, 12 February 2020). On how the elements of the package deal were influenced by different parties, see, generally, Millicay, supra note 9.

38 See, e.g. Report $1^{\text {st }}$ meeting, supra note 18 at para 51.

39 See, e.g. Ibid at paras 7, 8, 24, 26, 33, 37, 51 and 57; Report $2^{\text {nd }}$ meeting, supra note 18 at paras 7, 13 and 18 ; Report $6^{\text {th }}$ meeting, supra note 25 at para 14 ; Report $8^{\text {th }}$ meeting, supra note 25 at para 8.

40 See e.g. Report $1^{\text {st }}$ meeting, supra note 18 at para 45; Report $3^{\text {rd }}$ meeting, supra note 18 at para 34.

41 See e.g. Report $1^{\text {st }}$ meeting, supra note 18 at para 15 ; Report $5^{\text {th }}$ meeting, supra note 22 at para 29.

42 This is discussed in chapter 2 section 3.3 .3 above, and is also addressed in section 3.3 below.

43 Report $7^{\text {th }}$ meeting, supra note 25 at 19 , where the Informal Co-Chair's overview of issues specifically asks "How to deal with fisheries?".

44 See e.g. Report $1^{\text {st }}$ meeting, supra note 18 at para 45; Report $2^{\text {nd }}$ meeting, supra note 18 at para 40; Report $3^{\text {rd }}$ meeting, supra note 18 at paras 42,43 and 44 ; Report $6^{\text {th }}$ meeting, supra note 25 at para 22; Report $7^{\text {th }}$ meeting, supra note 25 at paras 41 and 47 ; Report $8^{\text {th }}$ meeting, supra note 25 at paras 19 and 35 ; Report $9^{\text {th }}$ meeting, supra note 28 at paras 15 and 19. 
and cooperation among instruments and bodies, rather than new provisions, should be focused on. ${ }^{45}$ Certain delegations defended the need for further legal and regulatory development, claiming that the regulation of fisheries on the high seas remained fragmented as to geographical and regulatory coverage. There was also the question of whether new mechanisms would interfere with or unnecessarily duplicate the work of RFMOs. ${ }^{46}$ Others argued that RFMOs did not have particular competences in conservation issues, and advocated for strengthening their mandate or creating new ones. ${ }^{47}$ The role of RFMOs in the development of EIAs, strategic environmental assessments (SEAs) and ABMTs was also mentioned and, conversely, so were the potential impacts that the establishment of ABMTs could have on fishing activities ${ }^{48}$ Despite much discussion on the topic, the Working Group did not come to any clear conclusion on the inclusion (or not) of fisheries in the BBNJ process, and, if they were to be included, on how to include them. ${ }^{49}$

Notwithstanding the lack of consensus on the scope and parameters of an eventual instrument within the next stages of the process, as well as the scope ratione materiae of such an instrument, delegations agreed that the UNGA remained the right forum to discuss this issue..$^{50}$ The work on $\mathrm{BBNJ}$ continued, transitioning from the Working Group to the PrepCom.

\subsection{Preparatory Committee (2016-2017)}

In June 2015, based on the commitments undertaken at the Rio+20 Conference and in The Future We Want, ${ }^{51}$ and based on the views exchanged on the recommendations of the Working Group, the UNGA decided to establish the PrepCom "to make substantive recommendations to the General Assembly on the elements of a draft text of an international legally binding instrument under the Convention, $[\ldots]$ to study issues relating to the conservation and sustainable use of marine biological

45 See e.g. Report $1^{\text {st }}$ meeting, supra note 18 at para 24; Report $3^{\text {rd }}$ meeting, supra note 18 at paras 12 and 59 ; Report $5^{\text {th }}$ meeting, supra note 22 at para 13 ; Report $8^{\text {th }}$ meeting, supra note 25 at para 43.

46 See e.g. Report $1^{\text {st }}$ meeting, supra note 18 at para 9; Report $4^{\text {th }}$ meeting, supra note 19 at para 14.

47 See e.g. Report $1^{\text {st }}$ meeting, supra note 18 at para 25; Report $4^{\text {th }}$ meeting, supra note 19 at para 55; Report $5^{\text {th }}$ meeting, supra note 22 at para 30.

48 See e.g. Report $1^{\text {st }}$ meeting, supra note 18 at paras 10 and 59; Report $2^{\text {nd }}$ meeting, supra note 18 at para 28; Report $3^{\text {rd }}$ meeting, supra note 18 at paras 52 and 66; Report $4^{\text {th }}$ meeting, supra note 19 at para 54; Report $6^{\text {th }}$ meeting, supra note 25 at para 6; Report $7^{\text {th }}$ meeting, supra note 25 at para 60 ; Report $8^{\text {th }}$ meeting, supra note 25 at paras 25 and $60-61$.

49 The potential impact of the Agreement on fisheries is discussed in section 4 below.

50 See, e.g., Report $1^{\text {st }}$ meeting, supra note 18 at paras 6-7; Report $3^{\text {rd }}$ meeting, supra note 18 at para 30; Report $4^{\text {th }}$ meeting, supra note 19 at para 9; Report $5^{\text {th }}$ meeting, supra note 22 at para 10 ; Report $6^{\text {th }}$ meeting, supra note 25 at para 12; Report $7^{\text {th }}$ meeting, supra note 25 at para 13.

51 The future we want, GA Res 66(CCLXXXVIII), UNGAOR, 66th Sess, UN Doc A/RES/66/288 (2012). See also chapter 2 section 3.2.3 above. 
diversity beyond areas of national jurisdiction".52 The PrepCom met on four occasions over the course of two years (2016-2017). ${ }^{53}$

Two elements found under Resolution 69/292 are of particular interest, as they have repeatedly arisen in the interventions made by delegates during the PrepCom and have shaped the course of the discussions. First, the preamble to the Resolution stresses "the need for a comprehensive global regime to better address the conservation and sustainable use of" BBNJ, pointing towards the necessity to develop a framework that is inclusive of all relevant activities taking place in $\mathrm{ABNJ}$ and of all the concerns that ensue. It also underlines the expected global, integrated and interconnected focus within the Agreement. The integration of the different elements of the package was in fact a significant characteristic throughout the work undertaken by the PrepCom. ${ }^{54}$ Second, Resolution 69/292 recognizes that, while working towards the conservation and sustainable use of BBNJ, the process should not undermine existing relevant legal instruments, frameworks and bodies. ${ }^{55}$ This influences the interpretation of the relationship between the instrument and other existing instruments, as well as between structures and bodies. ${ }^{56}$

The PrepCom met for the first time in March-April 2016, ${ }^{57}$ and its work was described as an unpacking and defragmenting exercise, ${ }^{58}$ reaching the stage of addressing the hows and not only the ifs. ${ }^{59}$ The work of the PrepCom also recognized the importance of interconnectedness, interlinkages and integration, thereby addressing the fragmented framework and the legal, regulatory, governance and implementation gaps that had so far been characterizing ABNJ. This focus on linkages also brought to light the connections between the Agreement and other instruments and mechanisms, which had evolved and grown in numbers since the beginning of the BBNJ process 10 years earlier. This connection with existing structures also raised some concerns from Japan, Iceland and Russia, among others, about the risk of interfering with RFMOs, especially when discussing measures related to ABMTs. ${ }^{60}$ Indeed, although there was a convergence of views on the fact

52 UNGA Res 69/292, supra note 31 at para $1($ a).

53 For an overview of the main points of discussion before PrepCom 3, see Ashley Roach, "Update on the BBNJ negotiations" in Myron Nordquist, John Norton Moore \& Ronan Long (eds) Legal Order in the World's Oceans. UN Convention on the Law of the Sea (Leiden, Boston: Brill Nijhoff, 2018) 91-123 at 101-107.

54 Richard Barnes, "The Proposed LOSC Implementation Agreement On Areas Beyond National Jurisdiction and Its Impact on International Fisheries Law" (2016) 31:4 International Journal of Marine and Coastal Law 583-619 at 591 [Barnes, "The Proposed LOSC IA"].

55 Ibid at para 3.

56 This is discussed in sections 4.2 and 4.3 below.

57 The discussion about PrepCom 1 conducted in the present paragraph is based on IISD, "Summary of the First Session of the Preparatory Committee on Marine biodiversity of areas beyond National Jurisdiction: 28 March - 8 April 2016" (2016) 25:116 Earth Negotiations Bulletin at 18-20 [Summary PrepCom 1]; and Chair's overview of the first session of the Preparatory Committee (April 2016), online: <https:// www.un.org/Depts/los/biodiversity/prepcom_files/PrepCom_1_Chair's_Overview.pdf>[Chair's overview PrepCom1].

58 Summary PrepCom 1, supra note 57 at 18.

59 Ibid.

60 Ibid at 4 
that ABMTs are good tools for conservation and sustainable use, major divergences seemed to exist on the way to designate such areas, which could interfere with the mandate of existing entities such as RFMOs. ${ }^{61}$ The question of how to deal with fisheries came up early on in the PrepCom's discussions, more specifically on whether to include or exclude fisheries management measures from the scope of the instrument, and on whether fish should be seen as a commodity or for their value as genetic material (and therefore falling under the scope of MGRs). ${ }^{62}$ Finally, some preliminary discussions started on eventual institutional arrangements, mostly related to MGRs and EIAs, suggesting a governing body, scientific/advisory committee and a compliance body. ${ }^{63}$

The second PrepCom (August-September 2016) ${ }^{64}$ saw delegations make more detailed proposals, even some suggestions for draft elements of the text of the instrument. The discussions were also marked by a greater - and more vocal presence of RFMOs, which defended their good practices. They were opposed by NGOs, which claimed that change still needed to be achieved, as RFMOs' priority remained fisheries and not conservation. ${ }^{65}$ Further, a working group on crosscutting issues was created and started its work. It mostly addressed questions related to the form of an instrument, the aim of universal participation, the relationship between the Agreement and other instruments and the necessity not to undermine existing structures, and whether - and if so how - guiding principles apply to all the elements of the package. This working group also discussed institutional arrangements, suggesting a decision-making forum, a scientific body and the possibility for a dispute resolution mechanism. ${ }^{66}$ It is also to be noted that the UNFSA Review Conference held three months before discussed questions related to the BBNJ process, especially in terms of cooperation and coordination between structures and instruments, and of the importance of performance reviews. ${ }^{67}$

61 Ibid at 19.

62 See, e.g., Chair's overview PrepCom1, supra note 57 at 6-7.

63 Ibid at 12 and 15.

64 The discussion about PrepCom 2 conducted in the present paragraph is based on IISD, "Summary of the Second Session of the Preparatory Committee on Marine biodiversity of areas beyond National Jurisdiction: 26 August - 9 September 2016" (2016) 25:118 Earth Negotiations Bulletin at 18-20 [Summary PrepCom 2]; and Chair's overview of the second session of the Preparatory Committee (September 2016), online: <https://www.un.org/Depts/los/biodiversity/prepcom_files/Prep_Com_II_Chair_overview_to_ MS.pdf> [Chair's overview PrepCom2].

65 Summary PrepCom 2, supra note 64 at 7.

66 Chair's overview PrepCom2, supra note 64 at 2 and 11-14.

67 IISD, "Summary of the Resumed Review Conference on the Agreement for the Implementation of the Provisions of the UN Convention on the Law of the Sea (UNCLOS) 1982 Relating to the Conservation and Management of Straddling Fish Stocks and Highly Migratory Fish Stocks: 23-27 May 2016" (2016) 7:71 Earth Negotiations Bulletin at 9 and 12. 
In March-April 2017, the Committee met for a third time, ${ }^{68}$ in a climate of great interest in the oceans, with the UN Ocean Conference to be held two months later. ${ }^{69}$ This third meeting was characterized by more clarity on architectural options for the instrument, and on more extensive discussions on "not to undermine", although without any clear conclusions on its exact meaning and scope. What became central to PrepCom 3 was the discussion on whether to develop the instrument's structural architecture on a global, regional/sectoral or hybrid model..$^{70}$ Raised in the context of ABMTs, it did not take long for these global/regional/hybrid suggestions to spread to the whole structural development of the instrument. The debate on what model to adopt was expected to explore views on "whether the 'centre of gravity' lies within a new global body or existing regional ones". ${ }^{11}$ This targets the necessary institutional arrangements and shapes the practical application of cooperation and coordination. ${ }^{72}$

The fourth and final meeting of the PrepCom (July 2017) ${ }^{73}$ benefitted from the "oceans momentum" created by the UN Ocean Conference. Indeed, delegates were building on the reiterated urgency to act, referring to the fact that the BBNJ process should also work in that direction, considering that the PrepCom had reached the stage of preparing recommendations to the UNGA. The agenda of PrepCom 4 took a more flexible format than previous meetings, and sessions were left open for delegations and groups to work among themselves or individually. ${ }^{74}$

The discussions led to the recommendations of the PrepCom, which are divided into two sections. Section A includes non-exhaustive elements that generated convergence among most delegations. Section B, for its part, lists the main issues on which there was divergence. ${ }^{75}$ This structure, and the specific mention that both

68 The discussion about PrepCom 3 conducted in the present paragraph is based on IISD, "Summary of the Third Session of the Preparatory Committee on Marine biodiversity of areas beyond National Jurisdiction: 27 March - 7 April 2017” (2017) 25:129 Earth Negotiations Bulletin at 14-16 [Summary PrepCom 3]; Chair's overview of the third session of the Preparatory Committee (April 2017), online: <https://www. un.org/Depts/los/biodiversity/prepcom_files/Chair_Overview.pdf> [Chair's overview PrepCom3].

69 The UN Ocean Conference, held in New York from 5-9 June 2017, gathered together State actors, scientists, civil society, academics and the private sector in order to raise awareness of the conservation and sustainable use of oceans and their resources. The aim of the Conference was also to mobilize action for the implementation of SDG 14. Various fisheries related topics were addressed, such as fisheries subsidies, overfishing, IUU fishing, and the importance of cross-sectoral dialogues between RFMOs and RSPs, see United Nations Ocean Conference (New York, USA, 5-9 June 2017), online: <https://oceanconference. un.org/about>. The UN Ocean Conference is also discussed in chapter 2 section 3.2.3 above.

70 Chair's overview PrepCom3, supra note 68 at 12.

71 Summary PrepCom 3, supra note 68 at 15.

72 See section 4.2 below.

73 The discussion about PrepCom 4 conducted in the present paragraph is based on IISD, "Summary of the Fourth Session of the Preparatory Committee on Marine biodiversity of areas beyond National Jurisdiction: 10-21 July 2017" (2017) 25:141 Earth Negotiations Bulletin at 19-20 [Summary PrepCom 4].

74 Provisional programme of work, Preparatory Committee established by General Assembly resolution 69/292: Development of an international legally binding instrument under the United Nations Convention on the Law of the Sea on the conservation and sustainable use of marine biological diversity of areas beyond national jurisdiction, 4th Sess, UN Doc A/AC.287/2017/PC.4/L.2 (2017).

75 These convergences and divergences are discussed further in sections 3 and 4 below. 
sections do not reflect consensus and do not represent all options discussed, was the formulation that succeeded in bringing some of the big players - Russia, the US, and to some extent China - on board. This compromise was initially very negatively received by the G77. In fact, the group was disappointed by this looser structure, and questioned how these elements could be used as conversation starters if they were labelled as not representing consensus. The G77's support for the final text was finally half-heartedly given, after a three-hour long debate behind closed doors, to avoid having to put the text to a vote. The final text of the recommendations ${ }^{76}$ was characterized by many as a delicate balance, representing the compromise that many delegations had to make in order to have the recommendations adopted by consensus. Such consensus was not only required under para 1(h) of Resolution $69 / 292$, but was also the aim to be reached to give a strong message about universal participation and a common will to hold an intergovernmental conference.

The Report of the PrepCom, including its recommendations, was adopted by the UNGA in December 2017, resulting in the convening of an intergovernmental conference to develop the text of an international legally binding instrument under UNCLOS on the conservation and sustainable use of marine biodiversity in ABNJ. ${ }^{77}$ Resolution $72 / 249$, although not referring to the need for a comprehensive global approach as found in resolution 69/292, retains the wording related to the need for the process and its result not to undermine existing relevant instruments, frameworks and bodies. ${ }^{78}$

\subsection{Intergovernmental Conference (2018-?)}

Following an organizational meeting in April 2018, which established the format, provisional agenda, and organization of work for the first session of the IGC, as well as the preparation of a document to guide discussions, ${ }^{79}$ the IGC met for its first session in September $2018 .^{80}$ In order to streamline the work of the conference, the conference's president, Rena Lee from Singapore, prepared the President's aid to

76 Report of the Preparatory Committee established by General Assembly resolution 69/292: Development of an international legally binding instrument under the United Nations Convention on the Law of the Sea on the conservation and sustainable use of marine biological diversity of areas beyond national jurisdiction, Preparatory Committee established by General Assembly resolution 69/292: Development of an international legally binding instrument under the United Nations Convention on the Law of the Sea on the conservation and sustainable use of marine biological diversity of areas beyond national jurisdiction, 4th Sess, UN Doc A/AC.287/2017/PC.4/2 (2017) [Report PrepCom].

77 UNGA Res $72 / 249$, supra note 2 at para 1.

78 Ibid at para 7.

79 IISD, "Summary of the Organizational Meeting for the Intergovernmental Conference on an International Legally Binding Instrument under the UN Convention on the Law of the Sea on the Conservation and Sustainable Use of Marine Biological Diversity of Areas Beyond National Jurisdiction: 16-18 April 2018" (2018) Earth Negotiations Bulletin.

80 For a recent overview of all three sessions of the IGC, see Efthymios Papastavridis, "A recent overview of the three sessions of the IGC can be found in The Negotiations for a New Implementing Agreement under the UN Convention on the Law of the Sea Concerning Marine Biodiversity" (2020) 69 International and Comparative Law Quarterly 585-610 at 591-593. 
discussions,$^{81}$ a document containing a list of questions and issues to be considered by delegations. This document format was appreciated by some, who considered that many delegations were not yet ready to engage in textual negotiations as no real consensus on the elements of a draft text had been achieved at the end of the PrepCom. Others, however, deplored the "PrepCom 5" format and the absence of a draft treaty text to ensure that discussions would move forward. In terms of substantial content, similar convergences and divergences remained. Within MGRs, the debates between common heritage of humankind and freedom of the high seas, and between monetary and non-monetary benefits persisted, although suggestions were made as to a hybrid regime, e.g. freedom of access, but common heritage of humankind in benefit sharing. Within EIAs, questions remained as to the internationalization of decision-making, as well as the inclusion of other types of assessments, such as SEAs and cumulative impact assessments (CIAs), which are found under other instruments. ${ }^{82}$ More progress seemed to have been achieved regarding ABMTs, although the format of decision-making (i.e. global or regional) remained a point of divergence. At the end of the session, there seemed to be a general agreement that the Conference should move away from concepts and delve into textual negotiations. ${ }^{83}$

The IGC resumed for its second session (March-April 2019) and focused its work on the President's aid to negotiations, ${ }^{84}$ a document containing an (almost) exhaustive list of options for treaty language still on the table for consideration. Delegates were asked by the president to "consider ideas and proposals that may narrow the range of options"; 85 yet, they mostly expressed preferences on text options laid out in the aid to negotiations. Some delegations said that it was a necessary exercise to understand where compromises needed to be made. Some additional points were identified as necessitating further discussions, including, in MGRs, the potential insertion of digital sequence information and derivatives, and questions of intellectual property

81 President's aid to discussions, Intergovernmental conference on an international legally binding instrument under the United Nations Convention on the Law of the Sea on the conservation and sustainable use of marine biological diversity of areas beyond national jurisdiction, 1st Sess, UN Doc A/CONF.232/2018/3 (2018).

82 IISD, "Summary of the First Session of the Intergovernmental Conference on an International Legally Binding Instrument under the UN Convention on the Law of the Sea on the Conservation and Sustainable Use of Marine Biodiversity of Areas Beyond National Jurisdiction: 4-17 September 2018" (2018) 25:179 Earth Negotiations Bulletin at 16 [Summary IGC 1]. SEAs, although not discussed under UNCLOS, are for example found under art. 14 CBD. Similarly, CIAs are recommended under the Voluntary Guidelines on Biodiversity-Inclusive Environmental Impact Assessment Contents, Annex to Impact assessment: Voluntary guidelines on biodiversity-inclusive impact assessment, CBD COP decision VIII/28, COP 8, UNEP/CBD/ COP/8/28 (2006).

83 See, generally, Summary IGC 1, supra note 82.

84 President's aid to negotiations, Intergovernmental Conference on an international legally binding instrument under the United Nations Convention on the Law of the Sea on the conservation and sustainable use of marine biological diversity of areas beyond national jurisdiction, 2nd Sess, UN Doc A/CONF.232/2019/1 (2019).

85 IISD, "Summary of the Second Session of the Intergovernmental Conference on an International Legally Binding Instrument under the UN Convention on the Law of the Sea on the Conservation and Sustainable Use of Marine Biodiversity of Areas Beyond National Jurisdiction: 25 March - 5 April 2019" (2019) 25:195 Earth Negotiations Bulletin at 17 [Summary IGC 2]. 
rights, in EIAs, the mandatory or discretionary nature of components of assessments, and in ABMTs, the question of implementation, monitoring and review. ${ }^{86}$

The IGC met for a third session in August 2019. For the first time since the beginning of the IGC, the discussions were led on the basis of a draft treaty text. ${ }^{87}$ The format of discussions also changed, where "informal informals" sessions were conducted to allow delegates to go deeper into certain issues. However, these sessions, accessible only to State delegates and a restricted number of delegates from NGOs and international organizations, raised questions in terms of transparency and availability of the information, not only for the general public, but also for smaller delegations which could not attend several parallel sessions ${ }^{88}$ On top of the recurrent progress and divergences regarding the four elements of the package deals, the IGC also addressed cross-cutting issues such as the question of institutional arrangements. While the creation of main bodies such as a COP, a scientific/technical body and a clearing-house mechanism seemed to gather consensus, defining the scope of their mandate remains a work in progress. ${ }^{89}$ There also seems to be general consensus regarding the provision on the relationship between the Agreement and other relevant instruments, frameworks and bodies, although questions on the practical implications of "not undermining", ${ }^{90}$ recurrent since the PrepCom, remained.

This question of the relationship with existing structures is of particular relevance when addressing fisheries in ABNJ. While the draft text formally excluded commercial fisheries from the scope of the Agreement, ${ }^{91}$

views remain far apart [...] on whether to include fish as a commodity or for their genetic properties - an issue that has been at the heart of negotiations from the early days of the Preparatory Committee [...]. Those opposed to including fish as a commodity have long pointed to existing management arrangements. Those in favor point to the lack of global management and oversight of this sector, with several developing countries "left vulnerable" to depleting fish stocks within their national jurisdiction, which have been overexploited by others in areas beyond national jurisdiction. ${ }^{92}$

86 See, generally, ibid.

87 Draft text of an agreement under the United Nations Convention on the Law of the Sea on the conservation and sustainable use of marine biological diversity of areas beyond national jurisdiction, Intergovernmental Conference on an international legally binding instrument under the United Nations Convention on the Law of the Sea on the conservation and sustainable use of marine biological diversity of areas beyond national jurisdiction, 3rd Sess, UN Doc A/CONF.232/2019/6 (2019) [Draft text].

88 IISD, "Summary of the Third Session of the Intergovernmental Conference (IGC) on the Conservation and Sustainable Use of Marine Biodiversity of Areas Beyond National Jurisdiction: 19-30 August 2019" (2019) 25:218 Earth Negotiations Bulletin at 21-22 [Summary IGC 3].

89 Draft text, supra note 87 at arts. 48-51.

$90 \mathrm{Ibid}$ at art. 4(3).

91 Ibid at art. 8(3)(a).

92 Summary IGC 3 , supra note 88 at 22. 
This observation underlines that, in the absence of a direct application of the Agreement to fisheries in ABNJ, there is a need to understand better the role that the Agreement could play as a catalyst for cooperation and coordination within the fisheries, an issue further discussed below. ${ }^{93}$

The fourth and last planned meeting under the initial mandate of the IGC was supposed to take place in late March 2020 and to discuss the Revised draft text $t^{94}$ published by the President in November 2019. This meeting was, however, postponed due to the COVID-19 pandemic, ${ }^{95}$ and, at the time of writing, the meeting had not yet been rescheduled. ${ }^{96}$ Following the publication of the Revised draft text, the President had asked delegations to submit observations and proposals in preparation for the fourth meeting, and in light of the postponement, published these proposals on 15 April 2020 in the form of an article-by-article compilation. ${ }^{97}$

Several proposals touching upon fisheries and/or the Agreement's role in cooperation and coordination stand out. First, while South Africa agrees to exclude fish from the scope of application of Part II of the Agreement (MGRs), it reiterates its firm position on not excluding fisheries management from the scope of the whole instrument, as "some of the [ABMTs] may need to include measures on fish and fishing if they are to be effective in ensuring conservation and sustainable use in ABNJ". ${ }^{98}$ This is also supported by its comment on article 16 on the identification of areas requiring protection, where it mentions that clarification should be given as to whether "areas that are under management for a particular sector objective, such as particular fish species, should still be able to be considered under indicative criteria for identification for conservation and other management objectives under this treaty", something that, according to South Africa, remains unclear. ${ }^{99}$

Second, an interesting proposal made by Iceland targets the notion of cooperation found under article 6 of the Revised draft text. ${ }^{100}$ The current, quite broad, language of article 6 provides that States parties to the Agreement must cooperate notably

93 See section 4.1 below.

94 Revised draft text, supra note 4.

95 Draft decision, supra note 3.

96 Informal talks with NGO representatives have revealed that many delegations are exerting pressure to have the meeting held in late 2020, but it is most likely to be rescheduled to 2021 .

97 Textual proposals submitted by delegations by 20 February 2020, for consideration at the fourth session of the Intergovernmental conference on an international legally binding instrument under the United Nations Convention on the Law of the Sea on the conservation and sustainable use of marine biological diversity of areas beyond national jurisdiction (the Conference), in response to the invitation by the President of the Conference in her Note of 18 November 2019 (A/CONF.232/2020/3) (15 April 2020), online: <https:// www.un.org/bbnj/sites/www.un.org.bbnj/files/textual_proposals_compilation_article-by-article_-_15_ april_2020.pdf> [Textual proposals].

98 Ibid at 68.

99 Ibid at 149.

$100 \mathrm{Ibid}$ at 52-54. The Icelandic proposal is also discussed in detail in Vito De Lucia, "Squaring the Oceanic Circle? On Regional Approaches to the Conservation of Marine Biodiversity in Areas beyond National Jurisdiction" (9 May 2020) NCLOS Blog, online: <http://site.uit.no/nclos/files/2020/05/Vito-De-LuciaRegional-Governance-BBNJ-.pdf $>$. 
through enhancing and strengthening cooperation with existing instruments, frameworks and bodies. What Iceland suggests is a specific procedure with regard to Part III (ABMTs) and Part IV (EIAs) of the Agreement, a procedure where regional consultations would be held with the regional and sectoral entities (e.g. RFMOs, RSPs, IMO, etc.) operating in a specific region in order to achieve cooperation. ${ }^{101}$ It also suggests the establishment of a "regional body with a mandate to establish conservation and management measures to protect biodiversity from specific human activities in ABNJ" in regions where none exists. The Icelandic proposal has been considered as having the merit of balancing "the need for an overall set of common rules and principles with the realities of regional and sectoral fragmentation." ${ }^{102}$ It has also been compared with the cooperative structure of the Collective Arrangement between OSPAR and NEAFC ${ }^{103}$ which also aims for a multisectoral platform for dialogue in the North-East Atlantic. ${ }^{104}$ It could, however, be understood from an additional suggestion by Iceland, which would include an article 6 bis reading " $t \mathrm{t}]$ his Agreement does not apply to conservation and management of fish stocks", ${ }^{105}$ that the above-mentioned consultation process would not apply to RFMOs. ${ }^{106}$ This interpretation, however, would not be consistent with the content of the proposal for a consultation process, which explicitly refers to RFMOs. ${ }^{107}$

Despite different points of interest standing out at each stage of the IGC, what is clear is the convergence of views on the role of this instrument as providing coordination and cooperation. Nonetheless, much work remains to be done in terms of the modalities on how this cooperation and coordination can be achieved in practice.

\section{THE BBNJ AGREEMENT AS A TOOL FOR COOPERATION AND COORDINATION IN ABNJ}

The overview conducted above has shown how issues related to the rights, obligations and interests of different parties in the conservation and sustainable use of BBNJ have been put forward throughout the different stages of the negotiations.

101 Nicaragua also supports such consultations, mentioning that the BBNJ should not interfere with the work done by other fisheries entities and/or the FAO, and that there should be an obligation to consult with fisheries entities when binding measures that could affect fisheries are taken, see Textual proposals, supra note 97 at 402-403.

102 De Lucia, supra note 100 at 3.

103 Ibid at 4.

104 Collective arrangement between competent international organisations on cooperation and coordination regarding selected areas in areas beyond national jurisdiction in the North-East Atlantic, OSPAR Agreement 2014-09, online: <https://www.ospar.org/documents?v=33030>.

105 Textual proposals, supra note 97 at 57.

106 De Lucia, supra note 100 at 5.

107 Paragraph b of the proposal reads as follows: "Relevant international legal instruments and frameworks and global, regional and sectoral bodies with competence under international law to control human activities in areas beyond national jurisdiction, including intergovernmental organizations for the protection of the marine environment, regional fisheries management organizations, the International Maritime Organization, the International Seabed Authority, shall, as appropriate, participate in regional consultation processes", see Textual proposals, supra note 97 at 53. 
The present section builds on this overview and focuses on how coordination and cooperation among those rights, obligations and interests are now taking shape within the Agreement. ${ }^{108}$ In that regard, this section analyses the potential contribution of the Agreement to cooperation and coordination through five selected aspects: the inclusion of the principles governing the oceans (3.1); the four elements of the package deal (3.2); the interaction between the law of the sea and environmental law, the two legal regimes being the focus of the present study (3.3); the question of the rights and interests of third States and coastal States, also known as "adjacency" (3.4); and the strengthening of compliance and monitoring, control and surveillance (MCS) (3.5). These five elements of a cross-cutting nature have been selected because of the potential impact they could have on the fisheries regime, mostly at a structural level. ${ }^{109}$

\subsection{Coherence through principles}

The present section aims to present a brief overview of the way the principles governing the high seas ${ }^{110}$ are being included in the BBNJ Agreement and, consequently, how they would apply to the conservation and sustainable use of BBNJ. This sheds light on the way those principles contribute to aligning the Agreement with other instruments of the law and the sea and environmental/biodiversity law regimes. Most importantly, principles guide States on the way to give effect to their duty to conserve and sustainably use BBNJ. ${ }^{111}$ The principles included in the Agreement and upon which it is developed contribute to coherence (within the Agreement itself and between the Agreement and other instruments) and, thus, to making the Agreement a tool for strengthening cooperation and coordination.

The principles are also meant to ensure guidance in the understanding and implementation of the obligations found under the Agreement. These principles underline the values upon which the Agreement is developed, and they advise what should be done in order to achieve good management for the conservation and sustainable use of BBNJ. ${ }^{12}$ Many of the principles are found in the list of general

108 It has been reported that, in the Revised draft text, the term 'cooperation' is found 24 times, the term 'coordination' 14 times, and the term 'coherence' five times, see Julien Rochette, Klaudija Cremers \& Glen Wright, "Les enjeux de coordination entre le futur traité haute mer et les organisations existantes" (Presentation delivered at the 16ème reunion du Groupe informel haute mer, 24 June 2020).

109 The structural level refers not only to the institutional structure (i.e. mandate of RFMOs, the way they interact among themselves, and also with other entities having competences in the same sector or geographical area) but also to the legal framework (i.e. how existing instrument will have to interact with the new BBNJ Agreement).

110 The principles governing the high seas are discussed in chapter 3 section 3.1 above.

111 In the same way as art. 5 UNFSA, see Kristina M. Gjerde, Nichola A. Clark \& Harriet R. Harden-Davies, "Building a Platform for the Future: the Relationship of the Expected New Agreement for Marine Biodiversity in Areas beyond National Jurisdiction and the UN Convention on the Law of the Sea" (2019) 33 Ocean Yearbook 3-44 at 26.

112 Richard Barnes, "Future fisheries and ABNJ" in Vito De Lucia, Lan Ngoc Nguyen \& Alex Oude Elferink (eds), International Law and Marine Areas beyond National Jurisdiction: Current Status and Future Trends (forthcoming) [Barnes, "Future fisheries"]. 
principles and approaches, ${ }^{113}$ while others have also found their way into other provisions of the Agreement and are informing the fulfilment of specific obligations.

First, three of the principles governing the high seas, namely the protection and preservation of the marine environment, sustainable use and international cooperation, are intrinsic to the core objectives of the Agreement. ${ }^{114}$ International cooperation is further reflected in article 6, where States are called upon to cooperate to achieve conservation and sustainable use of BBNJ, to strengthen and enhance cooperation among instruments, frameworks and bodies, and to promote cooperation in marine scientific research and the transfer of marine technology.

Second, the principle of the respect for the law of the sea permeates the role of the Agreement as an implementing agreement under UNCLOS, and which must be "interpreted and applied in the context of and in a manner consistent with" UNCLOS. ${ }^{115}$ The need for the Agreement to be "interpreted and applied in a manner that [respects the competences of and] does not undermine relevant"116 existing structures also reflects a respect for such structures. The "not undermining" requirement has however raised some difficulties in understanding the scope of application of the Agreement, an issue discussed in further detail in section 4.3 below.

Third, the precautionary ${ }^{117}$ and ecosystem approaches, ${ }^{118}$ the use of best available science ${ }^{119}$ as well as the principle of equity ${ }^{120}$ are reflected in the list of general principles and approaches of article 5. The "non-transfer, directly or indirectly, of damage or hazards from one area to another and the non-transformation of one type of pollution into another"121 could also be understood as forming part of the overarching principle for the protection and preservation of the marine environment. The first three are also founder under specific provisions related to different elements of the package deal, mainly with respect to ABMTs and EIAs. In fact, the precautionary and ecosystem approaches, as well as the reliance on best available science are found in the criteria to take into account for the identification of areas subject to ABMTs, ${ }^{122}$ and for the monitoring and review of such ABMTs. ${ }^{123}$

113 Revised draft text, supra note 4 at art. 5.

114 Ibid at art. 2, which reads "The objective of this Agreement is to ensure the [long-term] conservation and sustainable use of marine biological diversity of areas beyond national jurisdiction through effective implementation of the relevant provisions of the Convention and further international cooperation and coordination." The protection and preservation of the marine environment is here understood as forming part of the need to conserve the marine environment.

115 Ibid at art. 4(1).

116 Ibid at art. 4(3).

117 Ibid at art. 5(e).

$118 \mathrm{Ibid}$ at art. 5(f), but also found under the notions of ecosystem resilience and integrity of art. 5(h).

119 Ibid at art. 5(i).

$120 \mathrm{Ibid}$ at art. 5(d)

$121 \mathrm{Ibid}$ at art. 5(j).

122 Ibid at art. 16(1).

123 Ibid at art. 21(4). 
The ecosystem approach, for its part, also inform the notion of cumulative impacts, ${ }^{124}$ the need to rehabilitate and restore ecosystems as an objective of ABMTs, ${ }^{125}$ and the thresholds and criteria for EIAs, i.e. when States have reasonable grounds to believe there is potential harm to the marine environment and ecosystems. ${ }^{126}$

The principle for the public availability of information, and a transparent and open decision making processes is translated primarily through the creation of a clearing-house mechanisms, which aims to increase transparency and access to information. ${ }^{127}$ More specifically, public access to information/transparency/open decision-making are also visible through the need to make some documents and processes public, e.g., proposals for ABMTs, ${ }^{128}$ monitoring and review reports of ABMTs, ${ }^{129}$ decision-making documents for EIAs, ${ }^{130}$ decisions of the COP. ${ }^{131}$ There should also be public notifications and consultations for EIAs. ${ }^{132}$

Undoubtedly, the principles governing the high seas have strongly guided the development of the Agreement and have permeated its objectives, list of general principles and approaches, as well as many of its substantive provisions. It is to be noted, however, that most of the references to the principles discussed above remain for now under considerations (i.e. bracketed) in the text, and they are currently subject to variations under the many proposals made by delegations. ${ }^{133}$ Further, the principle of stewardship, now only addressed in the preamble to the Agreement, ${ }^{134}$ could be reflected in stronger provisions for implementation and compliance, which have so far not been discussed at great length. ${ }^{135}$ This could help strengthen States' accountability in the shared interest in and responsibility for the conservation and sustainable use of BBNJ. In any case, it is only once the final text is adopted that it will be possible to fully grasp the extent to which principles are expected to guide the Agreement's application, and, consequently, its role for strengthening cooperation and coordination in $\mathrm{ABNJ}$.

\footnotetext{
124 Ibid at art. 1(6).

125 Ibid at art. 14(e).

126 Ibid at art. 24(1 alt.2)(b).

127 Ibid at art. 51(4)(e).

128 Ibid at art. 18(2).

129 Ibid at art. 21(1).

130 Ibid at art. 38(3).

131 Ibid at art. 48(3 ter).

132 Ibid at art. 34 .

133 See, generally, Textual proposals, supra note 97.

134 "Desiring to act as stewards of the ocean in areas beyond national jurisdiction on behalf of present and future generations".

135 Implementation and compliance are discussed in sections 3.5 and 4.2 below.
} 


\subsection{A "rulebook" for the elements of the package deal}

Some of the initial cross-cutting provisions of the Agreement illustrate the role that the instrument plays for cooperation in ABNJ. ${ }^{136}$ Yet, in its aim to foster cooperation and coordination, the Agreement is first and foremost expected to do so with regard to the elements of the package deal. Simply put, it is meant as a big "rulebook" for these four elements, as a series of guidelines to make sure that all States conduct the activities in a coherent way. For example, it tells States what steps they should follow when they want to create a MPA on the high seas, from the identification of the area, to the implementation and monitoring of the area. It tells States what to do when collecting or accessing marine genetic resources and what they should do with the benefits that ensue. It tells States how EIAs should be conducted, what should be included in these assessments, and what issues should be considered such as transboundary impacts or cumulative impacts. It tells States what should be considered as capacity-building measures and how they should be performed.

For ABMTs and EIAs, the two elements of the package deal expected to have more direct implications for the regulatory and management framework for fisheries, the Agreement's role as a "rulebook" is mostly apparent in terms of the criteria and procedure to be followed. For example, with regard to ABMTs, the Agreement attempts to clarify the procedure and criteria that can be relied upon for the identification of areas, ${ }^{137}$ the preparation of the proposals ${ }^{138}$ and the review and assessment of such proposals. ${ }^{139}$ Although the implementation of ABMTs rests with States parties, the Agreement lays out ways in which such implementation could be achieved, for example by ensuring that "activities under their jurisdiction or control [in ABNJ...] are conducted consistently with the decision adopted" 140 in the Agreement, or that "States Parties shall promote the adoption of measures within relevant [structures] to support the implementation of the conservation and management objectives of the measures adopted under"141 the Agreement. It also gives an important role to the COP and the Scientific and Technical Body in overseeing the monitoring and review of ABMTs, ${ }^{142}$ thereby ensuring that those monitoring and reviewing exercises are conducted by the same entity.

With regard to EIAs, the Agreement reiterates that States parties must fulfil a series of steps for the conducting of EIAs, e.g. screening, ${ }^{143}$ scoping; ${ }^{144}$ establishing procedures

\footnotetext{
136 Those provisions include art. 4 on the relationship between the Agreement and other instruments, art. 5 on general principles and approaches (see section 3.1 above) and art. 6 on cooperation, see Revised draft text, supra note 4.

$137 \mathrm{Ibid}$ at art. 16.

$138 \mathrm{Ibid}$ at art. 17.

$139 \mathrm{Ibid}$ at art. 18.

140 Ibid at art. 20(1).

141 Ibid at art. 20(4).

$142 \mathrm{Ibid}$ at art. 21.

$143 \mathrm{Ibid}$ at art. 30.

144 Ibid at art. 31.
} 
for the prevention, mitigation and managing of potential adverse impacts; ${ }^{145}$ conducting public notification and consultation; ${ }^{146}$ preparing and publishing an EIA report; ${ }^{147}$ ensuring a continuous monitoring:; ${ }^{148}$ and reporting and reviewing. ${ }^{149}$ While indications on how to fulfil those steps are, however, generally left to the discretion of State parties, the Agreement does intend to provide an indicative list of activities requiring (or not requiring) an assessment, ${ }^{150}$ as well as indications on the content of the EIA report. ${ }^{151}$ The consideration and review of reports is also entrusted to the Agreement's Scientific and Technical Body ${ }^{152}$ thereby ensuring harmonization on that front. It remains for now unclear whether the threshold and criteria for conducting an EIA will rest with States or with the Scientific and Technical Body, ${ }^{153}$ or whether the decision to go ahead after an EIA will rest with States or the COP. ${ }^{154}$ As described in chapter 3 above, a general framework for EIAs in $\mathrm{ABNJ}$ is not well developed. Environmental assessment tools would therefore benefit from a framework for their high seas application. ${ }^{155}$ Harmonization could also limit the development of "EIAs of convenience" that would be conducted just for the sake of fulfilling a duty without necessarily considering biodiversity and conservation interests in any detail.

Although seemingly promising for ensuring a harmonization of practices, the Agreement does not appear to extend its role of coordination to existing structures, therefore calling into question its ability to reach a comprehensiveness of practices and measures in ABNJ. For example, the Agreement's objectives in terms of ABMT include the enhancement of "cooperation and coordination in the use of ABMTs", ${ }^{156}$ the establishment of "a comprehensive system of ABMTs", 157 as well as the promotion of "coherence and complementarity in the establishment of ABMTs". ${ }^{158}$ Yet, to reach such objectives, the Agreement suggests that conservation measures can be adopted to "complement measures designated under relevant"159 existing structures, or that ABMTs can be adopted "where there is no relevant" 160 existing structure, thereby

145 Ibid at art. 33.

146 Ibid at art. 34.

$147 \mathrm{Ibid}$ at arts. 35-36.

$148 \mathrm{Ibid}$ at art. 39.

149 Ibid at arts. 40-41.

$150 \mathrm{Ibid}$ at art. 29.

151 Ibid at art. 35.

$152 \mathrm{Ibid}$ at art. 37.

153 Both options are still included in the wording of Revised draft text, supra note 4 at art. 24 . One of the objectives of this Part IV is also to establish global minimum standards for EIAs, see at art. 23(3), which would seem to leave the determination of at least some standards and thresholds under the mandate of the Agreement.

154 Both options are still included in the wording of Revised draft text, supra note 4 at art. 38.

155 Alex Oude Elferink, "Governance Principles for Areas beyond National Jurisdiction" (2012) 27:2 International Journal of Marine and Coastal Law 205-260 at 249-250; Wright et al, "High seas fisheries", supra note 8 at 16 .

156 Revised draft text, supra note 4 at art. 14(1)(a).

157 Ibid at art. 14(1)(c).

158 Ibid at art. 15(1).

$159 \mathrm{Ibid}$ at art. 15(1)(b)(i).

$160 \mathrm{Ibid}$ at art. 15(1)(b)(ii). 
making the Agreement a complementary instrument to already existing structures, and less of a coordinator of such structures. For example, one scenario would imply the following: an MPA is established by the BBNJ COP, who then recommends States parties, who are also States parties to an RFMO in that region, to adopt conservation measures compatible with the MPA. However, the RFMO does not adopt the necessary measures. According to the current text of the Agreement, the COP can recommend States to adopt measures or adopt complementary measures, but cannot substitute itself to the RFMO. ${ }^{161}$ Similarly, the EIA framework under the Agreement is meant to be a default mechanism when no EIA procedure exists under other structures. ${ }^{162}$ These measures are probably phrased in this way to respect the overarching obligation that the "Agreement shall be interpreted and applied in a manner that $[. .$.$] does not undermine relevant legal instruments and frameworks$ and relevant $[\ldots]$ bodies". ${ }^{163}$

Types of ABMTs and EIAs that are more cross-sectoral in nature, and which could strengthen coordination, have also not been extensively discussed, or remain controversial. For example, references to marine spatial planning (MSP), an ABMT which seeks to reconcile the multiple uses of the marine environment in a defined geographical area, and to reach a balance between economic, social, developmental and conservation concerns, ${ }^{164}$ have been made sporadically during the sessions of the IGC, ${ }^{165}$ but cannot be found in the current text of the Agreement. ${ }^{166}$ Regarding EIAs, the inclusion of tools such as SEAs, which target overarching policies and explore broader alternatives and impacts, ${ }^{167}$ CIAs, which assess the cumulative impact of different activities, and transboundary impact assessments (TIAs), which assess the impacts of an activity across different maritime zones, remains debated. ${ }^{168}$ Further,

161 Rochette, Cremers \& Wright, supra note 108.

162 Revised draft text, supra note 4 at art. 23(4).

$163 \mathrm{Ibid}$ at art. 4(3). The issue of "not undermining" is discussed in further detail in section 4.3 below.

164 IOC, "Marine Spatial Planning", online: <http://www.ioc-unesco.org/index.php?option=com_content\& view=article\&id=147\&Itemid=76>.

165 E.g. by Fiji during IGC 1 (see Summary IGC 1, supra note 82 at 6), by Canada during IGC 2 (see Summary IGC 2, supra note 85 at 6), and by WWF during IGC 3 (see Summary IGC 3, supra note 88 at 9).

166 The last concrete references to MSP in official BBNJ related documents dates back to the PrepCom, see Chair's non-paper on elements of a draft text of an international legally-binding instrument under the United Nations Convention on the Law of the Sea on the conservation and sustainable use of marine biological diversity of areas beyond national jurisdiction (28 February 2017) at 7, 9, 57 and 101, online: <https:// www.un.org/depts/los/biodiversity/prepcom_files/Chair_non_paper.pdf $>$, and Chair's streamlined nonpaper, supra note 21 at 5 and 8 . Indonesia has however recently made a proposal to include a new Annex entitled "Indicative List of Area Based Management Tools that Can Be Applied to Areas Beyond National Jurisdiction", and MSP appears on that list, see Textual proposals, supra note 97 at 395 . Ways in which the BBNJ Agreement could be a good platform to strengthen MSP in ABNJ are discussed in Glen Wright et al, "Marine spatial planning in areas beyond national jurisdiction" (2019) Marine Policy, and, to some extent, in Susanne Altvater, Ruth Fletcher \& Cristian Passarello, “The Need for Marine Spatial Planning in Areas Beyond National Jurisdiction” in Jacek Zaucha \& Kira Gee (eds), Maritime Spatial Planning: past, present, future (Cham: Springer, 2019) 397-415.

167 See, e.g. OECD, "Strategic Environmental Assessment and Environmental Impact Assessment", online: $<$ http://www.oecd.org/env/outreach/eapgreen-sea-and-eia.htm>.

168 Each tool is currently addressed under a separate article, see Revised text, supra note 4 at art. 28 for SEA, art. 25 for CIA and art. 29 for TIA. 
the provisions dealing with the definition of such tools, ${ }^{169}$ as well as the modalities ${ }^{170}$ for their application remain under consideration and are not yet agreed upon. ${ }^{171}$

The potential role of the Agreement for promoting cooperation and coordination is further challenged by deeply embedded divergences with regard to some elements of the package deal. ${ }^{172}$ Many of these divergences have been reiterated since the early stages of the BBNJ process. ${ }^{173}$ For example, views diverged on whether MGRs should be considered under the freedom of the high seas or under the common heritage of humankind principle, ${ }^{174}$ whether both monetary and non-monetary benefits should be shared, and whether this should be done on a voluntary or mandatory basis. In relation to ABMTs, the main concern revolves around the level (global or regional) of decision-making and institutional organization. ${ }^{175}$ Regarding EIAs, it is the degree to which the assessments should be "internationalized" or conducted at the national level that represents the main divergence. ${ }^{176} \mathrm{~A}$ further debate remains as to whether the conducting of EIAs should be activity-based or impact-based, the latter option triggering the possibility of extending the scope of application of the Agreement to activities within national jurisdiction. ${ }^{177}$ The support for such an extension is, however, limited. All in all, these tensions create an obstacle to fully fleshing out the Agreement and its potential as a "rulebook" for coordination and cooperation.

\subsection{A bridge between the law of the sea and international environmental law}

A more overarching conceptual coordination and cooperation function of the Agreement resides in the role that it is expected to play in bridging the regimes of the law of the sea and of environmental/biodiversity law. Of course, the two regimes

169 Ibid at art. 1(13) for SEA and art. 1(6) for CIA.

$170 \mathrm{Ibid}$ at arts. 21bis(c) and 42(f)(vi) for SEA, arts. 21bis(b), 23(4 Alt. 4)(b), 31, 35(2)(d) and Annex I(q) for CIA, and arts. 34(4), 35(2)(d) and Annex I(q) for TIA.

171 The divergence of views regarding the way to include these tools or not (e.g. under a separate provision as it is currently the case, or as part of other provisions), their definition and the modalities for their application is also visible through the different proposals made by delegations in early 2020 , see, generally, Textual proposals, supra note 97.

172 Summary IGC 3, supra note 88 at 22. See also David Freestone, "Problems of High Seas Governance" in Peter Johan Schei \& Davor Vidas (eds), The World Ocean in Globalisation. Climate Change, Sustainable Fisheries, Biodiversity, Shipping, Regional Issues (Leiden: Brill, 2011) 99-130 at 130, which specifically refers to the impact that divergences regarding MGRs can have on the improvement of the ABNJ/oceans governance regime.

173 These divergences are cited in Report PrepCom, supra note 76 at 17-18.

174 The impact of the divergences regarding the common heritage of humankind versus the freedom of the high seas on the negotiations is discussed in Papastavridis, supra note 80 at 587 and 593-594.

175 Ibid at 588-589 and 595.

176 Ibid at 588-589 and 596.

177 See, e.g. the position of several delegations at "Utrecht informal meeting on rights and interests of coastal States (including issues relating to adjacent or subjacent maritime areas) and other States in the BBNJ Implementing Agreement - exploring scenarios and approaches" (Organized by the Netherlands Institute for the Law of the Sea (NILOS), Utrecht University, and the Netherlands Ministry of Foreign Affairs, Utrecht, 10-11 February 2020). The relationship between ABNJ and AWNJ is discussed in further detail in section 3.4 below. 
are not completely foreign to one another. The portrait of the legal framework for (international and high seas) fisheries law conducted in chapter 2 has demonstrated that the law of the sea does make references to rules and principles of environmental law found under other instruments and structures. ${ }^{178}$ Furthermore, within UNCLOS, there are provisions for the protection and preservation of the marine environment. However, these rules under UNCLOS, especially in their application to $A B N J$, are quite underdeveloped. Hence, the Agreement aims to directly bring within the UNCLOS' framework notions of environmental and biodiversity law that are either absent or underdeveloped.

The decision to develop the implementing agreement under UNCLOS appeared quite early in the BBNJ process. ${ }^{179}$ Although the necessity for a new instrument was opposed by many, expressing "the view that activities in [ABNJ] were either appropriately regulated under existing institutions and processes, or could be better regulated through the existing instruments and institutions and by enhancing cross-sectoral coordination and cooperation", ${ }^{180}$ the issue of having an implementing agreement under UNCLOS (compared to, e.g., the CBD) does not seem to have been contested. This is probably explained by the recognition of the role of UNCLOS as "the legal framework within which all activities in the oceans and seas must be carried out, and [that] any action relating to the conservation and sustainable use of marine biological diversity beyond areas of national jurisdiction should be consistent with its legal regime" ${ }^{181}$ Furthermore, the recognition that the CBD, although complementary in nature to UNCLOS, does not "extend to the conservation and sustainable use of components of marine biological diversity beyond areas of national jurisdiction since it applied only to processes and activities carried out under the control of States in those areas" ${ }^{182}$ could also explain why that forum was not chosen for the elaboration of the Agreement. Some BBNJ delegates have also informally mentioned that there was simply no political will or readiness to open discussions about ABNJ within the framework of the CBD. ${ }^{183}$

The bridging between the law of the sea and environmental/biodiversity law is also noticeable in the institutional structure that is expected to be created under the Agreement. The Agreement will in fact be managed by a COP as the plenary body

178 See, e.g. UNCLOS at art. 237. Rules of reference are also discussed in chapter 2 section 3.1.1.4 above.

179 See, e.g., Report $1^{\text {st }}$ meeting, supra note 18 at paras 25, 55 and 58. Since all four elements of the package deal are already addressed under the CBD and other existing instruments, it could legitimately be asked why the BBNJ process was not conducted under the auspices of one of these instruments. This question is discussed in Alex Oude Elferink \& Baine Kerr, "Finding a Home for BBNJ - The CBD, the LOSC and the General Assembly: complementarity or competition?" in Vito De Lucia, Lan Ngoc Nguyen \& Alex Oude Elferink (eds), International Law and Marine Areas beyond National Jurisdiction: Current Status and Future Trends (forthcoming), where the authors conclude that the decision to conduct the BBNJ process under the auspices of the UNGA can be explained by the important role that the UNGA plays in policy making with regard to oceans and the law of the sea, a role acknowledged by the CBD.

180 See, e.g., Report $2^{\text {nd }}$ meeting, supra note 18 at paras 47-48.

181 See, e.g., Report $1^{\text {st }}$ meeting, supra note 18 at annex I para 3.

182 Ibid at para 23.

183 See the present author's notes from the first session of the IGC (on file with author) [Author's notes IGC1]. 
meeting regularly and mandated to make decisions, ${ }^{184}$ along with subsidiary bodies such as a scientific/technical body. ${ }^{185}$ This institutional structure borrows from the institutional structures of environmental agreements ${ }^{186}$ and is in fact very different from the one found under UNCLOS or the UNFSA. ${ }^{187}$ Under the former, the plenary body consists of the MOP, which normally deals mostly with procedural matters, and is not mandated with the application or implementation of the provisions of UNCLOS. ${ }^{188}$ The UNFSA, for its part, does not have institutional arrangements; it is subject to a Review Conference, which meets every five or six years. ${ }^{189}$ This Review Conference is mandated to make observations and recommendations regarding the implementation of the UNFSA, but does not have a decision-making power per se, ${ }^{190}$ and does not amount to a review of States' compliance. ${ }^{191}$ This is seemingly the main reason why many delegations have in the course of the negotiations cautioned against the creation of a review conference for the BBNJ Agreement and that the IGC is currently inclined to establish a COP. ${ }^{192}$

Finally, although State driven, the BBNJ process has so far evolved in close collaboration with non-State actors, a characteristic also associated with environmental processes. Not only can international organizations and NGOs participate and intervene during the sessions of the IGC, ${ }^{193}$ but the importance of non-State actors for the process and in the eventual implementation of the Agreement is also reflected in the current text. In fact, several provisions of the

184 Revised draft text, supra note 4 at art. 48.

$185 \mathrm{Ibid}$ at art. 49.

186 See, e.g. CBD at arts. 23 and 25; CITES at art. XI.

187 In the law of the sea context, some RSPs have an institutional structure formed of, e.g., a decision-making body (e.g. the OSPAR Commission), a Secretariat (e.g. the Mediterranean Action Plan Secretariat of the Barcelona Convention) and/or a scientific body (e.g. the Scientific Committee of CCAMLR). This can be explained by the fact that RSPs are "environmental creatures" within a law of the sea context. Consequently, the potential institutional structure of the BBNJ Agreement might be different from the MOP of UNCLOS or the Review Conference of the UNFSA, but it is not entirely foreign to the law of the sea.

188 See, generally, DOALOS, "Meetings of States Parties to the 1982 United Nations Convention on the Law of the Sea", online: <https://www.un.org/Depts/los/meeting_states_parties/meeting_states_parties.htm>. The Meeting of the States Parties is convened in accordance with art. 319(2)(e) UNCLOS.

189 See, generally, DOALOS, "Review Conference on the Agreement for the Implementation of the Provisions of the United Nations Convention on the Law of the Sea of 10 December 1982 relating to the Conservation and Management of Straddling Fish Stocks and Highly Migratory Fish Stocks", online: $<$ https://www.un.org/Depts/los/convention_agreements/review_conf_fish_stocks.htm>. The Review Conference is convened in accordance with art. 36 UNFSA.

190 Alex Oude Elferink, "Exploring the future of the institutional landscape of the oceans beyond national jurisdiction" (2019) 28:3 Review of European and Comparative International Environmental Law 236243 at 240 [Oude Elferink, "Institutional landscape"]. The Review Conference is discussed in chapter 2 section 3.1 .2 above.

191 Solène Guggisberg, “Independent, Compulsory, and Centralized verification of States' Obligations in Fisheries: Can the IMO Audit Scheme for Shipping Law Be Used as an Example to Follow?” (2020) 22 International Community Law Review 513-531 at 517.

192 Kristine Dalaker Kraabel, "International Law and Areas Beyond National Jurisdiction: Imagining a Polycentric Approach to Institutional Governance for Marine Areas Beyond National Jurisdiction" in Vito De Lucia, Lan Ngoc Nguyen \& Alex Oude Elferink (eds), International Law and Marine Areas beyond National Jurisdiction: Current Status and Future Trends (forthcoming).

193 UNGA Res 72/249, supra note 2 at paras 12-13. It was also the case during the PrepCom, see UNGA 69/292, supra note 31 at para 1(a). 
Agreement make reference to the participation of and/or the need to consult with indigenous peoples, local communities, NGOs, the general public, academia, scientific experts, affected parties, adjacent communities and organizations that have special expertise or jurisdiction, those with existing interests in an area, the private sector and/or civil society. ${ }^{194}$ The inclusion of this wide range of actors has been characterized as a necessity to ensure a legitimate governance arrangement and fairness. ${ }^{195}$ However, the exact scope of non-State actors involvement, in a process that remains essential State-driven, still needs to be determined and will raise the "challenge of accommodating surrogate regulators". ${ }^{196}$

These various elements illustrate the role of the Agreement in fostering cooperation and coordination between two legal regimes relevant for the BBNJ. While biodiversity law and the CBD lay out the objectives of conservation and sustainable use of biodiversity, the Agreement could develop the tools to reach such objectives in ABNJ. ${ }^{197}$ The role of the Agreement could also be explained by the necessity to incorporate into the law of the sea notions of environmental law that did not exist or were underdeveloped during the negotiation of UNCLOS. However, the real impact of this bridging function on improved biodiversity considerations within the law of the sea will depend on whether the Agreement "will accomplish a truly teleological linkage between the CBD and the [UNCLOS] regarding the protection of marine biodiversity which supplants the exploitation of marine living resources or will merely establish functional linkages between the two instruments in regard to specific legal tools and methodologies". ${ }^{198}$

\subsection{Clarifying the relationship between areas beyond national jurisdiction and areas under coastal State jurisdiction}

Considering the ecological connectivity and interconnectedness characterizing the oceans, a fundamental question that arises is how to address the relationship between $\mathrm{ABNJ}$ and $\mathrm{AWNJ}$. In other words, this refers to the relationship between the rights and obligations of coastal States and the rights and obligations of other

194 See, e.g. Revised draft text, supra note 4 at arts. 5, 16, 17, 18, 21, 31, 32, 34, 35, 43, 46, 49, 51 and 52.

195 This issue was discussed at the workshop "Institutional Design at the Crossroads of Law, Governance and Fairness: What Institutional Architecture for an Instrument on Marine Biological Diversity beyond National Jurisdiction?" (Organized by the Utrecht University Centre for Global Challenges (UGlobe), the Netherlands Institute for the Law of the Sea (NILOS), the Copernicus Institute of Sustainable Development, and the Ethics Institute, Utrecht University, Utrecht, 27-28 June 2019) [Workshop "Institutional Design"].

196 Richard Barnes, “The Pursuit of Good Regulatory Design Principles in International Fisheries Law. What Possibility of Smarter International Regulation?” in Judith van Erp et al (eds), Smart Mixes for Transboundary Environmental Harm (Cambridge: Cambridge University Press, 2019) 97-125 at 120.

197 Basile de Havre, "Plateforme Biodiversité 2020 - Quatrième rencontre" (Webinar hosted by IDDRI, 19 March 2020).

198 Alexander Proelss \& Katherine Houghton, "Protecting Marine Species” in Rosemary Rayfuse (ed), Research Handbook on International Marine Environmental Law (Cheltenham: Edward Elgar, 2015) 229-258 at 257. 
States. ${ }^{199}$ For example, what would be the impact of the establishment of a high seas MPA on the rights of a coastal State to access the resources of its extended continental shelf? What would be the impact of the establishment of a high seas MPA just outside of a coastal State's EEZ on the possibility for this coastal State to exercise its rights within its EEZ?

One way of addressing this relationship is through the concept of adjacency. The term "adjacent" is primarily used in existing instrument ${ }^{200}$ in its geographical sense, and in this case simply refers to the rights and obligations of States which EEZ is physically located next to ABNJ. ${ }^{201}$ Another interpretation, however, suggests that adjacent coastal States should have a priority or greater rights over ABNJ next to their maritime zones. ${ }^{202}$ It has even been argued that "the overarching conservation mandate of UNCLOS would support granting to [coastal] States greater influence over management of those $\mathrm{ABNJ}$ resources to which they lie adjacent". ${ }^{203}$ For conservation purposes therefore, adjacent States would become the main holders of responsibilities, and would bear the duty of collaborating with other actors involved, which could lead to better accountability and stewardship. ${ }^{204}$ This is based on the ecological connectivity between ABNJ and AWNJ.

It is argued, however, that such priority for coastal States over ABNJ is neither found under the current law of the sea, nor under previous developments. ${ }^{205}$ During BBNJ sessions, some States were also very vocal against such interpretation. ${ }^{206}$ In fact, the balance between the interests of different States normally tends to be addressed in terms of reciprocity, embodied within the duty of due regard, ${ }^{207}$ which creates the necessity to balance concurring or overlapping interests, in an attempt to achieve conciliation between these interests. This duty might for example require a duty of consultation with the coastal State, or a balancing of competing rights and duties,

199 Joanna Mossop \& Clive Schofield, "Adjacency and due regard: The role of coastal States in the BBNJ treaty" (2020) Marine Policy article 103877, identify the following main interests for coastal States: 1) protecting their existing rights in AWNJ, 2) ensuring consultation with coastal States if activities in ABNJ have a potential impact in AWNJ, and 3) ensuring coastal States' access to mechanisms to protect biodiversity in ABNJ with an ecological connectivity to AWNJ. Other States, for their part, have the following main interests: 1) that coastal States do not impact unduly on biodiversity in ABNJ, and 2) that the freedoms of the high seas are not affected.

200 See, e.g. UNFSA at art. 7; UNCLOS at art. 63.

201 Mossop \& Schofield, supra note 199 at 2.

202 Daniel Dunn et al, “Adjacency: How legal precedent, ecological connectivity, and traditional knowledge inform our understanding of proximity" (2017) Nereus Scientific \& Technical Briefs on ABNJ series [Dunn et al, "Adjacency"], cited in Mossop \& Schofield supra note 199 at 2.

203 Dunn et al, "Adjacency", supra note 202 at 5, see also at 9.

204 Ibid.

205 Alex Oude Elferink, "Coastal States and MPAs in ABNJ: Ensuring Consistency with the LOSC" (2018) 33 International Journal of Marine and Coastal Law 437-466 at 446; Mossop \& Schofield supra note 199 at 4.

206 For example, China often reiterated that adjacency is not a legal concept found under UNCLOS, see the present author's notes from the third session of the PrepCom (on file with author) [Author's notes PrepCom3].

207 A discussion on due regard is conducted in chapter 2 section 3.1.1.1, and in chapter 3 section 3.1.1 above. 
and alternatives might have to be considered. ${ }^{208}$ This duty should also be used in the Agreement in order to be consistent with UNCLOS. Nevertheless, "the restatement of [the] principle [of due regard] on its own is insufficient. Rather, the principle will need to be 'operationalized' through criteria, priorities and mechanisms". ${ }^{209}$ In fact, as discussed above, what due regard or related concepts mean in practice is not always clear; ${ }^{210}$ there is therefore a general wish to get clarification on specific criteria or a specific procedure to follow when balancing the different rights, obligations and interests of different actors, e.g. the rights of a coastal State to exploit resources in its EEZ while fulfilling its obligations to protect and preserve the marine environment.

The $\mathrm{BBNJ}$ process is an open platform to address how to conduct this balancing exercise, and the Agreement could clarify the notion of adjacency on three fronts. ${ }^{211}$ First, the Agreement could specify what is meant by "adjacent State". Although the geographical meaning refers to States "next to" a specific area, an interpretation relying on ecological connectivity could involve States that are further away but potentially affected, similar to the notion of "range State" found under the CMS. ${ }^{212}$ Second, three broad approaches could be followed to define/frame the relationship: 1) there could be no assumption of priority for the coastal State, and therefore a reliance on the duty of due regard; 2) there could be some procedural rights in favour of coastal States, such as the duty to consult with adjacent States; and 3) there could also be a regional approach, where all States having an interest in a specific area get together and find an appropriate response. Third, the implications of adjacency for elements of the package deal could be addressed by the Agreement. In regard to MGRs, the difficulties lie mostly with sedentary species that can be found in different zones at different stages of their life cycle (e.g. in the water column at earlier stages of their development, which would therefore be subject to the freedom of the high seas, while sedentary species on the extended continental shelf of a State remain under the jurisdiction of that State). Collecting MGRs in the water column might also affect the broader ecosystem situated on the extended continental shelf. With regard to ABMTs, two issues could be clarified: the involvement of coastal States in designating and establishing MPAs in ABNJ, and the question of compatibility of measures (i.e. measures in the EEZ as opposed to on the high seas, similar to article 7 UNFSA). As regards EIAs, adjacency could trigger the need to consult with adjacent States, or could also extend to other potentially affected States.

208 Oude Elferink, "Coastal States and MPAs", supra note 205 at 454, discussing the Chagos Marine Protected Area Arbitration (Mauritius v United Kingdom), Award, (2015) PCA case 2011-03 at para 519.

209 Mossop \& Schofield supra note 199 at 3.

210 See, e.g., Papastavridis, supra note 80 at 607.

211 These elements are based on Mossop \& Schofield supra note 199 at 3-6, as well as on discussions held during the "Utrecht informal meeting", supra note 177.

212 CMS at art. 1(1)(h), which reads "any State [...] that exercises jurisdiction over any part of the range of that migratory species, or a State, flag vessels of which are engaged outside national jurisdictional limits in taking that migratory species". 
What adjacency means in practice is that the balance of rights and interests triggers the need for negotiations, consultations and cooperation in order to achieve that balance. Addressing the relationship between rights of coastal States and third States in the Agreement has the potential to reaffirm and/or strengthen methods on how to conduct this conciliation of interests. The Agreement could bring clarity regarding the cooperation mechanisms that need to be used to reach that conciliation, and the coordination of different measures undertaken by different actors in different zones for the purpose of conservation and sustainable use. If this cannot be reached in the Agreement itself, it is hoped that a mandate to develop such mechanisms for coordination will be delegated to the COP and/or other subsidiary bodies. ${ }^{213}$ For now, we need to rely on article 4(2) of the Agreement for the overarching question of the relationship between ABNJ and AWNJ, where it is stated that " $[\mathrm{t}]$ he rights and jurisdiction of coastal States in all areas under national jurisdiction, including the continental shelf within and beyond 200 nautical miles and the exclusive economic zone, shall be respected in accordance with the Convention". Although the phrasing seemingly gives priority to coastal States' rights and jurisdiction, the reference to UNCLOS brings back the notion of due regard and the necessity for a balancing exercise. $^{214}$

\subsection{Consolidating implementation and compliance through monitoring, control and surveillance (MCS)}

A recent study on MCS on the high seas has gathered information about the current legal and technical status of MCS, and has identified different ways in which MCS could be strengthened through the Agreement. ${ }^{215}$ Ensuring the implementation of and compliance with obligations in areas as remote and vast as ABNJ can trigger specific difficulties and obstacles. Implementation and enforcement actions on the high seas are in fact conducted mainly by flag States, and a lack of will or capacity on their part can influence the measures undertaken. Further, the complexity of the current legal framework for the high seas can trigger uncertainty for actors and can therefore have an impact on the efficiency of enforcement mechanisms. ${ }^{216}$

One way to see whether States are compliant with their obligations is to establish strong mechanisms for MCS. It is one way for States to see whether the vessels flying their flags are complying with the obligations that bind the State itself. MCS is composed of three different complementary concepts. The monitoring of human

\footnotetext{
213 Mossop \& Schofield supra note 199 at 6.

214 Ibid.

215 Klaudija Cremers, Glen Wright \& Julien Rochette, "Strengthening Monitoring, Control and Surveillance in Areas Beyond National Jurisdiction" (2020) STRONG High Seas Project [Cremers, Wright \& Rochette, "MCS Report"]. See also Klaudija Cremers, Glen Wright \& Julien Rochette, "Strengthening monitoring, control and surveillance of human activities in marine areas beyond national jurisdiction: Challenges and opportunities for an international legally binding instrument" (2020) Marine Policy article 103976 [Cremers, Wright \& Rochette, "MCS BBNJ"].

216 Difficulties related to MCS are discussed in chapter 5 section 2.3.1 below.
} 
activities can take the form of data collection or reporting, while the control of those activities refers to regulations and licensing. Surveillance refers mostly to the surveillance of vessels through technological and electronic systems. ${ }^{217}$ Tools for MCS have evolved and continue evolving with technological advances, ranging from traditional approaches, such as observers on board vessels or aerial surveillance, to modern electronic tools. They can be classified into data collection and reporting tools (e.g. logbooks, automatic identification systems, VMS), ${ }^{218}$ surveillance tools (e.g. aerial and patrol vessels, electronic monitoring systems), and cooperative frameworks (e.g. listing, joint inspection schemes). ${ }^{219}$ There also exist registration related mechanisms, such as a global public registry or records of vessels. ${ }^{220}$

Some initiatives for MCS already exist in the fisheries sector. Some examples of these initiatives are: standards within RFMOs; ${ }^{221}$ international platforms and networks; fisheries improvement projects (multi-stakeholder initiatives), the

217 Cremers, Wright \& Rochette, "MCS Report", supra note 215 at 9.

218 Vessel monitoring systems (VMS) and automatic identification systems (AIS) or probably the most common modern MCS tools in the fisheries sector. Both mechanisms function with on-board transmitters which communicate with the vessel's GPS. They differ in the frequency of data transmission (every couple of hours for VMS, every couple of seconds for AIS), and signals from AIS can also be received by other vessels, as the mechanism was initially designed to assist in the avoidance of collisions between vessels, see Daniel Dunn et al, "Empowering high seas governance with satellite vessel tracking" (2018) 19 Fish and Fisheries 729-739 at 732-733 [Dunn et al, "Empowering"].

219 A summary table of all existing MCS tools can be found in Cremers, Wright \& Rochette, "MCS Report", supra note 215 at 17-22. Within the fisheries sector, electronic tools are of particular relevance when attempting to cover immense areas such as ABNJ, as they are set to assist States in monitoring fishing vessels by providing a spatiotemporal coverage of their activities. The data collected can not only advise on the activities and patterns of vessels, but can also gather information about the state of the marine environment. For more on MCS tools generally, see, e.g., Kristina Gjerde, "High Seas Fisheries Governance: Prospects and Challenges in the 21st Century" in Peter Johan Schei \& Davor Vidas (eds), The World Ocean in Globalisation: Climate Change, Sustainable Fisheries, Biodiversity, Shipping, Regional Issues (Leiden: Brill, 2011) 221-232 at at 229; James Harrison, Saving the Oceans Through Law. The International Legal Framework for the Protection of the Marine Environment (Oxford: Oxford University Press, 2017) at 191-192; Kristina Gjerde et al, "Ocean in Peril: Reforming the Management of Global Ocean Living Resources in Areas Beyond National Jurisdiction” (2013) 74:2 Marine Pollution Bulletin 540-551 at 545; High Seas Task Force, "Closing the Net: Stopping Illegal Fishing on the High Seas. Final Report of the Ministerially led Task Force on IUU Fishing on the High Seas" (2006), at recommendations 1-2, 9, online: $<$ https://www.oecd.org/sd-roundtable/papersandpublications/39375276.pdf>, summarized in Freestone, supra note 172 at 111-113; Michele Kuruc, "Monitoring, Control and Surveillance Tools to Detect IUU Fishing and Related Activities" in Davor Vidas (ed), Law, Technology and Science for Oceans Globalisation. IUU Fishing, Oil Pollution, Bioprospecting, Outer Continental Shelf (Leiden: Brill Nijhoff, 2010) 101-108 at 107; Daniel Dunn et al, "Empowering", supra note 218 at 731.

220 See, e.g., vessel lists from RFMOs, e.g., A and B vessels under NEAFC, "NEAFC A and B Lists”, online: $<$ https://www.neafc.org/mcs/iuu>; Record of Vessels under SPRFMO, "Commission Record of Vessels Authorised to Fish in the Convention Area”, online: <https://www.sprfmo.int/measures/record-ofvessels/>; Record of Vessels under ICCAT, "ICCAT Record of Vessels" online: <https://www.iccat.int/en/ VesselsRecord.asp>; MCS measures by SIOFA, "Monitoring, Control and Surveillance”, online: <http:// www.apsoi.org/mcs>; MCS scheme under WCPFC, "WCPFC Monitoring, Control and Surveillance (MCS) and Compliance Monitoring", online: <https://www.wcpfc.int/wcpfc-monitoring-control-andsurveillance-mcs-scheme>. RFMOs also have special vessel lists for IUU fishing, see e.g. SPRFMO. "SPRFMO IUU List", online: < https://www.sprfmo.int/measures/iuu-lists/\#SPRFMO>, which also refers to the IUU lists of other RFMOs.

221 For a summary table of standards established by RFMOs, see Barbara Hutniczak, Claire Delpeuch \& Antonia Leroy, "Closing Gaps in National Regulations Against IUU Fishing" (2019) OECD Food, Agriculture and Fisheries Papers No. 120, cited in Cremers, Wright \& Rochette, "MCS Report", supra note 215 at 25. 
most common example being the Marine Stewardship Council; and civil society initiatives. ${ }^{222}$ However, the main difficulty with MCS, especially in ABNJ, is capacity limitations. MCS in ABNJ requires a substantial amount of financial resources, as well as knowledge, human resources, and infrastructure. These elements not only influence the capacity to collect data, but above all to process it, and to ensure coherence in data. ${ }^{223}$ Furthermore, these capacities vary considerably among States, and a question of capacity imbalance then arises. ${ }^{224}$

The role that the BBNJ Agreement can play with regard to MCS is therefore twofold: to ensure that the Agreement can strengthen MCS obligations themselves, and to ensure that the Agreement can address capacity imbalance and sharing of information. To address questions of MCS obligations, the Agreement suggests the monitoring and review of activities in relation to each element of the package deal. ${ }^{25}$ However, MCS obligations could be consolidated further, notably through enhanced transparency, ${ }^{226}$ which ensures that the conducting of activities and their results are transparent. Transparency could be achieved, among other measures, through the inclusion of MCS strategies in ABMT proposals. ${ }^{27}$ Reporting ${ }^{228}$ is also another strong mechanism to achieve transparency. However, the obligations of reporting and monitoring found under the current text lack "clear timelines and modalities", and "[e]xperience with reporting and monitoring obligations in UNCLOS and other instruments suggests that obligations may not be fully implemented in the absence of" such timelines and modalities. ${ }^{22}$ For example, article 21(1) of the Agreement requires States to report to the COP on the implementation of ABMTs. A similar overarching reporting obligation is found under article 53(2). However, no specification as to the content or frequency of these reports is mentioned. Article 21(5) of the Agreement further indicates that existing structures could be requested to report to the COP, which seems "crucial [to...] improve transparency by making States Parties to sectoral and regional organisations accountable for the implementation of these measures [and... ] would also enable the COP to act as a central platform for the discussion" ${ }^{230}$ It is however unlikely that this provision will make it to the final text - or at least not in its current form - because of the likelihood it would be considered to be contrary to the obligation for the Agreement not to undermine existing structures. ${ }^{231}$ In the case of EIAs, there is also an obligation to

222 All these initiatives are discussed in Cremers, Wright \& Rochette, "MCS Report", supra note 215 at 24-27.

$223 \mathrm{Ibid}$ at 30 .

224 Some difficulties linked to MCS are developed further in chapter 5 section 2.3.1 below.

225 See, e.g., Revised draft text, supra note 4 at arts. 13, 21, 39, 41 and 47.

226 Cremers, Wright \& Rochette, "MCS Report", supra note 215 at 33-34. See also, Cremers, Wright \& Rochette, "MCS BBNJ", supra note 215 at 4.

227 Cremers, Wright \& Rochette, "MCS Report", supra note 215 at 39. See also Revised draft text, supra note 4 at art. 17 where the (content of the) proposals are detailed.

228 On the potential role of the Agreement for strengthening reporting obligations, see Oude Elferink, "Institutional landscape", supra note 190 at 241.

229 Klaudija Cremers et al, "A preliminary analysis of the draft high seas biodiversity treaty" (2020) IDDRI Study No 01/20 at 9.

230 Ibid.

231 The question of not undermining is discussed in further detail in section 4.3 below. 
monitor and review, ${ }^{232}$ yet there is still no agreement as to what measures should be undertaken in the event that adverse impacts are identified. ${ }^{233}$

It is necessary to have institutions strong enough to ensure that reporting obligations are implemented and that information collected during MCS is acted upon. This is also relevant to address the second aspect of the Agreement's role with regard to MCS, i.e. questions of capacity imbalance and sharing of information. One interesting structure that is currently being developed under the Agreement, and which has received the support of most - if not all - delegations is the clearinghouse mechanism. ${ }^{234}$ This open-access platform and/or network for the sharing of information is meant to benefit States, although non-State actors could also be sharing information, knowledge, data, etc. However, "the draft text [of the Agreement] does not currently envisage a role for the mechanism in supporting [MCS] activities, which is a missed opportunity as the cooperation required for effective MCS could be enhanced through the clearing-house mechanism".235 This mechanism might also not directly address questions of capacity imbalance. Neverthelss, through its aim of making data more available, it could contribute to reducing capacity gaps by enhancing the sharing of information, knowledge and resources. This is essential considering "the importance of science-based decisionmaking and effective enforcement" and the role that the Agreement could play in "highlight[ing] the 'general lack of information and knowledge regarding biological diversity and of the urgent need to develop scientific, technical, and institutional capacity' (CBD preamble) and reiterat[ing] the call made in the [UNFSA] for 'more effective enforcement by flag States, port States and coastal States"'.236

In terms of additional institutions to help with compliance, the IGC has discussed the possibility of a compliance body. Such body does not, for now, appear in the Agreement's text, and questions of implementation and compliance are currently left mostly in the hands of States. ${ }^{237}$ The goal of a compliance body could be to assist parties in implementing agreed obligations within their national legal and policy structures and in complying with their obligations. Such a body could also be available to assist RFMOs in fulfilling their conservation obligations. The body could also establish measures to address non-compliance. Alternatively, the COP could be given the mandate to establish a compliance body if necessary at a later stage, although this suggestion, for now, does not seem to rally interest. It has,

232 Revised draft text, supra note 4 at art. 41.

233 Cremers et al, supra note 229 at 10.

234 Revised draft text, supra note 4 at art. 51; Cremers, Wright \& Rochette, "MCS Report", supra note 215 at 7; Cremers et al, supra note 229 at 38.

235 Cremers et al, supra note 229 at 7.

236 Ibid at 6.

237 Revised draft text, supra note 4 at art. 53. See also Papastavridis, supra note 80 at 608 . Other mechanisms currently exist for compliance, e.g. intervention of non-flag States on the high seas under art. 21 UNFSA, port States measures under the PSMA, existing MCS tools, see Papstavridis at 609. However, as is discussed below in chapter 5 section 2.3.1, those mechanisms present weaknesses, hence the desirability for a strong compliance mechanisms under the BBNJ Agreement. 
however, been suggested that existing compliance mechanisms could be examples from which to draw. ${ }^{238}$ The Compliance Committee of the Aarhus Convention, for example, examines, reports on and monitors compliance issues and makes recommendations. ${ }^{239}$ Similarly, the Implementation Committee of the Espoo Convention focuses on reviewing and making recommendations on submissions regarding the compliance of parties with their obligations under the Convention. ${ }^{240}$

In brief, the Agreement could contribute to the consolidation of implementation and compliance obligations, more specifically through the strengthening of MCS. This could be done by creating and/or solidifying structures and mechanisms for cooperation in the sharing of information, knowledge and capacities, and in conducting and coordinating these MCS measures. ${ }^{241}$ The coordination role of the Agreement could also contribute to avoiding a duplication of efforts among various overlapping monitoring, reviewing and reporting obligations and tools.

\section{THE RELATIONSHIP BETWEEN FISHERIES STRUCTURES AND THE BBNJ AGREEMENT}

The relationship between the Agreement and the current fisheries regulatory and management framework has, since the beginning of the BBNJ process, constituted "a major point of dispute". ${ }^{42}$ Views have ranged from the strong resistance of many delegations towards the inclusion of fisheries in the Agreement, to the express necessity to refer to "the conservation of species [as] a central element of such an agreement". ${ }^{243}$ At the time of writing, however, it remains uncertain to what extent the scope of application of the Agreement will encompass fisheries, although the latest trends in the negotiations tend towards their exclusion. Nevertheless, between the two ends of the spectrum lie options for ensuring the consideration of fisheries within the conservation and sustainable use of $\mathrm{BBNJ}$, and it is highly probable that the development of the Agreement will impact the regime for high seas fisheries. In fact, the role that the Agreement is expected to play for coordination and cooperation in ABNJ might very likely impact the way the fisheries regime currently addresses issues of conservation and sustainable use on the high seas.

238 Summary IGC 3, supra note 88 at 22.

239 UNECE, "Background”, online: <https://www.unece.org/env/pp/ccbackground.html>.

240 UNECE, "Implementation Committee", online: <https:/www.unece.org/env/eia/implementation/imple mentation_committee_meetings.html>.

241 Other measures are being envisaged, such as the improvement of technological tools, the co-creation of MCS systems (i.e. co-creation by various stakeholders) and the strengthening of measures by sectoral organizations, see Cremers, Wright \& Rochette, "MCS Report”, supra note 215 at 31-32.

242 Kristina Gjerde et al, "Options for Addressing Regulatory and Governance Gaps in the International Regime for the Conservation and Sustainable Use of Marine Biodiversity in Areas beyond National Jurisdiction" (2008) IUCN Environmental Policy and Law Papers, cited in Wright et al, "High seas fisheries", supra note 8 at 9 . More generally, on the question of the inclusion of fisheries in the agreement, see Ricard, supra note 1 at 7-8, and Millicay, supra note 9 at 173-174.

243 Robin Churchill, “The LOSC Regime for Protection of the Marine Environment - Fit for the Twenty-First Century?" in Rosemary Rayfuse (ed), Research Handbook on International Marine Environmental Law (Cheltenham: Edward Elgar, 2017) 3-30 at 20. 
This section therefore first looks into some options for considering fisheries in light of the subject matter of the Agreement (4.1). It then turns to assessing two elements that could impact the operationalization of the interaction between the fisheries regime in $\mathrm{ABNJ}$ and the Agreement: the structural and institutional approach of the Agreement (4.2) and the "not undermining" clause (4.3).

\subsection{How could/will the regulatory and management framework for high seas fisheries be influenced by the BBNJ process?}

The Agreement aims at promoting greater coherence in $A B N J$, and this raises the question of the position that fisheries regulation and management will take within that new/strengthened framework, ${ }^{244}$ as well as how fisheries could benefit from such a framework. Warner suggests different ways in which the Agreement could influence fisheries structures, ${ }^{245}$ both as part of cross-cutting issues and related to the elements of the package deal. First, it is expected that the Agreement will contain a list of principles and/or standards, ${ }^{246}$ which (partially) overlap with environmental law principles, as well as the principles governing the high seas addressed in chapter 3 above. Their inclusion in the BBNJ Agreement, as discussed in section 3.1 above, could therefore crystallize their use in these areas, and could inform the application/operationalization of these principles in sectoral regimes applicable in $\mathrm{ABNJ}$, including fisheries.

Second, the COP could act as a "focal point" for various organizations and could establish regular cooperation mechanisms, as opposed to the current ad hoc approach. For example, the Collective Arrangement between NEAFC and OSPAR, as well as the MoU between the GFCM and the Mediterranean Action Plan of the Barcelona Convention, ${ }^{247}$ are successful yet isolated initiatives. The BBNJ Agreement could therefore enhance coordination amongst various initiatives and mechanisms, ${ }^{248}$ which could be beneficial to RFMOs.

Third, the Agreement is expected to have a strong focus on the collection and gathering of information and data, notably through the clearing-house mechanism. ${ }^{249}$ This could help to establish environmental and ecological baselines for different regions, as well as helping to assess the impact of different sectors. The collection of information about marine biodiversity already exists through, for example,

244 Richard Caddell, "International Fisheries Law and Interactions with Global Regimes and Processes" in Richard Caddell \& Erik Molenaar (eds), Strengthening International Fisheries Law in an Era of Changing Oceans (Oxford: Hart, 2019) 133-163 at 149.

245 See this discussion in Robin Warner, "Conservation and Management of Marine Living Resources Beyond National Jurisdiction: Filling the Gaps" in Robert Beckman et al (eds), High Seas Governance: Gaps and Challenges (Leiden: Brill, 2018) 179-194 at 191-194.

246 A list of the general principles and approaches can be found under Revised draft text, supra note 4 at art. 5.

247 These initiatives are discussed in chapter 2 sections 3.3.2 and 3.3.4 above.

248 Wright et al, "High seas fisheries", supra note 8 at 12-15.

249 See the discussion about the clearing-house mechanisms in section 3.5 above. 
the clearing-house mechanism of the $\mathrm{CBD}$, or the International Council for the Exploration of the Sea (ICES), an intergovernmental marine science organization mandated with collecting and sharing "scientific understanding of marine ecosystems and the services they provide and to use this knowledge to generate state-of-theart advice for meeting conservation, management, and sustainability goals". ${ }^{250}$ The clearing-house mechanism of the Agreement could complement these initiatives by bringing "a more holistic picture of" BBNJ, ${ }^{251}$ which could help RFMOs in their assessment of the impact of fishing activities on, for example, by-catch or marine habitats. This gathering of information could complement provisions on capacitybuilding under the Agreement itself, ${ }^{252}$ but also articles 24 and 25 UNFSA in terms of assistance to and special requirements of developing States, which pinpoint the difficulty for these States to access information and technology.

In terms of the elements of the package deal, international fisheries management could mostly benefit "from unified methodologies for environmental assessment and area-based management", 253 even if only residually. First, ABMTs in themselves can contribute to the recovery of fish stocks, ${ }^{254}$ so the development of procedures and standards for ABMTs will hopefully lead to the designation and establishment of additional measures beneficial for stocks. These procedures and standards could also inform ABMTs under RFMOs, such as for VMEs. The monitoring obligations developed under the Agreement could also complement existing fisheries monitoring practices. ${ }^{255}$ Second, in regard to EIAs, "[a] globally and regionally coordinated approach to EIA processes [...] could also provide a broader context for fisheries assessments". ${ }^{256}$ If the Agreement ends up also including SEA and TIA, this could inform the application of these assessment tools in ABNJ, which could then be reproduced in the fisheries sector.

These suggestions must, however, be assessed in light of two considerations linked to political perceptions and motivations, as well as practical operationalization. First, the question of whether the Agreement will have an impact on the high seas fisheries regime cannot be addressed without mentioning political implications. Political drivers can have major impacts not only on whether fisheries are covered in the BBNJ process, but also on the way to include them. For example, the particular interests of specific groups, including high seas fishing nations and States with a strong fishing sector, small-island developing States which heavily rely on fisheries not only economically but also culturally, and the position of the "big players" - the United States, Russia and China - will trigger the need for diplomatic bargaining and unavoidable political compromise.

\footnotetext{
250 ICES, "Who we are", online: <https://www.ices.dk/explore-us/who-we-are/Pages/Who-we-are.aspx>.

251 Warner, supra note 245 at 193.

252 Revised draft text, supra note 4 at arts. 42-47.

253 Caddell, supra note 244 at 163.

254 Warner, supra note 245 at 193.

255 Ibid.

256 Ibid.
} 
Second, the impact of the Agreement also rests to a large extent on the way in which these suggestions for coordination can be operationalized, in other words, how these suggestions can be "effectively integrated into fisheries management undertaken by other actors", 257 and "applied consistently by those doing fisheries management". ${ }^{258}$ The practical influence of the Agreement on the enhancement of cross-sectoral focus ${ }^{259}$ within fisheries management and on the contribution for improved coherence within a legal framework that varies across regions, both in terms of legal obligations and of jurisdictional/geographical coverage, ${ }^{260}$ depends on two elements, which are addressed in the following sections.

\subsection{Institutional structure for the conservation and sustainable use of BBNJ}

The composition of the institutional arrangements for the Agreement is more or less clear. As discussed above, ${ }^{261}$ delegations have agreed to the establishment of several bodies, including a COP, a Scientific and Technical Body, a Secretariat and a clearing-house mechanism. There is also a possibility for the COP to establish "subsidiary bodies as deemed necessary for the implementation of the Agreement" . ${ }^{262}$ Although the text of the different provisions listed in Part VI of the Agreement (Institutional Arrangements) ${ }^{263}$ remains under consideration, the creation of these bodies does not seem to be contested. ${ }^{264}$ The remaining lack of specificity regarding several elements of these bodies' mandates is probably due to the "form follows function" approach taken by the negotiators during IGC 2, which means that further discussions on institutional arrangements are relegated to a later stage, once the substance has been agreed upon. ${ }^{265}$ However, the structure of this institutional architecture and, above all, how this structure will affect the interaction of the Agreement with other instruments and bodies remains open to question. Not only might different institutional responses be required for the different elements of the

257 Millicay, supra note 9 at 174.

258 Ibid.

259 Wright et al, "High seas fisheries", supra note 8 at 16; Robin Warner, "Strengthening Governance Frameworks for Conservation and Sustainable Use of Marine Biodiversity in Areas Beyond National Jurisdiction: Southern Hemisphere Perspectives" (2017) 32 International Journal of Marine \& Coastal Law 607-634 at 626-627.

260 Wright et al, "High seas fisheries", supra note 8 at 11.

261 See section 3.3 above.

262 Revised draft text, supra note 4 at art. 48(4)(d).

263 Ibid at arts. 48-51.

264 As mentioned by Gjerde, Clark \& Harden-Davies, supra note 111 at 36, it is necessary for the Agreement to adopt "at least four key elements: a central administrative body, a science-policy advisory mechanism or body, regular review of implementation, and power to adopt binding decisions". While the institutional arrangements discussed under Part VI of the draft Agreement would fulfil the first two and the last elements, the question of a review/compliance mechanism would have to be looked into further by the IGC, as questions of implementation and compliance are for now only briefly discussed under art. 53 (the sole provision of Part VIII) of the draft Agreement and rest mostly with States. On compliance, see also section 3.5 above.

265 Workshop “Institutional design”, supra note 195. 
package deal, ${ }^{266}$ but the institutional structure might also have implications for the Agreement's relationship with the fisheries regulation and management framework.

The BBNJ process has been built on the premise that there is a need for a comprehensive global regime ${ }^{267}$ to better address the conservation and sustainable use of BBNJ. This comprehensiveness is also supported by the fact that elements of the package deal must be dealt with "together and as a whole". ${ }^{268}$ One could therefore assume that it is through the lens of interconnectedness that one must look at the $\mathrm{BBNJ}$ and approach potential solutions. However, envisaging the practical measures to be undertaken to face the challenges of conservation and sustainable use might not always be purely global, and a regional/sectoral approach could be preferred. In fact, a "global" perspective has been opposed by several actors who claim that this could overlap with the mandate of existing organizations, which would go against the requirement that "the process and its result should not undermine existing relevant legal instruments and frameworks and relevant global, regional and sectoral bodies" ${ }^{269}$ While the question of not undermining is discussed below, ${ }^{270}$ the debate concerning the different types of approaches to an institutional structure shapes the present discussion.

While a global approach would be built on strong global institutions that have decision-making powers, a regional approach would rely on existing regional and/ or sectoral structures. The former would ensure a coherent overarching framework. The latter has the advantage of being less costly, as it would rely on existing institutions and structures. A third approach, presented by New Zealand during PrepCom 3, relies on a hybrid model, where the Agreement would suggest general guidance, objectives and standards, as well as oversight for decision-making and implementation at the global level, while science, implementation and compliance would be undertaken regionally/sectorally, relying on the authority and measures of regional bodies. ${ }^{271}$ Basically, there would be consistency of policies at the global level, as well as respect for regional specificities. ${ }^{272}$ Although this "three model approach" first arose in the context of ABMTs, it has now been used to assess the possibilities of institutional arrangements more generally. ${ }^{273}$ Even if the hybrid approach seems

266 Oude Elferink, "Institutional landscape”, supra note 190 at 238.

267 UNGA Res 69/292, supra note 31 at preamble.

268 UNGA Res 72/249, supra note 2 at para 2.

$269 \mathrm{Ibid}$ at para 7.

270 See section 4.3 below.

271 "PreparatoryCommitteeonConservationandSustainableUseofMarineBiologicalDiversityofAreasBeyond National Jurisdiction - New Zealand Submission” (December 2016) at 1, online: <https://www.un.org/ depts/los/biodiversity/prepcom_files/rolling_comp/New_Zealand.pdf $>$. See also Summary PrepCom 3, supra note 68 at 6 and 15.

272 See, e.g. Statement made by South Africa at PrepCom 4 (Plenary discussion on the draft recommendations 20 July 2017) in the present author's notes from the fourth session of the PrepCom (on file with author) [Author's notes PrepCom 4]; Oude Elferink, "Institutional landscape", supra note 190 at 240; Dalaker Kraabel, supra note 192.

273 For a recent overview of the three approaches, see Papastavridis, supra note 80 at 601-602. 
to have lost momentum following IGC $2,{ }^{274}$ the different approaches (global, hybrid, regional) can still be relevant for our understanding of the relationship between the Agreement and existing bodies. ${ }^{275}$

In a 2016 study, preceding the first discussions on institutional arrangements (that started at PrepCom 3), Barnes looked into institutional arrangements that could be applicable to high seas fisheries, and made four suggestions, using a matrix that ranges from strong to weak integration on one axis, and from centralized to decentralized on the other (see Figure 2 below). ${ }^{276}$ Although the nature of the main bodies has now been agreed upon, these suggestions remain relevant to give information about different ways in which the BBNJ bodies could interact with fisheries bodies. First, a strongly integrated and centralized structure (A1) would trigger the creation of a new institution that would manage all activities in ABNJ, and decisions would be taken solely by this entity. Second, a strongly integrated but decentralized option (B1) would rely on existing regional and sectoral bodies, such as RFMOs, but their work would be integrated and coordinated, and their mandates and competences would be extended to cover ABNJ. Third, in a weakly integrated but centralized structure (A2), which according to Barnes represents the status quo, regional structures would retain their functions, and more global considerations would be dealt with at the UN level, by the adoption of standards and guidelines to be implemented and followed regionally. Finally, a weakly integrated and decentralized approach (B2) would simply put the duty of managing $\mathrm{ABNJ}$ in the hands of regional bodies.

274 Vito De Lucia, "Rethinking the Conservation of Marine Biodiversity beyond National Jurisdiction: From 'Not Undermine' to Ecosystem-Based Governance" (2019) 8:4 ESIL Reflections at 4.

275 In a recent publication, Clark suggests to move away from the global/regional/hybrid nomenclature, which has triggered ambiguities, to a framework providing "a clearer understanding of the form and function for the institutional architecture proposed. This framework consists of four key questions: 1 . Which (if any) organs are critical for the implementation and operationalization of the BBNJ Agreement? 2. What are the powers and functions of each organ? 3. Are those powers and functions conditional? 4. What is the role of existing organizations?", see Nichola A. Clark, "Institutional arrangements for the new BBNJ agreement: Moving beyond global, regional, and hybrid" (2020) Marine Policy article 104143 at 5. These questions also guide the present analysis.

276 Barnes, “The Proposed LOSC IA", supra note 54 at 598. 
Figure 2: Scenarios and characteristics of institutional arrangements for ABNJ (Barnes, 2016)

Strong Integration

\begin{tabular}{|l|l|}
\hline $\begin{array}{l}\text { A1 Single ABNJ Management } \\
\text { Authority }\end{array}$ & $\begin{array}{l}\text { B1 Composite Regional ABNJ Management } \\
\text { Organizations } \\
\text { - ISA + option }\end{array}$ \\
$\begin{array}{l}\text { - Single multi-sector institution } \\
\text { with comprehensive planning/ } \\
\text { licensing authority, established } \\
\text { environmental management regimes } \\
\text { under a binding instrument. }\end{array}$ & $\begin{array}{l}\text { Revised mandates and institutional } \\
\text { arrangements governance under a } \\
\text { strong binding agreement. }\end{array}$ \\
\hline $\begin{array}{l}\text { A2 ABNJ Advisory Body/Process } \\
\text { - Status quo }\end{array}$ & $\begin{array}{l}\text { B2 Coordinated Sectoral Management } \\
\text { Organizations } \\
\text { Non-binding guidelines advanced } \\
\text { through resolutions of the UNGA. }\end{array}$ \\
& $\begin{array}{l}\text { 'Enhanced status quo' } \\
\text { - Retain regional bodies, subject to } \\
\text { structured coordination and revised } \\
\text { obligations set out in a framework } \\
\text { instrument. }\end{array}$ \\
\hline
\end{tabular}

Weak Integration

Current trends regarding high seas fisheries and the Agreement seem to lean towards the third option (A2), which does not bode well for an improvement of the status quo.

Similar models had also been contemplated by Tladi in a 2015 paper on the relationship between the eventual Agreement and RFMOs in the establishment of MPAs. He had raised similar possibilities for the architecture of the instrument, ranging from deference to non-recognition. ${ }^{277}$ While a deferential approach would make RFMOs, and potentially other regional/sectoral bodies, directly responsible for the establishment of MPAs (and eventually for other tasks), ${ }^{278}$ non-recognition would delegate the responsibility of establishing MPAs to a new entity, without seeking any action from RFMOs and other regional/sectoral bodies. ${ }^{279}$ Tladi, however, suggested that a middle ground should be found, one that would rely on the recognition of the mandate of regional/sectoral organizations, but that would not defer to them. ${ }^{280}$ Would this mean that regional/sectoral organizations would somehow be consulted, but that the decisions would be taken and implemented by Agreement-related bodies? It is difficult, as pointed out by Tladi, to know exactly "where, in this decision-making chain, RFMOs would fit". ${ }^{281}$

This question about decision-making further raises the issue of not only who is mandated with such decision-making power, but what this power entails, i.e.

277 Dire Tladi, “The Proposed Implementing Agreement: Options for Coherence and Consistency in the Establishment of Protected Areas Beyond National Jurisdiction” (2015) 30:4 International Journal of Marine and Coastal Law 654-673 at 666-668.

278 Ibid at 667.

279 Ibid at 668 .

$280 \mathrm{Ibid}$ at 672.

281 Ibid at 669. 
decision-making power about what, and to what extent. Decision-making must also be seen together with how decisions are then implemented, monitored and reviewed. As identified by Mahon et al, "for the [Agreement] to be successful in enabling a coherent framework it should include: (i) a clearly identifiable overarching mechanism for integrated policy development and coordination; and (ii) effective science-policy advisory mechanisms to ensure that critical scientific knowledge is communicated effectively". ${ }^{282}$ We could conclude that the current institutional arrangements do provide for such structures, through the COP and the Scientific and Technical Body respectively. Yet, this falls short of explaining what this overarching mechanism and science-policy advisory mechanisms could do to create a relationship and interact with existing fisheries bodies.

This is why others favour a focus on regional entities. Scanlon for example suggests that solidifying the regime for ABNJ should be made mostly through existing "mechanisms and devices within international law" and the "existing architecture in ABNJ". 283 Scanlon in fact underlines different mechanisms and measures developed by regional bodies (she mostly uses examples from RFMOs) that have had a positive impact on the regime for ABNJ. ${ }^{284}$ Accordingly,

when designing a new regime, existing bodies and legal frameworks, and their practice and potential should be focussed on, and consideration given to how their work can be facilitated and strengthened within those existing frameworks [...,] focussing on and facilitating [...] efforts and abilities [of regional bodies] to take action and to adapt to improve environmental protections would be highly beneficial. $^{285}$

The present author agrees that regional structures are important; it is most probably through them that measures could be implemented, as these structures are the ones having the expertise to operate "in the field". 286 The present author also recognizes the work done and the measures undertaken by regional entities, including RFMOs, to enshrine environmental concerns in their practice. However, relying on regional bodies and envisaging certain ways in which they can provide flexible mechanisms for change and adaptation is only one way forward; the necessity of overarching structures is also present. As highlighted by Oude Elferink, "[a] regional focus, with the absence of a body with [a] coordinating task at the global level, obviously carries the risk of regional differentiation. Moreover, such an approach may lead to a lack

282 Robin Mahon et al, “Transboundary Waters Assessment Programme (TWAP) Assessment of Governance Arrangements for the Ocean. Volume 2: Areas Beyond National Jurisdiction" (2015) UNESCO-IOC Technical Series 119, cited in Oude Elferink, "Institutional landscape", supra note 190 at 242.

283 Scanlon, supra note 21 at 414.

284 See generally, ibid at 409-414.

285 Ibid at 414-415.

286 See also Louise De La Fayette, "Principles and Objectives of the Legal Regime Governing Areas Beyond National - Commentary on Tullio Treves" in Alex Oude Elferink \& Erik Molenaar (eds), The International Regime of Areas Beyond National Jurisdiction: Current and Future Developments (Leiden: Martinus Nijhoff, 2010) 39-40 at 40. 
of coordination between the relevant regional bodies and between those bodies and sectoral bodies operating at the global level".287

This last view is supported by Friedman who, in an answer to Scanlon's study, explained that the solution to improving the performance of RFMOs rests within joint interplay management, which implies a strengthened coordination between entities. ${ }^{288}$ This interplay is two-faceted: will the Agreement create a new body to support its implementation and, if so, "what will be the scope of its authority and its potential for overlap with existing mandates"? 289 We are already able to answer the first question positively, as it is now clear that the Agreement will create a $\mathrm{COP}$ which will "keep under review the implementation of [the] Agreement". ${ }^{290}$ The exact answer to the second question is as yet unknown, as the scope of the COP's involvement in implementation remains uncertain, and also because implementation is mostly left in the hands of States. ${ }^{291}$

According to Friedman, if we rely on implementation through existing bodies, guided by general principles and guidelines, this would probably be the safest option to ensure that existing bodies are not undermined, but that would probably amount to maintaining the status quo. ${ }^{292} \mathrm{~A}$ new body could also be mandated to act as a "default" mechanism, when no other measure exists, although this could contribute to fragmentation. ${ }^{293}$ However, giving complete deference to fisheries bodies and excluding them from any interactions with the Agreement would be a mistake because of the threat that fisheries activities represent for marine biodiversity. ${ }^{294}$ The best option would therefore be a body that can adopt binding decisions, not necessarily imposable on other existing bodies, but binding decisions that could force parties to the Agreement to collaborate, which would force more interplay. ${ }^{295}$ Based on joint interplay management, it is not an "and/or" approach, a "regional versus global" approach that should be favoured, but one that relies on an interaction between the regional and the global levels. ${ }^{296}$

287 Oude Elferink, "Institutional landscape", supra note 190 at 242.

288 Andrew Friedman, "Beyond 'not undermining': possibilities for global cooperation to improve environmental protection in areas beyond national jurisdiction” (2019) 76:2 ICES Journal of Marine Science 452-456 at 453, relying on the work of Sebastian Oberthür, "Interplay Management: enhancing environmental policy integration among international institutions" (2009) 9 International Environmental Agreements 371-391. The notion of joint interplay management is discussed further in chapter 7 below.

289 Friedman, supra note 288 at 454.

290 Revised draft text, supra note 4 at art. 48(4).

$291 \mathrm{Ibid}$ at art. 53.

292 Friedman, supra note 288 at 454.

293 Ibid.

294 See chapter 2 section 2.2 above.

295 Friedman, supra note 288 at 455.

296 Ibid at 456. See also, generally, Kristina Gjerde et al, "Conservation and Sustainable Use of Marine Biodiversity in Areas Beyond National Jurisdiction: Options for Underpinning a Strong Global BBNJ Agreement through Regional and Sectoral Governance" (2018) STRONG High Seas Project [Gjerde et al, "Options for Underpinning"]; Carole Durussel et al, "Strengthening Regional Ocean Governance for the High Seas: Opportunities and Challenges to Improve the Legal and Institutional Framework of the Southeast Atlantic and Southeast Pacific" (2018) STRONG High Seas Project. 
The recent proposal made by Iceland, which would target the notion of cooperation found under article 6 of the Agreement, ${ }^{297}$ could also be seen as a way to foster interplay between the global and regional levels. Iceland indeed suggests a specific procedure to achieve cooperation regarding ABMTs and EIAs, where regional consultations, established under the Agreement, would be held with the regional and sectoral entities (e.g. RFMOs, RSPs, IMO) operating in a specific region. ${ }^{298}$ This proposal could contribute to balancing "the need for an overall set of common rules and principles with the realities of regional and sectoral fragmentation" 299 and could therefore amount to a hybrid mechanism.

While a hybrid model could be seen as going against the need of a global comprehensive approach, ${ }^{300}$ the model is also a promising way of reconciling views. It is also probably the best way to translate, in practice, the balance between conservation of biodiversity and respect for existing structures and bodies. However, a global component to the instrument cannot be ignored, as this component is inherent to the interconnectivity which $\mathrm{ABNJ}$ represent, ${ }^{301}$ and to the objectives of the $\mathrm{BBNJ}$ process. Indeed, if only measures from already existing regional bodies are applied, without envisaging global measures, why begin the BBNJ process in the first place? The possible interaction between the Agreement and fisheries bodies will also depend on the extent of the coordination and coherence mandate given to the institutional arrangements. It is to be questioned whether such a mandate will be sufficient to reinforce cooperation, or whether it will crystallize the autonomy of regional bodies, their existing interests, and adverse environmental impacts stemming from those interests. ${ }^{302}$

\subsection{The "not undermining" clause}

The institutional structure that would be most appropriate to establish the relationship between the Agreement and fisheries bodies is also closely linked to another central concept of the BBNJ process: the requirement "that this process and its result should not undermine existing relevant legal instruments and frameworks

297 Textual proposals, supra note 97 at 52-54. The Icelandic proposal is also discussed in section 2.3 above.

298 Nicaragua also supports such consultations, mentioning that the BBNJ Agreement should not interfere with the work done by other fisheries entities and/or the FAO, and that there should be an obligation to consult with fisheries entities when binding measures that could affect fisheries are taken, see Textual proposals, supra note 97 at 402-403.

299 De Lucia, supra note 100 at 3.

300 UNGA Res 69/292, supra note 31 at preamble.

301 See, e.g., Richard Kenchington \& Robin Warner, "Uncertain Seas Ahead: Legal and Policy Approaches to Conserving Marine Biodiversity in the Face of Changing Climate" in Robin Warner \& Clive Schofield (eds) Climate Change and the Oceans: Gauging the Legal and Policy Currents in the Asia Pacific and Beyond (Cheltenham: Edward Elgar, 2012) 51-73 at 57; Ichiro Nomura, "Sustainable World Fisheries: Elements of Success" in Michael Lodge and Myron Nordquist (eds), Peaceful Order in the World's Oceans. Essays in Honor of Satya N. Nandan (Leiden, Brill Nijhoff, 2014) 325-337 at 328; David Freestone, Richard Barnes \& David Ong, "The law of the sea: Progress and prospects" in David Freestone, Richard Barnes \& David Ong (eds), The Law of the Sea: Progress and Prospects (Oxford University Press, Oxford, 2006) 1-27.

302 Barnes, "Future fisheries", supra note 112. 
and relevant global, regional and sectoral bodies"303 (hereafter the not undermining clause). The not undermining clause can therefore be thought of as a conflict clause, because it regulates the relationship between the Agreement and other instruments dealing with the same subject matter. ${ }^{304}$

However, the not undermining clause raises a tension between the overarching goal of the $\mathrm{BBNJ}$ process and the need to respect existing frameworks. ${ }^{305}$ On the one hand, the $\mathrm{BBNJ}$ process seeks to: complement the fragmented regime in $\mathrm{ABNJ}$; better address the gaps and barriers in the management, conservation and sustainable use of marine biodiversity in these areas; and ensure coordination and cooperation. The not undermining clause, for its part, seeks to ensure the autonomy of existing institutions and, indirectly, respect the various individual interests put forward by delegations, in order to achieve universal participation as closely as possible. ${ }^{306}$ It is within this context that we need to position ourselves when assessing the meaning and scope of the not undermining clause, as well as its impact on the influence that the Agreement can have on international and high seas fisheries regulation and management.

The wording of the not undermining clause comes from the recommendations of the Working Group. A precursor of the clause first appeared using the wording "recogniz[ing] and respect[ing] the existing legal frameworks and the competence and mandates of global and regional bodies", ${ }^{307}$ and the necessity for negotiations not to undermine existing legal frameworks was later suggested by Japan. ${ }^{308}$ The wording evolved into the need for the new text to "recognize, respect and not undermine UNCLOS and other relevant legal instruments and frameworks, and relevant global, regional and sectoral bodies and arrangements". ${ }^{309}$ In the end, the ideas of "recognizing" and "respecting" did not make it to the final text and, after regional consultations, the need for "negotiations" or the "new text" not to undermine became the need for the "process" not to undermine. ${ }^{310}$ "Not undermining" existing instruments and bodies was also preferred to "not affecting the legal status" of parties and non-parties. ${ }^{311}$ Since "not affecting the legal status"

303 UNGA Res 72/249, supra note 2 at para 7. A similar wording was also found under UNGA Res 69/292, supra note 31 at para 3 , although it referred to the process only and not its result.

304 Nele Matz-Luck, “Treaties, Conflict Clause” (2006) Max Planck Encyclopedia of Public International Law at para 1.

305 See, e.g. Papastavridis, supra note 80 at 600.

306 The "not undermining" wording was probably chosen on purpose because it is vague, to gather the support of as many delegations as possible, see Author's note PrepCom 3.

307 Proposition made by New Zealand, supported by Mexico, Canada, Australia, the Republic of Korea and the Russian Federation, see IISD, "Summary of the ninth meeting of the working group on marine biodiversity beyond areas of national jurisdiction:20-23 January 2015” (2015) 25:94 Earth Negotiations Bulletin at 7.

308 Ibid.

309 Suggested by Australia, supported by the EU, the Russian Federation, Iceland, Canada and Japan, but opposed by the G-77 and China, see ibid.

$310 \mathrm{Ibid}$ at 8 .

$311 \mathrm{Ibid}$ at 10 . 
was set aside in favour of "not undermining", it could be asked whether the possible meaning of "not affecting the legal status" was expressly rejected, or whether "not undermining" can be seen as a broader term that includes the duty not to affect legal status. ${ }^{312}$

The influence of this variety of phrasing has left the exact meaning of the not undermining clause, as well as its practical implications, uncertain. If new global structures are created, would existing structures find themselves impacted and, if so, would that impact amount to undermining? If existing structures are maintained, would their mandate and functioning be modified or adapted and, if so, would that undermine them? It has been suggested that the phrasing of "not undermine" had been purposely chosen for its ambiguity, ${ }^{313}$ in order to reach a political compromise and rally parties which did not want certain entities - RFMOs in particular - to be affected by the process. ${ }^{314}$ As mentioned by Palmer, "[a]ll politicians know the value of ambiguity. It can serve to secure agreement where agreement may otherwise not be achieved". ${ }^{15}$

Throughout the PrepCom and the first meeting of the IGC, delegations suggested a wide array of possible interpretations and tentative meanings. These suggestions are summarized in Table $2 .{ }^{316}$ As underlined by the facilitator on cross-cutting issues during the third meeting of the PrepCom, all participants agree that existing structures must not be undermined, but people have different views on what that means in practice; it is a good term to convey the idea agreed upon, but it remains an idea about which everybody has a different understanding. ${ }^{317}$ Interestingly, although not surprisingly, a correlation seems to exist between the parties in favour of a global approach and those who think that "not undermine" should be applied restrictively (i.e. a higher threshold needs to be reached before a measure is considered as undermining). ${ }^{318}$

312 An overview of the different phrasing used during the discussions of the Ad-hoc Working Group is also found in Vito De Lucia, "Reflecting on the meaning of "not undermining" ahead of IGC-2" (21 March 2019) JCLOS Blog, online: <https://site.uit.no/nclos/2019/03/21/reflecting-on-the-meaning-of-notundermining-ahead-of-igc-2/>.

313 Friedman, supra note 288 at 452.

314 Informal statements made by delegates, see Author's notes PrepCom 3 and PrepCom 4.

315 Geoffrey Palmer, "New Ways to Make International Environmental Law" (1992) 86 American Journal of International Law 259-283 at 269.

316 It is in fact at PrepCom 3 that concrete suggestions on the meaning of the not undermining clause seem to have appeared among delegates' interventions. Since IGC 2, however, probably because of the streamlining of options in the draft texts, such discussions have been minimal. This is why Table 2 mainly contains, although not exclusively, suggestions that have been made during PrepCom 3, PrepCom 4 and IGC1.

317 "With regard to the relationship of an international instrument with other instruments and with regional and sectoral bodies, there was convergence that, as provided in resolution 69/292, an international instrument should not undermine existing relevant legal instruments and frameworks and relevant global, regional and sectoral bodies. However, different understandings were given of the meaning of 'not undermining", see Chair's overview PrepCom 3, supra note 68 at 26 (emphasis added).

318 De Lucia, supra note 274 at 5. 
Table 2: Suggestions on the meaning of "not undermining"

\begin{tabular}{|l|l|}
\hline \multicolumn{1}{|c|}{ Tentative meaning } & \multicolumn{1}{c|}{ Suggested by } \\
\hline $\begin{array}{l}\text { No alteration of rights and obligations under } \\
\text { existing treaties, including UNCLOS }\end{array}$ & EU, Russia, China, Canada ${ }^{319}$ \\
\hline $\begin{array}{l}\text { Similar to the non-prejudice provisions in } \\
\text { existing instruments }\end{array}$ & Norway $^{320}$ \\
\hline $\begin{array}{l}\text { No duplications or overlaps with existing } \\
\text { instruments }\end{array}$ & China, CARICOM, Tuvalu, EU, US ${ }^{321}$ \\
\hline $\begin{array}{l}\text { No interference with the work (e.g. mandate } \\
\text { and functioning) of existing bodies }\end{array}$ & $\begin{array}{l}\text { China, Japan, Iceland, Australia, South Korea, } \\
\text { Norway, EU }\end{array}$ \\
\hline $\begin{array}{l}\text { Not weaken existing bodies (regional/ } \\
\text { sectoral), not restricting }\end{array}$ & $\begin{array}{l}\text { Australia, Guatemala, Mexico, Costa Rica, } \\
\text { IUCN }\end{array}$ \\
\hline $\begin{array}{l}\text { Build on existing expertise of regional and } \\
\text { sectoral instruments, organizations and } \\
\text { mechanisms }\end{array}$ & $\begin{array}{l}\text { New Zealand, US, Argentina, EU, Iceland, } \\
\text { Fiji, G77, IUCN }\end{array}$ \\
\hline Coherence, consistency & CARICOM, China, El Salvador, Tuvalu \\
\hline Strengthen, harmonize and/or simplify & Costa Rica, Tuvalu, EU ${ }^{326}$ \\
\hline Promote coordination and cooperation & China, Norway, Australia, South Korea \\
\hline
\end{tabular}

319 EU: Summary PrepCom 3, supra note 68 at 12. Russia: Statement PrepCom 4 (Plenary on general elements 18 July 2017), Author's notes PrepCom 4. China: Statement PrepCom 3 (Working group on cross-cutting issues 3 April 2017), Author's notes PrepCom 3; Statement IGC1 (General exchange of views 4 September 2018), Author's notes IGC1. Canada: Statement IGC1 (General exchange of views 4 September 2018), Author's notes IGC1. See also, generally, Chair's overview PrepCom 1, supra note 57 at 4-5.

320 Summary PrepCom 2, supra note 64 at 16. See, generally, Chair's overview PrepCom 1, supra note 57 at 4-5.

321 China: Summary PrepCom 2, supra note 64 at 16-17. CARICOM and Tuvalu: Summary PrepCom 3, supra note 68 at 12. EU: Statement PrepCom 3 (Plenary on EIAs 5 April 2017), Author's notes PrepCom 3; Statement IGC1 (General exchange of views 4 September 2018), Author's notes IGC1. US: Statement IGC1 (General exchange of views 4 September 2018), Author's notes IGC1. See also, generally, Chair's overview PrepCom 1, supra note 57 at 4-5, and Chair's overview PrepCom 2, supra note 64 at 10.

322 China: Summary PrepCom 2, supra note 64 at 16. Japan: Summary PrepCom 2, supra note 64 at 17; Summary PrepCom 3, supra note 68 at 12; Statement PrepCom 3 (Working group on cross-cutting issues 3 April 2017), Author's notes PrepCom 3; Statement IGC 1 (Working group on ABMTs 7 September 2018), Author's notes IGC1. Iceland: Summary PrepCom 2, supra note 64 at 17. Australia: Summary PrepCom 3, supra note 68 at 12. Korea: Statement PrepCom 4 (General statements 10 July 2017), Author's notes PrepCom 4. Norway: Statement PrepCom 3 (Working group on cross-cutting issues 3 April 2017), Author's notes PrepCom 3. EU: Statement IGC 1 (General exchange of views 4 September 2018), Author's notes IGC1. See also, generally, Chair's overview PrepCom 1, supra note 57 at 4-5.

323 Australia: Summary PrepCom 2, supra note 64 at 17. Guatemala and Mexico: Summary PrepCom 3, supra note 68 at 12. Costa Rica and IUCN: Statements PrepCom 3 (Plenary on cross-cutting issues 7 April 2017), Author's notes PrepCom 3.

324 NZ, US and Argentina: Summary PrepCom 2, supra note 64 at 17. EU: Statement IGC 1 (General exchange of views 4 September 2018), Author's notes IGC1. G77: Statement IGC 1 (Working group on MGRs 12 September 2018), Author's notes IGC1. Iceland and IUCN: Statement IGC 1 (Working group on ABMTs 10 September 2018), Author's notes IGC1. Fiji: Statement IGC 1 (Working group on EIAs 11 September 2018), Author's notes IGC1. See also, generally, Chair's overview PrepCom 1, supra note 57 at 12; Summary PrepCom 1, supra note 57 at 18; and Chair's overview PrepCom 2, supra note 64 at 10.

325 Summary PrepCom 3, supra note 68 at 12.

326 Costa Rica: Summary PrepCom 2, supra note 64 at 17. Tuvalu: Summary PrepCom 3, supra note 68 at 12. EU: "Rolling position paper of the EU and its Member States" (9 March 2017) at 3 (on file with author). See also Chair's overview PrepCom 2, supra note 64 at 10.

327 China: Summary PrepCom 2, supra note 64 at 16. Norway and Australia: Summary PrepCom 3, supra note 68 at 12. Korea: Statement PrepCom 4 (General statements 10 July 2017), Autor's notes PrepCom 4. 


\begin{tabular}{|l|l|}
\hline \multicolumn{1}{|c|}{ Tentative meaning } & \multicolumn{1}{c|}{ Suggested by } \\
\hline Fill the gaps, complement & $\begin{array}{l}\text { US, CARICOM, Micronesia, Tuvalu, Norway, } \\
\text { Costa Rica, High Seas Alliance, Nigeria }\end{array}$ \\
\hline Not reducing the effectiveness & $\begin{array}{l}\text { Greenpeace, High Seas Alliance, PSIDS, } \\
\text { Morocco }^{329}\end{array}$ \\
\hline Not affect national efforts & Nauru $^{330}$ \\
\hline Should be interpreted on a case-by-case basis & Argentina $^{331}$ \\
\hline $\begin{array}{l}\text { No changes, modifications or adaptations } \\
\text { to the mandate and functioning of current } \\
\text { structures }\end{array}$ & Iceland ${ }^{332}$ \\
\hline $\begin{array}{l}\text { It is not because we cannot undermine } \\
\text { existing structures that the Agreement should } \\
\text { function in a vacuum }\end{array}$ & $\begin{array}{l}\text { Canada, } \\
\text { group }\end{array}$ \\
\hline
\end{tabular}

An alternative phrasing to "not undermining" was included in the Draft text discussed at IGC3, which suggested that relevant instruments should be "supportive of and not run counter to the objectives of [UNCLOS] and the" Agreement. ${ }^{334}$ This phrasing was quickly rejected, as it could be understood as giving precedence to the Agreement over UNCLOS. Such an interpretation would go against the not undermining clause as well as the relationship between the Agreement and UNCLOS, the former being an implementing agreement of the latter. ${ }^{335}$

More "positive phrasings" were also suggested; ${ }^{336}$ however, it is the following wording that we now find under article 4 of the Agreement:

328 US and Micronesia: Summary PrepCom 2, supra note 64 at 12 and 17. CARICOM, Tuvalu, Norway and HSA: Summary PrepCom 3, supra note 68 at 12. Costa Rica: Statement PrepCom 4 (Working group on cross-cutting issues 14 July 2017), Author's notes PrepCom 4. Nigeria: Statement IGC 1 (General exchange of views 5 September 2018), Author's notes IGC1.

329 Greenpeace and HSA: Summary PrepCom 2, supra note 64 at 17. PSIDS and Morocco: Summary PrepCom 3, supra note 68 at 12.

330 Statement IGC 1 (Working group on ABMTs 10 September 2018), Author's notes IGC1.

331 Summary PrepCom 3, supra note 68 at 12.

332 Statement PrepCom 3 (Plenary on cross-cutting Issues 7 April 2017), Author's notes PrepCom 3.

333 Canada: Summary PrepCom 3, supra note 68 at 12; Statement PrepCom 4 (Working group on Crosscutting issues 14 July 2017), Author's notes PrepCom 4. Algeria: Statement PrepCom 4 (Working group on Cross-cutting issues 14 July 2017), Author's notes PrepCom 4.

334 Draft text, supra note 87 at art. 4(3).

335 Summary IGC 3, supra note 92 at 5.

336 Canada proposed using the more positive wording of "promote greater coherence", see Summary PrepCom 4, supra note 73 at 7 . It should be noted that "promote greater coherence" between instruments and structures has found its way into the final recommendations of the PrepCom, see Report PrepCom, supra note 76 at 9. IUCN pushed the idea even further by suggesting the deletion of the clause, arguing that since "not undermining" refers to more coordination, coherence and cooperation, which are the goals of the BBNJ process, there is in fact no need for the clause itself, see Author's notes IGC1. The wording "promote greater coherence with and complement existing" structures was later on found in the President's aid to negotiations, supra note 84 at point 4.2, and was referred to as the issue of "recognition". Discussions on recognition happened mostly at IGC2. Although the objective of this recognition was to ensure coherence between structures, as supported by New Zealand, Canada and Singapore, it was rejected mainly because delegations in favour of a regional approach (e.g. Norway, Japan, Iceland, Russia) 
1. Nothing in this Agreement shall prejudice the rights, jurisdiction and duties of States under [UNCLOS]. This Agreement shall be interpreted and applied in the context of and in a manner consistent with [UNCLOS]. [...]

3. This Agreement shall be interpreted and applied in a manner that [respects the competences of and] does not undermine relevant legal instruments and frameworks and relevant global, regional, subregional and sectoral bodies.

These paragraphs of the conflict clause of the Agreement give rise to a particular observation. The concept of not prejudicing the rights and duties of States under UNCLOS is discussed separately from the issue of not undermining (respectively in the first and third paragraphs). Whilst not prejudicing the rights and duties of States relates to the relationship between the Agreement and UNCLOS, not undermining refers to the relationship between the Agreement and other structures. This could mean that "not to prejudice the rights and duties of States" and "not undermining" result in a different treatment of UNCLOS compared to other instruments under the new Agreement. This distinction could be explained by the different nature of UNCLOS, being the framework treaty for the oceans, and the fact that the new instrument would be developed under its auspices, creating a special relationship between UNCLOS and the new Agreement. ${ }^{337}$

The not undermining clause also seems to be broader in application compared with the wording of the conflict clause of UNCLOS, article 311(2), which states that the "Convention shall not alter the rights and obligations of States Parties which arise from other agreements compatible with this Convention and which do not affect the enjoyment by other States Parties of their rights or the performance of their obligations under this Convention" (emphasis added). ${ }^{338}$ While article 311(2) seems limited to rights and obligations, the not undermining clause applies to instruments, frameworks and bodies more broadly. The not undermining clause also does not refer to the notion of compatibility between the Agreement and other instruments.

Some attempts at interpreting the not undermining clause have also been made in the literature. ${ }^{339}$ Scanlon, for example, unpacks the different meanings of the clause and its implications for the fisheries sector. ${ }^{340}$ She states that relying on the

did not agree that existing measures should have to be recognized by the Agreement, see De Lucia, supra note 274 at 5 .

337 Catherine Blanchard, Otto Spijkers \& Wen Duan, “Three Structural Pillars of the Future Internationally Legally Binding Instrument for the Conservation and Sustainable Use of Marine Biodiversity in Areas Beyond National Jurisdiction" in Marta Chantal Ribeiro, Fernando Loureiro Bastos \& Tore Henriksen (eds), Global Challenges and the Law of the Sea (Cham: Springer, 2020) 351-378 at 368-369.

338 On the content of art. 311(2) see Nele Matz-Luck, "Article 311. Relation to other conventions and international agreements" in Alexander Proelss (ed), United Nations Convention on the Law of the Sea. A Commentary (Munich: Verlag C. H. Beck, 2017) 2009-2019 at 2014-2015.

339 See, e.g., Scanlon, supra note 21; Friedman, supra note 288; Anna-Maria Hubert \& Neil Craik, "Towards Normative Coherence in the International Law of the Sea for the Conservation and Sustainable Use of Marine Biological Diversity of Areas Beyond National Jurisdiction" (1 February 2018) ABlawg (originally on JCLOS Blog), online: <https://ablawg.ca/wp-content/uploads/2018/02/Blog_AMH_NC_JCLOS.pdf>.

340 See, generally, Scanlon, supra note 21. 
definition alone would be insufficient, as "undermine" has a broad meaning. ${ }^{341}$ This is why she suggests focusing on the meaning of the term according to the context in which the term is set. Whether it is the relevant legal instruments, or frameworks or global, regional and sectoral bodies that should not be undermined could alter the meaning of "not undermine" depending on what it is applied to. This suggestion is also supported by Hubert and Craik who conclude that the meaning of "not undermine" depends on what it applies to, consequently adding that it is the meaning of "relevant instruments, frameworks and bodies" that should also be clarified. ${ }^{342}$ Accordingly, this could lead to two possibilities. First, Scanlon suggests that "not undermine" refers to the mandate of bodies and the measures in existing instruments. The effect of this first interpretation would leave the bodies untouched, letting them do their work under the existing framework. The second meaning would target the effectiveness or objectives of framework and bodies. This means that new measures could be introduced, which could potentially alter the mandate of bodies and the measures found under existing instruments, as long as the effectiveness of bodies and frameworks remains unimpaired. Scanlon seems to be of the view that the first interpretation should be preferred, based on the wording of the PrepCom's report, ${ }^{343}$ which states that the decision-making and institutional set-up for ABMTs should avoid "undermining [...] the mandate of regional and/or sectoral bodies", ${ }^{34}$ thereby putting the emphasis on the bodies' mandate.

The present author takes another view. The two meanings described above can be seen as compatible. In fact, enhancing effectiveness and helping a body to improve itself does not necessarily mean that its mandate would be negatively affected; on the contrary, it would most likely be improved. For example, in the UNFSA, not undermining refers to the effectiveness of existing structures regarding conservation and management, ${ }^{345}$ i.e. their capacities and functioning. ${ }^{346}$ If we rely on this understanding, practically speaking, this does not mean that the Agreement should have no effect on the relevant bodies, including RFMOs. If their effectiveness is enhanced and complemented by the Agreement, and this leads to concrete operationalization of their mandate, support for their activities such as better consultation and reporting mechanisms, an increased role in the designation and management of MPAs, and better cooperation with RSPs, ${ }^{347}$ the bodies would not be

341 Ibid at 406-408.

342 Hubert \& Craik, supra note 339.

343 Scanlon, supra note 21 at 408.

344 Report PrepCom, supra note 76 at 17. Scanlon then analyses actions and measures undertaken by RFMOs that have been positive for sustainable fisheries management and marine biodiversity conservation, see section 4.2 above.

345 See, e.g., UNFSA at arts. 7(2)(a) (compatibility of conservation and management measures), 17(4) (nonmembers of organizations and non-participants in arrangements), 18(1) (duties of flag States) and 23(3) (measures taken by port States).

346 Duncan Currie, “Talking Points: The Meaning of 'Not Undermine' and the Relationship between Negotiations for a New Legally Binding Instrument and Regional Fisheries Management Organizations" (12 July 2017) at 3 (on file with author); Wright et al, "High seas fisheries", supra note 8 at 11.

347 Currie, supra note 346 at 4 . 
undermined. ${ }^{348}$ At the 2016 UNFSA Review Conference, delegations were clear on the need for more coordination, ${ }^{349}$ which supports the link between effectiveness, coordination and not undermining. The present author, however, agrees with Scanlon's caution that we should not simply "copy and paste" the meaning found in the UNFSA to the BBNJ process, but preferably use it as a source of inspiration, as the two instruments have a different scope of application. ${ }^{350}$

In answering to Scanlon, Friedman engaged in a more focused analysis on the impact of the not undermining clause for the institutional model under the new Agreement. ${ }^{351}$ According to him, leaving implementation in the hands of RFMOs implies that they are "fit for purpose"; however, despite the progress highlighted in Scanlon's analysis, progress that is positive and real, RFMOs' improvements are not consistent or widely spread and the organizations do not tend to collaborate much amongst themselves or across sectors. ${ }^{352}$ This is why Friedman suggests relying on joint interplay management, which implies a strengthened coordination between entities, between the global and the regional. ${ }^{353}$ It is this interplay, claims Friedman, which is the way to overcome the uncertainty created by the not undermining clause.

This need for interplay is especially pressing in the fisheries regime. The primary focus on RFMOs/fisheries structures (compared with other activities in ABNJ, e.g. shipping or mining) within the not undermining debate is understandable due to the nature of fisheries activities, where "biodiversity conservation and sustainability considerations have greater potential to intrude upon the deliberations of fisheries managers than those of other sectors" ${ }^{354}$ Nevertheless, it appears difficult to refrain from any intervention towards fishery bodies when these organizations praise their own actions in protecting the marine environment, but in fact take a long time to adopt measures that are often not effective, or when fishing nations claim that fish are not part of the marine environment and therefore do not fall under

$348 \mathrm{Ibid}$ at 3-4 and 6. See also Wright et al, "High seas fisheries", supra note 8 at 10.

349 Currie, supra note 346 at 5.

350 Scanlon, supra note 21 at 407. This idea is also supported by Olav Schram Stokke, "The Interplay of International Regimes: Putting Effectiveness Theory to Work" (2001) Report of the Fridtjof Nansen Institute at 21, who mentions that " $[\mathrm{t}]$ he temptation to take language that has already received approval in the earlier context from one treaty and transplant it into another always carries the risk that such readily available solutions will truncate the search for more appropriate responses".

351 Friedman, supra note 288 at 452, see section 4.2 above.

$352 \mathrm{Ibid}$ at 453 . Weakenesses of RFMOs are discussed in chapter 5 section 2.3 .2 below.

$353 \mathrm{Ibid}$ at 453 and 456, relying on the work of Oberthür, supra note 288. The notion of joint interplay management is discussed further in chapter 7 section 3.2 below. The idea that "international law-making should not be overly restricted by deference to existing competencies and mandates" because of the benefits of an "inclusive and adaptive approach to existing and future institutions" is also discussed in Margaret A. Young \& Andrew Friedman, "Biodiversity Beyond National Jurisdiction: Regimes and their Interaction" (2018) 112 AJIL Unbound 123-128 at 123. See also, Elizabeth De Santo et al, "Stuck in the middle with you (and not much time left): The third intergovernmental conference on biodiversity beyond national jurisdiction" (2020) 117 Marine Policy article 103957 at 8; Gjerde et al, "Options for Underpinning"; Durussel et al, supra note 296.

354 Jessica Battle, "Not Undermining' is a Two-Way Street" (2019) WWF BBNJ Briefing Paper No. 3 at 4. 
the scope of the Agreement. ${ }^{355}$ This is why it has been suggested that the principle underlying the not undermining clause should be one of a "two-way street": we should be respecting what sectoral bodies do (i.e. not undermine them) only if they are really doing what they are supposed and expected to do. ${ }^{356}$ Not undermining should therefore be seen as an opportunity to enhance cooperation, which could eventually support the actions of sectoral bodies in performing their mandate. ${ }^{357}$

Implications of the clause for institutional arrangements also seem to vary according to the elements of the package deal. Oude Elferink in fact observed that those implications seem greater with regard to ABMTs compared with EIAs (and MGRs) where

the focus rather seems to be on avoiding unnecessary duplications. This may in large part be explained by the fact that existing interests in $\mathrm{ABNJ}$ are much more entrenched in existing institutions in the case of area-based management tools. For the other two issue-areas it would be much harder to credibly argue that existing bodies provide an adequate regulatory framework. ${ }^{358}$

This can be illustrated in the fisheries sector, where ABMTs figure more clearly in the conservation and management measures of RFMOs, compared with environmental assessment procedures which are less clearly defined. ${ }^{359}$ The interplay suggested by Friedman would therefore also need to adapt to the mandate that the different institutional structures would have with regard to the different elements of the package deal. ${ }^{360}$

Currently, delegations are faced with the need to consider the impacts of translating the political compromise of the not undermining clause into a text with legal meaning. ${ }^{361}$ In order to move towards the interplay suggested by Friedman rather than an "and/or" approach, De Lucia suggests moving from "not undermine" to compatibility, where the focus is on an ecosystem perspective rather than a jurisdictional perspective. ${ }^{362}$ Through an ecosystem perspective, "the question of who adopts measures then becomes less important than the question of whether a measure is effective and helps meet the relevant objectives of protecting marine

355 Ibid at 4.

$356 \mathrm{Ibid}$ at 6.

$357 \mathrm{Ibid}$ at 7. As discussed by Gjerde, Clark \& Harden-Davies, supra note 111, the "not undermining" clause must be understood and applied in a way to "improve upon the status quo" (at 39) and strengthen the "integration of marine environmental and biodiversity considerations into management and decisionmaking of sectoral organizations" (at 4).

358 Oude Elferink, "Institutional landscape", supra note 190 at 239.

359 This flows from the discussion undertaken in chapter 3 sections 4.2.1 and 4.2.2.

360 See section 4.2 above where, referring to Oude Elferink, "Institutional landscape", supra note 190 at 238, it is mentioned that "different institutional responses be required for the different elements of the package deal".

361 This necessity of "translation" was highlighted by Japan, Statement PrepCom 4 (Working group on crosscutting issues 14 July 2017), Author's notes PrepCom 4.

362 De Lucia, supra note 274 at 1 and 6-7. 
biodiversity and ecosystems.". ${ }^{363}$ This last statement could however raise concerns, as it could be seen as endorsing unilateral actions in ABNJ, which could have the potential of encroaching on others' freedoms and rights.

All the statements and positions discussed above illustrate one clear point: everybody refers to the clause and lets it shape the discussions. However, reaching a consensus on a very precise meaning of the not undermining clause would probably be a Utopian achievement. ${ }^{364}$ Then, could a reconciliation be achieved? To do so, one should look back at the goals sought by the BBNJ process, at how these goals unfold and what concrete actions they can trigger. Delegations have expressed ideas that illustrate this reconciliation, regrouped around five sub-goals: to strengthen and complement existing mechanisms; to focus on coherence, coordination and harmonization; to fill in the gaps; to create an incentive for parties to act; and to adapt the regime to current realities. ${ }^{365}$ The sub-goals form the framework within which the not undermining clause must be examined, and they can eventually influence its application. In fact, as Mauritius stated during the third meeting of the PrepCom, it is important not to undermine structures, but we should also keep in mind that when UNCLOS was adopted, it was not really "biodiversity" oriented. ${ }^{366}$ By entering into the BBNJ process, States and non-State actors have agreed to discuss biodiversity concerns, and it is in the context of this main goal that the not undermining clause must be given its meaning and, eventually, its application.

\section{CONCLUSION: WHEN UNCERTAINTY REMAINS}

The international community is getting together to discuss the urgent crisis triggered by the loss of biodiversity in $\mathrm{ABNJ}$. The $\mathrm{BBNJ}$ process is promising for approaching the conservation and sustainable use of marine biodiversity in $\mathrm{ABNJ}$ from a global and comprehensive perspective. It suggests the necessity to enhance existing cooperation mechanisms, and develop new ones. It also recognizes the role that a BBNJ Agreement could play in harmonizing and integrating current practices and instruments which already address the conservation and sustainable use of biodiversity. ${ }^{367}$ As observed by Warner:

$[w]$ ith the right mix of flexible and supportive provisions tailored to the needs of particular regions and sectors, the [Agreement] has the potential to enhance and lift the performance of existing governance frameworks for biodiversity conservation and sustainable use [...]. At a minimum, the [Agreement] could contain international law principles and standards on conservation and

\footnotetext{
363 Ibid at 7.

364 Scanlon, supra note 21 at 406.

365 These sub-goals are based on a compilation of interventions from a variety of delegations, see Author's notes PrepCom 3 and PrepCom 4.

366 Statement PrepCom 3 (Working group on Cross-cutting issues 3 April 2017), Author's notes PrepCom 3. On the fact that biodiversity is not in UNCLOS, see Ricard, supra note 1 at 3.

367 Warner, supra note 259 at 611.
} 
sustainable use of marine biodiversity in $\mathrm{ABNJ}$ which are generally applicable to all States Parties. ${ }^{368}$

Additionally, the Agreement is expected to enable tools and practices regarding the four elements of the package deal, ${ }^{369}$ create a bridge between the law of the sea and environmental and biodiversity law, clarify the relationship between ABNJ and AWNJ, and to consolidate compliance. The Agreement also has the capacity to create and solidify mechanisms for gathering and sharing scientific and technical information, data and knowledge, through the contributions of a wide variety of actors and stakeholders. In that sense, the instrument could potentially act as a central repository. ${ }^{370}$ All these examples contribute to building up the role of the Agreement as a catalyst for interconnectedness, cooperation and coordination in ABNJ.

However, while using the momentum that the oceans currently benefit from and the enthusiasm that delegations share to achieve a positive outcome for biodiversity, one should remain realistic as to the concrete changes that the BBNJ process will be able to generate. As cautioned by Barnes, "[i]t is important not to regard [the process] as a panacea and to overburden it with expectations". ${ }^{371}$ While there is consensus amongst most delegations on the issues to address, how such issues would unfold within an instrument and eventually be implemented in practice will require extensive discussions, negotiations and compromise. However, such a compromise has the potential to dilute the strength of the instrument for the benefit of universal participation. ${ }^{372}$

Uncertainties are particularly present when facing the relationship between fisheries management and the BBNJ process. The basic question of whether fisheries management and regulations will fall under the scope of the Agreement remains for now uncertain; the impact of the Agreement on the high seas fisheries regime, however, is certain. Notably, principles governing the high seas, and that also have an impact on fisheries, could be operationalized further. The COP could facilitate cooperation mechanisms, such as the ones between RFMOs and RSPs. The data gathering role of the Agreement could also be beneficial for the fisheries sector. Finally, the development of procedures and standards for ABMTs and EIAs could provide a broader context for various existing fisheries tools. Two elements must,

368 Ibid at 626.

369 Kristina Gjerde, "Enhancing integrated management beyond national jurisdiction under the environmental provisions of the UN Convention on the Law of the Sea" in Marta Chantal Ribeiro (ed), 30 Years After the Signature of the United Nations Convention on the Law of the Sea: The Protection of the Environment and the Future of the Law of the Sea. Proceedings of the International Conference (Coimbra: Coimbra Editora, 2014) 441-452 at 452.

370 Warner, supra note 259 at 627.

371 Barnes, "The Proposed LOSC IA", supra note 54 at 616.

372 With regard to international negotiations more generally, Palmer, supra note 315 at 278 indeed states that "[a] recurring theme at international conferences is the last-minute effort to persuade one country or another to go along. Language is softened, material is removed, and much of substance is lost". 
however, be considered to fully understand and assess the practical implications of the interaction between the fisheries regime in $\mathrm{ABNJ}$ and the Agreement. The types of institutional arrangements chosen, including the mandate granted to each body, as well as the uncertainties linked to the necessity for the Agreement not to undermine existing structures, will strongly characterize the type of cooperation and coordination that can be expected from the Agreement. Other parts of the Agreement, for example provisions linked to dispute settlement, could also be of particular interest when dealing with questions of interpretation or jurisdiction. They could eventually shed light on the meaning and scope of instruments and bodies' mandates and interaction. Such provisions, however, remain underexplored for now. ${ }^{373}$

Nevertheless, many have warned against the dangers of excluding fisheries from the scope of the Agreement. Considering that fisheries are the main threat to marine biodiversity in ABNJ, expressly excluding them from the scope of application of the Agreement would appear as "a fatal weakness". ${ }^{374}$ Not only could it affect the objective of having the BBNJ Agreement become the new "constitution" for marine biodiversity in $\mathrm{ABNJ}$, but it could actually consolidate and institutionalize wellknown and recurring weaknesses associated with RFMOs. ${ }^{375}$

The upcoming Agreement is expected to act as a bridging mechanism between the law of the sea and biodiversity, and to provide answers to the regulatory and governance gaps in ABNJ. Nonetheless, in general, limited attention has been given to implementation and compliance. ${ }^{376}$ Further, "questions about the modalities of the cooperation and coordination the Agreement is supposed to bring remain unresolved". 377 Therefore, questions remain (partially or completely) unanswered, or answers seem unsatisfactory, in particular in relation to fisheries. The Agreement will not be sufficient to fully address the interconnectedness between high seas fisheries law and environmental/biodiversity law; alternatives to laying the foundations for more sustainable fisheries on the high seas must therefore be contemplated. ${ }^{378}$

\footnotetext{
373 Joanna Mossop, "Dispute Settlement in the New Treaty on Marine Biodiversity in Areas beyond National Jurisdiction” (23 December 2019) NCLOS Blog, online: <https://site.uit.no/nclos/2019/12/23/disputesettlement-in-the-new-treaty-on-marine-biodiversity-in-areas-beyond-national-jurisdiction/>.

374 Oude Elferink, "Institutional landscape", supra note 190 at 238.

375 Barnes, "Future fisheries", supra note 112.

376 Papastavridis, supra note 80 at 607.

377 Ibid at 603.

378 These alternatives are discussed in chapter 7 section 3 below.
} 



\title{
THE CHALLENGES TO REACH SUSTAINABILITY
}

\author{
Combining Values, Regulation and Behaviour
}

\section{INTRODUCTION}

The inability of States to control over-fishing, to reduce fishing capacity, to base decisions on adequate science, to set sustainable thresholds and adhere to them, and to take into account the impact of fishing on the wider ecosystem are the hallmark failings of contemporary domestic fisheries management. Similar problems are also a feature of high seas fisheries, with the additional problem that inadequate mechanisms exist for securing the agreement and implementation of conservation rules. ${ }^{1}$

This observation by Barnes summarizes the main challenges which fisheries management faces. International cooperation, which is central for the management of common pool resources like fish stocks on the high seas, remains a loosely formulated obligation, and its embryonic regime for ABNJ under UNCLOS "has not materialised". ${ }^{2}$ Actors other than flag States have a restricted jurisdiction to act on the high seas, limiting their ability to take enforcement measures. ${ }^{3}$ In terms of regulation, rule adoption and rule implementation are conducted at different levels (RFMOs and States respectively). ${ }^{4}$ The problem of free riders, as well as the reluctance of members of organizations to adhere to stricter rules also plague the effectiveness of the regime. ${ }^{5}$ Monitoring, data collection and processing are difficult

1 Richard Barnes, Property Rights and Natural Resources (Oxford: Hart, 2009) at 7.

2 David Freestone, "An Unfinished Agenda: Governance of Areas beyond National Jurisdiction" in Keyuan Zou (ed), Global Commons and the Law of the Sea (Leiden, Boston: Brill Nijhoff, 2018) 209-225 at 209 [Freestone, "An Unfinished Agenda"]. See also Richard Barnes \& Carmino Massarella, "High Seas Fisheries" in Elisa Morgera \& Kati Kulovesi (eds), Research Handbook on International Law and Natural Resources (Cheltenham: Edward Elgar, 2016) 369-389 at 373.

3 Olav Schram Stokke, "Management Options for High Seas Fisheries: Making Regime Complexes More Effective" in Richard Caddell \& Erik Molenaar (eds), Strengthening International Fisheries Law in an Era of Changing Oceans (Oxford: Hart, 2019) 51-77 at 52 [Stokke, “Management Options"]; Rosemary Rayfuse \& Robin Warner, "Securing a Sustainable Future for the Oceans Beyond National Jurisdiction: The Legal Basis for an Integrated Cross-Sectoral Regime for High Seas Governance for the 21st Century" (2008) 23:3 International Journal of Marine and Coastal Law 399-421 at 420.

4 James L. Anderson et al, "Principles for Fisheries Management in Areas Beyond National Jurisdictionthe Essential Role of Incentive-Based Approaches" (2018) at 2, online: <https://www.worldwildlife.org/ publications/principles-for-fisheries-management-in-areas-beyond-national-jurisdiction-the-essentialrole-of-incentive-based-approaches $>$.

5 Stokke, "Management Options", supra note 3 at 66-67. 
and demanding. ${ }^{6}$ These weaknesses are understandably linked with the nature of the subject matter: fish stocks, and transboundary ones in particular, are unpredictable. This makes it impossible "to prescribe fixed roles and functions to State and non-State actors such as non-governmental organizations, independent labelling companies, and fish product importers". Yet, despite normative development within the legal framework for international fisheries, ${ }^{8}$ international fisheries regulation and management are not sufficiently well constructed to effectively trigger sustainable performance.

Taking these deficiencies as a starting point, the present chapter first identifies and assesses some of the characteristics of particular importance for fisheries in $\mathrm{ABNJ}$ that negatively impact the regime's ability to respond to sustainability challenges (section 2). ${ }^{9}$ These characteristics are not only regulatory/normative; they are also rooted in values and understandings regarding science, conservation and exploitation, as well as in the behavioural responses towards these values and understandings. When relevant, section 2 further highlights mechanisms and methods already set up to mitigate the negative impacts triggered by these characteristics, and explores how compliance can be reached. This constitutes a starting point to assess whether more/different measures are needed.

The chapter then addresses the fragmentation of the regime, which happens at both the regulatory and implementation level (section 3). Such fragmentation creates uncertainty for actors when navigating between the various layers of obligations, and therefore also affects their behavioural responses. The chapter finally concludes by mapping initial thoughts on alternative and/or complementary management mechanisms (section 4). Where to find the building blocks for such alternatives and how to operationalise them, constitutes the core of the analysis undertaken in subsequent chapters.

\section{CHARACTERISTICS OF THE REGIME FOR INTERNATIONAL FISHERIES NEGATIVELY IMPACTING ON SUSTAINABILITY PERFORMANCE}

This section looks into characteristics of the regime for international fisheries law that are negatively impacting its ability to achieve sustainability. Many of these

6 Anderson et al, supra note 4 at 2. All the challenges discussed are also summarized in Barnes \& Massarella, supra note 2 at 388.

7 Anderson et al, supra note 4 at 2.

8 See, generally, Kim Friedman, Serge Garcia \& Jake Rice, “Mainstreaming Biodiversity in Fisheries” (2018) 95 Marine Policy 209-220 at 209-215.

9 For an exhaustive overview of structural issues afflicting the regime for fisheries, see Solène Guggisberg, The Use of CITES for Commercially-Exploited Fish Species: A Solution to Overexploitation and Illegal, Unreported and Unregulated Fishing? (Cham: Springer, 2016) at chapter 4 [Guggisberg, The Use of CITES]; and Kristina Gjerde et al, "Regulatory and governance gaps in the international regime for the conservation and sustainable use of marine biodiversity in areas beyond national jurisdiction" (2008) IUCN Marine Series no 1 [Gjerde et al, "Regulatory and governance gaps"]. 
characteristics have been underlined in previous chapters and, where relevant, cross-references to assessments made previously are mentioned.

In the present section, however, the analysis of those characteristic impacting on sustainability performance is structured around three tasks for resources management identified by Stokke: cognitional (2.1), regulatory (2.2) and behavioural (2.3) tasks. ${ }^{10}$ The cognitional task refers to the shared understandings of the goals to be achieved, the regulatory task is mandated with translating these understandings into commitments, while the behavioural task ensures that actors' behaviour complies with the commitments undertaken. ${ }^{11}$

An analysis structured around those three tasks is conducted with the aim of first identifying the weaknesses of the regime, and then of understanding at what stage of the process for resources management these weaknesses lie (e.g. is it a divergence of values between different actors? Are there regulatory gaps and if so what are they? Are there shortcomings in terms of implementation? Of enforcement? Of compliance?). Such analysis, this study submits, allows us to target better the causes underlying the weaknesses and suggest alternative mechanisms accordingly. Where appropriate, the present section also addresses existing mechanisms put in place or currently being developed to offset the difficulties stemming from the characteristics of the regime.

\subsection{Cognitional task: a shared understanding of the balance between conservation and use}

As noted by Stokke, "[t]he cognitional problem facing States and other stakeholders in fisheries management is to build a shared, well-founded understanding of how best to balance use and conservation". ${ }^{12}$ Reaching such a balance is not easy due to the different weight given to use and conservation by different actors from different sectors, rooted in often diverging interests and values. Balancing conservation and use can best be done by relying on recent and independent scientific data; yet obtaining such relevant data is often difficult. The following sections look into these two challenges: the balance of interests (2.1.1) and the gathering of scientific data (2.1.2). They impact the process necessary for developing shared understandings upon which a regulatory framework can be built.

10 Stokke, "Management Options", supra note 3 at 51; Olav Schram Stokke, "Introduction" in Olav Schram Stokke (ed), Governing High Seas Fisheries. The Interplay of Global and Regional Regimes (Oxford: Oxford University Press, 2001) 1-19 at 11.

11 Ibid. See also Olav Schram Stokke, "International fisheries politics: from sustainability to precaution" in Steina Andresen, Elin Lerum Boasson \& Geir Hønneland (eds), International Environmental Agreements: An introduction (Abingdon, Oxon: Routledge, 2011) 97-116 at 109-112 [Stokke, "International fisheries politics"].

12 Stokke, "Management Options", supra note 3 at 63. 


\subsubsection{The everlasting concern of balancing interests}

The oceans undoubtedly form a complex socio-ecological system, and so do international fisheries; ${ }^{13}$ not only are fisheries composed of ecological systems, i.e. the fish themselves and the ecosystem more generally, but fishing activities take place in social and economic systems. Fisheries are an important economic activity, but they are also important socially and culturally, as well as a main source of food. These human and natural systems are coupled, ${ }^{14}$ intertwined: "[s]ocio-economic systems rely on ecological systems for as basic things as daily survival (e.g. food, water), for larger economic activities (e.g. fisheries), as well as for cultural and/ or recreational purposes. Conversely, ecological systems are impacted by the way socio-economic systems use, regulate and manage them". ${ }^{15}$

The main debate stemming from this characterization of socio-ecological systems and which in fact characterizes any debate on the use of resources - is how to balance the different components of such systems. How do we reconcile the conservation/ protection of the ecological system with the fulfilment of interests linked to the socio-economic system? This debate is in fact embedded in "the original opposite strategies [between protection and growth] [...], thus continuing to create tensions within and between streams". ${ }^{16}$

However, it is not the acknowledgement of this necessary balance between food security, economic interests and preservation perspectives, between conservation and use that represents the main challenge. This balance is in fact recognized in many existing fisheries related instruments. ${ }^{17}$ It is also acknowledged that the viability of an agreement "introducing stricter obligations for the protection of the marine environment without any specific economic advantages" 18 could be compromised.

13 See chapter 1 section 2.2 above.

14 D.G. Webster, Beyond the Tragedy in Global Fisheries (Cambridge, Mass.: MIT Press, 2015) at 21.

15 Catherine Blanchard, Carole Durussel \& Ben Boteler, "Socio-ecological resilience and the law: Exploring the adaptive capacity of the BBNJ agreement" (2019) 108 Marine Policy article 103612 at 2, citing Carle Folke, "Resilience: the emergence of a perspective for social-ecological systems analyses" (2006) 16 Global Environmental Change 253-267 at 255, and Carlos Gómez et al, “The AQUACROSS Innovative Concept - Executive Summary. Deliverable 3.1” (2016) European Union's Horizon 2020 Framework Programme for Research and Innovation Grant Agreement No. 642317 at 6-7.

16 Serge Garcia, Jake Rice \& Anthony Charles, "Governance of marine fisheries and biodiversity conservation: Convergence or coevolution?” in Serge Garcia, Jake Rice \& Anthony Charles (eds), Governance of marine fisheries and biodiversity conservation: Interaction and Coevolution (Hoboken: Wiley, 2014) 18-36 at 32 [Garcia, Rice \& Charles, "Convergence or coevolution?"]. See also Elizabeth De Santo et al, "Protecting biodiversity in areas beyond national jurisdiction: An earth system governance perspective" (2019) 2 Earth System Governance article 100029 at 2.

17 UNCLOS at preamble; UNFSA at art. 2; CBD at art. 1; Code of Conduct for Responsible Fisheries, FAO, 28th Sess, FAO Doc 95/20/Rev/1 (1995) at art. 7.2.1 [Code of Conduct]. See also, generally, the instruments discussed in chapter 2.

18 Nele Matz-Lück \& Johannes Fuchs, “The impact of OSPAR on protected area management beyond national jurisdiction: Effective cooperation or a network of paper parks?” (2014) 49 Marine Policy 155166 at 163, cited in Holly Matley, "Developments in International Fisheries Law and Their Contribution to Improving Effectiveness of RFMOs and Other Environmental Regimes" in Neil Craik et al (eds), Global 
What is less clear, however, is what this balance means in practice, ${ }^{19}$ and how it can be achieved at the global and regional levels.

For example, Ridgeway identified the differences in the design process for conservation between fisheries management and environmental approaches:

In the case of fisheries, the focus or driver is the provision and sustainability of a single tangible ecosystem service (e.g. commercial or food fisheries). In designing optimal or pragmatic tools within ecosystem planning constraints, the question is how best to optimize that service (e.g. management regimes with area-based management tools designed for fisheries outcomes). However, environmental approaches argue that management needs to consider the full suite of ecosystem services [...]. This perspective gives a central position to consideration of conservation protection, existence values and cumulative threats which more rarely enter fisheries debates. ${ }^{20}$

The only effective way to reconcile these approaches, Ridgeway says, is through "cross-disciplinary teaching", where a specific stakeholder must not only be aware of the differences that exist between itself and others, but must also be willing to share tools and know-how. ${ }^{21}$

The first step for finding the most appropriate way to operationalise this balance therefore rests in understanding what the different interests in fisheries, and oceans resources more broadly, represent for States and other actors. ${ }^{22}$ Should allocation be based on fairness, a view often defended by small-island developing States, or on historical practice, a view favoured by distant waters fishing nations? How can we reconcile motivations from State representatives and motivations from the industry, which in turn might also vary across sectors? What should be prioritized: food security or reform of fisheries management (although the latter might lead to ensuring the former in the long run)? ${ }^{23}$ These questions represent a necessary first step, as "national interests, power relations and sometimes competing legal principles are major ingredients when states agree on regulatory measures for balancing use, conservation and distribution of fish resources". ${ }^{4}$

Environmental Change and Innovation in International law (Cambridge: Cambridge University Press, 2018) $102-122$ at 106.

19 Guggisberg, The Use of CITES, supra note 9 at 183.

20 Lori Ridgeway, "Global level institutions and processes: Assessment of critical roles, foundations of cooperation and integration and their contribution to integrated marine governance" in Serge Garcia, Jake Rice \& Anthony Charles (eds), Governance of marine fisheries and biodiversity conservation: Interaction and Coevolution (Hoboken: Wiley, 2014) 148-165 at 158 [Ridgeway, "Assessment"].

21 Ibid at 159.

22 Francisco Orrego Vicuña, “The Law governing High Seas Fisheries: in search of new principles” (2004) 18:1 Ocean Yearbook 383-394 at 383; Guggisberg, The Use of CITES, supra note 9 at 183. See also, generally, the scenarios in William Cheung, Vicky Lan \& Collette Wabnitz, "Future scenarios and projections for fisheries on the high seas under changing climate" (2019) IIED Working Paper at 34.

23 All these examples are listed in Anderson et al, supra note 4 at 25.

24 Stokke, "International fisheries politics", supra note 11 at 104. 
Once interests have been identified and understood, it must be decided how to address their interaction. The commonalities discussed in chapter 2 above can be used to illustrate how the balancing exercise can take shape. ${ }^{25}$ The common interest in resource exploitation (in the present case the exploitation of fish stocks) and the common concern in the well-being of the environment ${ }^{26}$ coexist, which creates a situation where cross-sectoral and sector specific commonalities face each other. The question that therefore arises is whether these commonalities have an equal status, or if the cross-sectoral common concern has priority over sectoral interests, therefore creating a hierarchy? ${ }^{27}$ If we use the "priority" approach, resource exploitation for food security would have to be seen in light of the "higher" crosssectoral common concern in protection, and fisheries management measures would therefore be primarily dictated by protection. If, on the other hand, the interests are equal, compromises would have to be reached to accommodate all commonalities. ${ }^{28}$

Kim and Bosselman have looked at this balance from the perspective of planetary boundaries (or thresholds), ${ }^{29}$ representing the "safe operating space" within which the socio-ecological resilience of Earth system processes can last. Biodiversity loss represents one process. ${ }^{30}$ The implication of these boundaries for international (environmental) law is that the respect for these boundaries can be reached through either a hierarchy or a compromise of interests. On the one hand, if focus is put on hierarchy, it is argued that these thresholds or boundaries represent a level of protection that cannot be compromised. This would mean that environmental protection would become a grundnorm that exists outside the legal system and by which other legal norms must abide. In practice, environmental considerations would have priority over social or economic considerations, and this hierarchy would, in turn, be reflected "in the design and interpretation of laws governing State behaviour". ${ }^{11}$ On the other hand, if focus is put on compromise, international (environmental) law would embrace the complexity that Earth system processes represent. This would require the acceptance that the "governance challenge $[\ldots]$ goes beyond the conventional debate in environmental policy integration - that is the relationships between environmental and development policies (for example, international trade)". ${ }^{32}$ Such an approach would therefore aim for internal coherence.

25 See chapter 2 section 2.3 above.

26 Atsuko Kanehara, "What Does a New International Legally Binding Instrument on Marine Biological Diversity of Areas Beyond National Jurisdiction 'under the UNCLOS’ Mean?” (2016) 59:4 Sophia Law Journal 53-73 at 68-71.

27 Ibid at 69. See also Catherine Blanchard, "Fragmentation in high seas fisheries: Preliminary reflections on a global oceans governance approach" (2017) 84 Marine Policy 327-332 at 330.

28 Kanehara, supra note 26 at 70.

29 Rakhyun E. Kim \& Klaus Bosselman, "International Environmental Law in the Anthropocene: Towards a Purposive System of Multilateral Environmental Agreements" (2013) 2:2 Transnational environmental law 285-309 at 288-292.

30 The other processes listed by Kim \& Bosselman are climate change, interference with the nitrogen and phosphorus cycles, stratospheric ozone depletion, ocean acidification, global freshwater use, changes in land use, chemical pollution, and atmospheric aerosol loading.

31 Kim \& Bosselman, supra note 29 at 290.

32 Ibid at 291-292. 
While a hierarchy of interests might appear to be a necessary approach in times of intense biodiversity loss, a compromise between such interests is more in line with the delicate balance embodied in UNCLOS, ${ }^{33}$ which is illustrated inter alia in the notion of "due regard for the interests of other States". ${ }^{34}$ Achieving such compromise, such balancing of interest, however, remains a "case by case" task under the current law. For example, a tool that has proven effective in the balancing of interests is MSP. It can assist actors and decision-makers in evaluating the interactions of different interests and sectors, and help to reach a balance between economic, social, developmental and conservation concerns. ${ }^{35}$ While MSP benefits from a strong legal framework in some regions, ${ }^{36}$ contemplating its application in the multilateral context of the high seas is more difficult, ${ }^{37}$ mainly because of capacity asymmetries. To address such asymmetries, sharing tools and know-how remains a promising practical measure, although the gathering and processing of such information can also trigger challenges, an issue to which we now turn.

\subsubsection{The difficulty of obtaining accurate and reliable scientific data}

Shared understandings upon which to develop commitments are best met by relying on research-based and independent scientific data. Decision-making should be embedded in science that is "accura[te] (widely perceived to be true); legitima[te] (achieved through impartial processes insulated from direct political influence) and salien [t] (policy relevant and politically tractable)". ${ }^{38}$ While these elements illustrate the "perfect picture" in terms of the role of science, the reality in high seas fisheries is, however, quite different; in fact, collecting accurate and reliable data on fish stocks

33 Catherine Blanchard, Otto Spijkers \& Wen Duan, “Three Structural Pillars of the Future Internationally Legally Binding Instrument for the Conservation and Sustainable Use of Marine Biodiversity in Areas Beyond National Jurisdiction" in Marta Chantal Ribeiro, Fernando Loureiro Bastos \& Tore Henriksen (eds), Global Challenges and the Law of the Sea (Cham: Springer, 2020) 351-378. The balance of interests that each treaty represents is also discussed by Seline Trevisanut, "Unsustainable International Law" (Inaugural lecture delivered at Utrecht University, 4 April 2019).

34 See, e.g., UNCLOS at art. 87. The notion of due regard is discussed in chapter 2 section 3.1.1.1, and chapter 3 section 3.1 above.

35 MSP is discussed in chapter 4 section 3.2 and, to some extent, in chapter 3 section 4.2 .1 above.

36 For example, in 2014, the European Parliament and Council adopted a Directive creating a framework for MSP (Directive 2014/89/EU of the European Parliament and of the Council of 23 July 2014 establishing a framework for maritime spatial planning, (2014) OJ, L 257/135). This complemented the Marine Strategic Framework Directive of 2008 (Directive 2008/56/EC of the European Parliament and of the Council of 17 June 2008 establishing a framework for community action in the field of marine environmental policy, (2008) OJ, L 164/19), the objective of which was to establish a framework for community action in the field of marine environmental policy, and which is considered as the environmental pillar of the Integrated Maritime Policy for the European Union.

37 The difficulties linked to the establishment of MSP in ABNJ are discussed in chapter 4 section 3.2 above.

38 Lori Ridgeway, "Global level institutions and processes: Frameworks for understanding critical roles and foundations of cooperation and integration" in Serge Garcia, Jake Rice \& Anthony Charles (eds), Governance of marine fisheries and biodiversity conservation: Interaction and Coevolution (Hoboken: Wiley, 2014) 139-147 at 143, referring to Peter Haas, "Scientific expertise, a question of legitimacy" (Presentation delivered at the IDDRI International Environmental Governance Conference, Paris 15-16 March 2004). The necessity to rely on the best available science is also discussed in chapter 3 section 3.1.4 above. 
and trends in fishing activities represents a nearly impossible task and is linked to a lot of uncertainties. ${ }^{39}$ This is due to four main reasons: the limited accuracy of national reports, different methods of data collection, difficulties in measuring the impact of some fishing practices on fish stocks, and the politicization of science.

First, the global statistics normally used as reference points are those of the FAO, which itself relies on national catch reports. However, national reports are often incomplete, inaccurate or simply missing due to multiple factors. ${ }^{40}$ Many regions in the world, mostly developing regions, are simply unable to provide data because of lack of resources and capabilities, which raises challenges linked to necessary capacity-building. Additionally, the difficulty in collecting data and establishing exact statistics is particularly present when determining specific numbers for captures in ABNJ. Indeed, due to the remoteness of some areas, combined with the fact that some fishing activities in ABNJ, mostly deep waters fishing, have been developed only recently, scientific information is not yet available. ${ }^{41}$ Limited scientific understanding of these areas therefore aggravates the threat to the species concerned, as the real impact of fishing activities cannot yet be measured. ${ }^{42}$

Second, different methods for data collection exist, ${ }^{43}$ which may therefore provide results of varying quality and objectivity. For example, data shared directly by fisheries related actors, i.e. fishing vessels, normally consists of catch data alone. If scientists travel on fishing vessels, i.e. if the collection of data is conducted by scientific observers on board commercial vessels, the data is normally fisherydependent, such as catch volume, age, size, maturity level, etc. On purely scientific missions, there are higher chances of collecting fishery-independent data and thereby providing a more comprehensive picture of different species and their environment. One could say that the last-mentioned method of data collection represents the most reliable and objective method, but, in practice, expecting that all oceans can be adequately surveyed as such is a Utopian dream, mainly for financial reasons. Additionally, figures on catches should be coupled with other methods, ${ }^{44}$ such as measuring changes in biomass, i.e. the mass of living organisms, or ecosystem modelling, which contribute to obtaining data about marine ecosystems, therefore placing fish stocks within the broader context of the ecosystem. These additional

39 See, e.g., Guillermo Ortuño Crespo et al, "High-seas fish biodiversity is slipping through the governance net” (2019) 3 Nature Ecology \& Evolution 1273-1276 at 1275; De Santo et al, supra note 16 at 2-3. On the difficulty of data collection, and on the imperfect nature of data, see Guggisberg, The Use of CITES, supra note 9 at 139-141. The difficulty to collect data, and more particularly high seas-specific data, is discussed in chapter 2 section 2.1 above.

40 Stokke, "International fisheries politics", supra note 11 at 103; Guggisberg, The Use of CITES, supra note 9 at 14-15.

41 Ortuño Crespo et al, supra note 39 at 1275; Glen Wright et al, "High seas fisheries: what role for a new international instrument?" (2016) IDDRI Paper 3/2016 at 5.

42 Cheung, Lan \& Wabnitz, supra note 22 at 8.

43 Maribus, "The future of Fish - The Fisheries of the Future" (2013) World Ocean Review at 44.

44 See e.g. Guggisberg, The Use of CITES, supra note 9 at 14-15. 
methods have been explored, but should be considered more systematically for global reporting, such as in the FAO report on the state of world fisheries. ${ }^{45}$

Third, it is also difficult to measure the impact of some practices on fish stocks. For example, a legal fishery conducted on the basis of MSY could still be detrimental to the stock and the environment if the MSY is in itself established above sustainable levels ${ }^{46}$ Further, as observed by Depypere, IUU fishing, one of the major threats to fish stocks, can only be partially measured. Unreported fishing can obviously only be estimated, since it is unreported. An additional difficulty with detecting, and consequently estimating, illegal fishing is also due to the classification of the act itself: an activity that was legal in the past might now be illegal because of an increase in regulation. ${ }^{47}$ Changes in regulations might therefore affect the understanding of what constitutes illegal fishing, and impact the way of discerning it and reporting it, consequently influencing data. All these factors lead to the inaccuracy of official statistics, which was outlined in an alarming study published at the beginning of 2016. Conducted worldwide over the course of a decade, this study, representing the largest global estimate apart from the work of the FAO, reported that due to artisanal, subsistence and illegal fishing that is not accounted for in official statistics, global marine fisheries catches are higher than reported by $53 \%{ }^{48}$

Fourth, the difficulty in gathering scientific data, especially in ABNJ, is further coupled with the politicization of science, ${ }^{49}$ when the quality of the information is defined depending on who provides it, or when certain actors possess a better access to a pool of information. ${ }^{50}$ To start with, there are criticisms of the impartiality of actors providing scientific advice. As noted by Garcia, Rice and Charles, "[a] rguments about 'whose science' is the appropriate basis for policy development remain unresolved" ${ }^{51}$ For example, they suggest that experts designated by national ministries are easily considered to be biased because they are perceived as carrying out the views of their appointers, while experts from NGOs or academics are not. ${ }^{52}$ The authors further argued that, at the same time, experts nominated by environmental NGOs are biased in favour of conservationist purposes. ${ }^{53}$ Scientific advice from

45 For example in the biennial FAO report, see FAO, "The State of World Fisheries and Aquaculture 2020. Sustainability in action" (2020) at 2-4, online: <http://www.fao.org/state-of-fisheries-aquaculture $>$ [FAO Report 2020].

46 On the central role played by MSY in the current regulation and management of fisheries, see chapter 2 section 3.1.1.1, and chapter 3 section 4.1 above. On the unsustainable character of MSY, see Barnes \& Massarella, supra note 2 at 373.

47 Stefaan Depypere, "Ocean Governance for Sustainable Fisheries" in Myron Nordquist, John Norton Moore \& Ronan Long (eds) Legal Order in the World's Oceans. UN Convention on the Law of the Sea (Leiden, Boston: Brill Nijhoff, 2018) 370-378 at 374.

48 Daniel Pauly \& Dirk Zeller, "Catch reconstruction reveals that global marine fisheries catches are higher than reported and declining" (2016) Nature Communications 1-9.

49 De Santo et al, supra note 16 at 2.

50 The access to information is once again linked to the question of capacity-building.

51 Garcia, Rice \& Charles, “Convergence or coevolution?", supra note 16 at 30.

$52 \mathrm{Ibid}$. On the partiality of public officers sitting on regional bodies, see also Stokke, "International fisheries politics", supra note 11 at 111.

53 Garcia, Rice \& Charles, “Convergence or coevolution?", supra note 16 at 30. 
independent scientific organizations, such as the ICES, is, however, relied upon frequently, especially by RFMOs, ${ }^{54}$ and considered to be a reliable source of scientific information. ${ }^{55}$ For their part, market-based instruments operated by private institutions play a growing role in the production of scientific data. For example, the main certification scheme for sustainable fisheries, the Marine Stewardship Council, certifies a fishery based on an independently conducted assessment relying on a "science-based set of requirements for sustainable fishing" ${ }^{36}$ By having to respect standards established under the scheme to obtain the certification, private industries are incentivized to "contribute more actively than before to the costs of scientific research", ${ }^{57}$ which costs, in ABNJ, are particularly significant. As Holthus mentioned, "[p]rotecting the seas to protect your business makes good business sense", ${ }^{8}$ and this is why business fora such as the World Oceans Council, an international, cross-sectoral business leadership alliance, ${ }^{59}$ develop programmes and initiatives for the involvement of businesses in data gathering. ${ }^{60}$ Industries can therefore contribute to "ensuring adequate funding for the underlying research activities". ${ }^{61}$ The involvement of private industries in scientific research, however, always raises the concern as to whether - and if so, to what extent - the interests of the industry are adversely impacting the collection of data and the scientific advice stemming from it. ${ }^{62}$ All these debates have a politicization effect on science,

54 Stokke, "Management options", supra note 3 at 63-64. RFMO/RFMAs relying on the scientific data from ICES include the JNRFC and NEAFC.

55 Ibid at 54-55. Stokke in fact mentions that the ICES is "well suited" to provide impartial evidence and scientific information because of two elements in its functioning: "its membership - comprising the national marine science organizations of regional coastal States - and certain procedures that insulate its operations from political pressure".

56 MSC, "What does the blue MSC label mean?", online: <https://www.msc.org/what-we-are-doing/ourapproach/what-does-the-blue-msc-label-mean>. The MSC is addressed further in chapter 7 section 3.3 below.

57 Stokke, "Management options", supra note 3 at 65.

58 Paul Holthus, "Ocean Industry Leadership and Collaboration in Sustainable Development of the Seas" in André Monaco \& Patrick Prouzet (eds) Governance of Seas and Oceans (Hoboken: Wiley, 2015) 281-296 at 291.

59 World Ocean Council, “About us”, online: <https://www.oceancouncil.org/>.

60 Holthus, supra note 58 at 294.

61 Stokke, "Management options", supra note 3 at 65.

62 The growing involvement of private actors, especially business and the industry, at all stages of law-making and enforcement, makes it now impossible to conclude that States are the only authority in international law (see, e.g., Anastasia Telesetky, "Co-Regulation and the Role of Transnational Corporations as Subjects in Implementing International Environmental Law” in Andrew Byrnes, Mika Hayashi \& Christopher Michaelsen (eds), International Law in the New Age of Globalization (Brill: Leiden, 2013) 287-319). While their involvement is not a problem per se, such involvement becomes questionable when it is done to the detriment of individuals and societies, which are the ones most affected by environmental degradation and overexploitation stemming from private actors' undertakings (see, e.g., Jutta Brunnée \& Ellen Hey, “Transparency and International Environmental Law” in Andrea Bianchi \& Anne Peters (eds), Transparency in International Law (Cambridge: Cambridge University Press, 2013) 23-48 at 26, cited in Seline Trevisanut, "The Role of Private Actors in Offshore Energy : Shifting models of participation" in Nigel Bankes \& Seline Trevisanut (eds), Energy From the Sea : An International Law Perspective on Ocean Energy (Leiden: Brill Nijhoff, 2015) 85-105 at 102). In order to avoid - or at least limit and control potentially negative outcomes from this involvement, while benefiting from the added value stemming from the complementary involvement of private actors, " $[\mathrm{t}]$ he crucial point, both at the national and the international level, is then to find a balance between the necessary involvement of the private actors and the regulatory power of States" (Trevisanut at 99). In order to do so, State authorities must establish the 
which "may inhibit agreement on whether to act, especially in a context of decisionmaking under uncertainty", as is the case in ABNJ. ${ }^{63}$

In summary, the observations made in the present section illustrate the difficulties in obtaining the material necessary - and the legitimacy of such material - to create a basis upon which shared understandings can be built. Not only is scientific data difficult to obtain, especially when talking about remote areas such as the high seas, but interests and values of specific actors impact the delicate balance that must be maintained between conservation and use of resources in order to formulate shared understandings on how to approach these resources. Without such understandings, it is more difficult to formulate the subsequent measures to be undertaken, i.e. the commitments to be included in the framework regulating high seas fisheries.

\subsection{Regulatory task: translating shared understandings into legal commitments}

The legal framework for international fisheries presents a large array of instruments which, taken together, cover the management of international fisheries, as well as the conservation of resources and, more broadly, the protection of the marine environment. The importance given to the ecosystem and precautionary approach through the UNFSA reflects the evolution towards an environment-related focus. ${ }^{64}$ Yet, despite an already fairly good regulatory toolbox ${ }^{65}$ there still exist some geographical and species gaps in the regulatory coverage of fisheries activities in $\mathrm{ABNJ}$ (2.2.1), showing that we remain in a context where specific regimes regulate specific resources ${ }^{66}$ Furthermore, only specific actors have jurisdiction on the high seas, which limits the overall capacity for implementation and enforcement (2.2.2). Finally, uncertainty as to the scope of application of and lack of harmonization between conservation and management measures could benefit from clarification (2.2.3). We are therefore equipped with a framework that does not fully translate the complexity and interconnectedness of the various components of high seas fisheries, and this highlights weaknesses in the translation of shared understandings into legal and regulatory commitments.

appropriate institutional and regulatory framework to ensure that environmental and labour standards, which are not necessarily a priority for businesses, are respected (Trevisanut at 103). For example, it might pose problems of independence and impartiality if legal instruments endorse funding from private actors to the commissions that subsequently regulate these actors' undertakings (Trevisanut at 99). A similar discussion is also conducted in Seline Trevisanut, "Is There Something Wrong with the Increasing Role of Private Actors? The Case of the Offshore Energy Sector" in Cedric Ryngaert, Erik Molenaar \& Sarah Nouwen (eds), What's Wrong with International Law? Liber Amicorum A.H.A. Soons (Leiden: Brill Nijhoff, 2015) 63-75, and in Seline Trevisanut, "The Role of Private Actors in Offshore Energy: Shifting Models of Participation" (2014) 29:4 International Journal of Marine \& Coastal Law 645-665. For a more detailed discussion on the role of non-State actors (non-State actors more generally, not only private actors and the industry) in law enforcement, see section 2.3.1 below.

63 De Santo et al, supra note 16 at 2.

64 See chapter 2 section 3.1.2, and chapter 3 section 4.1 above.

65 See chapter 2 section 4 above.

66 Klaus Bosselman, Earth Governance. Trusteeship of the Global Commons (Cheltenham: Edward Elgar, 2015) at 71-72. 


\subsubsection{Geographical and species gaps}

To start with, the gaps in the regulatory regime can be found at the level of the geographical areas covered. ${ }^{67}$ In fact, while tuna RFMOs cover most high seas regions, no general RFMOs (i.e. non-tuna) have been set up in the South West Atlantic, the Central Atlantic, the central Pacific Ocean and the northern Indian Ocean. ${ }^{68}$ This leaves fishing activities in these regions unmanaged and subject to a lack of regionally harmonized conservation measures, as the only applicable measures are those established by flag States.

Although, geographically speaking, not all areas are covered, it has been argued that, considering the high number of RFMOs operating in high seas areas, the coverage was in any event sufficient, as the existing bodies were covering the major fishing regions, therefore being comprehensive in practice. ${ }^{69}$ However, even if that were to be the case, not all species are regulated or assessed by existing RFMOs. ${ }^{70}$ For example, Ortuño Crespo et al have shown that "[o]f the 4,018 known species of fish in the deep ocean, more than $95 \%$ are non-targeted species whose populations are not assessed by [RFMOs]". ${ }^{71}$ For example, some RFMOs exclude from their scope of application species listed under Annex I of UNCLOS. ${ }^{72}$ While this annex includes some species of tuna, which would then find an alternative coverage under the scope of application of tuna RFMOs, this UNCLOS annex also includes some species of oceanic sharks. However, a limited number of RFMOs have adopted measures for the protection of sharks, and sometimes only with regard to specific shark-related practices (i.e. shark finning). ${ }^{73}$ A more encompassing protection of sharks would thus have to be sought under other instruments, such as the CMS and

67 Robin Warner, "Conservation and Management of Marine Living Resources Beyond National Jurisdiction: Filling the Gaps" in Robert Beckman et al (eds), High Seas Governance: Gaps and Challenges (Leiden: Brill, 2018) 179-194 at 186.

68 FAO, "Regional fisheries management organizations and deep-sea fisheries", online: <http://www.fao. org/fishery/topic/166304/en>; European Commission, "Regional fisheries management organisations (RFMOs)”, online: <https://ec.europa.eu/fisheries/cfp/international/rfmo_en>.

69 Stefan Asmundsson, "Regional Fisheries Management Organisations (RFMOs): Who are they, what is their geographic coverage on the high seas and which ones should be considered as General RFMOs, Tuna RFMOs and Specialised RFMOs?" (2016) CBD Meeting Documents, Sustainable Ocean Initiative (SOI) Global Dialogue with Regional Seas Organizations and Regional Fisheries Bodies on Accelerating Progress Towards the Aichi Biodiversity Targets at 4-5 and 7, online: <https://www.cbd.int/doc/meetings/ mar/soiom-2016-01/other/soiom-2016-01-fao-19-en.pdf>.

70 In fact, one should refer to the list of species regulated and/or reported on by each organization, see, e.g. NAFO, "Fishing in the NAFO Regulatory Area", online: <https://www.nafo.int/Fisheries/FishingActivity-in-the-NRA>; SPRFMO, "About the SPRFMO", online: <https://www.sprfmo.int/about/>; SIOFA, "SIOFA major fish species", online: <https://www.apsoi.org/species-list>; SEAFO, "Species summary", online: <http://www.seafo.org/Science/Species-Summary $>$.

71 "New UN high-seas treaty must close gaps in biodiversity governance" (29 August 2019) Science Daily, online: <https://www.sciencedaily.com/releases/2019/08/190829150640.htm>. See also Ortuño Crespo et al, supra note 39 at 1275 .

72 See, e.g. SIOFA at art 1(f); SPRFMO Convention at art 1.1(f); NEAFC Convention at art 1(b).

73 ICCAT, IATTC, NAFO and CCAMLR seem to be the only RFMOs which have, to varying degrees, adopted measures for the conservation of sharks, mostly with regard to shark finning, see IUCN Shark Specialist Group, "Regional Fisheries Management Organizations (RFMOS)", online: <https://www. iucnssg.org/rfmos.html>. 
CITES, and, in terms of soft law, the IPOA-Sharks. However, the listing of species under the CMS or CITES is often met with opposition, as was the case with the initial listing of sharks under CITES in the 1990s, based on the belief that sharks were adequately addressed under the framework of RFMOs. ${ }^{74}$ The shark example raises the issue of the disconnect that exists between RFMOs and other relevant instruments, and illustrates the lack of interplay between different instruments and institutions addressing the same subject matter. ${ }^{75}$ Finally, in terms of discrete high seas fish stocks (i.e. fish stocks that occur only on the high seas), the constitutive instruments of RFMOs do not exclude such stocks from their scope of application. ${ }^{76}$ Whether both pelagic fisheries and deep-sea fisheries are covered, however, depends on the list of living resources which each RFMO has agreed to include which, in most cases, is limited to a restricted number of species. ${ }^{77}$

One could argue that uncovered regions or species could still rely on the application of general instruments, i.e. UNCLOS and UNFSA; however, these regions or species would only be covered to the extent of the applicability of the instruments which, in themselves, present limitations. ${ }^{78}$ For example, the duty found under UNCLOS to conserve marine living resources "only offers a basic layer of regulation, founded upon an abstract standard of due diligence and further elementary procedural guarantees". ${ }^{79}$ Mostly articulated around article 119 and the general obligations to protect the marine environment under Part XII, the obligation of conservation is broadly phrased and leaves a wide discretion to States in the adoption of specific measures. ${ }^{80}$ Cooperation, one key mechanism for the management of common resources, ${ }^{81}$ also relies on "States taking positive and meaningful steps". ${ }^{82}$ However, all these obligations face a lack of operationalization. ${ }^{83}$ While the obligation of

74 This situation is discussed in Ellen Hey, "Regime Interaction and Common Interests in Regulating Human Activities in Areas Beyond National Jurisdiction" in Seline Trevisanut, Nikolaos Giannopoulos \& Rozemarijn Roland Holst (eds), Regime Interaction in Ocean Governance. Problems, Theories and Methods (Leiden: Brill Nijhoff, 2020) 85-123 at 87-90.

75 Techera \& Klein in fact recognize "the extent of regulatory activity in relation to shark conservation and management, but in the absence of a unifying framework and global 'champion', the actions are fragmented across different jurisdictions and sectors", see Elisa Techera \& Natalie Klein, International Law of Sharks. Obstacles, Options and Opportunities (Leiden: Brill Nijhoff, 2017) at 16.

76 Yoshinobu Takei, Filling regulatory gaps in high seas fisheries: discrete high seas fish stocks, deep-sea fisheries, and vulnerable marine ecosystems (Leiden: Martinus Nijhoff, 2013) at 135.

77 See ibid at 135-198, where the author analyses the practice of most non-tuna RFMOs in terms of discrete high seas fish stocks.

78 These limits are also discussed in chapter 2 sections 3.1.1 and 3.1.2 above.

79 James Harrison, Saving the Oceans Through Law. The International Legal Framework for the Protection of the Marine Environment (Oxford: Oxford University Press, 2017) at 301 [Harrison, Saving the Oceans]. See also Alexander Proelss \& Katherine Houghton, "Protecting Marine Species" in Rosemary Rayfuse (eds), Research Handbook on International Marine Environmental Law (Cheltenham: Edward Elgar, 2015) 229-258 at 230, who mention that protection of marine species is mostly found outside the law of the sea regime.

80 See chapter 2 section 3.1.1.2 above.

81 Its application as a principle governing the oceans is discussed in chapter 3 section 3.1.3 above.

82 Barnes \& Massarella, supra 2 at 373.

83 Freestone, "An Unfinished Agenda", supra note 2 at 209; Robin Churchill, "Fisheries and their impact on the marine environment: UNCLOS and beyond" in Marta Chantal Ribeiro (ed), 30 Years After the Signature of the United Nations Convention on the Law of the Sea: The Protection of the Environment and 
cooperation has been strengthened under the UNFSA, its text provides for its implementation mostly through the participation in RFMOs, which brings us back to square one in cases where regions or species are not covered by any regional organization. It is also to be noted that the UNFSA remains "fisheries specific": its scope of application "is limited to highly migratory and straddling fish stocks" and does not cover discrete high seas stocks, nor does it "extend to the management of broader biodiversity issues". ${ }^{4}$

\subsubsection{Difficulties in expanding implementation and enforcement jurisdiction on the high seas}

Exclusive flag State jurisdiction on the high seas ${ }^{85}$ entails that jurisdiction in terms of implementation and enforcement relies almost solely on the flag State's actions. ${ }^{86}$ This can become a problem, however, if its actions are absent or inadequate, or if conservation and management measures are circumvented, as is the case with flags of convenience. ${ }^{87}$ The main cause of IUU fishing actually lies in the lack of effective flag State control. ${ }^{88}$ Considering the difficulties faced by flag States in effectively monitoring and implementing measures on the high seas, ${ }^{89}$ further regulatory options have been considered to broaden the scope of actors mandated to take action on the high seas, in order to effectively face up to the limitations linked to the exclusive flag State jurisdiction. ${ }^{90}$ However, these alternatives remain limited.

For example, the UNFSA does include some - although limited - provisions for non-flag State enforcement. ${ }^{91}$ The first takes the form of inspection and boarding at sea by a vessel of a State other than the flag State. ${ }^{92}$ This has, so far, had limited success because inspection and boarding still requires a notification to the flag State, ${ }^{93}$ and because States are normally hesitant to engage in such a practice. ${ }^{94}$

the Future of the Law of the Sea. Proceedings of the International Conference (Coimbra: Coimbra Editora, 2014) 23-52 at 31; Barnes \& Massarella, supra 2 at 373. Questions of behaviours are addressed in section 2.3 below.

84 Dire Tladi, “The Proposed Implementing Agreement: Options for Coherence and Consistency in the Establishment of Protected Areas Beyond National Jurisdiction" (2015) 30:4 International Journal of Marine and Coastal Law 654-673 at 661. See also Rayfuse \& Warner, supra note 3 at 403; Barnes \& Massarella, supra 2 at 374.

85 UNCLOS at art. 92(1).

86 See, e.g., Stokke, "International fisheries politics", supra note 11 at 105-106. The question is also generally discussed in Request for an advisory opinion submitted by the Sub-Regional Fisheries Commission (SRFC), Advisory Opinion, (2015) ITLOS case 21 [Advisory Opinion on IUU Fishing]. Although ITLOS limited its opinion to the EEZ, see para 69, the explanation of ITLOS with regard to what the exclusivity of flag States' jurisdiction entails is of broader application, see chapter 2 section 3.3.1 above.

87 Matley, supra note 18 at 107. This is also discussed in chapter 2 section 3.3.1 above.

88 Matley, supra note 18 at 116.

89 See section 2.3.1 below.

90 See, e.g. Barnes \& Massarella, supra note 2 at 388. The potential role of other actors, such as NGOs, is discussed in section 2.3.1 below.

91 Barnes \& Massarella, supra note 2 at 376.

92 Both States must be party to the UNFSA for this measure to take effect, see UNFSA at arts. 21-22.

93 UNFSA at arts. 21(4), (5) and (6).

94 See, e.g., Barnes \& Massarella, supra note 2 at 376. 
Second, the UNFSA includes one provision on measures that can be taken by port States, which can also address activities in ABNJ. ${ }^{95}$ This was, however, considered insufficient to address adequately issues related to IUU fishing, especially on a global scale, ${ }^{96}$ in part because of the low ratification rate of the UNFSA. The subsequent adoption of the PSMA,${ }^{97}$ together with trade-base measures, constitutes an attempt to diversify the influence of other actors on the high seas. This is done for example through the restriction on the use of ports ${ }^{98}$ inspection actions, ${ }^{99}$ and the denial of access to port of vessels known or suspected to be engaged in IUU fishing. ${ }^{100}$ However, port State measures also raise difficulties: it can be difficult to establish what really has happened at sea and whether measures should be taken in ports. Further, limits to access to port might go against trade regulations, as was argued in the Swordfish Case brought before the WTO; ${ }^{101}$ and a lack of harmonization in measures might lead to the proliferation of "ports of convenience". ${ }^{102}$ The PSMA and related measures are recent and their real impact therefore remains to be seen. ${ }^{103}$

In a study analysing the actions undertaken by most RFMOs in terms of nonflag State enforcement in high seas fisheries, Rayfuse concludes that "a number of [RFMOs] have moved towards adopting and implementing non-flag control mechanisms, although to date none has gone so far as to adopt full non-flag enforcement mechanisms including a right of non-flag sanction". ${ }^{104}$ This control mechanism is only enforceable against members of that particular RFMO. Based on the practice of RFMOs, Rayfuse claims that the possibility of non-flag control has therefore reached the status of customary international law. To be truly effective, however, non-flag State measures need to extend beyond simply control, as well as

95 UNFSA at art. 23. The involvement of port States, as well as coastal States, in the operationalization of the regime is also discussed in chapter 2 section 3.3 .3 above.

96 David Freestone, "Problems of High Seas Governance" in Peter Johan Schei \& Davor Vidas (eds), The World Ocean in Globalisation. Climate Change, Sustainable Fisheries, Biodiversity, Shipping, Regional Issues (Leiden: Brill, 2011) 99-130 at 116; Churchill, supra note 83 at 38; Seokwoo Lee, Anastasia Telesetsky \& Clive Schofield, "Slipping the Net: Why Is It So Difficult to Crack Down on IUU Fishing?" in Myron Nordquist et al (eds), Freedom of Navigation and Globalization (Leiden: Brill Nijhoff, 2015) 89-119 at 101-103. This is also discussed in chapter 2 section 3.1 .7 above.

97 The PSMA is also discussed in chapter 2 section 3.1.7.2 above.

98 PSMA at art. 11.

99 Ibid at arts. 12-18.

100 Ibid at arts. 9 and 18.

101 The dispute was first brought by the then European Communities before the WTO for alleged violations of trade measures under the General Agreement on Tariffs and Trade (30 October 1947, entered into force 1 January 1948) 55 UNTS 187 [GATT] (see Chile - Measures affecting the transit and importation of swordfish, (2000) WTO Doc WT/DS1931/1 (request for consultation by the European Communities) and (2000) WTO Doc WT/DS192/2 (request for the establishment of a panel by the European Communities)), to which Chile replied by bringing the case before ITLOS on the basis of alleged violations of conservations measures under UNCLOS (Case concerning the Conservation and Sustainable Exploitation of Swordfish Stocks in the South-Eastern Pacific Ocean (Chile/European Communities), Order, (2000) ITLOS case no 7, case instituted in 2000 and removed from the Tribunal's list in 2009). Both cases, which were eventually discontinued, are discussed in further details in section 2.3.4 below.

102 These three difficulties are discussed in Barnes \& Massarella, supra note 2 at 377.

103 Warner, supra note 67 at 184.

104 Rosemary Rayfuse, Non-flag State enforcement in high seas fisheries (Leiden: Martinus Nijhoff, 2004) at 358 (emphasis added). 
beyond the membership of RFMOs. This would be consistent with the perception of the role of RFMOs as "custodians" of high seas fisheries. Whether full non-flag enforcement and sanction mechanisms have reached the status of customary law, however, is questionable, and such mechanisms would remain, for now, in breach of the pacta tertiis rule.

Rayfuse further suggests that non-flag State enforcement could also be achieved through rules of State responsibility and countermeasures. ${ }^{105}$ If, for example, a vessel is in breach of conservation measures, this would trigger the responsibility of its flag State, and would constitute a breach to which any other State could respond with countermeasures. ${ }^{106}$ Although such a situation could be defensible in cases where the State in breach and the injured State are clearly identifiable, as was the case of the Estai between Canada and Spain, ${ }^{107}$ countermeasures can only with difficulty be raised by any State on behalf of all, to protect a community interest. Direct causation would therefore have to be demonstrated, which can be difficult. ${ }^{108}$

The examples discussed above illustrate that flag State exclusivity has evolved and can further evolve, ${ }^{109}$ and that "the general concept of non-flag enforcement contained [in the UNFSA] has positively influenced the development of a customary assertion of non-flag control within [RFMOs]". ${ }^{110}$ However, operationalizing nonflag enforcement is difficult, bearing in mind that international law is still strongly enshrined in "the doctrines of sovereign equality and state supremacy", 111 and that "international compliance" is "closer to the core of sovereignty and [...] thus guarded more jealously by the flag state". ${ }^{112}$ This therefore impedes the expansion of implementation and enforcement jurisdiction on the high seas to actors others than the flag State.

105 Ibid at 372.

106 Articles on Responsibility of States for Internationally Wrongful Acts, in annex to Responsibility of States for internationally wrongful acts, GA Res 62(LXI), UNGAOR, 62nd Sess, UN Doc A/RES/62/61 (2008) [ARSIWA].

107 The events surrounding the arrest of the Estai and the ensuing procedures are discussed in chapter 1 section 1.1, and chapter 2 section 3.3.3 above.

108 The difficulty of demonstrating direct causation in the context of a community interest is discussed further in section 2.3.4 below.

109 Rayfuse, supra note 104 at 357.

110 Ibid at 375.

111 Ibid.

112 Stokke, "International fisheries politics", supra note 11 at 106. This protective interest of a flag State is also visible towards other flag States, not only towards non-flag States. In other words, the flag State is protective of its own enforcement jurisdiction, and will therefore be reluctant to accept enforcement by any other actor, be it, for example, another flag State or a coastal State. 


\subsubsection{Uncertain scope of application of conservation and management mechanisms}

Conservation and management measures adopted by RFMOs are normally binding on all member States. ${ }^{113}$ However, some mechanisms allow for their circumvention, as is the case with the opting-out mechanisms found under the constitutive instruments of most RFMOs. ${ }^{114}$ These opting-out mechanisms allow member States to withdraw from the obligation to implement and respect conservation and management measures adopted by the organization. ${ }^{115}$ If a State formally opts out of a measure, its subsequent actions, although de facto in contravention of a conservation measure, would remain legal. ${ }^{116}$ Although more recent RFMOs (e.g. SPRFMO and WCPFC) do provide for stricter opt-out procedures, making it more difficult for member States to opt out from certain measures, this is not the case for the majority of RFMOs, which still allow for a simple opting-out mechanism. In terms of reasoning, this seems to undermine the rationale behind the inclusion of conservation principles and management tools in the first place, and would seem to confirm the provocative yet enlightening comment by Stokke that "international fisheries management is a relatively malign problem, with [...] clear incentives to violate agreements on restraint and distribution". ${ }^{117}$ In terms of practical impacts, this creates uncertainty regarding the exact scope of application of the conservation

113 The conservation and management measures discussed under this section refer to the legally binding measures adopted by RFMOs and which bind its member States. These measures and must be differentiated from the generic nomenclature of conservation and management measures used to refer to the broader array of measures for the conservation and management of marine living resources, which target States and also non-State actors.

114 The opt-out mechanisms of RFMOs are also discussed in chapter 2 section 3.3.2

115 Daniela Diz Pereira Pinto, Fisheries Management in Areas beyond National Jurisdiction, The Impact of Ecosystem-Based Law-Making (Leiden: Martinus Nijhoff, 2013) at 127-133; Harrison, Saving the Oceans, supra note 79 at 207; Kristina Gjerde, "High Seas Fisheries Governance: Prospects and Challenges in the 21st Century" in Peter Johan Schei \& Davor Vidas (eds), The World Ocean in Globalisation: Climate Change, Sustainable Fisheries, Biodiversity, Shipping, Regional Issues (Leiden: Brill, 2011) 221-232 at 227 [Gjerde, "High Seas Fisheries Governance"].

116 Such a situation illustrates how difficult it can be to characterize a fishing activity as falling within the scope of IUU fishing. For example, a member State of an RFMO formally opting out of a conservation measure and undertaking activities that go again such a measure would not be considered in breach, and the activity would therefore not be IUU fishing. If another member State performs the same activity without having formally opted out, it would amount to illegal fishing.

117 Stokke, "International fisheries politics", supra note 11 at 99. The concept of "malign problem" is discussed in Arild Underdal, "One Question, Two Answers" in Edward L. Miles et al (eds), Environmental regime effectiveness: confronting theory with evidence (Cambridge, Mass: MIT Press, 2002) 3-45 at 15: "The political malignancy of a problem will here be conceived of primarily as a function of the configuration of actor interests and preferences that it generates. According to this conceptualization, a perfectly benign problem would be one characterized by identical preferences. The further we get from that state of harmony, the more malign the problem becomes." Underdal further describes a malign problem as being characterized by incongruity (e.g. competition and lack of coordination), asymmetry (e.g. incompatible values, interests negatively correlated), and cumulative cleavages (e.g. divisions in the different components of a multidimensional problem) (at 19-21). The more malign a problem is, the less likely will we achieve an effective cooperative solution (at 22). The concept is also discussed in section 4 below. 
and management measure concerned. ${ }^{118}$ It also reaffirms the primacy of State consent and the impossibility of imposing measures on members.

Furthermore, the lack of specific and harmonized requirements for the application of relevant management measures and mechanisms, such as ABMTs, EIAs, monitoring and reporting, review mechanisms, etc., ${ }^{119}$ in the current regulatory and management framework for high seas fisheries, creates uncertainty as to the scope of the commitment undertaken by States to be bound by such measures.

Uncertainty regarding the meaning of some concepts can also impact the way such concepts are addressed through conservation and management. This is, for example, the case with the definition of IUU fishing. The definition of the phenomenon found under the IPOA-IUU ${ }^{120}$ acts as a reference point, and allows flexibility for States and RFMOs to adopt measures adapted to their own reality. This flexibility has in turn led to a booming development of laws and regulations, often based, however, on different understandings of what IUU fishing encompasses. This has in the end prevented actors from taking effective measures to combat IUU fishing. ${ }^{121}$ Lee, Telesetsky and Schofield observe that:

The lack of a commonly or generally accepted definition of IUU fishing is then part of what makes it so difficult to crack down on IUU fishing. Until there is some uniform agreement on what constitutes IUU fishing, individual parties will continue to find ways to interpret their activities as either legal or consistent with de minimis State responsibilities. ${ }^{122}$

Uncertainty in terms of the scope of application of some core concepts therefore influences the impact that regulations can have.

\subsection{Behavioural task: implementation, enforcement and compliance weaknesses}

This study submits that, despite the flaws that the legal framework presents, we are still equipped with a fairly complete tool box in terms of regulatory commitments. The real difficulty, however, actually lies in the way in which these tools are used - or

118 Guggisberg, The Use of CITES, supra note 9 at 146, referring to Robin Churchill, "Legal uncertainties in international high seas fisheries management" (1998) 37 Fisheries Research 225-237 at 227.

119 Warner, supra note 67 at 186-187. The lack of coherence concerning those mechanisms is, to some extent, being addressed under the BBNJ Agreement, see chapter 4 sections 3.2 and 3.5. ABMTs and EIAs tools are also addressed under chapter 3 section 4.2 above. The review procedures available under the different instruments forming the regime are addressed generally in chapter 2 sections 3.1 and 3.2 above, while the review procedures for RFMOs are presented in chapter 2 section 3.3, and in chapter 3 section 3.1.8 above.

120 International Plan of Action to Prevent, Deter and Eliminate Illegal, Unreported and Unregulated Fishing, FAO COFI, 24th Sess (2001) at 2, online: <http://www.fao.org/3/Y1224E/y1224e.pdf >. See the discussion on the IUU IPOA in chapter 2 section 3.2.2.2 above.

121 Lee, Telesetsky \& Schofield, supra note 96 at 96-98.

122 Ibid at 98 . 
not used. ${ }^{123}$ In fact, commitments undertaken are only useful if they are sufficiently complied with.

Compliance with the commitments undertaken is measured through the behaviour of actors, ${ }^{124}$ namely whether they do what they are required or expected to do. Their behaviour towards compliance is translated through three main elements: implementation, enforcement and dispute settlement. While implementation refers to the actions necessary to perform the commitments, enforcement normally refers to more specific measures adopted to ensure that commitments are respected if a party is found not to be in compliance, and to identify who can initiate these measures. Dispute settlement, for its part, refers to the structures available for the resolution of disputes over compliance. ${ }^{125}$

Non-compliance can have a serious impact on the effectiveness of legal commitments. In fact, a regulatory regime can be very comprehensive but, if the obligations it provides are not met, the existing provisions cannot fulfil the goal for which they were established. Mitchell, however, warns against the analytical problem of equating strong compliance with a measure or an instrument to its degree of influence or effectiveness, as other factors might influence compliant behaviour, even in the absence of a measure or instrument. ${ }^{126}$ Dupuy and Viñuales also add that compliance and non-compliance are better seen as part of a process, with varying degrees. ${ }^{127}$ However, this study submits that, although acknowledging that compliance with a measure may not always lead to the effectiveness of such measure, ${ }^{128}$ compliance and effectiveness are correlated, and that the behaviour of

123 See, e.g., Alex Oude Elferink, "Exploring the future of the institutional landscape of the oceans beyond national jurisdiction" (2019) 28:3 Review of European and Comparative International Environmental Law 236-243 at 242: "As the current analysis also indicates, there is no lack of substantive principles and rules. What is missing are effective mechanisms to ensure their successful implementation in practice". See also Richard Barnes, "The Proposed LOSC Implementation Agreement On Areas Beyond National Jurisdiction and Its Impact on International Fisheries Law” (2016) 31:4 International Journal of Marine and Coastal Law at 583-619 at 615 [Barnes, "The Proposed LOSC IA"]; Harrison, Saving the Oceans, supra note 79 at 308; Margaret Young \& Andrew Friedman, "Biodiversity Beyond National Jurisdiction: Regimes and their Interaction" (2018) 112 AJIL Unbound 123-128 at 123.

124 See, e.g. Ronald Mitchel, "Compliance Theory. Compliance, Effectiveness, and Behaviour Change in International Environmental Law" in Daniel Bodansky, Jutta Brunnée \& Ellen Hey (eds) The Oxford Handbook of International Environmental Law (Oxford: Oxford University Press, 2007) 893-921 at 894.

125 Pierre-Marie Dupuy \& Jorge Viñuales, International Environmental Law, 2nd ed (Cambridge: Cambridge University Press, 2018) at 294. Philippe Sands \& Jacqueline Peel, with Adriana Fabra \& Ruth MacKenzie, Principles of International Environmental Law, 4th ed (Cambridge: Cambridge University Press, 2018) at 144.

126 Mitchell, supra note 124 at 895.

127 Dupuy \& Viñuales, supra note 125 at 293.

128 In fact, even if an actor does comply with the commitments undertaken, other elements might impede the effectiveness of such commitments. For example, in the framework of the present study, even if States do undertaken measures for the conservation of living resources on the high seas and even if they cooperate with others towards that goal, free riders who engage in IUU fishing will most likely undermine the effectiveness of such duties for the achievement of sustainable results. In short, this study acknowledges that compliance does not always lead to sustainability. On the insufficiency of compliance more generally, see, e.g. Underdal, supra note 117 at 6, who says that "[e]ven perfect compliance with a strong regime is therefore not a sufficient condition for achieving policy goals" (emphasis in original). 
actors towards the commitments they have undertaken forms an integral part of the good functioning of a legal regime. ${ }^{129}$

Assessing compliance involves various facets. Not only must the type of noncompliance - with substantive norms or with procedural requirements, ${ }^{130}$ etc. - be identified, but the underlying reasons for non-compliance might also be revealing of the weaknesses that need to be offset. While weak political will could also explain the lack of (strong) commitments undertaken, it is most often difficulties in terms of institutional, financial and human resources that underlie non-compliance. ${ }^{131}$ These underlying reasons must not only be considered when intending to fulfil already existing commitments, but also when setting out new commitments and evaluating their feasibility. The present section looks at existing structures and situations within the international fisheries regime that constitute a challenge to the implementation, enforcement and dispute settlement elements of non-compliance. These include questions of monitoring, control and surveillance (2.3.1), structural weaknesses of RFMOs (2.3.2), a lack of participation in key instruments (2.3.3), and difficulties linked to dispute settlement procedures (2.3.4).

\subsubsection{General difficulties for monitoring, control and surveillance}

Member States of RFMOs are mainly responsible, as flag States, for implementation and enforcement actions on the high seas, including fisheries related measures. As part of the jurisdiction they exercise over vessels flying their flags ${ }^{132}$ flag States must “'deploy adequate means, to exercise best possible efforts, to do the utmost' to prevent" 133 their vessels from breaching conservation and management measures, or from engaging in IUU fishing. This does not amount to an obligation of result, but represents an obligation of due diligence, which requires "a certain level of vigilance in their enforcement". ${ }^{134}$ One way for flag States to fulfil this obligation

129 Chapter 7 tests this submission. The alternative mechanisms analysed (smart mixes and joint interplay management) aim at improving compliance with a sustainable approach to fisheries management and, in turn, have shown some signs of improved effectiveness for sustainable management.

130 Sands et al, supra note 125 at 145. Dupuy \& Viñuales, supra note 125 at 295.

131 Sands et al, supra note 125 at 145 . See also Kyle Danish, "International Relations Theory" in Daniel Bodansky, Jutta Brunnée \& Ellen Hey (eds) The Oxford Handbook of International Environmental Law (Oxford: Oxford University Press, 2007) 205-230 at 226, referring to Abram Chayes \& Antonia Handler Chayes, The New Sovereignty: Compliance with International Regulatory Agreements (Cambridge, Mass.: Harvard University Press, 1995) at 10, where they explain that "when non-compliance does occur, it is rarely the product of willful disobedience but instead a result of the manageable deficiencies within the treaty regime or the lack of capacity of the non-complying state". See also Dupuy \& Viñuales, supra note 125 at 299-300, and Matley, supra note 18 at 109.

132 UNCLOS at art. 94; Compliance Agreement generally but more particularly art. III. See also section 2.2.2 above.

133 Advisory Opinion on IUU Fishing, supra note 86 at para 129, citing Responsibilities and obligations of States sponsoring persons and entities with respect to activities in the Area (Request for Advisory Opinion submitted to the Seabed Disputes Chamber), Advisory Opinion, (2011) ITLOS case no 17 at para 110 [Advisory Opinion on the Responsibility of Sponsoring States].

134 Advisory Opinion on IUU Fishing, supra note 86 at para 131, citing Pulp Mills on the River Uruguay (Argentina $v$ Uruguay), Merits, (2010) ICJ Rep 14 at para 197. 
of conduct, to assess whether vessels are compliant with enacted measures, is to establish mechanisms for MCS. MCS measures can also help to assess whether States themselves are compliant with their obligations. ${ }^{135}$

The physically large and remote areas which $\mathrm{ABNJ}$ cover present a practical difficulty for ensuring MCS. In fact, despite the significant proliferation of MCS technology and tools as presented under chapter 4 above, ${ }^{136}$ these MCS tools are not without problems, and several situations impede their optimal functioning. Thus, it is not uncommon to witness instances where vessels turn their VMS off, ${ }^{137}$ or where tools are "used for the benefit of more efficient fishing rather than to protect the oceans". ${ }^{138}$

In addition, although the UNFSA has reiterated the enforcement power of flag States over their own vessels, ${ }^{139}$ flag States can easily lack the resources and capacities to engage in surveillance activities. This has led to an uneven implementation of MCS measures/mechanisms. ${ }^{140}$ Limited capacities can also mean that only selected species or activities are monitored, therefore leaving gaps in the collected data and in actions undertaken. ${ }^{141}$ Moreover, in the face of a lack of resources, large amounts of data collected cannot be subsequently interpreted adequately, ${ }^{142}$ and this is exacerbated by a lack of coordination and sharing of information between actors. ${ }^{143}$

135 There is even the possibility of a double form of non-compliance: while a vessel fishing in contravention of a conservation and management measure represents one breach of compliance, a flag State failing to fulfil its obligation to control the wrongful vessel also amounts to non-compliance. The distinction between mechanisms to assess the performance of individual States and of vessels and other actors is also discussed in Yoshinobu Takei, "Demystifying Ocean Governance" in Seline Trevisanut, Nikolaos Giannopoulos \& Rozemarijn Roland Holst (eds), Regime Interaction in Ocean Governance. Problems, Theories and Methods (Leiden: Brill Nijhoff, 2020) 22-51 at 39-41 [Takei, "Demystifying Ocean Governance"].

136 An exhaustive overview of all MCS tools currently available can be found in Klaudija Cremers, Glen Wright \& Julien Rochette, "Strengthening Monitoring, Control and Surveillance in Areas Beyond National Jurisdiction" (2020) STRONG High Seas Project at 17-22 [Cremers, Wright \& Rochette, "MCS Report"]. See also, generally, Klaudija Cremers, Glen Wright \& Julien Rochette, "Strengthening monitoring, control and surveillance of human activities in marine areas beyond national jurisdiction: Challenges and opportunities for an international legally binding instrument" (2020) Marine Policy article 103976. A discussion on available tools for MCS in ABNJ is also conducted in chapter 4 section 3.5 above.

137 See, e.g., John Davis, "Monitoring Control Surveillance and Vessel Monitoring System Requirements to Combat IUU Fishing” (2000) Document AUS:IUU/2000/14 at para 9.7, online: <http://www.fao.org/3/ y3274e/y3274e0g.htm>; Pierre Girard \& Thomas Du Payrant, "An inventory of new technologies in fisheries. Challenges and opportunities in using new technologies to monitor sustainable fisheries" (2017) OECD Issue paper at 8 and 10, online: <https://www.oecd.org/greengrowth/GGSD_2017_Issue\%20 Paper_New\%20technologies\%20in\%20Fisheries_WEB.pdf>; "Going Dark: When vessels turn off AIS broadcasts" (30 July 2016) Global Fishing Watch, online: <https://globalfishingwatch.org/data/goingdark-when-vessels-turn-off-ais-broadcasts/>.

138 Techera \& Klein, supra note 75 at 243.

139 UNFSA at art. 19.

140 Daniel Dunn et al, "Empowering high seas governance with satellite vessel tracking" (2018) 19 Fish and Fisheries 729-739 at 731. The lack of capacities to conduct MCS is also an issue that, it is hoped, will be addressed under the BBNJ Agreement, see chapter 4 section 3.5 above.

141 Cremers, Wright \& Rochette, "MCS Report”, supra note 136 at 29.

142 Cremers, Wright \& Rochette, "MCS Report”, supra note 136 at 17.

$143 \mathrm{Ibid}$ at 32. 
Finding effective mechanisms for $\mathrm{MCS}^{144}$ that are appropriate to a State's needs and capacities therefore remains a difficult task. ${ }^{145}$

A lack of resources or abilities is not the only difficulty faced by actors in the performance of MCS; flags of convenience, i.e. flag States which offer conditions to shipowners to "cut costs and minimize risks at the expense of others, in order to attract them to register their vessels in their jurisdiction, ${ }^{146}$ are simply unwilling to undertake control and surveillance activities. ${ }^{147}$ As discussed above in section 2.2.2, the UNFSA broadened the possibility for a party to board and inspect vessels flying the flag of other States "for the purpose of ensuring compliance with conservation and management measures". ${ }^{148}$ However, the consent of the flag State is always required for boarding and inspection to take place, consent which a flag of convenience is unlikely to give. The unwillingness of some States to perform the MCS obligations linked to their status as flag States therefore affects the efficiency of the regulatory system as a whole, as compliance mechanisms will not be fully efficient if not applied by all. ${ }^{149}$

Furthermore, a lack of transparency and reporting ${ }^{150}$ (due to a lack of resources and/or will) on the part of flag States impacts the possibilities of monitoring the level of compliance of States themselves. Although the performance assessment procedures found under the 2015 Guidelines for Flag States ${ }^{151}$ have been praised for harmonizing all the relevant criteria for the assessment of flag State performance and for the interpretation of their obligations regarding conservation measures, ${ }^{152}$ such assessments are voluntary and currently lack structure. ${ }^{153} \mathrm{~A}$ review of States' performance in implementing the PSMA has also been enshrined under its article 24(1). To implement this obligation of review and monitoring, the PSMA MOP adopted in 2019 a questionnaire that States need to fill in on a regular basis to

144 A duty under the UNFSA at art. 10(h), and the Code of Conduct, supra note 17 at art. 7.7.3.

145 Guggisberg, The Use of CITES, supra note 9 at 150.

146 Eve de Coning, "Why Are Some Flag States Unable or Unwilling to Address IUU Fishing?" (2020) 22 International Community Law Review 487-512 at 497.

147 See, e.g., Judith Swan, "Fishing Vessels operating under open registers and the exercise of flag State responsibilities. Information and options" (2002) FAO Fisheries Circular No. 980 at introduction, online: $<$ http://www.fao.org/3/y3824e/y3824e00.htm\#Contents $>$; Camille Goodman, "The regime for flag State responsibility in international fisheries law - Effective fact, creative fiction, or further work required?" (2009) 23 Australia \& New Zealand Maritime Law Journal 157-169 at 159-160, cited in Matley, supra note 18 at 116.

148 UNFSA at art. 21, see section 2.2.2 above.

149 Guggisberg, The Use of CITES, supra note 9 at 151.

150 The issues fall under the principle for public availability of information, and transparent and open decision-making processes, discussed under chapter 3 section 3.1 .8 above.

151 Voluntary Guidelines for Flag State Performance (2015) at paras 44-46, online: <http://www.fao.org/3/ai4577t.pdf>.

152 Guggisberg, The Use of CITES, supra note 9 at 149.

153 See also Solène Guggisberg, "Independent, Compulsory, and Centralized verification of States' Obligations in Fisheries: Can the IMO Audit Scheme for Shipping Law Be Used as an Example to Follow?” (2020) 22 International Community Law Review 513-531 at 518. 
report on their own implementation of the PSMA. ${ }^{154}$ As the measures are new and voluntary, similar concerns arise to those raised by flag State performance reviews. ${ }^{155}$

The difficulty for individual States to efficiently implement MCS measures is being mitigated by other initiatives. ${ }^{156}$ First, States are encouraged to engage in MCS through collaborative actions with other States or international organizations, ${ }^{157}$ leading, among other measures, to the creation of international and regional MCS platforms and networks. These platforms aim to enhance cooperation in information gathering and exchange. For example, the International Monitoring, Control and Surveillance Network, established by States, RFMOs and regional economic integration organizations, "provide[s] a mechanism for fisheries law enforcement professionals to share information and experiences as they monitor the increasingly complex harvesting and marketing of fish around the world". 158 In addition, Fisheries Improvement Projects are multi-stakeholders initiatives normally relying on collaboration between State actors and private actors. These initiatives target the sustainability of a specific fishery or specific fisheries and rely on regular reporting and certification standards. ${ }^{159}$

More generally, the struggle - and sometimes inaction - of States in enforcement actions is also leading more and more non-State actors, mostly NGOs, to engage in MCS. ${ }^{160}$ NGOs have seen their role within fisheries management expand considerably over the past decade. ${ }^{161}$ Greenpeace and IUCN are examples of well-known NGOs holding States accountable for their commitments to include environmental objectives in their national policies, and also themselves engaging in actions at the global level. Not only do these NGOs collect and share data (on both

\section{Ibid at 519.}

155 These review procedures are also described in chapter 2 sections 3.1.7.2 and 3.2.2.3 above.

156 Cremers, Wright \& Rochette, "MCS Report", supra note 136 at 25-27.

157 UNFSA at art. 10(h).

158 International Monitoring, Control and Surveillance (MCS) Network for Fisheries-related Activities, online: <imcsnet.org>.

159 Cremers, Wright \& Rochette, "MCS Report", supra note 136 at 26. See also, generally, Fishery Progress, "Fishery Improvement Project Progress Tracking Database \& Tools", online: <https://fisheryprogress.org >.

160 Cremers, Wright \& Rochette, “MCS Report”, supra note 136 at 27. See also, generally, Solene Guggisberg, "The roles of nongovernmental actors in improving compliance with fisheries regulations" (2019) 28:3 Review of European and Comparative International and Environmental Law 314-327 [Guggisberg, "The role of NGOs"], which builds on previous literature on the role of NGOs in the field of fisheries, see, e.g., Marco Costantini, “The role of environmental non-governmental organizations in fisheries: scientific knowledge, its value in fisheries, and its underestimation in debates aimed at solving contingent issues" (2012) 11:3 Journal of Science Communication 1-3; Mette Eilstrup-Sangiovanni \& Teale Phelps Bondaroff, "From Advocacy to Confrontation: Direct Enforcement by Environmental NGOs" (2014) 58:2 International Studies Quarterly 348-361; Valentin Schatz, "Marine Fisheries Law Enforcement Partnerships in Waters under National Jurisdiction: The Legal Framework for Inter-State Cooperation and Public-Private Partnerships with Non-governmental Organizations and Private Security Companies" (2018) 32 Ocean Yearbook 329-375.

161 On the growing role of NGOs in the protection of the marine environment more generally, see James Harrison, "Actors and Institutions for the Protection of the Marine Environment" in Rosemary Rayfuse (ed), Research Handbook on International Marine Environmental Law (Cheltenham: Edward Elgar, 2015) 57-78 at 71-73. 
fish stocks and fishing activities), but they also directly intervene at sea, with the aim of impacting on the implementation of international obligations.

For example, in terms of data gathering, Global Fishing Watch is an initiative of non-State actors involved in the management of marine resources. Through the collaboration of three partners, ${ }^{162}$ Global Fishing Watch aims to improve transparency in commercial fishing activities, by conducting real-time tracking of such activities, ${ }^{163}$ and also making the data available to States and RFMOs. Furthermore, the pursuit of the Thunder by the Sea Shepherd Conservation Society illustrates the interventionist role undertaken by NGOs. In December 2014, while engaged in the fishing of Patagonian toothfish using illegal nets, the Thunder was intercepted by two vessels of Sea Shepherd in waters under the management of CCAMLR and pursued for 110 days, until it sank off the waters of Sao Tome and Principe. Crew members of the Thunder were then brought before Sao Tome officials, and were subsequently prosecuted. ${ }^{164}$ As underlined by Guggisberg, "NGOs, through their promotion of transparency and accountability, are playing key roles in" "tackl[ing] States' relative passivity towards fisheries issues" ${ }^{165}$

However, although seemingly efficient and responding to a need of monitoring and control, NGO involvement is not without concern and can raise issues of legality. For example, direct actions undertaken by an NGO vessel against another vessel could be classified as piracy, ${ }^{166}$ if the relevant conditions were to be met. ${ }^{167}$ Such actions could also potentially raise the responsibility of the flag State, as was the case in the Arctic Sunrise Case, ${ }^{168}$ or amount to a breach of the freedom of navigation of

162 Two non-profit organizations, Oceana, an international advocacy organization dedicated solely to ocean conservation, and Skytruth, which uses satellite technology to collect data on fishing activities, collaborate with Google, which processes the data.

163 Global Fishing Watch, online: <http://globalfishingwatch.org >.

164 Oliver Milman, "Captain deliberately sank illegal fishing vessel, claim Sea Shepherd rescuers” (7 April 2015) The Guardian, online: <https:/www.theguardian.com/environment/2015/apr/07/captain-deliberatelysank-illegal-fishing-vessel-claim-sea-shepherd-rescuers $>$.

165 Guggisberg, “The role of NGOs”, supra note 160 at 327.

166 Ibid at 324.

167 UNCLOS at art. 101.

168 The Arctic Sunrise Case (Kingdom of the Netherlands v. Russian Federation), Provisional Measures, (2013) ITLOS case no 22; The Arctic Sunrise Arbitration (Netherlands v. Russia), Award, (2015) PCA case 201402. In September 2013, members of the crew of the MV Arctic Sunrise, a Greenpeace vessel flying the flag of the Netherlands, tried to board an oil drilling platform in Russia's EEZ, in an act of protest against oil exploitation in the Arctic Ocean. The vessel and its crew were arrested by the Russian coast guard, and the Russian government initially intended to charge the crew for piracy. The substance of the case goes beyond the scope of this study, but it illustrates that the actions of NGOs at sea can trigger the responsibility of the flag State. For literature on this case, see, e.g. Richard Caddell, "Platforms, Protestors and Provisional Measures: The Arctic Sunrise Dispute and Environmental Activism at Sea" (2015) 45 Netherlands Yearbook of International Law 359-384; Alex Oude Elferink, "The Russian Federation and the Arctic Sunrise Case: Hot Pursuit and Other Issues under the LOSC" (2016) 92 International Law Studies 381-406; Maria Chiara Noto, “The Arctic Sunrise Arbitration and Acts of Protest at Sea" (2016) 2 Maritime Safety and Security Law Journal 36-56; Paula de Castro Silveira \& Grace Ladeira Garbaccio, "Protest at Sea: the Arctic Sunrise Case and the clarification of Coastal States Rights" (2019) 40:81 Sequência (Florianópolis) 32-46. 
the vessel pursued or intercepted. The conduct of the NGO vessel could also trigger issues related to safety of maritime navigation. ${ }^{169}$

In summary, what would be needed to improve MCS are general obligations of cooperation, transparency and reporting; the co-creation of MCS responses and tools with different stakeholders, especially the market; and the improvement of platforms for the sharing of information. ${ }^{170}$ Some initial steps have been undertaken, but much work needs to be done for MCS to be fully effective.

\subsubsection{Specific implementation and enforcement deficiencies within RFMOs}

RFMOs are the main fora through which States implement their commitments related to the conservation and management of living resources in ABNJ. Looking at certain characteristics of RFMOs' functioning therefore sheds some further light on practices that can be problematic for reaching sustainability performance. ${ }^{171}$

From the outset, it must be mentioned that despite the recurring criticisms targeting RFMOs, most have achieved considerable successes in terms of innovative developments to improve compliance. For example, RFMOs have taken measures for the protection of VMEs following relevant UNGA Resolutions and the Guidelines on Deep-sea Fisheries, ${ }^{172}$ including the adoption of bans and closed areas. They have in addition undertaken bottom fishing management and adopted by-catch and exploratory fisheries measures ${ }^{173}$ measures that have proved to be successful in achieving positive protection results for stocks and surrounding ecosystems. ${ }^{174}$ Moreover, a recent study reported by Friedman et al shows the progression in the status of governance measures and controls across RFMOs adopted and in place between 2006 and 2017. The study underlines that "[m]easures that incorporate biodiversity considerations into management continue to spread across RFBs [...], as RFBs give these issues increasing profile". ${ }^{175}$

Several RFMOs have also implemented different MCS measures. These include mandatory VMS, observer programmes, electronic reporting and/or other types

169 This could also potentially go against relevant IMO regulations or the Convention for the Suppression of Unlawful Acts against the Safety of Maritime Navigation (adopted 10 March 1988, entered into force 1 March 1992) 1678 UNTS 201, discussed in Guggisberg, “The role of NGOs”, supra note 160 at 327.

170 Cremers, Wright \& Rochette, "MCS Report", supra note 136 at 38-39. This is also discussed in chapter 4 section 3.5 above.

171 Weaknesses of RFMOs are also discussed in chapter 2 section 3.3.2 above, as well as section 2.1.2 above.

172 Zoey Scanlon, “The art of 'not undermining': possibilities within existing architecture to improve environmental protections in areas beyond national jurisdiction” (2018) 75:1 ICES Journal of Marine Science 405-416 at 411, referring to Matthew Gianni et al, "How Much Longer Will it Take? A tenyear review of the implementation of United Nations General Assembly Resolution 61/105, 64/72 and $66 / 68$ on the management of bottom fisheries in areas beyond national jurisdiction" (2016) Deep Sea Conservation Coalition at 4-5.

173 Scanlon, supra note 172 at 411-412.

174 See, generally, ibid. See also chapter 3 section 4.2 above.

175 Friedman, Garcia \& Rice, supra note 8 at 214. 
of monitoring systems, ${ }^{176}$ as well as the requirement that member States meet a list of minimum standards, such as catch reporting or measures for inspections in ports. ${ }^{177}$ Furthermore, newer RFMOs (mainly WCPFC and SPRFMO), in an attempt to focus on the underlying causes of non-compliance, have developed compliance monitoring schemes, that "identify priority areas of non-compliance [...], by focusing on the underlying purpose of the conservation and management measures that have been put in place to fulfil the objectives of the RFMO. A key focus of these compliance schemes is reporting obligations" ${ }^{178}$ Finally, most RFMOs have also developed lists of authorised vessels and vessels reported as engaging in IUU fishing (IUU vessels lists). ${ }^{179}$ There is also a sharing of the information found on those lists among RFMOs and other organizations. ${ }^{180}$

Unfortunately, these successes have not been sufficient to counterbalance the structural difficulties that plague the functioning of RFMOs. There are three main internal problems within RFMOs: difficulties linked to conservation and management measures, poor transparency (including issues linked to performance review), and a lack of harmonization among RFMOs.

The first problem concerns the fact that, while most RFMOs adopt binding conservation and managements measures (under their respective constitutive agreements and/or under the UNFSA), ${ }^{181}$ these measures are criticized for the weakness and inefficiency of their content, of the method for their adoption, and of the way in which they are implemented, enforced and complied with. ${ }^{182}$ First, in terms of content, as discussed in section 2.1.2 above, a lack of sufficient data, both on fish stocks and on the wider marine environment, often does not allow for measures to be adopted on a sound scientific basis. ${ }^{183}$ Furthermore, measures are often developed while deliberately disregarding scientific advice, ${ }^{184}$ and instead are based on political considerations. ${ }^{185}$ This is reflected in the fact that MSY remains the

176 Cremers, Wright \& Rochette, "MCS Report", supra note 136 at 24. These tools are also discussed in legal framework section 3.3.2, and listed in chapter 4 section 3.5 above.

177 Ibid at 25 .

178 Matley, supra note 18 at 109-110.

179 Examples of those lists are cited in BBNJ 4 section 3.5 above.

180 Cremers, Wright \& Rochette, "MCS Report", supra note 136 at 24.

181 See, generally, Solene Guggisberg, "Recent developments to improve compliance with international fisheries law" (2017) 42 L'Observateur des Nations Unies 145-175 [Guggisberg, "Recent developments"].

182 See, e.g., Andrew Friedman, "Beyond 'not undermining': possibilities for global cooperation to improve environmental protection in areas beyond national jurisdiction” (2019) 76:2 ICES Journal of Marine Science $452-456$ at 453.

183 Matley, supra note 18 at 107.

184 Diz, supra note 115 at 128; Harrison, Saving the Oceans, supra note 79 at 206-207; Gjerde, "High Seas Fisheries Governance", supra note 115 at 227; Kristina Gjerde, "High Seas Fisheries Management under the Convention on the Law of the Sea" in David Freestone, Richard Barnes, \& David Ong (eds), The Law of the Sea: Progress and Prospects (Oxford: Oxford University Press, 2006) 281-307 at 298-300; D.G. Webster, "International Fisheries: Assessing the Potential for Ecosystem Management" (2013) 3:2 Journal of Environmental Studies and Sciences 169-183 at 169.

185 Guggisberg, The Use of CITES, supra note 9 at 144-148. 
dominant concept on which management measures are based, ${ }^{186}$ and that RFMOs are struggling to effectively include the ecosystem and precautionary approaches in their measures, ${ }^{187}$ which represents the main challenge in RFMOs' decisionmaking. ${ }^{188}$ Second, the adoption of conservation and management measures is driven by political considerations, which accentuates a division and lack of coordination between those having the scientific expertise and those holding the decision-making power. ${ }^{189}$ Since most of these measures are adopted by consensus, the interests of distant waters fishing nations often override those of coastal States (especially developing States), which must consent to the "law of least ambitious program"190 in exchange for necessary financial considerations such as "development aid, fees for fishing licenses and, ultimately, access to consumer markets". ${ }^{191}$ National and regional influence groups and lobbies also have an impact on decision-making. ${ }^{192}$ Third, as to implementation and enforcement of and compliance with conservation and management measures, organizations are failing to comply with their own measures, ${ }^{193}$ especially with regard to highly migratory species. ${ }^{194}$ While there has been progress in terms of the conservation of target species, important work still needs to be done "concerning non-target species, vulnerable marine ecosystems and ecosystem-based management". ${ }^{195}$ Non-compliance with the commitments of cooperation in conservation is also illustrated through the opt-out procedure. ${ }^{196}$ Relatedly, another weakeness at the level of enforcement lies in the fact that "IUU vessel lists are notoriously underutilized and tend to focus more on instances of illegal (as opposed to unreported and unregulated) fishing. The reasons for their underutilization are not clear-cut; however, the political costs of listing a vessel can be high." 197

186 Webster, supra note 184 at 169. See also chapter 3 section 4.1, as well as section 2.1.2 above.

187 Michael Lodge et al, Recommended Best Practices For Regional Fisheries Management Organizations. Report of an Independent Panel to Develop a Model for Improved Governance by Regional Fisheries Management Organizations (London: The Royal Institute of International Affairs Chatham House, 2007) at $\mathrm{x}$.

188 Harrison, Saving the Oceans, supra note 79 at 206-207.

189 Stokke, "Management Options", supra note 3 at 54.

190 Agnes Yeeting \& Simon Bush, "RFMO-MSC Smart Regulatory Mixes for Transboundary Tuna Fisheries" in Judith van Erp et al (eds), Smart Mixes for Transboundary Environmental Harm (Cambridge: Cambridge University Press, 2019) 146-169 at 148. See also Matley, supra note 18 at 106-107.

191 Yeeting \& Bush, supra note 190 at 148.

192 Ibid.

193 Guggisberg, The Use of CITES, supra note 9 at 154, citing FAO, "The State of World Fisheries and Aquaculture 2016. Contributing to food security and nutrition for all" (2016) at 8, online: <http://www. fao.org/3/a-i5555e.pdf >; Sarika Cullis-Suzuki \& Daniel Pauly, "Failing the high seas: A global evaluation of regional fisheries management organizations" (2010) 34 Marine Policy 1036-1042; and Lodge et al, supra note 187 at ix.

194 On tuna RFMOs, see, e.g. Maria José Juan-Jordá et al, "Report card on ecosystem-based fisheries management in tuna regional fisheries management organizations" (2018) 19:2 Fish and Fisheries 321-339.

195 Cremers, Wright \& Rochette, “MCS Report", supra note 136 at 24.

196 See section 2.2.3 above.

197 Matley, supra note 18 at 109-110. 
A second structural difficulty lies in the lack of transparency in RFMOs practices. ${ }^{198}$ This can be illustrated with the performance review mechanisms to which they can submit themselves. ${ }^{199}$ First, although most RFMOs have submitted themselves to reviews, ${ }^{200}$ these reviews are still conducted on a voluntary basis, ${ }^{201}$ and in practice RFMOs often do not rely on the criteria established for the conducting of the assessments. ${ }^{202}$ Furthermore, even if an assessment is conducted, it is often the case that no measures will be undertaken to address the issues raised in such assessments. ${ }^{203}$ The perception that non-compliance will not be detected or punished because of the soft compliance nature of such assessments also influences actors to repeat non-compliant behaviours. ${ }^{204}$ The costs for non-compliance would therefore have to be raised in order to achieve higher compliance rates. ${ }^{205}$ More specifically for tuna RFMOs, although most of them have undergone at least one assessment procedure, ${ }^{206}$ the implementation of regular performance reviews recommended by the Kobe process is lacking. ${ }^{207}$ These difficulties illustrate the failure of RFMOs "to comply with performance standards expected of [them] under international agreements", ${ }^{208}$ and strengthening oversight mechanisms is a challenge. Despite such weaknesses, Depypere argues that the structural drivers for better performance of RFMOs reside in the strengthening of the Kobe process for tuna RFMOs, the performance reviews procedure for all RFMOs, and the UNFSA review process, which would motivate RFMOs in undertaking these reviews systematically. ${ }^{209} \mathrm{Effort}$ and commitment will, however, be necessary for these measures to succeed, coupled with potentially "supplementary processes" such as "regular performance audits and systematic follow up, using peer pressure and more systematic capacity-building,

198 Wright et al, supra note 41 at 9; Guggisberg, "Recent developments", supra note 181 at 158; Kristina Gjerde et al, "Ocean in Peril: Reforming the Management of Global Ocean Living Resources in Areas Beyond National Jurisdiction" (2013) 74:2 Marine Pollution Bulletin 540-551 at 542 [Gjerde et al, "Ocean in Peril"].

199 The discussion conducted in this paragraph is based on the contribution of the present author to Blanchard, Durussel and Boteler, supra note 15.

200 Péter D. Szigeti \& Gail L. Lugten, “The implementation of performance review reports by regional fishery bodies, 2004-2014" (2015) FAO Fisheries and Aquaculture Circular No. 1108. This, however, does not take into consideration more recent reviews of tuna RFMOs. In fact, the most recent reviews took place in 2012 (WCPFC), 2014 (CCSBT), 2015 (IOTC) and 2016 (IATTC and ICCAT), see Tuna-org, online: $<$ http://www.tuna-org.org $>$. The performance reviews of RFMOs are also addressed in chapter 2 section 3.3.2 above.

201 Except for the SPRFMO Convention at art. 30, which includes the necessity of a performance review every five years.

202 See, e.g., Sustainable fisheries, including through the 1995 Agreement for the Implementation of the Provisions of the United Nations Convention on the Law of the Sea of 10 December 1982 relating to the Conservation and Management of Straddling Fish Stocks and Highly Migratory Fish Stocks, and related instruments, GA Res 61(CV), UNGAOR, 61th Sess, UN Doc A/RES/61/105 (2006) at para 73, as well as the minimum criteria by the Kobe group, discussed in Szigeti \& Lugten, supra note 200 at 80-83 (annex 4).

203 For a comprehensive overview of the current developments regarding RFMOs performance reviews, see Guggisberg, "Recent developments", supra note 181.

204 Gjerde et al, "Ocean in Peril", supra note 198 at 543; Guggisberg, The Use of CITES, supra note 9 at 206.

205 Matley, supra note 18 at 122.

206 Depypere, supra note 47 at 376.

207 See, e.g., Gjerde et al, "Ocean in Peril”, supra note 198 at 542.

208 Ibid at 541.

209 Depypere, supra note 47 at 375-377. 
and creating conditions for all participants to fully engage in existing process". ${ }^{210}$ The creation of a more institutionalized structure within the performance review assessments, such as a performance evaluation board, would also be desirable. ${ }^{211}$

The third main structural problem lies in the disparity of performance among RFMOs, which "derives in part from distinctive institutional features like the impartiality of scientific advisory bodies, majority or consensual decision-making, substantive principles of management, the stringency of conservation measures, and the structures for collaborative surveillance and enforcement". 12 A good example is the requirement of RFMOs to only authorize, in the waters under their management, fishing activities of vessels that have monitoring and surveillance systems. ${ }^{213}$ While newer RFMOs implement this requirement more strictly, this is not a uniform practice. ${ }^{214}$ Blasiak and Yagi state, however, that while the diversity characterizing RFMOs might pose some challenges for the harmonization of practices, ${ }^{215}$ it can also be seen as an opportunity to develop regimes that match regional circumstances and necessities, and to share experiences. ${ }^{216}$

To these internal problems can be added the external difficulty linked to free riders who might impede the sustainability of management ${ }^{217}$ as well as the healthy development of the system. ${ }^{218}$ Free riding normally flows either from a simple "costbenefit analysis", i.e. when it is more profitable for a State not to cooperate, it is more likely that this State will not join the cooperative arrangement (e.g. RFMO/RFMA or other type of arrangement). It also stems from the impossibility to join an RFMO. ${ }^{219}$ Free riders are theoretically understood as all non-participants to an RFMO. However, with the adoption of the UNFSA, its parties are now bound by article 17, which provides that non-members in an RFMO still have the duty to cooperate in

210 Ibid at 378 .

211 Ibid.

212 Stokke, "International fisheries politics", supra note 11 at 114 . The wide variety of RFMO/RFMAs is also presented in chapter 2 section 3.3.2 above.

213 See, e.g., Vessel Monitoring System, WCPFC CMM 2007-02 (2007); SPRFMO Convention at art. 27(1)(a); Resolution on a CCSBT Record of Vessels Authorised to Fish for Southern Bluefin Tuna, CCSBT Res, 26th Sess (2019).

214 The specific actions of RFMOs are discussed in greater details in the following section 2.3.2.

215 This question is also discussed in Lodge et al, supra note 187 at ix-x; Warner, supra note 67 at 188190; Friedman, supra note 182 at 453 . On the variations among the weaknesses of different RFMOs, see Stokke, "International fisheries politics", supra note 11 at 98.

216 Robert Blasiak \& Nobuyuki Yagi, "Shaping and International Agreement on Marine Biodiversity Beyond Areas of National Jurisdiction: Lessons from High Seas Fisheries” (2016) 71 Marine Policy 210-216 at 214-215.

217 See, e.g., Lodge et al, supra note 187 at x; Guggisberg, The Use of CITES, supra note 9 at 71; Harrison, Saving the Oceans, supra note 79 at 207; Gjerde, "High Seas Fisheries Governance", supra note 115 at 221223. Gjerde et al, "Ocean in Peril", supra note 198 at 541.

218 See generally Pedro Pintassilgo et al, "Stability and Success of Regional Fisheries Management Organizations" (2010) 46:3 Environmental and Resource Economics 377-402 at 378.

219 See, e.g., Gordon Munro, Annick van Houtte \& Rolf Willmann, "The conservation and management of shared fish stocks: legal and economic aspects” (2004) FAO Fisheries Technical Paper. No. 465 at 33-34. The lack of will and/or possibility to join an RFMO or similar cooperative arrangement is also linked to the problem of new entrants, which is discussed in section 2.3 .3 below. 
the conservation and management of stocks, ${ }^{220}$ including by prohibiting their vessels from fishing the stocks under the management of the RFMO. ${ }^{221}$ External difficulties with free riders therefore mostly rest with non-participants in an RFMO that are also non-parties to the UNFSA, ${ }^{222}$ and who would then only be bound by the general - and somewhat vague - obligation of cooperation under article 118 UNCLOS. However, imposing an RFMO measure on a free rider would in fact be questionable in law, as imposing obligations on them would go against the pacta tertiis rule. ${ }^{223}$ Yet, addressing the problem of free riders is a core component for reaching effective enforcement by RFMOs, as "the success of international cooperation depends largely on the ability to deter free-riding". 224 Article 17 UNFSA is definitely a step in the right direction to ensure cooperation; however, considering the limited number of parties to the UNFSA, ${ }^{225}$ an effective deterrence of free riding requires that the underlying causes of free riding be addressed.

In brief, despite successes achieved by RFMOs, a lot remains to be done for those organizations' actions to be aligned with their conservation objectives. As long as questions of data collection, scientific research, and monitoring remain "unfilled priorities within RFMOs", ${ }^{226}$ we cannot expect RFMOs to fulfil a management of high seas fisheries that is truly aimed towards.

\subsubsection{Lack of participation in key fisheries related instruments and organizations}

In general, key instruments regulating international fisheries still suffer from relatively low membership. ${ }^{227}$ The number of accessions to and ratifications of the UNFSA has, however, slightly increased since 2016 bringing the parties to $90 .{ }^{228}$ Nevertheless, six major marine fishing nation $\mathrm{s}^{229}$ have not yet ratified or acceded to

220 UNFSA at art. 17(1).

221 Ibid at art. 17(2).

222 The non-participation in instruments is discussed in section 2.3.3 below.

223 Pacta tertiis, see VCLT at art. 34, discussed in Guggisberg, The Use of CITES, supra note 9 at 147. The impossibility to impose obligations on non-members is only applicable to the extent that the involved States are not parties to the UNFSA, which provides that a non-member of an RFMO "which does not otherwise agree to apply the conservation and management measures established by [an RFMO], is not discharged from the obligation to cooperate [...] in the conservation and management of the relevant" stocks (art. 17(1) UNFSA).

224 Lodge et al, supra note 187 at x. Also discussed in Pintassilgo et al, supra note 218 at 395-396.

225 The number of ratifications and accessions to the UNFSA and to other fisheries related instruments is discussed in section 2.3.3 below.

226 Kristina M. Gjerde, Nichola A. Clark \& Harriet R. Harden-Davies, "Building a Platform for the Future: the Relationship of the Expected New Agreement for Marine Biodiversity in Areas beyond National Jurisdiction and the UN Convention on the Law of the Sea" (2019) 33 Ocean Yearbook 3-44 at 34.

227 Gjerde et al, "Regulatory and governance gaps", supra note 9 at 10.

228 There have been eight new parties since the beginning of 2016, see UN, "Table recapitulating the status of the Convention and of the related Agreements" (27 June 2019, latest available version), online: <https:// www.un.org/Depts/los/reference_files/status2019.pdf>. These include three States (Chile, Thailand and Vietnam) figuring on the list of major capture producers, see FAO Report 2020, supra note 45 at 13.

229 From the list of major capture producers, see FAO Report 2020, supra note 45 at 13, China, Peru, Malaysia, Mexico, Myanmar and Argentina, have not ratified or acceded to the UNFSA (China and Argentina have however signed it). It is to be noted, however, that the ranking of the most important 
the treaty. Similarly, only 42 States are party to the 1993 Compliance Agreement, ${ }^{230}$ and 10 major fishing nations are not parties. ${ }^{231}$ Further, China, one of the 10 States leading fishing activities on the high seas, ${ }^{232}$ is neither a party to the UNFSA (it has, however, signed it) nor to the Compliance Agreement.

Molenaar has analysed the different reasons behind the decision of a State not to participate in the UNFSA. ${ }^{233}$ Reasons for non-participation embedded in objections to substantive aspects of the UNFSA rest mainly with potential interpretations of some of its provisions. For example, many Latin American States have interpreted article 4, regulating the relationship between the UNFSA and UNCLOS, as giving the UNFSA the power to amend and not only implement UNCLOS, a result with which they disagree. ${ }^{234}$ Similarly, the text of article 7 on compatibility of conservation measures has been interpreted by coastal States as favouring high seas fishing States, while the latter believe it is actually the exact opposite. Each group therefore objects to the UNFSA giving priority to the other group. ${ }^{235}$ Finally, some States consider that the enforcement power given to non-flag States and port States in articles 21-23 is too far-reaching and restricts the exclusive jurisdiction of flag States. ${ }^{236}$ Other reasons for non-participation in the UNFSA include a lack of capacity, a lack of awareness and misconceptions (i.e. States might think that the UNFSA applies only to the high seas and therefore has no relevance for conservation and management of stocks in the EEZ), a lack of direct interest for the stocks covered by the UNFSA, and a cost-benefit analysis. ${ }^{237}$ The present author's submits that identifying such reasons for non-participation is necessary to work towards an increased accession to the relevant fisheries instruments. Since positions regarding substantive aspects of the UNFSA are often linked to a State's interest and internal (political) considerations, those could difficulty be addressed by external actions.

fishing nations is also based on capture fisheries in the EEZ. The numbers used in the text are therefore meant for illustrative purposes only.

230 See FAO, "Agreement To Promote Compliance With International Conservation And Management Measures By Fishing Vessels On The High Seas - Parties to the Agreement" (2 July 2018, latest available version), online: <http://www.fao.org/fileadmin/user_upload/legal/docs/012s-e.pdf>. It is to be noted, however, that the list of parties includes the European Union, which consequently includes its members States.

231 From the list of major capture producers, see FAO Report 2020, supra note 45 at 13, China, Indonesia, Russia, India, Vietnam, Malaysia, Thailand, Iceland, Mauritania and Iran are not parties to the Compliance Agreement.

232 The 10 States with the highest average high-seas landed value are Japan, South Korea, Taiwan, Spain, the United States, Chile, China, the Philippines, France, Indonesia, see U. Rashid Sumaila et al, "Winners and losers in a world where the high seas is closed to fishing" (2015) 5 Scientific Reports article number 8481. The present author acknowledges that the paper cited covers the period 2001-2010, and the data might have changed over the recent years; however, this is, to the present author's knowledge, the only recent comprehensive overview of data related to States leading fishing activities on the high seas. This list is also referred to in chapter 2 section 2.1 above.

233 Erik Molenaar, "Non-Participation in the Fish Stocks Agreement: Status and Reasons" (2011) 26 International Journal of Marine and Coastal Law 195-234.

234 Ibid at 200-201.

$235 \mathrm{Ibid}$ at 201-204.

$236 \mathrm{Ibid}$ at 204-208.

237 Ibid at 199-213. 
However, reasons for non-participation related to a lack of awareness or resources could, for their part, be addressed through capacity-building measures or sharing of knowledge and information. Furthermore, getting clarifications from a court or tribunal on specific provisions could shed light on their interpretation, potentially easing concerns and uncertainties of some States as to the content and/or scope of application of said provisions. Understanding the reasons behind non-participation inform us on the concerns of different States regarding a specific subject matter, and initiatives can therefore be undertaken to ensure that such concerns be avoided in the development of related instruments, such as the BBNJ Agreement. ${ }^{238}$

Furthermore, the establishing of relevant regional fisheries organizations forms part of the obligations of States to cooperate in the conservation and management of living resources. ${ }^{239}$ However, although "participation commonly includes all coastal States as well as some or all of a small group of developed distant water fishing States and entities (China, the EU, Japan, Korea and the US)", ${ }^{240}$ most RFMOs do not include in their members all States or groups of States actually conducting fishing activities in the area which they cover. ${ }^{241}$ This means that not all actors actually fishing in a given region are bound by the conservation and management measures adopted by the relevant RFMOs. As reported by Stokke, "[e]stimates (necessarily rough) indicate that up to 20 per cent of the vessels fishing on the high seas fly flags of non-Members to the relevant regional fisheries management body". ${ }^{242} \mathrm{~A}$ certain degree of coherence is ensured through the obligation for non-members not to engage in non-cooperative behaviours; ${ }^{243}$ however, this obligation is only applicable to UNFSA parties. ${ }^{244}$ The effectiveness of conservation and management measures could therefore remain vulnerable to a lack of cooperation from non-parties to the UNFSA..$^{245}$

Lack of participation in an RFMO might not only be due to a lack of will on the part of the fishing nation itself, but also to other members of an RFMO. This is illustrated through the problem of accepting new members in an RFMO, referred to as "new

238 For example, the BBNJ Agreement will hopefully bring some clarification regarding the relationship between ABNJ and AWNJ, an issue linked, among other provisions, to the application of art. 7 UNFSA, see chapter 4 section 3.4 above. Understanding States' concerns as to the application of art. 7 UNFSA could inform the way of developing related measures under the upcoming Agreement.

239 UNCLOS at art. 118.

240 Erik Molenaar, "Participation in Regional Fisheries Management Organizations" in Richard Caddell \& Erik Molenaar (eds), Strengthening International Fisheries Law in an Era of Changing Oceans (Oxford: Hart, 2019) 103-129 at 128 [Molenaar, "Participation in RFMOs"].

241 Warner, supra note 67 at 186.

242 Stokke, "Management options", supra note 3 at 67, referring to Elizabeth DeSombre, Global Environmental institutions (Abingdon, Oxon: Routledge, 2006) at 92.

243 UNFSA at art. 17.

244 Non-UNFSA parties remain bound by the obligations of cooperation under Section 2, Part VII and Part XII of UNCLOS, although those obligations are somewhat more vague, see chapter 2 sections 3.1.1.1 and 3.1.1.2 above.

245 See a similar argument in section 2.3.2 above. 
entrants" ${ }^{246}$ Even if their constitutive instruments include eligibility criteria based on geographical location (i.e. coastal State), real interest, ${ }^{247}$ actual fishing activities and/or wish to conduct fishing, ${ }^{248}$ most RFMOs make it very difficult in practice for non-members to accede to membership. Molenaar observes:

The analysis of the rules and practices on participation in RFMOs highlights that a considerable number of the selected RFMOs are essentially 'closed' to all or certain new participants, despite their rights concerning high seas fishing and participation in RFMOs enshrined in [UNCLOS] and the [UNFSA]. [...] It should also be acknowledged that the preferential position of existing participants is likely to be even more pronounced when account is also taken of the (very) limited fishing opportunities that seem to be available to new participants of many RFMOs that are essentially 'open. ${ }^{249}$

The procedures on accession also vary considerably across RFMOs, but high thresholds, often based on consensus decision, majority or two-thirds majority, illustrate the preferential position given to existing members. The recent rejection of the EU's request to become a member of the $\mathrm{NPFC}^{250}$ shows the difficulty for nonmembers to accede to RFMOs because of a consensus-based invitation, despite the "wish to conduct fishing activities for fisheries resources in the Convention Area" being an eligibility criterion for new members under the NPFC Convention. ${ }^{251}$ As potential membership is also based on a certain level of fishing capacity and/or interest, this would also exclude the possible accession of States "interested solely in conservation or effective ocean management". ${ }^{252}$

\subsubsection{Uncertainties linked to the scope of dispute settlement procedures}

A number of cases addressing questions related to the conservation and management of marine living resources, including the cooperation for such management and conservation, have allowed the ICJ, ITLOS, ad hoc tribunals, ${ }^{253}$ and SPRFMO review panels to interpret and elaborate on the state of the law concerning these matters. ${ }^{254}$ At present, however, dispute settlement, despite having contributed to

246 On new entrants, see, generally, Andrew Serdy, The New Entrants Problem in International Fisheries Law (Cambridge: Cambridge University Press, 2016). See also Stokke, "International fisheries politics", supra note 11 at 108 .

247 It is to be noted that the notion of "real interest" is not defined, see chapter 2 section 3.3.2 above.

248 The right to become a new member of an RFMO is ensured under the UNFSA at art, 8(3). For a comprehensive analysis of the eligibility criteria and accession procedures of selected RFMOs, see Molenaar, "Participation in RFMOs", supra note 240 at 119-121.

249 Ibid at 128.

250 See Report $5^{\text {th }}$ Commission Meeting, NPFC, 5th Meeting, NPFC-2019-COM05-Final Report (2019) at annex E and F for the statements of Russia and the EU respectively, online: <NPFC-2019-COM05-Final Report>.

251 NPFC Convention at art. 24(2).

252 Matley, supra note 18 at 106.

253 Mostly tribunals constituted under annex VII of UNCLOS

254 See legal chapter 2 section 3.1.1.4 above. 
the evolution of the law of the sea and fisheries law by bringing some clarification to several terms and concepts, ${ }^{255}$ has had a limited impact on the development of fisheries management and cooperation towards an improvement of sustainability performance on the high seas.

This limited impact can be explained by two main elements. First, the settlement of disputes has so far been dealt with bilaterally. However, because of the nature of marine living resources on the high seas and the protection of the marine environment being common interests, it could be questioned whether a bilateral mechanism is the appropriate avenue for States to address issues of compliance. ${ }^{256}$ As mentioned by Payne, "[e]xpecting [courts and tribunals] to have the same influence over activities in marine ABNJ challenges the usual bilateral state-based system".257 Requesting an advisory opinion on States' obligations regarding cooperation and the conservation of marine living resources on the high seas could be an option to obtain clarifications on the content and extent of such obligations. ${ }^{258}$ It remains to be seen who would have the interest (and will) to request such advisory opinion.

Second, the jurisdiction of courts and tribunals is subject to limitations, which can restrict the possibility for States to use these dispute settlement mechanisms in case of non-compliance. Four potential situations in particular have a major effect on the possibility to use dispute settlement procedures in the context of the management and conservation of fisheries on the high seas.

The first situation is linked to the scope of application of the compulsory dispute settlement mechanisms found under Section 2, Part XV of UNCLOS. Both core elements of this study, fisheries and the protection of the marine environment, fall under these compulsory dispute settlement mechanisms, as per articles 297(3)(a) and 297(1)(c) UNCLOS respectively. However, uncertainties might arise when a dispute concerns transboundary stocks straddling between the EEZ and the high seas. In fact, disputes "relating to [a States] sovereign right with respect to the living resources in the exclusive economic zone" are excluded from the scope of application of the compulsory dispute settlement. ${ }^{259}$ Disputes regarding marine living resources on the high seas, however, are not excluded. ${ }^{260}$ In the Chagos Arbitration, the Arbitral Tribunal had to address the question of whether a dispute concerning straddling stocks could open up the possibility for a court or tribunal to exercise its jurisdiction by applying the ecosystem approach, even if part of the

255 See chapter 2 section 3.1.1.4 above. The interpretation of some of the principles governing the high seas has been conducted by courts and tribunals, see, generally, chapter 3 section 3.1 above.

256 Guggisberg, The Use of CITES, supra note 9 at 174-175.

257 Cymie R. Payne, "Negotiation and Dispute Prevention in Global Cooperative Institutions: International Community Interests, IUU Fishing, and the Biodiversity Beyond National Jurisdiction Negotiation" (2020) 22 International Community Law Review 428-438 at 429.

258 Similarly to the request made by the Sub-regional Fisheries Commission for an advisory opinion on flag States responsibilities for IUU fishing in the EEZ, see Advisory Opinion on IUU Fishing, supra note 86.

259 UNCLOS at art. 297(3)(a) (emphasis added).

260 Ibid. 
marine living resources was located in the EEZ. ${ }^{261}$ The Arbitral Tribunal, although acknowledging the desirability of managing fish populations "as a unified whole", found itself incapable of circumventing the exception of article 297(3)(a) linked to fisheries in the EEZ. It indeed underlined the absence of textual legal basis, neither in UNCLOS nor the UNFSA, for such circumvention and/or for an interpretation based on the ecosystem approach. ${ }^{262}$ Such a case could have been an opportune occasion for the Arbitral Tribunal to strengthen the applicability of the ecosystem approach to fisheries management. It therefore remains uncertain how a case of non-compliance regarding a straddling stock could be brought before a court or tribunal. It can be argued that the general obligations for international cooperation and for the protection and preservation of the marine environment are not excluded from the compulsory dispute settlement, ${ }^{263}$ therefore allowing a case to be brought on the ground of non-compliance with these obligations.

Under a second situation, the compulsory jurisdiction of the dispute settlement mechanisms under Part XV might be weakened because of its nature as a default mechanism. In fact, article 281 UNCLOS stipulates that if the parties have agreed to seek settlement of the dispute by a peaceful means under another procedure, Part XV will apply only if no settlement has been reached by recourse to the other procedure. The companion article 282, for its part, demands that "if the parties to a dispute have consented in advance to some other multilateral or bilateral dispute settlement mechanism, then, as long as that mechanism entails a binding decision and can be invoked at the request of any disputant party, it displaces the Part XV procedures unless they otherwise agree." 264 The Southern Bluefin Tuna Cases illustrates the default nature of Part XV mechanisms. In that case, Australia and New Zealand were claiming that Japan was failing to conserve and to cooperate in the conservation of the southern bluefin tuna stock. After ITLOS delivered provisional measures in favour of the applicants, ${ }^{265}$ and after it concluded that and Annex VII Tribunal would have prima facie jurisdiction, ${ }^{266}$ a Tribunal was created to address the case on the merits. The Tribunal however concluded that it had no jurisdiction over the case because article 16 CCSBT Convention, to which all were parties, provided that a "dispute [...] between two or more of the Parties concerning the interpretation or implementation of this Convention, those Parties shall consult

261 Chagos Marine Protected Area Arbitration (Mauritius v. United Kingdom), Award, (2015) PCA case 201103 at para 301.

$262 \mathrm{Ibid}$. The Arbitral Tribunal indeed mentioned that the UNFSA "afforded ample opportunity to remedy any ambiguity of drafting in the [UNCLOS], but nevertheless expressly" reiterates, in its art. 32 , the applicability of art. 297(3) UNCLOS.

263 Ibid at art. 297(1)(c).

264 Andrew Serdy, “Article 282. Obligations under general, regional or bilateral agreements" in Alexander Proelss (ed), United Nations Convention on the Law of the Sea. A Commentary (Munich: Verlag C. H. Beck, 2017) 1825-1829 at 1825. See also Donald Rothwell \& Tim Stephens, The International Law of the Sea (Oxford: Hart, 2016) at 481-482.

265 Southern Bluefin Tuna Cases (New Zealand v. Japan; Australia v. Japan), Provisional Measures, (1999) ITLOS cases $3 \& 4$.

266 Ibid at para 62. 
among themselves with a view to having the dispute resolved by negotiation, inquiry, mediation, conciliation, arbitration, judicial settlement or other peaceful means of their own choice". Since the settlement of the dispute had not been attempted under the CCSBT Convention, the provisions of Part XV of UNCLOS could not be relied upon. ${ }^{267}$ Such a conclusion was highly criticized; commentators were of the view that, to exclude the comprehensive dispute settlement regime of UNCLOS, there should be a clear wording to exclude it in the other instrument, which, they believe, was not the case in article 16 CCSBT Convention. ${ }^{268}$ This case also illustrates that different dispute settlement bodies can reach different decisions in terms of jurisdiction. In this case however, the diverging results between ITLOS and the Annex VII Tribunal might be due to the fact that the threshold for establishing jurisdiction is different (i.e. only a prima facie jurisdiction need to be proven at the stage of provisional measures), and this divergence does not necessarily represent a threat to legal coherence. ${ }^{269}$

In a third situation, coherence might however be at risk if different fora are called upon to examine a dispute from the perspective of different regimes; in fact, if you have the same dispute dealt with from the perspective of two different regimes (and the dispute settlement bodies of such regimes), the findings are "likely to differ, [... possibly endangering the coherence of international law" ${ }^{270}$ For example, in the Swordfish Case, the then European Communities contested port bans imposed by Chile in front of the WTO, ${ }^{271}$ a contestation against which Chile counterclaimed under Part XV of UNCLOS, on the basis of measures for the conservation of high seas fisheries, ${ }^{272}$ therefore leading to two dispute settlement procedures under two different bodies. ${ }^{273}$ Although both cases were suspended following a provisional agreement between the parties in early $2001,{ }^{274}$ the continuation of the procedures could have led to

the prospects for two dispute settlement systems to operate side by side in relation to the same law of the sea dispute. Although each would have had a particular jurisdiction, and be limited to apply determined applicable law specific to each

267 Southern Blufin Tuna Case between Australia and Japan and between New Zealand and Japan, Award on Jurisdiction and Admissibility, (2000) 23 RIAA 1-57.

268 See, e.g. Rothwell \& Stephens, supra note 264 at 481; Andrew Serdy, "Article 281. Procedure where no settlement has been reached by the parties" in Alexander Proelss (ed), United Nations Convention on the Law of the Sea. A Commentary (Munich: Verlag C. H. Beck, 2017) 1820-1824 at 1823.

269 Guggisberg, The Use of CITES, supra note 9 at 136.

270 Ibid at 135.

271 Based mainly on arts. XI (general elimination of quantitative restrictions for import and export) and $\mathrm{XX}(\mathrm{g})$ (exceptions based on the conservation of exhaustible natural resources) of the GATT.

272 Based mainly on arts. 64 (cooperation for conservation of highly migratory species) and 116-119 (conservation of marine living resources on the high seas) UNCLOS. A five-judge ITLOS Chamber was established to address the matter.

273 ITLOS Swordfish Case and WTO Chile - Measures Affecting the transit and importation of swordfish, supra note 101.

274 For an overview of both cases and the reasons for discontinuation, see, generally Marcos Orellana, "The EU and Chile Suspend the Swordfish Case Proceedings at the WTO and the International Tribunal of the Law of the Sea" (2001) 6:1 AJIL Insights. 
regime, it was possible that the two dispute settlement systems might have reached divergent conclusions on some legal issues, and upon factual matters, a clearly undesirable result. ${ }^{275}$

Finally, the fourth situation arises from the difficulty in invoking a State's responsibility for the breach of an obligation owed to the international community as a whole. ${ }^{276}$ In a first scenario, responsibility can be invoked by an injured State only if the breach of the obligation affects the performance of the obligation by others. ${ }^{277}$ This provision could prima facie be relied upon for the protection of marine living resources or the marine environment more generally: a measure is only fully efficient if applied by all, and free riders' actions would be counterproductive in achieving the protection, thereby triggering the responsibility of the non-compliant State. In a second scenario, a non-injured State could also invoke the responsibility of another State if the obligation breached is owed to the international community as a whole. ${ }^{278}$ Neither scenario has until now been raised in front of dispute settlement bodies, "which leaves the adequacy of using such avenue unsettled". ${ }^{279}$ As discussed above, the difficulty of gathering data could also be an obstacle in collecting sufficient material necessary to establish causation between the breach of an obligation and its attribution to a specific State or group of States. ${ }^{280}$

In brief, although dispute settlement bodies have brought some clarification to the conservation and management of fisheries more generally, ${ }^{281}$ the impact of decisions from those bodies with regard to fisheries on the high seas has been more limited. An advisory opinion to bring clarifications on the matter appears as an interesting avenue to explore, but questions remains as to who would have the interest and the will to request such opinion.

\section{THE CROSS-CUTTING CHARACTERISTIC OF FRAGMENTATION}

The discussion on the tasks for resource management conducted above has identified some characteristics and elements related to the construction of the regime, as well as to its functioning, which impact its ability to regulate and manage fishing activities in a way that ensures sustainability performance. However, this overview of relevant characteristics would be incomplete without looking into the question

275 Rothwell \& Stephens, supra note 264 at 483.

276 On that aspect, see Guggisberg, The Use of CITES, supra note 9 at 155-156; Payne, supra note 257 at 432-433.

277 ARSIWA, supra note 106 at art. 42(b)(ii).

$278 \mathrm{Ibid}$ at art. 48(1)(b). Olbligations regarding the preservation of the environment of the high seas have been considered by ITLOS as erga omnes obligations, see Advisory Opinion on the Responsibility of Sponsoring States, supra note 133 at para 180: "each State Party may also be entitled to claim compensation in light of the erga omnes character of the obligations relating to preservation of the environment of the high seas and in the Area.". It however seems like the issue is not fully crystalized in law, see Payne, supra note 257 at 434 .

279 Guggisberg, The Use of CITES, supra note 9 at 155.

280 Elements of an internationally wrongful act, see ARSIWA, supra note 106 at art. 2.

281 See e.g. Advisory Opinion on IUU Fishing, supra note 86. 
of fragmentation, which characterizes not only the regulatory and institutional framework of international fisheries law, but also the implementation of norms and obligations. The values and interests shared by actors are also fragmented, because it is possible to interpret them in different ways. This influences actors' behaviour, most notably their will to engage in collaborative actions. It is submitted that, because it impacts the legal framework and also the implementation and enforcement of its provisions, fragmentation acts as a cross-cutting challenge. This section therefore first looks at different ways to manage conflicts triggered by fragmentation, and how these different management approaches might provide better responses to different types of fragmentation (3.1). The section then looks at the potential of the $\mathrm{BBNJ}$ Agreement in addressing fragmentation in $\mathrm{ABNJ}$, while underlining the limits of any such potential (3.2).

\subsection{Managing fragmentation: regulation versus implementation and enforcement}

Fragmentation is often recognized as a contemporary characteristic of not only the law of the sea or the management of the oceans, but of international law more generally. Because of the heterogeneous, decentralized legislative and institutional nature of international law, and because it relies upon "relatively autonomous spheres of social action and structure"282 at the international level, fragmentation has always been seen as characterizing the international order. This issue has grown in significance with the "emergence of specialized and (relatively) autonomous rules or rule-complexes, legal institutions and spheres of legal practice", 283 illustrated through the development of specialized legal regimes, such as environmental law or trade law.

The fact that international law is fragmented does not in itself lead to negative consequences ${ }^{284}$ Fragmentation is actually necessary: it reflects the diversification and expansion of international law, which respond to the need to better address certain particularities (e.g. according to regions, values or interests) through specialized norms and institutions. ${ }^{285}$ Specialized, sectoral or regional regimes and

282 Fragmentation of International Law: Difficulties Arising From the Diversification and Expansion of International Law, International Law Commission, 58th Sess, UN Doc A/CN.4/L.682 (2006) at para 7, see also para 482 [ILC Fragmentation].

283 Ibid at para 8. See also Irina Buga, "Between Stability and Change in the Law of the Sea Convention: Subsequent Practice, Treaty Modification, and Regime Interaction” in Donald Rothwell et al (eds), Oxford Handbook on the Law of the Sea (Oxford: Oxford University Press, 2015) 46-68 at 61; Harrison, Saving the Oceans, supra note 79 at 275-277.

284 Karen Scott, "Managing Fragmentation Through Governance: International Environmental Law in a Globalised World" in Christopher Michaelsen, Mika Hayashi \& Andrew Byrnes (eds), International Law in the New Age of Globalization (Leiden: Brill Nijhoff, 2013) 207-238 at 209.

285 Charlotte $\mathrm{Ku}$, "Fragmentation in International Law and Governance: Understanding the Sum of the Parts" in Cedric Ryngaert, Erik Molenaar \& Sarah Nouwen (eds), What's Wrong with International Law? Liber Amicorum A.H.A. Soons (Leiden: Brill Nijhoff, 2015) 419-433 at 425; Guggisberg, The Use of CITES, supra note 9 at 186; Judith van Erp et al, "Introduction: The Concept of Smart Mixes for Transboundary Environmental Harm" in Judith van Erp et al (eds), Smart Mixes for Transboundary Environmental Harm (Cambridge: Cambridge University Press, 2019) 3-24 at 19. 
expertise can also play a role in underpinning the development or strengthening of global processes. ${ }^{286}$

Fragmentation becomes a problem, however, when it creates an obstacle for actors in understanding how to address and respond to conflicting interests and goals. A wide array of entitlements and duties found under various instruments and norms, and implemented by different structures makes it difficult for actors to navigate through these different layers of obligations and institutions. ${ }^{287}$ As explained by Barnes, "[t]his makes it difficult to plot and measure not just legal effectiveness, but also problem solving and behavioural effectiveness" of regimes. ${ }^{288}$ This study therefore focuses on fragmentation as a source of uncertainty for behavioural response. The challenge then becomes how to manage fragmentation in order to ensure effective behavioural responses. ${ }^{289}$

There are two ways to manage the conflicts ${ }^{290}$ that can ensue from fragmentation: ${ }^{291}$ through rules and principles relating to the interpretation and application of treaties, and through interaction to benefit from complementary/overlapping mandates. A vast body of literature ${ }^{292}$ has focused on the first approach to managing conflicts. There is a "danger of conflicting and incompatible [norms], rule-systems and institutional practices" ${ }^{293}$ stemming from fragmentation, and the potential mechanisms, more specifically rules and principles, to address such conflicts focus on how to solve those conflicts or manage interactions between norms. Among those rules and principles addressing (potential) conflict, we can name, e.g., lex specialis versus lex generalis, ${ }^{294}$ old law versus new law, ${ }^{295}$ as well as provisions addressing the relationship between instruments ${ }^{296}$ and rules of reference, ${ }^{297}$ or

286 Blanchard, Durussel \& Boteler, supra note 15 at 7.

287 See, e.g. Harrison, Saving the Oceans, supra note 79 at 275-277; Kim \& Bosselman, supra note 29 at 286.

288 Richard Barnes, "The Pursuit of Good Regulatory Design Principles in International Fisheries Law. What Possibility of Smarter International Regulation?" in Judith van Erp et al (eds), Smart Mixes for Transboundary Environmental Harm (Cambridge: Cambridge University Press, 2019) 97-125 at 99 [Barnes, "Good Regulatory Design"].

289 Jens Heidinsfelder \& Markus Beckmann, “A Governance Puzzle to Be Solved? A Systematic Literature Review of Fragmented Sustainability Governance" (2019) Management Review Quarterly at section 5.1.

290 A conflict is defined as a situation which suggests two or multiple different ways of addressing an issue, see ILC Fragmentation, supra note 282 at para 25.

291 Scott, supra note 284 at 209.

292 See, e.g., ILC Fragmentation, supra note 282; Subsequent agreements and subsequent practice in relation to the interpretation of treaties. Text of the draft conclusions adopted by the Drafting Committee on second reading, International Law Commission, 70th Sess, UN Doc A/CN.4/L.907 (2018); Buga, supra note 283 at 61-63; Margaret Young (ed), Regime Interaction in International Law. Facing Fragmentation (Cambridge: Cambridge University Press, 2012); Joost Pauwelyn, Conflict of Norms in Public International Law. How WTO Law Relates to other Rules of International Law (Cambridge: Cambridge University Press, 2003); Seline Trevisanut, Nikolaos Giannopoulos \& Rozemarijn Roland Holst (eds), Regime Interaction in Ocean Governance. Problems, Theories and Mathods (Leiden: Brill Nijhoff, 2020).

293 ILC Fragmentation, supra note 282 at para 14.

294 A specialized norm takes precedence over a general norm addressing the same subject matter.

295 A more recent norm takes precedence over an older norm addressing the same subject matter.

296 See, e.g., UNCLOS at arts. 237 and 311.

297 See, e.g. UNCLOS at arts. 119(1)(a) ("any generally recommended international minimum standards, whether subregional, regional or global”) and 211(1) ("international rules and standards"). See also W. van 
even the concept of systemic interpretation, which supports the interpretation of a particular instrument not only as a part of the regime in which it is embedded, but even more broadly as part of relevant rules of international law. ${ }^{298}$

A second - and broader - approach is based on the premise that, to manage conflicts, we must strengthen interactions. In a time characterized by the necessary interlinkages and interdependence stemming from globalization, fragmentation seems to be a contradictory concept. Globalization and fragmentation, however, trigger similar challenges: how to manage the existing interactions between actors, institutions, instruments and structures, and how to create the necessary new interactions. ${ }^{299}$ As explained by $\mathrm{Ku}$, we need to understand the structures created for specialization, but " $[\mathrm{m}]$ ost importantly, we need to understand their connection and relationship to each other and their long-term system-wide effects in the global governance and international law environment" ${ }^{300}$ The second approach therefore tries to manage fragmentation by building on - rather than solving - overlapping mandates and obligations. ${ }^{301}$ Such an approach is also echoed by Heidingsfelder and Beckmann, who suggest coordination and integration of structures and mandates as the two main management types for fragmentation in sustainability governance. ${ }^{302}$

In the fisheries regime, two types of fragmentation could create conflicts between regimes and affect actors' responses: a fragmentation of norms, and fragmentation at the level of implementation and enforcement. First, as demonstrated in chapters 2 and 3, international fisheries law, biodiversity conservation and environmental law have to some extent co-evolved ${ }^{303}$ in the development of a common legal framework. ${ }^{304}$ Although this framework is characterized by a fragmentation of norms and obligations coming from different regimes, different instruments and different institutions, it would be incorrect to completely deny the existence of interplay between the rules for the management of fisheries and environmental protection. ${ }^{305}$

Reenen, "Rules of Reference in the New Convention on the Law of the Sea, in particular in Connection with the Pollution of the Sea by Oil from Tankers" (1981) 3 Netherlands Yearbook of International Law 13-16. Rules of reference ensure legal certainty, see Guggisberg, The Use of CITES, supra note 9 at 188-192. 298 VCLT at art. 31(3)(c); Buga supra note 283 at 61.

299 Scott, supra note 284 at 207.

$300 \mathrm{Ku}$, supra note 285 at 430.

301 For these two approaches to fragmentation and its management, see Scott, supra note 284 at 210.

302 Heidingsfelder \& Beckmann, supra note 289 at section 5.2. Although this study does not exclude integration as a management method for fragmentation, it mostly focuses on coordination, as discussed further in chapter 7 below.

303 I.e. "when two or more interdependent adaptation processes intentionally (albeit sometimes reluctantly) adapt to each other in response to their direct interaction (cooperation or competition)", see Garcia, Rice \& Charles, "Convergence or coevolution?", supra note 16 at 18.

304 Serge Garcia, Jake Rice \& Anthony Charles, "Governance of marine fisheries and biodiversity conservation: The integration challenge" in Serge Garcia, Jake Rice \& Anthony Charles (eds), Governance of marine fisheries and biodiversity conservation: Interaction and Coevolution (Hoboken: Wiley, 2014) 3752 at 40 [Garcia, Rice \& Charles, "The integration challenge"]; Friedman et al, supra note 8 at 216.

305 See, generally, Friedman et al, supra note 8 at 215-216. 
The implementation and enforcement of these rules, however, has evolved in parallel. ${ }^{306}$ This is because implementation and enforcement in ABNJ operate mostly at the regional and national levels, and because fisheries management and marine environmental protection fall under the mandates of different entities. ${ }^{307}$ This fragmentation has advantages, namely, the reliance on different specialized expertise, and an adapted response to the specific needs and realities of different regions. However, in practice, this means that obligations are implemented through a variety of regional regimes which have different operational modalities. This means that one actor, although bound by the same "basic" obligations of management and conservation, has to adapt its behaviour for compliance according to the way rules are operationalized in different regions and by different organizations. For example, while the requirement for environmental assessments or MCS is generalized, different regions or organizations might have different ways of implementing and enforcing these requirements. ${ }^{308}$

This is why the conflicts stemming from fragmentation at the level of implementation and enforcement seem to find a better response through the second management approach, i.e. strengthening interactions. Such interactions exist; however, collaborative actions have so far happened in an uncoordinated, ad hoc fashion. ${ }^{309}$ In fact, while there is evidence of cooperation between instruments, organizations and structures, "the progress in translating this overlapping conceptual rhetoric into joint implementation is rather slow". ${ }^{310}$ This is due, among other things, to a lack of resources within the organizations involved in the cooperation, to cooperation that does not go further than the administrative level (compared, e.g., to cooperation of political interests and decision-making), or to national positions that vary depending on the different fora. ${ }^{311}$

Despite such difficulties, there have been successful examples of collaboration, mainly at the level of institutional interactions. The Collective Arrangement between NEAFC and OSPAR ${ }^{312}$ is often used as the "poster child" of a fruitful cooperation between institutions with distinct but complementary mandates. Other examples, although involving a lesser degree of integration, include cooperative actions between the Mediterranean Action Plan and the GFCM, and the conclusion of MoU between the WCPFC and the SPREP, as well as with CCAMLR. ${ }^{313}$ With regard to biodiversity more generally, the $\mathrm{CBD}$ has developed several collaborations, through

\footnotetext{
306 Garcia, Rice \& Charles, “The integration challenge”, supra note 304 at 40.

307 For example, the mandate of RFMOs and RSP is discussed in chapter 2 sections 3.3.2 and 3.3.4 above.

308 For example, different RFMOs might have different reporting thresholds, see section 2.3.2 above.

309 Gjerde et al, "Regulatory and governance gaps", supra note 9 at 3; Warner, supra note 67 at 187.

310 Garcia, Rice \& Charles, “Convergence or coevolution ?”, supra note 16 at 31.

311 Julien Rochette, Klaudija Cremers \& Glen Wright, "Les enjeux de coordination entre le futur traité haute mer et les organisations existantes" (Presentation delivered at the 16ème reunion du Groupe informel haute mer, 24 June 2020).

312 The Collective Arrangement is discussed in chapter 2 section 3.3.4, and chapter 3 section 3.1.3 above.

313 A discussion on MoUs between RSPs and RFMOs is conducted in chapter 2 section 3.3.4 above. For a specific discussion about the MoU between WCPFC and CCAMLR, see Scott, supra note 284 at 219.
} 
MoUs and partnership agreements, with numerous entities, ranging from other conventions, to international organizations and civil society initiatives. ${ }^{314}$ However, these examples of cooperation between separate sectors remain isolated successes, ${ }^{315}$ and are not undertaken on a systematic basis.

It is the unequal progress across regions as well as isolated success stories that trigger "the urgent need to replicate and re-adapt successful policies and measures in the light of the realities and needs of specific fisheries. It calls for new mechanisms to support the effective implementation of policy and management regulations for sustainable fisheries and ecosystems, as the only solution to ensure fisheries around the world are sustainable". ${ }^{316}$ This is why this study focuses on the fragmentation in implementation and enforcement as a main challenge for the fisheries regime in achieving sustainability performance.

\subsection{The limits of the BBNJ Agreement in addressing fragmentation}

The BBNJ Agreement is often seen as a core element of the solution to a more holistic management of ABNJ. Since the Agreement is expected to foster the interaction and collaboration of existing structures and institutions, as well as filling in the gaps, many of the shortcomings discussed in the present chapter could rely on its development for a stronger, more coordinated management of ABNJ. Consequently, it is also expected to generate better performance and results in terms of the conservation and sustainable use of these areas. However, although the instrument is undoubtedly promising, many elements related to its development still trigger divergences among delegations, which in turn creates uncertainties about the Agreement's scope and institutional framework. ${ }^{317}$ Nevertheless, two main elements of the Agreement's design allow us to conduct a preliminary assessment of its impact on the shortcomings it tries to remedy, and to highlight elements that are likely to perpetuate some weaknesses of the system. Although most of these elements have been addressed in chapter 4 above, they are framed here in the context of the current discussion on fragmentation.

On the one hand, the Agreement needs to ensure that implementation does not rely solely on the existing structures at the regional and/or national levels, which would support the status quo. ${ }^{318}$ However, implementation and compliance under the Revised draft text have not been discussed at great length and seem at present to rely mainly on State parties, ${ }^{319}$ although the creation of an implementation and

314 CBD, "Cooperation and Partnerships", online: <https://www.cbd.int/cooperation/>.

315 Friedman, supra note 182 at 453; Freestone, "An Unfinished Agenda", supra note 2 at 224; Takei,

"Demystifying Ocean Governance", supra note 135 at 36.

316 FAO Report 2020, supra note 45 at vi.

317 This is discussed in chapter 4 section 4.2 and 4.3 above.

318 Friedman, supra note 182 at 454; Oude Elferink, supra note 123 at 241.

319 Revised draft text of an agreement under the United Nations Convention on the Law of the Sea on the conservation and sustainable use of marine biological diversity of areas beyond national jurisdiction, 
compliance body remains a possibility. ${ }^{320}$ A global body with a coordination role is essential, or else "the current uncoordinated approach to governing ABNJ will remain", ${ }^{321}$ consequently maintaining the difficulties linked to a multi-layered set of obligations. To address this, the current text of the Agreement suggests mandating a COP with a strong review and monitoring role, ${ }^{322}$ and which would act as "a vehicle for more systematic cooperation on biodiversity". ${ }^{223}$ Establishing a COP as the Agreement's central institutional structure would also mirror the structure of a multilateral environmental agreement, (re)affirming the Agreement's status as an environmental treaty. At the moment, however, the COP seem to be designed as a "default" mechanism, especially regarding ABMTs and EIAs, undertaking measures where no other measure has been taken under any other structures. ${ }^{324}$ The exact role of the COP in contributing to relationships with other structures also remains to be confirmed, either in the Agreement's text or subsequently through decisions and/ or resolutions from the COP itself. Until then, the concrete role of the Agreement and of the different bodies under its institutional arrangements in addressing fragmentation remains uncertain.

On the other hand, some States, such as Iceland, Japan and Russia, have continuously and strongly defended the exclusion of the regime for fisheries from the scope of application of the instrument. However, such exclusion impacts the instrument's comprehensive character. ${ }^{325}$ In fact, how can the instrument aspire to a comprehensive approach to BBNJ if fisheries are excluded, considering that unsustainable fishing practices constitute one of the major threats to marine biodiversity? ${ }^{326}$ Additionally, this exclusion perpetuates the fragmentation in coverage, i.e. what would fall under the coordination mandate of the Agreement if mechanisms developed under the Agreement are not applicable to the fisheries regime? Under this scenario, the monitoring and review competences of the COP would not apply to RFMOs and other fisheries related bodies. While it has been suggested that this situation could be remedied through other cooperative ventures, ${ }^{327}$ everything rests on whether there is sufficient political support for such options and, if so, what it would entail in practice.

Intergovernmental conference on an international legally binding instrument under the United Nations Convention on the Law of the Sea on the conservation and sustainable use of marine biological diversity of areas beyond national jurisdiction, 4th Sess, UN Doc A/CONF.232/2020/3 (2019) at arts. 20 and 53 [Revised draft text]. See also Warner, supra note 67 at 190.

320 Revised draft text, supra note 319 at art. 48(4)(d)(iii).

321 Oude Elferink, supra note 123 at 243.

322 Revised draft text, supra note 319 at art. 48.

323 Friedman, supra note 182 at 454.

324 On the question of EIAs and ABMTs under the BBNJ Agreement as "default mechanism", see chapter 4 section 3.2 above.

325 Friedman, supra note 182 at 454.

326 Barnes, "The Proposed LOSC IA", supra note 123 at 594. See also chapter 4 section 4.3 and, to some extent, 4.2 .

327 For example, Friedman, supra note 182 at 454, discusses the attempt at harmonizing interactions between CITES and RFMOs. He explains that, after consultations, CITES decided "to append preambular text to their listing criteria 'noting the competence of certain intergovernmental organizations in relation to the management of marine species"', and the Secretariat of CITES was encouraged to consult relevant intergovernmental bodies. 
Although a balance always needs to be struck between preserving sovereignty and protecting the marine environment, ${ }^{328}$ this illustrates how "international fisheries law continues to develop (slowly) as a product of political interactions, rather than in response to a formal assessment of institutional effectiveness and sense checking of regulatory options" ${ }^{329}$

A balance therefore needs to be set between allowing development through regional actions and sustaining a comprehensive global regime, ${ }^{330}$ because "[s]trong effort in just a few regions will still not prevent loss of marine biodiversity at the global level". ${ }^{331}$ To achieve such a balance and to have a concrete impact on management practices, the Agreement needs to ensure more cross-sectoral cooperation and collaboration in terms of issues being addressed, at the institutional level, as well as in compliance and monitoring. ${ }^{332}$ To date, however, "there has been a notable lack of any discussion on a robust and effective institutional coordination of the competent international and regional bodies, or on an equally robust and effective implementation mechanism for the new agreement". ${ }^{333}$ It therefore remains to be seen if the Agreement will meet those fragmentation challenges.

\section{CONCLUSION: TARGETING STRUCTURES AND BEHAVIOURS}

The previous sections underlined the various characteristics of the regime for international fisheries that impact its ability to reach shared understandings in terms of the balance between conservation and use. It also looked into the translation of these understandings into regulatory commitments, and compliance with such commitments. What come across as important challenges are the need to develop regulatory mechanisms above and beyond flag States, to establish more effective criteria for MCS, and to increase the effectiveness of cooperation mechanisms. ${ }^{334}$ More generally, the main observations stemming from the above discussion can be summarized as follows:

328 Pascale Ricard, La conservation de la biodiversité dans les espaces maritimes internationaux. Un défi pour le droit international (Paris: Pedone, 2019) in general, but most particularly at 127.

329 Barnes, "Good Regulatory Design", supra note 288 at 121.

$330 \mathrm{Diz}$, supra note 115 at 120, referring to Alan Boyle, "Further Development of the Law of the Sea Convention: Mechanisms for Change" (2005) 54 International and Comparative Law Quarterly 563-584 at 566-567.

331 Raphaël Billé et al, "Regional Oceans Governance. Making Regional Seas Programmes, Regional Fishery Bodies and Large Marine Ecosystem Mechanisms Work Better Together" (2016) UNEP Regional Seas Report and Studies No 196 at 60.

332 Ridgeway, “Assessment”, supra note 20 at 163 . More generally on integration and cross-sectoral approach to governance structures, see Warner, supra note 67 at 184.

333 Efthymios Papastavridis, "A recent overview of the three sessions of the IGC can be found in The Negotiations for a New Implementing Agreement under the UN Convention on the Law of the Sea Concerning Marine Biodiversity" (2020) 69 International and Comparative Law Quarterly 585-610 at 610.

334 Barnes \& Massarella, supra note 2 at 388. These challenges are also analysed in Marcus Haward, Governing Oceans in a Time of Change. Fishing for the Future? (Cheltenham: Edward Elgar, 2020) generally at chapter 3. 
1. There is a fair inclusion of obligations related to conservation, protection and sustainable use in the current framework for the regulation and management of fisheries in $\mathrm{ABNJ}$. This is due to a broad variety of instruments of different legally binding natures, as well as general rules and principles addressing such duties. However, the regime would benefit from improvements in terms of coverage and legal certainties as to the scope of application of conservation measures.

2. Compliance with current norms, through implementation and enforcement, is affected by a lack of structures and mechanisms to ensure such compliance. This is due not only to a lack of resources, but also to a lack of accountability, resulting in a priority given to individual (versus common) interests.

3. Normative fragmentation and fragmentation in implementation, while accommodating regional and sectoral interests and specificities, also create uncertainty for actors to grasp the different layers of obligations that apply to them and how to align their behaviour accordingly. Examples of successful collaboration between structures remain isolated. This affects the comprehensiveness of the regime.

Several conclusions can be drawn from these observations. First, this study submits that international fisheries law, biodiversity conservation and environmental concerns have, to some extent, co-evolved in the development of a common legal framework, therefore showing an interplay between the management of fisheries and environmental protection. ${ }^{335}$ The main obstacle, thus, to reaching sustainability does not primarily stem from a lack of rules, but from the specificity of these rules and, consequently, the way States perceive these rules and act upon them. Second, what also makes it difficult for the effective implementation and enforcement of the regime is its complex nature, "magnified as a multiplicity of States, transnational actors, both governmental and civil society, become involved". ${ }^{336}$ The complexity of the regime is also embedded in the way actors perceive the weight to be given to certain elements. In fact, there might be a shared understanding on what to do (i.e. work towards sustainable fisheries) but not on how and to what extent to do it (i.e., through regional actors, global actors, through new structures, etc.).

What link these characteristics together are shortcomings in terms of collaboration. Rayfuse and Warner have even characterized the situation as an almost "total lack of coordination and cooperation between the fisheries regimes and between the fisheries and environmental sector". ${ }^{337}$ While the present author agrees that successes in addressing these shortcomings in practice through collaborative actions

335 See, generally, Friedman et al, supra note 8 at 215-216.

336 Barnes, “Good Regulatory Design", supra note 288 at 98-99.

337 Rayfuse \& Warner, supra note 3 at 402-403. See also Haward, supra note 334 at 9. 
(rather than unintentional convergence) ${ }^{338}$ remain isolated, it would be incorrect to ignore the fact that the current regime for fisheries management on the high seas has to some extent considered environmental concerns. However, coordination and operationalization seem to have so far happened through "minimal deliberate interactions"; ${ }^{339}$ what is needed is a deliberative, orchestrated process. ${ }^{340}$ The BBNJ Agreement is expected to contribute to such orchestration, by strengthening collaboration and coordination of structures in ABNJ. Its concrete impact on and relationship with the international fisheries regime remains, however, uncertain. In fact, whatever format is chosen to interact with fisheries structures, it would be surprising to see RFMOs - or any other sectoral organizations operating in ABNJ for that matter - agreeing to fall under the monitoring and review mechanisms of the new Agreement. However, as demonstrated earlier in this chapter, monitoring and review of implementation and enforcement are major weaknesses in RFMOs' behaviours, and having them further circumvent this obligation would significantly affect the efficiency of the regime. ${ }^{341}$

The findings summarized above complete the portrait of the regime for high seas fisheries presented in the first four substantive chapters of this study. These findings also assist us in assessing whether the current framework is sufficiently effective to achieve sustainability, i.e. whether the regime "successfully performs a certain (set of) function(s) or solves the problem(s) that motivated its establishment". ${ }^{42}$ In order to schematize such assessment, the findings can also be roughly presented according to the core elements of the line of reasoning for measuring regime effectiveness developed by Underdal. ${ }^{343}$ This schematization allows us to better picture where the shortcomings lie in order to find solutions to the challenges the regime is facing.

338 Kim \& Bosselman, supra note 29 at 288, 302, are of the view that self-organization might not be sufficient to achieve the desired objectives, and that institutional incentives are necessary. On the need for deliberate institutional incentives, see the chapter 7 section 3 (and more specifically 3.2) below.

339 Scott, supra note 284 at 211 (emphasis in original).

340 The distinction between organic and orchestrated practice and processes is used by Barnes, "Good Regulatory Design", supra note 288 at 119.

341 All these observations have been raised in the recent legal and policy literature regarding the management of living resources and its interaction with other activities in ABNJ more generally, see, e.g., Kristina Gjerde et al, "Conservation and Sustainable Use of Marine Biodiversity in Areas Beyond National Jurisdiction: Options for Underpinning a Strong Global BBNJ Agreement through Regional and Sectoral Governance" (2018) STRONG High Seas Project; Carole Durussel et al, "Strengthening Regional Ocean Governance for the High Seas: Opportunities and Challenges to Improve the Legal and Institutional Framework of the Southeast Atlantic and Southeast Pacific" (2018) STRONG High Seas Project; Harrison, Saving the Oceans, supra note 79 at 275-277; Wright et al, supra note 41; Warner, supra note 67; Oude Elferink, supra note 123.

342 Underdal, supra note 117 at 4.

343 It goes beyond the scope of the present study to embark in an exhaustive analysis of Underdal's elaborate and detailed model to measure the effectiveness of a regime. Such analysis, deeply embedded in political sciences, would depart too significantly from the legal analysis conducted in the present study. The perspective or approach presented through the model is mainly used here to provide input to and/or inform the legal analysis. It is also to be noted that this model presents weaknesses, as identified by the author himself. The model in fact presents a regime as a stand-alone arrangement (i.e. does not represent the potential interactions with other regimes) in a static fashion (i.e. does not take into consideration the dynamic potential of the regime), see Underdal supra note 117 at 36. 
As measuring effectiveness involves a comparison "against some standard of success or achievement", ${ }^{344}$ two points of reference, or dimensions of effectiveness, can be relied upon: ${ }^{345}$

1. the relative improvement brought by the regime (i.e. is the situation better than if we did not have this regime/better than before we had the regime); and

2. the achievement of a collective optimum (i.e. compare the regime's performance against the concept of an ideal solution).

As discussed above, while the various developments that have taken place over the past decades within the regime have shown a relative improvement, there remains an important distance between the current regime and the collective optimum (i.e. sustainability). Consequently, the effectiveness of the regime is good (because it shows some added value in comparison to a situation where no regime would exist), but is still imperfect (because the collective optimum is yet to be reached). ${ }^{346}$

Furthermore, two main elements (and their components) determine the effectiveness of a regime. First, the character of the problem addressed by the regime impacts its effectiveness. ${ }^{347}$ Generally speaking, it is more difficult to address a malign problem than a benign problem. A malign problem is characterized by incongruity (e.g. competition and lack of coordination), asymmetry (e.g. incompatible values, interests negatively correlated), and cumulative cleavages (e.g. divisions in the different components of a multidimensional problem). Second, the problemsolving capacity of a regime is based on its institutional setting, the distribution of power among the actors involved, as well as the skill and energy available for the engineering of cooperative solutions. ${ }^{348} \mathrm{~A}$ strong problem-solving capacity positively impacts a regime's effectiveness.

The regulation and management of high seas fisheries is undoubtedly a malign problem. ${ }^{349}$ It is characterized by competition in the access to resources (illustrated, e.g. by difficulty for new entrants to join RFMOs), ${ }^{350}$ a lack of cooperation (illustrated by isolated cooperative successes), ${ }^{351}$ and divisions in terms of interests and values related to the balancing of conservation and use. ${ }^{352}$ The problem-solving capacity of the regime could also be strengthened. As discussed in the present chapter, the main organizations mandated with the management and conservation of species on the high seas are plagued by shortcomings and struggles, which also affect their

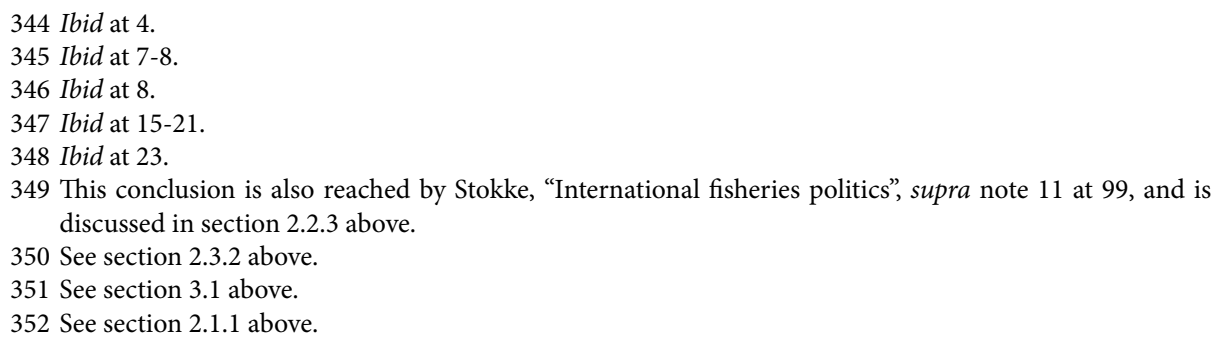


capacity to engineer solutions. ${ }^{353}$ The distribution of power varies immensely among actors involved in fishing, which triggers questions of capacity-building, sharing of knowledge, etc. ${ }^{354}$ Procedural mechanisms of RFMOs also perpetuate power asymmetries, e.g. by relying on consensus decision-making (which consequently gives all members a power of veto). ${ }^{355}$ Consequently, these elements directly impact the ability of the regime to proceed to the necessary behavioral changes to reach effectiveness, but they also affect the level of collaboration among actors (which in turn also impact the regime's effectiveness). ${ }^{356}$

The question that then arises, and which is addressed in the following chapters, is how to improve the interplay between fisheries management and environmental protection so that it permeates management structures and actors' behaviours. While the regime's normative structures seem to allow some level of interplay or co-evolution, it is clearly insufficient to ensure the operationalization of norms. However, to ensure the effectiveness of a complex and multidimensional system such as international fisheries, "two key aspects include compliance (e.g. actor behaviour) and results (e.g. environmental improvement), which may be independent of one another, but both are necessary".537

How, then can we work towards improved operationalization and, consequently, improved effectiveness? As Toope mentions, " $t \mathrm{t}]$ he new emphasis upon compliance or implementation $[\ldots]$ is the intellectual shift that forced international lawyers to open up inquiry in to the work of" other disciplines, ${ }^{358}$ which shows that solutions within the law alone are not enough. ${ }^{359}$ Complementary and alternative mechanisms to structure the framework for the management of fisheries on the high seas, ones that would assist actors in navigating more effectively through the complex interconnectedness between fisheries management and sustainability, therefore have to be explored "to overcome the impediments within formal legal regimes".

353 See section 2.3.2 above.

354 See, e.g. sections 2.3.1 and 2.3.2 above.

355 See section 2.3.2 above.

356 Underdal, supra note 117 at 37.

357 De Santo, supra note 16 at 39.

358 Stephen Toope, "Emerging Patterns of Governance and International Law" in Michael Byers (ed), The role of law in international politics. Essays in international relations and international law (Oxford: Oxford University Press, 2000) 91-108 at 92-93.

359 Garcia, Rice \& Charles, “The integration challenge”, supra note 304 at 38.

360 Barnes \& Massarella, supra note 2 at 388. 


\title{
THE INTERACTION BETWEEN LAW AND GOVERNANCE
}

\author{
An Avenue for Understanding the Adaptive Capacity of the Law
}

\section{INTRODUCTION}

In their book on the international law of sharks, Techera and Klein have identified the difficulty for the better conservation and management of this species with the current legal and regulatory approaches:

It is clear [...] that the international legal landscape for the conservation and management of sharks has matured in the last decade and now includes a range of laws and institutions, and yet species numbers continue to decline. What is essential in moving forward is to improve the effectiveness of these laws. It is clear that this involves becoming more outcomesbased, but the way forward is not clear. The myriad of laws and institutional responses need to be understood and organised in some meaningful way so that they may be effectively analysed. Only then can barriers and hurdles be overcome. ${ }^{1}$

Techera and Klein underline a reality that is not only true for the conservation and management of sharks, but also for international fisheries, and for the oceans more generally. As illustrated in the first chapters of this study, international fisheries law has evolved and expanded considerably - in the number and scope of instruments, and in the variety of actors involved - in recent years. However, "many established legal approaches to [and institutions for] controlling harmful activities and managing common resources are not adequately designed to cope with new circumstances in ways that succeed in promoting socio-ecological resilience; they appear too static, and in great need of improvement".

This observation triggers a reflection on how the law is currently structured within the regime for international fisheries, and on the role it plays in the toolbox for improving the effectiveness of the regime and changing behaviours towards

1 Elisa Techera \& Natalie Klein, International Law of Sharks. Obstacles, Options and Opportunities (Leiden: Brill Nijhoff, 2017) at 55.

2 Jonas Ebbesson, "The rule of law in governance of complex socio-ecological changes" (2010) 20 Global Environmental Change 414-422 at 421. 
sustainability performance. International law and the law of the sea have shown their potential for adaptability ${ }^{3}$ at the normative and regulatory level, but this adaptation has not (yet) fully translated into the necessary changes in compliance. We therefore question the law's ability to ensure compliance with undertaken legal commitments, as well as its impact on States' accountability.

This is why we explore the possibility of strengthening compliance within international fisheries law by drawing upon mechanisms, concepts and processes that originate from outside formal legal mechanisms and that rely "upon the crossfertilization of new ideas from within and outwith the system". ${ }^{4}$ A governance-based approach is one of those mechanisms. Governance, encompassing a wide variety of components, forms a broad toolbox and suggests different sorts of vehicles for social action and different functions for steering behaviour. ${ }^{5} \mathrm{Law}$ is one of those tools and one that creates a normative framework. Other governance-related components, however, might be better suited to induce the implementation and enforcement of those norms. In other words, while the law creates a framework for action, other components of governance might be better suited to ensuring that action is in fact taking place. Governance is relevant because it looks beyond just the legal structures and, in situations where complexity prevails, this might bring in the necessary tools to achieve the results we want. This study therefore perceives governance as a layer set over the legal framework, and the present chapter attempts to map how this layer could influence the legal framework.

In fact, "re-imagining the nature of law" and "thinking anew about global patterns of power and influence" is not something that belongs to the legal sphere exclusively, but is a process carried out in many other fields of social sciences. ${ }^{6}$ It shows an acceptance of the fact that our own disciplines, at least in their current state, are not always able to provide the necessary answers. This therefore triggers an interest in finding these answers elsewhere. However, thinking about the impact of governance for the development and adaptation of the laws is in its infancy. ${ }^{7}$ The inclusion and use of governance within the legal sphere must therefore be further explored.

This study is thus based on the hypothesis that an approach to international law, the law of the sea and international and high seas fisheries law that borrows from

3 Richard Barnes, “The Continuing Vitality of UNCLOS” in Jill Barrett \& Richard Barnes (eds), Law of the Sea: UNCLOS as a Living Treaty (British Institute of International and Comparative Law, 2016) 459-489 at $460,472,476$ and 478 .

$4 \quad$ Ibid at 478.

5 Oran R. Young, Governing Complex Systems. Social Capital for the Anthropocene (Cambridge, Mass.: MIT Press, 2017) at 121.

6 David Kennedy, “The Mystery of Global Governance” (2008) 34 Ohio Northern University Law Review $827-860$ at 827 .

7 See, e.g., Ebbesson, supra note 2; Barbara Cosens et al, "The role of law in adaptive governance" (2017) 22:1 Ecology and Society article 30; Jonas Ebbesson \& Ellen Hey, "Introduction: Where in law is socialecological resilience?" (2013) 18:3 Ecology and Society article 25; Cameron Holley, "Linking law and new governance: examining gaps, hybrids, and integration in water policy" (2016) 38:1 Law \& Policy 24-53. 
governance-related components could act as a potential avenue for transforming the way we perceive, and then consequently develop, implement and enforce rules and norms. By allowing the law to be permeated by other components of governance, this might facilitate the improvement of the law's adaptability and flexibility in facing uncertainty and complexity.

In order to achieve a better grasp of the concept of (oceans) governance and its potential impact on legal structures, this chapter starts by delving into the what of governance, through the commonalities among different understandings of the concept, its relationship with the law, and the influence it has had on the legal and policy frameworks for the environment, the oceans and fisheries (section 2 ). The chapter then turns to the how of governance: it assesses how governance perspectives can strengthen the adaptive capacity of the law in order to be more responsive to shortcomings in terms of the operationalization of existing obligations (section 3). The chapter concludes by contemplating the role that governance can play for widening the frame of thinking in relation to the implementation and enforcement of, as well as the compliance with the law of the sea, environmental law and international fisheries law (section 4). This chapter therefore intends to gain a better understanding of the dialogue between governance and adaptability and to map out an assessment framework that stems from this dialogue. These findings are subsequently used in the following chapter, first by testing the adaptability of the current regime for high seas fisheries, and then by suggesting ways in which the governance-adaptability dialogue can play a role for the development of alternative mechanisms for high seas fisheries management that focus on cooperation and coordination.

\section{GOVERNANCE: AN ALL-ENCOMPASSING CONCEPT?}

The concept of governance is difficult to define or explain. ${ }^{8}$ The lack of consensus around the scope of the concept, its components, and its different uses in various disciplines, has made the understanding of the term confusing and unclear. ${ }^{9}$ What is more, a general trend in its use cannot be identified; as a matter of fact, it is "a vague and amorphous concept, which is bedevilled by inconsistent use in a plural

8 See, e.g., Lawrence Finkelstein, "What is Global Governance?" (1995) 1:4 Global Governance 367-372 at 368 , who states that "we say 'governance' because we don't really know what to call what is going on"; and Stephen Toope, "Emerging patterns of Governance and International Law" in Michael Byers (ed), The Role of Law in International Politics. Essays in International Relations and International Law (Oxford: Oxford University Press, 2000) 91-108 at 97, who states that " $[\mathrm{t}]$ he literature on governance betrays no common theoretical thread". See also Richard Barnes, "Consolidating Governance Principles for Areas beyond National Jurisdiction Biological Diversity and Governance of Areas beyond National Jurisdiction" (2012) 27:2 International Journal of Marine and Coastal Law 261-290 at 263-264.

9 Georgia Nogueira de Souza Patu, Scope and evolution of ocean governance: improving cross-sectoral management by the adoption of principles of international law (Doctor of Philosophy thesis, Australian National Center for Ocean Resources and Security, University of Wollongong, 2011) at 31; Karl-Heinz Ladeur, "Theory of Governance" (2010) Max Planck Encyclopedia of Public International Law at para 1. 
and multi-disciplinary setting". ${ }^{10}$ The concept has also been criticized for "leav[ing] the definition open for an endless number of contextual interpretations". ${ }^{11}$ Others argue, however, that the ambiguity surrounding the concept has contributed to its popularity. ${ }^{12}$ Ocheje, for example, suggests that the ambiguity in the concept even serves a uniting purpose: "[i]n a divided and multicultural world, 'governance' is a value-laden concept, and this invariably militates against the emergence of a single universally acceptable definition." ${ }^{13}$

Despite the difficulty in grasping its meaning, the term governance is now widely used in the discourse for oceans uses, health and policy. ${ }^{14}$ Yet, there have been few attempts from legal scholars at analysing its content and scope in the particular context of the oceans. ${ }^{15}$ This section therefore aims to contribute to the exploration of what governance entails for the international (legal) order for the oceans, by first establishing the origins and contours of this broad yet indistinct concept, and understanding its value as an analytical tool (2.1). Then, since governance also has a programmatic function that, in many aspects, overlaps with the social function of the law, the section turns to analysing the relationship between law and governance (2.2). The section ends with an exploration of the way governance has impacted the

10 Louis Kotzé, "A juridical conceptual perspective on environmental governance" in Tuomas Kuokkanen et al (eds), International Environmental Law-making and Diplomacy: Insights and Overviews (Abingdon, Oxon: Routledge, 2016) 48-67 at 51.

11 Christopher Ansell \& Jacob Torfing, "Introduction: Theories of governance" in Christopher Ansell \& Jacob Torfing (eds) Handbook on Theories of Governance (Cheltenham: Edward Elgar, 2016) 1-17 at 4.

12 Olivier Treib, Holger Bähr \& Gerda Falkner, "Modes of governance: A note towards conceptual clarification" (2005) European Governance Papers no. N-05-02 at 4, cited in Ansell \& Torfing, supra note 11 at 3.

13 Paul Ocheje, "Exploring the Legal Dimension of Political Legitimacy: A 'Rights' Approach to Governance in Africa" in Edward Kofi Quashigah \& Obiora Chinedu Okafor (eds), Legitimate Governance in Africa: International and Domestic Legal Perspectives (The Hague: Kluwer Law International, 1999) 165-206 at 165, cited in Kotzé, supra note 10 at 52.

14 See, generally, FAO, “The State of World Fisheries and Aquaculture 2020. Sustainability in action" (2020), online: <http://www.fao.org/state-of-fisheries-aquaculture>; Summary of the First Global Integrated Marine Assessment, UNGAOR, 70th Sess, UN Doc A/70/112 (2015); IUCN, "International ocean governance", online: <https://www.iucn.org/theme/marine-and-polar/our-work/international-oceangovernance>; European Commission, "International ocean governance: an agenda for the future of our oceans”, online: <https://ec.europa.eu/maritimeaffairs/policy/ocean-governance_en>.

15 To the present author's knowledge, only a few authors have directly addressed the evolution and meaning of oceans governance in relation to (international) law, see, e.g., Yoshinobu Takei, "A Sketch of the Concept of Ocean Governance and Its Relationship with the Law of the Sea" in Cedric Ryngaert, Erik Molenaar \& Sarah Nouwen (eds), What's Wrong with International Law? Liber Amicorum A.H.A. Soons (Leiden: Brill Nijhoff, 2015) 48-62 [Takei, "A Sketch"]; Yoshinobu Takei, "Demystifying Ocean Governance" in Seline Trevisanut, Nikolaos Giannopoulos \& Rozemarijn Roland Holst (eds), Regime Interaction in Ocean Governance. Problems, Theories and Methods (Leiden: Brill Nijhoff, 2020) 22-51 [Takei, "Demystifying"]; Donald Rothwell \& Tim Stephens, The International Law of the Sea (Oxford: Hart, 2016) at 507; Douglas Johnston, "The Challenges of International Ocean Governance: Institutional, Ethical and Conceptual Dilemmas" in Donald R. Rothwell \& David L. VanderZwaag (eds), Towards Principled Oceans Governance: Australian and Canadian Approaches and Challenges (Abingdon, Oxon: Routledge, 2016) 349-399; Lawrence Juda, International Law and Ocean Use Management: The Evolution of Ocean Governance (Abingdon, Oxon: Routledge, 1996); Pradeep A. Singh \& Mara Ort, "Law and Policy Dimensions of Ocean Governance" in Simon Jungblut, Viola Liebich \& Maya Bode-Dalby (eds), YOUMARES 9 - The Oceans: Our Research, Our Future. Proceedings of the 2018 conference for YOUng MArine RESearcher in Oldenburg, Germany (Cham: Springer, 2020) 45-56. 
narrative for the environment, the oceans and fisheries, and of the potential added value of the concept in understanding these different regimes (2.3).

\subsection{The emergence and analytical conceptions of (global) governance}

Governance has somehow always formed a part of modern political practice, ${ }^{16}$ although it has not always been explicitly recognized and identified as such. However, it was in the late 1980s, in the face of critiques of traditional forms of government that the current focus on governance first occurred. At the global level, the end of the Cold War, the emergence of globalization, and a renewed interest in global institutions also established the use of the concept in the (international) political discourse. ${ }^{17}$ Traditional approaches based on State sovereignty and freedoms ${ }^{18}$ and on "command and control" regulation ${ }^{19}$ were viewed as "too formalistic, narrow-minded, exclusive, inflexible, uncoordinated, 'undemocratic' and, most importantly, out of step with reality". ${ }^{20}$ They were considered ill-equipped to accommodate "increasingly complex" societies, "autonomous social subsystems" and new "social coordination mechanisms". ${ }^{21}$ Governance therefore came as a tool for understanding the necessary sociopolitical changes. ${ }^{22}$ It was seen as bringing new perspectives to face the changing role and function of the State. ${ }^{23}$ It further explained the emerging methods and broader perspectives of norm-, rule-, lawand decision-making. ${ }^{24}$ Governance was therefore perceived as creating a new conceptual framework for new realities. ${ }^{25}$

The theoretical debate about the meaning of the concept can be traced back to the international relations literature, more specifically to the seminal work of Rosenau from the early 1990s. Rosenau uses the comparison between government and

16 See, e.g., Martin Hewson \& Timothy Sinclair, “The Emergence of Global Governance Theory” in Martin Hewson \& Timothy Sinclair (eds), Approaches to Global Governance Theory (Albany, NY: State University of New York Press, 1999) 3-22 at 16-17.

17 Glenn D. Hook \& Anthony Payne, "Introduction. Thinking about Global Governance and Japan" in Glenn D. Hook \& Hugo Dobson (eds), Global Governance and Japan: The Institutional Architecture (Abingdon, Oxon: Routledge, 2007) 1-22 at 3-4.

18 See, e.g., Holley, supra note 7 at 24.

19 See, generally, Martin Jänicke \& Helge Jörgens, "New approaches to environmental governance" in Martin Jänicke \& Klaus Jacob (eds), Environmental governance in global perspective. New approaches to ecological modernisation (Berlin: Freie Universität Berlin, 2006) 167-209; Judith van Erp et al (eds), Smart Mixes for Transboundary Environmental Harm (Cambridge: Cambridge University Press, 2019).

20 Ansell \& Torfing, supra note 11 at 4. See also Marie-Claude Smouts, "The proper use of governance in international relations" (1998) 50:155 International Social Science Journal 81-89 at 84.

21 Smouts, supra note 20 at 84 .

22 Frank Biermann \& Philipp Pattberg, "Global Environmental Governance: Taking Stock, Moving Forward” (2008) 33 Annual Review of Environment \& Resources 277-294 at 279; Ansell \& Torfing, supra note 11 at 1 and 14; Smouts, supra note 20 at 81; Jänicke \& Jörgens, supra note 19 at172.

23 See, e.g., Finkelstein, supra note 8 at 368-369.

24 Ansell \& Torfing, supra note 11 at 4 and 6.

25 Charlotte $\mathrm{Ku}$, "Fragmentation in International Law and Governance: Understanding the Sum of the Parts" in Cedric Ryngaert, Erik Molenaar \& Sarah Nouwen (eds), What's Wrong with International Law? Liber Amicorum A.H.A. Soons (Leiden: Brill Nijhoff, 2015) 419-433 at 421-423. 
governance and the changing portrait of State and social functions as starting points to understand what governance represents. He defines governance as "a more encompassing phenomenon than government", which "embraces governmental institutions, but it also subsumes informal, non-governmental mechanisms", and that "refers to activities backed by shared goals that may or may not derive from legal and formally prescribed responsibilities and that do not necessarily rely on police powers to overcome defiance and attain compliance". ${ }^{26}$ Despite criticisms of Rosenau's understanding of governance, and the suggested variations that ensued, ${ }^{27}$ his approach remains one that raises awareness towards "the changing patterns of international relations" and the participation of a wide mix of actors in the "shaping of systems of global rules". ${ }^{28}$

In parallel to the theoretical debate, the international political scene also reflected the growing use of the concept as an ideological endeavour in the work of global institutions, such as the UN and the Bretton Woods economic institutions. ${ }^{29}$ A major, yet criticized, ${ }^{30}$ study of the concept was made by the Commission on Global Governance, a group of political experts brought together to suggest ways to strengthen the UN. The ideas of "a broad, dynamic, complex, process of interactive decision-making" ${ }^{31}$ were echoed in the Commission's work, which characterized governance as: ${ }^{32}$

- a process, not a rule system;

- being based on accommodation, not domination;

- involving public and private actors;

- relying on continual interaction, not only on formal institutions.

26 James Rosenau, "Governance, order, and change in world politics" in James N. Rosenau \& Ernst-Otto Czempiel (eds), Governance without Government: Order and Change in World Politics (Cambridge: Cambridge University Press, 1992) 1-29 at 3. This can be differentiated from the definition of regime by the fact that regimes normally focus on one issue-area (see Stephen D. Krasner, "Structural causes and regime consequences: regimes as intervening variables" in Stephen D. Krasner (ed), International regimes (Ithaca, NY: Cornell University Press, 1983) 1-21) while governance refers to the whole global order.

27 For example, Finkelstein, finding Rosenau's definition too encompassing, suggests a slightly different focus, one that approaches governance as an activity, with institutions as means of conducting these activities (i.e. means of governance), and States, non-State actors, agencies and organizations as performing these activities (i.e. actors of governance). According to Finkelstein, this approach makes the definition of governance more flexible, as to scope (sectoral, functional, regional or global), subject (general or specific), actors (State and non-State), and processes (ad hoc and institutionalized, formal and informal), see Finkelstein, supra note 8 at 368. Finkelstein's approach was in turn criticized by Smouts, who questions its added value, equating it to multilateralism, an already well-functioning concept, see Smouts, supra note 20 at 82 . The definition by Rosenau has also been characterized as lacking relevance for explaining power struggles, see Hook \& Payne, supra note 17 at 5 .

28 Hook \& Payne, supra note 17 at 4.

29 Ibid at 2.

30 The criticisms came from States and groups which saw the Commission as a lobby in favour of increasing the UN's power.

31 Commission on Global Governance, Our Global Neighbourhood. The Report of the Commission on Global Governance (Oxford: Oxford University Press, 1995) at 4. See also Toope, supra note 8 at 94-99, where he discusses the insight from international relations on the conception of global governance.

32 Smouts, supra note 20 at $83-84$, summarizing the main findings of the Commission's report regarding the meaning of governance. 
The use of governance in the political discourse has, however, been the object of strong criticism. In fact, the concept has been seen as promoting, through the concept of "good governance", a disguised form of neo-colonialism (i.e. developing countries have to abide by criteria established by western powers). As a matter of fact, good governance, mostly used by the World Bank and other Bretton Woods institutions, relies on criteria to assess the performance of governing institutions in developing countries: the rule of law (respect for the law and independence of judges), good administration (correct and fair management of public spending), responsibility and accountability of political leaders, and transparency of information for the public, as well as free and fair elections, public participation, responsiveness, consensusoriented decision-making, equity and inclusiveness, effectiveness and efficiency. ${ }^{33}$ These assessment criteria have allowed good governance to become an "ideological tool for a minimum-state policy", ${ }^{34}$ based on assumptions of "goodness" that are sometimes difficult to export to other cultural and political contexts. ${ }^{35}$

It would be incorrect, however, to consider that the lens suggested by governance is, in and of itself, problematic; in fact, the different conceptions of governance, coming from both the theoretical debate and the political discourse, highlight common elements of relevance for understanding the description that governance supplies of the necessary approaches to current realities: 1) "new forms of regulations that differ from traditional hierarchical State activity, [... for example] self-regulation by societal actors" ${ }^{36}$ and non-centralized sources of power; $;^{37}$ 2) a multiplicity of actors "from different sectors and governing levels"; 38 and 3) the importance of the collaboration between such actors, ${ }^{39}$ through for example networks and partnerships. ${ }^{40}$ These elements differ from the components of traditional forms of

33 UNESCAP, "What is Good Governance?” (2009), online: <http://www.unescap.org/sites/default/files/ good-governance.pdf>; Ansell \& Torfing, supra note 11 at 2; Smouts, supra note 20 at 83; Edith Brown Weiss \& Ahila Sornarajah, "Good Governance" (2013) Max Planck Encyclopedia of Public International Law at paras 1-2 and 6.

34 Smouts, supra note 20 at 83.

35 See e.g., Young, supra note 5 at 170-171; The South Centre, For A Strong and Democratic United Nations: A South Perspective of UN Reform (Geneva: The South Centre, 1996), cited in Biermann \& Pattberg, supra note 22 at $279-280$.

36 Biermann \& Pattberg, supra note 22 at 278. See also Ladeur, supra note 9 at paras 14-15 and 17; Johnston, supra note 15 at 349; Ocean Governance and the Outcomes of Rio+20, FAO COFI, 30th Sess, Doc COFI/2012/6/Rev.1 (2012) at para 9 [FAO COFI]; Hewson \& Sinclair, supra note 16 at 5-10.

37 Ansell \& Torfing, supra note 11 at 9; Rosenau, supra note 26 at 8; FAO COFI, supra note 36 at para 9.

38 Ansell \& Torfing, supra note 11 at 8 . See also UNESCAP, supra note 33; Smouts, supra note 20 at 87 ; FAO COFI, supra note 36 at para 9; Toope, supra note 8 at 96. Biermann \& Pattberg also specify that, not only are there more actors (in terms of numbers), but there is a wider variety of actors, and a broader range of roles for existing actors, the rise of new actors, the emergence of new mechanisms and institutions, and the increasing segmentation and fragmentation across levels and functional spheres, supra note 22 at 280-281.

39 Ansell \& Torfing, supra note 11 at 10; Ladeur, supra note 9 at paras 22-24. See also Leon Gordenker \& Thomas G. Weiss "Pluralizing Global Governance: Analytical approaches and dimensions" in Thomas G. Weiss and Leon Gordenker (eds), NGOs, the UN, and Global Governance (Boulder, Colo.: Lynne Rienner, 1996) $17-47$ at 17 , cited in Johnston, supra note 36 at 387.

40 Ansell \& Torfing, supra note 11 at 9; Biermann \& Pattberg, supra note 22 at 282-284; Toope, supra note 8 at 97 on informal networks. For Smouts, the collaboration - the procedure - is as important as the result 
government through the increased role of non-State/private actors, and through the processual transformative nature of governance, which opposes the more static state emanating from traditional governmental perspectives. This does not mean that we will witness the disappearance of formal mechanisms and the State as the centre of authority, but it entails the emergence of "multiple layers of accountability with forms and units of governance operating simultaneously, and whose elements ideally leverage and complement each other". ${ }^{41}$ It moves away from a focus on the functioning of institutions, and emphasizes the importance of processes, both at the decision-making and the decision-implementing stages, that involve formal and informal actors, structures and interactions. ${ }^{42}$

Governance is therefore first an approach to analysing global change, a way of rethinking regimes to fit better with changing patterns, and an emblem for the change in the role and nature of organizations. ${ }^{43}$ It is an analytical tool, "to make sense of current sociopolitical transformations". ${ }^{44}$

\subsection{The programmatic function of governance: what role for the law?}

The discussion conducted above has portrayed governance as a lens for looking at a processual transformation, reacting to traditional forms of governments and traditional approaches based on State sovereignty and freedoms. However, governance can also be perceived as a programmatic tool, which is in fact expected to be used to fulfil tasks. These tasks can range from establishing overarching principles and objectives, to creating more specific regulatory frameworks and policies, and also to finding ways to accommodate interests, maintain coherence among interactions, allocate power and resources, and ensure iteration. ${ }^{45}$ In that sense, Juda and Hennessey have defined governance as:

the formal and informal arrangements, institutions, and mores that structure:

- how resources or an environment are utilized,

- how problems and opportunities are evaluated and analyzed,

- what behavior is deemed acceptable or forbidden, and

- what rules and sanctions are applied to affect the pattern of use. ${ }^{46}$

reached, see supra note 27 at 86 . This can be related to Finkelstein's understanding that the activities and the outcomes are as important, see supra note 20.

$41 \mathrm{Ku}$, supra note 25 at 430.

42 See, e.g., UNESCAP, supra note 33; FAO COFI, supra note 36 at para 10, referring to Robin Mahon, Lucia Fanning \& Patrick McConney, "CLME TDA update for fisheries ecosystems: governance issues" (2011) Caribbean LME Project.

43 See, generally, Hewson \& Sinclair, supra note 16.

44 Biermann \& Pattberg, supra note 22 at 279.

45 FAO COFI, supra note 36 at para 8.

46 Lawrence Juda \& Timothy Hennessey, "Governance Profiles and the Management of the Uses of Large Marine Ecosystems" (2001) 32 Ocean Development and International Law 43-69 at 44. 
Based on this definition of the programmatic function, one can easily observe that the law also performs these tasks and, consequently, could question the added-value of governance. The growing use of the concept of governance is, however, not simply a question of terminology; it reflects a desire to adapt the way in which resources, activities and behaviours are tackled and managed ${ }^{47}$ However, few legal scholars in the fields of environmental law, resource management and law of the sea ${ }^{48}$ have embarked on an analysis of the role that law plays in relation to governance, and how the two relate, compare and differ. The relationship between law and governance is two-pronged: it is influenced firstly by the approach taken to explain governance, and secondly - and chiefly - by the complementary role that law and governance play for social change.

First, the prima facie overlap between the functions of law and governance is influenced by the approach taken to explain governance. ${ }^{49}$ Although different approaches to governance are observed by Techera and Klein within environmental governance theories, they are here used to illustrate governance, as well as its relationship with the law, more broadly. A first, hierarchical approach to governance is the one that has so far been the most prominent in the spheres of international law, hence the seeming overlap between governance and international law. A hierarchical approach to governance is top-down and strongly relies on formal institutions and rule-based mechanisms. Although not necessarily excluding participatory and multi-level mechanisms, they are not at the core of this hierarchical approach. A second, multi-layered approach to governance, on the other hand, is strongly rooted in cooperation and collaboration, and is based on decentralization. It relies on sustainability and environmental law principles as guiding mechanisms, and on a broader range of actors and loose networks. It is on this second, multi-layered conception of governance that this study relies, because it best takes into account and reflects the common elements of governance - new forms of regulation, multiplicity of actors, and collaborations - identified previously as commonalities throughout various conceptions of governance.

Second, within this multi-layered conception, the relationship between law and governance revolves around the role each of them plays for social change. The law is undoubtedly an important regulatory tool designed "to establish and maintain a specific type of desired social order". ${ }^{50}$ However, the law was traditionally considered as the main mechanism for social change, identifying the desirable outcomes and, to some extent, the ways in which to reach them, leaving "the rest to implementation

47 Takei, "Demystifying", supra note 15 at 26.

48 To the present author's knowledge, it is mostly through the work of Kotzé, Takei, Houghton, Holley, Singh \& Ort and Techera \& Klein, all of whose publications are cited throughout this chapter, that the specific relationship between governance and the law, as well as the role that the former plays to complement the latter, has been explored in the context of environmental law, resource management and the law of the sea.

49 Techera \& Klein, supra note 1 at 68-70.

50 Louis Kotzé \& Rakhuyn Kim, "Earth system law: The juridical dimensions of earth system governance" (2019) 1 Earth System Governance article 100003 at 3. 
and enforcement". ${ }^{51}$ However, this framework cannot be sufficient to "engineer social change", 52 to find solutions "to the barriers preventing effective conservation and management". ${ }^{53}$

This is why the present study suggests that law's main function is to create a normative and procedural framework. Governance, for its part, does not only focus on normative implications $;{ }^{54}$ it includes rules as well as institutions and processes. ${ }^{55}$ This offers a "practical lens through which to seek solutions". ${ }^{56}$ Simply put, law establishes the rules of the game, defines the scope within which actors and institutions are to play the game and, to some extent, elaborates on the sanctions for non-compliance with the rules. Governance, for its part, offers different tools for nudging actors towards abiding by those rules. Law is therefore "one of the societal constructs $[\ldots]$ that humans use to govern themselves and their actions". ${ }^{77}$ Indeed, although "governance can be accomplished by law",58 law is not the only social construct contributing to governance; actors' behaviours can also be influenced through a variety of other components. Gunningham puts law and governance at the two ends of the same continuum: while law is normally quite specific, enacted by States and interpreted by courts, governance approaches law as "simply one node amongst many in a world of diffused power and responsibility". ${ }^{59}$ Law is therefore "merely one instrument among others in the environmental regulator's toolkit", ${ }^{60}$ as illustrated in Figure 3.

51 Holley, supra note 7 at 24.

52 Ibid.

53 Techera \& Klein, supra note 1 at 86.

54 Toope, supra note 8 at 97.

55 Techera \& Klein, supra note 1 at 66.

56 Ibid at 86.

57 Kotzé, supra note 10 at 55.

58 Robert Keohane \& Joseph Nye, “Governance in a Globalizing world” in Robert Keohane (ed), Power and Governance in a partially globalized world (Abingdon, Oxon: Routledge, 2002) 193-218 at 203, cited in Kotzé, supra note 10 at 63 (emphasis added).

59 Neil Gunningham, "Environmental Law, Regulation and Governance: Shifting Architectures” (2009) 21:2 Journal of Environmental Law 179-212 at 181 [Gunningham, "Shifting Architecture"].

60 Techera \& Klein, supra note 1 at 86, citing Gunningham, "Shifting Architecture”, supra note 59 at 179. See also Lewis A. Kornhauser, "Governance Structures, Legal Systems, and the Concept of Law" (2004) 79:2 Chicago-Kent Law Review 355-381 357-358, cited in Kotzé, supra note 10 at 54. 
Figure 3: Components of governance and their interactions ${ }^{61}$

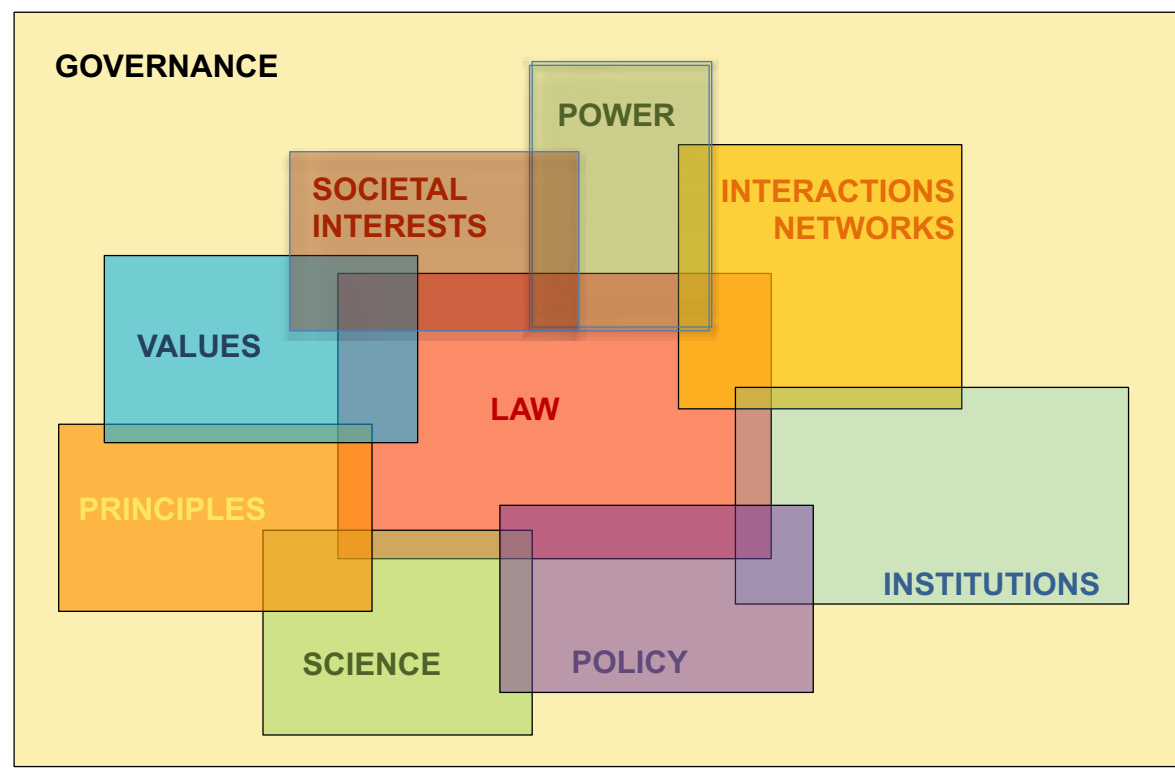

This is why governance is relevant: because it looks beyond legal structures and, in a situation where complexity prevails, ${ }^{62}$ this might offer a broader set of elements for achieving the results sought in terms of compliance and enforcement. ${ }^{63}$ In that sense, governance can be seen as broadening "legal perspectives on law-making, implementation, enforcement and regulation" ${ }^{64}$ It is on this broadening capacity of governance that this study relies to explore alternatives for strengthening international fisheries law towards sustainable practices. Simply put, the "frame of thinking must expand".65

Nevertheless, legal scholars and practitioners remain hesitant to embrace a governance-based approach. This is explained first by the methodological challenge that governance represents for lawyers, because it involves a "trans-disciplinary legal view" and "a multi-disciplinary foundation", resulting in uncertainty as to what "the content and meaning of the concept are for [...] lawyers". ${ }^{66}$ It therefore requires legal scholars "to take a 'more diverse view of state authority and its exercise' but, in doing so, it is not clear what form such a 'diverse view' should take and how it differs from existing scholarly approaches" ${ }^{67}$ It also hampers the formulation of a clear

61 This figure represents a simplified understanding of the relationship between law and governance as presented in this study. It is in no way exhaustive, as other components of governance could be included, current elements might be related to one another differently, etc.

62 See, e.g., Cosens et al, Holley, and Ebbesson \& Hey, supra note 7; Ebbesson, supra note 2.

63 Techera \& Klein, supra note 1 at 87.

64 Kotzé, supra note 10 at 50.

65 Techera \& Klein, supra note 1 at 86.

66 Kotzé, supra note 10 at 49.

67 Elizabeth Fisher et al, "Maturity and Methodology: Starting a Debate about Environmental Law Scholarship" (2009) 21:2 Journal of Environmental Law 213-250 at 235, cited in Kotzé, supra note 10 at 49, 
definition, a method normally employed by legal scholars to understand certain concepts. ${ }^{68}$

Second, Takei underlines three differences between law and governance that could explain jurists' reluctance in using the latter. ${ }^{69}$ (1) Law and governance have a different focus. While they both address institutions and instruments, law focuses more on the legally binding aspects of such instruments and the characterization of a norm as being legal or not. Law also puts a strong emphasis on dispute settlement mechanisms, which is not necessarily a priority in governance literature. (2) Although approaches and principles are elements strongly relied upon in governance, their legal status is still discussed in law. In fact, despite the growing perception that the traditional theory of sources of international law creates an obstacle for change in the discipline, and despite critiques of that traditional theory, ${ }^{70}$ the reliance on the traditional sources of international law (the "article 38 ICJ Statute" sources, in particular treaty and custom) to give legal status to norms remains the main trend in international law. ${ }^{71}$ Building on elements that come from outside this framework could therefore conceivably feel uncomfortable for jurists. (3) The concepts have different goals: governance is often employed as a tool to fill in the gaps in the legal framework, thereby being seen as going beyond the current state of the law and suggesting reforms.

What might also feel uncomfortable for legal scholars and practitioners rests in the respective nature of law and of governance. As stated by Houghton,

governance is first and foremost a dynamic, interactive decision-making process and does not necessarily require a coherent, comprehensive legal system in order to function $[\ldots$ while 1$]$ aw, in contrast, serves an essential stabilizing function by aspiring to provide a consistent and comprehensive response to challenges, but this is potentially at the expense of a more dynamic response that would be more appropriate in the realm of governance. ${ }^{72}$

see also at 50-51.

68 Kotzé, supra note 10 at 49.

69 These differences are explained in Takei, "A Sketch", supra note 15 at 58-59.

70 See, generally, Jean D’Aspremont, “Towards a New Theory of Sources in International Law” in Anne Orford \& Florian Hoffmann (eds), The Oxford Handbook of the Theory of International Law (Oxford: Oxford University Press, 2016) 545-563.

71 Ulrich Beyerlin, "Different Types of Norms in International Environmental Law: Policies, Principles, and Rules" in Daniel Bodansky, Jutta Brunnée \& Ellen Hey (eds) The Oxford Handbook of International Environmental Law (Oxford: Oxford University Press, 2007) 425-448 at 447, where the author says that a principle or norm will have legal status, i.e. be legally binding, only if included in/recognized by a treaty or a custom.

72 Katherine Houghton, "Identifying New Pathways for Ocean Governance: The Role of Legal Principles in Areas Beyond National Jurisdiction" (2014) 49 Marine Policy 118-126 at 119. See also Ebbesson, supra note 2 at 415 . 
She even warns against merging the concepts or including law in governance, qualifying such approaches as dangerous for the "critical stabilizing function of law".73

Without ignoring the "warnings" raised about blurring the two concepts, the present author disagrees that law and governance are incompatible,$^{74}$ and instead submits that they are complementary. The present study does not intend to "subordinate" law to governance; it suggests letting legal regimes be permeated, inspired and complemented by elements stemming from a governance focus. It also suggests that the "critical stabilizing functions of law" and the "volatile" characterization of governance are overstated. ${ }^{75}$ In times of change and of complexity in the management of natural resources, the law needs to be revisited and re-thought, so that it can provide not stability at all costs, but stability adapted to changing circumstances. Law by itself is insufficient to find solutions.

Of course, the legal user of governance-related elements should not merely transpose the results from the political science/international relations field to legal research; the transposition will only be worth doing "as long as the meaning and implications of the concept [for the legal discipline] are made clear". ${ }^{76}$ For that purpose, Ladeur mentions that legal research must first observe "the work done on 'governance' as an analytical instrument in political science", and then assess whether the concept can be adjusted to the understanding of legal phenomena. ${ }^{77}$

Governance therefore represents a different lens through which regimes, including legal regimes, can be assessed, developed and implemented. Looking into different approaches

enables international lawyers to take a fresh look at their discipline. Taking that fresh look does not mean that we must dismiss as unimportant state consent, or 'sources' of international law, the creation of courts and tribunals, or better enforcement mechanisms. Rather, it places these elements in the broader context of the international legal enterprise, so as to better appreciate the roles they play, their potential, and their limitations. ${ }^{78}$

This fresh look could therefore represent one of the "international lawyers' quest[s] to stretch the frontiers of their own discipline". ${ }^{79}$ In the case of international fisheries law, the overarching and far-reaching scope of governance might prove to

73 Houghton, supra note 72 at 119.

74 Ibid, referring to the "incompatibilities of international law and governance".

75 Ibid.

76 Smouts, supra note 20 at 81.

77 Ladeur, supra note 9 at paras 1-3.

78 Jutta Brunée \& Stephen Toope, Legitimacy and Legality in International Law. An Interactional Account (Cambridge: Cambridge University Press, 2010) at 7-8.

79 D'Aspremont, supra note 70 at 555. 
be a beneficial alternative mechanism for strengthening the regime as a process of change towards effective solutions for improving sustainability performance.

\subsection{Using the lens of governance for the environment, oceans and fisheries}

Taking governance as an alternative lens of analysis through which to approach changing patterns, and to extend the framework of thinking of the law as a mechanism for social change, the present section looks at the way in which governance has been used in relation to the environment, the oceans and fisheries. It first questions how governance has impacted the narrative and "toolkit" for the protection of the environment, and how the legal literature in this field has so far referred to the concept (2.3.1). It then assesses how governance has (re)aligned the legal and policy oceans discourse around an outcome-based approach to reaching sustainable and integrated oceans management (2.3.2). The section ends with a reflection on how the understandings of environmental and oceans governance could inform a more environment-oriented and integrated conception of fisheries governance which, although being an encompassing concept, remains intrinsically sectoral (2.3.3).

\subsubsection{Environmental governance}

The use of the concept of governance in the environmental discourse arose with the recognition of the intertwinement of humans and the environment, originally acknowledged in the Stockholm Declaration and reaffirmed 20 years later in the Rio Declaration, which reiterated the need for States to cooperate in order to protect the Earth's ecosystem..$^{80}$ An acceleration in the frequency and intensity of environmental impacts, ${ }^{81}$ combined with a realization that environmental impacts are often transboundary ${ }^{82}$ and also multi-sectoral (e.g. environmental factors, human factors and scientific factors), triggered the need for a concept that encompassed the globality and complexity of environmental issues which could not be tackled by individual and/or national measures alone. Environmental governance therefore appeared as a satisfactory way to picture a multiplicity of "channels through which human impacts on the natural environment are ordered and regulated". ${ }^{83}$ These channels include "rule creation, institution-building, and monitoring and enforcement [as well as] a soft infrastructure of norms, expectations, and social

80 Rio Declaration at principle 7.

81 What Young refers to as the "Great Acceleration", see Oran Young, On Environmental Governance: Sustainability, Efficiency, and Equity (Abingdon, Oxon: Routledge, 2016) at 56, cited in Margherita Paola Poto \& Lara Fornabaio, "Participation as the Essence of Good Governance: Some General Reflections and a Case Study on the Arctic Council” (2017) 8 Arctic Review on Law and Politics 137-157 at 146.

82 Ibid.

83 David L. Levy \& Peter J. Newell, "Introduction" in David L. Levy \& Peter J. Newell (eds), The Business of Global Environmental Governance (Cambridge, Mass.: MIT Press, 2005) 1-16 at 2, cited in Kotzé, supra note 10 at 60 . 
understandings of acceptable behaviour towards the environment, in processes that engage the participation of a broad range of stakeholders". ${ }^{4}$

To face this acceleration and the complexity triggered by socio-ecological systems, environmental governance is applied to "identify a common toolbox that can be used as a strategy to address the problems resultant from this acceleration", a toolbox based on "flexibility, inclusiveness, transparency, and [on] a shift from hierarchy to networking cooperation" ${ }^{85}$ The Arctic Council ${ }^{86}$ is used as an example of an institution that has built its functioning on such a toolbox. Indeed, the Council is a "cooperative platform where states and non-state actors cooperate in a global dynamic, and where plenty of room for new forms of cooperation and engagement is left, especially thanks to its flexible structure and its ability to accommodate new collaborative mechanisms" ${ }^{87}$

Although environmental governance is an extra-legal concept, legal literature on the topic, although still scarce, is growing. Kotzé, for example, observes that, despite growing interest from lawyers in using the concept, there is "no universally accepted definition, description or typology of the concept that should allow for consistent and universal application to environmental law problems", which leads legal scholars to be "hesitant at best, or unable at worst to understand, systematically to describe, and justifiably to concretize the notion of environmental governance". 88

To fill this gap in the legal conceptualization of environmental governance, Kotzé suggests the following understanding:

environmental governance is a normative institutional regulatory intervention and social construct that is predominantly based on law and that aims to influence how people interact with the environment. It entails a pluralistic, dynamic, multi-level, multi-actor response and process of change which pragmatically aims to change human behaviour vis-à-vis the environment, and idealistically to optimize environmental benefits and use, while at the same time

84 Ibid.

85 Poto \& Fornabaio, supra note 81 at 146, referring to Neil Gunningham, "The New Collaborative Environmental Governance: The Localization of Regulation” (2009) 36:1 Journal of Law and Society 145-166.

86 "The Arctic Council is the leading intergovernmental forum promoting cooperation, coordination and interaction among the Arctic states, Arctic Indigenous communities and other Arctic inhabitants on common Arctic issues, in particular on issues of sustainable development and environmental protection in the Arctic." The Council's work is done by six working groups dealing with contaminants; monitoring and assessment; conservation of flora and fauna; emergency prevention, preparedness and response; protection of the marine environment; and sustainable development, see Arctic Council, "About", online: $<$ https://arctic-council.org/index.php/en/about-us>.

87 Poto \& Fornabaio, supra note 81 at 146. More generally on the Arctic Council, see, e.g., Erik Molenaar, "Current and Prospective Roles of the Arctic Council System within the Context of the Law of the Sea" (2012) 27:3 International Journal of Marine \& Coastal Law 553-595; Erik Molenaar, "The Arctic, the Arctic Council, and the Law of the Sea" in Robert Beckman et al (eds), Governance of Arctic Shipping. Balancing Rights and Interests of Arctic States and User States (Leiden: Brill Nijhoff, 2017) 24-67.

88 Kotzé, supra note 10 at 48. 
seeking to protect and preserve sufficient environmental capital for present and future generations. ${ }^{89}$

This understanding of environmental governance remains strongly rooted in legal structures; however, its focus on flexible elements, such as pluralism, dynamism, multi-levels and multi-actors, opens the door for the "normative institutional regulatory intervention" to being permeated by other components that also have the potential of shaping human behaviours in their interactions with the environment. Environmental governance therefore can be seen as an analytical tool to understand the increased complexity triggered by a more interconnected conception of environmental reality, and as a programmatic tool to develop pathways aligned with such reality.

\subsubsection{Oceans governance}

Interconnectedness also acts as a driver in the emergence of the concept of oceans governance. Although found sporadically in the legal and policy literature in the late $1990 \mathrm{~s},{ }^{90}$ the concept of oceans governance started to be used more regularly in ocean policy documentation in the early 2000s. Its appearance in fact seems to coincide with the changes in the UN ocean-related discourse, which started referring to the necessity for interconnectedness, interlinkages, and integration. ${ }^{91}$ Oceans governance became the concept which was employed to explain how to reach those interlinkages and integration, and how to reach this interconnectedness in order to, ultimately, improve oceans health. Singh and Ort in fact observe that, from a legal perspective, oceans governance "usually relates to regulating maritime activities with a particular focus on marine environmental protection". ${ }^{92}$ This is why oceans governance became understood as "the way to go" to reach a more sustainable, better coordinated management of the oceans and their resources. ${ }^{93}$

Oceans governance has in fact been considered as an approach to oceans management that replaces "the traditional issue-by-issue and zone-by-zone approach to oceans management". ${ }^{44}$ Although it is not yet clear whether there exists a causal link between oceans governance and management, ${ }^{95}$ this study submits that

89 Louis Kotzé, Global Environmental governance: Law and regulation for the 21st century (Cheltenham: Edward Elgar, 2012) at 200.

90 Takei, "Demystifying", supra note 15 at 23-24.

91 See chapter 1 section 2.1 above.

92 Singh \& Ort, supra note 15 at 47, referring to Pradeep Singh \& Aline Jaeckel, "Future prospects of marine environmental governance" in Markus Solomon \& Till Markus (eds), Handbook on marine environment protection (Cham: Springer, 2018) 621-636.

93 "International ocean governance is about managing and using the world's oceans and their resources in ways that keep our oceans healthy, productive, safe, secure and resilient", see European Commission, supra note 14 .

94 Rothwell \& Stephens, supra note 15 at 506.

95 Causal link means that we ask whether effective oceans governance necessarily leads to good management and vice versa. 
the two are correlated. Tanaka in fact suggests that oceans governance is built upon the interaction and complementarity of two management approaches: the zonal and the integrated. The zonal approach refers to the management of activities according to the maritime zone in which they take place and the status of the regulatory and governance framework in such a zone. ${ }^{96}$ The integrated approach, for its part, starts from the premise that current problems cannot be solved only with the existing sectoral framework. ${ }^{97}$ It involves integration at three levels: ecological and biological interactions, cross-sectoral normative framework, and implementation in an integrated manner. ${ }^{98} \mathrm{Scott}$, also writing on the integrated approach, describes it as a holistic management "of activities that impact upon [...] the oceans across sectors, space and time". ${ }^{99}$ While the zonal approach is clearly entrenched in the law of the sea and, more generally in oceans management, the integrated approach, although already being used (e.g. ecosystem approach), is still developing. ${ }^{100}$

Despite the lack of a clear definition of oceans governance, which has not yet crystallized as an accepted concept, ${ }^{101}$ most understandings of the concept go back to its link with oceans management, by referring to what oceans governance can bring to oceans management. For example, the FAO COFI refers to the variety of institutions, instruments and processes, and links them more specifically to their use for "short term operational management to long term policy development and planning and from conventional forms of administration to modern forms of participative decision-making processes [which] include policy (high level governance) and management (practical implementation of policies)". ${ }^{102}$ Similarly, in the scholarly literature, Rothwell and Stephens explain the concept as:

those formal and informal rules, arrangements, institutions and concepts which structure the ways in which sea space is used, how ocean problems are monitored and assessed, what activities are permitted or prohibited, and how sanctions and other responses are applied. It is therefore a broad conception of oceans management, implicating an array of global and regional organisations, directed at 'integrat[ing] the management of activities that impact upon or affect the oceans across sectors, space and time under a unified over-arching vision. ${ }^{103}$

96 Yoshifumi Tanaka, A Dual Approach to Ocean Governance. The Cases of Zonal and Integrated Management in International Law of the Sea (Farnham, England, Burlington, USA: Ashgate, 2008) at 1, 25.

97 Ibid at $17-18$.

98 Ibid at $18-21$.

99 Karen N. Scott, "Integrated Oceans Management: A New Frontier in Marine Environmental Protection" in Donald Rothwell et al (eds), The Oxford Handbook on the Law of the Sea (Oxford: Oxford University Press, 2015) 463-490 at 465-466 and 487-488.

100 Tanaka, supra note 96 at 16-17.

101 de Souza Patu, supra note 9 at 31-32.

102 FAO COFI, supra note 36 at para 8. See also FAO, “The State of World Fisheries and Aquaculture 2016. Contributing to food security and nutrition for all” (2016) at 83-86, online: <http://www.fao.org/3/ai5555e.pdf>.

103 Rothwell \& Stephens, supra note 15 at 507 (emphasis added), citing Scott, supra note 99 at 465 . See also Theodore Okonkwo, "Managing the Ocean Commons Beyond National Jurisdiction" (2016) 2 China Oceans Law Review 56-82 at 64: "The governance framework for the high seas - that is, the legal rules, political processes and institutional structures through which those rules are applied and enforced”. 
This inclusive description of oceans governance, although a seemingly more encompassing vision for ocean management, does share commonalities with the law of the sea, traditionally understood as the rules and principles determining the status and control of oceans space, and guiding States in the conduct of their maritime affairs. ${ }^{104}$ Following the discussion conducted above, it is to be asked, then, how the concept of oceans governance can broaden our frame of thinking in relation to the oceans.

It is acknowledged that the international legal framework for the oceans, with UNCLOS at its core, as well as (environmental) principles and mechanisms to operationalize such principles (i.e. ABMTs, EIAs), represent fundamental building blocks of oceans governance. ${ }^{105}$ Such a statement, however, implies that the two cannot be equated; ${ }^{106}$ the law of the sea represents one component of oceans governance, which also encompasses concepts stemming from environmental law and even, to some extent, human rights law, ${ }^{107}$ but also from outside the law. Consequently, oceans governance does not represent a simple "change in semantics", but shows a "desire to reform the current state of the management and regulation of ocean activities". ${ }^{108}$

Then, is there something wrong with the law of the sea as a regulator of international relations in oceans affairs, asks Takei? ${ }^{109}$ Not per se, he submits, but "to keep (or make) it an effective framework, international lawyers always need to make efforts to ensure that law plays the important role it is expected to play in international relations" ${ }^{110}$ However, facing the array of changing issues, circumstances, actors, instruments and situations that currently characterize international fisheries, and in the face of the indeterminacy or lack of finality typical to ecosystems but required by policy makers and economic interests, ${ }^{111}$ the law finds itself having more difficulty dealing with processes that change over time. Oceans governance, which aims at addressing the interconnectedness in environmental protection, therefore represents a way to fulfil the "pressing need for a more effective response to the cumulative effects of human activities (and natural phenomena) to the marine environment". ${ }^{112}$

\footnotetext{
104 Rothwell \& Stephens, supra note 15 at 1.

105 Takei, "Demystifying", supra note 15 at 25; Johnston, supra note 15 at 379-380; Juda, supra note 15 at 2. On principles, see chapter 3 above.

106 Singh \& Ort, supra note 15 at 47.

$107 \mathrm{Ibid}$. The authors give the example of sustainable development, a building block of oceans governance, which also includes environmental and human components.

108 Takei, "Demystifying", supra note 15 at 26.

109 Takei, "A Sketch", supra note 15 at 62.

110 Ibid.

111 Annecoos Wiersema, "Uncertainty, Precaution, and Adaptive Management in Wildlife Trade" (2015) 36 Michigan Journal of International Law 375-424 at 382-383. See also Barbara A. Cosens, "Legitimacy, Adaptation, and Resilience in Ecosystem Management" (2013) 18:1 Ecology and Society 3-11 at 6.

112 Singh \& Ort, supra note 15 at 49, see also at 55, referring to Scott, supra note 99.
} 
Both environmental and oceans governance suggest the use of a broader toolkit to address the interaction between humans, the environment and natural resources. However, what oceans governance additionally represents is an outcome-based approach, one that aims at triggering changes in oceans management towards improved sustainability of oceans. It is this outcome-based approach that represents a useful perspective for exploring alternative solutions for improved sustainability performance.

\subsubsection{Fisheries governance}

In a similar way to oceans governance, fisheries governance is often used in the policy literature in way that seemingly assimilates it to fisheries management, or to structures ensuring such management. In fact, as put by two commentators, fisheries governance "is now a prominent part of the discourse on how best to manage fisheries." 113 In that sense, fisheries governance is related to fisheries management in that the former provides a broader range of tools and processes to perform the latter.

The definition of fisheries governance normally referred to is the one suggested by the FAO. Characterized as a "systemic concept", fisheries governance relevantly illustrates the encompassing nature of governance and the position of the law as one of its components. The definition of the FAO in fact indicates that fisheries governance is characterized by:

- guiding principles and goals, both conceptual and operational;

- the ways and means of organization and coordination;

- the infrastructure of socio-political, economic and legal institutions and instruments;

- the nature and modus operandi of the processes;

- the actors and their roles;

- the policies, plans and measures that are produced; as well as

- the outcomes of the exercise. ${ }^{114}$

Furthermore, the FAO also recognizes the multiscale nature of fisheries governance as well as the interaction of public and private actors.

Another study has identified four dimensions of fisheries governance: research, monitoring and assessment; management response to stock status; enforcement of management measures; and social and economic aspects. ${ }^{115}$ This shows once again the intertwinement between fisheries governance and management.

113 Ratana Chuenpagdee \& Rashid Sumaila, "Fisheries governance and governability" (2011) 11:3 Fish and Fisheries 234 at 234.

114 FAO, "Fisheries and aquaculture governance", online: <http://www.fao.org/fishery/governance/en>.

115 Ocean Propserity Roadmap, "Governance \& Marine Fisheries. Comparing across countries and stocks", online: <https://www.oceanprosperityroadmap.org/wp-content/uploads/2015/05/5.-Fisheries- 
These understandings, although including most of the components of governance illustrated in Figure 3 above, remains intrinsically sectoral. Further, while not necessarily excluding the reliance on more environmentally oriented forms of fisheries governance, ${ }^{116}$ its focus is primarily on "the exercise of economic, political and administrative authority". ${ }^{117}$ In order for fisheries governance to operationalize its encompassing nature while fully recognizing the dynamic and complex system that high seas fisheries represent and the multiple objectives they aim to achieve, this study submits that fisheries governance should also be assessed in light of environmental and oceans governance. In fact, environmental governance, which targets the interactions between humans and the environment, and oceans governance, which suggests an interconnected approach to oceans management with a focus on environmental protection, helps position fish stocks as one component of the environment, and fisheries as one of the multiple oceans uses.

Understanding the encompassing nature of fisheries governance in a way that also accommodates an intertwinement of issues can indeed be the basis for an even more adaptive approach to operationalizing existing fisheries-related obligations. This can in turn inform potential alternative mechanisms that integrate high seas fisheries management with marine environmental protection.

\section{A FRAMEWORK FOR ASSESSING THE LAW'S ADAPTIVE CAPACITY IN OPERATIONALIZING EXISTING OBLIGATIONS}

Relying on a governance perspective allows us to extend our thinking in terms of potential alternatives to nudging actors' behaviours and, hopefully, improving implementation, enforcement and compliance. This might be useful for exploring solutions to the shortcomings of the legal regime in terms of compliance, collaboration and coordination, identified previously as the main challenges to recognizing interconnectedness between high seas fisheries and marine environmental protection and to achieving sustainability performance. ${ }^{118}$

International and high seas fisheries law has proved successful in addressing other shortcomings in the past. For example, a growing knowledge of the interconnectedness between fisheries and ecosystems has been reflected in the development of a fisheries management objective rooted in an ecosystem approach and, subsequently, in the inclusion of this objective in several legally and nonlegally binding instruments. ${ }^{119}$ Similarly, the expansion of the jurisdiction of port States to fight IUU fishing, through the PSMA inter alia, has shown the recognition

Governance_survey_052715.pdf>.

$116 \mathrm{FAO}$, supra note 114 .

117 Ibid.

118 These main challenges are discussed generally in the chapter 5 above.

119 For a discussion on the instruments which have included an ecosystem approach to fisheries, see, generally, chapter 2 above. For the evolution of objectives for fisheries management, see chapter 3 section 4.1 above. 
of the role that non flag-States can play regarding implementation and enforcement related to actions on the high seas. ${ }^{120}$ These examples show the law's normative and regulatory adaptive capacity.

Evolution and adaptability at the level of instruments and norms, despite being part and parcel of the legal framework, has however demonstrated not to be sufficient to deliver in terms of improving compliance, collaboration and coordination. On that aspect of the operationalization of the legal framework, it is therefore submitted that the law's adaptive capacity has the potential of being strengthened by governance to, ultimately, ensure the resilience of the legal regime and, consequently, of the socioecological system it oversees. However, how can the adaptive capacity of the law be assessed? And how can the common elements of governance identified above help in developing this adaptive capacity towards more effective operationalization of existing obligations, towards strengthening cooperation and coordination more specifically?

In an attempt to answer these questions, the present section looks at two models found in the literature for understanding what an "adaptive capacity" of a legal regime means (3.1). It is against these models that the adaptive character of international and high seas fisheries law is assessed in the following chapter. The section then highlights two characteristics, rooted in the broader and more dynamic perspective offered by governance, that must underlie adaptive strategies for the law to become more responsive in terms of collaboration and coordination (3.2). By establishing a framework to test the adaptability of international and high seas fisheries law and, subsequently, suggest possible developments, the discussion conducted in the present section triggers a reflection and creates a path for concrete policy action in order to improve the compatibility between the legal regime for high seas fisheries and sustainability.

\subsection{A framework for assessing the adaptive capacity of the law}

A tentative framework identifying the different components for assessing the adaptive capacity of a legal regime is rooted in common variables identified in the literature on adaptiveness. First, it relies on an iterative decision-making process ${ }^{121}$ as opposed to one-time decision-making. ${ }^{122}$ Second, adaptiveness is also "built around a continuous process of monitoring the effects of decisions and adjusting

120 For a discussion on the PSMA, see chapter 2 section 3.1.7.2 above.

121 Holly Doremus, "Adaptive Management as an Information Problem" (2011) 89 North Carolina Law Review 1455-1498, cited in Nigel Bankes, "Adaptive management, Adaptive governance and the role of law: a literature review" (2018) (unpublished, on file with author).

122 Wiersema, supra note 111 at 393. 
decisions accordingly"; ${ }^{123}$ hence, it commits to learning over time. ${ }^{124}$ Furthermore, Ebbesson lists four criteria that help socio-ecological systems and common pool resources to face changes: ${ }^{125}$

1. Flexibility in social systems and institutions to deal with changes.

2. Openness of institutions so as to provide for broad participation, not least in local decision-making and administration.

3. Effectiveness of multilevel governance.

4. Social structures that promote learning and adaptability without limiting the options for future development.

The first criterion refers to flexibility both in decision-making procedures (e.g. through permits and authorizations which can be reviewed periodically, or through general review procedures) and in the nature of rules and principles forming the regime. ${ }^{126}$ The second and third criteria refer to the participation of all ranges of actors, their effective involvement at different levels (i.e. local, national, regional, global), and "the use of different forms of collaboration and networking". ${ }^{127}$ The last element denotes the "open-minded" nature of the processual transformation.

However, what does it mean for the law to be adaptive, and how is adaptive capacity assessed? Although there are abundant assessment criteria for adaptive strategies in the fields of policy and management, the legal literature that has attempted to transpose factors and conditions for adaptiveness into an assessment framework of the law's adaptive capacity is scarce. To the present author's knowledge, only two studies have done so in the fields of environmental law and the law related to water/ oceans.

First, Arnold and Gunderson have developed a set of four features - goals, structure, methods and processes - that describe a legal system that would be adaptive and resilient. This constitutes an attempt at "situat[ing] legal reform in the empirical context of how social forces and natural forces interact with one another". ${ }^{128}$ What the authors seek to do is to develop tools for assessing the "the adaptive capacity of

123 J.B. Ruhl, "Regulation by adaptive management - Is it Possible?” (2005) 7:1 Minnesota Journal of Law, Science \& Technology 21-57, cited in Bankes, supra note 121.

124 Emily Boyd \& Carl Folke, "Conclusions: Adapting Institutions and Resilience" in Emily Boyde \& Carl Folke (eds), Adapting Institutions: Governance, Complexity and Social-Ecological Resilience (Cambridge: Cambridge University Press, 2011) 264-280 at 268.

125 Ebbesson, supra note 2 at 414 (emphasis in original).

126 Ibid at 417-418.

127 Gunnar Baldwin Jr. et al, "International Compliance and Enforcement Networks: The Critical Role of Collaboration in Environmental Protection" in Grant Pink \& Rob White (eds), Environmental Crime and Collaborative State Intervention (London: Palgrave Macmillan, 2016) 21-38 at 31.

128 Craig Anthony Arnold \& Lance H. Gunderson, "Adaptive Law and Resilience" (2013) 43:5 Environmental Law Reporter News \& Analysis 10426-10443 at 10428 [Arnold \& Gunderson, "Adaptive Law and Resilience"]. A similar analysis is conducted by the same authors in "Adaptive Law" in Ahjond S. Garmestani \& Craig R. Allen (eds), Social-Ecological Resilience and Law (New York: Columbia University Press, 2014) 317-364. 
environmental law" more systematically and "not merely [through] the occasional use of specific adaptive methods". ${ }^{129}$ Developed in the context of environmental law in the United States, these features are relevant beyond the American context, because they are linked to the adaptive capacity for complex socio-ecological systems, which are also found - even more so - at the international level. The four features described by Arnold and Gunderson are summarized in Table 3 below. ${ }^{130}$

Table 3: Comparison of features of maladaptive law and adaptive law (Arnold \& Gunderson, 2013)

\begin{tabular}{|l|l|l|}
\hline Feature & \multicolumn{1}{|c|}{ Maladaptive Law } & \multicolumn{1}{|c|}{ Adaptive Law } \\
\hline Goals & $\begin{array}{l}\text { Legal regimes aim to advance particular } \\
\text { stability of single systems. Current } \\
\text { regimes focus primarily on political } \\
\text { and economic goals. Alternative } \\
\text { (reform) regimes focus primarily on } \\
\text { ecological goals. }\end{array}$ & $\begin{array}{l}\text { Legal regimes aim for multiple forms of } \\
\text { resilience: the resilience and adaptive } \\
\text { capacity of both social and ecological } \\
\text { systems, including constituent } \\
\text { subsystems, such as institutions and } \\
\text { communities. }\end{array}$ \\
\hline Structure & $\begin{array}{l}\text { Law is monocentric utilizing } \\
\text { fragmented and unimodal responses to } \\
\text { problems. }\end{array}$ & $\begin{array}{l}\text { Law is polycentric, utilizing } \\
\text { multidimensional and multiscalar } \\
\text { responses to problems that are loosely } \\
\text { integrated. }\end{array}$ \\
\hline Methods & $\begin{array}{l}\text { Law controls society through rules, } \\
\text { limits on action and authority, demand } \\
\text { for certainty, and legal abstractions that } \\
\text { resist change. }\end{array}$ & $\begin{array}{l}\text { Law facilitates social and ecological } \\
\text { resilience through moderate/ } \\
\text { evolutionary adaptation to } \\
\text { changing conditions, context- } \\
\text { regarding standards, tolerance for } \\
\text { uncertainty, and flexible discretionary } \\
\text { decisionmaking. }\end{array}$ \\
\hline Processes & $\begin{array}{l}\text { Law presumes rational, linear } \\
\text { decisionmaking and implementation } \\
\text { processes by a single authority and the } \\
\text { centrality of law to the ordering and } \\
\text { management of human affairs. }\end{array}$ & $\begin{array}{l}\text { Law recognizes and embraces iterative } \\
\text { processes with feedback loops among } \\
\text { multiple participants, limits to human } \\
\text { and organizational rationality, and the } \\
\text { effects of social and ecological forces on } \\
\text { the ordering and management of human } \\
\text { affairs, and accountability mechanisms } \\
\text { for the conservation of capital. }\end{array}$ \\
\hline
\end{tabular}

In terms of goals, a legal regime should aim to ensure the resilience of all spheres of a socio-ecological system (i.e. the social and economic spheres, as well as the environmental sphere), and find a balance between objectives that target one or the other. ${ }^{131}$ Structures loosely refers to sources of authority and institutions, as well as legal instruments and policies. ${ }^{132}$ Adaptive structures should rely on polycentricity, multiscalarity and a multiplicity of actors. Methods are mostly linked to the establishment of standards, guidelines and decision-making that ensure an

129 Arnold \& Gunderson, "Adaptive Law and Resilience", supra note 128 at 10426.

130 Ibid at 10429.

131 Ibid at 10428-10429.

132 Ibid at 10432. 
adaptation to changing conditions. ${ }^{133}$ Finally, processes refer to the steps taken for a measure, obligation or management plan to be set up, and such processes must allow for iteration and new input coming from feedback loops. ${ }^{134}$

A second framework by Soininen and Platjouw, which builds on the features highlighted by Arnold and Gunderson, synthesizes the main observations and requirements found in the literature for adaptiveness, and transposes them to the legal sphere by focusing on criteria for assessing the adaptive capacity of legal instruments more specifically. These criteria cover five aspects of legal instruments: the substance of the law, procedure, the choice of regulatory instruments, enforcement measures, and the cross-cutting element of coherence. ${ }^{135}$ The criteria are summarized in Figure 4 below.

Figure 4: Criteria for analysing resilience and adaptive capacity of legal instruments (Soininen \& Platjouw, 2019)

\begin{tabular}{|c|c|}
\hline $\begin{array}{l}\text { Substance } \\
\text { 1. Plurality if goals, or goals of narrow scope } \\
\text { coupled with exemptions; } \\
\text { 2. Discretion to adjust management in light } \\
\text { of new scientific knowledge. }\end{array}$ & $\begin{array}{l}\text { Procedure } \\
\text { 1. Increasing knowledge; } \\
\text { 2. Iteration; } \\
\text { 3. Crossing sectoral, jurisdictional and } \\
\text { public/private boundaries; } \\
\text { 4. Access to information and Justice. }\end{array}$ \\
\hline $\begin{array}{r}\text { Reg } \\
\text { resilie } \\
\text { ada }\end{array}$ & $\begin{array}{l}\text { atory } \\
\text { ce and } \\
\text { ivity }\end{array}$ \\
\hline $\begin{array}{l}\text { Instrument choice } \\
\text { 1. Direct regulation coupled with economic } \\
\text { and voluntary instruments. }\end{array}$ & $\begin{array}{l}\text { Enforcement } \\
\text { 1. Legally binding and specific obligations to } \\
\text { archieve procedural and substantive goals; } \\
\text { 2. Time limits for goals; } \\
\text { 3. Sanctioning of non-compliance. }\end{array}$ \\
\hline
\end{tabular}

First, in terms of the substance of the law, adaptive strategies would include goals, which establish a clear objective whilst leaving discretion on how to reach such an objective and to adjust in the light of new knowledge. ${ }^{136}$ Second, procedural aspects of the law should ensure iteration, cross-sectoral approaches, and an increased access to knowledge and information. ${ }^{137}$ Third, the choice of regulatory instruments

133 Ibid at 10436.

134 Ibid at 10438 .

135 Niko Soininen \& Froukje Maria Platjouw, "Resilience and Adaptive Capacity of Aquatic Environmental Law in the EU: An Evaluation and Comparison of the WFD, MSFD, and MSPD" in David Langlet \& Rosemary Rayfuse (eds) The Ecosystem Approach in Ocean Planning and Governance (Leiden: Brill Nijhoff, 2019) 17-79 at 26-30.

136 Ibid at 26.

137 Ibid at 26-27. 
should be varied, ranging from direct regulation (either legally or non-legally binding) to instruments not originating from traditional sources of authority (i.e. not from States) or even voluntary instruments. ${ }^{138}$ Fourth, enforcement measures should ensure the effectiveness of substantive and procedural rules. ${ }^{139}$ Finally, coherence between all instruments in the same sector or region ensures that adaptation does not only happen at the level of single instruments, but also at the level of all instruments within a regime. ${ }^{140}$

Unfortunately, this framework is not particularly enlightening in terms of adaptability in enforcement; although it mentions that enforcement should ensure that substantive and procedural goals are achieved, the present author does not believe that it specifically targets issues of adaptiveness. In fact, the enforcement criterion merely repeats what enforcement obligations should be about, but does not offer any additional suggestions on how to ensure adaptiveness through enforcement or adaptiveness in enforcement. Nonetheless, the framework remains particularly informative with regard to the adaptiveness of specific procedural aspects, as well as choice of instruments, which are very indicative in terms of alternatives that can be found to strengthen cooperation and coordination, notably through decisionmaking, sharing of knowledge, and cross-sectoral and multi-scalar undertakings.

These two frameworks remain abstract, as they represent "both a set of principles for a more resilient legal system and an emergent phenomenon as the legal system evolves to adapt to changing conditions" ${ }^{141}$ However, despite the fact that they have not yet been widely tested, they allow us to identify common elements of what the inclusion of adaptive strategies within a legal regime can look like. First, the substance of a legal regime or instrument should be based on goals ${ }^{142}$ that leave enough discretion for actors to adopt measures to fulfil these goals in consideration of their capacities and resources and of new knowledge. These goals or objectives should target the adaptive capacity of both the social and the ecological systems, which is referred to as poly-resilience. ${ }^{143}$ If legal changes are made to accommodate one system only, unintended consequences might be felt in the other system, which could even lead the changes to achieve opposite goals from what was expected in the first place. For example, if goals of environmental/biodiversity protection and conservation only are sought, without ensuring their integration by the institutions of the social system, such goals might face opposition and, eventually, not be implemented. ${ }^{144}$ Furthermore, the adaptive capacity of the law to address socioecological systems should not be limited to the regime of environmental law, but should also apply to all related regimes, e.g. "property law, energy law, land use law,

138 Ibid at 27.

139 Ibid at 27-28.

140 Ibid at 28.

141 Arnold \& Gunderson, "Adaptive Law and Resilience", supra note 128 at 10442.

142 Soininen \& Platjouw, supra note 135 at 26.

143 Arnold \& Gunderson, "Adaptive Law and Resilience", supra note 128 at 10429

144 Ibid at 10428-10429; Soininen \& Platjouw, supra note 135 at 26. 
water law, agricultural law, disaster law, constitutional law, business law, tort law, international law, human rights law, and so forth". ${ }^{145}$ Finally, poly-resilience can be supported by laws producing co-benefits, e.g. a rule that protects the environment, and such protection turns out to trigger economic benefits. Adaptive law must therefore facilitate the adoption and implementation of such co-benefits.

Second, adaptive strategies rely on a polycentric structure, ${ }^{146}$ meaning that "there are multiple centers or sources of authority". ${ }^{147}$ This can for example refer to a variety in the choice of instruments (i.e. multimodal), ${ }^{148}$ and also to cross-sectoral and multiscalar procedural responses. It is therefore important to rely on broad sources of authority: from within governmental spheres (State, regional, local, etc.), as well as outside (i.e. private sector and civil society). ${ }^{149}$ Diversifying and multiplying these sources of authority and the connections between them allows for a diversification of risks and a diversification of responses. It also protects the whole system from a crisis of legitimacy if only one source of authority is affected. In situations where diverse values, cultures, norms and politics coexist - a situation particularly true at the international level, as well as with high seas fisheries - polycentricity might also be a way to connect different perspectives.

Finally, adaptive strategies require iteration. Since complex systems are non-linear, applying linear processes (i.e. identifying the problem, assessing the problem, planning the response, making a decision as to this response, and implementing $\mathrm{it}^{150}$ ) can end up being inadequate. This is why iterative processes, characterized by repetitive or reviewed decision-making, as well as feedback loops (i.e. using the output obtained from a system to influence the input that is coming back to that same system) allow for new knowledge to be included in the decision-making process. Access to and sharing of this knowledge is therefore necessary in order for iteration to be meaningful. ${ }^{151}$

\subsection{Selected governance components as building blocks for adaptive strategies targeting cooperation and coordination}

The discussion conducted in the previous section has mapped out frameworks currently presented in the (legal) literature to test the adaptive capacity of legal regimes and legal instruments. The common elements identified illustrate the overlap between adaptive strategies and the broad and dynamic perspective suggested by governance, found in the definition and analysis of the concept conducted in previous sections. New forms of regulation, a multiplicity of actors,

\footnotetext{
$145 \mathrm{Ibid}$ at 10431.

146 Arnold \& Gunderson, "Adaptive Law and Resilience”, supra note 128 at 10432-10436.

147 Ibid at 10433 .

148 Soininen \& Platjouw, supra note 135 at 27.

149 Ibid.

150 Arnold \& Gunderson, "Adaptive Law and Resilience", supra note 128 at 10442.

151 Soininen \& Platjouw, supra note 135 at 26-27.
} 
and the reliance on collaborations have distinguished governance from traditional legal and regulatory mechanisms, and it can be concluded from the framework above that these elements are also what adaptive strategies are built on.

As a matter of fact, most of these elements are not unfamiliar to the international legal field, and they characterize, to some extent, the structure of many of its regimes, including environmental law, law of the sea and international fisheries law. However, the way in which these regimes have been shaped through reliance on these elements sheds light on how international fisheries law could further be developed and adapted around these indicators and on how they could be used to steer actors' behaviours within the regime.

The present section looks into two governance-related components on which adaptive strategies within legal discourse should rely to specifically target shortcomings in terms of compliance, and strengthen cooperation and coordination: polycentricity (3.2.1) and networks (3.2.2). Although these are not the only components discussed in adaptive strategies, they have great potential to provide answers to the crosscutting and transboundary realities currently characterizing international and high seas fisheries law. ${ }^{152}$ These elements, we believe, target the structure of the regime and, more importantly, the behaviour of actors within and across regimes. Furthermore, while looking at each of these components allows us to understand their respective characteristics, assessing them together also allows us to explore the benefits that could stem from their interactions.

\subsubsection{Polycentricity}

Polycentricity refers to the structure of a system, based in multiple centres of agency and authority ${ }^{153}$ rather than one centralized body. ${ }^{154}$ These authorities overlap, but are also complementary; ${ }^{155}$ in case one authority cannot offer a response in a given situation/moment, the response can be ensured by another authority, which takes over. Polycentricity does not reject authority in itself, but moves away from "preselected and rigid legal determinations about which entity will have governance authority". ${ }^{156}$

152 See, e.g., Daniel DeCaro et al, "Legal and Institutional Foundations of Adaptive Environmental Governance" (2017) 22:1 Ecology and Society article 32.

153 Ibid.

154 See, generally, Kristine Dalaker Kraabel, "International Law and Areas Beyond National Jurisdiction: Imagining a Polycentric Approach to Institutional Governance for Marine Areas Beyond National Jurisdiction" in Vito De Lucia, Lan Ngoc Nguyen \& Alex Oude Elferink (eds), International Law and Marine Areas beyond National Jurisdiction: Current Status and Future Trends (forthcoming), referring to Elinor Ostrom, "Beyond Markets and States: Polycentric Governance of Complex Economic Systems" (2010) 100:3 The American Economic Review 641-672 [Ostrom, "Beyond Markets and States"].

155 Cosens et al, supra note 7 at 33.

156 Arnold \& Gunderson, “Adaptive Law and Resilience”, supra note 128 at 10435. 
The importance of polycentric approaches for the management of common pool resources was recognized in the seminal work of Ostrom, who developed a model in response to Harden's two approaches to manage common pool resources, i.e. private property or regulation. ${ }^{157}$ Ostrom in fact submits that polycentricity stems from successful examples of long-term sustainable resources management that did not fall under the private property or public regulation categories. ${ }^{158}$ Polycentricity is therefore a "hybrid problem-solving" structure where different actors collaborate "to address certain kinds of highly complex problems that appear to be beyond the capacity of sovereign states alone to solve". ${ }^{159}$ It recognizes "that regulation will play a critical role but will need to be structurally adaptable". ${ }^{160}$

Polycentricity relies on responses based on three characteristics: multimodality, multiscalarity and a multiplicity of actors. Multimodal responses refer to the use of multiple modes or methods for achieving a certain objective. In the face of a complex problem, multimodality offers a tool-box of different instruments and methods that can be used. In the legal sphere, this translates into law-making and law-enforcing mechanisms that draw from a variety of sources, instruments and methods. It has been argued that international law-making is already based on such a variety of instruments. However, the present author points out that, although it is true that the use of soft-law instruments and principles is growing, such instruments do not have a legal status of their own; they obtain such legal status only if they are included in the text of a treaty or are recognized by custom. ${ }^{161}$ This limits the use and application, in international law, of instruments that have not officially entered the realm of treaties or customs, but that could be well suited to address the specificities of complex socio-ecological systems.

The second characteristic, multiscalarity, relies on organizations at all institutional levels (local, regional, national, global) and on their horizontal and vertical interactions. ${ }^{162}$ Multiscalarity suggests keeping "the authority for decision-making

157 These two approaches to common-pool resources managements are discussed in chapter 2 section 2.3 above.

158 Elinor Ostrom, “A Long Polycentric Journey" (2010) 13:1 Annual Review of Political Science 1-23 at 1, cited in Dalaker Kraabel, supra note 154. Dalaker Kraabel further explains that Ostrom's work also suggests that a polycentric governance that ensures sustainability rests on robust institutions. Based on the performance of different institutions in sustainably managing common-pool resources in different fields, Ostrom developed a set of design principles, or best practices, that characterize robust institutions. These principles were further developed by Michael Cox, Gwen Arnold \& Sergio Villamayor Tomas, "A Review of Design Principles for Community-based Natural Resource Management" (2010) 15:4 Ecology and Society article 38, and adopted by Ostrom, see Ostrom, "Beyond Markets and States", supra note 154 at 653. These design principles are: 1) clearly defined user and resources boundaries, 2) congruence with local conditions, 3) collective-choice arrangements, 4) monitoring the resources and users; 5) graduated sanctions, 6) conflict resolution mechanisms, 7) rights to organize, and 8) nested enterprises.

159 Bradley C. Karkkainen, "Post-Sovereign Environmental Governance" (2004) 4:1 Global Environmental Politics 72-96 at 74, cited in Dalaker Kraabel, supra note 154.

160 Arnold \& Gunderson, "Adaptive Law and Resilience", supra note 128 at 10436.

161 Beyerlin, supra note 71 at 447.

162 For a brief overview of the necessity of multi-level responses to complex issues such as the interactions between the ecological implications and management implications related to the exploitation of marine 
as close to the [scale of the resource or problem] as possible while still operating within a larger [...] framework that facilitates management implementation and achievement of long-term goals". ${ }^{163}$ This is referred to by Ostrom as "nested enterprises", i.e. where small-scale local organizations are part of a large-scale system, "allowing for systems to exist at multiple levels, with some autonomy at each level". ${ }^{164}$ This allows responses to address local specificities, while an overarching organization ensures monitoring, impose sanctions, share information, etc. ${ }^{165}$ Hence, one can turn not only to a variety of modes of responses, but also some that are undertaken at several levels. ${ }^{166}$

Multimodal and multiscalar responses lead to the third characteristic, the multiplicity of actors. Brunée and Toope have compared this multiplicity with animals in the jungle: "there is law in the jungle. It is made through the interactions of a variety of actors, including elites, the media, NGOs and 'ordinary' citizens. States - though still dominant - are not the only animals in the jungle, and the law of the jungle is not made only by the strongest: nor is it broken with impunity". 167 The interaction between the actors is also necessary to ensure communication within levels of authority (e.g. national, global), and also between those levels. ${ }^{168}$ These relationships are also based on reciprocity, which can exist when actors "collaborate to build shared understandings". ${ }^{169}$ The involvement of all relevant actors also contributes to the transparency and openness of the process and, consequently, increases its legitimacy.

As underlined by Dalaker Kraabel, although "polycentric systems often appear to be overly 'complex, chaotic and fragmented', they may be more ordered than they appear, allowing for mutual monitoring and adaptation over time". ${ }^{170}$ Polycentricity, however, does not give an answer to concerns often raised in the legal realm about duplication of instruments and structures. This is why polycentricity needs

living resources, see Fikret Berkes et al, “Globalization, Roving Bandits, and Marine Resources” (2006) 311 Science 1557-1558.

163 Cosens et al, supra note 7 at 33.

164 Dalaker Kraabel, supra note 154, referring to, e.g., David Sloan Wilson, Elinor Ostrom \& Michael E. Cox, "Generalizing the Core Designs Principles for the Efficacy of Groups" (2013) 90S Journal of Economic Behavior \& Organization 21-32; Elinor Ostrom, "Institutional Analysis, Design Principles, and Threats to Sustainable Community Governance and Management of Commons" in Erling Berge \& Nils Christian Stenseth (eds), Law and the Governance of Renewable Resources: Studies from Northern Europe and Africa (Manilla: ICS Press, 1998) 34-51 at 39; and Elinor Ostrom et al, The Future of the Commons. Beyond Market Failure and Government Regulation (London: The Institute of Economic Affairs, 2012) at 82.

165 See, e.g., Robin Mahon \& Lucia Fanning, "Regional Ocean Governance: Integrating and Coordinating Mechanisms for Polycentric Systems” (2019) 107 Marine Policy article 103589 at 3. See also Dalaker Kraabel, supra note 154, referring to, e.g., Cox, Arnold \& Villamayor Tomas, supra note 158; Elinor Ostrom, "Crossing the Great Divide: Coproduction, Synergy, and Development" (1996) 224:6 World Development 1073-1087 at 1082; and Elinor Ostrom, Understanding Institutional Diversity (Princeton: Princeton University Press, 2005) at 278.

166 The "levels" are also referred to as "layers", see Techera \& Klein, supra note 1 at 87.

167 Brunée \& Toope, supra note 78 at 5.

168 Techera \& Klein, supra note 1 at 224.

169 Brunée \& Toope, supra note 78 at 7.

170 Dalaker Kraabel, supra note 154, referring to Mahon \& Fanning, supra note 165 at 3. 
to be seen together with the element of networks (see below). This reiterates the importance of not only the variety of instruments, methods and actors, but also the cooperation that is developed between them, as polycentricity is also about enhancing the connections between the various forms of authority. ${ }^{171}$ This helps to reach harmonisation, ${ }^{172}$ a useful tool in the face of fragmentation.

\subsubsection{Networks}

As underlined previously, it is not only the multiplicity of instruments, methods, modesand actors that is of relevance, butalso the relationships and interconnectedness between them. Since " $[\mathrm{t}]$ he key unit of analysis is [...] the links that hold the system together", ${ }^{173}$ studying these relationships and the interconnectedness between the elements is important, and is done here through the perspective of networks. The present author believes that networks put the emphasis on such relationships and, above all, on what comes out of these relationships. Understanding networks has also been identified as being essential for the study of the adaptive capacity of structures. ${ }^{174}$

Networks are formed by individual actors or elements - what are referred to as nodes - which have connections to one another. Studying networks implies looking not only at these nodes, but also at the relationships that link them, at the patterns of these relationships. ${ }^{175}$ This change of focus, from the study of the characteristics of individual nodes to the study of relations between nodes, is described by Kenis:

connections that are linked together form a field or system of interdependencies that is called a network. This gives network theorizing a holistic or contextualized flavor in which explanations are sought not only from the [nodes] themselves but in their network environments as well; this process may include elements which are unknown to the [nodes] but are nonetheless linked to the [node] through these connections. ${ }^{176}$

171 For example, Mahon \& Fanning have analysed the regional integration and coordination of 20 regional oceans regimes (mostly RSPs) according to different categories of polycentric coordination ranging from fragmented polycentricity (i.e. minimal interactions between centres of authority) to functioning polycentricity (i.e. functioning codesigned integration mechanisms between centres of authority), see Mahon \& Fanning, supra note 165 generally, but in particular at 4 .

172 Techera \& Klein, supra note 1 at 83-84.

173 Rakhyun E. Kim \& Brendan Mackay, "International Environmental Law as a Complex Adaptive System" (2014) 14 International Environmental Agreements 5-24 at 7.

174 Boyd \& Folke, supra note 124 at 275.

175 Patrick Kenis, "Network" in Christopher Ansell \& Jacob Torfing (eds) Handbook on Theories of Governance (Cheltenham: Edward Edgar, 2016) 149-157 at 149; Linton C. Freeman, The Development of Social Network Analysis. A Study in the Sociology of Science (Vancouver: Empirical Press, 2004) at 2; Frijtof Capra \& Ugo Mattei, The Ecology of Law: Toward a Legal System in Tune with Nature and Community (Oakland, CA: Berrett-Koehler Publishers, 2015) at 4.

176 Kenis, supra note 175 at $150,152$. 
One must also determine what are the nodes and the links being analysed. ${ }^{177}$ In the present study, the nodes are actors as well as what they produce (e.g. instruments, agreements, understandings, and also institutions). As for links, we look at the relationships between actors, between products, and between actors and products (who adheres to what, who implements what, who enforces what, who complies with what, etc).

Although understanding who/what the nodes are is an important step, the main feature of a network analysis lies in the importance of the way in which these nodes interact. ${ }^{178}$ Consequently, the study of networks is based on two propositions. The first proposition suggests that the behaviours, interests and motivations of individual actors are understood through the role they play in the networks of which they are a part. ${ }^{179}$ The second proposition suggests that a network analysis looks at the development of the networks themselves, at the way they function and the effects they produce, ${ }^{180}$ at the interactions, ${ }^{181}$ the interactivity, i.e. how the "operation of each affects others' performance", ${ }^{182}$ and the mutual dependence ${ }^{183}$ of nodes. Ensuring communications between nodes, at different levels and scales of the network, is also essential in these interactions. ${ }^{184}$ Simply put, looking at how networks evolve through these interactions is like looking at the way in which a whole is more than the mere sum of the parts composing it.

Based on these two propositions, ensuring that networks are considered and relied upon is a way of "amplify[ing] the operationalization and understanding of the governance approach". ${ }^{185}$ As a matter of fact, when talking about resources to which all are entitled - in our case fish stocks in $\mathrm{ABNJ}$ - and when looking at management measures for such resources, the governance and management of shared resources "would [certainly] benefit from actors agreeing on common rules and practices, coordinating usage, engaging in conflict resolution, negotiating various tradeoffs,

177 See, e.g. Oscar Widerberg, "Mapping Institutions and Actors in Global Climate Governance: A Network Approach" (Presented at the General Conference of the European Consortium for Political Research, Glasgow, 3-6 September 2014) at 6-8; James Hollway \& Johan Koskinen, "Multilevel Embeddedness: The Case of Global Fisheries Governance Complex" (2016) 44 Social Networks 281-294 at 281-282.

178 Kenis, supra 175 at 150, referring to Freeman, supra note 175 at 3.

179 Allen Barton, "Bringing society back in: Survey research and macro-methodology" (1968) 12:2 American Behavioral Scientist 1-9 at 1, cited in Freeman, supra note 175 at 1.

180 Kenis, supra 175 at 150, 152; Freeman, supra note 175 at 2.

181 Brunée \& Toope, supra note 78 at 13-14. The argument of these authors is based in the constructivist theory of international relations.

182 Oran Young, "Building an international regime complex for the Arctic: current status and next steps" (2012) 2:2 The Polar Journal 391-407 at 394.

183 Lori Ridgeway, "Global level institutions and processes: Frameworks for understanding critical roles and foundations of cooperation and integration" in Serge Garcia, Jake Rice \& Anthony Charles (eds), Governance of marine fisheries and biodiversity conservation: Interaction and Coevolution (Hoboken: Wiley, 2014) 139-147 at 140.

184 Techera \& Klein, supra note 1 at 224 and 276-277.

185 Kenis, supra 175 at 150, 156. 
sharing information, and building common knowledge". ${ }^{186}$ Yet such collaborative management is hard to achieve, but understanding networks and relying on them can improve this collaboration, by contributing to the diffusion and sharing of knowledge and information, by allocating the appropriate resources for governance purposes, by engaging in monitoring actions, and even by working towards conflict resolution. ${ }^{187}$

Bodin and Crona have conducted an analysis of the role of networks for the governance and management of natural resources, which is relevant for the present study. To put it simply, they have looked at the way networks can be used to manage and allocate resources. They submit that the main structural characteristics of networks - the types of relations involved, and the content of these relations influence social processes or, in other words, the behaviours of actors and their interrelations. ${ }^{188}$ The presence of sub-groups and the way they relate to one another can be beneficial for the sharing of information and knowledge within a group, the development of diversity when shared among groups, as well as the building of trust within and among groups. ${ }^{189}$ Finally, the level of centralization of a network and the position which actors occupy in it also influence governance measures and their outcomes. For example, centralization might not be appropriate for complex tasks, including the management and governance of natural resources.

Through the collaborations networks bring forward, they "facilitate the development of common norms and values", which in turn "can trigger some change of behavior" and influence governance strategies. ${ }^{190}$ The capacity of networks to evolve over time is beneficial in the face of changes, and brings forward the necessary adaptability ${ }^{191}$ "for analyzing a future which is 'fragmented, distributed or constrained". ${ }^{192}$ And because of the general nature of its features, the network approach has been applied broadly, across disciplines. ${ }^{193}$ As the legal, regulatory and implementation framework for fisheries in $\mathrm{ABNJ}$ is characterized by fragmentation and by its link with other fields (e.g. biology, economics, policy, etc.), a network approach is therefore considered a relevant source of alternative input for more adaptiveness in the legal regime for international fisheries.

\footnotetext{
186 Orjan Bodin \& Beatrice Crona, “The Role of Social Networks in Natural Resource Governance: What Relational Patterns Make a Difference?” (2009) 19 Marine Policy 366-374 at 366.

187 Ibid at 367.

188 Ibid.

189 Ibid at 368 and 372.

190 Ibid at 372.

191 Ibid.

192 Kenis, supra note 175 at 156.

193 Freeman, supra note 175 at 5-6.
} 


\section{CONCLUSION: COMPLEMENTING THE LAW AS A TOOL FOR SOCIAL CHANGE}

International fisheries law can be characterized as a complex socio-ecological system. The wide variety of actors, instruments, mechanisms and structures that encompass legal and scientific, and also policy, economic and social components, raise the threshold of flexibility needed for the legal regime for high seas fisheries to ensure sustainability performance and the promotion of the necessary interconnectedness between fishing activities on the high seas and the protection of the marine environment. The law ensures predictability and stability, by bringing into the equation norms, rules and principles that inform actors about the conduct they should adopt in order to fulfil obligations. Yet, the law is "merely one instrument among others", 194 and law alone is not enough to ensure that actors feel accountable for the implementation and enforcement of, and compliance with, these rules.

The analysis of the concept of governance - the what of governance - conducted in this chapter has allowed us to see how institutions, actors, instruments and structures are considered and understood from a broader, more dynamic governance perspective. This analysis positioned the law within a broader set of elements performing multiple social functions. The relationship between (international) law and governance was then assessed in the context of environmental, oceans and fisheries governance. Oceans governance has been especially informative in showing the practicality of governance perspectives for the oceans, by linking governance to the improvement of oceans management and, consequently, offering an outcome-based approach. The analysis of adaptability - the how of governance - has, for its part, shown how governance perspectives have the potential to strengthen the law's adaptive capacity in order to operationalize normative and behavioural changes. It has allowed us to explore a set of tools that, although not necessarily new to international law, have shed light on the importance of relationships and interconnectedness. More specifically, polycentricity and networks are governance components that target shortcomings in operationalizing collaboration and coordination, and represent building blocks of potential alternative mechanisms for improving sustainability performance.

A primary function of the law is to hold actors accountable for their actions, which is one of the main weaknesses of the current regime for international fisheries law. It is submitted that this function can be strengthened through a legal regime with a more adaptive character. As a matter of fact, an adaptive system ensures better accommodation of various interests and, consequently, makes actors feel more accountable to such a regime. A better grasp of interconnectedness allows actors to position themselves within the regime and among other sets of interests. Adaptiveness creates "mechanisms of accountability for the conservation of capital:

194 Techera \& Klein, supra note 1 at 86. 
natural capital, financial capital, human capital, social capital, and political capital", ${ }^{195}$ all of which play a role in socio-ecological systems.

Going beyond traditional legal approaches does not make traditional legal structures irrelevant. In fact, law and governance have "their own distinctive merits", 196 which support their complementarity. In the context of the law of the sea and oceans governance, Takei underlines that, although some functions cannot "be performed by the law of the sea [...] due to the consensual nature of international law", ${ }^{197}$ law remains necessary for providing the juridical framework within which actors find the rules of conduct and common ground for cooperation. ${ }^{198}$ Further, Ebbesson underlines that the law still matters for the questions of "access to justice", as law provides a forum for "members of the public [...] to challenge decisions, acts and omissions by public authorities as well as by private subjects". ${ }^{199}$ This study therefore does not suggest setting the law aside, but rather complementing the law with other mechanisms in order to allow the system to find alternatives to work towards sustainability performance, which it has so far not been fully able to get grips with. And since " $[t]$ he challenge facing high seas fisheries management is a familiar one: governance without government", ${ }^{200}$ an approach rooted in governance might be better suited to address this reality.

Does this focus on governance amount to a reconceptualization of the law, or does it amount to new regulatory and policy frameworks leading to a change in paradigms? It has been suggested that the current anthropocentric framework, i.e. revolving around human activities, should shift towards a nature-centred framework, ${ }^{201}$ so that the particularities of ecological systems are equally seen as priorities. The importance of bridging the gap between humans and nature is also at the heart of the UN Dialogue of the UNGA on Harmony with Nature, which puts forward "perspectives regarding the construction of a new, non-anthropocentric paradigm in which the fundamental basis for right and wrong action concerning the environment is grounded not solely in human concerns". ${ }^{202}$ These ideas overlap with the concept that both ecological and social systems need to be included for systems to be adaptable and resilient.

The present study believes in the necessity of picturing the law within a broader framework, of adapting "le discours entourant le droit et de le replacer dans un

195 Arnold \& Gunderson, "Adaptive Law and Resilience", supra note 128 at 10441.

196 Takei, "A Sketch", supra note 15 at 61.

197 Ibid.

198 Ibid at 62.

199 Ebbesson, supra note 2 at 416.

200 Olav Schram Stokke, "Conclusions" in Olav Schram Stokke (ed), Governing High Seas Fisheries. The Interplay of Global and Regional Regimes (Oxford: Oxford University Press, 2001) 329-360 at 329.

201 Capra \& Mattei, supra note 175 at 3-4. See also Kotzé \& Kim, supra note 50.

202 Harmony with Nature United Nations, "Programme", online: <http://www.harmonywithnatureun.org>. 
plus large contexte théorique et pratique dépassant la cloison disciplinaire". ${ }^{203}$ However, it is not a complete change of paradigms that is sought. On the contrary, it is suggested that there is a lot we can do with what already exists; we simply need to use what already exists in a different way. ${ }^{204}$ What this study puts forward is the need to recognize the limits of international fisheries law in reaching sustainable outcomes, and to suggest ways of improving the situation, by using mechanisms of governance and adaptiveness. Considering such alternatives contributes to a better alignment of the regime with the collective optimum of sustainability performance and, consequently, to ensuring its effectiveness. ${ }^{205}$ This reconceptualization can help to understand the transformations that have happened - or that need to happen to the law because of changes in the state of the structures which the law is trying to regulate (e.g. because of environmental changes, or because of globalization). Furthermore, not only does the reconceptualization show how the structure of the law (characterized by fragmentation and global changes) can be explained, but it suggests ways of enabling the law to adapt. We have most of the tools we need; (oceans) governance gives us a perspective to consider using them differently.

203 "the discourse of the law and to replace it in a larger theoretical and practical context that goes beyond the border of the discipline" (free translation), see Hélène Mayrand, "Déconstruire et repenser les fondements du droit international de l'environnement" (2018) Hors-Série Revue québécoise de droit international 35-59 at 57.

204 Techera \& Klein, supra note 1 at 87, 238.

205 Achieving this collective optimum is one of the dimensions of regime effectiveness described in Arild Underdal, "One Question, Two Answers" in Edward L. Miles et al (eds), Environmental regime effectiveness: confronting theory with evidence (Cambridge, Mass: MIT Press, 2002) 3-45 and identified in the previous chapter as a weakness of the current regime for high seas fisheries, see chapter 5 section 4 above. 



\title{
OPERATIONALIZING THE GOVERNANCE-ADAPTABILITY DIALOGUE FOR HIGH SEAS FISHERIES LAW
}

\author{
Towards a Systematic Reliance upon Cooperation \\ and Coordination
}

\section{INTRODUCTION}

The theoretical framework developed in the previous chapter suggested the adoption of a different lens through which to look at high seas fisheries law, which could subsequently influence the management of fisheries operations in these areas. This lens, rooted in governance, and more specifically its applicability to the oceans, adopts a broader vision on mechanisms for social change that puts the emphasis on components complementary to legal and regulatory norms and processes. This study submits that relying on broader components is not necessarily completely foreign to the construction, implementation and enforcement of such norms. However, by looking at the law through the perspective of governance, by letting the law be permeated by these components, this can strengthen its adaptive capacity to operationalize the existing framework for ultimately improving sustainability performance.

Building on this theoretical framework, and in order to address the challenges that the legal regime for international fisheries currently faces in reaching sustainability, the present chapter embarks on an exploration of how governance may be operationalized to foster adaptability within the legal regime for high seas fisheries and, ultimately, be used by policy-makers and negotiators to improve the processes in which they are involved at the national, regional and multilateral levels. Although better compliance and deliberate cooperation and coordination have already been identified in the literature as areas in which there are problems in need of solutions, ${ }^{1}$

1 See, generally, chapter 5 above, which refers, inter alia, to Kristina Gjerde $e t$ al, "Regulatory and governance gaps in the international regime for the conservation and sustainable use of marine biodiversity in areas beyond national jurisdiction" (2008) IUCN Marine Series no 1 at 3; David Freestone, "An Unfinished Agenda: Governance of Areas beyond National Jurisdiction" in Keyuan Zou (ed), Global Commons and the Law of the Sea (Leiden, Boston: Brill Nijhoff, 2018) 209-225 at 224; Robin Warner, "Conservation and Management of Marine Living Resources Beyond National Jurisdiction: Filling the Gaps" in Robert Beckman et al (eds), High Seas Governance: Gaps and Challenges (Leiden: Brill, 2018) 179-194 at 187; 
the present study goes one step further by asking how these solutions could be developed and set in motion.

In order to map out potential answers, the chapter first tests out, in section 2 , the models of adaptive capacity and their related components presented in the previous chapter on selected elements of the current legal regime for international and high seas fisheries. It pays particular attention to elements that help operationalize existing obligations and that target actors' behaviours, e.g. goals, review mechanisms, platforms for knowledge exchange, and cross-sectoral collaboration. These elements have also been selected because they are concerned with multilateral practice on (marine) biodiversity conservation, including the $\mathrm{BBNJ}$ process, and regional practice, through the structure and actions of RFMOs as the main vehicles for fisheries management on the high seas. This assessment of the adaptive capacity of the regime for international fisheries law is conducted within a scheme of analysis dedicated to using case studies in order to "evaluate the dynamic interplay of multiple systems, actions, and forces over time with respect to a particular legal phenomenon".2

Nevertheless, despite leading to useful suggestions on elements and structures for improving cooperation and coordination, the adaptive capacity of the regime has so far been relied upon in a piecemeal and haphazard fashion. Section 3 therefore presents two alternative mechanisms, namely smart mixes and interplay management, which would assist in a more systematic reliance on adaptive strategies and components of an (oceans) governance perspective. The present study focuses on the way in which these mechanisms, being rooted in polycentricity, networks and multi-level governance, allow for more effective coordination, coherence and cooperation which are all needed for the sustainable management of fisheries on the high seas.

Section 4, for its part, goes one step further by discussing structures which could reconceive the landscape of international fisheries law. While these reconceptions would probably lack sufficient political support to effectively be implemented, they suggest other ways of envisaging a flexible approach to the law that could benefit the legal regime for high seas fisheries.

Finally, section 5 concludes with reflections on the practicality of adaptive strategies for improving the coordination and coherence of international fisheries regulation

Yoshinobu Takei, "Demystifying Ocean Governance" in Seline Trevisanut, Nikolaos Giannopoulos \& Rozemarijn Roland Holst (eds), Regime Interaction in Ocean Governance. Problems, Theories and Methods (Leiden: Brill Nijhoff, 2020) 22-51 at 36; and Andrew Friedman, "Beyond 'not undermining': possibilities for global cooperation to improve environmental protection in areas beyond national jurisdiction" (2019) 76:2 ICES Journal of Marine Science 452-456 at 453.

2 Craig Anthony Arnold \& Lance H. Gunderson, "Adaptive Law" in Ahjond S. Garmestani \& Craig R. Allen (eds), Social-Ecological Resilience and Law (New York: Columbia University Press, 2014) 317-364 at 356 [Arnold \& Gunderson, "Adaptive Law"]. 
and management. It submits that the suggestions presented in this chapter pinpoint novel yet practical ways of bridging the identified gaps in the legal regime in terms of fragmentation and behaviours for the management of high seas fisheries. This is a first step towards a better grasp of the issue of complexity and interconnectedness ${ }^{3}$ and, eventually, the achieving of better sustainability performance.

\section{SIGNS OF ADAPTABILITY WITHIN THE CURRENT REGIME FOR HIGH SEAS FISHERIES LAW}

From the outset, it is worth mentioning that adaptability and its components can be found in the framework regulating the management of fisheries in ABNJ. The regime in fact shows signs of flexibility, adaptability and transformability that are the hallmarks of adaptive strategies. These characteristics therefore act as an indispensable foundation upon which alternative and complementary mechanisms can be considered later on. The present section explores how adaptive components have found their way into selected elements of the current regime for international fisheries. It does so first by looking at references to adaptability within the text of selected instruments (2.1) as well as through selected structures and mechanisms (2.2). It also looks at components of adaptive strategies that have found their way into the current text of the BBNJ Agreement (2.3). This section finally reflects upon the contributions of adaptability for the legal regime of high seas fisheries (2.4).

\subsection{References to adaptability in the text of selected instruments}

Before assessing the flexibility of structures, goals and mechanisms that form the current framework for international fisheries law, looking into direct references to adaptability in the text of existing instruments can reveal the nature of the instrumental basis upon which alternative mechanisms can later be built. The inclusion of six selected terms related to adaptability (i.e. adaptability, flexibility, resilience, uncertainty, complexity and review $)^{4}$ in 24 chosen global and regional instruments, legally and non-legally binding, ${ }^{5}$ was monitored in order to obtain a

3 The concept of interconnectedness is discussed in chapter 1 section 2.1 above.

4 These terms have been selected on the basis of the conceptual framework designed in the introductory chapter of this study (see chapter 1 section 2 above), as well as on the theoretical framework on adaptability outlined in the previous chapter (see chapter 6 section 3 above). Flexibility is one feature of adaptability; resilience of a system is what is sought through adaptability; uncertainty and complexity trigger the need for adaptability; and review acts as one of the main mechanisms for adaptability. Variations of these terms have been looked at, by using the search terms 'adapt $t^{*}$,' 'flex ${ }^{*}$ ', 'resil', 'uncert ${ }^{*}$ ', 'complex*' and 'review'.

5 These instruments have been selected on the following basis: the global, legally-binding instruments are the ones described and assessed in chapter 2 section 3.1 above; the global, non-legally binding instruments are the ones related to the UNGA and the FAO, described and assessed in chapter 2 section 3.2 above (however, only the IPOA IUU has been selected among the four IPOAs because it is the most recent and the most often cited in the literature on fisheries and sustainability); the four RFMOs analysed have been chosen because they represent a variety in the year of creation (before/after UNFSA), in their geographical area, and in the species they cover (general/tuna RFMOs), and they are mentioned in chapter 2 section 3.3.2 above; the five RSPs are the ones that cover high seas areas, which are described and assessed in chapter 2 section 3.3.4 above. 
general portrait of the use of these terms. The findings are summarized in Table 6 found at the end of the present chapter.

We can observe that variations of the term 'adaptability' are found in five instruments, and the term is used in relation to the adaptation of a particular strategy, plan or programme, to adaptive management and implementation and, more generally, regarding climate change adaptation. Variations of the term 'flexibility', for their part, are only found in two constitutive instruments of recent RFMOs, regarding the way the observer programme should be organized. Variations of the term 'resilience' are used on three occasions: in Annex II of the UNFSA, where it is indicated that the precautionary approach should be used to account for the resilience of each stock, and in both 2019 UNGA Resolutions, where the importance of ecosystems resilience in the face of climate change, ocean acidification, other pressures, and natural disasters is reiterated. Variations of the term 'uncertainty' are found in six instruments, mostly with regard to the precautionary approach and the uncertainty linked to the quality and/or access to data. This in turn leads to uncertainty in (stock and performance) assessments and, more generally, to uncertainty facing climate change. Variations of the term 'complexity' are found in four instruments, where the term is used to define (marine) biological diversity, (vulnerable) ecosystems or the relationship between living resources and their environment.

It is the term 'review' that is the most widespread among the selected instruments; all but two include it at least once. It is used mostly in relation to the several bodies' mandates to (continuously or periodically) review the implementation and/or effectiveness of the instrument. There are also specific references to the review of knowledge/data, measures (e.g. catches, prohibitions) and plans, and to the review of compliance and performance of certain actors. Some instruments, mostly the constitutive instruments of RFMOs, provide more specifically the review of conservation and management measures. These review tasks are normally attributed to one or several bodies within the architectural design of an instrument, including the decision-making body (e.g., COP, MOP, Commission), the scientific/ technical body and/or the compliance body. More particularly, the UNFSA creates the Review Conference, charged with a similar implementation review mandate. Finally, both the WCPFC and SPRFMO include the possibility of setting up a review panel mandated to examine an objection to a Commission decision raised by a member. Often seen as acting as dispute settlement bodies within the RFMO system, review panels can also be considered as a form of review mechanism for learning, iteration and feedback loops purposes.

The assessment of the inclusion of the selected terms leads to a number of observations. First and foremost, the time of adoption of the instrument is highly indicative of the use of the terms themselves, and also to what other concepts they are related. For example, it is not surprising that the 1946 ICRW or the 1966 ICCAT Convention do not refer to (almost) any of the terms, which have appeared 
mostly in the oceans and environmental discourse in the late 1990s to the early 2000s. Similarly, resilience and adaptation to climate change appear only in recent instruments. Second, the words adaptability and flexibility, the terms most directly related to adaptive strategies, are not widely used in the context of fisheries management. Third, the term resilience, a characteristic of socio-ecological systems to be ensured through adaptability, is also almost completely absent. Its only occurrence is found in relation to the resilience of an ecological system (i.e. the fish stock), and not in relation to the legal instrument itself. Fourth, the use of the word "complex" in relation to biological diversity and ecosystems recognizes the importance of these concepts as particular characteristics of socio-ecological systems. This does not, however, indicate any particular response that actors should have towards such systems. Fifth, uncertainty arises more often in relation to the precautionary approach. This is not a surprise since precaution exists as a mechanism to face scientific and knowledge uncertainty of the impact of an activity on the environment. Measures such as reviews act as ways to tackle uncertainty, and they are welcomed as a way of ensuring a regular revision of measures linked to evolving knowledge about a changing environment.

The current framework for international fisheries regulation therefore includes some references to adaptability and its components within its key regulatory instruments. However, there is no indication that these terms have been chosen systematically for the deliberate inclusion of adaptive components within the instruments. Nonetheless, they remain important normative indicators of adaptability upon which structures and mechanisms have been developed. These structures and mechanisms are addressed in the following section.

\subsection{Adaptability through existing structures and mechanisms}

The theoretical framework developed in the previous chapter for assessing adaptive capacities relies on factors and conditions revolving around flexibility and openness of institutions, effectiveness of multi-level governance, and social structures promoting learning. ${ }^{6}$ In order to reach such conditions, two models have looked at what it means for the law to be adaptive and how adaptive capacities can be assessed. A first model ${ }^{7}$ suggests the targeting of four features: the goals, which must reflect both the social and ecological components of a system; the structure, which must be polycentric, multimodal and multiscalar; the methods, presenting flexible decision-making; and the process, revolving around iteration and feedback loops, and including multiple participants. Under a similar systematization of features,

6 Jonas Ebbesson, “The rule of law in governance of complex socio-ecological changes" (2010) 20 Global Environmental Change 414-422.

7 Craig Anthony Arnold \& Lance H. Gunderson, “Adaptive Law and Resilience” (2013) 43:5 Environmental Law Reporter News \& Analysis 10426-10443. A similar analysis is conducted by the same authors in Arnold \& Gunderson, "Adaptive Law", supra note 2. 
a second model ${ }^{8}$ looked at the substance (plurality of goals and discretion to adjust measures), procedure (reliance on new knowledge, iteration, cross-sectoral approach, and access to information), choice of instruments (direct regulation combined with instruments of other types), and enforcement (specific obligations to reach goals, time limits, and sanctions for non-compliance) in order to evaluate the resilience and adaptability of instruments. Commonalities can be identified from these two models: the goals of a regime must balance both ecological and socio-economic systems; the regime must rely on a multiplicity of actors and types of instruments, and must operate at various levels; and the regime must allow for iteration in order to consider new knowledge and modify actions and decisionmaking if necessary.

It is against these features and criteria that the regime for international fisheries is tested in order to identify those of its aspects which present characteristics of adaptability. ${ }^{9}$ The assessed aspects are presented in light of their contribution to the implementation and enforcement of and compliance with existing obligations, as well as their contribution to improving cooperation and coordination. Aspects where adaptability has not (yet) necessarily succeeded in reaching sustainability outcomes and performance are also identified. Five aspects of the current regime are looked at here: the overarching structure and types of actors involved (2.2.1); the substance of instruments, articulated around goals and objectives (2.2.2); mechanisms for iteration and review (2.2.3); platforms for sharing knowledge, science and expertise (2.2.4); as well as cross-sectoral collaborations (2.2.5). It is to be noted that the characterization of these aspects is somewhat artificial and does not necessarily reflect their often overlapping nature; this characterization is done for ease of presentation only. For a graphic visualization of the aspects of the legal regime for high seas fisheries tested in light of the different elements of adaptive capacities, the assessment discussed in the present section is summarized in Table 7 found at the end of the present chapter.

\subsubsection{Overarching structure of the regime and actors involved}

Starting with the overarching structure of the regime, one can conclude that it is both polycentric and multiscalar. From the global and overarching coordinating (yet limited) role of the FAO, to the regional management role of RFMOs, to the national enforcement role of flag States, individually, through bilateral agreements or through RFMOs, the regime has various centres of authority dispersed through

8 Niko Soininen \& Froukje Maria Platjouw, "Resilience and Adaptive Capacity of Aquatic Environmental Law in the EU: An Evaluation and Comparison of the WFD, MSFD, and MSPD" in David Langlet \& Rosemary Rayfuse (eds) The Ecosystem Approach in Ocean Planning and Governance (Leiden: Brill Nijhoff, 2019) 17-79.

9 The structure of the analysis conducted in this section builds on the adaptability assessment of the BBNJ Agreement conducted in Catherine Blanchard, Carole Durussel \& Ben Boteler, "Socio-ecological resilience and the law: Exploring the adaptive capacity of the BBNJ agreement" (2019) 108 Marine Policy article 103612 . 
varying scales and levels. Such structure also fulfils some of the design principles developed by Ostrom to assess the robustness of institutions enshrined in a polycentric approach; for example, the different institutions at different levels of action ensures that local conditions are considered, and this also ensures the "nesting" of enterprises, i.e. where small-scale local organizations are part of a largescale system, "allowing for systems to exist at multiple levels, with some autonomy at each level". ${ }^{10}$ It could be argued, however, that, local/regional organizations are currently working in isolation, and are therefore not sufficient nested in larger scale structures.

In terms of the openness of institutions, also related to the multiplicity of actors and broad participation, although a wide variety of actors is involved in fisheries management, this is not necessarily translated into legal norms. A formalization of their involvement could help to legitimize their actions and ensure that they are also subject to general rules and standards. In fact, while soft law instruments, such as the FAO IPOAs and the Code of Conduct do extend their scope of application to all actors, ${ }^{11}$ subordinating them to the same good practices, the involvement of non-State actors in implementation, enforcement and procedures for sanctioning of non-compliance remains a matter of debate. ${ }^{12}$ Legal structures also often make it difficult for new State actors to get involved in regional organizations, as is the case with new entrants in RFMOs. ${ }^{13}$

10 Kristine Dalaker Kraabel, "International Law and Areas Beyond National Jurisdiction: Imagining a Polycentric Approach to Institutional Governance for Marine Areas Beyond National Jurisdiction" in Vito De Lucia, Lan Ngoc Nguyen \& Alex Oude Elferink (eds), International Law and Marine Areas beyond National Jurisdiction: Current Status and Future Trends (forthcoming), referring to, e.g., David Sloan Wilson, Elinor Ostrom \& Michael E. Cox, "Generalizing the Core Designs Principles for the Efficacy of Groups" (2013) 90S Journal of Economic Behavior \& Organization 21-32; Elinor Ostrom, "Institutional Analysis, Design Principles, and Threats to Sustainable Community Governance and Management of Commons" in Erling Berge \& Nils Christian Stenseth (eds), Law and the Governance of Renewable Resources: Studies from Northern Europe and Africa (Manilla: ICS Press, 1998) 34-51 at 39; and Elinor Ostrom et al, The Future of the Commons. Beyond Market Failure and Government Regulation (London: The Institute of Economic Affairs, 2012) at 82. On polycentricity, see also chapter 6 section 3.2.1 above.

11 See, e.g. Code of Conduct for Responsible Fisheries, FAO, 28th Sess, FAO Doc 95/20/Rev/1 (1995) at art. 1.2 [Code of Conduct]: "The Code is global in scope, and is directed toward members and nonmembers of FAO, fishing entities, sub regional, regional and global organizations, whether governmental or nongovernmental, and all persons concerned with the conservation of fishery resources and management and development of fisheries, such as fishers, those engaged in processing and marketing of fish and fishery products and other users of the aquatic environment in relation to fisheries"; and International Plan of Action to Prevent, Deter and Eliminate Illegal, Unreported and Unregulated Fishing, FAO COFI, 24th Sess (2001) at art. 9.1, online: <http://www.fao.org/3/Y1224E/y1224e.pdf >: "The full participation of stakeholders in combating IUU fishing, including industry, fishing communities, and non-governmental organizations, should be encouraged".

12 On the involvement of NGOs in implementation and enforcement of fisheries regulation, see chapter 5 section 2.3.1 above.

13 On new entrants, see chapter 5 section 2.3.3 above. 


\subsubsection{Substance: goals, objectives, and the reliance on science}

The substance of the instruments forming the legal regime must also be flexible. To start with, the goals of the regime for fisheries management tend to make reference to both conservation (ecological component of the system) and use (socioeconomic component of the system), which ensures polyresilience, i.e. resilience of all components of a system. ${ }^{14}$ For example, objectives such as "recognizing [...] the equitable and efficient utilization of their resources, the conservation of their living resources, and the study, protection and preservation of the marine environment", ${ }^{15}$ ensuring both long-term conservation and sustainable use, ${ }^{16}$ or recognizing all aspects of the socio-ecological system that fisheries represent (related to, e.g. aesthetic, scientific, cultural, recreational and economic issues), ${ }^{17}$ are normally found in the preamble or in a general provision of most instruments discussed in chapter 2. These overarching goals or objectives, along with more specific principles and goal-oriented norms, form a set of "open-textured rules"18 that "are advantageous for allowing more responsiveness to changes, and to accommodate a plethora of actors who have different resources, strengths and weaknesses". ${ }^{19}$ These open-textured rules normally prescribe either a conduct to be adopted, a result to be achieved, or both. They also allow for discretion in decision-making and for adjusting management according to new circumstances. The current regime for fisheries management on the high seas, and for ABNJ more generally, includes a strong set of principles to guide behaviours. ${ }^{20}$ However, one weakness of principles is that they "lack the capacity to advance more detailed technical content", ${ }^{21}$ which is an obstacle in the quest for balance between stability and flexibility.

Another important substantive element is that adjustments must first and foremost be achieved by relying on science. In fact, science already plays a central role in the regime for marine environmental protection. As observed by Platjouw, UNCLOS "explicitly endorses adaptive governance through Article 201 which specifies that data acquired through scientific research [...] should be used to form the basis for the rules and standards under Part XII. In this sense, [UNCLOS] affirms that

14 Arnold \& Gunderson, "Adaptive Law", supra note 2 at 325.

15 UNCLOS at preamble.

16 See, e.g., CBD at preamble; UNFSA at preamble; OSPAR Convention at preamble.

17 Code of conduct, supra note 11 at art. 2(a). See also, regarding the environment and species more generally, CBD at preamble, and CITES at preamble.

18 Ebbesson, supra note 6 at 418.

19 Blanchard, Durussel \& Boteler, supra note 9 at 4, referring to Elisa Techera \& Natalie Klein, International Law of Sharks. Obstacles, Options and Opportunities (Leiden: Brill Nijhoff, 2017) at 86-87.

20 See, generally, chapter 3 above.

21 Richard Barnes, "The Pursuit of Good Regulatory Design Principles in International Fisheries Law. What Possibility of Smarter International Regulation?" in Judith van Erp et al (eds), Smart Mixes for Transboundary Environmental Harm (Cambridge: Cambridge University Press, 2019) 97-125 at 119 [Barnes, "Good Regulatory Design"]. This was also underlined as a challenge in chapter 5 section 2.3.4 above. 
scientific understanding is the primary basis for the development of the law".22 Similar obligations are found under most instruments forming the regime for fisheries management, ${ }^{23}$ and reliance on best available science is one of the principles governing the high seas. ${ }^{24}$ It must however not be forgotten that the difficulties linked to the collection and gathering of scientific data regarding high seas fisheries creates an obstacle to the operationalization of this science-based approach. ${ }^{25}$

\subsubsection{Iteration, feedback loops and review}

For objectives, principles, goal-oriented norms and science-based adaptations to be operationalized, substantial flexibility must be combined with procedural flexibility. One way of reaching this procedural flexibility is to ensure that there are possibilities for iteration and for learning from feedback loops, which can be achieved by relying on review mechanisms. In order to assess new and emerging needs, it is important that institutions and fora have the power to periodically review and assess the behaviour of actors in complying with commitments, as well as with the changes in external circumstances that might affect the compliance (e.g. state of scientific knowledge).

Different forms of review exist under the current regime, ranging from more informal review processes, to formal performance review or review mandate. Iteration and feedback loops without a formal review process are, for example, embodied in the creation and structure of the recent CAOFA. The CAOFA is a unique agreement in terms of what it represents for "the management of high seas fisheries under conditions of uncertainty" ${ }^{26}$ since it in fact regulates an activity that has yet to take place. ${ }^{27}$ It has been characterized as "a model of adaptive law making" ${ }^{28}$ because of its stepwise approach, i.e. rely first on the CAOFA, and later consider the necessity of developing an RFMO or similar body, which also shows openness for adaptation. The CAOFA ensures a feedback loop between law and science, where new scientific

22 Froukje Maria Platjouw, "Dimensions of transboundary legal coherence needed to foster ecosystembased governance in the Arctic" (2019) 110 Marine Policy article 103666 at 4.

23 See, e.g. UNFSA at arts. 5(b) and 6(3)(a); Code of conduct, supra note 11 at arts. 6.4, 6.5, 7.1.1, 7.2.1 and 7.5.3; CBD at preamble.

24 See chapter 3 section 3.1.4 above.

25 A discussion on these shortcomings is conducted in chapter 5 section 2.1 .2 above.

26 Rosemary Rayfuse, "The role of law in the regulation of fishing activities in the Central Arctic Ocean" (2019) 110 Marine Policy article 103562 at 5 [Rayfuse, "CAOFA"].

27 For a recent overview of the CAOFA, see, generally, Erik Molenaar, "Participation in the Central Arctic Ocean Fisheries Agreement" in Akiho Shibata et al (eds), Emerging Legal Orders in the Arctic. The Role of Non-Arctic Actors (Abingdon, Oxon: Routledge, 2019) 132-170. In fact, the parties to the CAOFA, realizing that there were large-scale commercial fisheries conducted in the adjacent Bering Sea and Barents Sea, started to ask whether, and if so when, it would become possible to engage in commercial fishing in the Central Arctic Ocean. This reflection motivated the negotiations of the CAOFA. The CAOFA is briefly discussed in chapter 2 section 3.3.4 above.

28 Rayfuse, "CAOFA", supra note 26. More generally, this paper by Rayfuse looks into the potential of international law in "ensuring the adaptive and effective management of high seas fisheries in the" Central Arctic Ocean, see at 1. 
knowledge is expected to directly impact decision-making for conservation and management, thereby contributing to flexibility and adaptability.

More formal review processes exist, for example, and as discussed in previous chapters, for RFMOs and flag States, the two main actors for fisheries management and implementation on the high seas. They are subject to performance reviews, in order to assess their functioning and the effectiveness of measures which they adopt, and to undertake changes if necessary. ${ }^{29}$ Formal review mechanisms also exist within institutional bodies or structures, which have the mandate to review the implementation and effectiveness of the instrument under which they were established, and of other measures adopted by its provisions. Examples of such overarching bodies with a review mandate (of varying nature) include the UNFSA Review Conference and COPs. These mechanisms therefore assess the strengths and weaknesses of different aspects of the regime, and allow for the possibility to bring in new knowledge and to adjust decision-making accordingly.

However, "reviews are really meaningful only if they are conducted by an independent body and/or according to objective, pre-established criteria. They are also relevant only if there are methods in place to act upon the results stemming out from them; indeed, if changes need to be made, but there are no ways of undertaking them, adaptability cannot be ensured". ${ }^{30}$ Many of the existing mechanisms unfortunately seem to lack the consistent and systematic application needed in order to effectively benefit from iteration and feedback loops stemming from reviews. For example, the UNFSA Review Conference, which has so far met only on three occasions, ${ }^{31}$ mostly identifies progress and weaknesses with the implementation and enforcement of the UNFSA, but seems to identify the same weaknesses over time. ${ }^{32}$ This probably stems from the fact that the Review Conference's powers are limited to making recommendations, which are seemingly not acted upon, and the Review Conference does not have the mandate/competence to make decisions, ${ }^{33}$ nor to assess States' compliance. ${ }^{34}$ This is why it is often suggested that, to be efficient and have a real influence on the implementation of an instrument, a review forum must also be coupled with mechanisms to make actual decisions "that have a direct impact on

29 For a lengthier discussion on the review process of RFMOs, see chapter 2 section 3.3.2, and chapter 5 section 2.3.2 above. For a lengthier discussion on performance assessment of flag States, see chapter 2 section 3.3.1, and chapter 5 section 2.3.1 above.

30 Blanchard, Durussel \& Boteler, supra note 9 at 4.

31 The UNFSA Review Conference met in 2006, 2010, and 2016, and a fourth meeting is expected to take place in 2021, see chapter 2 section 3.1.2 above.

32 IISD, "Summary of the resumed review conference on the agreement for the implementation of the provisions of the UN convention on the law of the sea (UNCLOS) 1982 relating to the conservation and management of straddling fish stocks and highly migratory fish stocks" (2016) 7:71 Earth Negotiations Bulletin at 11-13.

33 For a lengthier discussion on the mandate of the UNFSA Review Conference, see chapter 2 section 3.1.2, and chapter 4 section 3.3 above.

34 Solène Guggisberg, "Independent, Compulsory, and Centralized verification of States' Obligations in Fisheries: Can the IMO Audit Scheme for Shipping Law Be Used as an Example to Follow?" (2020) 22 International Community Law Review 513-531 at 517. 
the functioning of the instrument and its related structures" ${ }^{35}$ This is normally the case with a COP, the plenary forum of most multilateral environmental agreements, which has a better potential for ensuring iteration through a decision-making power that can lead to the adoption, at regular intervals, ${ }^{36}$ of measures and plans of action that reflect new knowledge and new focuses of interest. ${ }^{37}$ This possibility for meaningful actions through flexibility and iteration in decision-making, especially in the context of the constant increase of knowledge concerning $A B N J$, is also seemingly the reason why the BBNJ process is currently considering building its institutional arrangement around a COP. ${ }^{38}$

Successful advancements reached through COP decisions include, for example, decisions from the CBD that have led to the adoption of the Jakarta mandate ${ }^{39}$ and the development of the EBSA process. ${ }^{40}$ Another well-functioning plenary body which holds strong decision-making powers is the CITES COP. Through its resolutions, the CITES COP can create additional bodies, ${ }^{41}$ has the power to clarify and/or develop treaty provisions ${ }^{42}$ and to recommend measures for compliance. ${ }^{43}$ An "innovative CITES system of economic sanctions for non-compliance" ${ }^{44}$ stemming from States' practice was reaffirmed in Resolution 14.3/2007, ${ }^{45}$ which lists compliance procedures. These economic sanctions can take the form of a collective trade embargo, as a countermeasure to the breach of CITES obligations. ${ }^{46}$ Such a collective embargo can also be used against non-members to deter freeriding, and is in theory more effective than dispute resolution, to which both parties must agree. ${ }^{47}$ All these elements "have made CITES demonstrably more effective in

35 Blanchard, Durussel \& Boteler, supra note 9 at 5.

36 E.g. The CBD COP meets every 2 years (CBD at art. 23), the CITES COP meets every 2-3 years (CITES at art. XI), the CMS COP meets every 2-3 years (CMS at art. VII).

37 As discussed in Dupuy \& Viñuales, the types of mechanisms for monitoring and review by a treaty body depend on the scope of the power conferred by the constitutive treaty. A treaty that provides for more precise procedural obligations (e.g. specific deadlines, specific formats for reporting, etc.) might lead to more detailed verifications, but also necessitates "a higher level of institutionalization". This need for higher institutionalization might have an impact on the flexibility of the structure and/or the processes that ensue, see Pierre-Marie Dupuy \& Jorge Viñules, International Environmental Law, 2nd ed (Cambridge: Cambridge University Press, 2018) at 296-298.

38 This is discussed in further detail under section 2.3 below. See also chapter 4 sections 3.3 and 4.2 above.

39 Conservation and Sustainable Use of Marine and Coastal Biological Diversity, CBD COP Decision II/10, COP 2, UNEP/CBD/COP/DEC/II/10 (1995). See also chapter 2 section 3.1.3 above.

40 Marine and coastal biodiversity, CBD COP decision IX/20, COP 9, UNEP/CBD/COP/Dec/IX/20 (2008). See also chapter 2 section 3.1 .3 above.

41 Peter H. Sand, "Endangered Species, International Protection" (2017) Max Planck Encyclopedia of Public International Law at para 13.

42 See, e.g., Definition of 'primarily commercial purposes', CITES COP resolution 5.10 (Rev COP15), COP 5 (1985).

43 Sand, supra note 41 at para 10.

44 Ibid at para 17.

45 CITES compliance procedure, Resolution Conf. 14.3 (Rev. CoP18), COP 14 (2007).

46 Sand, supra note 41 at para 17. See also at para 18, where it is discussed that this form of countermeasure respects the rules on State responsibility.

47 Ibid at para 18. 
practice than most other comparable treaty regimes"48 and show that a COP can possess significant powers that have a concrete impact on parties' compliance.

In terms of iteration and reviews found at the level of RFMOs, the adoption and regular revisions of conservation and management measures allow RFMOs to adapt their actions in light of new knowledge and changing circumstances. Furthermore, the performance review that RFMOs must regularly undergo shows an openness of the institutions to adjust their management and functioning. Both mechanisms include iteration and feedback loops, which are important for increasing knowledge. However, conservation and management measures are often politically tainted, while the performance reviews are undergone voluntarily and the recommendations found therein are often not acted upon. ${ }^{49}$ Similar observations can be made regarding flag States' performance assessments. ${ }^{50}$ This shows that, although theoretically relevant, these methods for adapting management and behaviours do not, in this case, translate into improved behaviours for sustainability.

In the case of the PSMA, a periodic review process is enshrined in article 24(1). ${ }^{51}$ It was agreed at the first meeting of the parties that States would need to fill in a questionnaire every other year to report on their implementation of the PSMA. Such a questionnaire was adopted in June 2019, and it remains to be seen what the consequences will be for States which fail to answer the questionnaire or which fail to implement the PSMA..$^{52}$ It is also too early to assess the impacts of this review and reporting mechanism on States' behaviour.

\subsubsection{Platforms and networks: sharing science, knowledge and expertise}

First, the regime comprises different types of networks and platforms to facilitate the diffusion of science, and for the exchange of data and knowledge. For example, the clearing-house mechanism under the CBD allegedly aims for "knowledge sharing and information exchange, and to establish a fully operational network of Parties and partners", and this is done "through effective information services and other appropriate means in order to promote and facilitate scientific and technical cooperation". ${ }^{53}$ Similarly, the Regular Process is an intergovernmental process that aims "to contribute to the strengthening of the regular scientific assessment of the state of the marine environment in order to enhance the scientific basis for

48 Ibid at para 10.

49 On RFMOs' performance reviews, see chapter 2 section 3.3.2, and chapter 5 section 2.3.2 above.

50 On flag States' performance assessments, see chapter 2 section 3.3.1, and chapter 5 section 2.3.1 above.

51 "Parties shall, within the framework of FAO and its relevant bodies, ensure the regular and systematic monitoring and review of the implementation of this Agreement as well as the assessment of progress made towards achieving its objective", see PSMA at art. 24(1).

52 Guggisberg, supra note 34 at 519.

53 CBD, "Clearing-house mechanism", online: <https://www.cbd.int/chm/>. 
policymaking". ${ }^{54}$ Its meetings are also open to States, international organizations, NGOs and scientific institutions, making it a multi-actor and knowledge exchange platform. Having such mechanisms being open to receiving data and knowledge, also from non-State actors, might increase the quantity and diversity of data, as well as the resources to process the data. ${ }^{55}$

Second, other networks and platforms have also been created for the exchange of expertise and good practices. For example, the International Monitoring, Control and Surveillance Network brings together actors involved in fisheries law enforcement. ${ }^{56}$ Further, the Regional Fishery Body Secretariats Network, described as "a unique forum to foster cooperation, facilitate discussion and exchange of experiences" 57 between 43 secretaries of RFBs, ${ }^{58}$ acts as a valuable platform for knowledge exchange and raising awareness on good practices. Similarly, the Kobe process was created to harmonize knowledge and practices across tuna-RFMOs. ${ }^{59}$ The Kobe process, however, has not been very active in recent years, and the two other networks seem to lead to limited results, therefore raising questions about their usefulness and effectiveness for the improvement of sustainability performance. ${ }^{60}$ However, these structures remain relevant and might act as a good starting point for the development and improvement of mechanisms that could deliver more systematic reliance on these platforms, an alternative discussed in further detail below. ${ }^{61}$

54 Regular Process, online: <https://www.un.org/regularprocess/>. The Regular Process has published in 2015 the First Global Integrated Marine Assessment (see Summary of the first global integrated marine assessment, UNGAOR, 70th Sess, UN Doc A/70/112 (2015)), the outcome of its first cycle which aimed at establishing baseline. The second cycle, which aims to evaluating trends and identifying gaps, is scheduled to end in 2020 with the publication of the second Global Assessment, see Background information on the Regular Process, online: <https://www.un.org/depts/los/global_reporting/Background_to_the_ Regular_Process.pdf $>$. The Regular Process was established through Oceans and the law of the sea, GA Res 57(CXLI), UNGAOR, 57th Sess, UN Doc A/RES/57/141 (2003) at para 45.

55 The lack of resources to actually process the data collected is becoming a growing concern for monitoring, control and surveillance, because it affects the ability to pinpoint and develop the appropriate measures necessary for implementation, see IASS, IDDRI \& TMG, "Marine Regions Forum 2019: Achieving a healthy ocean - regional ocean governance beyond 2020. Conference Report” (2019) at 60-61, online: <https://www.prog-ocean.org/marine-regions-forum/wp-content/uploads/sites/2/2020/02/MRF2019_ Conference-Report_fin_04.02.2020.pdf>.

56 For more on the difficulties stemming from lack of monitoring, control and surveillance, see chapter 5 section 2.3.1 above.

57 FAO, "Regional Fishery Body Secretariats Network", online: <http://www.fao.org/fishery/rsn/en>. See also FAO, "20 years Looking Back: The Journey so Far" (2019) RSN Magazine No 18, online: <http:// www.fao.org/3/ca3925en/ca3925en.pdf>.

58 It is to be noted, however, that not all of these 43 RFBs operate on the high seas. For a discussion on high seas RFBs and RFMOs, see chapter 2 sections 3.3.2 and 3.3.4 above.

59 See, e.g. "Kobe II Process Recommendations. Excerpts from Reports of Kobe II Meeting and Workshops" (2009-2010), online: <http://www.tuna-org.org/Documents/TRFMO3/BackgroundInfo.pdf>.

60 See chapter 5 section 2.3 .2 above.

61 See section 3.2 below. 


\subsubsection{Cross-sectoral collaborations}

Cross-sectoral collaborations represent the final way discussed in this study for adaptive capacity to influence a legal regime, most particularly through the complementarity that can be attained between instruments and institutions operating in different sectors and having different mandates. Cross-sectoral collaborations also show how the interaction between different nodes can lead to different results from the ones that the nodes achieve independently. Incentivizing cross-sectoral collaborations can therefore trigger benefits stemming from sharing complementary expertise. In fact, it is submitted that " $[\mathrm{k}]$ nowledge learning and sharing is [...] the resilience factor that links together all elements of the analysis of [a framework's] adaptive capacity. [...] it is [...] necessary to ensure that [...] decisions and management are made and undertaken in a way that takes into consideration the evolution and changes in the complex socio-ecological system". ${ }^{62}$ Fostering mechanisms to exchange knowledge and information on good practices must therefore be strengthened to eventually lead to a systematic coordination of rules and mechanisms.

Some examples within the current regime for international and high seas fisheries illustrate the improvements in sustainability performance that have been achieved through cross-sectoral collaborations. First, the evolution of the collaboration between NEAFC and OSPAR over the last two decades probably represents the example of greatest achievement in existing institutional crosssectoral collaboration. ${ }^{63}$ The initially informal relationship between the secretariats of the two organizations led to the adoption, in 2008, of a MoU "which state[d] the complementary competences of both organisations, including in [ABNJ], and also allow[ed] for a reciprocal participation in each other's relevant committees". ${ }^{64}$ In 2014, however, the collaboration moved one step further when the two organizations adopted the "Collective Arrangement between competent international organisations on cooperation and coordination regarding selected areas in areas beyond national jurisdiction in the North-East Atlantic".65 This Collective Arrangement has led to an improvement of policy coherence between the two organizations, and to the operationalization of the ecosystem approach (by working towards the protection of an ecosystem by going beyond - and combining - mandates, competences and jurisdiction). Although only NEAFC and OSPAR have so far adopted the Arrangement, the ultimate goal of this arrangement is to

62 Blanchard, Durussel \& Boteler, supra note 9 at 7-8.

63 See, e.g. David Johnson, "Can Competent Authorities Cooperate for the Common Good: Towards a Collective Arrangement in the North-East Atlantic" in Paul Arthur Berkman \& Alexander N. Vylegzhanin (eds), Environmental Security in the Arctic Ocean (Cham: Springer, 2013) 333-343.

64 OSPAR Commission, "Collective Arrangement", online: <https://www.ospar.org/about/internationalcooperation/collective-arrangement>.

65 Collective arrangement between competent international organisations on cooperation and coordination regarding selected areas in areas beyond national jurisdiction in the North-East Atlantic, OSPAR Agreement 2014-09, online: <https://www.ospar.org/documents?v=33030>. 
become a multilateral forum for all organizations operating in $\mathrm{ABNJ}$ in the NorthEast Atlantic, thereby creating a fully cross-sectoral collaboration. Talks have been undertaken with the International Seabed Authority, the IMO, and ICCAT to broader the work of collaboration and coordination in the region. Similar collaborations exist in other regions, ${ }^{66}$ although not yet to the coordination level of the OSPAR-NEAFC Collective Arrangement.

A second example is to be found with the Sargasso Sea Commission, ${ }^{67}$ which represents a unique political initiative aimed at fostering the support from and the cooperation between governments, scientists, conservation groups and private donors towards the protection of the unique ecosystem of the Sargasso Sea. ${ }^{68}$ The Commission works under a flexible format, acts as an active platform for information and data gathering, ${ }^{69}$ as well as for raising awareness about conservation in the region. This is why the Sargasso Sea initiative embodies adaptive strategies, by developing strong networks between a wide diversity of actors working at different scales and levels. Being a political initiative, the Commission has a limited mandate in terms of management and implementation; however, the Commission works closely with international organizations that do have such mandates and are operating in the region. For example, representatives of the Commission attend meetings of ICCAT to advocate for conservation measures for the Sargasso Sea and work with its Ecosystem Subcommittee to develop ecosystem-based fisheries management proposals. ${ }^{70}$ This illustrates coordination of measures and resources for conservation. However, as with the CAOFA mentioned above, it is important to reiterate that the Sargasso Sea Commission was established when no similar structures existed; this allowed for questions of adaptability and an ecosystembased approach to be borne in mind from the outset. The exercise of developing an adaptive framework almost from scratch is a different exercise from finding ways to improve existing structures. Understanding the development of these initiatives is, however, useful for two main reasons: to identify the manifestation of adaptability within these initiatives and the reason(s) triggering such adaptability.

A final type of cross-sectoral collaboration is to be found in the growing importance of interlinkages between the public and the private realms. This type of collaboration

66 For example, in the Mediterranean Sea between the Barcelona Convention and the GFCM, see chapter 2 section 3.3.4 above.

67 The functioning and structure of the Sargasso Sea Commission is discussed in chapter 2 section 3.3.4 above.

68 Hamilton Declaration on Collaboration for the Conservation of the Sargasso Sea (11 March 2014) at annex II, paras i), j) and k), online: <http://www.sargassoseacommission.org/storage/Hamilton_Declaration_ with_signatures_April_2018.pdf>[Hamilton Declaration]. See, generally, David Freestone, "Governance of Areas Beyond National Jurisdiction: An Unfinished Agenda?" in Jill Barrett \& Richard Barnes (eds), Law of the Sea UNCLOS as a Living Treaty (British Institute of International and Comparative Law, 2016) 231-265 at 245 .

69 Hamilton Declaration, supra note 68 at annex II para e).

70 Work Programme Priorities (2016-2018), Sargasso Sea Commission Doc SSC/2017/3/Doc.1 (2017) at 2-3, online: <http://www.sargassoseacommission.org/storage/NEW_Horta_Updated_Work_Plan_2016-18.pdf>. 
can be operationalized through the increasing reliance on non-State based instruments and mechanisms. For example, economic incentives have been relied upon as mechanisms for sanctioning non-compliance, by economically rewarding behaviours that are in line with sustainability (the sanction for non-compliance therefore being a poor performance in the market). This multimodal approach has so far been promising in fostering complementary actions in the face of deadlock in RFMOs' actions, and this is why this alternative is also studied below. ${ }^{71}$

\subsection{The BBNJ Agreement and its expected role for the adaptability of the regime}

Adaptability is not per se found in the text of the BBNJ Agreement. Flexibility, one component of adaptability, ${ }^{72}$ however appeared as a general principle in the draft version discussed at IGC 3 and read as follows: "In order to achieve the objective of this agreement, States Parties shall [...] (g) Take into consideration flexibility, pertinence and effectiveness" ${ }^{73}$ This principle was, however, rejected by almost all delegations (if not all of them), ${ }^{74}$ claiming that they did not understand the full

71 See section 3.1 below.

72 See chapter 6 section 3.1 above.

73 Draft text of an agreement under the United Nations Convention on the Law of the Sea on the conservation and sustainable use of marine biological diversity of areas beyond national jurisdiction, Intergovernmental Conference on an international legally binding instrument under the United Nations Convention on the Law of the Sea on the conservation and sustainable use of marine biological diversity of areas beyond national jurisdiction, 3rd Sess, UN Doc A/CONF.232/2019/6 (2019) at art. 5(g) (emphasis added) [Draft text].

74 IISD “BBNJ IGC-3 Highlights: Wednesday, 28 August 2019” (2019) 25:216 Earth Negotiations Bulletin at 3. It is unclear how flexibility, pertinence and effectiveness were first included in the working documents of the IGC. As not all statements are shared by delegations and/or made accessible to the general public or reported in the Earth Negotiations Bulletin, it is not possible to identify specifically who was the original instigator of the inclusion of such principles in the text, nor the reason underlying the inclusion. The President's aid to discussion published in January 2019 in preparation for IGC 2 (see President's aid to discussions, Intergovernmental conference on an international legally binding instrument under the United Nations Convention on the Law of the Sea on the conservation and sustainable use of marine biological diversity of areas beyond national jurisdiction, 1st Sess, UN Doc A/CONF.232/2018/3 (2018)) listed flexibility, pertinence and effectiveness as part of the principles and approaches specific to the section on CB\&TT. Following several comments from delegations during IGC 2 that a separate list of principles and approaches for each element of the package deal was not necessary, flexibility, pertinence and effectiveness were probably moved to the list of general principles and approaches under art. 5 of the Draft text, supra note 73. Following the comments made by delegations during IGC 3 , the principles were removed from the draft text and do not appear in the Revised draft text published in November 2019 (see Revised draft text of an agreement under the United Nations Convention on the Law of the Sea on the conservation and sustainable use of marine biological diversity of areas beyond national jurisdiction, Intergovernmental conference on an international legally binding instrument under the United Nations Convention on the Law of the Sea on the conservation and sustainable use of marine biological diversity of areas beyond national jurisdiction, 4th Sess, UN Doc A/CONF.232/2020/3 (2019) [Revised Draft Text]). In the compilation of proposals published in April 2020 (in light of the postponement of IGC4, see Textual proposals submitted by delegations by 20 February 2020, for consideration at the fourth session of the Intergovernmental conference on an international legally binding instrument under the United Nations Convention on the Law of the Sea on the conservation and sustainable use of marine biological diversity of areas beyond national jurisdiction (the Conference), in response to the invitation by the President of the Conference in her Note of 18 November 2019 (A/CONF.232/2020/3) (15 April 2020), online: <https:// www.un.org/bbnj/sites/www.un.org.bbnj/files/textual_proposals_compilation_article-by-article_-_15_ april_2020.pdf> [Textual proposals]), only the Core Latin-American Group suggested a reference to 
scope of its meaning. ${ }^{75}$ Delegations have, however, opted for the inclusion of "an integrated approach" as part of the general principles, ${ }^{76}$ highlighting the need for integration, another feature of adaptability. Such development shows that the notions of adaptability and flexibility might need to be fleshed out and better defined for policy-makers to grasp their added-value for making the Agreement more responsive to the complex system it tries to address, something to which the present study aims to contribute.

Despite the absence of textual references to adaptability, the Agreement does embody some components of adaptive strategies, through its structures and mechanisms it includes. The adaptability of the future BBNJ Agreement as a whole has in fact been assessed in the contribution of the present author to a previous publication. ${ }^{77}$ It was concluded there that the BBNJ process and the draft Agreement present signs of adaptability, mostly through "a strong will for knowledge gathering and sharing, which contributes to learning and adapting over time", the "references to regional bodies [that] point towards the inclusion of structures operating at several levels of governance", and the openness of the process "to the participation of various stakeholders". ${ }^{78}$

The aim of the present section is to build on this previous analysis of the Agreement's adaptability, and to focus on the way in which these adaptive components could most likely impact the regime for international fisheries. It has been discussed in chapters 4 and 5 above that it remains uncertain whether fisheries will be covered by the Agreement. This has been criticized for its non-sequitur with the premise and rationale of the Agreement, namely to conserve biodiversity, fisheries being its main threat in ABNJ. ${ }^{79}$ Nonetheless, five elements discussed in relation to the BBNJ Agreement, although not directly targeting fisheries, deserve further attention

flexibility, pertinence/relevance and effectiveness as part of "other criteria" to be included under art. 5 on general principles and approaches, see Textual proposals at 43-44.

75 This discussion on the meaning of the concepts of flexibility and resilience could trigger the need to further elaborate on the scope of these concepts in the context of the development and implementation of legal provisions.

76 Revised draft text, supra note 74 at art. 5(g). The use of the term "integrated approach" is more in line with the UN language, as can be found in the annual UNGA Resolutions on Oceans and the law of the sea since 2001, see chapter 1 section 2.1 above. This could therefore explain the use of these terms in the BBNJ principles, simply because delegates are more "comfortable" with them. In the Textual proposals, supra note 74, most proposals suggest keeping the reference to an integrated approach, except for the United States which suggested its deletion (see at 49 ). IUCN also mentioned that a simple reference to "integrated approach" without further explanation might not be sufficiently clear as to what such an approach means or entails (see at 50).

77 See, generally, Blanchard, Durussel \& Boteler, supra note 9.

78 Ibid at 8 .

79 See, e.g., Richard Barnes, "The Proposed LOSC Implementation Agreement On Areas Beyond National Jurisdiction and Its Impact on International Fisheries Law" (2016) 31:4 International Journal of Marine and Coastal Law at 583-619 at 593; Warner, supra note 1 at 183; Richard Barnes, "Future fisheries and ABNJ" in Vito De Lucia, Lan Ngoc Nguyen \& Alex Oude Elferink (eds), International Law and Marine Areas beyond National Jurisdiction: Current Status and Future Trends (forthcoming). 
because they illustrate the potential positive impacts that adaptability features could have on fisheries management through the Agreement.

First, the current text of the Agreement contains several review tools in order to ensure that decisions can be reviewed according to evolving and new knowledge. Those review mechanisms found within the framework of ABMTs and EIAs are the most interesting, as these are the two issue-areas having the biggest potential impact on fisheries management. ${ }^{80}$ Results from review procedures could demonstrate the need to strengthen cooperation and potentially coordination with already existing organizations that have a mandate in a geographical area of concern. Strengthening cooperation and coordination could for example be done with existing ABMT tools related to fisheries, such as VMEs used by some RFMOs, or MPAs established by CCAMLR. This need for coordination might also arise in the case of EIAs, where a new or continuing activity might prove to overlap with fisheries in the same region.

Second, the Agreement represents an opportunity to develop further tools that are more cross-sectoral and/or dynamic, especially with regards to ABMTs and EIAs. However, these tools have so far not been extensively discussed, or remain controversial. For example, MSP does not appear in the current version of the Agreement, while the modalities of more encompassing environmental assessment tools such as SEAs, CIAs and TIAs remain under consideration and are currently not well understood by delegates. ${ }^{81} \mathrm{~A}$ recent study has also presented the benefits of dynamic, or non-static, ABMTs. Dynamic tools present advantages in responding "to the fast-changing conditions of the global ocean" ${ }^{22}$ because they allow "their geographic boundaries [to] change over time" ${ }^{83}$ However, such types of ABMTs are so far not considered in the text of the Agreement, which defines ABMTs as "geographically defined areas". ${ }^{84}$ Explicitly including these tools in the Agreement, tools which have so far not been (extensively) used in ABNJ, could be an opportunity to acknowledge the potential of mechanisms that are by nature more flexible, encompassing and adaptable for embedding the management of different activities in $\mathrm{ABNJ}$, including fisheries, in marine environmental protection perspectives. ${ }^{85}$

80 See chapter 4 sections 3.2 and 4.1 above.

81 See, e.g. IISD, "Summary of the Third Session of the Intergovernmental Conference on an International Legally Binding Instrument under the UN Convention on the Law of the Sea on the Conservation and Sustainable Use of Marine Biodiversity of Areas Beyond National Jurisdiction: 19-30 August 2019" (2019) 25:218 Earth Negotiations Bulletin at 11 [Summary IGC 3]. The uncertainty regarding the inclusion and/ or scope of these tools in the Agreement is discussed in chapter 4 section 4.1 above.

82 Guillermo Ortuño Crespo et al, "Beyond static spatial management: Scientific and legal considerations for dynamic management in the high seas" (2020) Marine Policy article 104102 at 8, see also at 3.

83 Ibid at 7-8.

84 Revised draft text, supra note 74 at art. 1(3) (emphasis added), discussed in ibid at 7.

85 A short discussion on the fact that most of these tools are not used in ABNJ is conducted in chapter 3 section 4.2 .1 and chapter 4 section 3.2 above. 
Third, an important mechanism for the Agreement's institutional structure will be the clearing-house mechanism. ${ }^{86}$ This mechanism could contribute to the gathering of new knowledge through "an open-access web-based platform [and ...] a network of experts and practitioners in relevant fields", as it "shall serve as a centralized platform to enable States Parties to have access to [...] and disseminate information". ${ }^{37}$ What is still being discussed during the negotiations is the establishment of the precise functions of such a mechanism and its content, i.e. what sort of information should be expected to be shared on the platform. This last point raises strong concerns from States about confidentiality related to intellectual property rights..$^{88}$ For RFMOs, RSPs and other actors involved in monitoring and enforcement on the high seas, information shared about ABMTs and EIAs more specifically could be a relevant starting point for developing their own measures, as well as for coordinating conservation measures across organizations. It would also depend on who would be sharing information and who would be given access to the information shared on the platform. In any case, the clearing-house mechanism has the potential to be a strong tool for facilitating adaptable decision-making based on recent knowledge. The openness of such platform must, however, be specified in more detail.

Fourth and relatedly, a COP and a scientific/technical body will form the institutional structure of the Agreement. As discussed previously, having a COP could help to ensure a continuous and more efficient monitoring and control of the effectiveness of the treaty, by allowing for iteration and flexibility in decision-making. ${ }^{89}$ The COP would act together with a scientific and/or technical body which would provide the recommendations and knowledge needed for such decisions. To do so, however, the COP must be mandated with a decision-making power, and the extent to which the rules and decisions it adopts contribute to supplementing, interpreting or even modifying the treaty provisions (i.e. being a "driver of change") can vary substantially depending on several elements, e.g., the nature of the post-treaty instrument (i.e. either a rule or a decision), the wording of that rule or decision, whether the rule or decision concerns the operation of a treaty regime or is aimed at treaty parties or the regulation of private actors. ${ }^{90}$ Generally, however, there seems to be a shared belief in the authority of post-treaty rules "explained by a large measure on social legitimacy", ${ }^{91}$ i.e. the acceptance of a rule's authority by a certain community. ${ }^{92}$ At the moment, there is a widespread interest in delegating many tasks to the BBNJ COP (e.g. determining SEAs, establishing guidelines for cumulative impact assessment, developing a list of activities for which EIAs are requested and establishing further

86 Revised draft text, supra note 74 at art. 51.

87 Ibid at art. 51(2) and (3).

88 Summary IGC 3, supra note 81 at 18.

89 See section 2.2.3 above.

90 Tim Staal, Authority and Legitimacy of Environmental Post-Treaty Rules (Oxford: Hart, 2019) at 45-46.

91 Ibid at 188-189.

92 Ibid at 185. 
bodies), ${ }^{93}$ and it could therefore be concluded that such new rules, bodies, plans or measures adopted by the COP would have similar authority to the provisions of the Agreement themselves. A COP therefore has the possibility to adopt rules and decisions of equally perceived authority, but through more flexible channels.

Finally, and more generally with regard to institutional structures, the current preference for an hybrid approach to institutional arrangements ${ }^{94}$ could also contribute to embedding polycentric structures in the Agreement. For example, mandating the central body (i.e. the COP) with overarching and standard-setting duties, while existing sectoral and regional organizations focus on questions of implementation would represent a model where authority rests at different levels. To ensure the development of nested enterprises, i.e. where smaller-scale/regional organizations are part of a large-scale/global system, ${ }^{95}$ such approach will have to go hand in hand with cooperation and coordination, to which the Agreement is expected to play an important role. In fact, while cooperation is reflected in the preamble and in the fundamental principles of some of the instruments discussed in chapter $2,{ }^{96}$ coordination does not appear anywhere as an overarching objective. ${ }^{97}$ It is therefore one aspect on which the BBNJ Agreement could leave an important mark, further supporting the necessity for the Agreement to consider cooperation and coordination as stand-alone objectives and not only as ways of achieving other obligations found in other provisions.

\subsection{Reflections on adaptability within the current regime for international fisheries law}

Several features of adaptability can be found in legal structures and instruments regulating the management of fisheries on the high seas, as well as in the draft text of the BBNJ Agreement. However, although present, the features of adaptability remain difficult to implement, and they have so far been implemented in a piecemeal and haphazard fashion. For example, performance reviews could become truly efficient iteration mechanisms if they were undertaken regularly and acted upon. Platforms for the exchange of knowledge and practices could be valuable tools for the harmonization of good practices if they were used to their full potential. It can also be observed from the analysis conducted above, while reiterating a comment made previously, ${ }^{98}$ that the presence of adaptability features directly

93 Summary IGC 3, supra note 81 at $11,17$.

94 The institutional structure of the BBNJ Agreement is discussed in chapter 4 section 4.2 above.

95 Nested enterprises and polycentricity are discussed in chapter 6 section 3.2.1 above.

96 Cooperation is found in UNFSA at preamble, CBD at preamble, CITES at preamble, CMS at art. II(1), and Compliance Agreement at preamble.

97 Coordination is mentioned in the preamble to the PSMA but not in art. 2 that lists the objectives.

98 As mentioned previously, the models are not particularly enlightening in terms of adaptability in enforcement; although they mention that enforcement should ensure that substantive and procedural goals are achieved, the present author does not believe that it specifically targets issues of adaptiveness, see chapter 6 section 3.1 above. 
targeting enforcement is somewhat limited. One could therefore ask to what extent adaptability of legal/regulatory structures is part of the solution for improving sustainability performance within the regime for fisheries management.

How, then, can features of adaptability "enhance the regulatory system in that they create potential regulatory approaches that can be applied to diverse, nonlinear and complex problems, despite the fact that [these problems] are also obstacles to effective implementation of many of these features"?99 What could an "enhancement of the regulatory system" look like? First, since we already have "a stable legal framework from which a regime for the management of [...] fisheries might emerge", 100 Rayfuse suggests that the next step would be to have "a regulatory design that is capable of mainstreaming both the best available science and adaptive managerial capacity". ${ }^{101}$ It is therefore this regulatory design that we must target, which, in the management of fisheries, might primarily result in alternatives to support administrative law-like tasks, such as decision-making. ${ }^{102}$ Second, to address the question of compliance, alternatives for adaptability of the legal regime must also function, as far as possible, independently from State-based enforcement and/or trigger enforcement through different channels. In order to do so, we suggest using the dialogue between governance and adaptability as the vector of a key to approaching existing mechanisms from a different perspective, to use what we already have in a different way.

\section{SUGGESTIONS FOR ALTERNATIVE MECHANISMS}

Following the observations made above, how can we build on adaptive features to develop further cooperation and coordination among measures and structures and, consequently, ensure coherence and improve compliance? More specifically, how can we use polycentricity and networks, two governance-related components, as building blocks for an outcome-based approach, one that aims to trigger changes in high seas fisheries management so as to achieve improved sustainability of oceans?

The present section looks at two alternative mechanisms to operationalize adaptive strategies for the regulation and management of high seas fisheries: smart mixes and interplay management. They illustrate that "[s]ustaining and conserving fisheries and marine species can be achieved through a coordinated mix of interventions [...] including multi-level coordination across stakeholders". ${ }^{103}$ Smart mixes and

99 Brita Bohman, Transboundary Law for Social-Ecological Resilience? A Study on Eutrophication in the Baltic Sea Area (Academic dissertation for the Degree of Doctor of Laws in Environmental Law, Stockholm University, 2017) at 391.

100 Rayfuse, "CAOFA", supra note 26 at 2.

101 Ibid.

102 Nigel Bankes, "Adaptive management, Adaptive governance and the role of law: a literature review" (2018) at 6-7 (unpublished, on file with author).

103 IPBES, Summary for Policymakers of the IPBES Global Assessment Report on Biodiversity and Ecosystem Services (2019) at 18, para D7: online: <https://ipbes.net/sites/default/files/inline/files/ipbes_global_ 
interplay management are relevant mechanisms to look into because they tackle the complex nature that characterizes high seas and international fisheries, by suggesting methods to improve interaction between multiple scales, actors, instruments, and institutions. They also tackle the lack of enforcement and compliance that stems from this complexity, by suggesting ways of enhancing actors' accountability towards the interconnectedness between fisheries management and environmental protection.

Some of the components of smart mixes and interplay management are not completely foreign to fisheries management and conservation; what these mechanisms do however is to suggest using what is already available, but in a different way. This exploration is undertaken in the light of a recent tendency "to focus on refining the effectiveness of [...] instruments and institutions, or developing new techniques of regulation, in light of new knowledge and experience of success and failure in regulation" ${ }^{104}$ These mechanisms also illustrate that the management of fisheries towards improved sustainability performance has evolved from technical measures (e.g. mesh sizes and bans on certain fishing techniques) to measures that involve cross-sectoral and cross-regime complementarity such as trade-related control or economic incentives. ${ }^{105}$

Smart mixes and interplay management have been discussed mostly in governance, and more specifically environmental governance, and policy literature, but have so far not been extensively studied in the legal scholarly literature. ${ }^{106}$ This assessment in the context of a legal framework is therefore exploratory. These alternatives constitute policy recommendations: what is suggested is to ensure their consideration when making policy decisions, which could, ultimately, impact the adaptive capacity of the legal landscape of international fisheries management. For example, these alternative mechanisms could help States to clarify the "large margin of appreciation in determining how to give shape to their cooperation". ${ }^{107}$ It could give meaning to the generic obligation of cooperation in the specific case of high seas fisheries management, where cooperation would be considered as fulfilled only

assessment_report_summary_for_policymakers.pdf $>$.

104 Barnes, "Good Regulatory Design", supra note 21 at 104.

105 Serge Garcia, Jake Rice \& Anthony Charles, "Governance of marine fisheries and biodiversity conservation: Convergence or coevolution?” in Serge Garcia, Jake Rice \& Anthony Charles (eds), Governance of marine fisheries and biodiversity conservation: Interaction and Coevolution (Hoboken: Wiley, 2014) 18-36 at 19.

106 See, e.g. Judith van Erp et al (eds), Smart Mixes for Transboundary Environmental Harm (Cambridge: Cambridge University Press, 2019); Olav Schram Stokke, "Management Options for High Seas Fisheries: Making Regime Complexes More Effective" in Richard Caddell \& Erik Molenaar (eds), Strengthening International Fisheries Law in an Era of Changing Oceans (Oxford: Hart, 2019) 51-77 [Stokke, "Management Options"]; Harro van Asselt, notably in "Legal and Political Approaches in Interplay management. Dealing with the Fragmentation of Global Climate Governance" in Sebastian Oberthür \& Olav Schram Stokke (eds), Managing Institutional Complexity. Regime Interplay and Global Environmental Change (Cambridge, Mass.: MIT Press, 2011) 59-85.

107 Alex Oude Elferink, Erik Molenaar \& Donald Rothwell, "The Regional Implementation of the Law of the Sea and the Polar Regions" in Alex Oude Elferink, Erik Molenaar \& Donald Rothwell (eds), The Law of the Sea and the Polar Regions. Interactions between Global and Regional Regimes (Leiden: Brill Nijhoff, 2013) $1-16$ at 10 . 
if smart mixes and interplay management are systematically considered in decisionmaking and policy development.

To understand better how the alternative mechanisms could trigger changes in high seas fisheries management towards improved sustainability performance, this section first delves into the analysis of smart mixes regulation, which mostly targets the collaboration and complementarity between instruments and actors normally operating in different fields and at different levels (3.1). It then turns to interplay management, a mechanism whose impact is mostly felt at the institutional level (3.2). The section ends with observations on ways in which these mechanisms have been used for improving sustainability performance in international fisheries (3.3). It must be mentioned, however, that the alternatives explored below should not be considered as a panacea for weak compliance while moving towards sustainability performance within the system of international fisheries. Smart mixes and interplay management represent modest suggestions towards the operationalization of adaptability within the management of international fisheries, which could benefit from further testing through case studies.

\subsection{Experimenting with smart mixes}

The concept of smart mixes, also called smart regulation, emerged from the work of Gunningham, Grabosky and Sinclair. ${ }^{108}$ Simply put, the concept of smart mixes represents a design of "complementary combinations of policy instruments, tailored to particular environmental goals and circumstances, [which] will produce more effective and efficient policy outcomes" ${ }^{109}$ The concept arises as a necessity when addressing complex systems; ${ }^{110}$ in fact, smart mixes bring forward the capacity to consider "various policy instruments as alternatives" and also in combination. ${ }^{111}$ These combinations allow for more flexibility and resilience for the regulatory structure, as one instrument can act as a mitigator of the weaknesses of another. ${ }^{112}$

In the context of international regulations, smart mixes embrace a broad understanding of regulatory instruments, going beyond State-based law, and including self-regulation, economic instruments and incentives, private standards,

108 Neil Gunningham \& Peter Grabosky, with Darren Sinclair, Smart regulation. Designing Environmental Policy (Oxford, Oxford University Press, 1998).

$109 \mathrm{Ibid}$ at 15.

110 Elinor Ostrom, Governing the Commons. The Evolution of Institutions for Collective Action (Cambridge: Cambridge University Press, 1990) at 214, cited in Neil Gunningham \& Darren Sinclair, "Regulatory Pluralism: Designing Policy Mixes for Environmental Protection” (1999) 21:1 Law \& Policy 49-76 at 51.

111 Gunningham \& Sinclair, supra note 110 at 50. See also Judith van Erp et al, "Introduction: The Concept of Smart Mixes for Transboundary Environmental Harm” in Judith van Erp et al (eds), Smart Mixes for Transboundary Environmental Harm (Cambridge: Cambridge University Press, 2019) 3-24 at 5-6 [van Erp et al, "Introduction"].

112 Gunningham \& Sinclair, supra note 111 at 50; Agnes Yeeting \& Simon Bush, "RFMO-MSC Smart Regulatory Mixes for Transboundary Tuna Fisheries" in Judith van Erp et al (eds), Smart Mixes for Transboundary Environmental Harm (Cambridge: Cambridge University Press, 2019) 146-169 at 148. 
and or other forms of control stemming from civil society or businesses. ${ }^{113}$ It has been said that envisaging this consideration of other forms of regulation "fits in the broader shift from 'government' to 'governance' in networks of states, business and civil society". ${ }^{114}$ Smart mixes therefore suggest combining different actors and "modes of societal steering". ${ }^{115}$

In an attempt at conceptualizing smart mixes and creating a matrix for the assessment of its effectiveness, we rely on a classification by Gunningham and Sinclair, which relies on five broad categories of instruments: ${ }^{116}$

1) Command and control regulation: regulation emanating mainly from the State or a similar overarching authority, which establishes rules to command certain activity or behaviours and control whether and how those behaviours are achieved. ${ }^{117}$ Gunningham and Sinclair identify three types of command and control regulations, two of which are relevant for the analysis conducted in the present study: performance standards, designed in order to achieve a solution or goal, and process standards, defining the procedures and parameters for achieving that solution or goal.

2) Economic instruments: instruments triggering some sort of economic incentive. Gunningham and Sinclair identify three types of economic instruments, two of which are relevant for the analysis conducted in the present study: supply side incentives or subsidies, and legal liability, where actors can be held liable for causing environmental harm.

3) Self-regulation: when "an organized group [normally at the industry level, and not including government actors] regulates the behavior of its members". 118

4) Voluntarism: when an individual actor decides unilaterally to act. The government can act as coordinator, but the action comes from the individual actor voluntarily.

5) Information strategies: education, capacity-building, reporting, etc.

There already exists a diversity of instruments within fisheries management. First, as illustrated in chapter 2 of this study, most of the legal instruments regulating fisheries

113 van Erp et al, "Introduction", supra note 111 at 7.

$114 \mathrm{Ibid}$. See also Yeeting \& Bush, supra note 112 at 148.

115 James L. Anderson et al, "Principles for Fisheries Management in Areas Beyond National Jurisdictionthe Essential Role of Incentive-Based Approaches" (2018) at 3, online: <https:/www.worldwildlife.org/ publications/principles-for-fisheries-management-in-areas-beyond-national-jurisdiction-the-essentialrole-of-incentive-based-approaches $>$.

116 Gunningham \& Sinclair, supra note 110 at 53-54. Zacharias \& Ardron suggest a similar classification: regulatory/legal instruments, economic instruments, cooperative instruments (voluntary), and informational instruments (persuasive), see Mark Zacharias \& Jeff Ardron. Marine Policy: An Introduction to Governance and International Law of the Oceans, 2nd ed (Abingdon, Oxon: Routledge, 2019) at 120-121.

117 See, e.g. Zacharias \& Ardron, supra note 116 at 124, using definitions from OECD, "Regulatory Policies in OECD Countries: From Interventionism to Regulatory Governance" (2002) OECD Reviews of Regulatory Reform at Annex 2.

118 Gunningham \& Sinclair, supra note 110 at 54. 
management, either legally binding or not, are command and control instruments. However, non-State based actors and instruments are increasingly relied upon to steer behaviours towards improved sustainability performance. In fact, alternative instruments (i.e. non-State based) "can affect cooperation of States and/or fleets in RFMO or sub-regional management in ways that supersede legal instruments". ${ }^{119}$ Most of these alternatives are incentive-based tools, relying on incentives for sustainable investment in fisheries ${ }^{120}$ either through pull incentives, targeting the market or demand for fish, or push incentives, targeting those producing the products. ${ }^{121}$ These instruments include, for example, rights-based measures, such as the Vessel Day scheme established under the WCPFC which allocated fishing days to specific fishing entities; fiscal measures, including both charges related to fishing activities and/or subsidies for sustainable measures; regulation improving the generation and use of information; ${ }^{122}$ and private fisheries certification initiatives, the most visible and well-known being the Marine Stewardship Council (MSC). ${ }^{123}$

Based on the categories of instruments identified by Gunningham and Sinclair, examples of instruments currently used for the management of high seas fisheries could be classified as follows:

Table 4: Categories of instruments illustrated with examples from the management of international fisheries

\begin{tabular}{|c|c|c|}
\hline Category & Sub-category & Example from the (high seas) fisheries regime \\
\hline \multirow{2}{*}{$\begin{array}{l}\text { Command } \\
\text { and control } \\
\text { regulation }\end{array}$} & Performance standards & $\begin{array}{l}\text { Most of UNCLOS, UNFSA and Code of Conduct } \\
\text { E.g. Art. } 119 \text { UNCLOS on conservation of marine } \\
\text { living resources }\end{array}$ \\
\hline & Process standards & $\begin{array}{l}\text { Most of UNCLOS, UNFSA and Code of Conduct } \\
\text { E.g. Art. } 118 \text { UNCLOS on cooperation for } \\
\text { conservation and management }\end{array}$ \\
\hline \multirow{2}{*}{$\begin{array}{l}\text { Economic } \\
\text { instruments }\end{array}$} & Supply side incentives & $\begin{array}{l}\text { Subsidies for "environmentally friendly" gear or } \\
\text { practices }\end{array}$ \\
\hline & Legal liability & $\begin{array}{l}\text { Charges or taxes for (potentially) harmful } \\
\text { activities (based on the polluter pays principle) }\end{array}$ \\
\hline Self-regulation & & MSC certification \\
\hline Voluntarism & & $\begin{array}{l}\text { Some provisions of the Code of Conduct are based } \\
\text { on voluntary undertakings by actors }\end{array}$ \\
\hline $\begin{array}{l}\text { Information } \\
\text { strategies }\end{array}$ & & $\begin{array}{l}\text { Several information gathering and } \\
\text { capacity-building campaigns from the FAO }\end{array}$ \\
\hline
\end{tabular}

119 Anderson et al, supra note 115 at 8.

120 Barnes, "Good Regulatory Design", supra note 21 at 117.

121 Anderson et al, supra note 115 at 5 .

122 Examples discussed in Barnes, "Good Regulatory Design”, supra note 21 at 116-118.

123 See, generally, Markos Karavias, "Mixing Regional Fisheries Management and Private Certification” in Judith van Erp et al (eds), Smart Mixes for Transboundary Environmental Harm (Cambridge: Cambridge University Press, 2019) 126-145. The use of MSC certification by RFMOs, based on Yeeting \& Bush, supra note 112 , is discussed in further detail in section 3.3 below. 
The application and use of this variety of instruments has mostly been done "in isolation from each other". ${ }^{124}$ The question that this study therefore asks is: are these instruments simply seen as alternatives to one another or could they also be used in combination? This is the added value of the concept of smart mixes: it goes further than concluding that the tool box is full of a diversity of instruments; it relies on the possibility of using these instruments together.

What this study suggests is that smart mixes should be considered more systematically in policy development and decision-making for fisheries management. In fact, the adaptability potential of such a combination of instruments could contribute to countering the lack of coherence often triggered by fragmentation. Smart mixes operationalize polycentricity by suggesting the encompassing of a larger pool of instruments, regulations and actors and, above all, the connectivity between them. This appears to be a satisfactory way to proceed in the face of the complexity which characterizes the high seas fisheries regime. ${ }^{125}$

The concept of smart mixes supports the idea that instruments which are not primarily legal in nature must be accommodated within a legal regime. The present author is of the view that this is not incompatible with the State-centred legal process of international law. In fact, through smart mixes, State-based rules are not completely set aside; the combination of instruments relies on their complementarity, which "work[s] with the logic of State-centered legal process, rather than trying to challenge the patterns of authority and competence in the international legal system.". ${ }^{126}$

Nevertheless, an essential debate remains about the legitimacy of the use of nonState norms/mechanisms: the legitimacy of State-based mechanisms normally stems from the authority that States have as central actors in international law, ${ }^{127}$ but one could question this source of legitimacy for non-State based mechanisms. While smart mixes do not threaten the use of State-based norms and mechanisms per se, the combination of instruments which this approach advocates is what raises questions of legitimacy: i.e. that State-based norms and mechanisms are not central anymore. Additionally, the use of smart mixes can also trigger issues of: (1) democratic representation (e.g. the argument that non-State based mechanisms represent interests that have not been democratically recognized); (2) delegation of power and how State responsibility remains (e.g. if an internationally wrongful act ensues from the use of smart mixes, how could a non-State actor be held liable? Would rules of attribution be applicable? Does the State remain fully responsible,

124 Anderson et al, supra note 115 at 5.

125 van Erp et al, "Introduction", supra note 111 at 4.

126 Barnes, "Good Regulatory Design", supra note 21 at 120.

127 See, e.g. Louis Kotzé \& Rakhuyn Kim, "Earth system law: The juridical dimensions of earth system governance" (2019) 1 Earth System Governance article 100003 at 5, citing Ulrich Beyerlin \& Thilo Marauhn, International Environmental Law (Oxford: Hart, 2011) at 247 who mention that "states legitimately are and remain the primary authors of international [...] law". 
or can it escape liability if it shows due diligence?); and (3) transparency (e.g. would obligations of transparency, to which State actors are bound, also apply to non-State actors?). In fact, the combination advocated by smart mixes might be successful in contexts where the legal order is strong but might not be so successful - and even detrimental to State legitimacy - when the legal order is weak. This is why the use of smart mixes must always take into consideration a broader and contextual environment, where the actors and instruments must be seen with regard to the position which they hold "within an interaction network", ${ }^{128}$ especially in a context such as fisheries law, where there are "multiple actors with asymmetrical power". ${ }^{129}$ Although a detailed discussion on the legitimacy of smart mixes goes beyond the scope of this study, it remains important to raise the issue in order for policy makers and (legal) scholars interested in the use of smart mixes for the development of regulatory strategies for sustainable performance to know the (legal) difficulties that the use of such an alternative can entail.

Legitimacy can be defined according to different conceptions, and the conception illustrated above relies on a source-oriented understanding, i.e. whether the actors who undertake measures have been authorized to act. ${ }^{130}$ Based on a processoriented and result-oriented definition of legitimacy, ${ }^{131}$ however, mechanisms that would be fit for purpose and ensure effectiveness would be legitimate; thus, smart mixes that are fit for purpose and that ensure effectiveness would be legitimate. In order to ensure a good regulatory design for the management of fisheries in $\mathrm{ABNJ}$ through the mix of instruments and tools (i.e. for the mix to be smart and fit for purpose), a recent study ${ }^{132}$ by the Global Think Tank for the World Bank's Ocean Partnerships for Sustainable Fisheries and Biodiversity Conservation ${ }^{133}$ has identified nine principles upon which smart mixes for fisheries in ABNJ must be designed and which can help to measure the potential success of a combination of instruments. ${ }^{134}$ First, the compatibility of instruments must be ensured, as some combinations of instruments might lead to counterproductive results or cause additional complexity. Determining this best mix will be the result of an iterative

128 Judith van Erp et al, "Conclusion. Smart Mixes in Relation to Transboundary Environmental Harm" in Judith van Erp et al (eds), Smart Mixes for Transboundary Environmental Harm (Cambridge: Cambridge University Press, 2019) 329-343 at 332 [van Erp et al, "Conclusion"], referring to the chapter in the same book by Pattberg \& Widerberg (Philipp Pattberg \& Oscar Widerberg, "Smart Mixes and the Challenge of Complexity. Lessons from Global Climate Governance" 49-69).

129 van Erp et al, "Conclusion", supra note 128 at 333, referring to the chapter in the same book by Barnes, "Good Regulatory Design", supra note 21.

130 See, e.g. Allen Buchanan \& Robert Keohane, “The Legitimacy of Global Governance Institutions" in Rüdiger Wolfrum \& Volker Röben (eds), Legitimacy in International Law (Berlin: Springer, 2008) 25-62, cited in Rüdiger Wolfrum, "Legitimacy in International Law" (2006) Max Planck Encyclopedia of Public International Law at paras 6-8; Tim Staal, Authority and Legitimacy of Environmental Post-Treaty Rules (Oxford: Hart, 2019) at 185-188.

131 Wolfrum, supra note 130 at 6-8.

132 See, generally, Anderson et al, supra note 115.

133 FAO, "Common Oceans - A partnership for sustainability in the ABNJ", online: <http://www.fao.org/ in-action/commonoceans/projects/ocean-partnerships/en/>.

134 Anderson et al, supra note 115 at 8. Each of these nine principles is also illustrated by case studies. Elaborating further on each of these case studies, however, falls beyond the scope of the present study. 
process. ${ }^{135}$ Second, considering the limited resources of decision makers, the combinations should always aim for low cost, low conflict and maximum impact results. ${ }^{136}$ Third, combinations should be done in sequence to give the system time to react and adjust. ${ }^{137}$ Fourth, there should not only be a smart mix of instruments, but also a smart mix of decision-makers, through the involvement of several actors able to influence or trigger change in management. ${ }^{138}$ Fifth, the mix should enable stakeholders to engage in decision-making that will lead to net gain outcomes. ${ }^{139}$ Sixth, a smart mix must ensure the engagement of stakeholders, which can vary across jurisdictions, and across institutional, social and cultural contexts. The mix must therefore ensure room for bottom-up management. ${ }^{140}$ Seventh, while the previous principles support bottom-up approaches, these must be balanced with the need to scale them up to global levels, which means that regional and global structures must also be included. ${ }^{141}$ Eighth, the mix must be adaptable in light of effectiveness assessments. ${ }^{142} \mathrm{Ninth}$, it is important to acknowledge the limit of the effectiveness of a mix in order to contemplate new combinations. ${ }^{143}$ These characteristics highlight the highly context-specific nature of smart mixes for the management of high seas fisheries and the necessity for these diverse instruments and tools to adapt to the relevant regions and actors, ${ }^{144}$ "to ever-changing circumstances, and [to] new understandings of social and environmental problems." ${ }^{145}$ A general observation that stems from these characteristics is therefore that smart mixes foster and stimulate adaptability.

These criteria could be relied upon and/or act as a starting point for developing a framework to guide actors in the active design and/or use of smart mixes. In fact, until now, examples of smart mixes have shown that they are normally not planned, not deliberately designed, and that they are the result of uncoordinated efforts. ${ }^{146}$ Existing studies have mostly taken an observational role, looking at instances where smart mixes have produced useful results for sustainability performance, but have not, to the present author's knowledge, made a deliberate use of smart mixes. It has even been questioned whether, in the face of complex systems which produce unexpected outcomes, "rational mixing and orchestrating work" ${ }^{147}$ would even be possible and/or desirable.

135 Anderson et al, supra note 115 at 11-12. Guggingham \& Sinclair, supra note 110 at 55-65.

136 Anderson et al, supra note 115 at 13-15.

137 Ibid at 17-18.

138 Ibid at 19-21.

$139 \mathrm{Ibid}$ at. $23-24$

140 Ibid at 25-27.

141 Ibid at 29-30.

142 Ibid at 31 .

143 Ibid at 33-34.

144 Ibid at 3; Yeeting \& Bush, supra note 112 at 149.

145 van Erp et al, "Introduction", supra note 111 at 20.

$146 \mathrm{Ibid}$ at 15.

147 Pattberg \& Wideberg, supra note 128 at 50. The concept of non-linearity refers to something that does not follow a linear response, i.e. identifying the problem, assessing the problem, planning the response, making a decision as to this response, and implementing it, see, generally, Rakhyun E. Kim \& Brendan 
However, considering the positive outcomes from the use of smart mixes in complementing shortcomings in fisheries management, positive outcomes which are discussed in further detail below, ${ }^{148}$ this study believes that smart mixes have a potential for improving coherence and complementarity between instruments, a potential that is rooted in flexibility. Smart mixes should be considered more systematically as an addition to the policy "toolkit for decision-makers to work with when trying to develop and evaluate potential interventions in current fisheries management arrangements". ${ }^{149}$ What this study highlights is two-fold: first, smart mixes represent a practical embodiment of networks between instruments and actors, and second, smart mixes can bring an important level of flexibility and adaptability to the landscape of fisheries management strategies.

\subsection{Interplay management: when institutions work together}

While smart mixes present options primarilyrelated to the interaction of instruments and actors, adaptive strategies for the legal framework must also include mechanisms that allow for the development and interaction of institutions. For that aim, this study assesses the potential of interplay management, described by Stokke as "deliberate efforts by States or other actors to improve the interplay of the institutions involved". ${ }^{150}$ Interplay management focuses on the coordination between elements of a regime; in other words, it is the relationships between elements that are targeted, but not the elements themselves. ${ }^{151}$ Interplay management can thus be considered as one tool to address regime interaction and manage fragmentation, but where the interaction is deliberately encouraged and not simply observed. ${ }^{152}$

Mackay, "International Environmental Law as a Complex Adaptive System" (2014) 14 International Environmental Agreements 5-24.

148 See section 3.3 below.

149 Anderson et al, supra note 115 at 8.

150 Stokke, "Management Options", supra note 106 at 62. See also Olav Schram Stokke, "The Interplay of International Regimes: Putting Effectiveness Theory to Work" (2001) Report of the Fridtjof Nansen Institute at 11 [Stokke, “The Interplay”].

151 Jens Heidinsfelder \& Markus Beckmann, "A Governance Puzzle to Be Solved? A Systematic Literature Review of Fragmented Sustainability Governance" (2019) Management Review Quarterly at section 5.2.1.

152 A three-fold approach to regime interaction (i.e. process (interaction of institutions), form (interaction of instruments), and substance (interaction of norms)) is suggested by Seline Trevisanut, Nikolaos Giannopoulos \& Rozemarijn Roland Holst, "Conclusion: Proposing a Three-Fold Approach to Regime Interaction in Ocean Governance" in Seline Trevisanut, Nikolaos Giannopoulos \& Rozemarijn Roland Holst (eds), Regime Interaction in Ocean Governance. Problems, Theories and Methods (Leiden: Brill Nijhoff, 2020) 222-234. This three-fold approach builds on the three characteristic dimensions of regime conflicts by Pulkowski (regime conflict as a consequence of goal conflicts, as a product of institutional conflict and power struggle, and manifesting themselves in conflicts of legal rules), see, generally, Dirk Pulkowski, The Law and Politics of International Regime Conflict (Oxford: Oxford University Press, 2014). These dimensions presented by Pulkowski, however, seem to focus on a treaty-oriented approach to regime conflict. The three-fold approach also overlaps with the four-fold approach to regime interaction presented by Stokke: diffusive interaction (i.e. when the substantive or operational rules of regime A become a model for regime B), political interaction (i.e. interactions between interests and capabilities), normative interaction (i.e. norms of regime A contradict or validate norms of regime B), and operational interaction (i.e. focusing on the coordination of activities), see Olav Schram Stokke, "Conclusion" in Olav Schram Stokke (ed), Governing High Seas Fisheries. The Interplay of Global and Regional Regimes (Oxford: Oxford University Press, 2001) 329-360 at 345-353. Under the three-fold approach of Trevisanut, 
As the main challenge faced by the regime is linked to its effectiveness in ensuring sustainability performance, the aspect of interplay studied here focuses on the role of interplay for reaching this effectiveness within the regime. ${ }^{153}$

There have been extensive policy debates on a reform of the entire architecture of environmental institutions to accommodate interplay and achieve coherence through a centralized body. ${ }^{154}$ As early as 1992 , when the development of environmental instruments and institutions started to boom, the benefit of such centralization was advanced as a way to evaluate gaps, "develop means of assigning priorities among competing claims for attention", or to ensure coordination. ${ }^{155}$ The absence of any concrete development in that direction, however, supports the fact that such an institutional revolution is not likely to gather sufficient support. This is particularly the case in the context of fisheries management, ${ }^{156}$ where the autonomy of regional entities is strongly embedded in the regime. This is why interplay management acts as the realistic alternative to a complete institutional centralization, an alternative that responds more satisfactorily to the reality of international fisheries structures.

In fact, the different categories of challenges to international and high seas fisheries law described previously (cognitive, regulatory, behavioural), ${ }^{157}$ as well as the overarching problems stemming from fragmentation confirm the necessity to find varied solutions adapted to particular needs, while fulfilling the objective of coherence. This is further supported by the fact that international fisheries management and the implementation of high seas fisheries law are intrinsically regional, therefore presenting a variety of methods, actions and results. Furthermore, the most developed and established structures of marine environmental management and protection are also to be found at the regional and sectoral levels. ${ }^{158}$ The regional orientation of fisheries-related institutions is not per se an impediment to coherence; this orientation simply needs to be taken into

Giannopoulos \& Roland Holst, smart mixes could be considered as a tool to manage interactions of form, while interplay management could be understood as a tool to manage institutions. What the present study suggests with regard to smart mixes and interplay management, however, contains one additional step, i.e. that interactions should not only be identified and managed, but also deliberately encouraged and fostered. It could further be concluded that the present study further shares similarities with the operational interactions identified by Stokke, since it targets coordination.

153 Stokke, "The Interplay", supra note 150 at 1 . The other aspects are interplay for regime formation and interplay for regime maintenance. Effectiveness is chosen in the present study as it answers one of the main challenges identified in chapter 5 sections 3 and 4 above: we have the instruments we need but they are not being applied/used properly.

154 See, e.g., Frank Biermann, Olwen Davies \& Nicolien van der Grijp, "Environmental policy integration and the architecture of global environmental governance" (2009) 9 International Environmental Agreements 351-369 at 364 .

155 Geoffrey Palmer, "New Ways to Make International Environmental Law" (1992) 86 American Journal of International Law 259-283 at 263.

156 The reluctance to approach the topic within the BBNJ negotiations, for example, illustrates such observation.

157 See, generally, chapter 5 section 2 above.

158 The main institutions holding that mandate are RSPs, see chapter 2 section 3.3.4 above. Examples of sectoral ABMTs include VMEs, APEIs, PSSAs, EBSAs, etc., mentioned in chapter 3 section 4.2.1 above. 
consideration when developing interplay mechanisms so that "the management approach fit $[s]$ the particular [...] conditions of the interaction situation". 159

Interplay management further acts as an interesting solution for regimes affected by prominent disconnects. In fact, even if different regimes are working towards the same and/or compatible goals, their instruments and related institutions do not necessarily work synergistically because they are grounded in different approaches, methods and actors. ${ }^{160}$ An interesting example resides in the regime for the protection of sharks. As explained in chapter 5 above, ${ }^{161}$ the legal framework for the management and protection of sharks is scattered among a variety of instruments and institutions. Only a limited number of RFMOs have adopted measures for the protection of sharks. ${ }^{162}$ A more encompassing protection of sharks would thus have to be sought under other instruments, such as CITES; however, the listing of marine species under CITES, including sharks, is often met with opposition, based on the conviction that they are adequately addressed under the framework of RFMOs. ${ }^{163}$ Although some shark species are now listed under CITES, ${ }^{164}$ this example illustrates the disconnect between RFMOs and other instruments addressing shark protection and the lack of understanding of the potential complementarity between instruments and institutions. This example from the regime for sharks shows that interplay management could be useful to reinforce synergies.

This is why, to ensure synergies and coherence among different forms of fragmentations and disconnects, interplay management can also take different forms; in fact, it "may involve overarching principles of international law or explicit cross-institutional coordination of regulatory or programmatic activities, but often takes the less ambitious form of unilateral or mutual adaptation of the objectives

159 Sebastian Oberthür, "Interplay management: enhancing environmental policy integration among international institutions” (2009) 9 International Environmental Agreements 371-391 at 373.

160 Ellen Hey, "Regime Interaction and Common Interests in Regulating Human Activities in Areas Beyond National Jurisdiction" in Seline Trevisanut, Nikolaos Giannopoulos \& Rozemarijn Roland Holst (eds), Regime Interaction in Ocean Governance. Problems, Theories and Methods (Leiden: Brill Nijhoff, 2020) 85-123 at 87. In terms of methods, Hey gives the example of voting arrangements within institutions. In CITES for example, decisions are made on a $2 / 3$ majority of all parties, meaning that non-fishing States could also influence decisions related to fish species. Within RFMOs, decision-making is limited to members States, who are themselves limited to States of the regions, operating in the region or having an interest in fishing in the region, see at 99. Similarly, she mentions that different actors can influence the position of a certain delegation, e.g. if a delegation is composed of members of the industry, of NGOs or of representatives from different ministries, all of whom have different priorities and interests.

161 See chapter 5 section 2.2 .1 above.

162 ICCAT, IATTC, NAFO and CCAMLR seem to be the only RFMOs which have, to varying degrees, adopted measures for the conservation of sharks, and those measures seem to be mostly targeting shark finning, see IUCN Shark Specialist Group, "Regional Fisheries Management Organizations (RFMOs)", online: <https://www.iucnssg.org/rfmos.html>.

163 For example, the initial listing of sharks was met with some opposition in the early 1990s. This situation is discussed in Hey, supra note 160 at $87-90$.

164 CITES, "Appendices I, II and III" (as of 26 November 2019), online: <https://www.cites.org/eng/app/ appendices.php>. 
or measures of other institutions" ${ }^{165}$ It can occur at four different levels, ${ }^{166}$ which all apply to the regime for high seas fisheries. First, at the centralized end of the spectrum, interplay management relies on overarching institutional frameworks. In the current structure of fisheries regulation and management, the FAO could be considered as bearing some centralized tasks through the sharing of information, as well as its role in the development of rules and principles through the adoption of legally and non-legally binding instruments. To develop this centralized role further, it has been suggested that the FAO could for example act as an overarching platform for reviewing the performance of RFMOs. ${ }^{167}$ However, it would be difficult to imagine increasing the role of the FAO beyond one of coordination, especially in terms of decision-making and review, which remain the sole preserve of regional organizations. Similarly, the UNGA could also be considered as bearing some centralized tasks through, e.g., the adoption of the yearly Sustainable fisheries resolution ${ }^{168}$ which can have significant impacts on the development of measures and practices for sustainable fisheries management, as was the case for the management of bottom-fishing. ${ }^{169}$ The UNGA also holds an important role in policy making with regards to the oceans, which could explain the decision to conduct the BBNJ process under its auspices. ${ }^{170}$ In a similar fashion to the FAO however, it would be difficult to envisage enhancing further the role of the UNGA beyond one of coordination and "umbrella forum" as fisheries management lies with RFMOs. A second level, joint interplay management, involves coordination between sectoral regimes and the development of possible joint rules of interaction. Thirdly, unilateral management by individual institutions refers to cooperation in actions, while decision-making remains independent and without deliberate coordination efforts. The Collective Arrangement between NEAFC and OSPAR ${ }^{171}$ illustrates a mix of these two levels of interplay; in fact, it represents an inter-sectoral coordination of measures, ${ }^{172}$ although decision-making remains independent. The Kobe process and the Regional Fishery Body Secretariats Network would probably best illustrate the level of cooperation reached through unilateral management by individual institutions, as the decision-making remains within each individual organization. Finally, at the decentralized end of the spectrum, autonomous management efforts rely on the

165 Stokke, "Management Options”, supra note 106 at 62. See also Stokke, “The Interplay", supra note 150 at 12. 166 Oberthür, supra note 159 at 375-376.

167 See, generally, Guggisberg, supra note 34, especially at 530-531.

168 On relevant UNGA Resolutions, see chapter 2 section 3.2.1 above.

169 Sustainable fisheries, including through the 1995 Agreement for the Implementation of the Provisions of the United Nations Convention on the Law of the Sea of 10 December 1982 relating to the Conservation and Management of Straddling Fish Stocks and Highly Migratory Fish Stocks, and related instruments, GA Res 61(CV), UNGAOR, 61st Sess, UN Doc A/RES/61/105 (2006). This crucial resolution for the sustainable management of deep-sea ecosystems is further discussed in chapter 3 section 4.2.1 above.

170 The UNGA remains the main "umbrella" entity under which the BBNJ process is being conducted, see Alex Oude Elferink \& Baine Kerr, "Finding a Home for BBNJ - The CBD, the LOSC and the General Assembly: complementarity or competition?” in Vito De Lucia, Lan Ngoc Nguyen \& Alex Oude Elferink (eds), International Law and Marine Areas beyond National Jurisdiction: Current Status and Future Trends (forthcoming). This issue is also briefly mentioned in chapter 4 section 3.3 above.

171 See section 2.2 .5 above.

172 See, e.g. Collective arrangement, supra note 65. 
management action of each autonomous institution, without any primary focus on cooperation. The forms that interplay management could take for the management of fisheries on the high seas and how this could be reflected in current institutional structures is tentatively summarized in Table 5 below.

Table 5: Levels of interplay management among current fisheries structures

\begin{tabular}{|l|l|l|}
\hline \multicolumn{1}{|c|}{$\begin{array}{c}\text { Levels of interplay } \\
\text { management }\end{array}$} & \multicolumn{1}{|c|}{$\begin{array}{c}\text { Classification of current } \\
\text { structures }\end{array}$} & \multicolumn{1}{|c|}{ How it could be improved } \\
\hline Overarching institutional \\
framework & UNGA & $\begin{array}{l}\text { Strengthening the UNGA's role } \\
\text { of coordination }\end{array}$ \\
\cline { 2 - 3 } & $\begin{array}{l}\text { FAO (to some extent, } \\
\text { although no decision- } \\
\text { making role) }\end{array}$ & $\begin{array}{l}\text { Strengthening FAO's role of } \\
\text { coordination }\end{array}$ \\
\hline Joint interplay management & $\begin{array}{l}\text { Agreements between } \\
\text { RFMOs and RSPs (e.g. } \\
\text { NEAFC \& OSPAR) }\end{array}$ & $\begin{array}{l}\text { Contemplate the possibility of } \\
\text { coordinating decision-making } \\
\text { on top of the (already existing) } \\
\text { coordination of joint measures }\end{array}$ \\
\hline \multirow{2}{*}{\begin{tabular}{l} 
individual institutions \\
\cline { 2 - 3 }
\end{tabular}} & Kobe process & $\begin{array}{l}\text { Focus on the development of } \\
\text { joint rules/measures that would } \\
\text { go beyond mere collaborations } \\
\text { and information exchange }\end{array}$ \\
\cline { 2 - 3 } & RFBs Secretariat Network \\
\hline Autonomous management \\
efforts & $\begin{array}{l}\text { Management actions of } \\
\text { RFMOs }\end{array}$ & \multicolumn{2}{|l}{} \\
\hline
\end{tabular}

Despite these examples of cooperation and coordination, there is an "absence of any mechanisms to systematically foster interorganizational cooperation". ${ }^{173}$ Most of the conservation and management actions for fisheries on the high seas take place within autonomous management efforts and, to some extent, unilateral management by individual institutions at the level of individual RFMOs. However, "[w]hile it is important to recognize the role and potential of individual actors in affecting and managing institutional interaction, options for a systematic elevation of interplay management [...] will have to move beyond autonomous management" ${ }^{174}$ In fact, this study believes that no regime and no institution is completely self-sufficient when it comes to addressing the complexity characterizing the management of international fisheries within a changing (political, legal and ecological) environment. This is why more coordinated forms of interplay management should be systematically used for international fisheries management.

Interplay management could actually help define better the obligations of cooperation. In fact, the promotion of cooperation is legally rooted in the obligation of cooperation (e.g. article 197 UNCLOS). However, while the obligation of

173 Andrew Friedman, "Beyond 'not undermining': possibilities for global cooperation to improve environmental protection in areas beyond national jurisdiction" (2019) 76:2 ICES Journal of Marine Science 452-456 at 453, citing Elizabeth Druel \& Kristina Gjerde, "Sustaining marine life beyond boundaries: Options for an implementing agreement for marine biodiversity beyond national jurisdiction under the United Nations Convention on the Law of the Sea" (2014) 49 Marine Policy 90-97 at 92 (emphasis added).

174 Oberthür, supra note 159 at 376. 
cooperation for States is widely recognized in treaty and customary law, ${ }^{175}$ and while cooperating through the establishment of institutions is a way for States to fulfil their obligation of cooperation (e.g. article 118 UNCLOS), the scope of this obligation is not as clear. For example, would omitting to establish such institutions amount to a violation of the obligation to cooperate? It has been argued that, in the context of fisheries on the high seas, the establishment of an RFMO or other similar arrangement would "be necessary in order to fulfil the obligation to cooperate". ${ }^{176}$ Consequently, not establishing an institution or arrangement could amount to a violation of cooperation. This is supported by the fact that, in the context of framework agreements, especially in environmental matters and in the context of common interests, cooperation underlies the development of a regime through supplementary instruments and institutions. ${ }^{177}$ In the context of article 197 UNCLOS, the reference to regional cooperation in the protection of the marine environment has also been understood as making a particular reference to RSPs, which started to be established by the UNEP in 1974 while UNCLOS was still being negotiated. It could therefore be understood that article 197 UNCLOS would require some form of collaboration with RSPs in order for the obligation to be fulfilled. However, in the case of article 118 UNCLOS, it "provides a framework for cooperative action but provides no guidance on the actions that might be taken against States who fail to cooperate or against RFMOs which fail to live up to their mandate", 178 thereby making it difficult for "violators" to be held accountable. This lack of guidance also makes it difficult to determine whether setting up an institution would, in itself, be sufficient to fulfil the obligation to cooperate, or if one would also need to ensure that such institution worked effectively (and even go further and ask what would amount to an effective functioning). Based on a resultsbased legitimacy approach, this study tentatively believes that there should at least be evidence that efforts are being undertaken by the institution to work towards the purpose for which it has been established, and requiring interplay management to be considered systematically in decision-making could help to achieve exactly that.

This uncertainty regarding the scope of application of the obligation of cooperation is one of the reasons why, ideally, joint interplay management could bring some clarification. It could become the minimum threshold, the benchmark, leading institutions to move towards inter-institutional coordination of decision-making. This could amount to a sort of obligation of "interplay cooperation", which could clarify and complement the current obligations of cooperation, mostly sectoral,

175 The obligation of cooperation is discussed in chapter 2 sections 3.1 .1 and 3.1.2, and chapter 3 section 3.1.3 above.

176 Rosemary Rayfuse, "Article 118. Cooperation of States in the conservation and management of living resources" in Alexander Proelss (ed), United Nations Convention on the Law of the Sea. A Commentary (Munich: Verlag C. H. Beck, 2017) 817-830 at 828 ([Rayfuse, "Article 118”)].

177 Rüdiger Wolfrum, “Cooperation, International Law of” (2010) Max Planck Encyclopedia of Public International Law at paras 31 and 39.

178 Rayfuse, "Article 118", supra note 176 at 830. Although this suggestion refers to art. 118 only, the present author believes that the lack of guidance also applies to other provisions that include an obligation of cooperation, such as art. 197 UNCLOS, see chapter 2 section 3.1.1.2 above. 
under UNCLOS. For example, this could mean that a RFMO would systematically seek to coordinate its conservation and management measures with complementary measures enacted by a RSP, another RFMO acting in the same region, or another sectoral organization. Not only would such deliberate coordinated management increase coherence among institutional regulatory and enforcement frameworks (regulatory interplay management), but it would also enable learning, capacity building and allocation of resources (enabling interplay management), ${ }^{179}$ including the potential sharing of resources, which could lead to a lowering of costs for entities faced with capacity shortcomings. These are all elementary objectives to be reached in the strengthening of sustainability performance in high seas fisheries.

Joint interplay management further builds on characteristics of adaptability that must be recognized and relied upon when developing and implementing legal instruments. First, by encouraging interaction, joint interplay management triggers the creation of networks between institutions, as well as encouraging the sharing of knowledge, which supports the enabling mode of interplay management by ensuring learning and capacity-building. ${ }^{180}$ Second, and above all, joint interplay management puts forward the idea of interconnectedness, by impelling institutions which sometimes present diverging priorities/interests and regulate different components of a common socio-ecological system, to recognize the necessity of coordinating their activities because of the interconnectedness characterizing the system they regulate or manage. Overall, joint interplay management, by strengthening "the interaction of various independent sectoral governance systems and their policies without elaborate structures and designated fora", 181 allows for coordination as well as for the flexibility needed to face the complexity of the regime for international fisheries.

Moreover, coordinated forms of interplay management embrace the polycentricity that characterizes the regulatory and management framework of international fisheries, i.e. polycentricity in terms of interests involved (i.e. environmental versus non-environmental considerations), as well as in terms of levels of regulatory institutions. By ensuring interplay management between regional institutions, and across levels of institutions, a pathway is created for this sharing of expertise and experience, thereby contributing to coherence. This, however, can only be achieved if the institutions themselves are strong enough to respond effectively to this interplay; they must have a structure that provides a certain degree of flexibility and openness to deal with change and allow for future development triggered by the interplay. ${ }^{182}$ Institutions must also have sufficient financial capacities; flexibility is not independent from financial aspects and this triggers the problem of evaluating the amount and scope of costs that might be occasioned by engaging in the interplay

179 These are the two modes of joint interplay management conceptualized by Oberthür, supra note 159 at 377.

180 Ibid at 378-379.

181 Ibid at 374 .

182 This is based on (some of) the factors and criteria identified in Ebbesson, supra note 6 at 414 . 
(which might differ according to each institution), as well as the problem of finding ways to pay these costs.

In sum, what interplay management suggests is that institutional coordination should systematically be considered, not only as an option but as a necessity, when making policy decisions about topics as interconnected as fisheries and marine environmental protection. Bearing in mind that institutions very often do not have both resource management and protection mandates, relying on the expertise of others might be beneficial. Interplay management deliberately creates (the pathways towards) coordination, and does more than simply observe it (whether deliberately created or not). Relying on interplay management therefore ensures that synergetic interactions are systematically considered from the beginning of any policy decision, and not only at a later stage to fill in the gaps. ${ }^{183}$

Interplay management acts as a practical embodiment of adaptive strategies as it addresses polycentricity and multi-level governance, while promoting the coordination of measures, and also knowledge and capacities, stemming from different sectors and levels. This is how the law must be operationalized to be adaptive: by supporting, strengthening and/or developing institutions that deliberately work towards the coordination of their activities and the sharing of knowledge. Not only does this act as a way of operationalizing the duty of cooperation in international fisheries management and marine environmental protection ${ }^{184}$ as well as the duty to take environmental factors into consideration when determining the allowable catch, ${ }^{185}$ but it also ensures the resilience of managerial structures by developing multifaceted measures to answer to interconnected situations, based on the best available science. With interplay management, an institutional complex is created, where synergies can lead to a complex "that is greater than the sum of its parts". ${ }^{186}$ When "time, perseverance and trust are key elements in any strategy to achieve [an integrated approach to decision-making]", 187 interplay management thus contributes to building this required trust.

\subsection{How would these alternative mechanisms impact the management of fisheries? Reflections on a public-private relationship}

Smart mixes and interplay management are based on a managerial approach to compliance. This approach targets the facilitation and encouragement of compliance

183 See, e.g., Elizabeth De Santo et al, "Protecting biodiversity in areas beyond national jurisdiction: An earth system governance perspective" (2019) 2 Earth System Governance article 100029 at 5. Although the reasoning in De Santo et al applies to the BBNJ process, the present author believes that it can also be applied more broadly.

184 See, e.g., UNCLOS at arts. 118 and 197; UNFSA at art. 8.

185 UNCLOS at art. 119(1)(a).

186 De Santo et al, supra note 183 at 3.

187 James Harrison, Saving the Oceans Through Law. The International Legal Framework for the Protection of the Marine Environment (Oxford: Oxford University Press, 2017) at 300. 
rather than the punishment of non-compliance, also known as enforcement compliance. ${ }^{188}$ Managerial compliance assumes that States normally comply unless they are incapable of doing so. Based on the observation made in chapter 5 that noncompliance in international fisheries often stems from a lack of capacity rather than willful violations, ${ }^{189}$ solutions embedded in managerial compliance appear to be an appropriate focus for the purpose of the present study. In fact, the two alternatives mechanisms described above aim to assist actors in orchestrating and coordinating instruments and structures to improve the interconnectedness between fisheries management and marine environmental protection.

To illustrate the potential benefits that fisheries management could gain from the alternative mechanisms embodying adaptive strategies described above, this study briefly looks into an example of an interaction between public and private actors to see how a private structure "influences and facilitates public regulation and coordination" 1190 and how such interactions are needed to rally the plurality of interests that characterize fisheries as a transboundary resource. This example also illustrates how changes at the conceptual level of fisheries structures can influence fisheries management.

The private structure looked at in particular is a private performance standard, which aims at "changing the production processes in a particular way, and at gearing production methods and resource consumption of a business and industry towards sustainability" ${ }^{191}$ The specific standards and certification scheme assessed here are the ones from the Marine Stewardship Council (MSC). In short, the MSC, a non-profit organization, uses an "ecolabel and fishery certification program [...] by recognising and rewarding sustainable fishing practice". ${ }^{192}$ It sets out standards or requirements "that a fishery must meet to enable it to claim that its fish come from a well-managed and sustainable source". These standards rely on three core principles: the sustainability of stocks, the minimization of impacts on the environment, and effective management. ${ }^{193}$

188 See, e.g., Holly Matley, "Developments in International Fisheries Law and Their Contribution to Improving Effectiveness of RFMOs and Other Environmental Regimes" in Neil Craik et al (eds), Global Environmental Change and Innovation in International Law (Cambridge: Cambridge University Press, 2018) 102-122 at 108-109, referring to the work of Chayes \& Chayes discussed in George Downs, Kyle Danish \& Peter Barsoom, "The transformational model of international regime design: triumph of hope or experience?” (1999-2000) 38 Columbia Journal of Transnational Law 465-514 at 482, and to the work of Bodansky, see Daniel Bodansky, The Art and Craft of International Environmental Law (Cambridge, MA: Harvard University Press, 2011) at 235-237.

189 On lack of capacity, see chapter 5 section 2.3 above. See also Matley, supra note 188 at 109 .

190 Yeeting \& Bush, supra note 112 at 147.

191 Jürgen Friedrich, "Environment, Private Standard-Setting” (2009) Max Planck Encyclopedia of Public International Law at para 15.

192 MSC, "Marine Fisheries Standards", online: <https://www.msc.org/standards-and-certification/fisheriesstandard $>$. For more on the establishment, structure and functioning of the MSC, see the description in Marcus Haward, Governing Oceans in a Time of Change. Fishing for the Future? (Cheltenham: Edward Elgar, 2020) at 17.

193 MSC, “The MSC Fisheries Standard (version 2.01)" (2018) at 4, online: <https://www.msc.org/docs/ default-source/default-document-library/for-business/program-documents/fisheries-program- 
Private standards are used with the aim of changing actors' behaviours towards compliance, mostly by triggering an economic interest. In the case of the MSC, the interest resides in a positive market incentive, where customers are interested in sustainable products, which, in turn, positively impacts the sales of the producer offering such a sustainably certified product. ${ }^{194}$ Private standards can also have an impact on regulation, as they can initiate "processes of institutional reform, trigger normative developments, and stimulate business efforts in ways that lie beyond the influence of the legal sphere". ${ }^{195}$ However, private standards are not a panacea for effectiveness and, as discussed above, ${ }^{196}$ can raise issues of legitimacy; they should therefore be seen as "valuable complements, but not alternatives"197 to public regulation stemming from States and/or States-driven institutions. This is exactly why the use of the performance standard of the MSC, a private structure, builds on smart mixes and interplay management, as it relies on the interplay, coherence and harmonization of instruments, actors and institutions, as well as their interactions.

A case study conducted by Yeeting and Bush ${ }^{198}$ examined the benefits that can ensue from an interaction between public regulation and private performance standard within fisheries management. The study assesses the way in which three tuna RFMOs (the WCPFC, the IOTC, and ICCAT) have interacted with the private certification scheme of the MSC and how this has impacted the "outcomes in terms of achieving the application of precautionary approach to management through the definition and adoption of ${ }^{\prime 199}$ harvest control rules. To assess how the interactions between the MSC and RFMOs have impacted the cooperation between member States, the authors conducting the study first identified the challenges for the three selected tuna RFMOs in applying the precautionary approach, then looked at the implementation of the MSC's certification scheme in each RFMO, and finally assessed the improvement made. ${ }^{200}$ While looking at this case study in more detail is relevant to understand the impact of a practical application of smart mixes on fisheries management on the high seas, this example of public-private interaction also illustrates a situation where joint interplay management has been proved to contribute to achieving sustainable practices.

documents/msc-fisheries-standard-v2-01.pdf?sfvrsn=8ecb3272_11>.

194 Friedrich, supra note 191 at para 31.

$195 \mathrm{Ibid}$ at para 49 , see also para 23.

196 See section 3.1 above.

197 Friedrich, supra note 191 at para 46.

198 This case study from Yeeting \& Bush, supra note 112, can be found in Judith van Erp et al (eds), Smart Mixes for Transboundary Environmental Harm (Cambridge: Cambridge University Press, 2019). In this book, different case studies from various fields of resource exploitation, including fisheries, are analysed. Although smart mixes of instruments in the field of fisheries have mostly been used for domestic fisheries, the examples presented in the book, including the one from Yeeting \& Bush, embark on the exploration of the applicability of a regulatory mix to international fisheries.

199 Yeeting \& Bush, supra note 112 at 147.

200 The methodology is further discussed in ibid at 149 . 
Within the WCPFC, ${ }^{201}$ difficulties arose due to the politically sensitive nature of establishing limit reference points, i.e. limiting catches to ensure safe biological limits, and harvest control rules because of different fishing techniques used by different member States, therefore triggering the need to balance the interests of coastal States and distant-water fishing nations. Because of this deadlock at the level of the RFMO, the Parties to the Nauru Agreement (PNA), ${ }^{202}$ a sub-regional agreement for cooperation in the management of fisheries in the western Pacific, started, as part of their mandate to conserve tuna resources, the procedure to have certain tuna species certified by the MSC, which they obtained in 2010. In order to obtain recertification, ${ }^{203}$ a request was made for effective harvest control rules to be established throughout the whole region, thus also necessitating the adoption of harvest control rules by the WCPFC. Following the efforts by the PNA to fulfil the conditions for recertification, the WCPFC also adopted binding conservation and management measures towards the establishment of target reference points and harvest control rules, "as a result of or in parallel with the MSC conditions for the PNA." ${ }^{204}$ This interaction between the PNA, the MSC and the WCPFC demonstrates that the former played the role of an incentive for the measures adopted by the latter, and that the mix of these instruments helped to compensate for the weaknesses stemming from the use of the WCPFC's conservation and management measures only. Further, the PNA, as a sub-regional entity, acted to counter the deadlock at the RFMO level. Without necessarily reaching the level of coordination of rules between the two bodies, the complementarity of the bodies' competences created an incentive for the RFMO to take action.

Within the IOTC, ${ }^{205}$ a lack of political support and of capacity of the Scientific Committee to support the adoption of the precautionary approach, coupled with the absence of a reference to the precautionary approach in the organization's constitutive instrument, ${ }^{206}$ led to difficulties in establishing a MSY for certain species of tuna covered by the organization. In this case, improvements were reached through the engagement of a regional State actor. In fact, the Maldives unilaterally applied for a MSC certification of some of its fisheries, and one requirement for obtaining such certification was to contribute to the IOTC's conservation actions by becoming a member. The IOTC and the Maldives therefore developed an action plan, and the Maldives, with the support of international and private organizations such as the World Bank and World Wildlife Fund (WWF), conducted sessions with

201 Ibid at 150-154.

202 Nauru Agreement Concerning Cooperation in the Management of Fisheries of Common Interest (11 February 1982), online: <http://www.pnatuna.com/sites/default/files/Nauru\%20Agreement_0.pdf>.

203 Certificates are valid for a period of 5 years, see MSC, "MSC General Certification Requirements (version 2.3)" (2018) at para 7.5.6, online: <https://www.msc.org/docs/default-source/default-document-library/ for-business/program-documents/general-certification-requirements/msc-general-certificationrequirements-v2-3.pdf?sfvrsn=f055d4ac_7>.

204 Yeeting \& Bush, supra note 112 at 152.

205 Ibid at 154-158.

206 The IOTC was established in 1993, prior to the adoption of the UNFSA, and therefore does not refer to the precautionary approach, see ibid at 155 . 
other member States to discuss the importance of harvest control rules. This led to the adoption of IOTC resolutions on the implementation of the precautionary approach and harvest strategies within the IOTC. Here, the MSC was relied upon to introduce the precautionary approach to the organization, showing the ability of the MSC to fill in the gaps left by an RFMO's constitutive instrument. Further, relying on complementary structures, in this case a State's political capacity, to influence decision-making within an RFMO, contributed to improving the coherence of rules and approaches at the national (Maldives) and regional level.

Within ICCAT, ${ }^{207}$ despite the adoption of recovery plans to counter the overexploitation of some species falling under the mandate of the organization, recovery has been slow. This has been attributed to the failure to follow recommendations from the Standing Committee on Research and Statistics, because of political and industry pressure. The lack of adoption of the ecosystem and precautionary approaches, identified by a performance review in 2008, was also disputed by ICCAT, which stated that these approaches had already been implemented. The MSC certification was relied upon regarding three distinct fisheries, although to a different extent. In a first case, a MSC certification failed, but still managed to raise awareness regarding the failures of ICCAT. With regard to a second case, the inaction from ICCAT led the Organization of Associated Producers of Large Tuna Freezer Vessels, a private organization, with the support of WWF, to establish recovery plans. Although no certification was attempted, MSC standards and requirements guided the development of these plans. A third fishery obtained a MSC certification, under the condition that harvest control rules would be improved, since the ones already in place were considered "too poorly defined to assess the [species] as a separate stock" ${ }^{208}$ This condition triggered a process of harmonization of existing rules. In these three situations related to ICCAT, a combination of instruments and cooperation between institutions and actors through the MSC certification, or reliance on its standards, has played a role in strengthening a process to develop recovery plans and establish well-defined harvest control rules.

Despite these positive observations, it is important to underline that the MSC certification and similar schemes are not without controversy. For example, the three main MSC principles have been characterized as too lenient and discretionary, ${ }^{209}$ and certifications do not always lead to positive and sustainable fisheries. ${ }^{210}$ It is therefore important to consider these weaknesses when using them in a mix of instruments or as a basis for fostering interplay between actors and institutions. Further, relying on certifications such as the one from the MSC to ensure better sustainability performance should not be considered as a panacea. In fact, while such certifications can contribute to ensure more effectiveness, as in the examples

207 Ibid at 159-162.

208 Ibid 162.

209 See, e.g., Claire Christian et al, "A review of formal objections to marine stewardship council fisheries certifications" (2013) 161 Biological Conservation 10-17 at 15-16.

210 Zacharias \& Ardron, supra note 116 at 140. 
discussed above, it is not always the case as many other conditions and elements might come into play. ${ }^{211}$

These observations regarding the MSC do not, however, discredit the contribution that smart mixes and interplay management can make for achieving better sustainable management of high seas fisheries, and this study participates in understanding better the potential they can have to achieve such an objective. Smart mixes not only contribute to ensuring a complementarity between different types of instruments operating at different scales and by different actors, but also to enhancing cooperation between States, international organizations and private actors, and "to the alignment of states and industry interests across multiple dimensions of borders, sectors and institutional levels". ${ }^{212}$ This form of coordination of interests leads to improved results that stem from open and dynamic understanding of regulation and management. ${ }^{213}$ Such an observation further supports the use of joint interplay management, where the reliance on MSC standards has acted as a mechanism for coherence and harmonization of actions. This shows that smart mixes and joint interplay management can be used as tools to create "incentives for more adaptive fishing strategies"214 and regulations.

\section{PUSHING OPERATIONALIZATION FURTHER: RE-THINKING EXISTING LEGAL STRUCTURES}

The analysis of alternative mechanisms conducted above has introduced concepts that can be considered for improving sustainability performance in the management of fisheries on the high seas. The analysis has relied on the potential of importing policy options into the legal framework for international fisheries to strengthen its effective operationalization.

But what if we pushed these reflections on operationalization further, not only by finding mechanisms to complement the current regime, but by presenting options that re-think some well-known structures, mechanisms and components of the international legal system, by "re-conceiving the legal landscape" ?215 Although these suggestions are located in the academic debate and have not, at least up to now, garnered sufficient political support to be put into action, or still remain too abstract to be concretely operationalized, they stem from widely accepted international legal concepts, thereby supporting the legitimacy of these suggestions. This section presents two of them, the high seas fisheries trust (4.1) and the virtual treaty (4.2),

211 For a a more detailed analysis of the effectiveness of MSC certifications, see, e.g. Agni Kalfagianni \& Philipp Pattberg, "Global fisheries governance beyond the state: unraveling the effectiveness of the Marine Stewardship Council” (2013) 3:2 Journal of Environmental Studies and Sciences 184-193.

212 Yeeting \& Bush, supra note 112 at 163.

213 Ibid at 166.

214 Brita Bohman, "Regulatory control of adaptive fisheries: Reflections on the implementation of the landing obligation in the EU common fisheries policy" (2019) 110 Marine Policy article 103557 at 3.

215 Techera \& Klein, supra note 19 at 244. 
in order to continue the exercise of broadening the frame of reference for thinking about high seas fisheries management.

\subsection{The high seas fisheries trust}

The idea of a high seas fisheries trust finds its roots in the concept of a public trusteeship for environmental resources. An environmental trusteeship at the national level would imply that certain natural resources are considered as part of a public trust protected by the government or other public authorities, acting as trustees, on behalf of the citizens, the beneficiaries of the trust. ${ }^{216}$ Transposed to international law, the concept of environmental trusteeship, also sometimes referred to as custodianship or stewardship, ${ }^{217}$ forms a trilateral relationship where the resources are designated as a trust by the international community (i.e. the settlor), which mandates States to protect them (i.e. the trustees) for the benefit of the people (i.e. the beneficiaries). ${ }^{218}$

The concept of the common heritage of humankind, currently applicable to the Area, ${ }^{219}$ is sometimes though to be similar to an environmental trusteeship. ${ }^{220}$ However, relying on such idea to extend the environmental trusteeship to the high seas has been criticized. In fact, States accept extending to the high seas "the elements of non-appropriation, international management and peaceful purposes", but what "makes application of the principle [of the common heritage] so objectionable to so many" is "the aspect of benefit-sharing which is in direct opposition with the exclusive ownership notion inherent in the capture based common property regime". ${ }^{221}$ In short, the benefit-sharing, a core aspect of the common heritage of humankind, is seemingly irreconcilable with the common property principle,

216 Peter H. Sand, "Sovereignty Bounded: Public Trusteeship for Common Pool Resources?" (2004) 4:1 Global Environmental Politics $47-71$ at 49.

217 On the high seas principle of stewardship, see chapter 3 section 3.1 .9 above.

218 Sand, supra note 216 at 55 . Sand admits that this model is oversimplified and leaves many questions open, e.g. what is "the definition of the community concerned as [...] settlor (the global community? or the community of members of specific international regimes; e.g., contracting parties to a multilateral convention?); of the sovereign entity concerned as trustee (states only? or also intergovernmental institutions acting in areas outside national jurisdiction; e.g., the UN International Seabed Authority?); of the people concerned as beneficiaries (present and future civil society? individuals and groups?); and of the corpus of the trust (designated resources only? or the global commons? or the whole environment?)”.

219 UNCLOS at art. 136.

220 Sand, supra note 216 at 55-56, mentions that there are three options for creating an environmental trusteeship: 1) through a specific designation of a particular resource for a particular benefit, based on agreed criteria (e.g. UNESCO heritage list), 2) through a treaty designating a whole category of resources (e.g. FAO Plant Gene Treaty), and 3) through customary law, where a conventional trust regime would be extended to all States. The example of the common heritage of humankind would fall under the third category.

221 Rosemary Rayfuse \& Robin Warner, "Securing a Sustainable Future for the Oceans Beyond National Jurisdiction: The Legal Basis for an Integrated Cross-Sectoral Regime for High Seas Governance for the 21st Century" (2008) 23:3 International Journal of Marine and Coastal Law 399-421 at 409. 
stemming from the global commons nature of the high seas resources, ${ }^{222}$ where benefits are gained only by those who participate in the exploitation.

This is why a public trusteeship for the high seas could be portrayed as a "half-way" solution between the principles of common heritage of humankind and common property, where a balance between the common exploitation and common interests can be reached. ${ }^{223}$ Contrary to the common heritage principle, however, the public trusteeship would not require a redistribution of benefits; the benefits would rather be used by the trusteeship itself for the good management and protection of the object of the trust (in this case the high seas). The concept of public trust is also different from common concern, ${ }^{224}$ because the former "might seem to be more specific in content, implying, inter alia, stronger commitment to and basis for joint action". 225

The idea of a high seas trust surfaced in the 1995 Commission on Global Governance, which observed that "the global commons should be subject to trusteeship exercised by a body acting on behalf of all nations". 226 The idea was also raised in 1997 by the then UN Secretary-General Kofi Annan in a report on governance reform, ${ }^{227}$ where he suggested that a trusteeship for the "integrity of the global environment and common areas such as the oceans" could be operated by the restructured and revived UN Trusteeship Council. ${ }^{228}$ This was later echoed by the recommendations of the 1998 Independent World Commission on the Oceans that "the 'high seas' be treated as a public trust to be used and managed in the interests of present and future generations".229 The issue was then put on the agenda of other fora, ${ }^{230}$ but the idea seems to have been abandoned in the early 2000s, on the basis that revamping the Trusteeship Council would trigger the need to amend the UN Charter, a task considered to be too difficult. ${ }^{231}$

222 On the global commons/open-access nature of the resources of the high seas, see chapter 2 section 2.3 above.

223 Rayfuse \& Warner, supra note 221 at 410.

224 On common concern, see chapter 2 section 2.3 above.

225 Alex Oude Elferink, "Governance Principles for Areas beyond National Jurisdiction" (2012) 27:2 International Journal of Marine and Coastal Law 205-260 at 245.

226 Commission on Global Governance, Our Global Neighbourhood. The Report of the Commission on Global Governance (Oxford: Oxford University Press, 1995) at 251.

227 Sand, supra note 216 at 53, citing Report of the Secretary-General to the General Assembly, Renewing the United Nations: A Programme for Reform, UNGAOR, 51st Sess, UN Doc A/51/950 (1997) at para 85.

228 Sand, supra note 216 at 53. See also, generally, Ross Shotton, "Managing the World's High-Seas Fisheries: A Proposal for a High-Seas Fisheries Trust" in Ragnar Arnason \& Birgir Runolfsson (eds), Advances in Rights Based Fishing. Extending the Role of Property in Fisheries Management (2008 RSE Research Papers, Reykjavik, Iceland) 247-290.

229 Independent World Commission on the Oceans, The Ocean: Our Future (Cambridge: Cambridge University Press, 1998) at 17, cited in Rayfuse \& Warner, supra note 221 at 410.

230 Sand, supra note 216 at 53.

231 For an overview of the concept of public trusteeship, as well as examples of its application to the oceans, both within and beyond national jurisdiction, see Peter H. Sand, "Public Trusteeship for the Oceans" in Rüdiger Wolfrum et al (eds), Law of the Sea, Environmental Law and Settlement of Disputes Liber Amicorum Judge Thomas A. Mensah (Leiden: Brill Nijhoff, 2007) 521-543. 
Other suggestions have been made for different oceans and high seas trusteeships "formats". ${ }^{32}$ For example, in the context of the development of the BBNJ Agreement, commentators have also recently suggested relying on a rights of nature perspective ${ }^{233}$ to develop a Council of Ocean Custodians under the new Agreement. This Council would be "representing the interests of the ocean in ABNJ" and help "foster greater collective responsibility and long-term management". 234 Another example suggests the creation of a high seas fisheries trust, where a trustee would manage the exploitation of resources, but would also administer the benefits coming from this exploitation for the trust itself. ${ }^{235}$ Although this last-mentioned suggestion is theoretically interesting, Shotton identifies a number of requirements necessary for this global fisheries trust to work $^{236}$ which, considering the protectionist attitude towards existing fisheries structures ${ }^{237}$ would prove difficult to operationalize. First, there needs to be an acknowledgement that fisheries rights exist on the high seas, rights that could later on be managed by the trust. This would already trigger the need to change and/or adapt existing allocation mechanisms, e.g. allocation based on historic catches. Second, a trustee would have to be designated, and its mandate would have to be determined (e.g. would it be mandated with enforcement powers or only allocation?), which might collide with current mandates and powers of RFMOs. Third, it would have to be determined how and to whom the trust is accountable, and how entitlements are divided/allocated. The challenges of accommodating new entrants $\mathrm{s}^{238}$ therefore remain, and this model does not suggest any solutions for the problem of free riders, since entities could still decide not to join the trust. ${ }^{239}$

Although unlikely to be operationalized, the idea of a public trust for environmental matters has the merit of putting two elements at the forefront of the debate. First, at the

232 E.g. the Global Commons Trust Fund, discussed in Christopher Stone, "Mending the Seas through a Global Commons Trust Fund" in Jon van Dyke, Durwood Zealke \& Grant Hewison (eds), Freedom for the 21st Century: Ocean Governance and Environmental Harmony (Washington: Island Press, 1993) 171186, or the World Ocean Public Trust, discussed in Montserrat Gorina-Ysern, Kristina Gjerde \& Michael Orbach, "Ocean Governance: A New Ethos through a World Ocean Public Trust" in Linda Glover, Silvia Earle \& Graeme Kelleher, Defying Oceans End: An Agenda for Action (Washington: Island Press, 2004) 197-212, both cited in Rayfuse \& Warner, supra note 221 at 410.

233 As explained in Harriet Harden-Davies et al, "Rights of Nature: Perspectives for Global Ocean Stewardship" (2020) Marine Policy article 104059 at 3, "[f]rom a Rights of Nature perspective, legal systems should recognise nature as a rights-bearing subject, rather than an object owned and controlled by humans".

$234 \mathrm{Ibid}$ at 8 . The authors indeed suggest that the Council of Ocean Custodians could, e.g., "enable civil society to participate in decision-making, on par with States; serve as a 'guardian' to manage or supervise MPAs and review the effectiveness of other ABMTs; participate in the review of environmental impact assessments; and guide CB/TT and implementation of benefit-sharing measures of MGR".

235 Shotton, supra note 228.

236 Ibid.

237 E.g., the opposition to including fisheries in the scope of the BBNJ Agreement, see chapter 4 generally, and chapter 5 section 3.2 above.

238 For more on new entrants, see chapter 2 section 3.3.2, and chapter 5 section 2.3 .2 above.

239 The issues of new entrants and free riders could potentially be addressed if the Trusteeship Council were to be revamped and mandated with the management of the high seas fisheries trust, because all UN States would therefore be members of the trust. However, as explained above, the idea of restructuring the UN Trusteeship Council does not rally much support and, to the present author's knowledge, the idea has not significantly resurfaced since the early 2000 s. 
procedural level, since a trusteeship requires transparency on the part of the trustee, such a requirement could be a solid basis upon which better transparency could be reached within the fisheries regime, especially if RFMOs are mandated as trustees. Second, an environmental public trust would not necessarily be incompatible with the freedoms applicable to the high seas. In fact, a trustee normally has some leeway over the use and management of the trust, as long as this is not contrary to the interests of the beneficiary. Not only could this be seen as an operationalization of the duty of due regard applicable to high seas freedoms, ${ }^{240}$ but "the balance between a trustee's current use and long-term conservation of the resource is the key economic issue (converging in the 'sustainable development' paradigm)". ${ }^{241}$ A high seas fisheries trust would therefore bring together the considerations of common interests and common concerns in the exploitation of natural resources, thereby contributing to the bridging of a gap between conservation and use, and to reconciling diverse - and too often divergent - interests.

\subsection{The virtual treaty regime}

In exploring alternative solutions for the sustainable governance of sharks, Techera and Klein have observe "that the state-centric governance and regulation has not worked and a more sophisticated and integrated approach is needed". ${ }^{42}$ Focusing on the linkages between the components of a regime, and in an attempt to rethink the legal framework for sharks, they devised the idea of the virtual treaty regime. ${ }^{243}$ Such a legal vehicle, they submit, would aim to facilitate greater coherence and collaboration:

A virtual treaty would provide a forum for discussion and exchange of ideas, a clearinghouse mechanism [...]. It would not be a lawmaking body but rather a hub or super node. This super node would be linked to existing actors, institutions and frameworks and channel information in and out of them. [...] The virtual $[\ldots]$ treaty would thus be at the centre of a nodal array in three dimensions allowing for the transmission of information, experience and discourse between instruments and actors at the same level, and between global and local levels. Such a system would also allow new and unconventional linkages to be made between actors: for example, between an industry body and a state government, or an NGO and a treaty framework. ${ }^{244}$

For the management of living resources, a virtual treaty regime would represent a central node around which other nodes addressed in the present study, e.g. UNCLOS, UNFSA, CITES, FAO, RFMOs, RSPs, MSC, States, NGOs, would revolve.

240 UNCLOS at art. 87(2). See also the discussion on due regard conducted in chapter 2 section 3.1.1.1, and chapter 3 section 3.1.1 above.

241 Sand, supra note 216 at 56.

242 Techera \& Klein, supra note 19 at 239.

243 Ibid at 238-239.

244 Ibid at 239. 
The virtual treaty regime would not aim to centralize the expertise of all nodes, but would "channel information in and out of them". ${ }^{245}$ The virtual treaty regime also suggests some concrete measures, such as the facilitation of "physical engagement through for example, co-located and temporally aligned conferences and meetings of the parties". ${ }^{246}$ All these measures could help to improve weaknesses in terms of compliance, as States lacking resources could benefit from this interconnected forum.

The virtual treaty regime seems to be sharing characteristics of both a clearinghouse mechanism, similar to the ones currently existing in some environmental regimes or developed in the framework of the BBNJ Agreement, ${ }^{247}$ and an epistemic community, where experts from a specific field share knowledge for the purposes of amelioration and not gain, with the aim of informing decision-making and policy solutions. ${ }^{248}$ It also shares similarities with the Regular Process because of its aim to enhance scientific knowledge and exchange, ${ }^{249}$ and it is because its meetings are also open to States, international organizations, NGOs and scientific institutions, making it a multi-actor and knowledge exchange platform. Although the virtual treaty would seemingly be including components of such processes and platforms and would rely on an enhanced scientific basis to develop further the science/ policy/law interface, the virtual treaty seems to go one step further, by creating a forum, "a 'living' structure that can adapt and change with greater agility than a traditional international organization". ${ }^{250}$ In a way, the virtual treaty represents a form of meta-governance, by offering a way to manage "the plurality of governance approaches for a given issue". ${ }^{251}$

Although the virtual treaty remains for now at the level of concept and could difficultly be tangibly established, it presents elements of adaptability that can be explored to understand the role they could play in the development of new processes. The virtual treaty is in fact characterized by interconnectedness, different actors and instruments operating at different levels, the sharing of knowledge, as well as the idea of nodes and decentralization. The authors included in their analysis a wide array of different legal, regulatory and governance related materials and, to make sense of it all, decided to focus on the dynamic interactions between them. For

245 Ibid.

246 Ibid at 241.

247 For more on the clearing-house mechanisms developed in the context of the BBNJ Agreement, see chapter 4 sections 3.5 and 4.1 above, and section 2.3 .2 above

248 The concept of the epistemic community was first used by Peter M. Haas, "Introduction: epistemic communities and international policy coordination" (1992) 46:1 International Organization 1-35. See also James K. Sebenius, "Challenging conventional explanations of international cooperation: negotiation analysis and the case of epistemic communities" (1992) 46:1 International Organization 323-365; Hey, supra note 160 at 103.

249 The contribution of the Regular Process to science and knowledge sharing is also addressed in section 2.2.4 above.

250 Techera \& Klein, supra note 19 at 239-240.

251 Heidinsfelder \& Beckmann, supra note 151 at section 5.2 . 
example, although they underline the limits to command and control regulation, they also acknowledge the "strong need for direct regulation in the form of binding rules backed by enforced sanctions", ${ }^{252}$ emphasising that it is the mix of instruments that ultimately gives rise to the formation of a stronger regulatory response.

Through the alignment of conferences and the reliance on a diversity of regulatory instruments for example, the virtual treaty also integrates the models of joint interplay management and smart mixes described above. As such, the virtual treaty does not suggest rebuilding or replacing, but rather focusing on unification of what already exists. It promotes the different components of adaptability in a holistic, inclusive and interconnected way, which can serve as a platform and a source of inspiration for the development of ways forward for steering the legal regime for high seas fisheries towards better sustainability performance.

\section{CONCLUSION: GIVING REAL MEANING TO COORDINATION AND INTERACTIONS}

Adaptive strategies inform us on the law's responsiveness to the reality of the complex socio-ecological system it tries to regulate. This is why the concept of adaptability is often linked to the concept of resilience: what we are trying to develop is a system that is resilient and flexible to change, as also should be the legal framework that regulates such a system. Adaptive features rely on iteration, on open institutions and structures, on polycentricity, multimodality and multiscalarity. These adaptive features apply to the substance of the law as well as to procedural aspects and the choice of instruments.

However, adaptive strategies are often questioned, because they are prima facie held to be a threat to the stability expected from the rule of law. The fact of the matter is this: in a context of complexity, goals addressing ecological, social and economic considerations, decision-making that is subject to iteration and review, and that is undertaken at different levels and from different centres of authority, are the necessary elements to ensure the effectiveness of the rule of law. This is the case because complexity cannot be managed without iteration, without multi-level governance, without openness of institutions and, especially, without an appreciation of the interconnectedness of the components that form the system with which we are dealing. Finally, complexity cannot be managed without coordination.

This is why the balance between stability and flexibility is rooted in a stable, overarching legal framework coupled with adaptive strategies in terms of implementation and enforcement. ${ }^{253}$ As stated by de Santo et al, "[w] hen dealing with complex systems where the potential for significant and surprising shifts is 
high, negotiators must design governance systems to be agile". ${ }^{254}$ This is where components and factors rooted in the broader and outcome-based perspective of (oceans) governance complement the law in its role as a mechanism for social change. Relying on governance-rooted concepts and widening the path to adaptive law, this study submits, helps in "finding the correct balance between flexibility and constraint on State action".255

International fisheries are complex, and in the face of a complex system enduring decades of strong political sensibilities and economic interests, changing "old habits" - probably even more so than forging new ones - will not be done easily. This is why the "regulation of high sea fisheries must correspond to the nature of the resource base and its location, to accurately encompass the social, economic and political realities of fishing, as well as the wider international regulatory context". ${ }^{256}$ Exploring ways of tackling this complexity through tools targeting behaviours are necessary, because there is a need for actions to match the sustainability commitments which are undertaken in legal texts. ${ }^{257}$

The present chapter has delved into assessing ways of operationalizing adaptive features within the structures of high seas fisheries law, which could subsequently influence their management. The chapter focused first on signs of adaptability in the existing legal instruments, structures and selected regional initiatives. A short section was also dedicated to analysing the features of adaptability within the BBNJ Agreement that could in turn positively impact on the regime's ability to ensure sustainability. The core of this chapter then embarked on an exploration of two alternative and complementary mechanisms, namely smart mixes and interplay management, which it was suggested could introduce more adaptability into the legal regime and foster coordination and cooperation. The examples discussed showed how adaptability can help to deal with complexity, and how it can contribute to addressing enforcement issues.

The goal of this chapter was two-fold. It first suggested ways of strengthening existing adaptive mechanisms, as well as developing complementary tools to assist policy-makers in adapting their perspective when approaching decisions targeting the management of fisheries on the high seas. It suggested using the

254 De Santo et al, supra note 183 at 4.

255 Lori Ridgeway, "Global level institutions and processes: Frameworks for understanding critical roles and foundations of cooperation and integration" in Serge Garcia, Jake Rice \& Anthony Charles (eds), Governance of marine fisheries and biodiversity conservation: Interaction and Coevolution (Hoboken: Wiley, 2014) 139-147 at 142.

256 Richard Barnes \& Carmino Massarella, "High Seas Fisheries” in Elisa Morgera \& Kati Kulovesi (eds), Research Handbook on International Law and Natural Resources (Cheltenham: Edward Elgar, 2016) 369389 at 369.

257 I\&O Research, "Duurzaam denken is nog niet duurzaam doen" (2009), online: <https://ioresearch. nl/Home/Nieuws/duurzaam-denken-is-nog-niet-duurzaam-doen\#.XMMtxy-B0Wo>, cited in Seline Trevisanut, "Unsustainable International Law" (Inaugural lecture delivered at Utrecht University, 4 April 2019). 
dialogue between governance and adaptability as the vector of a key to approach existing mechanisms from a different perspective, to use what we already have in a different way. Second and relatedly, the exploration of alternative mechanisms aimed to broaden the mindset of fisheries management ${ }^{258}$ which, in turn, might increase actors' accountability towards the interconnectedness and coordination between fisheries management and marine environmental protection. Broadening this mindset is not only achieved by adding to the countless existing regulatory mechanisms, but also by looking into their interaction with and inclusion in the current framework. Because " $[t]$ he first challenge $[\ldots]$ is to understand the manners in which traditional and novel forms of fisheries governance interact with each other, and to map such interactions".259 


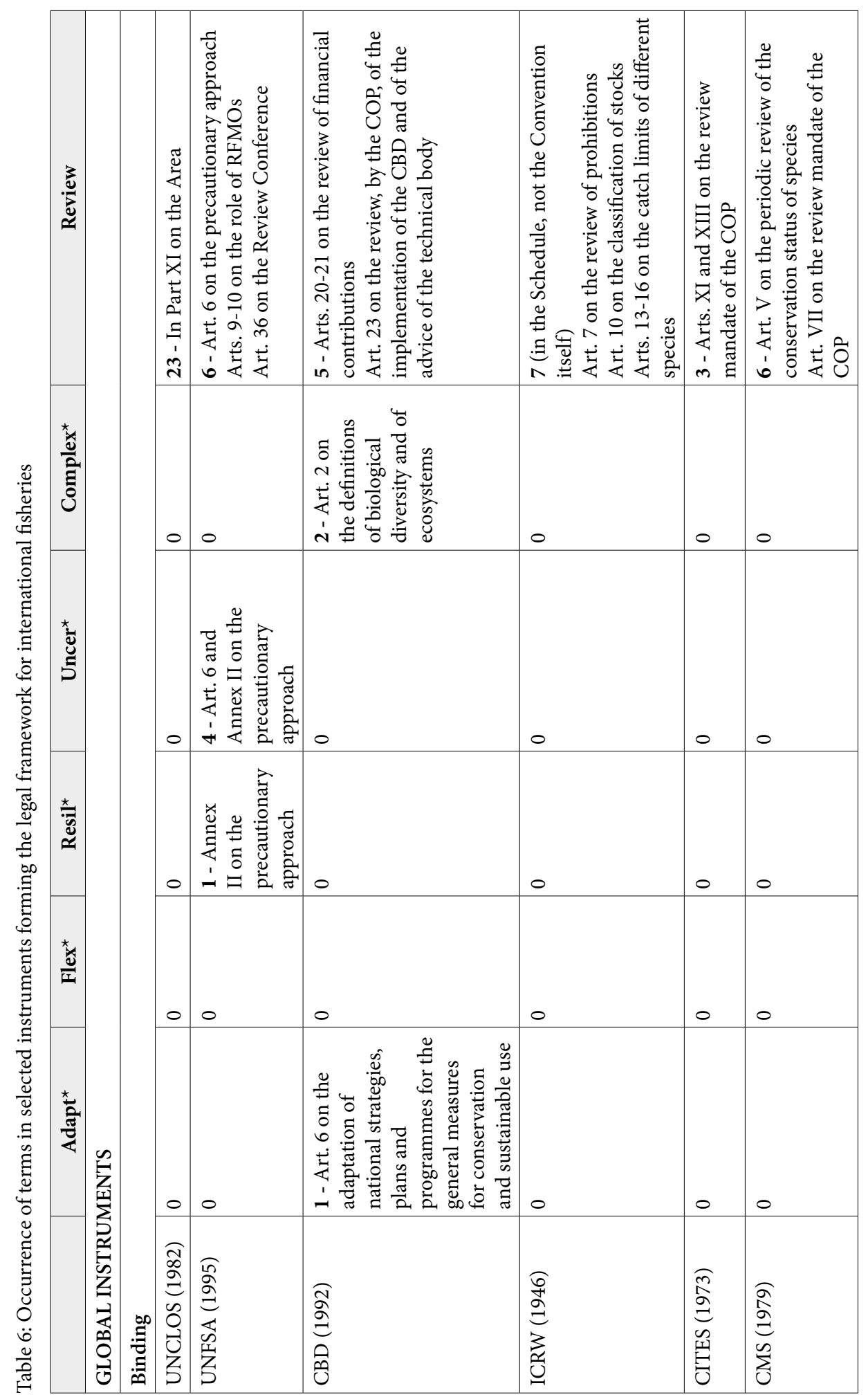




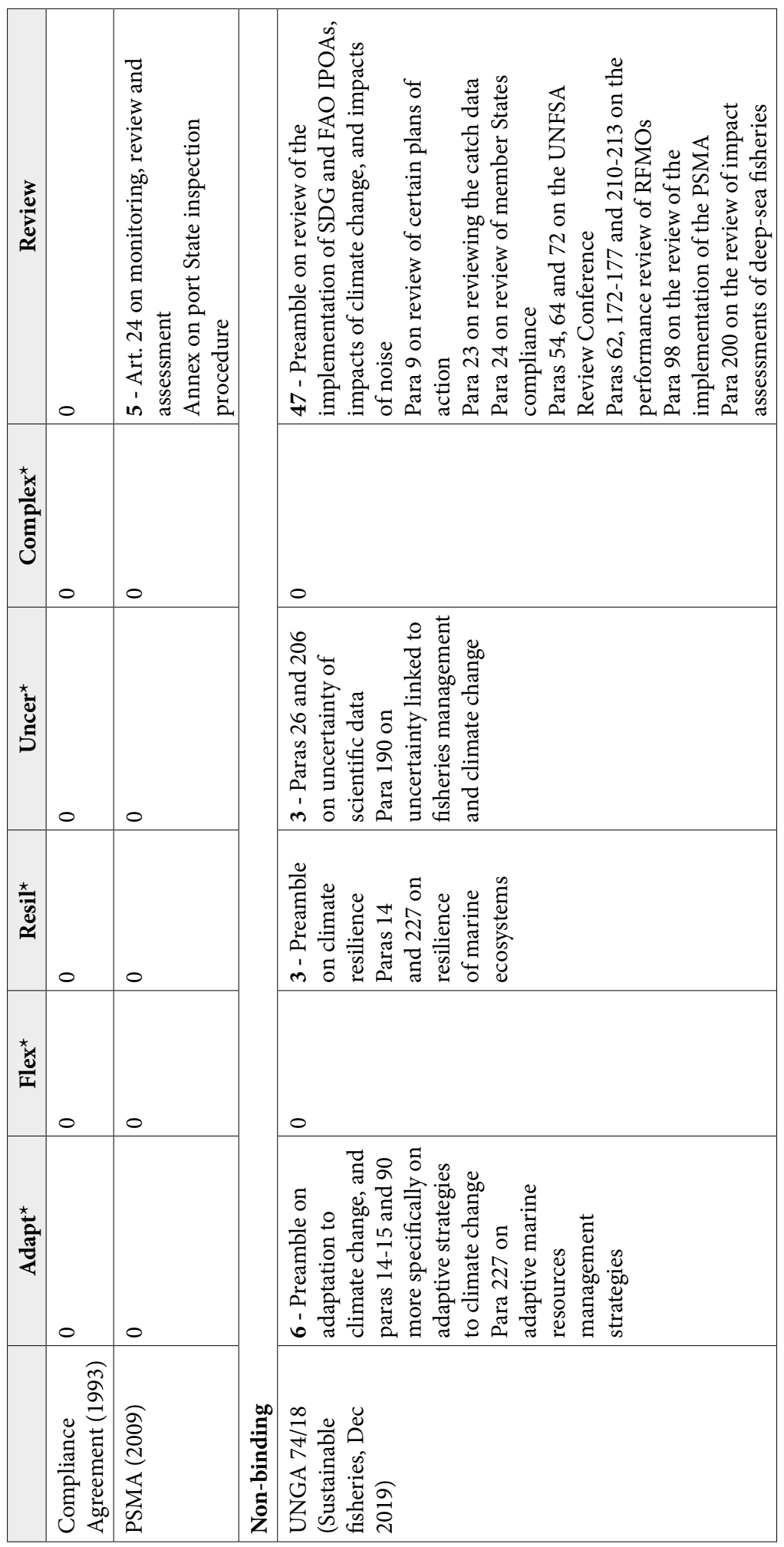




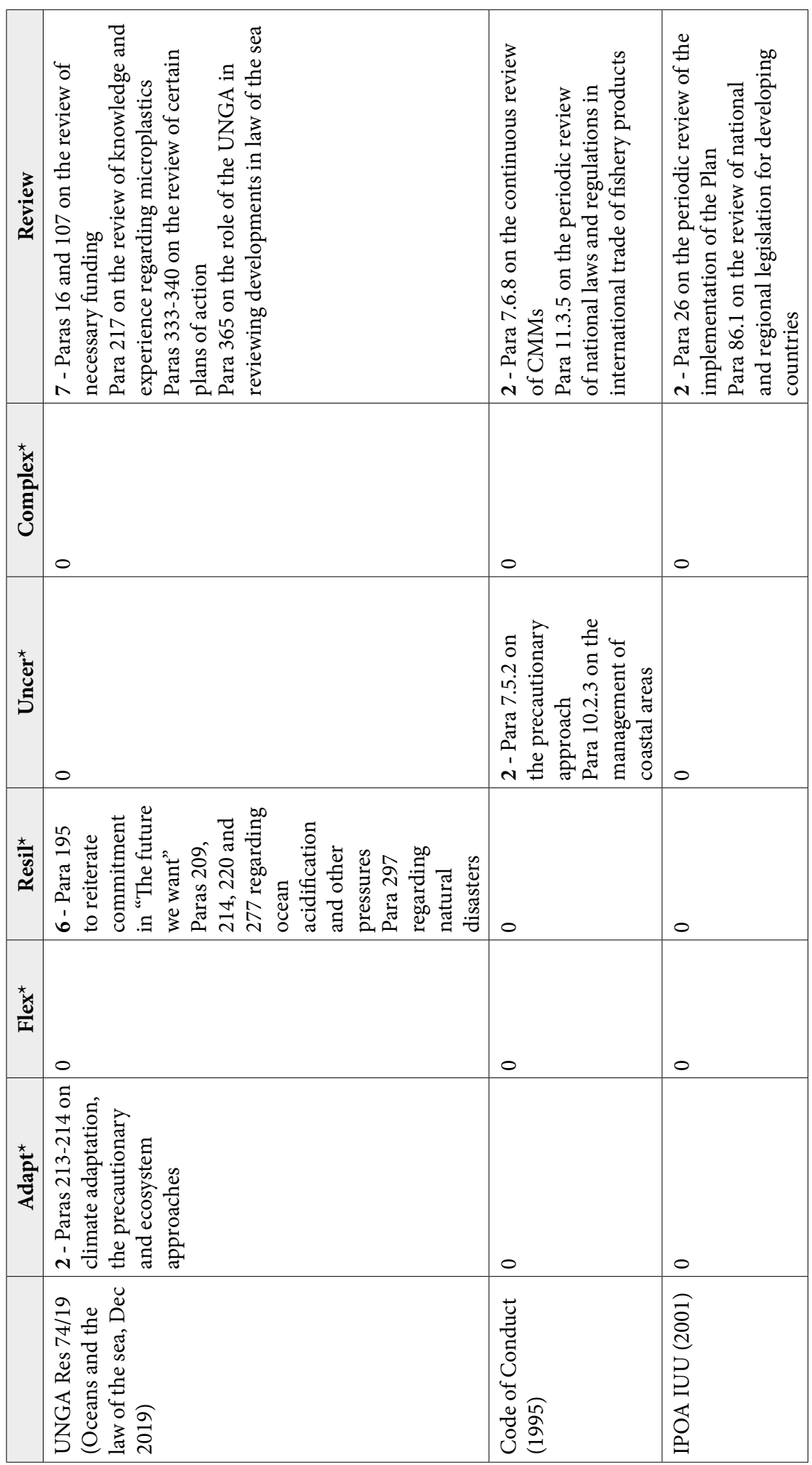




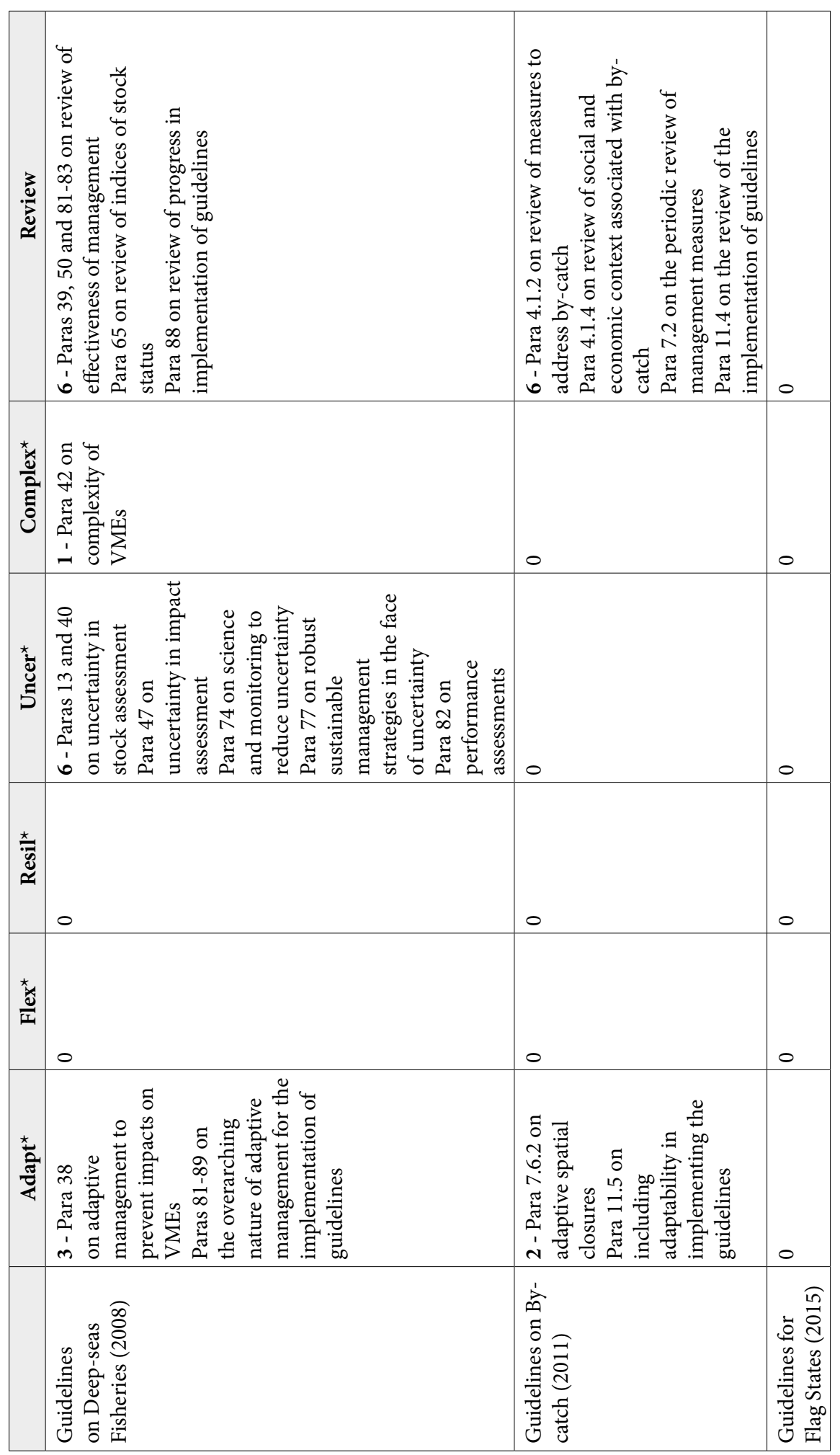


CHAPTER 7

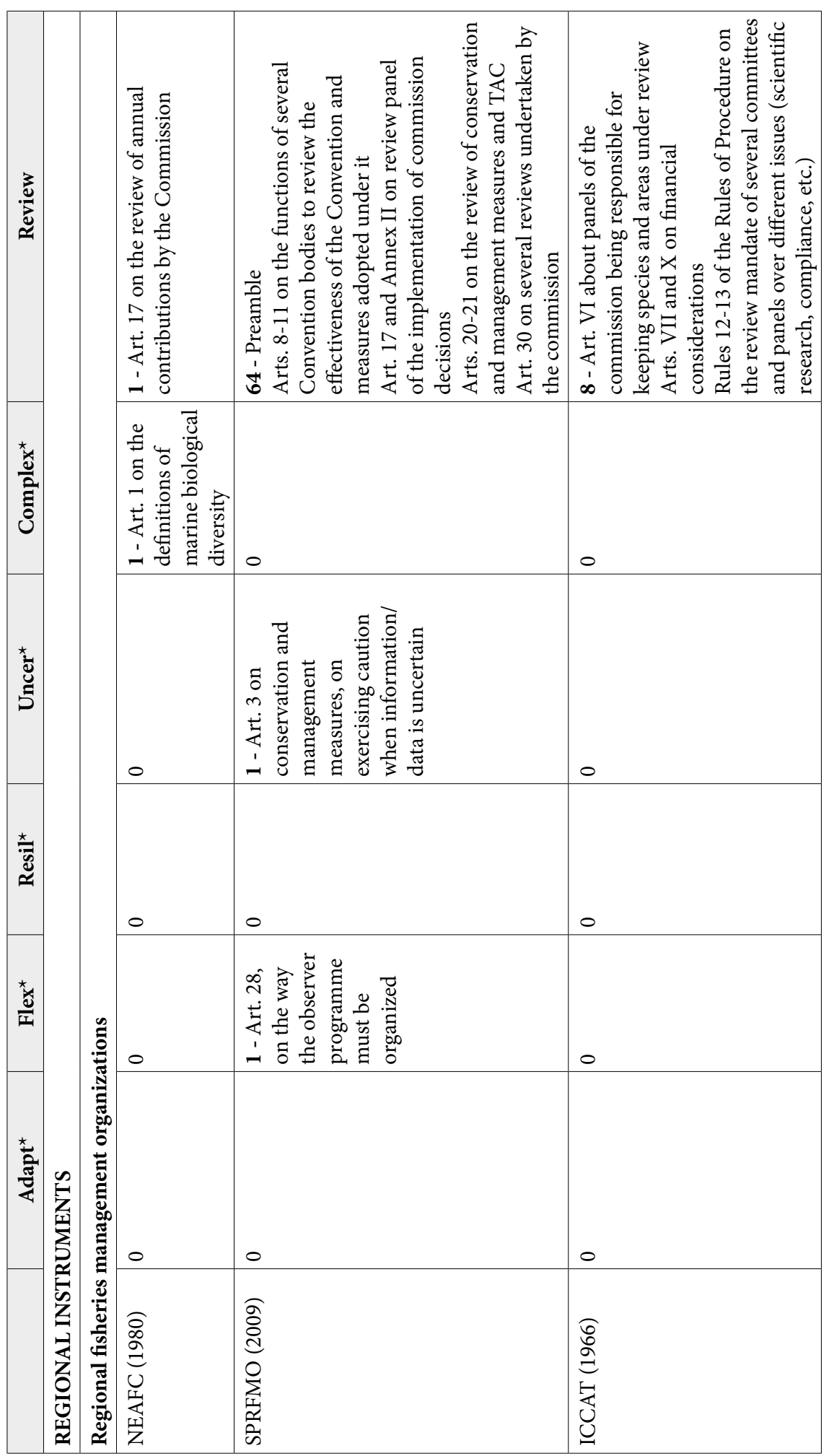




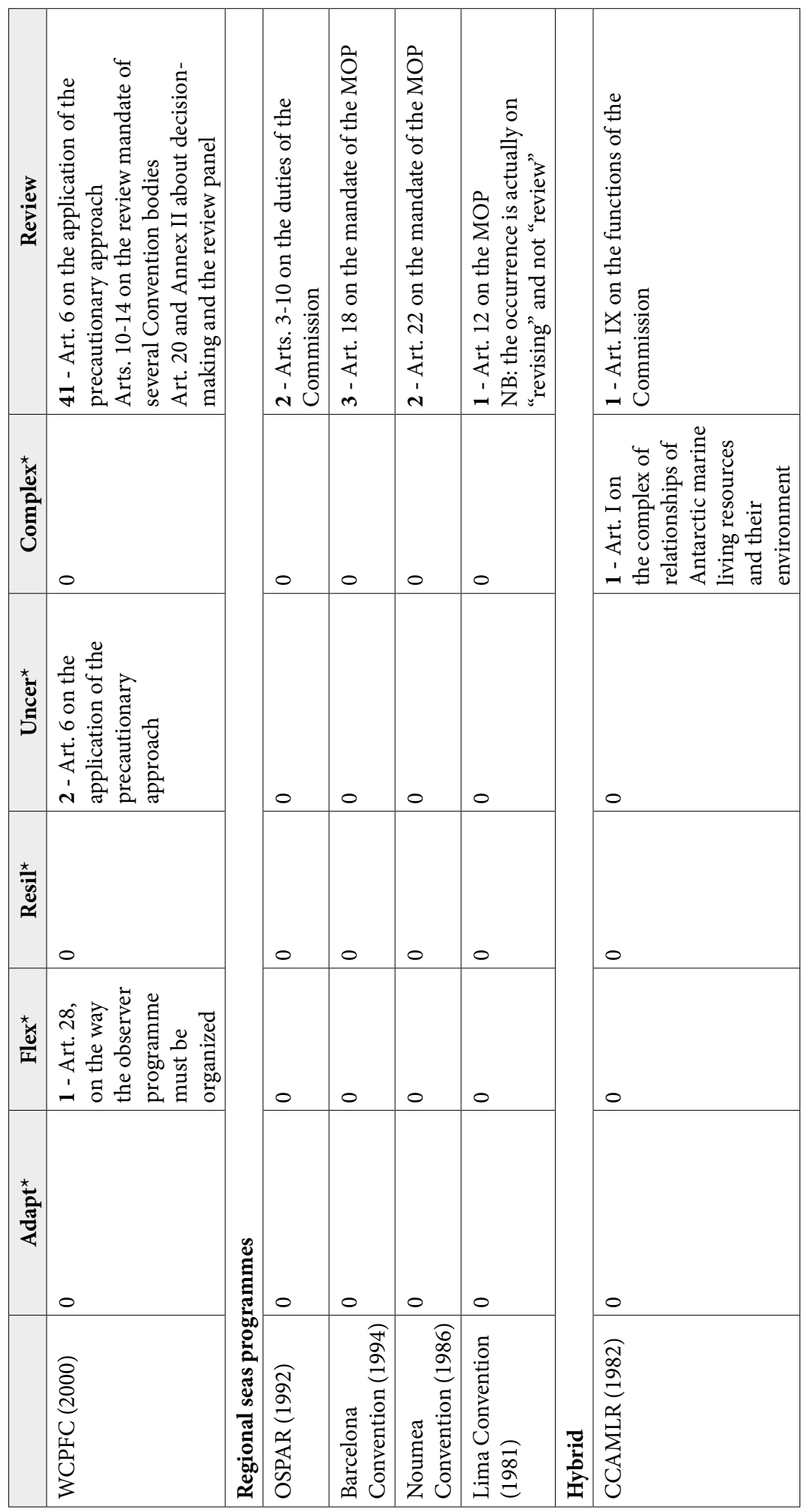




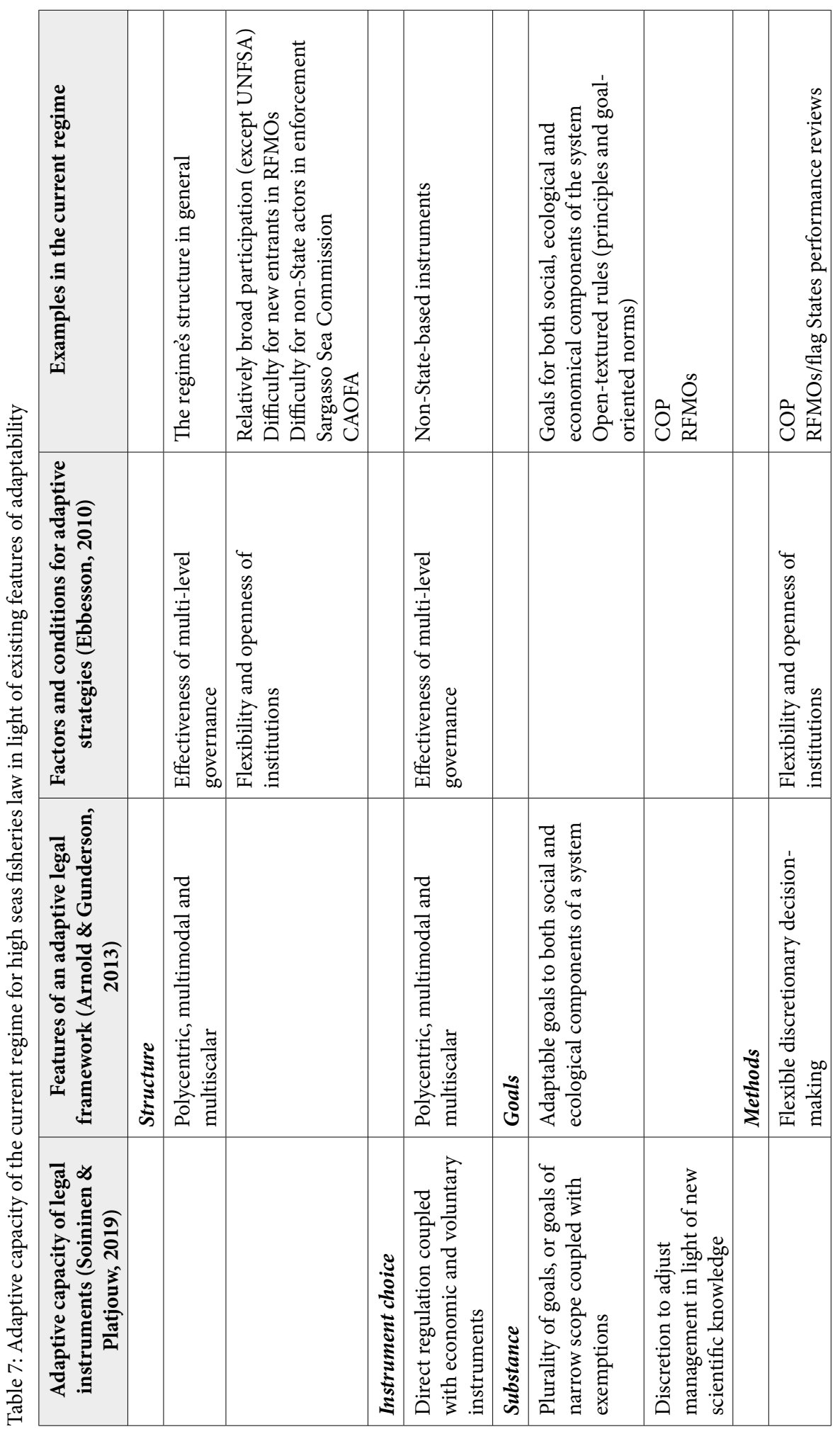




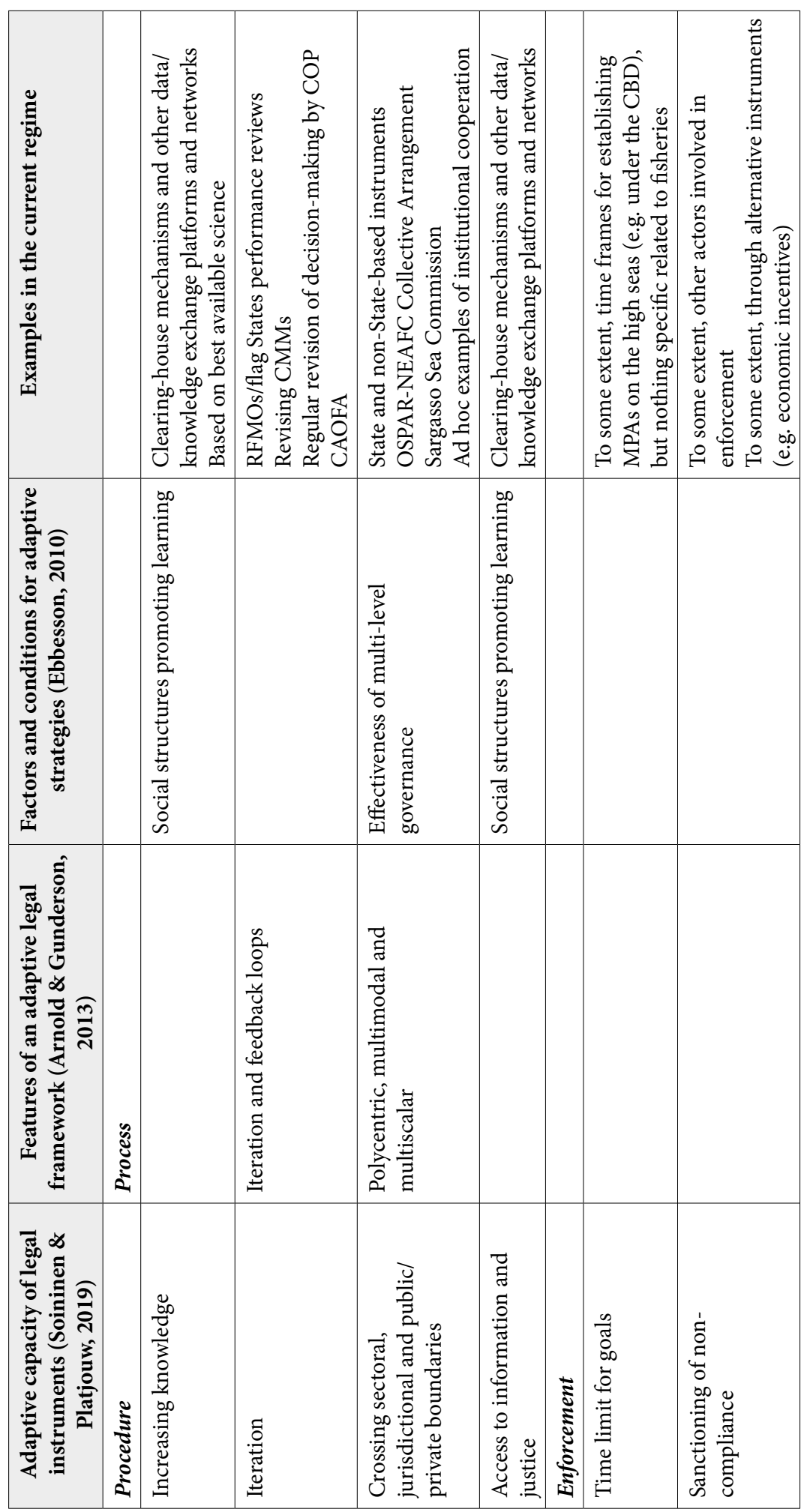





\section{CONCLUSION}

\section{New Insights to Reshape and Complement the Legal Regime for the Sustainable Management of High Seas Fisheries}

\section{AN OVERVIEW OF THE FINDINGS}

Despite decades of regulatory and institutional developments, the legal regime for the management of high seas fisheries has not been able to secure the sustainable use of living resources in ABNJ. Indeed, high seas fish stocks face perennial problems of overexploitation. ${ }^{1}$ Efforts have been made to prevent IUU fishing and overfishing, and to improve the way we address the impacts of fishing activities on the marine environment, and such efforts have led to positive developments in terms of mainstreaming biodiversity within fisheries management; ${ }^{2}$ yet actions have mostly been conducted in a piecemeal and haphazard fashion, and systematic undertakings towards the improvements of sustainability performance - if any are scarce. Additionally, the significant economic and (geo)political interests that drive the management of fisheries on the high seas block attempts at establishing mechanisms for the protection of the marine environment, ${ }^{3}$ and suggestions for the restructuring of the regime towards a better connection between conservation and sustainable use of high seas fisheries resources have been faced with vehement opposition. ${ }^{4}$ The strong momentum currently aiming for the enhancement of knowledge and awareness of the oceans, the interconnectedness of activities and interests on the high seas, and a multisectoral and multidisciplinary dialogue for the oceans $s^{5}$ has looked into those challenges, but this still needs to translate into concrete and sustained actions that lead to concrete and sustained results.

1 Rosemary Rayfuse, Non-flag State enforcement in high seas fisheries (Leiden: Martinus Nijhoff, 2004) at 3-4.

2 Kim Friedman, Serge Garcia \& Jake Rice, "Mainstreaming Biodiversity in Fisheries" (2018) 95 Marine Policy 209-220 at 209.

3 See, e.g. "Talks on Antarctic marine sanctuary fail for eighth straight year" (2 November 2019) The Japan Times, online: https://www.japantimes.co.jp/news/2019/11/02/asia-pacific/science-health-asia-pacific/ talks-antarctic-marine-sanctuary-fail/\#.Xcbwyi17SL8.

4 See, e.g. the opposition to including fisheries within the BBNJ Agreement, see, generally, chapter 4 above.

5 This multidisciplinary and multiscalar dialogue for the oceans is embodied, inter alia, in United Nations Ocean Conference (New York, USA, 5-9 June 2017), online: <https://oceanconference.un.org/about>. The conference consisted of a multi-actors platform to mobilize action for the conservation and sustainable use of the oceans and its resources. A second conference was planned for June 2020, but was postponed due to the COVID-19 pandemic. 
In the face of the need for change in a sector strongly entrenched in long-standing rights and interests, strongly entrenched in the "sacrosanct" freedom of fishing, this study aimed at approaching the regulation of high seas fisheries from a different perspective, one that looks for alternatives beyond the law. It assessed how international fisheries law might be reshaped and adapted through the growing importance of (oceans) governance for reaching more sustainable management of the oceans and living resources on the high seas. The ultimate objective of such an assessment is to equip decision-makers with additional tools with which to face complexity.

In order to grasp the shortcomings of the current regime in reaching sustainability performance, and to develop tools that could appropriately address these shortcomings, the present section intends to bring together the interim conclusion of each chapter. The study has first delved into the understanding of how things are: it has looked at the current legal framework as well as recent developments (1.1), and has identified the challenges currently faced by the regime (1.2). It has then explored how things could (should) be, through potential alternatives to steer actors' behaviours towards the collaborative and coordinative undertakings that the regime is urgently in need of (1.3).

\subsection{The interconnectedness between fisheries management and environmental and biodiversity protection in the current legal regime for the high seas}

The study's first aim was to achieve a better understanding of the current legal framework for the management and conservation of living resources on the high seas. Not only must we look at the different obligations it contains in light of the necessary interconnectedness between fisheries activities and the marine environment, but also the interconnectedness with other activities being conducted in ABNJ.

As presented in chapter 2, the legal regime for the regulation and management of high seas fisheries is composed of a wide array of legally binding and non-legally binding instruments, which lay out obligations and duties for actors in their use and exploitation of marine living resources, as well as in their actions for the protection of the marine environment (chapter 2, sections 3.1 and 3.2). The legal framework also mandates different actors to operationalize the various relevant obligations (chapter 2 , section 3.3). In fact, it can be said that fisheries law and biodiversity conservation "co-evolved in the right direction within a common legal framework", and that the

6 Solène Guggisberg, The Use of CITES for Commercially-Exploited Fish Species: A Solution to Overexploitation and Illegal, Unreported and Unregulated Fishing? (Cham: Springer, 2016) at 211.

7 Serge Garcia, Jake Rice \& Anthony Charles, "Governance of marine fisheries and biodiversity conservation: The integration challenge" in Serge Garcia, Jake Rice \& Anthony Charles (eds), Governance of marine fisheries and biodiversity conservation: Interaction and Coevolution (Hoboken: Wiley, 2014) 37-52 at 40. See also Friedman, Garcia \& Rice, supra note 2 at 216. 
framework has been "broadening and better specifying States' responsibilities". ${ }^{8}$ The current framework therefore offers a fairly good tool box.

Chapter 3 has then delved into the analysis of the role of principles, which form an intrinsic part of any legal regime. They act as tools for coherence and systematization of obligations, for guidance in the interpretation and application of existing rules, and as parameters for the development of the law (chapter 3, section 2). It is also in light of these functions that their effectiveness within a legal regime can be assessed.

Principles governing the high seas are no exception. A series of principles have shaped the development of the international legal regime for the high seas, and have, in turn, also influenced high seas fisheries law (chapter 3, section 3). Some of these principles have now reached the status of legal obligations (either customary or conventional), while others act as policy goals. Yet, despite their varying legal nature, the principles governing the high seas act as common elements within the complexity characterizing the legal framework for high seas fisheries. As unifying elements, they give an opportunity to see conservation and use in light of one another, and allow us to contemplate exploitation in light of conservation.

Principles further find relevance in the way they are operationalized. In the case of the international legal regime for fisheries, principles have informed the development of tools that bring together conservation and use within management (chapter 3 , section 4). They have been of particular relevance in the shaping of area-based tools and assessment tools in high seas fisheries. Principles governing the high seas therefore systematize the interconnectedness between fisheries management and environmental and biodiversity protection, and act as reminders of the objectives we want to achieve.

To complete the portrait of the regime, chapter 4 has focused on the current negotiations for the development of the new BBNJ Agreement (chapter 4, section 2), which constitutes the most important current development in the law of the sea, and in multilateral negotiations more generally. The BBNJ process has gathered, and continues to gather, a lot of attention in the legal literature, and also within the science/policy interface. This supports the intertwinement between science and policy, through the fact that scientific knowledge is fundamental to the development of up-to-date policies and regulations, while science needs the platform of policy and law to be adequately implemented.

The Agreement is expected to play an important role in improving cooperation and coordination in $\mathrm{ABNJ}$ (chapter 4, section 3). However, the precise cooperation and coordination role that the Agreement will play for fostering interconnectedness between fisheries management and biodiversity conservation more specifically is 
obscured by the fact that it remains uncertain to what extent the scope of application of the Agreement will encompass fisheries. ${ }^{9}$ The scope of the Agreement's influence on fisheries structures therefore rests on the way cooperation and coordination can be "effectively integrated into fisheries management undertaken by other actors", and "applied consistently by those doing fisheries management" ${ }^{10}$ (chapter 4 , section 4 ). This in turns rests on three elements: political bargaining between fishing powers; the institutional structure of the Agreement; and the balance between the role of the $\mathrm{BBNJ}$ process in complementing the fragmented regime in $\mathrm{ABNJ}$ on one side, and the protection of the autonomy and functioning of existing institutions and interest through the necessity not to undermine existing structures on the other side.

Despite the co-evolution of its many components, the current legal regime does not fully promote interconnectedness between fisheries management and biodiversity conservation. First, the obligations of cooperation, due regard and marine environmental protection, at the heart of the legal framework for the high seas, could act as the bridging obligations between sustainable use and conservation of marine living resources. Yet, these obligations remain vague and lack content on how they can be operationalized, and so are ill-equipped to guide actors' behaviours in ABNJ. Second, and most importantly, despite this co-evolution, as the framework is composed of instruments coming from and actors operating in different regimes, ranging from the law of the sea and international fisheries law to environmental and conservation law, this has resulted in a context where specific regimes regulate specific resources; ${ }^{11}$ the framework therefore does not fully translate the complexity and interconnectedness present "in the field". The role of the BBNJ Agreement to catalyse interconnectedness, cooperation and coordination in $\mathrm{ABNJ}$ is not contested, but the extent to which this role is operationalized in relations to fisheries will

9 See Revised draft text of an agreement under the United Nations Convention on the Law of the Sea on the conservation and sustainable use of marine biological diversity of areas beyond national jurisdiction, Intergovernmental conference on an international legally binding instrument under the United Nations Convention on the Law of the Sea on the conservation and sustainable use of marine biological diversity of areas beyond national jurisdiction, 4th Sess, UN Doc A/CONF.232/2020/3 (2019). For example, its art. 8(2)(a) currently states that "The provisions of this [Part II of the Agreement, Part covering MGRs] shall not apply to: (a) The use of fish and other biological resources as a commodity”. While there seems to be a convergence of views towards the exclusion of fish as a commodity in relation to MGRs, it remains uncertain whether this exclusion will apply to the Agreement in its entirety, see, generally Textual proposals submitted by delegations by 20 February 2020, for consideration at the fourth session of the Intergovernmental conference on an international legally binding instrument under the United Nations Convention on the Law of the Sea on the conservation and sustainable use of marine biological diversity of areas beyond national jurisdiction (the Conference), in response to the invitation by the President of the Conference in her Note of 18 November 2019 (A/CONF.232/2020/3) (15 April 2020), online: <https:// www.un.org/bbnj/sites/www.un.org.bbnj/files/textual_proposals_compilation_article-by-article_-_15_ april_2020.pdf>.

10 Fernanda Millicay, "Marine Biodiversity of Areas Beyond National Jurisdiction Securing a Sound Law of the Sea Instrument" in David Joseph Attard, David Ong \& Dino Kritsiotis (eds), The IMLI Treatise on Global Ocean Governance, vol I: UN and Global Ocean Governance (Oxford: Oxford University Press, 2018) $167-177$ at 174 .

11 Klaus Bosselmann, Earth Governance. Trusteeship of the Global Commons (Cheltenham: Edward Elgar, 2015) at 71-72. 
depend on the mandate given to the different bodies created under the Agreement's institutional architecture, and the scope of such mandate.

\subsection{Behaviours, compliance and lack of coordination as main challenges for sustainability performance}

After delving into the assessment, in previous chapters, of the different components of the current legal regime for the regulation and management of high seas fisheries, chapter 5 has identified and analysed several challenges currently impacting the need for cooperation and coordination for the management of fisheries on the high seas. Relying on the three tasks of resource management identified by Stokke, ${ }^{12}$ the main challenges hindering sustainability performance for high seas fisheries have been classified according to whether they refer to the shared understandings of the goals to be achieved (i.e. cognitional task), the translation of these understandings into (legal) commitments (i.e. regulatory task), or the compliance of actors' behaviours with the commitments undertaken (i.e. behavioural task).

Within the cognitional task, actors face the difficulty of balancing and reconciling the various interests shaping the different components of socio-ecological systems, and further struggle to collect and process sufficient (good) data on which to understand science, set targets and base decision-making (chapter 5, section 2.1). Within the regulatory task, the current legal framework presents gaps that need to be filled (chapter 5, section 2.2). This is the case regarding certain geographical areas or species that are currently not covered by any RFMO or RFMA. The jurisdiction to implement and enforce measures on the high seas is also limited to certain actors, who often lack the ability to act; extending the jurisdiction to other actors could therefore help fill in the gaps and work towards improve sustainability performance. Finally, there is uncertainty linked to the scope of application of conservation and management measures, due to the possibility for some States to opt out of these measures, to a lack of harmonized requirements for their application, or to a lack of comprehensive understanding of concepts forming part of these measures.

Despite these important shortcomings, it is still possible to conclude that the current regime presents a satisfactory toolbox in terms of norms and institutions. However, it is the third task, namely the behavioural task, which remains the most problematic for improving sustainability performance (chapter 5, section 2.3 ). First, States often lack the knowledge and/or the resources to undertake meaningful and systematic actions for monitoring, control and surveillance. There is also a

12 Olav Schram Stokke, "Management Options for High Seas Fisheries: Making Regime Complexes More Effective" in R. Caddell \& E. Molenaar (eds), Strengthening International Fisheries Law in an Era of Changing Oceans (Oxford: Hart, 2019) 51-77; Olav Schram Stokke, "International fisheries politics: from sustainability to precaution" in Steinar Andresen, Elin Lerum Boasson \& Geir Hønneland (eds), International Environmental Agreements: An introduction (Abingdon, Oxon: Routledge, 2011) 97-116 at 109-112. 
lack of transparency regarding States' practice and implementation performance. This is why certain implementation and enforcement actions are often undertaken by NGOs and/or business in order to fill in the gaps, but their involvement often triggers questions of legality and legitimacy. Second, RFMOs, although having showed significant efforts and progress in terms of sustainable practices, remain plagued by structural deficiencies that affect their capacity to ensure sustainable performance, ranging from lack of transparency, to failing to follow scientific advice, to disparities in practices. Third, a lack of participation from States in key fisheries instruments influences the way in which obligations found within those instruments can be effectively implemented. Finally, dispute settlement mechanisms, because of uncertainties linked to exceptions to jurisdiction and overlapping jurisdiction, have had a limited impact on the development of fisheries management in light of environmental protection and species conservation. ${ }^{13}$

The overarching challenge faced by the high seas fisheries regime, however, resides in the fragmentation of its structures (chapter 5, section 3). Fragmentation is necessary to obtain expertise, especially when facing a complex system such as high seas fisheries; yet it becomes a problem when it affects the actors' ability to navigate through the obligations that bind them and to undertake the necessary actions to fulfil such obligations adequately. While the discourse on the fragmentation of norms is quite well-rounded, ${ }^{14}$ fragmentation in terms of implementation and enforcement of those norms remains more abstract. In the face of isolated examples of progress for compliance and a lack of comprehensiveness for the regime, solutions for managing fragmentation need to be found through more systematic interactions and coordination. In other words, what is needed is a deliberative, orchestrated process, ${ }^{15}$ which entails a stronger reliance on coordination.

Through the assessment of the challenges hindering the international legal regime for fisheries management, it can be concluded that this regime in its present state is insufficient to adequately and efficiently address shortcomings in terms of nudging actors towards compliance, cooperation and coordination. This is why, as Toope mentions, "[t]he new emphasis upon compliance or implementation $[\ldots]$ is the intellectual shift that forced international lawyers to open up inquiry in to the work of" other disciplines, ${ }^{16}$ which shows that solutions within the law alone are not enough. ${ }^{17}$

13 See, e.g., Guggisberg, supra note 6 at 166-181.

14 See, e.g., Fragmentation of International Law: Difficulties Arising From the Diversification and Expansion of International Law, International Law Commission, 58th Sess, UN Doc A/CN.4/L.682 (2006).

15 The distinction between organic and orchestrated practice and processes is used by Richard Barnes, "The Pursuit of Good Regulatory Design Principles in International Fisheries Law. What Possibility of Smarter International Regulation?" in Judith van Erp et al (eds), Smart Mixes for Transboundary Environmental Harm (Cambridge: Cambridge University Press, 2019) 97-125 at 119.

16 Stephen Toope, "Emerging patterns of Governance and International Law" in Michael Byers (ed), The role of law in international politics. Essays in international relations and international law (Oxford: Oxford University Pres, 2000) 91-108 at 92-93.

17 Garcia, Rice \& Charles, supra note 7 at 38. 


\subsection{Relying on the governance-adaptability dialogue as a vector of the key to develop alternative regulatory and policy responses}

The law plays a critical role as a mechanism for nudging actors' behaviours and, more broadly, for social change. However, the law finds itself in a broader toolbox for trigerring social action. Governance, encompassing a wide variety of components, forms this broader toolbox and suggests other means for social action and other functions for steering behaviour. ${ }^{18}$ Chapter 6 has therefore explored the possibility of strengthening compliance within international fisheries law by drawing upon mechanisms, concepts and processes that originate from outside formal legal mechanisms and that rely "upon the cross-fertilization of new ideas from within and outwith the system". ${ }^{19}$ Although "governance can be accomplished by law", ${ }^{20}$ law is not the only social construct contributing to governance; actors' behaviours can also be influenced through a variety of other components (chapter 6 , section 2.2). Governance, in fact, observes that socio-political change, in order to adequately accommodate complexity, revolves around the necessity for new forms of regulation, the intervention of a multiplicity of actors, and the importance of collaborations $^{21}$ (chapter 6 , section 2.1 ).

In the marine context, the concept of oceans governance has been especially informative in showing the practicality of the dynamism and broad perspective offered by governance for the improvement of oceans management (chapter 6, section 2.3.2). In fact, oceans governance has been described as "those formal and informal rules, arrangements, institutions and concepts which structure the ways in which sea space is used, how ocean problems are monitored and assessed, what activities are permitted or prohibited, and how sanctions and other responses are applied" as a "broad conception of oceans management".22 Oceans governance is considered as an approach to oceans management that replaces "the traditional

18 Oran R. Young, Governing Complex Systems. Social Capital for the Anthropocene (Cambridge, Mass.: MIT Press, 2017) at 121.

19 Richard Barnes, "The Continuing Vitality of UNCLOS” in Jill Barrett \& Richard Barnes (eds), Law of the Sea: UNCLOS as a Living Treaty (British Institute of International and Comparative Law, 2016) 459-489 at 478 .

20 Robert Keohane \& Joseph Nye, "Governance in a Globalizing World" in Robert Keohane (ed), Power and Governance in a partially globalized world (Abingdon, Oxon: Routledge, 2002) 193-218 at 203, cited in Louis Kotzé, "A juridical conceptual perspective on environmental governance" in Tuomas Kuokkanen et al (eds), International Environmental Law-making and Diplomacy: Insights and Overviews (Abingdon, Oxon: Routledge, 2016) 48-67 at 63 (emphasis added).

21 See, e.g., Frank Biermann \& Philipp Pattberg, "Global Environmental Governance: Taking Stock, Moving Forward” (2008) 33 Annual Review of Environment \& Resources 277-294 at 278, 280-284; Douglas Johnston, "The Challenges of International Ocean Governance: Institutional, Ethical and Conceptual Dilemmas" in Donald R. Rothwell \& David L. VanderZwaag (eds), In Towards Principled Oceans Governance: Australian and Canadian Approaches and Challenges (Abingdon, Oxon: Routledge, 2016) 349-399 at 349; Martin Hewson \& Timothy Sinclair, "The Emergence of Global Governance Theory" in Martin Hewson \& Timothy Sinclair (eds), Approaches to Global Governance Theory (Albany, NY: State University of New York Press, 1999) 3-22 at 17; Christopher Ansell \& Jacob Torfing, "Introduction: Theories of governance" in Christopher Ansell \& Jacob Torfing (eds) Handbook on Theories of Governance (Cheltenham: Edward Edgar, 2016) 1-17 at 9-10; Toope, supra note 16 at 96-97.

22 Donald Rothwell \& Tim Stephens, The International Law of the Sea (Oxford: Hart, 2016) at 507. 
issue-by-issue and zone-by-zone approach to oceans management". ${ }^{23}$ Oceans governance therefore additionally represents an outcome-based approach, one that aims at triggering changes in oceans management towards improved sustainability of oceans.

A combined understanding of environmental governance (chapter 6, section 2.3.1) and oceans governance can inform a more environment-oriented and integrated conception of fisheries governance. In fact, although being an encompassing concept which includes many of the components of a governance approach, fisheries governance remains for now intrinsically sectoral. Therefore, looking at fisheries governance in a way that also accommodates an intertwinement of issues can help position fish stocks as one component of the environment, and fisheries as one of the multiple oceans uses (chapter 6, section 2.3.3). This can, in turn, be the basis for an even more adaptive approach to operationalizing existing fisheriesrelated obligations and inform potential alternative mechanisms that integrate high seas fisheries management with marine environmental protection.

Against this backdrop, the study has relied on the potential of the (oceans) governance perspective to strengthen the law's adaptive capacity in order to operationalize changes which will, ultimately, ensure the resilience of the legal regime and, consequently, of the socio-ecological system it oversees. Through the understanding of two models for assessing the law's adaptive capacity, the study has been able to explore tools for adaptability (chapter 6, section 3). Although not necessarily new to international law, these tools reiterate the importance of open-textured rules, of multiplicity in scale, modes and actors, and of iteration and review. In particular, polycentricity and networks are two governance-related components on which adaptive strategies within the legal discourse should be relied to specifically target shortcomings in terms of compliance, and strengthen cooperation and coordination. They represent the building blocks of potential alternative mechanisms for improving sustainability performance. Governance can therefore help the law to be more adaptive, while a legal system that is more adaptive will ensure that legal commitments are translated into actions that will effectively influence oceans management.

This dialogue between oceans governance and adaptive strategies contributes to the creation of a platform for the "frame of thinking [to] expand". ${ }^{24}$ The growing use of the concept of governance is not simply a question of terminology; it reflects a desire to adapt the way in which resources, activities and behaviours are tackled and managed. ${ }^{25}$ In fact, what the governance-adaptability dialogue reflects is that

23 Ibid at 506.

24 Elisa Techera \& Natalie Klein, International Law of Sharks. Obstacles, Options and Opportunities (Leiden: Brill Nijhoff, 2017) at 86.

25 Yoshinobu Takei, "Demystifying Ocean Governance" in Seline Trevisanut, Nikolaos Giannopoulos \& Rozemarijn Roland Holst (eds), Regime Interaction in Ocean Governance. Problems, Theories and Methods (Leiden: Brill Nijhoff, 2020) 22-51 at 26. 
we have most of the tools we need, and what (oceans) governance gives us is a perspective to consider using them differently.

Testing the current legal regime for high seas fisheries against the two models analysed in chapter 6 , chapter 7 first observed that several features of adaptability can be found in legal structures and instruments regulating the management of fisheries on the high seas, as well as in the draft text of the BBNJ Agreement (chapter 7 , section 2 ). However, although present, the features of adaptability remain difficult to implement, and they have so far been implemented in a piecemeal and haphazard fashion.

To enhance the legal regime in a way that targets the behavioural and fragmentation challenges characterizing the regime for high seas fisheries, two mechanisms have been suggested that build on the dialogue between (oceans) governance and adaptability. Smart mixes and interplay management contribute to creating a regime design that focuses on structures for decision-making and on enforcement through different channels (chapter 7, section 3).

Smart mixes are a design of complementary policy instruments. In a context where complexity prevails, the potential combination between instruments can allow for more flexibility and resilience for the regulatory structure, as one instrument can act as the mitigator of the weakness(es) of another. ${ }^{26}$ Within international regulations, smart mixes embrace a broad understanding of regulatory instruments, going beyond State-based law, and including self-regulation, economic instruments and incentives, private standards, and/or other forms of control stemming from civil society or businesses. ${ }^{27}$ Although legitimacy questions arise in using non-State based instruments, a result-oriented approach to legitimacy (i.e. a process is legitimate if it reaches the outcome it has been set to reach) would support the inclusion of alternative regulatory instruments in order to effectively achieve sustainability performance. This is why this study believes that smart mixes have an interesting potential for improving coherence and complementarity between instruments, one that is rooted in adaptability and flexibility (chapter 7, section 3.1).

Interplay management, for its part, represents the deliberate efforts by States, and actors more generally, to improve the interplay between relevant institutions. Interplay management can thus be considered as one tool to address regime interaction and manage fragmentation, but where the interaction is deliberately encouraged and not only observed. Interplay management can occur at different levels, and through different scales of coordination or integration, ranging from

26 See, e.g., Neil Gunningham \& Darren Sinclair, "Regulatory Pluralism: Designing Policy Mixes for Environmental Protection" (1999) 21:1 Law \& Policy 49-76 at 50.

27 Judith van Erp et al, "Introduction: The Concept of Smart Mixes for Transboundary Environmental Harm" in Judith van Erp et al (eds), Smart Mixes for Transboundary Environmental Harm (Cambridge: Cambridge University Press, 2019) 3-24 at 7. 
a nearly centralized coordination to autonomous and independent management. This study submits that the regime for high seas fisheries would benefit from joint interplay management, where the development of possible joint rules of interaction does not necessarily amount to a full merging or integration of components, but where bridging, orchestration and coordination between components is deliberately sought. The ultimate goals are deliberate and systematic actions towards interorganizational coordination and cooperation, which would be rooted in the obligation for international cooperation ${ }^{28}$ (chapter 7 , section 3.2).

To illustrate the use of smart mixes and interplay management in reaching sustainable results in fisheries management, the study has looked at three examples where the conservation and management measures of RFMOs have been complemented by measures linked to the certification standards requirements of the Marine Stewardship Council (MSC). ${ }^{29}$ These examples have shown the positive outcomes stemming from the complementarity between different types of instruments implemented and enforced on different scales and by different actors, whilst also enhancing cooperation between States, international organizations and private actors. These examples have further shown that the reliance on MSC standards can foster coherence and the harmonization of actions between institutions. Smart mixes and interplay management therefore have the potential to contribute to improved results that stem from open and dynamic understandings of regulation and management ${ }^{30}$ (chapter 7 , section 3.3).

Through its different chapters, the study has allowed to reflect on the way the two research themes have been brought together. First, it assessed the interconnectedness between fisheries management and environmental and biodiversity protection within the current regime for high seas fisheries regulation and management, as well as within its upcoming instruments. It has also identified some shortcomings in reaching the objectives which this regime is set to safeguard. Second, it suggested an alternative perspective, one that relies on the dialogue between oceans governance and adaptability, to develop regulatory and policy responses that allow for the different components of the regime to interact more efficiently with one another. These responses also aim to ensure that the behaviour of the various stakeholders is effectively aligned with contributing to an improved sustainable management of high seas stocks.

When read in light of one another, the different chapters form an analysis that is therefore more than just another study of fisheries management; this analysis contributes to broadening the frame of thinking for adapting a regime that, despite

28 See, e.g., UNCLOS at arts. 118 and 197; UNFSA at art. 8.

29 Agnes Yeeting \& Simon Bush, "RFMO-MSC Smart Regulatory Mixes for Transboundary Tuna Fisheries" in Judith van Erp et al (eds), Smart Mixes for Transboundary Environmental Harm (Cambridge: Cambridge University Press, 2019) 146-169.

30 Ibid at 166. 
having a wide range of interesting tools, remains entrenched in traditional and illequipped mechanisms and principles, and struggles to deliver what it is expected to do. By broadening this frame of thinking, we do not suggest to "disregard the existing laws, policies and governance frameworks that have been established over the last half a century". ${ }^{31}$ What we suggest are "ways to work better with what we have". 32

\section{NAVIGATING INTERCONNECTEDNESS TOWARDS ALTERNATIVE POLICY SUGGESTIONS}

The study has tackled the sustainable potential of the high seas fisheries regime from a structural perspective, which has enabled a focus to be made on ways "for strengthening international fisheries law through its interconnections with alternative domains of international law", which "has generally been little explored". ${ }^{33}$ Interconnectedness in fact allows to shed light on the linkages between social, political, economic and ecological processes that form the system of high seas fisheries. Bridging all knowledge and all interests represents a clear and relevant challenge, and this is why there is a need for the development of complementary insights and conceptualizations for regulating and managing complex socialecological systems.

This is why interconnectedness has driven the analysis conducted in this study. Interconnectedness has in fact informed the concepts which we address, the issues we face, and the solutions we propose. Interconnectedness further underlies the perspective which this study has proposed to use to understand the changes we are currently facing, and to adapt our frame of thinking. Interconnectedness shapes the alternative and complementary mechanisms suggested in this study, which invite us to revisit our approach to high seas fisheries regulation and management.

These alternative and complementary mechanisms have a main aim, one of a policy nature: to contribute to the "toolkit for decision-makers to work with when trying to develop and evaluate potential interventions in current fisheries management arrangements". ${ }^{34}$ The improvement of this "tool-kit" has more particularly focused on strengthening the operationalization of existing measures, mechanisms, institutions and structures. Looking specifically at operationalization is necessary within the discourse on the adaptive capacity of the law; in fact, our current legal

31 Techera \& Klein, supra note 24 at 16.

32 Ibid.

33 Erik Molenaar \& Richard Caddell, "Options and Pathways to Strengthen International Fisheries Law in an Era of Changing Oceans" in Richard Caddell and Erik Molenaar (eds) Strengthening International Fisheries Law in an Era of Changing Oceans (Oxford: Hart, 2019) 423-429 at 425 (emphasis added).

34 James L. Anderson et al, "Principles for Fisheries Management in Areas Beyond National Jurisdictionthe Essential Role of Incentive-Based Approaches” (2018) at 8, online: <https://www.worldwildlife.org/ publications/principles-for-fisheries-management-in-areas-beyond-national-jurisdiction-the-essentialrole-of-incentive-based-approaches $>$. 
regime might have a strong normative and institutional adaptive and evolutionary capacity to accommodate change, but if there are no ways to implement such a capacity, then the potential for adaptability and evolution will not be (fully) realized.

To understand interconnectedness in the context of high sea fisheries management, this study has embraced the approach relied upon by the UNGA to address problems of oceans space, i.e. by building on interdisciplinary and intersectoriality ${ }^{35}$ to develop cooperation, coherence, and coordination, where the components of a system and the regime regulating it are bridged and orchestrated. This study has also, to some extent, looked into possibilities for integration, which would represent the most complete achievement of interconnectedness; in fact, integration represent a situation where components are altered to eventually be merged. ${ }^{36}$ However, the scope of a fully integrated approach to fisheries management has yet to be understood better, in order to ensure that the regional particularities characterizing this regime can underpin the development of global strategies. ${ }^{37}$ Because, ultimately, what we want is not to lose specificity, but to benefit from it.

\section{IN CLOSING}

In answering the main question posed by this study, one can conclude that oceans governance does have the potential to shape and complement high seas fisheries law, by channeling this interaction towards the operationalization of existing norms. In a long-standing established regime for a traditional use of the oceans i.e. fisheries - where old habits die hard and where patterns of power are strongly embedded in decision-making and structures, the dialogue created between oceans governance and adaptability has led to a focus on actors' responses with regard to implementation, enforcement and compliance. Oceans governance has in fact contributed to fulfilling the "need for input from another discipline" 38 and has provided "a source of argument or inspiration" for the legal research. ${ }^{39}$

35 See, e.g., Oceans and the law of the sea, GA Res 74 (XIX), UNGAOR, 74th Sess, UN Doc A/RES/74/19 (2019) at preamble.

36 Jens Heidinsfelder \& Markus Beckmann, "A Governance Puzzle to Be Solved? A Systematic Literature Review of Fragmented Sustainability Governance" (2019) Management Review Quarterly at section 5.2.

37 See, e.g., Kristina Gjerde et al, "Conservation and Sustainable Use of Marine Biodiversity in Areas Beyond National Jurisdiction: Options for Underpinning a Strong Global BBNJ Agreement through Regional and Sectoral Governance" (2018) STRONG High Seas Project; Carole Durussel et al, "Strengthening Regional Ocean Governance for the High Seas: Opportunities and Challenges to Improve the Legal and Institutional Framework of the Southeast Atlantic and Southeast Pacific" (2018) STRONG High Seas Project.

38 Sanne Taekema \& Bart van Klink, "On the Border. Limits and Possibilities of Interdisciplinary Research" in Sanne Taekema \& Bart van Klink (eds), Law and Method, Interdisciplinary Research into Law (Tübingen, Germany: Mohr Siebeck, 2010) 7-32 at 11.

39 Ibid at 10-11. For all types of multi- and interdisciplinary research, see ibid at 10-13. 
It could be asked whether the use of oceans governance really brings something new, something that is not already included in the law of the sea framework. ${ }^{40}$ Is governance only a "catchy" word that we use to describe something that already exists? We believe that it is not. Governance expands our frame of thinking, ${ }^{41}$ it puts the emphasis on different components that are not the centre of the law's attention, or are even not considered by the law at all. Above all, it puts the emphasis on the relationships and interconnectedness between such components. Governance seems to be asking the law to get outside its comfort zone; yet, this might be easier than expected, because "the history of a system of law is largely a history of borrowing of legal materials from other legal systems, and of assimilation of materials from outside the law".42

Despite the adaptive potential of the legal discipline, it always remains difficult to consider adapting and re-thinking our current legal structures to new approaches because of cultural practices, strongly established institutions ${ }^{43}$ and a belief in the stabilizing function of the law. As Machiavelli's Prince taught us almost five centuries ago:

It ought to be remembered that there is nothing more difficult to take in hand, more perilous to conduct, or more uncertain in its success, than to take the lead in the introduction of a new order of things. [...] This coolness arises partly from fear of the opponents, who have the laws on their side, and partly from the incredulity of men, who do not readily believe in new things until they have had a long experience of them.

While it is undoubtedly difficult to change the current order of things, we cannot ignore the fact that " $[t]$ he world is changing. Our conventional legal picture of the patterns of power is no longer adequate. We need new thinking". ${ }^{44}$ However, one needs to remember that this new thinking has happened before: the now traditional legal disciplines were also once the response to a changing world, the "projects of reinventions", ${ }^{45}$ the results of re-thinking. ${ }^{46}$

40 Yoshinobu Takei, "A Sketch of the Concept of Ocean Governance and Its Relationship with the Law of the Sea" in Cedric Ryngaert, Erik Molenaar \& Sarah Nouwen (eds), What's Wrong with International Law? Liber Amicorum A.H.A. Soons (Leiden: Brill Nijhoff, 2015) 48-62 at 49.

41 Techera \& Klein, supra note 24 at 86.

42 Peter H. Sand, “Sovereignty Bounded: Public Trusteeship for Common Pool Resources?” (2004) 4:1 Global Environmental Politics 47-71 at 50, citing Roscoe Pound, former Dean of Harvard Law School in Alan Watson, Legal Transplants: An Approach to Comparative Law, 2nd ed (Athens, Ga.: University of Georgia Press, 1993) at 22.

43 Emily Boyd \& Carl Folke, "Conclusions: Adapting Institutions and Resilience" in Emily Boyde \& Carl Folke (eds), Adapting Institutions: Governance, Complexity and Social-Ecological Resilience (Cambridge: Cambridge University Press, 2011) 264-280 at 275.

44 David Kennedy, "The Mystery of Global Governance" (2008) 34 Ohio Northern University Law Review $827-860$ at 835 .

45 Ibid.

46 Van Dyke, Zaelke \& Hewison also talk about the ability of people to "conceive ideas, to encourage change, and ultimately, to act", an "ability to think and act creatively", see John M. Van Dyke, Durwood Zaelke \& Grant Hewison, "A New Look at Ocean Governance" in John M. Van Dyke, Durwood Zaelke \& Grant 
In the case of sustainable high seas fisheries, the process of reinvention and of re-thinking that is expected does not, however, translate into the necessity for a completely new regime; ${ }^{47}$ what is needed is a newly invigorated regime. It is not a revolution that is needed, but a strong evolution. We have the tools we need; we just need to use them differently. And we believe governance can help us to achieve just that. By using alternative and complementary approaches to fisheries management and regulation, the solution to achieving sustainable high seas fisheries might not be so elusive after all.

Hewison (eds), Freedom for the Seas in the 21st century. Ocean governance and environmental harmony (Washington DC: Island Press Washington DC, 1993) 7-12 at 9.

47 As mentioned by Kennedy, "[t]hinking about global governance, I do not think we ought to try to constitute the world anew. There is too much work we still need to do simply to understand how it works, how the forces and factors we have overlooked might be brought into the analysis", see supra note 44 at 858. 


\title{
ANNEX
}

\author{
Glossary
}

Adaptability. Adaptability is considered as one of the components of resilience (see definition below). It refers to "the capacity of actors in a system to influence resilience"1 or to maintain the system within sustainability boundaries through common action. A related yet different concept, transformability, goes a step further by relying on this collective action "to create fundamentally new systems when ecological, economic, or social (including political) conditions make the existing system untenable". ${ }^{2}$ The applicability of adaptive strategies to a legal regime, the components used to assess the adaptive capacity of the regulatory and management framework for high seas fisheries, as well as the relationship between adaptability and flexibility are further discussed in chapter 6 .

Areas beyond national jurisdiction (ABNJ). These are all areas that are not subject to the sovereignty, sovereign rights or jurisdiction of States. In the context of the law of the sea, ABNJ refer to the high seas, as defined under article $86 \mathrm{UNCLOS},{ }^{3}$ and the Area (the deep seabed), as defined under article 1(1)(1) UNCLOS. ${ }^{4}$

Despite being located beyond the national (coastal) jurisdiction of States, ABNJ are not under no jurisdiction or control. For example, vessels on the high seas are under the exclusive jurisdiction of the flag States, ${ }^{5}$ and some RFMOs also hold a management mandate in certain geographical areas and/or over certain species in $\mathrm{ABNJ}$.

Biological diversity. "[T]he variability among living organisms from all sources including, inter alia, terrestrial, marine and other aquatic ecosystems and the ecological complexes of which they are part: this includes diversity within species, between species and of ecosystems", as defined under article $2 \mathrm{CBD}$.

Marine biological diversity. "[T] he variability among marine living organisms and the ecological complexes which they are part of; this includes diversity within species, between species and of ecosystems", as defined under the preamble to the NEAFC Convention.

Biodiversity Beyond National Jurisdiction (BBNJ). BBNJ is used to refer to the components of biological diversity found in ABNJ. The term "BBNJ process" refers to the different stages of the international discussions on the topic, including the work of the Informal Consultative Process, the Ad-hoc Working Group, the Preparatory Committee and the Intergovernmental Conference. The BBNJ process is further discussed in chapter 4.

Coherence. Used to describe and evaluate the relation between instruments or institutions, ${ }^{6}$ coherence refers to "the connectedness of a rule or institution to other norms acknowledged

1 Brian Walker et al, "Resilience, Adaptability and Transformability in Social-ecological Systems" (2004) 9:2 Ecology and Society article 5.

2 Ibid. For more on adaptability and transformability within the broader context of resilience, see Carlos Gómez et al, "The AQUACROSS Innovative Concept. Deliverable 3.1” (2016) European Union's Horizon 2020 Framework Programme for Research and Innovation grant agreement No. 642317 at 80-81.

3 "all parts of the sea that are not included in the exclusive economic zone, in the territorial sea or in the internal waters of a State, or in the archipelagic waters of an archipelagic State".

4 "the seabed and ocean floor and subsoil thereof, beyond the limits of national jurisdiction".

5 UNCLOS at art. 92(1).

6 Judith van Erp et al, "Introduction: The Concept of Smart Mixes for Transboundary Environmental Harm" in Judith van Erp et al (eds), Smart Mixes for Transboundary Environmental Harm (Cambridge: 
by the international community"7 More specifically regarding institutions, coherence assesses whether "activities conducted under each institution in the relevant governance complex align well", or whether "institutions [...] do not disrupt the positive contributions that other institutions make to each of the governance tasks" concerned, and institutions will be considered coherent if they "clearly support each other's effectiveness". It also refers to "the extent to which component institutions are well aligned, providing complementary or synergistic capacities [...] and promoting the same governance policy objectives".

Complexity. This study describes complexity through its main characteristics, identified by Kim and Mackay: non-linearity (i.e. which does not follow a linear response, e.g. identifying the problem, assessing the problem, planning the response, making a decision as to this response, and implementing it), emergence (i.e. behaviours stem from the interactions of the different parts of a system, behaviours that could not have been foreseen within one part of the system alone), scale (local, regional and global) and uncertainty (from data gaps, but also from indeterminacy, i.e. the lack of a determined end point). ${ }^{10}$

Conservation. The protection of nature done through an economic development respectful of the environment. ${ }^{11}$

Often used as a synonym for preservation (see definition below), conservation is distinguished by the fact that it normally includes a component of (sustainable) use. This study, however, uses the terms interchangeably, unless specified otherwise.

Cooperation/Collaboration. This study follows the general understanding of these terms, i.e. when two or more entities work together towards common goals. This can be achieved, e.g. through sharing of resources or information, through the creation of an organization or platform, through the undertaking of joint actions.

Coordination. Coordination is understood in this study as going further than the simple joint work put forward by cooperation (see definition above). It aims to structure the space ${ }^{12}$ between rules, methods, modes of operation, institutions, and even decision-making. Coordination should at least lead to avoiding contrary and/or contradictory decisions, while it can at best be conducted with the aim of achieving more coherence and complementarity. ${ }^{13}$

Ecosystem. "[A] dynamic complex of plant, animal and micro-organism communities and their non-living environment interacting as a functional unit", as defined under article 2 CBD.

Cambridge University Press, 2019) 3-24 at 18.

7 Olav Schram Stokke, "The Interplay of International Regimes: Putting Effectiveness Theory to Work" (2001) Report of the Fridtjof Nansen Institute at 17 [Stokke, “The Interplay"].

8 Olav Schram Stokke, "Management Options for High Seas Fisheries: Making Regime Complexes More Effective" in Richard Caddell \& Erik Molenaar (eds), Strengthening International Fisheries Law in an Era of Changing Oceans (Oxford: Hart, 2019) 51-77 at 55 [Stokke, "Management Options"].

9 Ibid at 51-52.

10 Rakhyun E. Kim \& Brendan Mackay, "International Environmental Law as a Complex Adaptive System" (2014) 14 International Environmental Agreements 5-24 in general but in particular at 6.

11 Free translation from Patrick Blandin, Biodiversité, L'avenir du vivant (Paris: Albin Michel Sciences, 2010) at 165, cited in Pascale Ricard, La conservation de la biodiversité dans les espaces maritimes internationaux. Un défi pour le droit international (Paris: Pedone, 2019) at 21-22.

12 Jens Heidingsfelder \& Markus Beckmann, "A governance puzzle to be solved? A systematic literature review of fragmented sustainability governance" (2019) Management Quarterly Review at section 5.2.2.

13 Julien Rochette, Klaudija Cremers \& Glen Wright, "Les enjeux de coordination entre le futur traité haute mer et les organisations existantes" (Presentation delivered at the 16ème reunion du Groupe informel haute mer, 24 June 2020). 
Effectiveness. A structure is effective if it "contributes significantly to solving the problem it was set up to address", ${ }^{14}$ either through "compliance with legal obligations (legal effectiveness)" or by triggering "states, private actors and individuals to modify their behaviour (behavioural effectiveness)". ${ }^{15}$ Underdal adds that effectiveness is a tool of comparison, i.e. that it "firstly, defines a point or trajectory against which actual performance can be compared, and, secondly, provides a common metric that can be applied across a wide range of cases." ${ }^{\prime 16}$ Haward, for his part, uses four criteria to assess the effectiveness of RFMOs: capacity, coordination, coherence and responsiveness. ${ }^{17}$

Fishing operations. Although the present study generally uses the term "fishing activities" to refer to fishing at sea, it sometimes adopts the broader concept of "fishing operations", drawing from Vidas' use of "IUU operations" instead of "IUU fishing". ${ }^{18}$ These operations include the fishing activities themselves (i.e. the fishing at sea), but also the acts that precede the fishing activities (e.g. vessel purchase and registration), and acts that follow them (e.g. transportation and processing of the fish products, actions taken by the port States, exportation, sale and consumption of fish products).

Fragmentation. In international law, fragmentation is characterized by "fragments of normative and institutional activity", ${ }^{19}$ namely that rules are found in various instruments and applied by different institutions. Such fragments should be interpreted and applied in light of one another, ${ }^{20}$ but also have different "procedures and preferences".

Scott refers to two ways of approaching fragmentation: "the first approach draws on the international rules and principles relating to the interpretation and application of treaties and focuses on managing conflict between regimes; the second approach seeks to utilise and develop environmental governance mechanisms, not only to manage conflict between regimes, but also to maximise the benefits that can be derived from conflated and overlapping mandates".22 The

14 Stokke, "Management Options", supra note 8 at 55, citing Arild Underdal "The Concept of Regime 'Effectiveness"' (1992) 27 Cooperation and Conflict 227-240. See also Stokke, "The Interplay”, supra note 7 at 1, citing Peter M. Haas, Marc A. Levy \& Robert Keohane, Institutions for the Earth: Sources of Effective International Environmental Protection (Cambridge, MA: MIT University Press, 1993); Robert Keohane \& Marc A. Levy, Institutions for Environmental Aid: Pitfalls and Promise (Cambridge, MA: MIT Press, 1996); Olav Schram Stokke \& Davor Vidas, “The Effectiveness and Legitimacy of International Regimes" in Olav Schram Stokke \& Davor Vidas (eds), Governing the Antarctic: The Effectiveness and Legitimacy of the Antarctic Treaty System (Cambridge: Cambridge University Press, 1996) 13-31; Oran R. Young, Governance in World Affairs (Ithaca, NY: Cornell University Press, 1999).

15 van Erp et al, supra note 6 at 16.

16 Arild Underdal, "Explaining Regime Effectiveness" (2002) Jubilee Booklet of the Centre for Advanced Study at the Norwegian Academy of Science and Letters.

17 Marcus Haward, Governing Oceans in a Time of Change. Fishing for the Future (Cheltenham: Edward Elgar, 2020) listed at 5 and detailed generally in chapter 3.

18 Davor Vidas, "IUU Fishing or IUU Operations? Some Observations on Diagnosis and Current Treatment" in David Caron \& Harry Scheiber (eds), Bringing New Law to Ocean Waters (Leiden: Brill Nijhoff, 2004) 125-144 at 131. See also Seokwoo Lee, Anastasia Telesetsky \& Clive Schofield, "Slipping the Net: Why Is It So Difficult to Crack Down on IUU Fishing?" in Myron Nordquist et al (eds), Freedom of Navigation and Globalization (Leiden: Brill Nijhoff, 2015) 89-119 at 97.

19 Margaret Young, "Introduction: The Productive Friction between Regimes" in Margaret Young (ed), Regime Interaction in International Law. Facing Fragmentation (Cambridge: Cambridge University Press, 2012) $1-20$ at 2.

20 Fragmentation of International Law: Difficulties arising from the Diversification and Expansion of International Law, International Law Commission, 58th Sess, UN Doc A/CN.4/L.682 and Corr.1 (2006) at para 1 [ILC Fragmentation].

21 Martti Koskenniemi, "International Legislation Today: Limits and Possibilities" (2005) 23 Wisconsin International Law Journal 61-92 at 81.

22 Karen Scott, "Managing Fragmentation through Governance: International Environmental Law in a Globalised World” in Andrew Byrnes, Mika Hayashi \& Christopher Michaelsen (eds), International Law 
present study mainly focuses on the second approach: it goes beyond the discussion on conflict rules, and focuses on ways to address the weaknesses triggered by a lack of coordination between instruments and institutions within a regime, and/or by the presence of gaps in effective coherent structures for the management of particular activities.

The concept of fragmentation is further discussed in chapter 5 .

Framework. Although linked to the concept of regime (see definition below), framework is normally understood in the current study as having a narrower scope. It is mostly used to describe the legal and/or regulatory framework for international fisheries, i.e. a set of instruments listing the rights and obligations held by different actors, and the entities ensuring the respect of rights and fulfilment of obligations. The present study, however, sometimes uses the terms framework and regime interchangeably.

Governance. This study understands governance as the compilation of institutions, actors, rules, science, policy and law that make up a guiding framework for an activity in a geographical space, showing that law is only one of many components of governance. Governance can be better understood when compared with government, which refers to the "making and enforcement of decisions by a centralised formal authority". 23

It is worth mentioning that the understanding of governance in the context of this study encompasses more than just institutions/bodies and their performance, in the sense of good versus bad governance. ${ }^{24}$

Governance is also linked to the concept of management (see definition below): while the former refers to the macro, structural level, the latter refers to the micro level related to practical measures and mechanisms. However, this study considers that the two terms are correlated (e.g. changes in governance structures might influence management practices and, vice versa, new management measures might help to forge new governance approaches).

Oceans governance. Considering the absence of a clear definition of oceans governance in the literature, and considering its intertwinement with the concept of oceans management, this study relies on the understanding of oceans governance used by Rothwell and Stephens, i.e. "those formal and informal rules, arrangements, institutions and concepts which structure the ways in which sea space is used, how ocean problems are monitored and assessed, what activities are permitted or prohibited, and how sanctions and other responses are applied. It is therefore a broad conception of oceans management, implicating an array of global and regional organisations, directed at 'integrat[ing] the management of activities that impact upon or affect the oceans across sectors, space and time under a unified overarching vision"”. 25

The concepts of governance and oceans governance are discussed in further detail in chapter 6.

in the New Age of Globalization (Leiden: Brill Nijhoff, 2013) 207-238 at 210.

23 Donald Rothwell \& Tim Stephens, The International Law of the Sea (Oxford: Hart, 2016) at 507. See also, generally, Lawrence Juda \& Timothy Hennessey, "Governance Profiles and the Management of the Uses of Large Marine Ecosystems" (2001) 32 Ocean Development and International Law 43-69; Douglas M. Johnston, "The challenge of international ocean governance. Institutional, ethical and conceptual dilemmas" in Donald Rothwell \& David VanderZwaag (eds), Towards Principled Governance. Australian and Canadian approaches and challenges (Abingdon, Oxon: Routledge, 2006) 349-399; and David Freestone, "Problems of High Seas Governance" in Peter Johan Schei \& Davor Vidas (eds), The World Ocean in Globalisation. Climate Change, Sustainable Fisheries, Biodiversity, Shipping, Regional Issues (Leiden: Brill, 2011) 99-130 at 121-130.

24 Such as the approach taken in, e.g., Eyal Benvenisti, “The Law of Global Governance" in The Hague Academy of International Law, Recueil de Cours, vol 368 (Leiden: Brill Nijhoff, 2014) at 15, who focuses on "international organizations and other global governance bodies".

25 Rothwell \& Stephens, supra note 23 at 507, citing Karen N. Scott, "Integrated Oceans Management: A New Frontier in Marine Environmental Protection" in Donald Rothwell et al (eds), The Oxford Handbook on the Law of the Sea (Oxford: Oxford University Press, 2015) 463-490 at 465. 
Instrument. "[A] catch-all term for a range of documents or agreements, such as a document of title, lease, permit, contract, legislation, treaty, or soft-law instrument. These include both formally binding and non-binding measures."

Integration. Heidingsfelder and Beckmann refer to integration as going one step further than coordination (see definition above), where there is not only an attempt at structuring the space between different fragments (i.e. instruments, institutions, actors, structures), and where those fragments are altered and merged. ${ }^{27}$ The alternative and complementary approaches and mechanisms proposed in chapters 6 and 7 do not go as far as advocating for a complete integration, because the study recognizes the value of having solutions that target regional specificities and that are adaptable to different situations. The term is, in this study, mostly understood with regard to interconnectedness, where fragments must be seen in light of one another.

International fisheries. Marine capture fisheries (i.e. not taken in coastal waters) of stocks straddling between multiple EEZ and/or between an EEZ and the high seas, or located on the high seas. ${ }^{28}$

International fisheries law. As defined by Molenaar, "[i]nternational fisheries law is the domain (or: "rule-complex") of international law that relates specifically to the conservation, management and/or development of marine capture fisheries. It consists of substantive norms (e.g. rights, obligation and objective), substantive fisheries standards (e.g. catch restrictions) as well as institutional rules and arrangements (e.g. mandates and decisionmaking procedures). International fisheries law is a part of public international law and can also be seen as a branch or part of the domain of the international law of the sea".29 Barnes further adds that "[a] key feature of 'international' fisheries' is that the subject matter cannot be regulated by States in isolation". ${ }^{30}$

High seas fisheries (law). Marine capture fisheries taking place entirely on the high seas and targeting stocks straddling between EEZs and the high seas, or located on the high seas (and the legal and regulatory arrangements covering these fisheries).

Since data exclusively on high seas fisheries is difficult to find (this issue is further discussed in chapters 2 and 5), data on international fisheries is often referred to in the present study. Further, the legal framework described in this study can cover international fisheries more broadly, but tries to pinpoint as far as possible provisions applying specifically to high seas fisheries.

Interplay. Often assimilated to interaction, interplay is however understood in this study as having an additional proactive function, i.e. where interactions are not only identified and managed, but are also deliberately encouraged and fostered. In that sense, interplay and coordination (see definition above) are closely related as the latter aims to improve the former. ${ }^{31}$ The meaning of interplay is discussed further in chapter 7.

26 James L. Anderson et al, "Principles for Fisheries Management in Areas Beyond National Jurisdictionthe Essential Role of Incentive-Based Approaches" (2018) at 5, online: <https://www.worldwildlife.org/ publications/principles-for-fisheries-management-in-areas-beyond-national-jurisdiction-the-essentialrole-of-incentive-based-approaches>.

27 Heidingsfelder \& Beckmann, supra note 12 at section 5.2 .

28 D.G. Webster, "International Fisheries: Assessing the Potential for Ecosystem Management" (2013) 3:2 Journal of Environmental Studies and Sciences 169-183 at 169; Richard Barnes, "The Pursuit of Good Regulatory Design Principles in International Fisheries Law. What Possibility of Smarter International Regulation?" in Judith van Erp et al (eds), Smart Mixes for Transboundary Environmental Harm (Cambridge: Cambridge University Press, 2019) 97-125 at 102.

29 Erik Molenaar, "Participation in the Central Arctic Ocean Fisheries Agreement" in Akiho Shibata et al (eds) Emerging Legal Orders in the Arctic. The Role of Non-Arctic Actors (Abingdon, Oxon: Routledge, 2019) $132-170$ at 143.

30 Barnes, supra note 29 at 102.

31 Ibid at section 5.2.1. 
Legitimacy. In international law, legitimacy is normally understood as "a property of a rule or rulemaking institution which itself exerts a pull towards compliance on those addressed normatively because those addressed believe that the rule or institution has come into being and operates in accordance with generally accepted principles of right process". ${ }^{32}$ This definition contains three different focuses for assessing the legitimacy of a system of law: ${ }^{33}$ legitimacy can be source-oriented, process-oriented, or result-oriented. The first refers to whether the actors who undertake measures have been authorized to act. ${ }^{34}$ The second refers to whether the processes and the norms employed are adequate, i.e. if they are fit for the purpose they were created for. The third refers to the effectiveness of structures (see definition above). As this study explores alternative mechanisms aiming for the improved effectiveness of sustainable fisheries management, it relies primarily on the third approach to legitimacy.

Living marine resources. "[A]ll living components of marine ecosystems", as defined under the preamble to the NEAFC Convention.

Management. This study understands management as the combination of policy, law and agreements set at the local, national and international levels to hold the actors engaged in an activity accountable and ensure the respect of scientific limits.

Management is also linked to the concept of governance (see definition above): while the latter refers to the macro, structural level, the former refers to the micro level related to practical measures and mechanisms. However, this study considers that the two terms are correlated (e.g. changes in governance structures might influence management practices and, vice versa, new management measures might help to forge new governance approaches).

Oceans management. The understanding of oceans management borrows from the definition of fisheries management suggested by the FAO, which includes "information gathering, analysis, planning, consultation, decision-making, allocation of resources and formulation and implementation, with enforcement as necessary [...] in order to ensure the continued productivity of the resources and the accomplishment of other [...] objectives". ${ }^{35}$ This understanding builds on the consideration of a set of tools aiming for the coordination of interests and activities on the oceans.

Policy. As described by Zacharias and Ardron in the context of their study on marine policy and the relationship between governance and international law of the oceans, a policy is "a plan or

32 Stokke, “The Interplay”, supra note 7 at 16, referring to Thomas M. Franck, The Power of Legitimacy Among Nations (Oxford: Oxford University Press, 1990). See also Jutta Brunnée \& Stephen Toope, Legitimacy and Legality in International Law. An Interactional Account (Cambridge: Cambridge University Press, 2010) at 52-53. Brunnée \& Toope summarize the four factors identified by Franck ("Legitimacy in the International System" (1998) 82 American Journal of International Law 705-759 at 713) as being necessary for the "identification of legitimate rules: determinacy (ability of a rule to convey a clear message), symbolic validation (ability of a rule to communicate authority through ritual or regularized practice), coherence (consistency of the rule and its application with other rules), and adherence (vertical nexus of a rule to a pyramid of secondary rules)". These factors are not, however, developed further in the present study as they are not central to its framework of analysis.

33 Allen Buchanan \& Robert Keohane, “The Legitimacy of Global Governance Institutions” in Rüdiger Wolfrum \& Volker Röben (eds), Legitimacy in International Law (Cham: Springer, 2008) 25-62, cited in Rüdiger Wolfrum, "Legitimacy in International Law" (2006) Max Planck Encyclopedia of Public International Law at paras 6-8.

34 Staal refers to this right to exercise authority over others as the normative conception of legitimacy (c.f. the social conception of legitimacy, i.e. how people believe a structure or actor has this right), see Tim Staal, Authority and Legitimacy of Environmental Post-Treaty Rules (Oxford: Hart, 2019) at 185-188.

35 FAO, “4. Fisheries Management - Technical Guidelines for Responsible Fisheries” (1997) at para 1.2, online: <http://www.fao.org/3/w4230e/w4230e00.htm>. 
course of action to influence and determine decisions, actions and other matters" ${ }^{36}$ They also add that while "[l] aw is concerned with the legality of an action, [... ] [p]olicy, on the other hand, is concerned with the efficacy of an action". ${ }^{37}$

Preservation. The integral protection of nature. ${ }^{38}$

Often used as a synonym to conservation (see definition above), preservation is distinguished by the fact that it normally does not include a component of (sustainable) use. The South China Sea Arbitration has also raised a slight distinction between preservation and protection, the latter referring to the protection "of the marine environment from future damage", and the former as "maintaining or improving its present condition" ${ }^{39}$ This study, however, uses these terms interchangeably, unless specified otherwise.

Principle. Principles are generally understood as "guides to proper conduct" ${ }^{40}$ When applied to the legal sphere, a principle refers to a "legal statement which describes obligations of conduct or obligations to achieve an objective", obligations that are "described in abstract rather than concrete terms ready for direct application". ${ }^{41}$ The notion of principle and the functions of principles are described in further detail in chapter 3.

Regime. This study uses Margaret Young's "hybrid definition of 'regimes', which combines many of the approaches and insights of international law, transnational law and international relations literature: regimes are sets of norms, decision-making procedures and organisations coalescing around functional issue-areas and dominated by particular modes of behaviour, assumptions and biases". ${ }^{42}$ Accordingly, the regime for international/high seas fisheries would therefore include norms, rules and institutions, but it also pays great attention to actors' behaviours and their interactions.

Since the definition of regime used in this study borrows from perspectives of both international law and international relations, it is important to elaborate briefly on what features each discipline highlights and on what feature it relies. First, from a legal perspective, the International Law Commission, in its analysis of "special regimes", refers to a set of binding and non-binding rules and principles relating to a geographic area, a substantive subject matter, or both. ${ }^{43}$ Margaret Young further elaborates on this definition, underlining four elements that help define a regime from an international legal perspective. These elements are the actors making the regime (in international law, mostly States, but also the growing role of organizations and private actors), the organizations on which the institutional structure of a regime is based, the stages of legal development, discussing the way the law is made, implemented and enforced, and the possibility of systems-based or emergent practices, which refers to the danger of losing the generality of international law by focusing only on one of its branches. ${ }^{44}$

Second, from an international relations perspective, Krasner defines regimes as "sets of principles, norms, rules and decision-making procedures around which actor expectations converge in a

36 Mark Zacharias \& Jeff Ardron. Marine Policy: An Introduction to Governance and International Law of the Oceans, 2nd ed (Abingdon, Oxon: Routledge, 2019) at 94.

37 Ibid at 96.

38 Free translation from Blandin, supra note 11 at 165, cited in Ricard, supra note 11 at 21-22.

39 The South China Sea Arbitration (The Republic of the Philippines v The People's Republic of China), Award, (2016) PCA case 2013-19 at para 941.

40 Oran Young, Governing Complex Systems. Social Capital for the Anthropocene (Cambridge, MA: MIT Press, 2017) at 162.

41 Wolfrum, supra note 33 at para 6. According to Wolfrum, this forms the distinction between a principle and a rule.

42 M. Young, supra note 19 at 11.

43 ILC Fragmentation, supra note 20 at para 12, cited in M. Young, supra note 19 at 5. It is interesting to note that this broader definition of regimes is similar to the definition used in the international relations literature, see Krasner, infra note 45.

44 M. Young, supra note 19 at 5-11. 
given issue-area" ${ }^{45}$ Oran Young highlights the role of actors within such regimes and defines them as "social institutions that define practices, assign roles and guide the interaction of occupants of such roles within given issue areas". ${ }^{46}$ Focusing on actors' behaviours, regimes would not only be based on short-term calculated interests, but necessitate "some sense of general obligation" ${ }^{47}$ towards other actors, some sense of cooperation and reciprocity, and, as suggested by Nilsson et al, the optimisation of "collective outcomes". ${ }^{48}$ This links the understanding of regime to the liberal tradition of international relations.

Third, this study further follows Oran Young's focus on the functions of regimes, i.e. regimes are more than just regulatory arrangements. Regimes do have regulatory functions (the formulation of rules and how actors comply with them), but they also perform other functions, such as programmatic activities (States getting together for a concrete activity, e.g. cleaning up a transboundary river), generative roles (how the participation of certain actors in a regime contributes to the growth of knowledge), and the embodiment of common goals (i.e. the regime for environmental protection shows the will of actors to reach that protection goal). ${ }^{49}$ These functions once again bring forward the role that actors' behaviours play in shaping regimes.

Although linked to the concept of framework (see definition above), regime is normally understood in the current study as having a broader scope. Framework refers to, in the present study, the legal and/or regulatory framework for international fisheries, i.e. a set of instruments listing the rights and obligations held by different actors, and the institutions ensuring the respect of rights and fulfilment of obligations. The present study, however, sometimes uses the terms framework and regime interchangeably. Conversely, this study understands the scope of the term regime as being narrower than systems (see definition below), which generally put the emphasis on the relations and interconnectedness between their different components, and normally do not focus on one issue-area only. A system is also different in nature: a system might have a regulatory regime, but not the other way around.

Resilience. According to the seminal work of Holling, resilience refers to the ability of a system to tolerate change, to absorb changes and still persist. ${ }^{50}$

Review. The term review is used in the present study in two different ways. First, review refers to formal review processes and mechanisms which normally target the performance of structures or institutions, such as RFMOs performance review. Second, the term is also used in a more informal and overarching way, for example in cases where measures and instruments, or institutions' mandate and functioning, can be reviewed in light of new knowledge and science. The different uses of the concept are particularly discernible in chapters 6 and 7.

Structure. This study defines structure as a catch-all term loosely referring to 1) all institutions, bodies and organizations, 2) their formal and informal practices, and 3) the instruments regulating their mandate and competences, all of them contributing to shaping interactions and behaviours.

45 Stephen D. Krasner, "Structural causes and regime consequences: regimes as intervening variables" in Stephen D. Krasner (ed), International regimes (Ithaca, NY: Cornell University Press, 1983) 1-21 at 1-2.

46 Oran Young, International Governance: Protecting the Environment in a Stateless Society (Ithaca, NY: Cornell University Press, 1994) at 3, cited in Stokke, "The Interplay", supra note 7 at 2.

47 Krasner, supra note 45 at 3.

48 Mans Nilsson, Marc Pallemaerts \& Ingmar von Homeyer, "International regimes and environmental policy integration: introducing the special issue" (2009) 9:4 International environmental agreements 337369 at 341 .

49 Oran Young, "Sugaring Off: Enduring Insights from Four Decades of Theorizing About Environmental Governance" (Lecture delivered at the Bren School of Environmental Science \& Management of the University of California, Santa Barbara, 2011), online: <https://www.youtube.com/watch?v=I0VVlk47OvI $>$.

50 Crawford Stanley Holling, "Resilience and stability of ecological systems" (1973) 4 Annual Review of Ecological Systems 1-23 at 17. 
Sustainability. Following the general definition of the term, sustainability refers to the necessity to use resources at a level which allows for their renewal or which does not trigger their exhaustion; this use should avoid damage to the wider environment. In international environmental law, sustainability also includes the need to ensure the ability of future generations to meet their own needs. ${ }^{51}$ The understanding of sustainability used in this study also includes social and economic components; in fact, it also relies on Kotzés observation that the term "has been developed, inter alia, to embed or articulate the increased realization that environmental issues cannot be viewed in isolation from various other considerations, including, inter alia: adaptation, infrastructural development, migration, protection of human rights, social development, and socio-economic development". ${ }^{52}$ Sustainability is discussed in further detail in chapter 3.

Sustainable fisheries. According to Gjerde et al, " '[s] ustainable fisheries' are fisheries whose fishing practices can, in theory, be maintained indefinitely without reducing the targeted species' ability to maintain its population at levels which can be sustained over the longterm, and without causing unsustainable impacts on other species within the ecosystem". ${ }^{33}$

Sustainability performance. This study defines sustainability performance as the ability of an actor, instrument or structure to ensure the sustainability of the activities undertaken and/or to reach sustainable outcomes.

System. "[A] set of things [...] interconnected in such a way [they] produce their own pattern of behavior over time", ${ }^{54}$ or a combination of interdependent elements that are interconnected through meaningful relationships. ${ }^{55}$ This study understands the scope of systems as being broader than regimes (see definition above), which normally focus on one issue-area. A system is also different in nature: a system might have a regulatory regime, but not the other way around. A system finally puts the emphasis on the relations and interconnectedness between its different components.

Socio-ecological system. It is defined by the Stockholm Resilience Center as "linked systems of people and nature". ${ }^{56}$ While ecological systems (ecosystems) focus on the interaction between organisms, and between organisms and their environment (see definition above), social-economic systems represent the network of relationships between individuals, groups and institutions. Socio-ecological systems therefore represent the necessity to see humans as part of nature and that "the delineation between social and ecological systems is artificial and arbitrary" ${ }^{57}$ considering the fact that both systems influence one another.

51 See, e.g. Philippe Sands \& Jacqueline Peel, with Adriana Fabra \& Ruth MacKenzie, Principles of International Environmental Law, 4th ed (Cambridge: Cambridge University Press, 2018) at 217-218.

52 Louis Kotzé, "A Juridical-Conceptual Perspective on Environmental Governance" in Tuomas Kuokkanen et al (eds), International Environmental Law-Making and Diplomacy. Insights and Overview (Abingdon, Oxon: Routledge, 2016) 48-67 at 61.

53 Kristina Gjerde et al, "Ocean in Peril: Reforming the Management of Global Ocean Living Resources in Areas Beyond National Jurisdiction” (2013) 74:2 Marine Pollution Bulletin 540-551 at 541.

54 Donella Meadows, Thinking in systems. A primer (White River Junction, VT: Chelsea Green Publishing, 2008 ) at 2, cited in Kim \& Mackay, supra note 10 at 7.

55 Kim \& Mackay, supra note 10 at 10-11.

56 Stockholm Resilience Center, "Resilience dictionary", online: <https://www.stockholmresilience.org/ research/resilience-dictionary.html>.

57 Ibid. See also Carl Folke, "Resilience: the emergence of a perspective for social-ecological systems analyses" (2006) 16 Global Environmental Change 253-267 at 255. 



\section{SAMENVATTING}

\section{De ongrijpbare zoektocht naar duurzame visserij op volle zee Wat is de rol voor een oceaanbeheerbenadering?}

Decennia van reglementaire en institutionele ontwikkelingen ten spijt, is de regelgeving rondom het management van visserij op volle zee er niet in geslaagd het duurzaam gebruik van levende rijkdommen te waarborgen in gebieden die buiten de nationale jurisdictie vallen. Sterker nog, de visbestanden op volle zee worden doorlopend bedreigd door overbevissing. Er zijn inspanningen geleverd om illegale, ongereguleerde en ongemelde visserij en overbevissing te voorkomen, en om de manier te verbeteren waarop we de gevolgen van visserij voor het mariene milieu adresseren. Dit heeft geleid tot positieve ontwikkelingen wat betreft de integratie van biodiversiteit in visserijmanagement, maar deze maatregelen zijn meestal fragmentarisch en lukraak uitgevoerd, en stelselmatige ondernemingen om duurzaamheidsprestaties te verbeteren zijn - indien aanwezig - schaars. Bovendien hebben de aanzienlijke economische en (geo)politieke belangen die meespelen in het management van de visserij op volle zee pogingen geblokkeerd om mechanismen op te zetten voor de bescherming van het mariene milieu, en voorstellen om de regelgeving te herstructureren ten behoeve van een betere verbinding tussen natuurbehoud en duurzaam gebruik van de visbestanden op volle zee zijn op felle tegenstand gestuit. Het sterke momentum dat momenteel gericht is op het vergroten van kennis en bewustzijn van de oceanen, evenals een multisectorale en multidisciplinaire dialoog over de oceanen, heeft deze uitdagingen wel benoemd, maar dit moet nog worden omgezet in concrete en duurzame maatregelen die leiden tot concreet en duurzaam resultaat.

In het licht van de noodzaak tot verandering in een sector die sterk is verankerd in langlopende rechten en belangen, en in de 'heilige' vrijheid van visserij, benadert dit onderzoek de regulering van visserij op volle zee vanuit een ander perspectief, dat buiten het rechtsstelsel naar alternatieven zoekt. Dit onderzoek beoordeelt hoe internationale visserijwetgeving hervormd en aangepast zou kunnen worden middels het toenemende belang van (oceaan)beheer (governance) voor de ontwikkeling van duurzamer management voor oceanen en levende rijkdommen op volle zee. Het uiteindelijke doel van zon beoordeling is om besluitvormers aanvullende handvatten te geven om deze complexiteit het hoofd te bieden.

Om de tekortkomingen van de huidige regelgeving bij het bereiken van duurzaamheidsprestaties te begrijpen en tools te kunnen ontwikkelen waarmee deze tekortkomingen op gepaste wijze kunnen worden aangepakt, gaat het onderzoek eerst in op de huidige stand van zaken: er wordt gekeken naar het huidige wet- 
en regelgevingskader en recente ontwikkelingen, en de uitdagingen waarmee het stelsel momenteel kampt worden geïdentificeerd. Vervolgens wordt onderzocht hoe dit alles zou kunnen (moeten) zijn, middels mogelijke andere manieren om het gedrag van actoren richting de samenwerkingsverbanden en gecoördineerde ondernemingen te sturen die dit stelsel zo dringend nodig heeft.

\section{De onderlinge verbondenheid van visserijmanagement en bescherming van milieu en biodiversiteit in het huidige wettelijke kader voor de volle zee}

Het eerste doel van het onderzoek is een beter begrip verwerven van het huidige weten regelgevingskader voor management en behoud van levende rijkdommen op volle zee. We moeten niet alleen kijken naar de verschillende verplichtingen die dit kader bevat in het licht van de noodzakelijke verbondenheid van visserijactiviteiten en het mariene milieu, maar ook de verwevenheid met andere activiteiten die plaatsvinden in gebieden die buiten de nationale jurisdictie vallen.

De regelgeving bestaat uit een breed scala aan juridisch bindende en juridisch nietbindende instrumenten, die de verplichtingen en taken van actoren omschrijven bij het gebruik en de exploitatie van levende rijkdommen op zee, en bij hun acties ter bescherming van het mariene milieu. Ook mandateert de regelgeving verschillende actoren en entiteiten om de verscheidene relevante verplichtingen te implementeren en te handhaven. In feite kan worden gesteld dat de visserijwetgeving en het behoud van biodiversiteit gezamenlijk zijn geëvolueerd en dat het huidige kader de verplichtingen en verantwoordelijkheden van staten heeft verhelderd. Het kader biedt daarom een redelijk goede gereedschapskist van wettelijke instrumenten en normen.

Dat gezegd hebbende, vertoont het huidige wettelijke kader nog steeds twee belangrijke tekortkomingen bij het bevorderen van de verwevenheid van visserijmanagement en het behoud van biodiversiteit. Ten eerste: de verplichtingen inzake samenwerking en aandacht voor en bescherming van het mariene milieu, die aan de basis staan van het regelgevingsstelsel voor de volle zee, zouden kunnen fungeren als overbruggingsverplichtingen tussen duurzaam gebruik en instandhouding van de levende rijkdommen van de zee. Deze verplichtingen blijven echter vaag en missen inhoud over hoe ze kunnen worden geoperationaliseerd, en zijn dus slecht toegerust om het gedrag van actoren te beïnvloeden in gebieden die buiten de nationale jurisdictie vallen. Ten tweede, en nog belangrijker: het kader is samengesteld uit instrumenten afkomstig van, en actoren werkzaam in, verschillende stelsels, variërend van zeerecht en internationale visserijrecht tot milieu- en instandhoudingsrecht; ondanks hun co-evolutie, reguleren specifieke stelsels specifieke rijkdommen, en het huidige kader vertaalt niet volledig de complexiteit en verwevenheid die aanwezig is "in het veld". 


\section{De rol van rechtsbeginselen in de integratie van biodiversiteit en duurzaamheid binnen het internationale visserijrecht}

Rechtsbeginselen vormen een intrinsiek onderdeel van een juridisch stelsel en fungeren als tools ten behoeve van de samenhang en systematisering van verplichtingen, als leidraad bij de interpretatie en toepassing van bestaande regels en als parameters voor de ontwikkeling van de wet. Het is ook in het kader van deze functies dat hun effectiviteit binnen een rechtsstelsel kan worden beoordeeld.

Rechtsbeginselen in de visserijwetgeving op volle zee zijn hierin geen uitzondering. Een reeks rechtsbeginselen heeft de ontwikkeling van de internationale regelgeving voor de volle zee gevormd en heeft daarmee ook invloed gehad op de wetgeving rondom visserij op volle zee. Sommige van deze beginselen hebben ondertussen de status bereikt van wettelijke verplichtingen (volgens gewoonterecht of contractenrecht), terwijl andere dienst doen als beleidsdoelstellingen. Ondanks hun uiteenlopende juridische aard fungeren rechtsbeginselen als verbindende elementen, bieden ze de mogelijkheid om behoud en gebruik in het licht van elkaar te zien, en stellen ze ons in staat na te denken over exploitatie in het licht van conservatie.

Voorts vinden rechtsbeginselen relevantie in de manier waarop ze worden geoperationaliseerd. In het geval van de internationale regelgeving voor de visserij hebben beginselen een stempel gedrukt op de ontwikkeling van tools die behoud en gebruik binnen management samenbrengen. Ze zijn in het bijzonder van belang geweest bij het vormgeven van gebiedsgerichte handvatten en beoordelingstools in de visserij op volle zee. Rechtsbeginselen rondom het beheer van de volle zee systematiseren daarom de verwevenheid van visserijmanagement en bescherming van milieu en biodiversiteit, en dienen als herinneringen aan de doelstellingen die we willen bereiken.

\section{Het BBNJ-proces als katalysator voor onderlinge verbondenheid}

De onderhandelingen voor een nieuw internationaal juridisch bindend instrument voor het behoud en duurzaam gebruik van mariene biodiversiteit buiten de nationale jurisdictie (De Biodiversity beyond National Jurisdiction- of BBNJ-overeenkomst) vormen op dit moment de belangrijkste ontwikkeling op het gebied van zeerecht, en van multilaterale onderhandelingen in het algemeen. Deze onderhandelingen en de discussies daaromtrent, ook wel 'het BBNJ-proces' genoemd, krijgen tot op de dag van vandaag veel aandacht in de juridische literatuur en de wetenschapbeleidinterface. Dit ondersteunt de vervlechting van wetenschap en beleid, gezien het feit dat wetenschappelijke kennis fundamenteel is voor de ontwikkeling van upto-date beleid en regelgeving, en de wetenschap op haar beurt het platform van beleid en recht nodig heeft om adequaat te worden geïmplementeerd. 
De BBNJ-overeenkomst zal naar verwachting een belangrijke rol spelen bij het verbeteren van de samenwerking en coördinatie in gebieden die buiten de nationale jurisdictie vallen. De precieze samenwerkings- en coördinerende rol die de overeenkomst zal spelen bij het bevorderen van specifiek de verwevenheid van visserijmanagement en het behoud van biodiversiteit, wordt echter verdoezeld door het feit dat de mate waarin de overeenkomst en de visserijregeling interacteren onduidelijk blijft. Er is gewaarschuwd voor de gevaren van het uitsluiten van de visserij van de werkingssfeer van de overeenkomst, omdat een dergelijke uitsluiting het "eindproduct" van de overeenkomst en wat deze vertegenwoordigt zou kunnen beïnvloeden. Zo zou het nadrukkelijk uitsluiten van de visserij van de werkingssfeer van de overeenkomst bekende en terugkerende gebreken die worden geassocieerd met regionale organisaties rondom visserijmanagement kunnen consolideren en institutionaliseren.

Ondanks dit onheilspellende vooruitzicht voor de rol van de overeenkomst in het bevorderen van de verbinding tussen exploitatie en conservatie binnen de visserijregeling op volle zee, kunnen de visserijstructuren nog steeds worden beïnvloed door de rol die een Conferentie van de Partijen zou kunnen spelen bij het systematiseren van samenwerkings- en coördinatie-initiatieven, en door het clearing-house mechanism (een mechanisme voor de uitwisseling van informatie). De daadwerkelijke invloed van de overeenkomst op de visserijstructuren hangt echter af van de manier waarop coördinatie effectief kan worden geïntegreerd in de huidige structuren voor visserijmanagement. Dit hangt, op zijn beurt, af van drie elementen: politieke onderhandelingen tussen visserijmogendheden; de institutionele structuur van de overeenkomst; en het evenwicht tussen de rol van het BBNJ-proces als aanvulling op de gefragmenteerde regelgeving in gebieden die buiten de nationale jurisdictie vallen enerzijds, en de bescherming van de autonomie en het functioneren van bestaande instellingen en belangen door de noodzaak om bestaande structuren niet te ondermijnen anderzijds.

De rol van de BBNJ-overeenkomst als katalysator voor onderlinge verbondenheid, samenwerking en coördinatie in gebieden buiten de nationale jurisdictie wordt niet betwist, maar de mate waarin deze rol wordt geoperationaliseerd in de betrekkingen met de visserij zal afhangen van het mandaat dat wordt gegeven aan de verschillende organen die onder de institutionele structuur van de overeenkomst worden opgericht, en de reikwijdte van een dergelijk mandaat.

\section{Gedrag, naleving en gebrek aan coördinatie als grootste uitdagingen voor duurzaamheidsprestaties}

$\mathrm{Na}$ een uitgebreide beoordeling van de verschillende componenten van het huidige juridische kader voor de regulering en het management van visserij op volle zee, onderscheidt en analyseert het onderzoek verschillende uitdagingen die momenteel van invloed zijn op de nood aan samenwerking en coördinatie 
inzake het management van visserij op volle zee. Op basis van de drie door Stokke geïdentificeerde taken van het management van levende rijkdommen, worden de belangrijkste uitdagingen die duurzaamheidsprestaties voor de visserij op volle zee belemmeren ingedeeld naargelang ze verwijzen naar de gedeelde opvattingen over de te bereiken doelen (d.w.z. cognitieve taak), de vertaling van deze opvattingen naar (wettelijke) verplichtingen (d.w.z. regelgevende taak) of naar het naleven van actoren van de aangegane verplichtingen (d.w.z. gedragstaak).

Binnen de cognitieve taak wacht actoren de moeilijkheid om de verschillende belangen die samen de componenten van sociaalecologische systemen vormgeven te balanceren en combineren, en de verdere uitdaging om voldoende (goede) data te verzamelen en interpreteren, om aan de hand daarvan de wetenschap te begrijpen, doelen te stellen en beslissingen te nemen. Binnen de regelgevende taak vertoont het huidige wettelijke kader hiaten die moeten worden opgevuld. Dit is het geval voor bepaalde geografische gebieden of soorten die momenteel niet onder een regionale organisatie voor visserijmanagement vallen. De jurisdictie om maatregelen op volle zee te implementeren en te handhaven is bovendien beperkt tot bepaalde actoren, die vaak niet goed in staat zijn om op te treden; het uitbreiden van de jurisdictie naar andere actoren zou daarom kunnen helpen de hiaten op te vullen en te werken aan betere duurzaamheidsprestaties. Ten slotte bestaat er onzekerheid over het toepassingsgebied van instandhoudings- en managementmaatregelen, vanwege de mogelijkheid voor sommige staten om van deze maatregelen af te zien, een gebrek aan geharmoniseerde voorschriften voor de toepassing ervan, of een gebrek aan overkoepelend begrip van concepten die deel uitmaken van deze maatregelen.

Ondanks deze belangrijke tekortkomingen kan nog steeds worden geconcludeerd dat het huidige stelsel een bevredigend instrumentarium biedt wat betreft normen en instituties. Het is echter de derde taak, de gedragstaak, die het meest problematisch blijft voor het verbeteren van duurzaamheidsprestaties. Ten eerste ontbreekt het staten vaak aan de kennis en/of de middelen die nodig zijn om zinvolle en systematische maatregelen te nemen voor toezicht, controle en inspectie. Ook is er een gebrek aan transparantie wat betreft de manier waarop staten deze taken implementeren en uitvoeren. Om deze redenen nemen nietgouvernementele organisaties en/of bedrijven vaak bepaalde maatregelen om de hiaten te vullen, maar hun betrokkenheid roept veel vragen op over legaliteit en legitimiteit. Ten tweede blijven regionale organisaties voor visserijmanagement, hoewel ze aanzienlijke inspanning en vooruitgang hebben getoond op het gebied van duurzame werkpraktijken, geplaagd door structurele tekortkomingen die hun vermogen beïnvloeden om duurzame prestaties te garanderen, variërend van een gebrek aan transparantie, tot het niet opvolgen van wetenschappelijk advies, tot uiteenlopende werkpraktijken. Ten derde heeft gebrekkige deelname van staten aan belangrijke visserij-instrumenten invloed op de manier waarop de verplichtingen die in deze instrumenten zijn vastgelegd effectief kunnen worden geïmplementeerd. Tot slot hebben mechanismen voor geschillenbeslechting, vanwege onzekerheden die 
verband houden met uitzonderingen op de jurisdictie en overlappende jurisdictie, slechts een beperkte impact gehad op de ontwikkeling van visserijmanagement en samenwerking ter verbetering van duurzaamheidsprestaties.

De overkoepelende uitdaging voor de visserijregeling op volle zee zit hem echter in de fragmentatie van de structuren daarbinnen. Fragmentatie is nodig om expertise te verwerven, vooral bij een complex systeem zoals visserij op volle zee, maar het wordt een probleem wanneer dit het vermogen van actoren aantast om de verplichtingen waaraan ze gebonden zijn te navigeren, en om de benodigde maatregelen te nemen om aan dergelijke verplichtingen te voldoen. Hoewel het discours over de fragmentatie van normen behoorlijk breed wordt gevoerd, blijft fragmentatie op het gebied van implementatie en handhaving van die normen abstracter. Gelet op geïsoleerde voorbeelden van vooruitgang inzake naleving, en een gebrek aan volledigheid van de regelgeving, moeten oplossingen om fragmentatie tegen te gaan worden gevonden via meer systematische interacties en coördinatie. Met andere woorden: wat nodig is, is een weloverwogen, georkestreerd proces, wat een sterkere afhankelijkheid van coördinatie inhoudt.

Uit de beoordeling van de uitdagingen die de internationale regelgeving voor visserijmanagement hinderen, kan worden geconcludeerd dat dit stelsel in zijn huidige vorm onvoldoende in staat is om tekortkomingen in het sturen van actoren richting naleving, samenwerking en coördinatie adequaat en efficiënt aan te pakken.

\section{Het promoten van alternatieve componenten van (oceaan)beheer als hulpmiddelen voor naleving, gebruikmakend van het aanpassingsvermogen van de wet}

De wet speelt een cruciale rol als mechanisme om bepaald gedrag van actoren te stimuleren en, breder, als mechanisme voor maatschappelijke verandering. De wet is echter onderdeel van een grotere gereedschapskist voor maatschappelijke actie, die wordt gevormd door governance (beheer). Governance, dat een grote verscheidenheid aan componenten omvat, brengt andere middelen met zich mee voor maatschappelijke actie en andere functies om gedrag te sturen. Dit onderzoek verkent daarom de mogelijkheid om de naleving van het internationale visserijrecht te vergroten door gebruik te maken van mechanismen, concepten en processen die oorspronkelijk van buiten de formele juridische mechanismen komen. Dit berust op het idee dat de wet niet de enige sociale constructie is die bijdraagt aan governance; het gedrag van actoren kan ook worden beïnvloed middels een keur aan andere componenten.

Governance is ontstaan als reactie op de tekortkomingen die voortvloeien uit traditionele gezagsstructuren. Dit betekent niet dat de staat als bron van gezag wordt vervangen, maar dat we getuige zijn van de opkomst van complexe en gevarieerde bestuurssystemen. Governance stelt in feite vast dat sociaalpolitieke verandering, wil deze adequaat tegemoetkomen aan complexiteit, draait om: de noodzaak 
nieuwe vormen van regulering te ontwikkelen; de tussenkomst van een veelvoud van actoren; en het belang van samenwerkingen.

In de mariene context is het concept van oceaangovernance of oceaanbeheer in het bijzonder informatief geweest door de toepasbaarheid te tonen van de dynamiek en het brede perspectief dat governance biedt wat betreft de verbetering van oceaanmanagement. Oceaanbeheer, beschreven als een compilatie van instellingen, actoren, regels, wetenschap, beleid en wetgeving die een leidend kader vormen voor oceaanproblematiek en -activiteiten, is daarom geen kwestie-perkwestie of visgrond-per-visgrond-benadering van oceaanmanagement, maar een resultaatgerichte benadering gefocust op het teweegbrengen van veranderingen in oceaanmanagement ter verbetering van hun duurzaamheid.

Een goed begrip van oceaanbeheer kan leiden tot een meer op het milieu gerichte en geïntegreerde opvatting van visserijbeheer. Hoewel het een alomvattend concept is dat veel componenten van een bestuursbenadering omvat, blijft visserijbeheer voorlopig intrinsiek sectoraal. Daarom kan het kijken naar visserijbeheer op een manier die ook ruimte biedt voor het vervlechten van kwesties, helpen om de visbestanden te bezien als een onderdeel van het milieu, en de visserij als een van meerdere functies van de oceanen. Dit kan op zijn beurt de basis vormen van een nog meer adaptieve benadering van het operationaliseren van bestaande visserijgerelateerde verplichtingen en als bron voor mogelijke alternatieve mechanismen die het management van visserij op volle zee integreren met de bescherming van het mariene milieu.

Tegen deze achtergrond leunt dit onderzoek op de potentie van de invalshoek van (oceaan)beheer om het aanpassend vermogen van de wet te versterken, om zo veranderingen in de regelgeving te operationaliseren die uiteindelijk de veerkracht zullen verzekeren van het rechtsstelsel en, bijgevolg, van het sociaalecologische systeem dat dit stelsel overziet. Gebruikmakend van twee modellen (ontwikkeld door Arnold \& Gunderson, en door Soininen \& Platjouw) voor het beoordelen van het aanpassingsvermogen van de wet, verkent het onderzoek verschillende tools voor aanpasbaarheid. Deze tools, hoewel niet per se nieuw in het internationaal recht, onderstrepen het belang van regels met een open structuur; van veelheid in schaal, modi en actoren; en van herhaling en herziening. Polycentriciteit en netwerken in het bijzonder zijn twee bestuursgerelateerde componenten waarop adaptieve strategieën binnen het juridische discours moeten steunen, om specifiek tekortkomingen in naleving aan te pakken, en samenwerking en coördinatie te versterken. $\mathrm{Zij}$ representeren de bouwstenen van mogelijke alternatieve mechanismen om duurzaamheidsprestaties te verbeteren. Governance kan er daarom voor zorgen dat de wet flexibeler wordt, terwijl een meer adaptief rechtssysteem ervoor zorgt dat onze juridische verplichtingen worden omgezet in maatregelen die oceaanmanagement effectief zullen beïnvloeden. 
Deze dialoog tussen oceaanbeheer en adaptieve strategieën verbreedt ons denkkader. Het toenemende gebruik van het concept governance is niet slechts een kwestie van terminologie; het weerspiegelt de wens om de manier te veranderen waarop resources, activiteiten en gedragingen worden aangepakt en beheerd. Wat de dialoog tussen governance en aanpassingsvermogen in feite weerspiegelt, is dat we de meeste tools die nodig zijn al hebben, en wat (oceaan)beheer ons geeft is een invalshoek om te overwegen ze op een andere wijze toe te passen.

\section{Mechanismen voor een systematisch vertrouwen op samenwerking, coördinatie en onderlinge verbondenheid}

In juridische structuren en instrumenten die het management van de visserij op volle zee reguleren zijn verscheidene kenmerken van aanpassingsvermogen te vinden, evenals in de concepttekst van de BBNJ-overeenkomst. Deze kenmerken blijven, hoewel aanwezig, echter moeilijk te implementeren, en zijn tot dusver op een fragmentarische en lukrake manier ingevoerd.

Om de regelgeving te verbeteren op een manier die de uitdagingen aanpakt op gebied van gedrag en fragmentatie die kenmerkend zijn voor de visserij op volle zee, zijn twee mechanismen voorgesteld die voortbouwen op de dialoog tussen (oceaan)beheer en aanpassingsvermogen. Smart mixes en interplay management dragen bij aan de creatie van een regelgevingsontwerp dat zich richt op structuren voor besluitvorming en op handhaving via verschillende kanalen.

Smart mixes zijn een ontwerp bestaande uit complementaire beleidsinstrumenten. In een complexe context kan de potentiële combinatie van instrumenten de regelgevingsstructuur flexibeler en veerkrachtiger maken, aangezien het ene instrument kan fungeren als verzachtende factor voor de zwakke punten van het andere. Binnen de internationale regelgeving omvatten smart mixes een breed begrip van regelgevende instrumenten, dat verder gaat dan staatsrecht en bijvoorbeeld ook zelfregulering, economische instrumenten en prikkels, particuliere normen en/of andere vormen van controle voortvloeiend uit maatschappelijke organisaties of bedrijven bevat. Hoewel het gebruik van staatsgrensoverschrijdende instrumenten legitimiteitsvragen oproept, zou een resultaatgerichte benadering van legitimiteit de toevoeging ondersteunen van alternatieve regelgevende instrumenten om effectief duurzaamheidsprestaties te bereiken. Daarom gelooft dit onderzoek dat smart mixes een interessante potentie hebben om de samenhang tussen en complementariteit van instrumenten te verbeteren, een die geworteld is in aanpassingsvermogen en flexibiliteit.

Interplay management, van zijn kant, vertegenwoordigt de bewuste inspanningen van staten, en actoren meer in het algemeen, om de interactie tussen relevante structuren te verbeteren. Interplay management kan dus worden beschouwd als een hulpmiddel om interactie tussen stelsels aan te pakken en fragmentatie te beheersen, 
waarbij interactie bovendien niet alleen wordt waargenomen, maar bewust aangemoedigd. Interplay management kan plaatsvinden op verschillende niveaus en via verschillende schalen van coördinatie of integratie, variërend van een bijna gecentraliseerde coördinatie tot een autonome en onafhankelijke bewindvoering. Dit onderzoek stelt dat de regelgeving voor visserij op volle zee baat zou hebben bij een gezamenlijk interplay management, waarbij de ontwikkeling van mogelijke gemeenschappelijke regels voor interactie niet per se culmineert in een volledige samenvoeging of integratie van componenten maar waar het orkestreren van, en het bruggen bouwen en coördineren tussen, componenten bewust wordt nagestreefd. De uiteindelijke doelen zijn weloverwogen en systematische maatregelen ter bevordering van de coördinatie en samenwerking tussen organisaties, geworteld in de verplichting tot internationale samenwerking.

Om de bruikbaarheid van smart mixes en interplay management bij het behalen van duurzame resultaten in visserijmanagement te illustreren, bekijkt het onderzoek drie voorbeelden waarin de instandhoudings- en managementmaatregelen van regionale organisaties voor visserijmanagement zijn aangevuld met maatregelen die verband houden met de certificeringsnormen van de Marine Stewardship Council. Deze voorbeelden laten de positieve resultaten zien die voortkomen uit de complementariteit tussen verschillende soorten instrumenten die op verschillende schalen en door verschillende actoren worden geïmplementeerd en gehandhaafd, terwijl ook de samenwerking tussen staten, internationale organisaties en particuliere actoren wordt verbeterd, evenals de afstemming van hun belangen. Verder tonen ze aan dat het vertrouwen op normen de samenhang en harmonisatie van maatregelen van verschillende instellingen kan bevorderen. Smart mixes en interplay management hebben daarom de potentie om bij te dragen aan verbeterde resultaten, voortkomend uit open en dynamische opvattingen van regelgeving en management.

Concluderend reflecteert dit onderzoek op twee onderzoeksthema's. Ten eerste beoordeelt het de onderlinge verbondenheid van visserijmanagement en de bescherming van milieu en biodiversiteit binnen de huidige regels rondom regulering en management van de visserij op volle zee, alsook enkele tekortkomingen bij het bereiken van de doelstellingen die deze regels beogen te waarborgen. Ten tweede suggereert dit onderzoek een alternatief perspectief, dat steunt op de dialoog tussen oceaanbeheer en aanpassingsvermogen, om regulerings- en beleidsmaatregelen te ontwikkelen die een efficiëntere interactie van de verschillende regelgevingscomponenten mogelijk maken. Deze maatregelen zijn ook bedoeld om ervoor te zorgen dat het gedrag van de verschillende belanghebbenden effectief in lijn wordt gebracht met het bijdragen aan een duurzaam management van de visbestanden op volle zee.

Dit onderzoek is dus meer dan een zoveelste onderzoek naar visserijmanagement; het draagt bij aan de verbreding van het denkkader voor het aanpassen van een 
stelsel dat, ondanks een breed scala aan interessante tools, verankerd blijft in traditionele en slecht toepasbare mechanismen, en worstelt om te leveren wat ervan wordt verwacht. Dit onderzoek draagt bij aan het uitlichten van de verbindingen tussen maatschappelijke, politieke, economische en ecologische processen die het systeem vormen van de visserij op volle zee. Het draagt ook bij aan de ontwikkeling van complementaire inzichten en conceptualiseringen voor het reguleren en beheren van complexe sociaalecologische systemen, gezien door de lens van aanpassingsvermogen. 


\section{RÉSUMÉ}

\section{La recherche insaisissable d'une pêche durable en haute mer Quel rôle pour une approche de gouvernance des océans?}

Malgré des décennies de développements réglementaires et institutionnels, le régime juridique pour la gestion des pêcheries en haute mer n'a pas été en mesure de garantir l'utilisation durable des ressources biologiques dans les zones situées au-delà de la juridiction nationale. En effet, les stocks de poissons en haute mer sont confrontés à des problèmes de surexploitation perpétuels. Des efforts pour empêcher la surpêche et la pêche illégale, non déclarée et non réglementée, et pour améliorer la manière dont nous traitons les impacts des activités de pêche sur le milieu marin ont été faits et ont conduit à des développements positifs en termes d'intégration de la biodiversité dans la gestion des pêcheries. Pourtant, les actions ont pour la plupart été menées au cas par cas et au hasard, et les engagements systématiques visant à améliorer les résultats en matière de durabilité - le cas échéant - sont rares. En outre, les intérêts économiques et (géo) politiques qui guident la gestion des pêcheries en haute mer ont bloqué les tentatives de mise en place de mécanismes de protection du milieu marin, et les suggestions pour la restructuration du régime dans le but de permettre un meilleur lien entre la conservation et l'utilisation durable des ressources halieutiques en haute mer se sont heurtées à une opposition véhémente. La dynamique qui vise actuellement le renforcement des connaissances et la sensibilisation aux océans, ainsi que le dialogue multisectoriel et multidisciplinaire pour les océans ont contribué à relever ces défis, mais cela doit se traduire par des actions concrètes et soutenues qui débouchent sur des résultats concrets et durables.

Face à la nécessité de changement dans un secteur profondément influencé par des droits et intérêts séculaires dont la « sacro-sainte » liberté de pêche en haute mer, cette étude aborde la régulation des pêcheries en haute mer sous un angle différent, un angle qui cherche des alternatives au-delà du droit. Létude évalue comment le droit international de la pêche pourrait être remodelé et adapté grâce à la présence croissante du concept de la gouvernance des océans pour parvenir à une gestion plus durable des océans et des ressources biologiques en haute mer. Lobjectif ultime d'une telle évaluation est de doter les décideurs d'outils supplémentaires pour faire face à la complexité qui caractérise le régime de la gestion des pêcheries dans les zones situées au-delà de la juridiction nationale.

Afin de comprendre les lacunes du régime actuel dans l'atteinte de résultats positifs en matière de durabilité et de développer des outils qui pourraient remédier de manière appropriée à ces lacunes, l'étude se penche d'abord sur la compréhension de la situation : elle examine le cadre juridique et réglementaire actuel ainsi que les 
développements récents, et identifie les défis auxquels le régime est actuellement confronté. Ensuite, à travers des alternatives pour orienter les comportements des acteurs, létude explore comment les choses pourraient (devraient) être pour concrétiser l'amélioration de la collaboration et de la coordination dont le régime a un urgent besoin.

\section{L'interdépendance entre la gestion des pêches et la protection de l'environnement et de la biodiversité dans le cadre juridique actuel de la haute mer}

Le premier objectif de létude est de mieux comprendre le cadre juridique et réglementaire actuel pour la gestion et la conservation des ressources biologiques en haute mer. Nous devons non seulement examiner les différentes obligations qu'il contient à la lumière de l'interdépendance nécessaire entre les activités de pêche et le milieu marin, mais également l'interdépendance avec d'autres activités menées dans des zones situées au-delà de la juridiction nationale.

Le régime juridique est composé d'un large éventail d'instruments, juridiquement contraignants et non juridiquement contraignants, qui définissent les obligations et les devoirs des acteurs dans leur utilisation et exploitation des ressources marines biologiques, ainsi que dans leurs actions pour la protection du milieu marin. Le régime juridique mandate également différents acteurs et entités pour mettre en œuvre et faire respecter les diverses obligations pertinentes. On peut conclure que le droit de la pêche et la conservation de la biodiversité ont co-évolué, et que le cadre juridique a clarifié les obligations et les responsabilités des États. Le cadre actuel offre donc une large gamme d'outils.

Néanmoins, ce cadre juridique présente deux lacunes dans la promotion de l'interdépendance entre la gestion des pêches et la conservation de la biodiversité. Premièrement, les obligations de coopération, de respect et de protection du milieu marin, au cœur du régime de réglementation de la haute mer, pourraient servir de pont entre l'utilisation durable et la conservation des ressources marines biologiques. Pourtant, ces obligations demeurent vagues et manquent de précision sur la manière dont elles peuvent être mises en œuvre, et sont donc mal adaptées pour guider les comportements des acteurs dans les zones situées au-delà de la juridiction nationale. Deuxièmement, et principalement, le cadre juridique est composé d'instruments provenant de différents régimes, allant du droit de la mer, au droit international de la pêche, et au droit de lenvironnement et de la conservation, de même que d'acteurs opérant dans ces différents régimes. Toutefois malgré leur co-évolution, ces régimes spécifiques régulent des ressources spécifiques, et le cadre juridique ne traduit pas pleinement la complexité et l'interdépendance présentes «sur le terrain». 
Le rôle des principes pour l'intégration de la biodiversité et de la durabilité dans le droit international de la pêche

Les principes font partie intégrante d'un régime juridique et agissent comme des dispositifs de cohérence et de systématisation des obligations, dorientation pour l'interprétation et l'application des règles existantes, et comme paramètres pour le développement du droit. C'est également à la lumière de ces rôles que leur efficacité au sein d'un régime juridique peut être appréciée.

Les principes relatifs au droit de la pêche en haute mer ne font pas exception. Une série de principes ont façonné le développement du régime juridique international pour la haute mer et ont, à leur tour, influencé le droit de la pêche en haute mer. Certains de ces principes ont maintenant atteint le statut dobligations juridiques (coutumières ou conventionnelles), tandis que d'autres agissent comme des objectifs politiques. Malgré leur nature juridique variable, les principes agissent comme des éléments unificateurs au sein du régime, et nous permettent d'envisager lexploitation à la lumière de la conservation.

Les principes trouvent également leur pertinence dans la manière dont ils sont opérationnalisés. Dans le cas du régime juridique international des pêches, des principes ont guidé lélaboration doutils de gestion des pêcheries qui associent conservation et utilisation. Ils ont joué un rôle particulièrement important dans lélaboration d'outils de gestion par zone et d'outils d'évaluation environnementale pour les pêcheries en haute mer. Les principes régissant la haute mer systématisent doncl'interdépendance entre la gestion des pêches et la protection de lenvironnement et de la biodiversité, et servent de rappel des objectifs que nous voulons atteindre.

\section{Le processus BBNJ comme catalyseur d'interconnexion}

Les négociations pour un nouvel instrument international juridiquement contraignant sur la conservation et l'utilisation durable de la biodiversité marine dans les zones situées au-delà de la juridiction nationale (Accord BBNJ) constituent actuellement le développement le plus significatif en droit de la mer, et dans les négociations multilatérales plus généralement. Ces négociations et les discussions qui les entourent, i.e. le "processus BBNJ », ont suscité et continuent de susciter beaucoup d'intérêt dans la littérature juridique, ainsi que dans l'interface sciences naturelles/sciences politiques. Cela soutient l'interdépendance entre la science et la politique, par le fait que la connaissance scientifique est fondamentale pour le développement de politiques et de réglementations pertinentes, tandis que la science a besoin de la plateforme politique et juridique pour être mise en œuvre de manière adéquate.

L'Accord BBNJ devrait jouer un rôle important dans l’amélioration de la coopération et de la coordination dans les zones situées au-delà de la juridiction nationale. 
Toutefois, le rôle précis de coopération et de coordination que l'Accord jouera pour favoriser l'interdépendance entre la gestion des pêches et la conservation de la biodiversité est obscurci par le fait que la portée de l'interaction entre l'Accord et le régime des pêcheries reste incertaine. Des mises en garde contre les dangers d'exclure les pêcheries du champ d'application de l'Accord ont été formulées, car une telle exclusion pourrait influencer le " produit final " de l'Accord et ce qu'il représente. Par exemple, exclure expressément les pêcheries du champ d'application de l'Accord pourrait en fait consolider et institutionnaliser les faiblesses reconnues et récurrentes associées aux organisations régionales de gestion des pêches.

Malgré cette perspective inquiétante en regard du rôle limité de l'Accord dans la promotion de l'interdépendance entre l'utilisation et la conservation au sein du régime des pêches en haute mer, il est possible que les structures de gestion des pêches soient influencées par le rôle qu'une Conférence des Parties pourrait jouer dans la systématisation des initiatives de coopération et de coordination. Cependant, l'influence de l'Accord sur les pêcheries dépend de la manière dont la coordination peut être intégrée efficacement dans les structures actuelles de gestion des pêches. Ceci repose sur trois éléments : la négociation politique entre les États qui sont de grandes puissances en matière de pêches; la structure institutionnelle de l'Accord; et léquilibre entre, d'un côté, le rôle du processus $\mathrm{BBNJ}$ pour compléter le régime fragmenté dans les zones au-delà de la juridiction nationale, et, de lautre côté, la protection de lautonomie et du fonctionnement des institutions et des intérêts existants.

Le rôle de l'Accord BBNJ en tant que catalyseur d'interconnexion, de coopération et de coordination dans les zones situées au-delà de la juridiction nationale nest pas contesté, mais la mesure dans laquelle ce rôle est opérationnalisé en lien avec la gestion des pêches dépendra du mandat donné aux différents organes créés dans le cadre de l'architecture institutionnelle de l'Accord et de la portée de ce mandat.

\section{Comportements, conformité et manque de coordination comme principaux défis pour l'atteinte de résultats positifs en matière de durabilité}

Après avoir approfondi lévaluation des différentes composantes du cadre juridique actuel pour la réglementation et la gestion des pêches en haute mer, létude identifie et analyse plusieurs défis qui ont actuellement un impact sur le besoin de coopération et de coordination pour la gestion des pêcheries en haute mer. S'appuyant sur les trois tâches de gestion des ressources identifiées par Stokke, les principaux défis entravant la durabilité des pêcheries en haute mer sont classés selon qu'ils se réfèrent à la compréhension partagée des objectifs à atteindre (i.e. tâche cognitive), la traduction de cette compréhension en engagements légaux (i.e. tâche réglementaire), ou la conformité des comportements des acteurs avec les engagements pris (i.e. tâche comportementale). 
Dans le cadre de la tâche cognitive, les acteurs font face à la difficulté déquilibrer et de réconcilier les multiples intérêts qui façonnent les différentes composantes des systèmes socio-écologiques. Ils font aussi face à des difficultés de collecte et d'analyse de données fiables pour comprendre la science, fixer des objectifs et appuyer les décisions. Dans le cadre de la tâche réglementaire, le cadre juridique actuel présente des lacunes qui doivent être comblées. C’est le cas de certaines zones géographiques ou d'espèces qui ne sont actuellement couvertes par aucune organisation régionale de gestion des pêches. La compétence pour mettre en ouvre et appliquer des mesures en haute mer est également limitée à certains acteurs, qui nont souvent pas la capacité d'agir; l'extension de la juridiction à d'autres acteurs pourrait donc aider à combler les lacunes et à ouvrer à lamélioration des performances en matière de durabilité. Enfin, il existe une incertitude liée au champ d'application des mesures de conservation et de gestion, en raison de la possibilité pour certains États de se retirer de ces mesures, d'un manque d'harmonisation pour leur application ou d'un manque de compréhension globale des concepts faisant partie de ces mesures.

Malgré ces lacunes, il est encore possible de conclure que le régime actuel présente une gamme satisfaisante doutils en termes de normes et d'institutions. Cependant, c'est la tâche comportementale, qui reste la plus problématique pour améliorer les performances en matière de durabilité. Premièrement, les États manquent souvent de connaissances et / ou de ressources pour entreprendre des actions significatives et systématiques de suivi, de contrôle et de surveillance. Il y a également un manque de transparence concernant la pratique des États et leurs performances de mise en œuvre. C'est pourquoi les organisations non gouvernementales et / ou les entreprises privées entreprennent souvent certaines actions pour combler les lacunes, mais leur implication soulève souvent des questions de légalité et de légitimité. Deuxièmement, les organisations régionales de gestion des pêches, bien quayant fait des progrès en termes de pratiques durables, continue à afficher des carences structurelles qui affectent leur capacité à garantir des performances durables, allant du manque de transparence au non-respect des avis scientifiques, en passant par des disparités dans leurs pratiques. Troisièmement, le manque de participation des États aux principaux instruments juridiques relatifs à la pêche influe sur la manière dont les obligations énoncées dans ces instruments peuvent être effectivement mises en œuvre. Enfin, les mécanismes de règlement des différends, en raison des incertitudes liées aux exceptions et au chevauchement des compétences, ont jusquà présent eu un impact limité sur le développement de la gestion des pêches et de la coopération en vue d'améliorer les performances en matière de durabilité.

Le défi majeur auquel est confronté le régime des pêches en haute mer réside cependant dans la fragmentation de ses structures. La fragmentation est nécessaire pour acquérir une expertise, en particulier face à un système complexe tel que la pêche en haute mer; mais cela devient un problème lorsque la fragmentation affecte la capacité des acteurs à naviguer à travers les obligations qui les lient et à entreprendre les actions nécessaires pour remplir ces obligations de manière 
adéquate. Si le discours sur la fragmentation des normes est assez complet, la notion de fragmentation en termes de mise en œuvre et d'application de ces normes reste plus abstraite. Face à un régime incomplet et à des exemples isolés de progrès en matière de conformité, des solutions pour gérer la fragmentation doivent être trouvées grâce à des interactions et une coordination plus systématiques. En d'autres termes, ce qu'il faut, c'est un processus délibératif et orchestré, qui s’appuie solidement sur la coordination.

En évaluant les défis qui entravent le régime juridique international de gestion des pêches, nous pouvons conclure que le régime, dans son état actuel, est insuffisant pour remédier de manière adéquate et efficace aux lacunes relatives à l'incitation des acteurs au respect, à la coopération et à la coordination.

\section{Promouvoir des composantes alternatives de la gouvernance des océans comme outils de conformité grâce à la capacité d’adaptation du droit}

Le droit joue un rôle essentiel en tant que vecteur de changement des comportements des acteurs et, plus largement, de laction sociale. Cependant la gouvernance, qui englobe une grande variété de composantes, suggère d'autres moyens d'action sociale et d'autres outils de modification du comportement. L'étude explore donc la possibilité de renforcer le respect du droit international des pêches en s'appuyant sur des mécanismes, des concepts et des processus qui proviennent d'instruments extérieurs au droit. Elle repose sur l'idée que le droit n'est pas le seul concept social contribuant à la gouvernance; les comportements des acteurs peuvent également être influencés par d’autres éléments.

La gouvernance est apparue comme une réponse aux lacunes des structures traditionnelles d'autorité. Cela ne veut pas dire que l'État est remplacé en tant que source d'autorité, mais que nous assistons à l'émergence de systèmes de gouvernement complexes et variés. La gouvernance, en effet, observe que le changement sociopolitique, pour s'adapter adéquatement à la complexité, tourne autour de la nécessité de nouvelles formes de règlementation, de l'intervention d'une multiplicité d'acteurs et de l'importance des collaborations.

Dans le contexte marin, le concept de gouvernance des océans a été particulièrement instructif en démontrant le caractère pratique du dynamisme et de la vaste perspective qu'offre la gouvernance pour l'amélioration de la gestion des océans. La gouvernance des océans, décrite comme une compilation d'institutions, d'acteurs, de règles, de science, de politique et de droit qui constituent un cadre directeur pour les problèmes et les activités océaniques, nest donc pas une approche "problème par problème » ou "zone par zone » des océans, mais une approche basée sur les résultats, une approche qui vise à déclencher des changements dans la gestion des océans vers une durabilité améliorée. 
Une compréhension de la gouvernance des océans peut renseigner quant à une conception de la gouvernance des pêches plus intégrée et davantage axée sur lenvironnement. En fait, bien quétant un concept englobant, la gouvernance des pêches reste pour l'instant intrinsèquement sectorielle. Par conséquent, examiner la gouvernance des pêches d'une manière qui tient également compte de l'interdépendance des problèmes peut aider à positionner les stocks de poissons comme une composante de l'environnement et la pêche comme l'une des multiples utilisations des océans. Cela peut, à son tour, être à la base d'une approche encore plus adaptative de lopérationnalisation des obligations existantes en matière de pêche, et souligner les mécanismes alternatifs potentiels qui intègrent la gestion des pêches en haute mer à la protection de l'environnement marin.

Dans ce contexte, létude s'appuie sur le potentiel de la perspective de la gouvernance (des océans) pour renforcer la capacité d'adaptation du droit afin dopérationnaliser les changements réglementaires qui, à terme, assureront la résilience du régime juridique et, par conséquent, du système qu'il chapeaute. À travers la compréhension de deux modèles (développés par Arnold \& Gunderson et par Soininen \& Platjouw) pour évaluer la capacité d’adaptation du droit, létude explore des outils d'adaptabilité. En particulier, la polycentricité et les réseaux sont deux composantes liées à la gouvernance sur lesquelles les stratégies adaptatives du discours juridique devraient s'appuyer pour cibler spécifiquement les lacunes en termes de conformité et renforcer la coopération et la coordination. Ils représentent des éléments constitutifs de mécanismes alternatifs potentiels pour améliorer les performances en matière de durabilité. La gouvernance peut donc aider le droit à être plus adaptatif, ce qui garantira que les engagements juridiques se traduisent en actions qui influenceront efficacement la gestion des océans.

Ce dialogue entre la gouvernance des océans et les stratégies adaptatives élargit notre cadre de réflexion. L'utilisation croissante du concept de gouvernance nest pas simplement une question de terminologie; il traduit une volonté d'adapter la manière dont les ressources, les activités et les comportements sont abordés et gérés. En fait, ce que reflète le dialogue gouvernance-adaptabilité, c'est que nous avons la plupart des outils dont nous avons besoin, et ce que la gouvernance (des océans) nous donne, c'est une perspective pour envisager de les utiliser différemment.

\section{Mécanismes pour un recours systématique à la coopération, à la coordination et à l'interdépendance}

Plusieurs caractéristiques d’adaptabilité se retrouvent dans les structures et instruments juridiques régissant la gestion des pêcheries en haute mer, ainsi que dans le projet de texte de l'Accord BBNJ. Cependant, bien que présentes, ces caractéristiques d'adaptabilité restent difficiles à mettre en œuvre, et elles ont, jusquà présent, été mises en œuvre de manière fragmentaire et aléatoire. 
Pour améliorer le cadre réglementaire de manière à cibler les défis comportementaux et de fragmentation caractérisant le régime des pêches en haute mer, deux mécanismes qui sappuient sur le dialogue entre la gouvernance (des océans) et l'adaptabilité sont suggérés. Les smart mixes et la gestion des interactions (interplay management) contribuent à créer une conception réglementaire qui se concentre sur les structures de prise de décision et sur l'application selon différentes stratégies.

Les smart mixes reposent sur la complémentarité de certains instruments et politiques. Dans un contexte où la complexité prévaut, la combinaison potentielle entre les instruments peut permettre plus de flexibilité et de résilience pour la structure de réglementation, car un instrument peut agir comme atténuateur de la (des) faiblesse (s) d'un autre. Dans le contexte international, les smart mixes englobent une large compréhension de ce que constitue un instrument juridique ou réglementaire, allant au-delà du droit étatique, et comprenant l'autorégulation, les instruments et incitatifs économiques, les normes privées et / ou d'autres formes de contrôle émanant de la société civile ou des entreprises privées. Bien que des questions de légitimité se posent lors de l'utilisation d'instruments non étatiques, une approche de la légitimité axée sur les résultats appuierait l'inclusion d'autres instruments réglementaires afin d’obtenir des résultats positifs en matière de durabilité. C'est pourquoi cette étude estime que les smart mixes ont un potentiel intéressant pour améliorer la cohérence et la complémentarité entre les instruments, un potentiel qui est enraciné dans l'adaptabilité et la flexibilité.

La gestion des interactions, pour sa part, représente les efforts délibérés des États et autres acteurs pour améliorer l'interaction entre les structures concernées. La gestion des interactions peut donc être considérée comme un outil pour aborder l'interaction des régimes et gérer la fragmentation, mais l'interaction est ici délibérément encouragée et pas seulement observée. La gestion des interactions peut se produire à différents niveaux et à travers différentes échelles de coordination ou d'intégration, allant d'une coordination presque centralisée à une gestion autonome et indépendante. Cette étude soutient que le régime des pêcheries en haute mer bénéficierait d'une gestion conjointe des interactions, où lélaboration déventuelles règles communes d'interaction néquivaut pas nécessairement à une fusion ou une intégration complète des composantes, mais où l'orchestration et la coordination entre les composantes sont délibérément recherchées. Les objectifs ultimes sont des actions délibérées et systématiques en faveur de la coordination et de la coopération interorganisationnelles, qui seraient ancrées dans l'obligation internationale de coopération.

Pour illustrer l'utilisation des smart mixes et de la gestion des interactions, létude examine trois exemples où les mesures de conservation et de gestion des organisations régionales de gestion des pêches ont été complétées par des mesures liées aux exigences des normes de certification du Marine Stewardship Council. Ces exemples ont dévoilé des résultats positifs découlant de la complémentarité entre 
différents types d'instruments mis en œuvre et appliqués à différentes échelles et par différents acteurs, tout en renforçant la coopération entre les États, les organisations internationales et les acteurs privés, et l’alignement de leurs intérêts. Ils ont en outre démontré que le recours aux normes de certification peut favoriser la cohérence et l'harmonisation des actions entre les institutions. Les smart mixes et la gestion des interactions ont donc le potentiel de contribuer à l'amélioration des résultats qui découlent d'une compréhension ouverte et dynamique de la réglementation et de la gestion.

En conclusion, l'étude se penche sur deux thèmes de recherche. Premièrement, elle évalue l'interdépendance entre la gestion des pêches et la protection de l'environnement et de la biodiversité dans le cadre du régime actuel de réglementation et de gestion des pêches en haute mer, ainsi que certaines lacunes dans la réalisation des objectifs que ce régime est censé sauvegarder. Deuxièmement, il suggère une perspective alternative, qui repose sur le dialogue entre la gouvernance des océans et l'adaptabilité, pour développer des réponses réglementaires et politiques qui permettent aux différentes composantes du régime d'interagir plus efficacement les unes avec les autres. Ces réponses visent également à garantir que le comportement des différentes parties prenantes est effectivement aligné sur la contribution à une meilleure gestion durable des stocks en haute mer.

Cette étude est donc plus qu'une simple analyse de la gestion des pêches; elle contribue à élargir le cadre de réflexion pour adapter un régime qui, malgré un large éventail d'outils intéressants, reste ancré dans des mécanismes traditionnels et mal équipés, et peine à livrer ce quoon attend de lui. Cette étude contribue à mettre en lumière les liens entre les processus sociaux, politiques, économiques et écologiques qui forment le système de la pêche en haute mer. Il contribue également à développer des idées et des conceptualisations complémentaires pour réguler et gérer des systèmes socio-écologiques complexes à travers le prisme de l'adaptabilité. 



\section{LIST OF PRIMARY LEGAL SOURCES}

\section{International legally binding instruments}

Abidjan Convention for Cooperation in the Protection, Management and Development of Marine and Coastal Environment of the Atlantic Coast of the West, Central and Southern Africa Region (23 March 1981, entered into force 5 August 1984).

Agreement between the Government of Iceland, the Government of Norway and the Government of the Russian Federation concerning certain aspects of cooperation in the area of fisheries (15 May 1999) (1999) 41 Law of the Sea Bulletin 53.

Agreement between the Government of the Kingdom of Norway and the Government of the Union of Soviet Socialist Republics on Co-operation in the Fishing Industry (11 April 1975) 983 UNTS 7.

Agreement concerning Cooperation in the Management of Fisheries of Common Interest (11 February 1982, entered into force 2 December 1982).

Agreement for the Establishment of the General Fisheries Commission for the Mediterranean (24 September 1949, entered into force 20 February 1952) 2275 UNTS 157.

Agreement for the Establishment of the Indian Ocean Tuna Commission

(25 November 1993, entered into force 27 March 1996) 1925 UNTS 329.

Agreement for the Implementation of the Provisions of the United Nations Convention on the Law of the Sea of 10 December 1982 relating to the Conservation and Management of Straddling Fish Stocks and Highly Migratory Fish Stocks (4 August 1995, entered into force 11 December 2001) 2167 UNTS 3.

Agreement on Port State Measures to prevent, deter and eliminate illegal, unreported and unregulated fishing (22 November 2009, entered into force 5 June 2016) UNTS No 541333.

Agreement on Subsidies and Countervailing Measures, (1994) OJ, L326/156.

Agreement on the conservation of cetaceans of the Black Sea, Mediterranean Sea and contiguous Atlantic area (24 November 1996, entered into force 1 June 2001) 2183 UNTS 303.

Agreement on the Conservation of Small Cetaceans of the Baltic, North East Atlantic, Irish and North Seas (17 March 1992, entered into force 29 March 1994) 1772 UNTS 217.

Agreement relating to the implementation of Part XI of the United Nations Convention on the Law of the Sea of 10 December 1982 (28 July1994, entered into force 28 July 1996) 1836 UNTS 3.

Agreement to prevent unregulated high seas fisheries in the Central Arctic Ocean, (2019) OJ, L 73/3.

Agreement to Promote Compliance with International Conservation and Management Measures by Fishing Vessels on the High Seas (24 November 1993, entered into force 24 April 2003) 2221 UNTS 91.

Annex IV to the Protocol on Environmental Protection to the Antarctic Treaty, Marine Pollution (4 October 1991, 14 entered into force January 1998) 2941 UNTS 3.

Convention for the Conservation of Anadromous Stocks in the North Pacific Ocean (11 February 1992, entered into force 16 February 1993) (1993) 22 Law of the Sea Bulletin 21.

Convention for the Conservation of Salmon in the North Atlantic Ocean (2 March 1982, entered into force 1 October 1983) 1338 UNTS 33. 
Convention for the Conservation of Southern Bluefin Tuna (10 May 1993, entered into force 20 May 1994) 1819 UNTS 360.

Convention for the Establishment of an Inter-American Tropical Tuna Commission (31 May 1949, entered into force 3 March 1950) 80 UNTS 3.

Convention for the prohibition of fishing with long driftnets in the South Pacific (24 November 1989, entered into force 17 May 1991) 1899 UNTS 3.

Convention for the Protection of the Marine Environment and Coastal Area of the South-East Pacific (12 November 1981, entered into force 19 May 1986) 1648 UNTS 3.

Convention for the Protection of the Marine Environment of the North-East Atlantic (22 September 1992, entered into force 25 March 1998) 2354 UNTS 67.

Convention for the protection of the Mediterranean Sea against pollution (16 February 1976, entered into force 12 February 1978) 1102 UNTS 27, renamed Convention for the Protection of the Marine Environment and the Coastal Region of the Mediterranean (10 June 1995, entered into force on 9 July 2004).

Convention for the Protection of the Natural Resources and Environment of the South Pacific Region (24 November 1986, entered into force 22 August 1990) (1987) 26:1 International Legal Materials 38.

Convention for the Strengthening of the Inter-American Tropical Tuna Commission Established by the 1949 Convention Between the United States of America and the Republic of Costa Rica (14 November 2003, entered into force 27 August 2010), (2006) OJ, L 224/24.

Convention for the Suppression of Unlawful Acts against the Safety of Maritime Navigation (adopted 10 March 1988, entered into force 1 March 1992) 1678 UNTS 201.

Convention on Access to Information, Public Participation in Decision-Making and Access to Justice in Environmental Matters, 25 June 1998, 2161 UNTS 447.

Convention on Biological Diversity (5 June 1992, entered into force 29 December 1993) 1760 UNTS 79 .

Convention on Cooperation in the Northwest Atlantic Fisheries, originally Convention on Future Multilateral Cooperation in the Northwest Atlantic Fisheries (24 October 1978, entered into force 1 January 1979) 1135 UNTS 369.

Convention on Environmental Impact Assessment in a Transboundary Context (25 February 1991, entered into force 10 September 1997) 1989 UNTS 309.

Convention on Fishing and Conservation of the Living Resources of the High Seas (29 April 1958, entered into force 20 March 1966) 559 UNTS 285.

Convention on Future Multilateral Cooperation in the North-East Atlantic Fisheries (18 November 1980, entered into force 17 March 1982) 1285 UNTS 129.

Convention on international trade in endangered species of wild fauna and flora (3 March 1973, entered into force 1 July 1975) 993 UNTS 243.

Convention on the Conservation and Management of Fishery Resources in the South East Atlantic Ocean (10 April 2001, entered into force 13 April 2003) 2221 UNTS 189.

Convention on the Conservation and Management of Highly Migratory Fish Stocks in the Western and Central Pacific Ocean (5 September 2000, entered into force 19 June 2004) 2275 UNTS 43.

Convention on the Conservation and Management of High Seas Fisheries Resources in the North Pacific Ocean (24 February 2012, entered into force 19 July 2015). 
Convention on the Conservation and Management of High Seas Fishery Resources in the South Pacific Ocean (14 November 2009, entered into force 24 August 2012) 2899 UNTS 211.

Convention on the Conservation and Management of Pollock Resources in the Central Bering Sea (16 June 1994, entered into force 8 December 1995) (1995) 34:1 International Legal Materials 67-77.

Convention on the Conservation of Antarctic Marine Living Resources (20 May 1980, entered into force 7 April 1982) 1329 UNTS 47.

Convention on the conservation of migratory species of wild animals (23 June 1979, entered into force 1 November 1983) 1651 UNTS 333.

Framework Agreement for the Conservation of the Living Marine Resources of the High Seas of the South Pacific (14 August 2000).

General Agreement on Tariffs and Trade (30 October 1947, entered into force 1 January 1948) 55 UNTS 187.

International Convention for the Conservation of Atlantic Tunas (14 May 1966, entered into force 21 March 1969) 673 UNTS 63.

International Convention for the control and management of ship's ballast water and sediments (13 February 2004, entered into force 8 September 2017) UNTS No. 55544.

International Convention for the Regulation of Whaling (2 December 1946, entered into force 10 November 1948) 161 UNTS 72.

Nairobi Convention for the Protection, Management and Development of the Marine and Coastal Environment of the Western Indian Ocean (21 June 1985, entered into force 30 May 1996).

Nauru Agreement Concerning Cooperation in the Management of Fisheries of Common Interest (11 February 1982), online: <http://www.pnatuna.com/sites/default/files/Nauru\%20 Agreement_0.pdf>.

Protocol concerning Specially Protected Areas and Biological Diversity in the Mediterranean (10 June 1995, entered into force 12 December 1999), (1999) OJ, L 322/3.

Protocol No. I to the Convention for the prohibition of fishing with long driftnets in the South Pacific (20 October 1990, entered into force 28 February 1992) 1899 UNTS 37.

Protocol No. II to the Convention for the prohibition of fishing with long driftnets in the South Pacific (20 October 1990, entered into force 5 October 1993) 1899 UNTS 47.

Southern Indian Ocean Fisheries Agreement (7 July 2006, entered into force 21 June 2012) 2835 UNTS 409.

Statute of the International Court of Justice (26 June 1945, entered into force 24 October 1945) 3 Bevans 1179.

United Nations Convention on the Law of the Sea (10 December 1982, entered into force 16 November 1994), 1833 UNTS 3.

United Nations Framework Convention on Climate Change (9 May 1992, entered into force 21 March 1994) 1771 UNTS 107.

Vienna Convention on the Law of Treaties (23 May 1969, entered into force 27 January 1980) 1155 UNTS 331. 


\section{United Nations instruments, documents, resolutions, reports and decisions}

\section{General Assembly}

Articles on Responsibility of States for Internationally Wrongful Acts, in annex to Responsibility of States for internationally wrongful acts, GA Res 62(LXI), UNGAOR, 62nd Sess, UN Doc A/RES/62/61 (2008).

Charter of Economic Rights and Duties of States, GA Res 29(MMMCCLXXXI), UNGAOR, 29th Sess, UN Doc A/RES/29/3281 (1974).

Declaration on Principles of International Law concerning Friendly Relations and Co-operation among States in accordance with the Charter of the United Nations, GA Res 2625(XXV), UNGAOR, 25th Sess, UN Doc A/RES/2625 (1970).

Development of an international legally binding instrument under UNCLOS on the conservation and sustainable use of marine biological diversity of areas beyond national jurisdiction, GA Res 69(CCXCII), UNGAOR, 69th Sess, UN Doc A/RES/69/292 (2015).

Draft decision submitted by the President of the General Assembly. Intergovernmental conference on an international legally binding instrument under the United Nations Convention on the Law of the Sea on the conservation and sustainable use of marine biological diversity of areas beyond national jurisdiction, GA Res 74(DXLIII), UNGAOR, 74th Sess, UN Doc A/74/L.41 (2020).

Institutional arrangement to follow up the United Nations Conference on Environment and Development, GA Res 47(XXCI), UNGAOR, 47th Sess, UN DocA/RES/47/191 (1992).

International legally binding instrument under the United Nations Convention on the Law of the Sea on the conservation and sustainable use of marine biological diversity of areas beyond national jurisdiction, GA Res 72(CCXLIX), UNGAOR, 72nd Sess, UN Doc A/RES/72/249 (2017).

Large-scale pelagic drift-net fishing and its impact on the living marine resources of the world's oceans and seas, GA Res 46(CCXV), UNGAOR, 46th Sess, UN Doc A/RES/46/215 (1991).

Large-scale pelagic drift-net fishing, unauthorized fishing in zones of national jurisdiction and on the high seas/illegal, unreported and unregulated fishing, fisheries by-catch and discards, and other developments, GA Res 57(CXLII), UNGAOR, 57th Sess, UN Doc A/RES/57/142 (2002).

Letter dated 15 May 2008 from the Co-Chairpersons of the Ad Hoc Open-ended Informal Working Group to study issues relating to the conservation and sustainable use of marine biological diversity beyond areas of national jurisdiction addressed to the President of the General Assembly, UNGAOR, 63rd Sess, UN Doc A/63/79 (2008).

Letter dated 16 March 2010 from the Co-Chairpersons of the Ad Hoc Open-ended Informal Working Group to the President of the General Assembly, UNGAOR, 65th Sess, UN Doc A/65/68 (2010).

Letter dated 30 June 2011 from the Co-Chairs of the Ad Hoc Open-ended Informal Working Group to the President of the General Assembly, UNGAOR, 66th Sess, UN Doc A/66/119 (2011).

Letter dated 8 June 2012 from the Co-Chairs of the Ad Hoc Open-ended Informal Working Group to the President of the General Assembly, UNGAOR, 67th Sess, UN Doc A/67/95 (2012).

Letter dated 23 September 2013 from the Co-Chairs of the Ad Hoc Open-ended Informal Working Group to the President of the General Assembly, UNGAOR, 68th Sess, UN Doc A/68/399 (2013).

Letter dated 5 May 2014 from the Co-Chairs of the Ad Hoc Open-ended Informal Working Group to the President of the General Assembly, UNGAOR, 69th Sess, UN Doc A/69/82 (2014).

Letter dated 25 July 2014 from the Co-Chairs of the Ad Hoc Open-ended Informal Working Group to the President of the General Assembly, UNGAOR, 69th Sess, UN Doc A/69/177 (2014). 
Letter dated 13 February 2015 from the Co-Chairs of the Ad Hoc Open-ended Informal Working Group to the President of the General Assembly, UNGAOR, 69th Sess, UN Doc A/69/780 (2015).

Oceans and the law of the sea, GA Res 55(VII), UNGAOR, 55th Sess, UN Doc A/RES/55/7 (2000).

Oceans and the law of the sea, GA Res 56(XII), UNGAOR, 56th Sess, UN Doc A/RES/56/12 (2001).

Oceans and the law of the sea, GA Res 57(CXLI), UNGAOR, 57th Sess, UN Doc A/RES/57/141 (2003).

Oceans and the law of the sea, GA Res 59(XXIV), UNGAOR, 59th Sess, UN Doc A/RES/59/24 (2004).

Oceans and the law of the sea, GA Res 60(XXX), UNGAOR, 60th Sess, UN Doc A/RES/60/30 (2005).

Oceans and the Law of the Sea, GA Res 61(CCXXII), UNGAOR, 61st Sess, UN Doc A/RES/61/222 (2006).

Oceans and the Law of the Sea; GA Res 64(LXXI), UNGAOR, 64th Sess, UN Doc A/RES/64/71 (2009).

Oceans and the law of the sea, GA Res 74(XIX), UNGAOR, 74th Sess, UN Doc A/RES/74/19 (2019).

Report of the Ad Hoc Open-ended Informal Working Group to study issues relating to the conservation and sustainable use of marine biological diversity beyond areas of national jurisdiction, UNGAOR, 61st Sess, UN Doc A/61/65 (2006).

Report of the resumed Review Conference on the Agreement for the Implementation of the Provisions of the United Nations Convention on the Law of the Sea of 10 December 1982 relating to the Conservation and Management of Straddling Fish Stocks and Highly Migratory Fish Stocks, UNGAOR, UN Doc A/CONF.210/2010/7 (2010).

Report of the resumed Review Conference on the Agreement for the Implementation of the Provisions of the United Nations Convention on the Law of the Sea of 10 December 1982 relating to the Conservation and Management of Straddling Fish Stocks and Highly Migratory Fish Stocks, UNGAOR, UN Doc A/CONF.210/2016/5 (2016).

Report of the Secretary-General to the General Assembly, Renewing the United Nations: A Programme for Reform, UNGAOR, 51st Sess, UN Doc A/51/950 (1997).

Report of the World Commission on Environment and Development: Our Common Future, UNGAOR, 42nd Sess, UN Doc A/42/427 (1987).

Report on the work of the United Nations Open-ended Informal Consultative Process on Oceans and the Law of the Sea at its fifth meeting, UNGAOR, 59th Sess, UN Doc A/59/122 (2004).

Results of the review by the Commission on Sustainable Development of the sectoral theme of "Oceans and seas": international coordination and cooperation, GA Res 54(XXXIII), UNGAOR, 54th Sess, UN Doc A/RES/54/33 (1999).

Summary of the first global integrated marine assessment, UNGAOR, 70th Sess, UN Doc A/70/112 (2015).

Sustainable fisheries, including through the 1995 Agreement for the Implementation of the Provisions of the United Nations Convention on the Law of the Sea of 10 December 1982 relating to the Conservation and Management of Straddling Fish Stocks and Highly Migratory Fish Stocks, and related instruments, GA Res 59(XXV), UNGAOR, 59th Sess, UN Doc A/RES/59/25 (2004).

Sustainable fisheries, including through the 1995 Agreement for the Implementation of the Provisions of the United Nations Convention on the Law of the Sea of 10 December 1982 relating to the Conservation and Management of Straddling Fish Stocks and Highly Migratory Fish Stocks, and related instruments, GA Res 61(CV), UNGAOR, 61th Sess, UN Doc A/RES/61/105 (2006). 
Sustainable fisheries, including through the 1995 Agreement for the Implementation of the Provisions of the United Nations Convention on the Law of the Sea of 10 December 1982 relating to the Conservation and Management of Straddling Fish Stocks and Highly Migratory Fish Stocks, and related instruments, GA Res 64(LXXII), UNGAOR, 64th Sess, UN Doc A/RES/64/72 (2009).

Sustainable fisheries, including through the 1995 Agreement for the Implementation of the Provisions of the United Nations Convention on the Law of the Sea of 10 December 1982 relating to the Conservation and Management of Straddling Fish Stocks and Highly Migratory Fish Stocks, and related instruments, GA Res 66(LXVI), UNGAOR, 66th Sess, UN Doc A/RES/66/68 (2011).

Sustainable fisheries, including through the 1995 Agreement for the Implementation of the Provisions of the United Nations Convention on the Law of the Sea of 10 December 1982 relating to the Conservation and Management of Straddling Fish Stocks and Highly Migratory Fish Stocks, and related instruments, GA Res 72(LXXII), UNGAOR, 72nd Sess, UN Doc A/RES/72/72 (2017).

Sustainable fisheries, including through the 1995 Agreement for the Implementation of the Provisions of the United Nations Convention on the Law of the Sea of 10 December 1982 relating to the Conservation and Management of Straddling Fish Stocks and Highly Migratory Fish Stocks, and related instruments, GA Res 73(CXXV), UNGAOR, 73rd Sess, UN Doc A/RES/73/125 (2018).

Sustainable fisheries, including through the 1995 Agreement for the Implementation of the Provisions of the United Nations Convention on the Law of the Sea of 10 December 1982 relating to the Conservation and Management of Straddling Fish Stocks and Highly Migratory Fish Stocks, and related instruments, GA Res 74(XVIII), UNGAOR, 74th Sess, UN Doc A/RES/74/18 (2019).

The Future We Want, GA Res 66(CCLXXXVIII), UNGAOR, 66th Sess, UN Doc A/RES/66/288 (2012).

Towards a Global Pact for the Environment, GA Res 72(CCLXXVII), UNGAOR, 72nd Sess, UN Doc A/RES/72/277 (2018).

Transforming our world: the 2030 Agenda for Sustainable Development, GA Res 70 (I), UNGAOR, 70th Sess, UN Doc A/RES/70/1 (2015).

United Nations Millennium Declaration, GA Res 52(II), UNGAOR, 52nd Sess, UN Doc A/ RES/52/2 (2000).

World Charter for Nature, GA Res 37(VII), UNGAOR, 37th Sess, UN Doc A/RES/37/7 (1982).

\section{Biodiversity Beyond National Jurisdiction (BBNJ) process}

Chair's non-paper on elements of a draft text of an international legally-binding instrument under the United Nations Convention on the Law of the Sea on the conservation and sustainable use of marine biological diversity of areas beyond national jurisdiction (28 February 2017), online: $<$ https://www.un.org/depts/los/biodiversity/prepcom_files/Chair_non_paper.pdf>.

Chair's overview of the first session of the Preparatory Committee (April 2016), online: <https:// www.un.org/Depts/los/biodiversity/prepcom_files/PrepCom_1_Chair's_Overview.pdf>.

Chair's overview of the second session of the Preparatory Committee (September 2016), online: $<$ https://www.un.org/Depts/los/biodiversity/prepcom_files/Prep_Com_II_Chair_overview_to_ MS.pdf $>$.

Chair's overview of the third session of the Preparatory Committee (April 2017), online: <https:// www.un.org/Depts/los/biodiversity/prepcom_files/Chair_Overview.pdf $>$.

Chair's streamlined non-paper on elements of a draft text of an international legally-binding instrument under the United Nations Convention on the Law of the Sea on the conservation and sustainable use of marine biological diversity of areas beyond national jurisdiction (June 2017), 
online: <https://www.un.org/Depts/los/biodiversity/prepcom_files/Chairs_streamlined_nonpaper_to_delegations.pdf $>$.

Draft text of an agreement under the United Nations Convention on the Law of the Sea on the conservation and sustainable use of marine biological diversity of areas beyond national jurisdiction, Intergovernmental Conference on an international legally binding instrument under the United Nations Convention on the Law of the Sea on the conservation and sustainable use of marine biological diversity of areas beyond national jurisdiction, 3rd Sess, UN Doc A/CONF.232/2019/6 (2019).

President's aid to discussions, Intergovernmental conference on an international legally binding instrument under the United Nations Convention on the Law of the Sea on the conservation and sustainable use of marine biological diversity of areas beyond national jurisdiction, 1st Sess, UN Doc A/CONF.232/2018/3 (2018).

President's aid to negotiations, Intergovernmental Conference on an international legally binding instrument under the United Nations Convention on the Law of the Sea on the conservation and sustainable use of marine biological diversity of areas beyond national jurisdiction, 2nd Sess,

UN Doc A/CONF.232/2019/1 (2019).

Provisional programme of work, Preparatory Committee established by General Assembly resolution 69/292: Development of an international legally binding instrument under the United Nations Convention on the Law of the Sea on the conservation and sustainable use of marine biological diversity of areas beyond national jurisdiction, 4 th Sess,

UN Doc A/AC.287/2017/PC.4/L.2 (2017).

Report of the Preparatory Committee established by General Assembly resolution 69/292:

Development of an international legally binding instrument under the United Nations Convention on the Law of the Sea on the conservation and sustainable use of marine biological diversity of areas beyond national jurisdiction, Preparatory Committee established by General Assembly resolution 69/292: Development of an international legally binding instrument under the United Nations Convention on the Law of the Sea on the conservation and sustainable use of marine biological diversity of areas beyond national jurisdiction, 4th Sess,

UN Doc A/AC.287/2017/PC.4/2 (2017).

Revised draft text of an agreement under the United Nations Convention on the Law of the Sea on the conservation and sustainable use of marine biological diversity of areas beyond national jurisdiction, Intergovernmental conference on an international legally binding instrument under the United Nations Convention on the Law of the Sea on the conservation and sustainable use of marine biological diversity of areas beyond national jurisdiction, 4th Sess,

UN Doc A/CONF.232/2020/3 (2019).

Textual proposals submitted by delegations by 20 February 2020, for consideration at the fourth session of the Intergovernmental conference on an international legally binding instrument under the United Nations Convention on the Law of the Sea on the conservation and sustainable use of marine biological diversity of areas beyond national jurisdiction (the Conference), in response to the invitation by the President of the Conference in her Note of 18 November 2019 (A/ CONF.232/2020/3) (15 April 2020), online: <https://www.un.org/bbnj/sites/www.un.org.bbnj/ files/textual_proposals_compilation_article-by-article_-_15_april_2020.pdf >.

\section{Food and Agriculture Organization (FAO)}

CITES Issues with Respect to International Fish Trade and the CITES/FAO MOU, COFI SubCommittee on Fish Trade, 10th Sess, Doc COFI:FT/X/2006/3 (2006).

Code of Conduct for Responsible Fisheries, FAO, 28th Sess, FAO Doc 95/20/Rev/1 (1995). 
International Guidelines for the Management of Deep-sea Fisheries in the High Seas (2009), online: <http://www.fao.org/3/i0816t/i0816t00.htm>.

International Guidelines on By-catch Management and Reduction of Discards (2011), online: $<$ http://www.fao.org/3/a-ba0022t.pdf $>$.

International Plan of Action for Reducing Incidental Catch of Seabirds in Longline Fisheries, FAO Committee on Fisheries, 23rd Sess (1999), online: <http://www.fao.org/tempref/docrep/fao/006/ x3170e/X3170E00.pdf>.

International Plan of Action for the conservation and management of sharks and International Plan of Action for the management of fishing capacity, FAO Committee on Fisheries, 23rd Sess (1999), online: <http://www.fao.org/tempref/docrep/fao/006/x3170e/X3170E00.pdf >.

International Plan of Action for the Management of fishing capacity, FAO Committee on Fisheries, 23rd Sess (1999), online: <http://www.fao.org/tempref/docrep/fao/006/x3170e/X3170E00.pdf>.

International Plan of Action to Prevent, Deter and Eliminate Illegal, Unreported and Unregulated Fishing, FAO Committee on Fisheries, 24th Sess (2001), online: <http://www.fao.org/3/a-y1224e. pdf $>$.

Ocean Governance and the Outcomes of Rio+20, FAO Committee on Fisheries, 30th Sess, Doc COFI/2012/6/Rev. 1 (2012).

Progress in the Implementation of the Code of Conduct for Responsible Fisheries and Related Instruments, FAO Committee on Fisheries, 33rd Sess, Doc COFI/2018/3 (2018).

Voluntary Guidelines for Flag State Performance (2015), online: <http://www.fao.org/3/a-i4577t.pdf>.

\section{International Law Commission (ILC)}

Fragmentation of International Law: Difficulties Arising From the Diversification and Expansion of International Law, International Law Commission, 58th Sess, UN Doc A/CN.4/L.682 (2006).

Subsequent agreements and subsequent practice in relation to the interpretation of treaties. Text of the draft conclusions adopted by the Drafting Committee on second reading, International Law Commission, 70th Sess, UN Doc A/CN.4/L.907 (2018).

\section{International Maritime Organization (IMO)}

Revised Guidelines For The Identification And Designation Of Particularly Sensitive Sea Areas, IMO Resolution A.982(24) (2005).

\section{United Nations Economic and Social Council (ECOSOC)}

Report of the 24th Session of the Commission on Crime Prevention and Criminal Justice, ECOSOCOR, 24th Sess, Un Doc E/CN.15/2015/19 (2015).

\section{United Nations Environment Programme (UNEP)}

Oceans Compact. Healthy Oceans for Prosperity, UNEP, 14th Global Meeting of the Regional Seas Convention and Action Plans, UNEP (DEPI)/RS.14/WP.9.RS (2012), online: <https://wedocs. unep.org/bitstream/handle/20.500.11822/12476/RS.14_WP.9.RS.pdf? sequence=1\&isAllowed=>. 
Documents, resolutions, reports and decisions of Conferences of the Parties (COPs) and other similar treaty bodies

\section{Convention on Access to Information, Public Participation in Decision-making and Access to Justice in Environmental Matters (Aarhus Convention) \\ Promoting the Application of the Principles of the Aarhus Convention in International Forums (the Almaty Guidelines), Meeting of the Parties Aarhus Convention Dec II/4, 2nd Sess, ECE/MP.PP/2005/2/Add.5 (2005).}

\section{Convention on Biological Diversity (CBD)}

Akwé: Kon Voluntary guidelines for the conduct of cultural, environmental and social impact assessments regarding developments proposed to take place on, or which are likely to impact on, sacred sites and on lands and waters traditionally occupied or used by indigenous and local communities, which can be found in an annex to Article $8(j)$ and related provisions,

CBD COP Dec VII/16, COP 7, UNEP/CBD/COP/7/16 (2004).

Conservation and Sustainable Use of Marine and Coastal Biological Diversity,

CBD COP decision II/10, COP 2, UNEP/CBD/COP/DEC/II/10 (1995).

Conservation and sustainable use of marine and coastal biological diversity, including a programme of work, CBD COP decision IV/5, COP 4, UNEP/CBD/COP/DEC/IV/5 (1998).

Ecosystem Approach, CBD COP decision V/6, COP 5, UNEP/CBD/COP/DEC/V/6 (2000).

Marine and coastal biodiversity, CBD COP 9 decision IX/20, COP 9 ,

$\mathrm{UNEP} / \mathrm{CBD} / \mathrm{COP} / \mathrm{DEC} / \mathrm{IX} / 20$ (2008).

Marine and coastal biodiversity, CBD COP decision X/29, COP 10 ,

$\mathrm{UNEP} / \mathrm{CBD} / \mathrm{COP} / \mathrm{DEC} / \mathrm{X} / 29$ (2010).

Marine and coastal biodiversity: ecologically or biologically significant marine areas,

CBD COP decision XI/17, COP 11, UNEP/CBD/COP/DEC/XI/17 (2012).

Marine and coastal biodiversity: ecologically or biologically significant marine areas (EBSAS),

CBD COP decision XII/22, COP 12, UNEP/CBD/COP/DEC/XII/22 (2014).

Marine and coastal biodiversity: ecologically or biologically significant marine areas,

CBD COP decision XIII/12, COP 12, UNEP/CBD/COP/DEC/XIII/12 (2016).

Protected Areas and Other Effective Area-Based Conservation Measures,

CBD COP Decision, COP 14, UNEP/CBD/COP/DEC/14/8 (2018).

The Strategic Plan for Biodiversity 2011-2020 and the Aichi Biodiversity Targets,

CBD COP decision X/2, COP 10, UNEP/CBD/COP/DEC/X/2 (2010).

Voluntary Guidelines on Biodiversity-Inclusive Environmental Impact Assessment Contents, Annex to Impact assessment: Voluntary guidelines on biodiversity-inclusive impact assessment,

CBD COP decision VIII/28, COP 8, UNEP/CBD/COP/8/28 (2006).

Zero Draft of the Post-2020 Global Biodiversity Framework, Open-Ended Working Group on the Post-2020 Global Biodiversity Framework, 2nd Meeting, CBD/WG2020/2/3 (2020).

\section{Convention on the Conservation of Migratory Species and Wild Animals (CMS)}

By-Catch, CMS COP Res 12.22, COP 12 (2017).

Memorandum of understanding on the conservation of migratory sharks (2018), online: $<$ https://www.cms.int/sharks/sites/default/files/basic_page_documents/Sharks_MOU_Text_ annexes_2018_e.pdf>. 


\section{Convention on International Trade in Endangered Species of Wild Fauna and Flora (CITES)}

Cooperation between CITES and the Commission for the Conservation of Antarctic Marine Living Resources regarding trade in toothfish, CITES COP Resolution 12.4 (Rev. COP18),

COP 12 (2002).

Definition of 'primarily commercial purposes', CITES COP Resolution 5.10 (Rev. COP 15), COP 5 (1985).

Guidelines for Cooperation Between the International Commission for the Conservation of Atlantic Tunas (ICCAT) and the Conference of the Parties to the Convention on International Trade in Endangered Species of Wild Fauna and Flora (CITES), Annex to CITES Standing Committee Document 14.6, SC 62 (2012).

Proposal to include Atlantic Bluefin Tuna (Thunnus thynnus (Linnaeus, 1758)) on Appendix I of CITES in accordance with Article II 1 of the Convention, CITES COP 15 Prop.19 (2010).

\section{Documents of the World Trade Organization (WTO)}

Fisheries Subsidies. Working Documents on: Definitions; Scope; Prohibited Subsidies Relating to IUU Fishing, Overfished Stocks, Overcapacity, Capacity-Enhancing Subsidies, and Overfishing; Notifications and Transparency; Special and Differential Treatment; Transitional Provisions; and Institutional Arrangements, WTO Negotiation Group on Rule, Doc TN/RL/W/274/Rev. 5 (2018).

\section{Conservation and management measures, resolutions and recommendations of Regional Fisheries Management Organizations (RFMOs)}

\section{Commission for the Conservation of Antarctic Marine Living Resources (CCAMLR)}

Best available science, CCAMLR Resolution 31/XXVIII (2009).

Exploratory fisheries, CCAMLR CMM 21-02 (2017).

Notification that Members are Considering Initiating a New Fishery, CCAMLR CMM 21-01 (2010).

Restrictions on the use of bottom trawling gear in high-seas areas of the Convention Area, CCAMLR CMM 22-05 (2008).

Ross Sea region marine protected area, CCAMLR CMM 91-05 (2016).

\section{Commission for the Conservation of Southern Bluefin Tuna (CCSBT)}

Resolution on a CCSBT Record of Vessels Authorised to Fish for Southern Bluefin Tuna, CCSBT Res, 26th Sess (2019).

\section{North-East Atlantic Fisheries Commission (NEAFC)}

Recommendation on the protection of vulnerable marine ecosystems in the NEAFC Regulatory Area as Amended by Recommendation 09:2015, NEAFC Recommendation 19-2014 (2014).

\section{North Pacific Fisheries Commission (NPFC)}

Report $5^{\text {th }}$ Commission Meeting, NPFC, 5th Meeting, NPFC-2019-COM05-Final Report (2019) at annex $\mathrm{E}$ and $\mathrm{F}$ for the statements of Russia and the EU respectively, online: <NPFC-2019-COM05-Final Report>. 


\section{South-East Atlantic Fisheries Organization (SEAFO)}

Bottom Fishing Activities and Vulnerable Marine Ecosystems in the SEAFO Convention Area, SEAFO Conservation Measure 30/15 (2016).

\section{South Pacific Regional Fisheries Management Organization (SPRFMO)}

Conservation and Management Measure for Gillnets in the SPRFMO Convention Area, SPRFMO CMM 08-2013 (2013).

\section{Western and Central Pacific Fisheries Commission (WCPFC)}

Memorandum of Understanding between the Western and Central Pacific Fisheries Commission and the Secretariat of the Pacific Regional Environment Programme, online: <https://www.wcpfc. int/doc/wcpfc-sprep-memorandum-understanding $>$.

Vessel Monitoring System, WCPFC CMM 2007-02 (2007).

\section{Documents, resolutions and recommendations of Regional Seas Programmes (RSPs)}

\section{OSPAR}

Collective arrangement between competent international organisations on cooperation and coordination regarding selected areas in areas beyond national jurisdiction in the North-East Atlantic, OSPAR Agreement 2014-09, online: <https://www.ospar.org/documents?v=33030>.

Network of Marine Protected Areas, OSPAR Recommendation 2003/3 (2003).

\section{International conferences}

United Nations Conference on Environment and Development (Rio de Janeiro, Brazil, 3-14 June 1992).

United Nations Conference on Sustainable Development (Rio de Janeiro, Brazil, 20-22 June 2012).

United Nations Ocean Conference (New York, USA, 5-9 June 2017), online: <https:// oceanconference.un.org/about>.

World Summit on Sustainable Development (Johannesburg, South Africa, 26 August - 4 September 2002)

\section{Other international soft law instruments}

Agenda 21 of the United Nations Conference on Environment and Development, UNCED Report A/CONF.151/26/Rev. 1 (1993).

Draft Global Pact for the Environment, online <https://globalpactenvironment.org/uploads/EN.pdf>.

Hamilton Declaration on Collaboration for the Conservation of the Sargasso Sea (11 March 2014), online: <http://www.sargassoseacommission.org/storage/Hamilton_Declaration_with_ signatures_April_2018.pdf $>$.

Plan of Implementation of the World Summit on Sustainable Development (2002) at para 30, online: <https://www.un.org/esa/sustdev/documents/WSSD_POI_PD/English/WSSD_ PlanImpl.pdf $>$.

Tarawa Declaration on Driftnet Fishing (10 July 1989, entry into force 6 March 2008) PITSE 17.

"United Nations Conference on Environment and Development: Rio Declaration on

Environment and Development" (1992) 31:4 International Legal Materials 874-880. 
"United Nations Conference on the Human Environment: Final Documents" (1972) 11:6 International Legal Materials 1416-1469

\section{Documents of the European Union}

Combating illegal fishing at the global level European Parliament resolution of 17 November 2011 on combating illegal fishing at the global level - the role of the EU (2010/2210(INI)), (2011) OJ, C 153E/148.

Council Regulation (EC) No 850/98 of 30 March 1998 for the conservation of fishery resources through technical measures for the protection of juveniles of marine organisms, (1998) OJ, L 125/1.

Council Regulation (EC) No 1967/2006 of 21 December 2006 concerning management measures for the sustainable exploitation of fishery resources in the Mediterranean Sea, amending Regulation (EEC) No 2847/93 and repealing Regulation (EC) No 1626/94, (2006) OJ, L 409/11.

Council Regulation (EC) No. 1005/2008 of 29 September 2008 establishing a Community system to prevent, deter and eliminate illegal, unreported and unregulated fishing, (2008) OJ, L 286/1.

Council Regulation (EC) No 1005/2008 establishing a Community system to prevent, deter and eliminate illegal, unreported and unregulated fishing, amending Regulations (EEC) No 2847/93, (EC) No 1936/2001 and (EC) No 601/2004 and repealing Regulations (EC) No 1093/94 and (EC) No 1447/1999, (2008) OJ, L 286/1.

Directive 2008/56/EC of the European Parliament and of the Council of 17 June 2008 establishing a framework for community action in the field of marine environmental policy, (2008) OJ, L 164/19.

Directive 2014/89/EU of the European Parliament and of the Council of 23 July 2014 establishing a framework for maritime spatial planning, (2014) OJ, L 257/135.

"Draft EU position on the outcome of the third meeting of the BBNJ Working group, Written comments by the Netherlands" (2010).

Regulation (EU) No 1380/2013 of the European Parliament and of the Council of 11 December 2013 on the Common Fisheries Policy, amending Council Regulations (EC) No 1954/2003 and (EC) No 1224/2009 and repealing Council Regulations (EC) No 2371/2002 and (EC) No 639/2004 and Council Decision 2004/585/EC (Common Fisheries Policy), (2003) OJ, L 354/222.

"Rolling position paper of the EU and its Member States" (9 March 2017).

\section{National laws}

Constitución de la República del Ecuador (2008), online:

$<$ https://www.ministeriodegobierno.gob.ec/wp-content/uploads/2015/04/constitucion-de-larepublica-del-ecuador1.pdf $>$.

Constitución Política de la República de Colombia (1991), online:

$<$ https://www.funcionpublica.gov.co/eva/gestornormativo/norma_pdf.php?i=4125>.

Ley No. 18.302 de Seguridad Nuclear (16 April 1984) (Chile).

Ley no 18.892 general de pesca y acuicultura (1989) (Chile).

Ley No. 19.300 Sobre Bases Generales Del Medio Ambiente (1 March 1994) (Chile).

Te Awa Tupua (Whanganui River Claims Settlement) Act (2017) (New Zealand).

The Constitution of the Republic of the Philippines (1987), online:

$<$ https://www.officialgazette.gov.ph/constitutions/1987-constitution/>. 


\section{LIST OF CASES}

\section{International Court of Justice}

Corfu Channel Case (United Kingdom v Albania), Merits, (1949) ICJ Rep 4.

Fisheries Jurisdiction Case (UK v Iceland), Separate Opinion of Judge de Castro, (1974) ICJ Rep 72.

Legality of the Threat or Use of Nuclear Weapons, Advisory Opinion, (1996) ICJ Rep 226.

Gabčíkovo-Nagymaros Project (Hungary v Slovakia), Judgment, (1997) ICJ Rep 7.

Gabčíkovo-Nagymaros Project (Hungary v Slovakia), Separate Opinion of Vice-President Weeramantry, (1997) ICJ Rep 7.

Fisheries Jurisdiction (Spain v Canada), Jurisdiction of the Court, (1998) ICJ Rep 432.

Pulp Mills on the River Uruguay (Argentina v Uruguay), Merits, (2010) ICJ Rep 14.

Whaling in the Antarctic (Australia v Japan: New Zealand intervening), Merits, (2014) ICJ Rep 226.

Certain Activities Carried Out by Nicaragua in the Border Area (Costa Rica v Nicaragua)

and Construction of a Road in Costa Rica along the San Juan River (Nicaragua v Costa Rica), Judgment, (2015) ICJ Rep 665.

\section{International Tribunal for the Law of the Sea}

The M/V "SAIGA" (No. 2) Case (Saint Vincent and the Grenadines v Guinea), (1999) ITLOS case 2.

Southern Bluefin Tuna Cases (New Zealand v Japan; Australia v Japan), Provisional Measures, (1999) ITLOS cases $3 \& 4$.

Case concerning the Conservation and Sustainable Exploitation of Swordfish Stocks in the South-Eastern Pacific Ocean (Chile/European Union), Order, (2000) ITLOS case 7.

Case concerning the Conservation and Sustainable Exploitation of Swordfish Stocks in the South-Eastern Pacific Ocean (Chile/European Union), Order, (2009) ITLOS case 7.

The MOX Plant Case (Ireland v United Kingdom), Provisional Measures, (2001) ITLOS case 10.

Responsibilities and obligations of States sponsoring persons and entities with respect to activities in the Area (Request for Advisory Opinion submitted to the Seabed Disputes Chamber), Advisory Opinion, (2011) ITLOS case 17.

Request for an advisory opinion submitted by the Sub-Regional Fisheries Commission (SRFC), Advisory opinion, (2015) ITLOS case 21.

The Arctic Sunrise Case (Kingdom of the Netherlands v Russian Federation), Provisional Measures, (2013) ITLOS case no 22.

\section{Arbitral Tribunals}

Trail Smelter Arbitration (United States v Canada), (1938 and 1941) 3 RIAA 1905.

Southern Bluefin Tuna Case between Australia and Japan and between New Zealand and Japan, Award on Jurisdiction and Admissibility, (2000) 23 RIAA 1-57. 


\section{LIST OF CASES}

Chagos Marine Protected Area Arbitration (Mauritius v United Kingdom), Award, (2015) PCA case 2011-03.

The Arctic Sunrise Arbitration (Netherlands v Russia), Award, (2015) PCA case 2014-02.

The South China Sea Arbitration (The Republic of the Philippines $v$ The People's Republic of China), Award, (2016) PCA case 2013-19.

\section{RFMOs Review Panels}

Objection by the Russian Federation, (2013) SPRFMO, Findings and Recommendations of the Review Panel.

Objection by the Republic of Ecuador, (2018) SPRFMO, Findings and Recommendations of the Review Panel.

\section{World Trade Organization (WTO)}

Chile - Measures affecting the transit and importation of swordfish,

(2000) WTO Doc WT/DS1931/1 (request for consultation by the European Communities) and (2000) WTO Doc WT/DS192/2 (request for the establishment of a panel by the European Communities).

United States - Import Prohibition of Certain Shrimp and Shrimp Products (India, Malaysia, Pakistan, Thailand $v$ United States), Report of the Appellate Body, (2001) WTO AB-2001-4.

\section{National case law}

M.C. Mehta v Kamal Nath, (1997) 1 SCC 388 (India). 


\section{BIBLIOGRAPHY}

\section{Monographs and edited volumes}

Attard, David J., The Exclusive Economic Zone in International Law (Oxford: Clarendon Press, 1987).

Barnes, Richard, Property Rights and Natural Resources (Oxford: Hart, 2009).

Barry, Donald, Bob Applebaum \& Earl Wiseman, Fishing for a Solution: Canada's Fisheries Relations with the European Union, 1977-2013 (Calgary: University of Calgary Press, 2014).

Beyerlin, Ulrich \& Thilo Marauhn, International Environmental Law (Oxford: Hart, 2011).

Birnie, Patricia, Alan Boyle \& Catherine Redgwell, International Law of the Environment, 3rd ed (Oxford: Oxford University Press, 2009).

Blandin, Patrick, Biodiversité, L’avenir du vivant (Paris: Albin Michel Sciences, 2010).

Bodansky, Daniel, The Art and Craft of International Environmental Law (Cambridge, MA: Harvard University Press, 2011).

Bosselmann, Klaus, Earth Governance. Trusteeship of the Global Commons (Cheltenham: Edward Elgar, 2015).

Brunée, Jutta \& Stephen Toope, Legitimacy and Legality in International Law. An Interactional Account (Cambridge: Cambridge University Press, 2010).

Capra, Frijtof \& Ugo Mattei, The Ecology of Law: Toward a Legal System in Tune with Nature and Community (Oakland, CA: Berrett-Koehler Publishers, 2015).

Chayes, Abram \& Antonia Handler Chayes, The New Sovereignty: Compliance with International Regulatory Agreements (Cambridge, Mass.: Harvard University Press, 1995).

Churchill, Robin \& Vaughan Lowe, The law of the sea, 3rd ed (Manchester: Manchester University Press, 1999).

Commission on Global Governance, Our Global Neighbourhood. The Report of the Commission on Global Governance (Oxford: Oxford University Press, 1995).

DeSombre, Elizabeth, Global Environmental institutions (Abingdon, Oxon: Routledge, 2006).

Diz Pereira Pinto, Daniela, Fisheries Management in Areas beyond National Jurisdiction, The Impact of Ecosystem-Based Law-Making (Leiden: Martinus Nijhoff, 2013).

Dupuy, Pierre-Marie \& Jorge Viñuales, International Environmental Law, 2nd ed (Cambridge: Cambridge University Press, 2018).

Epiney, Astrid \& Martin Scheyli, Unweltvölkkerrecht (Baden-Baden: Stämpfli-Verlag, 2000)

Franck, Thomas M., The Power of Legitimacy Among Nations (Oxford: Oxford University Press, 1990)

Freeman, Linton C., The Development of Social Network Analysis. A Study in the Sociology of Science (Vancouver: Empirical Press, 2004).

Grafton, R. Quentin, James Kirkley \& Dale Squires, Economics for Fisheries Management (Abingdon, Oxon: Routledge, 2006).

Guggisberg, Solène, The Use of CITES for Commercially-Exploited Fish Species: A Solution to Overexploitation and Illegal, Unreported and Unregulated Fishing? (Cham: Springer, 2016).

Gunningham, Neil \& Peter Grabosky, with Darren Sinclair, Smart regulation. Designing Environmental Policy (Oxford, Oxford University Press, 1998). 
Haas, Peter M., Marc A. Levy \& Robert Keohane, Institutions for the Earth: Sources of Effective International Environmental Protection (Cambridge, MA: MIT University Press, 1993).

Harrison, James, Saving the Oceans Through Law. The International Legal Framework for the Protection of the Marine Environment (Oxford: Oxford University Press, 2017).

Haward, Marcus, Governing Oceans in a Time of Change. Fishing for the Future (Cheltenham: Edward Elgar, 2020).

Independent World Commission on the Oceans, The Ocean: Our Future (Cambridge: Cambridge University Press, 1998).

Keohane, Robert \& Marc A. Levy, Institutions for Environmental Aid: Pitfalls and Promise (Cambridge, MA: MIT Press, 1996).

Kotzé, Louis, Global Environmental governance: Law and regulation for the 21st century (Cheltenham: Edward Elgar, 2012).

The South Centre, For A Strong and Democratic United Nations: A South Perspective of UN Reform (Geneva: The South Centre, 1996).

Henriksen, Tore, Geir Hønneland \& Are Sydnes, Law and Politics in Ocean Governance. The UN Fish Stocks Agreement and Regional Fisheries Management Regimes (Leiden: Martinus Nijhoff, 2006).

Juda, Lawrence, International Law and Ocean Use Management: The Evolution of Ocean Governance (Abingdon, Oxon: Routledge, 1996).

Knight, H. Gary, The Future of International Fisheries Management (St. Paul, Minnesota: West Publishing Co., 1975).

Lodge, Michael et al, Recommended Best Practices For Regional Fisheries Management Organizations. Report of an Independent Panel to Develop a Model for Improved Governance by Regional Fisheries Management Organizations (London: The Royal Institute of International Affairs Chatham House, 2007).

Marr, Simon, The Precautionary Principle in the Law of the Sea: Modern Decision Making in International Law (Leiden: Martinus Nijhoff, 2003).

Meadows, Donella, Thinking in systems. A primer (White River Junction, VT: Chelsea Green Publishing, 2008).

Nguyen, Lan Ngoc, The development of the law of the sea by UNCLOS tribunals (Cambridge: Cambridge University Press, forthcoming).

Orrego Vicuña, Francisco, The changing international law of high seas fisheries (Cambridge: Cambridge University Press, 1999).

Ostrom, Elinor, Governing the Commons. The Evolution of Institutions for Collective Action (Cambridge: Cambridge University Press, 1990).

Ostrom, Elinor, Understanding Institutional Diversity (Princeton: Princeton University Press, 2005).

Ostrom, Elinor et al, The Future of the Commons. Beyond Market Failure and Government Regulation (London: The Institute of Economic Affairs, 2012).

Pauwelyn, Joost, Conflict of Norms in Public International Law. How WTO Law Relates to other Rules of International Law (Cambridge: Cambridge University Press, 2003).

Pulkowski, Dirk, The Law and Politics of International Regime Conflict (Oxford: Oxford University Press, 2014).

Rayfuse, Rosemary, Non-flag State enforcement in high seas fisheries (Leiden: Martinus Nijhoff, 2004).

Ricard, Pascale, La conservation de la biodiversité dans les espaces maritimes internationaux. Un défi pour le droit international (Paris: Pedone, 2019). 
Rothwell, Donald \& Tim Stephens, The International Law of the Sea (Oxford: Hart, 2016).

Sands, Philippe, Principles of International Environmental Law, 2nd ed (Cambridge: Cambridge University Press, 2003).

Sands, Philippe \& Jacqueline Peel, with Adriana Fabra \& Ruth MacKenzie, Principles of International Environmental Law, 4th ed (Cambridge: Cambridge University Press, 2018).

Serdy, Andrew, The New Entrants Problem in International Fisheries Law (Cambridge: Cambridge University Press, 2016).

Staal, Tim, Authority and Legitimacy of Environmental Post-Treaty Rules (Oxford: Hart, 2019).

Stokke, Olav Schram (ed), Governing High Seas Fisheries. The Interplay of Global and Regional Regimes (Oxford: Oxford University Press, 2001).

Takei, Yoshinobu, Filling Regulatory Gaps in High Seas Fisheries: Discrete High Seas Fish Stocks, Deep-Sea Fisheries, and Vulnerable Marine Ecosystems (Leiden: Martinus Nijhoff, 2013).

Tanaka, Yoshifumi, A Dual Approach to Ocean Governance. The Cases of Zonal and Integrated Management in International Law of the Sea (Farnham, England, Burlington, USA: Ashgate, 2008).

Techera, Elisa \& Natalie Klein, International Law of Sharks. Obstacles, Options and Opportunities (Leiden: Brill Nijhoff, 2017).

Telesca, Jennifer E., Red Gold. The Managed Extinction of the Giant Bluefin Tuna (Minneapolis: University of Minnesota Press, 2020).

The Oxford English Dictionary, 2d ed, sub verbo "principle".

Trevisanut, Seline, Nikolaos Giannopoulos \& Rozemarijn Roland Holst (eds), Regime Interaction in Ocean Governance. Problems, Theories and Mathods (Leiden: Brill Nijhoff, 2020).

van Erp, Judith et al (eds), Smart Mixes for Transboundary Environmental Harm (Cambridge: Cambridge University Press, 2019).

Vidas, Davor, "IUU Fishing or IUU Operations? Some Observations on Diagnosis and Current Treatment" in David Caron \& Harry Scheiber (eds), Bringing New Law to Ocean Waters (Leiden: Brill Nijhoff, 2004) 125-144.

Webster, D.G., Beyond the Tragedy in Global Fisheries (Cambridge, Mass.: MIT Press, 2015).

World Commission on Environment and Development, Our Common Future (Oxford: Oxford University Press, 1987).

Wyssbrod, Valérie, Lexploitation des ressources génétiques marines hors juridiction nationale (Leiden: Brill Nijhoff, 2018).

Young, Margaret (ed), Regime Interaction in International Law. Facing Fragmentation (Cambridge: Cambridge University Press, 2012).

Young, Oran, International Governance: Protecting the Environment in a Stateless Society (Ithaca, NY: Cornell University Press, 1994).

Young, Oran R., Governance in World Affairs (Ithaca, NY: Cornell University Press, 1999).

Young, Oran, On Environmental Governance: Sustainability, Efficiency, and Equity (Abingdon, Oxon: Routledge, 2016).

Young, Oran, Governing Complex Systems. Social Capital for the Anthropocene (Cambridge, MA: MIT Press, 2017).

Zacharias, Mark \& Jeff Ardron. Marine Policy: An Introduction to Governance and International Law of the Oceans, 2nd ed (Abingdon, Oxon: Routledge, 2019). 


\section{Books chapters}

Altvater, Susanne, Ruth Fletcher \& Cristian Passarello, "The Need for Marine Spatial Planning in Areas Beyond National Jurisdiction" in Jacek Zaucha \& Kira Gee (eds), Maritime Spatial Planning: past, present, future (Cham: Springer, 2019) 397-415.

Ansell, Christopher \& Jacob Torfing, "Introduction: Theories of Governance" in Christopher Ansell \& Jacob Torfing (eds), Handbook on Theories of Governance (Cheltenham: Edward Elgar, 2016) 1-17.

Arnold, Craig Anthony \& Lance H. Gunderson, "Adaptive Law" in Ahjond S. Garmestani \& Craig R. Allen (eds), Social-Ecological Resilience and Law (New York: Columbia University Press, 2014) 317-364.

Baldwin Jr, Gunnar et al, "International Compliance and Enforcement Networks: The Critical Role of Collaboration in Environmental Protection" in Grant Pink \& Rob White (eds), Environmental Crime and Collaborative State Intervention (London: Palgrave Macmillan, 2016) 21-38.

Balton, David, "The Bering Sea Doughnut Hole Convention: Regional Solution, Global Implications" in Olav Schramm Stokke (ed), Governing High Seas Fisheries: The Interplay of Global and Regional Regimes (Oxford University Press: Oxford, 2001) 143-177.

Barnes, Richard, "The Convention on the Law of the Sea: An Effective Framework for Domestic Fisheries Conservation?" in David Freestone, Richard Barnes \& David Ong (eds), The Law of the Sea. Progress and Prospects (Oxford: Oxford University Press, 2006) 233-260.

Barnes, Richard, “The Continuing Vitality of UNCLOS” in Jill Barrett \& Richard Barnes (eds), Law of the Sea: UNCLOS as a Living Treaty (British Institute of International and Comparative Law, 2016) 459-489.

Barnes, Richard, "The Pursuit of Good Regulatory Design Principles in International Fisheries Law. What Possibility of Smarter International Regulation?" in Judith van Erp et al (eds), Smart Mixes for Transboundary Environmental Harm (Cambridge: Cambridge University Press, 2019) 97-125.

Barnes, Richard, "Future fisheries and ABNJ" in Vito De Lucia, Lan Ngoc Nguyen \& Alex Oude Elferink (eds), International Law and Marine Areas beyond National Jurisdiction: Current Status and Future Trends (forthcoming).

Barnes, Richard \& Carmino Massarella, "High Seas Fisheries" in Elisa Morgera \& Kati Kulovesi (eds), Research Handbook on International Law and Natural Resources (Cheltenham: Edward Elgar, 2016) 369-389.

Barrett, Jill, “The UN Convention on the Law of the Sea: A 'Living' Treaty?” in Jill Barrett \& Richard Barnes (eds), Law of the Sea: UNCLOS as a Living Treaty (British Institute of International and Comparative Law, 2016) 3-37.

Benvenisti, Eyal, "The Law of Global Governance" in The Hague Academy of International Law, Recueil de Cours, vol 368 (Leiden: Brill Nijhoff, 2014).

Beyerlin, Ulrich, "Different types of norms in international environmental law: Policies, principles, and rules" in Daniel Bodansky, Jutta Brunée \& Ellen Hey (eds), The Oxford Handbook on International Environmental Law (Oxford: Oxford University Press, 2007) 425-448.

Blanchard, Catherine, Otto Spijkers \& Wen Duan, "Three Structural Pillars of the Future Internationally Legally Binding Instrument for the Conservation and Sustainable Use of Marine Biodiversity in Areas Beyond National Jurisdiction" in Marta Chantal Ribeiro, Fernando Loureiro Bastos \& Tore Henriksen (eds), Global Challenges and the Law of the Sea (Cham: Springer, 2020) 351-378.

Bosselman, Klaus, "Conclusion: Governing the Commons - Can States Be Trustees?" in Laura Westra, Janice Gray \& Antonio D’Aloia (eds), The Common Good and Ecological Integrity Human Rights and the Support of Life, (Abingdon, Oxon: Routledge, 2016) 267-283. 
Boyd, Emily \& Carl Folke, "Conclusions: Adapting Institutions and Resilience" in Emily Boyde \& Carl Folke (eds), Adapting Institutions: Governance, Complexity and Social-Ecological Resilience (Cambridge: Cambridge University Press, 2011) 264-280.

Boyle, Alan E., "The Principle of Co-operation: the Environment" in Vaughan Lowe \& Colin Warbrick (eds), The United Nations and the Principles of International Law: Essays in Memory of Michael Akehurst (Abingdon, Oxon: Routledge, 1994) 120-136.

Boyle, Alan, "Climate change and oceans governance" in Marta Chantal Ribeiro (ed), 30 Years After the Signature of the United Nations Convention on the Law of the Sea: The Protection of the Environment and the Future of the Law of the Sea. Proceedings of the International Conference (Coimbra: Coimbra Editora, 2014) 357-382.

Boyle, Alan, "Climate change, Ocean governance and UNCLOS" in Jill Barrett \& Richard Barnes (eds), Law of the Sea UNCLOS as a Living Treaty (British Institute of International and Comparative Law, 2016) 211-230.

Brunnée, Jutta \& Ellen Hey, "Transparency and International Environmental Law" in Andrea Bianchi \& Anne Peters (eds), Transparency in International Law (Cambridge: Cambridge University Press, 2013) 23-48.

Buchanan, Allen \& Robert Keohane, "The Legitimacy of Global Governance Institutions" in Rüdiger Wolfrum \& Volker Röben (eds), Legitimacy in International Law (Cham: Springer, 2008) 25-62.

Buga, Irina, "Between Stability and Change in the Law of the Sea Convention: Subsequent Practice, Treaty Modification, and Regime Interaction" in Donald Rothwell et al (eds), Oxford Handbook on the Law of the Sea (Oxford: Oxford University Press, 2015) 46-68.

Burke, William, "Unregulated High Seas Fishing and Ocean Governance" in Jon M. Van Dyke, Durwood Zaelke \& Grant Hewison (eds), Freedom for the Seas in the 21st Century: Ocean Governance and Environmental Harmony (Washington: Island Press, 1993) 235-271.

Caddell, Richard, “'Only Connect'? Regime Interaction and Global Biodiversity Conservation" in Michael Bowman, Peter Davies \& Edward Goodwin (eds), Handbook on Biodiversity and Law (Cheltenham: Edward Elgar, 2016).

Caddell, Richard, "International Fisheries Law and Interactions with Global Regimes and Processes" in Richard Caddell \& Erik Molenaar (eds), Strengthening International Fisheries Law in an Era of Changing Oceans (Oxford: Hart, 2019) 133-163.

Churchill, Robin, "Fisheries and their impact on the marine environment: UNCLOS and beyond" in Marta Chantal Ribeiro (ed), 30 Years After the Signature of the United Nations Convention on the Law of the Sea: The Protection of the Environment and the Future of the Law of the Sea. Proceedings of the International Conference (Coimbra: Coimbra Editora, 2014) 23-52.

Churchill, Robin, "The LOSC Regime for Protection of the Marine Environment - Fit for the Twenty-First Century?" in Rosemary Rayfuse (ed), Research Handbook on International Marine Environmental Law (Cheltenham: Edward Elgar, 2017) 3-30.

Czybulka, Detlef, "Article 194. Measures to prevent, reduce and control pollution of the marine environment" in Alexander Proelss (ed), United Nations Convention on the Law of the Sea. A Commentary (Munich: Verlag C. H. Beck, 2017) 1295-1315.

Czybulka, Detlef, "Article 237. Obligations under other conventions on the protection and preservation of the marine environment" in Alexander Proelss (ed), United Nations Convention on the Law of the Sea. A Commentary (Munich: Verlag C. H. Beck, 2017) 1596-1604.

Dalaker, Kraabel Kristine, "International Law and Areas Beyond National Jurisdiction: Imagining a Polycentric Approach to Institutional Governance for Marine Areas Beyond National Jurisdiction" in Vito De Lucia, Lan Ngoc Nguyen \& Alex Oude Elferink (eds), International Law and Marine Areas beyond National Jurisdiction: Current Status and Future Trends (forthcoming). 
Danish, Kyle, "International Relations Theory" in Daniel Bodansky, Jutta Brunnée \& Ellen Hey (eds) The Oxford Handbook of International Environmental Law (Oxford: Oxford University Press, 2007) 205-230.

D’Aspremont, Jean, "Towards a New Theory of Sources in International Law" in Anne Orford \& Florian Hoffmann (eds), The Oxford Handbook of the Theory of International Law (Oxford: Oxford University Press, 2016) 545-563.

De La Fayette, Louise, "Principles and Objectives of the Legal Regime Governing Areas Beyond National - Commentary on Tullio Treves" in Alex Oude Elferink \& Erik Molenaar (eds), The International Regime of Areas Beyond National Jurisdiction: Current and Future Developments (Leiden: Martinus Nijhoff, 2010) 39-40.

Depypere, Stefaan, "Ocean Governance for Sustainable Fisheries" in Myron Nordquist, John Norton Moore \& Ronan Long (eds) Legal Order in the World's Oceans. UN Convention on the Law of the Sea (Leiden, Boston: Brill Nijhoff, 2018) 370-378.

Dunn, Daniel, Guillermo Ortuño Crespo \& Richard Caddell, "Area-based fisheries management" in Richard Caddell \& Erik Molenaar (eds), Strengthening International Fisheries Law in an Era of Changing Oceans (Oxford: Hart, 2019) 189-217.

Duun, Euan, "Reducing Seabird Bycatch: From Identifying Problems to Implementing Policy" in Peter Johan Schei \& Davor Vidas (eds), The World Ocean in Globalisation. Climate Change, Sustainable Fisheries, Biodiversity, Shipping, Regional Issues (Leiden: Brill, 2011) 247-261.

Franckx, Erik, "The Protection of Biodiversity and Fisheries Management: Issues Raised by the Relationship between Cites and LOSC" in David Freestone, Richard Barnes \& David Ong (eds), The Law of the Sea: Progress and Prospects (Oxford: Oxford University Press, 2006) 210-232.

Freestone, David, "Problems of High Seas Governance" in Peter Johan Schei \& Davor Vidas (eds), The World Ocean in Globalisation. Climate Change, Sustainable Fisheries, Biodiversity, Shipping, Regional Issues (Leiden: Brill, 2011) 99-130.

Freestone, David, "Satya Nandan's Contribution to the Development of the Precautionary Approach in International Law" in Michael Lodge \& Myron Nordquist (eds), Peaceful Order in the World's Oceans. Essays in Honor of Satya N. Nandan (Leiden: Brill Nijhoff, 2014) 308-324.

Freestone, David, "Governance of Areas Beyond National Jurisdiction: And Unfinished Agenda?" in Jill Barrett \& Richard Barnes (eds), Law of the Sea UNCLOS as a Living Treaty (British Institute of International and Comparative Law, 2016) 231-265.

Freestone, David, "An Unfinished Agenda: Governance of Areas beyond National Jurisdiction" in Keyuan Zou (ed), Global Commons and the Law of the Sea (Leiden, Boston: Brill Nijhoff, 2018) 209-225.

Freestone, David, Richard Barnes \& David Ong, “The law of the sea: Progress and prospects" in David Freestone, Richard Barnes \& David Ong (eds), The Law of the Sea: Progress and Prospects (Oxford University Press, Oxford, 2006) 1-27.

Galletti, Florence, "Les transformations du droit international de la mer: Entre gouvernance de 'lespace' et gouvernance de la 'ressource' en mer" in André Monaco \& Patrick Prouzet (eds), Gouvernance des mers et des océans (London: ISTE Editions, 2015) 21-53.

Garcia, Serge, “The Ecosystem Approach to Fisheries: On the Way to Implementation" in Myron Nordquist et al (eds) Law, Science and Ocean Management (Leiden: Martinus Nijhof, 2007) 171-216.

Garcia, Serge, “Glossary” in Kevern Cochrane \& Serge Garcia (eds), A fishery manager's guidebook (Rome and Hoboken: FAO and Wiley, 2009) 473-505.

Garcia, Serge, "Annex I - History of Fisheries and biodiversity conservation: A timeline of key events (1850-2012)" in Serge Garcia, Jake Rice \& Anthony Charles (eds), Governance of marine fisheries and biodiversity conservation: Interaction and Coevolution (Hoboken: Wiley, 2014) 429-460. 
Garcia, Serge, Jake Rice \& Anthony Charles, "Governance of marine fisheries and biodiversity conservation: A history" in Serge Garcia, Jake Rice \& Anthony Charles (eds), Governance of marine fisheries and biodiversity conservation: Interaction and Coevolution (Hoboken: Wiley, 2014) 3-17.

Garcia, Serge, Jake Rice \& Anthony Charles, "Governance of marine fisheries and biodiversity conservation: Convergence or coevolution?" in Serge Garcia, Jake Rice \& Anthony Charles (eds), Governance of marine fisheries and biodiversity conservation: Interaction and Coevolution (Hoboken: Wiley, 2014) 18-36.

Garcia, Serge, Jake Rice \& Anthony Charles, "Governance of marine fisheries and biodiversity conservation: The integration challenge" in Serge Garcia, Jake Rice \& Anthony Charles (eds), Governance of marine fisheries and biodiversity conservation: Interaction and Coevolution (Hoboken: Wiley, 2014) 37-52.

Geiß, Robin \& Christian J. Tams, "Non-Flag States as Guardians of the Maritime Order: Creeping Jurisdiction of a Different Kind?" in Henrik Ringbom (ed), Jurisdiction over Ships. PostUNCLOS Developments in the Law of the Sea (Leiden: Brill Nijhoff, 2015) 19-49.

Gjerde, Kristina, "High Seas Fisheries Management under the Convention on the Law of the Sea" in David Freestone, Richard Barnes, \& David Ong (eds), The Law of the Sea: Progress and Prospects (Oxford: Oxford University Press, 2006) 281-307.

Gjerde, Kristina, "High Seas Fisheries Governance: Prospects and Challenges in the 21st Century" in Peter Johan Schei \& Davor Vidas (eds), The World Ocean in Globalisation: Climate Change, Sustainable Fisheries, Biodiversity, Shipping, Regional Issues (Leiden: Brill, 2011) 221-232.

Gjerde, Kristina, "Enhancing integrated management beyond national jurisdiction under the environmental provisions of the UN Convention on the Law of the Sea" in Marta Chantal Ribeiro (ed), 30 Years After the Signature of the United Nations Convention on the Law of the Sea: The Protection of the Environment and the Future of the Law of the Sea. Proceedings of the International Conference (Coimbra: Coimbra Editora, 2014) 441-452.

Golitsyn, Vladimir, "Major Challenges of Globalisation for Seas and Oceans: Legal Aspects" in Davor Vidas (ed) Law, Technology and Science for Oceans Globalisation. IUU Fishing, Oil Pollution, Bioprospecting, Outer Continental Shelf (Leiden: Brill Nijhoff, 2010) 59-73.

Gordenker, Leon \& Thomas G. Weiss "Pluralizing Global Governance: Analytical approaches and dimensions" in Thomas G. Weiss and Leon Gordenker (eds), NGOs, the UN, and Global Governance (Boulder, Colo.: Lynne Rienner, 1996) 17-47.

Gorina-Ysern, Montserrat, Kristina Gjerde \& Michael Orbach, "Ocean Governance: A New Ethos through a World Ocean Public Trust" in Linda Glover, Silvia Earle \& Graeme Kelleher, Defying Oceans End: An Agenda for Action (Washington: Island Press, 2004) 197-212.

Guilfoyle, Douglas, "Article 87. Freedom of the high seas" in Alexander Proelss (ed), United Nations Convention on the Law of the Sea. A Commentary (Munich: Verlag C. H. Beck, 2017) 678-682.

Gullett, Warwick \& Quentin Hanich, "Rethinking High Seas Fishing Freedoms: How High Seas Duties Are Catching Up" in Keyuan Zou (ed), Global Commons and the Law of the Sea (Leiden, Boston: Brill Nijhoff, 2018) 112-123.

Harrison, James, "Actors and Institutions for the Protection of the Marine Environment" in Rosemary Rayfuse (ed), Research Handbook on International Marine Environmental Law (Cheltenham: Edward Elgar, 2017) 57-78.

Harrison, James, "Key Challenges Relating to the Governance of Regional Fisheries" in Richard Caddell \& Erik Molenaar (eds), Strengthening International Fisheries Law in an Era of Changing Oceans (Oxford: Hart, 2019) 79-102.

Hayashi, Moritaka, "Illegal, Unreported, and Unregulated (IUU) Fishing: Global and Regional Responses" in David Caron \& Harry Scheiber (eds), Bringing New Law to Ocean Waters (Leiden: Brill Nijhoff, 2004) 95-124. 
Hayasi, Moritaka, "Regional Fisheries Management Organizations and Non-Members" in Tafsir Malick Ndiaye \& Ruidiger Wolfrum (eds), Law of the Sea, Environmental Law and Settlement of Disputes - Liber Amicorum Judge Thomas A. Mensah (Martinus Nijhoff Publishers, Leiden, 2007) 751-765.

Hewson, Martin \& Timothy Sinclair, “The Emergence of Global Governance Theory" in Martin Hewson \& Timothy Sinclair (eds), Approaches to Global Governance Theory (Albany, NY: State University of New York Press, 1999) 3-22.

Hey, Ellen, "Regime Interaction and Common Interests in Regulating Human Activities in Areas Beyond National Jurisdiction" in Seline Trevisanut, Nikolaos Giannopoulos \& Rozemarijn Roland Holst (eds), Regime Interaction in Ocean Governance. Problems, Theories and Methods (Leiden: Brill Nijhoff, 2020) 85-123.

Holthus, Paul, "Ocean Industry Leadership and Collaboration in Sustainable Development of the Seas” in André Monaco \& Patrick Prouzet (eds) Governance of Seas and Oceans (Hoboken: Wiley, 2015) 281-296.

Hook, Glenn D. \& Anthony Payne, "Introduction. Thinking about Global Governance and Japan" in Glenn D. Hook \& Hugo Dobson (eds), Global Governance and Japan: The Institutional Architecture (Abingdon, Oxon: Routledge, 2007) 1-22.

Hoydal, Karsten, David Johnson \& Alf Håkon Hoel, "Regional governance: The case of NEAFC and OSPAR" in Serge Garcia, Jake Rice \& Anthony Charles (eds), Governance of marine fisheries and biodiversity conservation: Interaction and Coevolution (Hoboken: Wiley, 2014) at 225-238.

Jänicke, Martin \& Helge Jörgens, "New approaches to environmental governance" in Martin Jänicke \& Klaus Jacob (eds), Environmental governance in global perspective. New approaches to ecological modernisation (Berlin: Freie Universität Berlin, 2006) 167-209.

Johnson, David, "Can Competent Authorities Cooperate for the Common Good: Towards a Collective Arrangement in the North-East Atlantic" in Paul Arthur Berkman \& Alexander N. Vylegzhanin (eds), Environmental Security in the Arctic Ocean (Cham: Springer, 2013) 333-343.

Johnston, Douglas, “The Challenges of International Ocean Governance: Institutional, Ethical and Conceptual Dilemmas" in Donald R. Rothwell \& David L. VanderZwaag (eds), Towards Principled Oceans Governance: Australian and Canadian Approaches and Challenges (Abingdon, Oxon: Routledge, 2016) 349-399.

Juda, Lawrence, "Changing Perspectives on the Oceans: Implications for International Fisheries and Oceans Governance" in David Caron \& Harry Scheiber (eds), Bringing New Law to Ocean Waters (Leiden: Brill Nijhoff, 2004) 17-28.

Karavias, Markos, "Mixing Regional Fisheries Management and Private Certification" in Judith van Erp et al (eds), Smart Mixes for Transboundary Environmental Harm (Cambridge: Cambridge University Press, 2019) 126-145.

Kelleher, Kieran, "Ocean acidification impacts on fisheries and aquaculture" in Nathalie Hilm et al (eds), Bridging the Gap Between Ocean Acidification Impacts and Economic Valuation: Regional Impacts of Ocean Acidification on Fisheries and Aquaculture (Gland, Switzerland: IUCN, 2015).

Kenchington, Richard \& Robin Warner, "Uncertain Seas Ahead: Legal and Policy Approaches to Conserving Marine Biodiversity in the Face of Changing Climate" in Robin Warner \& Clive Schofield (eds) Climate Change and the Oceans: Gauging the Legal and Policy Currents in the Asia Pacific and Beyond (Cheltenham: Edward Elgar, 2012) 51-73.

Kenis, Patrick, "Network" in Christopher Ansell \& Jacob Torfing (eds) Handbook on Theories of Governance (Cheltenham, Edward Edgar, 2016) 149-157.

Keohane, Robert \& Joseph Nye, “Governance in a Globalizing world” in Robert Keohane (ed), Power and Governance in a partially globalized world (Abingdon, Oxon: Routledge, 2002) 193-218. 
Kotzé, Louis, "A Juridical-Conceptual Perspective on Environmental Governance" in Tuomas Kuokkanen et al (eds), International Environmental Law-Making and Diplomacy. Insights and Overview (Abingdon, Oxon: Routledge, 2016) 48-67.

Krasner, Stephen D., "Structural causes and regime consequences: regimes as intervening variables" in Stephen D. Krasner (ed), International regimes (Ithaca, NY: Cornell University Press, 1983) 1-21.

$\mathrm{Ku}$, Charlotte, "Fragmentation in International Law and Governance: Understanding the Sum of the Parts" in Cedric Ryngaert, Erik Molenaar \& Sarah Nouwen (eds), What's Wrong with International Law? Liber Amicorum A.H.A. Soons (Leiden: Brill Nijhoff, 2015) 419-433.

Kuruc, Michele, "Monitoring, Control and Surveillance Tools to Detect IUU Fishing and Related Activities" in Davor Vidas (ed), Law, Technology and Science for Oceans Globalisation. IUU Fishing, Oil Pollution, Bioprospecting, Outer Continental Shelf (Leiden: Brill Nijhoff, 2010) 101-108.

Kwiatkowska, Barbara, “The high seas fisheries regime: at a point of no return?" (1993) 8:3 International Journal of Marine and Coastal Law 327-358.

Langlet, David \& Rosemary Rayfuse, "Challenges in Implementing the Ecosystem Approach: Lessons Learned" in David Langlet \& Rosemary Rayfuse (eds) The Ecosystem Approach in Ocean Planning and Governance (Leiden: Brill Nijhoff, 2019) 445-461.

Lee, Seokwoo, Anastasia Telesetsky \& Clive Schofield, "Slipping the Net: Why Is It So Difficult to Crack Down on IUU Fishing?" in Myron Nordquist et al (eds), Freedom of Navigation and Globalization (Leiden: Brill Nijhoff, 2015) 89-119.

Levy, David L. \& Peter J. Newell, "Introduction" in David L. Levy \& Peter J. Newell (eds), The Business of Global Environmental Governance (Cambridge, Mass.: MIT Press, 2005) 1-16.

Long, Ronan, "Commentary: The Anthropocene, Autopoiesis And The Disingenuousness Of The Genuine Link: Addressing Enforcement Gaps In The Legal Regime For Areas Beyond National Jurisdiction" in Alex Oude Elferink \& Erik Molenaar (eds), The International Legal Regime of Areas beyond National Jurisdiction Current and Future Developments (Leiden: Brill, 2010) 191-204.

Marsden, Simon, "Environmental Assessment and International Fisheries Law" in Richard Caddell \& Erik Molenaar (eds), Strengthening International Fisheries Law in an Era of Changing Oceans (Oxford: Hart, 2019) 219-246.

Marten, Bevan, "Port State Jurisdiction, International Conventions, and Extraterritoriality: An Expansive Interpretation" in Henrik Ringbom (ed), Jurisdiction over Ships. Post-UNCLOS Developments in the Law of the Sea (Leiden: Brill Nijhoff, 2015) 105-139.

Matley, Holly, "Developments in International Fisheries Law and Their Contribution to Improving Effectiveness of RFMOs and Other Environmental Regimes" in Neil Craik et al (eds), Global Environmental Change and Innovation in International Law (Cambridge: Cambridge University Press, 2018) 102-122.

Matz-Luck, Nele, "Article 311. Relation to other conventions and international agreements" in Alexander Proelss (ed), United Nations Convention on the Law of the Sea. A Commentary (Munich: Verlag C. H. Beck, 2017) 2009-2019.

Millicay, Fernanda, "Marine Biodiversity of Areas Beyond National Jurisdiction Securing a Sound Law of the Sea Instrument" in David Joseph Attard, David Ong \& Dino Kritsiotis (eds), The IMLI Treatise on Global Ocean Governance, vol I: UN and Global Ocean Governance (Oxford: Oxford University Press, 2018) 167-177.

Mitchel, Ronald, "Compliance Theory. Compliance, Effectiveness, and Behaviour Change in International Environmental Law" in Daniel Bodansky, Jutta Brunnée \& Ellen Hey (eds) The Oxford Handbook of International Environmental Law (Oxford: Oxford University Press, 2007) 893-921. 
Molenaar, Erik, "New Maritime Zones and the Law of the Sea" in Henrik Ringbom (ed), Jurisdiction over Ships. Post-UNCLOS Developments in the Law of the Sea (Leiden: Brill Nijhoff, 2015) 249-277.

Molenaar, Erik, "Port and Coastal States" in Donald Rothwell et al (eds), Oxford Handbook on the Law of the Sea (Oxford: Oxford University Press, 2015) 280-303.

Molenaar, Erik, "International Regulation of Central Arctic Ocean Fisheries" in Myron Nordquist, John Norton Moore \& Ronan Long (eds), Challenges of the Changing Arctic. Continental Shelf, Navigation, and Fisheries (Leiden, Boston: Brill Nijhoff, 2016) 429-463.

Molenaar, Erik, "The Arctic, the Arctic Council, and the Law of the Sea" in Robert Beckman et al (eds), Governance of Arctic Shipping. Balancing Rights and Interests of Arctic States and User States (Leiden: Brill Nijhoff, 2017) 24-67.

Molenaar, Erik, "Participation in Regional Fisheries Management Organizations" in Richard Caddell \& Erik Molenaar (eds), Strengthening International Fisheries Law in an Era of Changing Oceans (Oxford: Hart, 2019) 103-129.

Molenaar, Erik, "Participation in the Central Arctic Ocean Fisheries Agreement" in Akiho Shibata et al (eds), Emerging Legal Orders in the Arctic. The Role of Non-Arctic Actors (Abingdon, Oxon: Routledge, 2019) 132-170.

Molenaar, Erik \& Richard Caddell, "Options and Pathways to Strengthen International Fisheries Law in an Era of Changing Oceans" in Richard Caddell \& Erik Molenaar (eds) Strengthening International Fisheries Law in an Era of Changing Oceans (Oxford: Hart, 2019) 423-429.

Nomura, Ichiro, "Sustainable World Fisheries: Elements of Success" in Michael Lodge \& Myron Nordquist (eds), Peaceful Order in the World's Oceans. Essays in Honor of Satya N. Nandan (Leiden: Brill Nijhoff, 2014) 325-337.

Ocheje, Paul, "Exploring the Legal Dimension of Political Legitimacy: A 'Rights' Approach to Governance in Africa" in Edward Kofi Quashigah \& Obiora Chinedu Okafor (eds), Legitimate Governance in Africa: International and Domestic Legal Perspectives (The Hague: Kluwer Law International, 1999) 165-206.

Okowa, Phoebe, "Environmental Dispute Settlement: Some Reflections on Recent Developments" in Malcolm D. Evans (ed), Remedies in International Law: The Institutional Dilemma (Oxford: Hart, 1998) 157-172.

Oral, Nilufer, "Forty years of the UNEP Regional Seas Programme: from past to future" in Rosemary Rayfuse (ed), Research Handbook on International Marine Environmental Law (Cheltenham: Edward Elgar, 2017) 339-362.

Orrego, Vicuña Francisco, "The International Law of High Seas Fisheries: From Freedom of Fishing to Sustainable Use" in Olav Schram Stokke (ed), Governing High Seas Fisheries. The Interplay of Global and Regional Regimes (Oxford: Oxford University Press, 2001) 23-52.

Ostrom, Elinor, "Institutional Analysis, Design Principles, and Threats to Sustainable Community Governance and Management of Commons" in Erling Berge \& Nils Christian Stenseth (eds), Law and the Governance of Renewable Resources: Studies from Northern Europe and Africa (Manilla: ICS Press, 1998) 34-51.

Oude Elferink, Alex, "Reviewing the Implementation of the LOSC Convention: The Role of the United Nations General Assembly and the Meeting of States Parties" in Alex Oude Elferink \& Donald Rothwell (eds), Oceans Management in the 21 st century: Institutional Frameworks and Responses (Leiden: Martinus Nijhoff, 2004) 295-312.

Oude Elferink, Alex \& Baine Kerr, "Finding a Home for BBNJ - The CBD, the LOSC and the General Assembly: complementarity or competition?" in Vito De Lucia, Lan Ngoc Nguyen \& Alex Oude Elferink (eds), International Law and Marine Areas beyond National Jurisdiction: Current Status and Future Trends (forthcoming). 
Oude Elferink, Alex, Erik Molenaar \& Donald Rothwell, “The Regional Implementation of the Law of the Sea and the Polar Regions" in Erik Molenaar, Alex Oude Elferink \& Donald Rothwell (eds), Law of the Sea and the Polar Regions. Interactions Between Global and Regional Regimes (Leiden: Brill Nijhoff, 2013) 1-16.

Owen, Daniel, "Principles and Objectives of the Legal Regime Governing Areas Beyond National Jurisdiction - Commentary on Tullio Treves" in Alex G Oude Elferink \& Erik J Molenaar (eds), The International Legal Regime of Areas Beyond National Jurisdiction: Current and Future Development (Leiden: Martinus Nijhoff, 2010) 27-37.

Pattberg, Philipp \& Oscar Widerberg, "Smart Mixes and the Challenge of Complexity. Lessons from Global Climate Governance" in Judith van Erp et al (eds), Smart Mixes for Transboundary Environmental Harm (Cambridge: Cambridge University Press, 2019) 49-69.

Proelss, Alexander, "Article 56. Rights, jurisdiction and duties of the coastal State in the exclusive economic zone" in Alexander Proelss (ed), United Nations Convention on the Law of the Sea. A Commentary (Munich: Verlag C. H. Beck, 2017) 418-437.

Proelss, Alexander \& Katherine Houghton, "Protecting Marine Species" in Rosemary Rayfuse (ed), Research Handbook on International Marine Environmental Law (Cheltenham: Edward Elgar, 2015) 229-258.

Pulvenis, Jean-François, "FAO, Ocean Governance and the Law of the Sea" in Harry N. Scheiber \& Jin-Hyun Paik (eds), Regions, Institutions, and Law of the Sea: Studies in Ocean Governance (Leiden: Brill Nijhoff, 2013) 111-128.

Rayfuse, Rosemary, "The Anthropocene, Autopoiesis And The Disingenuousness Of The Genuine Link: Addressing Enforcement Gaps In The Legal Regime For Areas Beyond National Jurisdiction" in Alex Oude Elferink \& Erik Molenaar (eds), The International Legal Regime of Areas beyond National Jurisdiction: Current and Future Developments (Leiden: Brill, 2010) 163-190.

Rayfuse, Rosemary, "Article 117. Duty of States to adopt with respect to their national measures for the conservation of the living resources of the high seas" in Alexander Proelss (ed), United Nations Convention on the Law of the Sea. A Commentary (Munich: Verlag C. H. Beck, 2017) 803-817.

Rayfuse, Rosemary, "Article 118. Cooperation of States in the conservation and management of living resources" in Alexander Proelss (ed), United Nations Convention on the Law of the Sea. A Commentary (Munich: Verlag C. H. Beck, 2017) 817-830.

Rayfuse, Rosemary, "Article 119. Conservation of the living resources of the high seas" in Alexander Proelss (ed), United Nations Convention on the Law of the Sea. A Commentary (Munich: Verlag C. H. Beck, 2017) 830-850.

Rayfuse, Rosemary, "Addressing Climate Change Impacts in Regional Fisheries Management Organizations" in Richard Caddell \& Erik Molenaar (eds), Strengthening International Fisheries Law in an Era of Changing Oceans (Oxford: Hart, 2019) 247-267.

Ridgeway, Lori, "Global level institutions and processes: Assessment of critical roles, foundations of cooperation and integration and their contribution to integrated marine governance" in Serge Garcia, Jake Rice \& Anthony Charles (eds), Governance of marine fisheries and biodiversity conservation: Interaction and Coevolution (Hoboken: Wiley, 2014) 148-165.

Ridgeway, Lori, "Global level institutions and processes: Frameworks for understanding critical roles and foundations of cooperation and integration" in Serge Garcia, Jake Rice \& Anthony Charles (eds), Governance of marine fisheries and biodiversity conservation: Interaction and Coevolution (Hoboken: Wiley, 2014) 139-147.

Ridgeway, Lori, "Key global institutions, bodies and processes: Roles, participation and main focus" in Serge Garcia, Jake Rice \& Anthony Charles (eds), Governance of marine fisheries and biodiversity conservation: Interaction and Coevolution (Hoboken: Wiley, 2014) 462-495. 
Roach, Ashley, "Update on the BBNJ negotiations" in Myron Nordquist, John Norton Moore \& Ronan Long (eds) Legal Order in the World's Oceans. UN Convention on the Law of the Sea (Leiden, Boston: Brill Nijhoff, 2018) 91-123.

Rosenau, James, "Governance, order, and change in world politics" in James N. Rosenau \& ErnstOtto Czempiel (eds), Governance without Government: Order and Change in World Politics (Cambridge: Cambridge University Press, 1992) 1-29.

Sand, Peter H., "Public Trusteeship for the Oceans" in Rüdiger Wolfrum et al (eds), Law of the Sea, Environmental Law and Settlement of Disputes Liber Amicorum Judge Thomas A. Mensah (Leiden: Brill Nijhoff, 2007) 521-543.

Schei, Peter Johan \& Davor Vidas, The World Ocean in Globalisation. Climate Change, Sustainable Fisheries, Biodiversity, Shipping, Regional Issues (Leiden: Brill, 2011).

Scott, Karen, "Managing Fragmentation Through Governance: International Environmental Law in a Globalised World" in Christopher Michaelsen, Mika Hayashi \& Andrew Byrnes (eds), International Law in the New Age of Globalization (Leiden: Brill Nijhoff, 2013) 207-238.

Scott, Karen N., "Integrated Oceans Management: A New Frontier in Marine Environmental Protection" in Donald Rothwell et al (eds), The Oxford Handbook on the Law of the Sea (Oxford: Oxford University Press, 2015) 463-490.

Serdy, Andrew, "Article 281. Procedure where no settlement has been reached by the parties" in Alexander Proelss (ed), United Nations Convention on the Law of the Sea. A Commentary (Munich: Verlag C. H. Beck, 2017) 1820-1824.

Serdy, Andrew, "Article 282. Obligations under general, regional or bilateral agreements" in Alexander Proelss (ed), United Nations Convention on the Law of the Sea. A Commentary (Munich: Verlag C. H. Beck, 2017) 1825-1829.

Singh, Pradeep \& Aline Jaeckel, "Future prospects of marine environmental governance" in Markus Solomon \& Till Markus (eds), Handbook on marine environment protection (Cham: Springer, 2018) 621-636.

Singh, Pradeep A. \& Mara Ort, "Law and Policy Dimensions of Ocean Governance" in Simon Jungblut, Viola Liebich \& Maya Bode-Dalby (eds), YOUMARES 9 - The Oceans: Our Research, Our Future. Proceedings of the 2018 conference for YOUng MArine RESearcher in Oldenburg, Germany (Cham: Springer, 2020) 45-56.

Soininen, Niko \& Froukje Maria Platjouw, "Resilience and Adaptive Capacity of Aquatic Environmental Law in the EU: An Evaluation and Comparison of the WFD, MSFD, and MSPD" in David Langlet \& Rosemary Rayfuse (eds) The Ecosystem Approach in Ocean Planning and Governance (Leiden: Brill Nijhoff, 2019) 17-79.

Stephens, Tim, "Warming Waters and Souring Seas: Climate Change and Ocean Acidification" in Donald Rothwell et al (eds), Oxford Handbook on the Law of the Sea (Oxford: Oxford University Press, 2015) 777-798.

Olav Schram Stokke, "Conclusion" in Olav Schram Stokke (ed), Governing High Seas Fisheries. The Interplay of Global and Regional Regimes (Oxford: Oxford University Press, 2001) 329-360.

Stokke, Olav Schram, "Introduction” in Olav Schram Stokke (ed), Governing High Seas Fisheries. The Interplay of Global and Regional Regimes (Oxford: Oxford University Press, 2001) 1-19.

Stokke, Olav Schram, "International fisheries politics: from sustainability to precaution" in Steina Andresen, Elin Lerum Boasson \& Geir Honneland (eds), International Environmental Agreements: An Introduction (Abingdon, Oxon: Routledge, 2011) 97-116.

Stokke, Olav Schram, "Management Options for High Seas Fisheries: Making Regime Complexes More Effective" in Richard Caddell \& Erik Molenaar (eds), Strengthening International Fisheries Law in an Era of Changing Oceans (Oxford: Hart, 2019) 51-77. 
Stokke, Olav Schram \& Davor Vidas, “The Effectiveness and Legitimacy of International Regimes" in Olav Schram Stokke \& Davor Vidas (eds), Governing the Antarctic: The Effectiveness and Legitimacy of the Antarctic Treaty System (Cambridge: Cambridge University Press, 1996) 13-31.

Stone, Christopher, "Mending the Seas through a Global Commons Trust Fund" in Jon van Dyke, Durwood Zealke \& Grant Hewison (eds), Freedom for the 21st Century: Ocean Governance and Environmental Harmony (Washington: Island Press, 1993) 171-186.

Sydnes, Are, "Regional Fishery Organizations: How and Why Organizational Diversity Matters" (2001) 32:4 Ocean Development and international law 349-372.

Taekema, Sanne \& Bart van Klink, "On the Border. Limits and Possibilities of Interdisciplinary Research” in Sanne Taekema \& Bart van Klink (eds), Law and Method, Interdisciplinary Research into Law (Tübingen, Germany: Mohr Siebeck, 2010) 7-32.

Takei, Yoshinobu, "A Sketch of the Concept of Ocean Governance and Its Relationship with the Law of the Sea" in Cedric Ryngaert, Erik Molenaar \& Sarah Nouwen (eds), What's Wrong with International Law? Liber Amicorum A.H.A. Soons (Leiden: Brill Nijhoff, 2015) 48-62.

Takei, Yoshinobu, "Demystifying Ocean Governance” in Seline Trevisanut, Nikolaos Giannopoulos \& Rozemarijn Roland Holst (eds), Regime Interaction in Ocean Governance. Problems, Theories and Methods (Leiden: Brill Nijhoff, 2020) 22-51.

Tanaka, Yoshifumi, "Principles of international marine environmental law" in Rosemary Rayfuse (ed), Research Handbook on International Marine Environmental Law (Cheltenham: Edward Elgar, 2015) 31-56.

Telesetky, Anastasia, "Co-Regulation and the Role of Transnational Corporations as Subjects in Implementing International Environmental Law" in Andrew Byrnes, Mika Hayashi \& Christopher Michaelsen (eds), International Law in the New Age of Globalization (Brill: Leiden, 2013) 287-319.

Telesetsky, Anastasia, “'Good Faith' Obligations to Protect and Preserve the Marine Environment: A Proposal on Uniform High Seas Fisheries Management" in Clive Schofield, Seokwoo Lee \& Moon-Sang Kwon (eds), The Limits of Maritime Jurisdiction (Leiden: Brill, 2013) 449-471.

Tladi, Dire, "Conservation and sustainable use of marine biodiversity in areas beyond national jurisdiction: towards an implementing agreement" in Rosemary Rayfuse (ed), Research Handbook on International Marine Environmental Law (Chentenham: Edward Elgar, 2017) 259-271.

Toope, Stephen, "Emerging Patterns of Governance and International Law" in Michael Byers (ed), The role of law in international politics. Essays in international relations and international law (Oxford: Oxford University Press, 2000) 91-108.

Treves, Tulio, "Principles and Objectives of the Legal Regime Governing Areas Beyond National Jurisdiction" in Alex Oude Elferink \& Erik Molenaar (eds), The International Regime of Areas Beyond National Jurisdiction: Current and Future Developments (Leiden: Martinus Nijhoff, 2010) 5-25.

Trevisanut, Seline, "La Convention des Nations Unies sur le droit de la mer et le droit de l'environnement : développement intrasystémique et renvoi intersystémique" in Hélène Ruiz Fabri \& Lorenzo Gradoni (eds), La circulation des concepts juridiques : le droit international de l'environnement entre mondialisation et fragmentation (Sociéte区 de législation comparée: Paris, 2009) 397-426.

Trevisanut, Seline, "Is There Something Wrong with the Increasing Role of Private Actors? The Case of the Offshore Energy Sector" in Cedric Ryngaert, Erik Molenaar \& Sarah Nouwen (eds), What's Wrong with International Law? Liber Amicorum A.H.A. Soons (Leiden: Brill Nijhoff, 2015) 63-75.

Trevisanut, Seline, "The Role of Private Actors in Offshore Energy : Shifting models of participation" in Nigel Bankes \& Seline Trevisanut (eds), Energy From the Sea : An International Law Perspective on Ocean Energy (Leiden: Brill Nijhoff, 2015) 85-105. 
Trevisanut, Seline, Nikolaos Giannopoulos \& Rozemarijn Roland Holst, "Conclusion: Proposing a Three-Fold Approach to Regime Interaction in Ocean Governance" in Seline Trevisanut, Nikolaos Giannopoulos \& Rozemarijn Roland Holst (eds), Regime Interaction in Ocean Governance. Problems, Theories and Methods (Leiden: Brill Nijhoff, 2020) 222-234.

Underdal, Arild, "One Question, Two Answers" in Edward L. Miles et al (eds), Environmental regime effectiveness: confronting theory with evidence (Cambridge, Mass: MIT Press, 2002) 3-45.

van Asselt, Harro, "Legal and Political Approaches in Interplay management. Dealing with the Fragmentation of Global Climate Governance" in Sebastian Oberthür \& Olav Schram Stokke (eds), Managing Institutional Complexity. Regime Interplay and Global Environmental Change (Cambridge, Mass.: MIT Press, 2011) 59-85.

van Bohemen, Gerard, "High Seas Fisheries Management: reflections on Experience with Regional Fisheries management Organisations in the South Pacific" in Peter Johan Schei \& Davor Vidas (eds), The World Ocean in Globalisation: Climate Change, Sustainable Fisheries, Biodiversity, Shipping, Regional Issues (Leiden: Brill, 2011) 233-245.

van der Marel, Eva Romée, "An Opaque Blacklist: the Lack of Transparency in Identifying Non Cooperating Countries under the EU IUU Regulation" in Lawrence Martin, Constantinos Salonidis \& Christina Hioureas (eds), Natural Resources and the Law of the Sea. Exploration, Allocation, Exploitation of Natural Resources in Areas under National Jurisdiction and Beyond (New York: JurisNet, 2017) 237-256.

van der Marel, Eva Romée, "Problems and Progress in Combatting IUU Fishing" in Richard Caddell \& Erik Molenaar (eds), Strengthening International Fisheries Law in an Era of Changing Oceans (Oxford: Hart, 2019) 291-318.

Van Dyke, John M., Durwood Zaelke \& Grant Hewison, "A New Look at Ocean Governance" in John M. Van Dyke, Durwood Zaelke \& Grant Hewison (eds), Freedom for the Seas in the 21st century. Ocean governance and environmental harmony (Washington DC: Island Press Washington DC, 1993) 7-12.

van Erp, Judith et al, "Conclusion. Smart Mixes in Relation to Transboundary Environmental Harm" in Judith van Erp et al (eds), Smart Mixes for Transboundary Environmental Harm (Cambridge: Cambridge University Press, 2019) 329-343.

van Erp, Judith et al, "Introduction: The Concept of Smart Mixes for Transboundary Environmental Harm" in Judith van Erp et al (eds), Smart Mixes for Transboundary Environmental Harm (Cambridge: Cambridge University Press, 2019) 3-24.

Vidas, Davor \& Peter Johan Schei, “The World Ocean in Globalisation: Challenges and Responses for the Anthropocene Epoch" in Peter Johan Schei \& Davor Vidas (eds), The World Ocean in Globalisation. Climate Change, Sustainable Fisheries, Biodiversity, Shipping, Regional Issues (Leiden: Brill, 2011) 3-15.

Wakefield, Jill, “The Ecosystem Approach and the Common Fisheries Policy" in David Langlet \& Rosemary Rayfuse (eds) The Ecosystem Approach in Ocean Planning and Governance (Leiden: Brill Nijhoff, 2019) 288-316.

Warner, Robin, "Conservation and Management of Marine Living Resources Beyond National Jurisdiction: Filling the Gaps" in Robert Beckman et al (eds), High Seas Governance: Gaps and Challenges (Leiden: Brill, 2018) 179-194.

Watson, Alan, Legal Transplants: An Approach to Comparative Law, 2nd ed (Athens, Ga.: University of Georgia Press, 1993).

Wiener, Jonathan B., "Precaution" in Daniel Bodansky, Jutta Brunnee \& Ellen Hey (eds), Oxford Handbook of International Environmental Law (Oxford: Oxford University Press 2008) 597-612.

Yeeting, Agnes \& Simon Bush, "RFMO-MSC Smart Regulatory Mixes for Transboundary Tuna Fisheries" in Judith van Erp et al (eds), Smart Mixes for Transboundary Environmental Harm (Cambridge: Cambridge University Press, 2019) 146-169. 
Young, Margaret, "Introduction: The Productive Friction between Regimes" in Margaret Young (ed), Regime Interaction in International Law. Facing Fragmentation (Cambridge: Cambridge University Press, 2012) 1-20.

Yzquierdo, Marine, "The 1992 Convention on Biological Diversity" in Malgosia Fitzmaurice, Attila Tanzi \& Angeliki Papantoniou (eds), Multilateral Environmental Treaties (Cheltenham: Edward Elgar, 2017) 9-24.

\section{Journals and periodicals}

Agarwal, Sunil Kr., "Legal Issues in the Protection of Marine Biological Diversity Beyond National Jurisdiction" (2015) 11:1 Maritime Affairs: Journal of the National Maritime Foundation of India 84-98.

Agnew, David J. et al, "Estimating the Worldwide Extent of Illegal Fishing" (2009) 4:2 PLoS ONE $1-8$.

Ardron, Jeff et al, "Tracking twenty-four years of discussions about transparency in international marine governance: where do we stand?" (2014) 33 Stanford Environmental Law Journal 167-190.

Arnold, Craig Anthony \& Lance H. Gunderson, "Adaptive Law and Resilience" (2013) 43:5 Environmental Law Reporter News \& Analysis 10426-10443.

Ban, Natalie et al, "Better integration of sectoral planning and management approaches for the interlinked ecology of the open oceans" (2014) 49 Marine Policy 127-136.

Barnes, Richard, "Consolidating Governance Principles for Areas beyond National Jurisdiction Biological Diversity and Governance of Areas beyond National Jurisdiction" (2012) 27:2 International Journal of Marine and Coastal Law 261-290.

Barnes, Richard, “The Proposed LOSC Implementation Agreement On Areas Beyond National Jurisdiction and Its Impact on International Fisheries Law" (2016) 31:4 International Journal of Marine and Coastal Law at 583-619.

Barton, Allen, "Bringing society back in: Survey research and macro-methodology" (1968) 12:2 American Behavioral Scientist 1-9.

Berkes, Fikret et al, "Globalization, Roving Bandits, and Marine Resources" (2006) 311 Science 1557-1558.

Biermann, Frank \& Philipp Pattberg, "Global Environmental Governance: Taking Stock, Moving Forward” (2008) 33 Annual Review of Environment \& Resources 277-294.

Biermann, Frank, Olwen Davies \& Nicolien van der Grijp, "Environmental policy integration and the architecture of global environmental governance" (2009) 9 International Environmental Agreements 351-369.

Blanchard, Catherine, "Fragmentation in high seas fisheries: Preliminary reflections on a global oceans governance approach" (2017) 84 Marine Policy 327-332.

Blanchard, Catherine, Carole Durussel \& Ben Boteler, "Socio-ecological resilience and the law: Exploring the adaptive capacity of the BBNJ agreement" (2019) 108 Marine Policy article 103612.

Blasiak, Robert \& Nobuyuki Yagi, "Shaping an International Agreement on Marine Biodiversity Beyond Areas of National Jurisdiction: Lessons from High Seas Fisheries" (2016) 71 Marine Policy 210-216.

Bodin, Orjan \& Beatrice Crona, "The Role of Social Networks in Natural Resource Governance: What Relational Patterns Make a Difference?” (2009) 19 Marine Policy 366-374.

Bohman, Brita, "Regulatory control of adaptive fisheries: Reflections on the implementation of the landing obligation in the EU common fisheries policy" (2019) 110 Marine Policy article 103557. 
Boyle, Alan, "Further Development of the Law of the Sea Convention: Mechanisms for Change" (2005) 54 International and Comparative Law Quarterly 563-584.

Brooks, Cassandra et al, "Challenging the 'Right to Fish' in a Fast-Changing Ocean" (2014) 33:3 Stanford Environmental Law Journal 289-324.

Caddell, Richard, "Platforms, Protestors and Provisional Measures: The Arctic Sunrise Dispute and Environmental Activism at Sea" (2015) 45 Netherlands Yearbook of International Law 359-384.

Caddell, Richard, "Precautionary management and the development of future fishing opportunities: The international regulation of new and exploratory fisheries" (2018) 33 International Journal of Marine and Coastal Law 199-260.

Cheung, William, Reg Watson \& Daniel Pauly, "Signature of ocean warming in global fisheries catch" (2013) 497 Nature 365-368.

Christian, Claire et al, "A review of formal objections to marine stewardship council fisheries certifications" (2013) 161 Biological Conservation 10-17.

Chuenpagdee, Ratana \& Rashid Sumaila, "Fisheries governance and governability" (2011) 11:3 Fish and Fisheries 234.

Churchill, Robin, "Legal uncertainties in international high seas fisheries management" (1998) 37 Fisheries Research 225-237.

Churchill, Robin \& Geir Ulfstein, "Autonomous Institutional Arrangements in Multilateral Environmental Agreements: A Little-Noticed Phenomenon in International Law" (2000) 94:5 American Journal of International Law 623-659.

Clark, Elise Anne, "Strengthening Regional Fisheries Management - An analysis of the duty to cooperate" (2011) 9 New Zealand Journal of Public International Law 223-246.

Clark, Nichola A., "Institutional arrangements for the new BBNJ agreement: Moving beyond global, regional, and hybrid" (2020) Marine Policy article 104143.

Clark, Nichola A., Jeff A. Ardon \& Linwood H. Pendleton, "Evaluating the basic elements of transparency of regional fisheries management organizations" (2015) 57 Marine Policy 158-166.

Colburn, Jamison, “Turbot Wars: Straddling Stocks, Regime Theory, and a New UN Agreement” (1996-1997) 6:2 Transnational Law and Policy 323-366.

Cosens, Barbara A., "Legitimacy, Adaptation, and Resilience in Ecosystem Management" (2013) 18:1 Ecology and Society 3-11.

Cosens, Barbara et al, "The role of law in adaptive governance" (2017) 22:1 Ecology and Society article 30 .

Costantini, Marco, "The role of environmental non-governmental organizations in fisheries: scientific knowledge, its value in fisheries, and its underestimation in debates aimed at solving contingent issues" (2012) 11:3 Journal of Science Communication 1-3.

Cox, Michael, Gwen Arnold \& Sergio Villamayor Tomas, "A Review of Design Principles for Community-based Natural Resource Management" (2010) 15:4 Ecology and Society article 38.

Cremers, Klaudija, Glen Wright \& Julien Rochette, "Strengthening monitoring, control and surveillance of human activities in marine areas beyond national jurisdiction: Challenges and opportunities for an international legally binding instrument" (2020) Marine Policy article 103976.

Cullis-Suzuki, Sarika \& Daniel Pauly, "Failing the high seas: A global evaluation of regional fisheries management organizations" (2010) 34 Marine Policy 1036-1042.

de Bruyn, Paul, Hilario Murua \& Martin Aranda, "The Precautionary Approach to Fisheries Management: How This Is Taken Into Account by Tuna Regional Fisheries Management Organisations (RFMOs)" (2013) 38 Marine Policy 397-406.

DeCaro, Daniel et al, "Legal and Institutional Foundations of Adaptive Environmental Governance" (2017) 22:1 Ecology and Society article 32. 
de Castro Silveira, Paula \& Grace Ladeira Garbaccio, "Protest at Sea: the Arctic Sunrise Case and the clarification of Coastal States Rights" (2019) 40:81 Seqüência (Florianópolis) 32-46.

de Coning, Eve, "Why Are Some Flag States Unable or Unwilling to Address IUU Fishing?" (2020) 22 International Community Law Review 487-512.

De Lucia, Vito, "Rethinking the Conservation of Marine Biodiversity beyond National Jurisdiction: From 'Not Undermine' to Ecosystem-Based Governance" (2019) 8:4 ESIL Reflections.

De Santo, Elizabeth et al, "Stuck in the middle with you (and not much time left): The third intergovernmental conference on biodiversity beyond national jurisdiction" (2020) 117 Marine Policy article 103957.

Doremus, Holly, "Adaptive Management as an Information Problem" (2011) 89 North Carolina Law Review 1455-1498.

Downs, George, Kyle Danish \& Peter Barsoom, “The transformational model of international regime design: triumph of hope or experience?” (1999-2000) 38 Columbia Journal of Transnational Law 465-514.

Druel, Elizabeth \& Kristina Gjerde, "Sustaining marine life beyond boundaries: Options for an implementing agreement for marine biodiversity beyond national jurisdiction under the United Nations Convention on the Law of the Sea" (2014) 49 Marine Policy 90-97.

Duarte, Carlos et al, "Rebuilding Marine Life" (2020) 580 Nature 39-51.

Dunn, Daniel et al, "Empowering high seas governance with satellite vessel tracking" (2018) 19 Fish and Fisheries 729-739.

Ebbesson, Jonas, "The rule of law in governance of complex socio-ecological changes" (2010) 20 Global Environmental Change 414-422.

Ebbesson, Jonas \& Ellen Hey, "Introduction: Where in law is social-ecological resilience?" (2013) 18:3 Ecology and Society article 25.

Eilstrup-Sangiovanni, Mette \& Teale Phelps Bondaroff, "From Advocacy to Confrontation: Direct Enforcement by Environmental NGOs" (2014) 58:2 International Studies Quarterly 348-361.

Finkelstein, Lawrence, "What is Global Governance?” (1995) 1:4 Global Governance 367-372.

Fischer, Johanne, "How transparent are RFMOs? Achievements and challenges" (2020) Marine Policy article 104106.

Fisher, Elizabeth et al, "Maturity and Methodology: Starting a Debate about Environmental Law Scholarship" (2009) 21:2 Journal of Environmental Law 213-250.

Folke, Carl, "Resilience: the emergence of a perspective for social-ecological systems analyses" (2006) 16 Global Environmental Change 253-267.

Franck, Thomas M., "Legitimacy in the International System" (1998) 82 American Journal of International Law 705-759.

Freestone, David, "Principles Applicable to Modern Ocean Governance" (2008) 23 International Journal of Marine and Coastal Law 385-391.

Freestone, David, "Modern Principles of High Seas Governance - The Legal Underpinnings" (2009) 39-1 Environmental Policy and Law 44-49.

Freestone, David, "The Limits of Sectoral and Regional Efforts to Designate High Seas Marine Protected Areas" (2018) 112 AJIL Unbound 129-133.

Friedman, Andrew, "Beyond 'not undermining': possibilities for global cooperation to improve environmental protection in areas beyond national jurisdiction” (2019) 76:2 ICES Journal of Marine Science 452-456.

Friedman, Kim, Serge Garcia \& Jake Rice, "Mainstreaming Biodiversity in Fisheries" (2018) 95 Marine Policy 209-220. 
Garcia, Serge, “The Precautionary Principle: its Implications in Capture Fisheries Management” (1994) 22 Ocean and Coastal Management 99-125.

Gillepsie, Alexander, "Noise Pollution, the Oceans, and the Limits of International Law" (2010) 21:1 Yearbook of International Environmental Law 114-139.

Gjerde, Kristina et al, "Ocean in Peril: Reforming the Management of Global Ocean Living Resources in Areas Beyond National Jurisdiction” (2013) 74:2 Marine Pollution Bulletin 540-551.

Gjerde, Kristina \& Anna Rulska-Domino, "Marine Protected Areas Beyond National Jurisdiction: some Practical Perspectives for Moving Ahead" (2012) 27 International Journal of Marine and Coastal Law 351-373.

Gjerde, Kristina M., Nichola A. Clark \& Harriet R. Harden-Davies, "Building a Platform for the Future: the Relationship of the Expected New Agreement for Marine Biodiversity in Areas beyond National Jurisdiction and the UN Convention on the Law of the Sea" (2019) 33 Ocean Yearbook 3-44.

Goodman, Camille, "The regime for flag State responsibility in international fisheries law Effective fact, creative fiction, or further work required?" (2009) 23 Australia \& New Zealand Maritime Law Journal 157-169.

Grote Stoutenburg, Jenny, "Implementing a New Regime of Stable Maritime Zones to Ensure the (Economic) Survival of Small Island States Threatened by Sea-Level Rise" (2011) 26:2 International Journal of Marine and Coastal Law 263-312.

Guggisberg, Solene, "Recent developments to improve compliance with international fisheries law” (2017) 42 L'Observateur des Nations Unies 145-175.

Guggisberg, Solene, "Funding coastal and marine fisheries projects under the climate change regime” (2019) 107 Marine Policy article 103352.

Guggisberg, Solene, "The roles of nongovernmental actors in improving compliance with fisheries regulations" (2019) 28:3 Review of European and Comparative International and Environmental Law 314-327.

Guggisberg, Solène, "Independent, Compulsory, and Centralized verification of States' Obligations in Fisheries: Can the IMO Audit Scheme for Shipping Law Be Used as an Example to Follow?" (2020) 22 International Community Law Review 513-531.

Gunningham, Neil, "Environment Law, Regulation and Governance: Shifting Architectures" (2009) 21:2 Journal of Environmental Law 179-212.

Gunningham, Neil, “The New Collaborative Environmental Governance: The Localization of Regulation" (2009) 36:1 Journal of Law and Society 145-166.

Gunningham, Neil \& Darren Sinclair, "Regulatory Pluralism: Designing Policy Mixes for Environmental Protection" (1999) 21:1 Law \& Policy 49-76.

Haas, Peter M., "Introduction: epistemic communities and international policy coordination" (1992) 46:1 International Organization 1-35.

Harden-Davies, Harriet et al, "Rights of Nature: Perspectives for Global Ocean Stewardship" (2020) Marine Policy article 104059.

Hardin, Garrett, “The Tragedy of the Commons" (1968) 3859 Science 1243-1248.

Harrison, James, "International Transparency Obligations in Fisheries Conservation and Management: Inter-State and Intra-State Dimensions" (2020) Marine Policy article 104105.

Heidingsfelder, Jens \& Markus Beckmann, "A governance puzzle to be solved? A systematic literature review of fragmented sustainability governance" (2019) Management Quarterly Review.

Hoey, Laura, "The Battle over Scientific Whaling: A New Proposal to Stop Japan's Lethal Research and Reform the International Whaling Commission" (2017) 41 William \& Mary Environmental Law \& Policy Review 435-470. 
Holley, Cameron, "Linking law and new governance: examining gaps, hybrids, and integration in water policy" (2016) 38:1 Law \& Policy 24-53.

Holling, Crawford Stanley, "Resilience and stability of ecological systems" (1973) 4 Annual Review of Ecological Systems 1-23.

Hollway, James \& Johan Koskinen, "Multilevel Embeddedness: The Case of Global Fisheries Governance Complex" (2016) 44 Social Networks 281-294.

Houghton, Katherine, "Identifying New Pathways for Ocean Governance: The Role of Legal Principles in Areas Beyond National Jurisdiction" (2014) 49 Marine Policy 118-126.

Jamieson, Alan et al, "Bioaccumulation of persistent organic pollutants in the deepest ocean fauna" (2017) 1 Nature Ecology and Evolution article number 0051.

Jaques, Peter \& Rafaella Lobo, "The Shifting Context of Sustainability: Growth and The World Ocean Regime" (2018) 18:4 Global Environmental Politics 85-106.

Juan-Jorda囚, Maria José et al, "Report card on ecosystem-based fisheries management in tuna regional fisheries management organizations" (2018) 19:2 Fish and Fisheries 321-339.

Juda, Lawrence \& Timothy Hennessey, "Governance Profiles and the Management of the Uses of Large Marine Ecosystems" (2001) 32 Ocean Development and International Law 43-69.

Kalfagianni, Agni \& Philipp Pattberg, "Global fisheries governance beyond the state: unraveling the effectiveness of the Marine Stewardship Council" (2013) 3:2 Journal of Environmental Studies and Sciences 184-193.

Kanehara, Atsuko, "What Does a New International Legally Binding Instrument on Marine Biological Diversity of Areas Beyond National Jurisdiction 'under the UNCLOS' Mean?" (2016) 59:4 Sophia Law Journal 53-73.

Karkkainen, Bradley C., "Post-Sovereign Environmental Governance" (2004) 4:1 Global Environmental Politics 72-96.

Kennedy, David, "The Mystery of Global Governance" (2008) 34 Ohio Northern University Law Review 827-860.

Kim, Rakhyun E. \& Klaus Bosselman, "International Environmental Law in the Anthropocene: Towards a Purposive System of Multilateral Environmental Agreements" (2013) 2:2 Transnational Environmental Law 285-309.

Kim, Rakhyun E. \& Brendan Mackay, "International Environmental Law as a Complex Adaptive System” (2014) 14 International Environmental Agreements 5-24.

Kirk, Elizabeth A., "Marine Governance, Adaptation, and Legitimacy" (2011) 22:1 Yearbook of international environmental law 110-139.

Kohler Gary, Luis, "El mar presencial de Chile, su desafiao actual" (2001) 118:862 Revista de Marina 251-257.

Kornhauser, Lewis A., "Governance Structures, Legal Systems, and the Concept of Law" (2004) 79:2 Chicago-Kent Law Review 355-381.

Koskenniemi, Martti, "International Legislation Today: Limits and Possibilities" (2005) 23 Wisconsin International Law Journal 61-92.

Kotzé, Louis \& Rakhuyn Kim, "Earth system law: The juridical dimensions of earth system governance" (2019) 1 Earth System Governance article 100003.

Krasner, Stephen D., "Structural causes and regime consequences: regimes as intervening variables" (1982) 36:2 International Organization 185-205.

Kroodsma, David A. et al, "Tracking the global footprint of fisheries" (2018) 359:6378 Science 904-908.

Leal-Arcas, Rafael, "Sustainability, Common Concern and Public Goods" (2017) 49 George Washington International Law Review 801-877. 
Mahon, Robin \& Lucia Fanning, "Regional Ocean Governance: Integrating and Coordinating Mechanisms for Polycentric Systems" (2019) 107 Marine Policy article 103589.

Matz-Lück, Nele \& Johannes Fuchs, "The impact of OSPAR on protected area management beyond national jurisdiction: Effective cooperation or a network of paper parks?” (2014) 49 Marine Policy 155-166.

Mayrand, Hélène, "Déconstruire et repenser les fondements du droit international de l'environnement" (2018) Hors-Série Revue québécoise de droit international 35-59.

Meltzer, Evelyne, "Global Overview of Straddling and Highly Migratory Fish Stocks: Maps and Charts Detailing RFMO Coverage and Implementation" (2005) 20:3-4 International Journal of Marine and Coastal Law 571-604.

M'Gonigle, Michael \& Louise Takeda, "The Liberal Limits of Environmental Law: A Green Legal Critique" (2013) 30:3 Pace Environmental Law Review 1005-1115.

M'Gonigle, Michael \& Paula Ramsay “Greening Environmental Law: From Sectoral Reform to Systemic Re-Formation” (2004) 17 Journal of Environmental Law and Policy 333-356.

Molenaar, Erik, "Ecosystem-Based Fisheries Management, Commercial Fisheries, Marine Mammals and the 2001 Reykjavik Declaration in the Context of International Law" (2001) 17:4 International Journal of Marine and Coastal Law 561-595.

Molenaar, Erik, "Port State Jurisdiction: Toward Comprehensive, Mandatory and Global Coverage" (2007) 38:1-2 Ocean Development \& International Law 225-257.

Molenaar, Erik, "Non-Participation in the Fish Stocks Agreement: Status and Reasons" (2011) 26 International Journal of Marine and Coastal Law 195-234.

Molenaar, Erik, "Current and Prospective Roles of the Arctic Council System within the Context of the Law of the Sea" (2012) 27:3 International Journal of Marine \& Coastal Law 553-595.

Mossop, Joanna \& Clive Schofield, "Adjacency and due regard: The role of coastal States in the BBNJ treaty" (2020) Marine Policy article 103877.

Myers, Ransom A., Jeffrey A. Hutchings \& Nicholas J. Barrowman, "Why do Fish Stocks Collapse? The Example of Cod in Atlantic Canada" (1997) 7:1 Ecological Applications 91-106.

Nilsson, Mans, Marc Pallemaerts \& Ingmar von Homeyer, "International regimes and environmental policy integration: introducing the special issue" (2009) 9:4 International environmental agreements 337-369.

Noto, Maria Chiara, "The Arctic Sunrise Arbitration and Acts of Protest at Sea" (2016) 2 Maritime Safety and Security Law Journal 36-56.

Oberthür, Sebastian, "Interplay Management: enhancing environmental policy integration among international institutions" (2009) 9 International Environmental Agreements 371-391.

Okonkwo, Theodore, "Managing the Ocean Commons Beyond National Jurisdiction" (2016) 2 China Oceans Law Review 56-82.

Orrego, Vicuña Francisco, "The Law governing High Seas Fisheries: in search of new principles" (2004) 18:1 Ocean Yearbook 383-394.

Orellana, Marcos, "The EU and Chile Suspend the Swordfish Case Proceedings at the WTO and the International Tribunal of the Law of the Sea" (2001) 6:1 AJIL Insights.

Ortuño Crespo, Guillermo et al, "High-seas fish biodiversity is slipping through the governance net” (2019) 3 Nature Ecology \& Evolution 1273-1276.

Ortuño Crespo, Guillermo et al, "Beyond static spatial management: Scientific and legal considerations for dynamic management in the high seas" (2020) Marine Policy article 104102.

Ostrom, Elinor, “Crossing the Great Divide: Coproduction, Synergy, and Development" (1996) 224:6 World Development 1073-1087.

Ostrom, Elinor, “A Long Polycentric Journey" (2010) 13:1 Annual Review of Political Science 1-23. 
Ostrom, Elinor, "Beyond Markets and States: Polycentric Governance of Complex Economic Systems" (2010) 100:3 The American Economic Review 641-672.

Oude Elferink, Alex, "Environmental Impact Assessments in Areas beyond National Jurisdiction" (2012) 27:2 International Journal of Marine and Coastal Law 449-480.

Oude Elferink, Alex, "Governance Principles for Areas Beyond National Jurisdiction” (2012) 27:2 International Journal of Marine and Coastal Law 205-259.

Oude Elferink, Alex, "The Russian Federation and the Arctic Sunrise Case: Hot Pursuit and Other Issues under the LOSC” (2016) 92 International Law Studies 381-406.

Oude Elferink, Alex, "Coastal States and MPAs in ABNJ: Ensuring Consistency with the LOSC" (2018) 33 International Journal of Marine and Coastal Law 437-466.

Oude Elferink, Alex, "Exploring the future of the institutional landscape of the oceans beyond national jurisdiction" (2019) 28:3 Review of European and Comparative International Environmental Law 236-243.

Palmer, Geoffrey, "New Ways to Make International Environmental Law" (1992) 86 American Journal of International Law 259-283.

Papastavridis, Efthymios, "A recent overview of the three sessions of the IGC can be found in The Negotiations for a New Implementing Agreement under the UN Convention on the Law of the Sea Concerning Marine Biodiversity" (2020) 69 International and Comparative Law Quarterly 585-610.

Pauly, Daniel \& Dirk Zeller, "Catch reconstruction reveals that global marine fisheries catches are higher than reported and declining" (2016) Nature Communications 1-9.

Payne, Cymie, "Introduction to the Symposium on Governing High Seas Biodiversity" (2018) 112 AJIL Unbound 118-122.

Payne, Cymie R., "Negotiation and Dispute Prevention in Global Cooperative Institutions: International Community Interests, IUU Fishing, and the Biodiversity Beyond National Jurisdiction Negotiation" (2020) 22 International Community Law Review 428-438.

Petersson, Matilda et al, "Patterns and trends in non-state actor participation in regional fisheries management organizations” (2019) 104 Marine Policy 146-156.

Pintassilgo, Pedro et al, "Stability and Success of Regional Fisheries Management Organizations" (2010) 46:3 Environmental and Resource Economics 377-402.

Platjouw, Froukje Maria, "Dimensions of transboundary legal coherence needed to foster ecosystem-based governance in the Arctic" (2019) 110 Marine Policy article 103666.

Poto, Margherita Paola \& Lara Fornabaio, "Participation as the Essence of Good Governance: Some General Reflections and a Case Study on the Arctic Council" (2017) 8 Arctic Review on Law and Politics 137-157.

Rayfuse, Rosemary, "Countermeasures and high seas fisheries enforcement" (2004) 51:1 Netherlands International Law Review 41-76.

Rayfuse, Rosemary, “To Our Children's Children's Children: From Promoting to Achieving Compliance in High Seas Fisheries" (2005) 20 International Journal of Marine \& Coastal Law 509-532.

Rayfuse, Rosemary, "The Role of Law in the Regulation of Fishing Activities in the Central Arctic Ocean” (2019) 110 Marine Policy article 103562.

Rayfuse, Rosemary \& Robin Warner, "Securing a Sustainable Future for the Oceans Beyond National Jurisdiction: The Legal Basis for an Integrated Cross-Sectoral Regime for High Seas Governance for the 21st Century" (2008) 23:3 International Journal of Marine and Coastal Law 399-421.

Ruhl, J.B., "Regulation by adaptive management - Is it Possible?" (2005) 7:1 Minnesota Journal of Law, Science \& Technology 21-57. 
Sala, Enric et al, "The economics of fishing the high seas" (2018) 4:8 Science Advances.

Sand, Peter H., "Sovereignty Bounded: Public Trusteeship for Common Pool Resources?” (2004) 4:1 Global Environmental Politics 47-71.

Scanlon, Zoey, "The art of 'not undermining': possibilities within existing architecture to improve environmental protections in areas beyond national jurisdiction” (2018) 75:1 ICES Journal of Marine Science 405-416.

Schatz, Valentin, "Marine Fisheries Law Enforcement Partnerships in Waters under National Jurisdiction: The Legal Framework for Inter-State Cooperation and Public-Private Partnerships with Non-governmental Organizations and Private Security Companies" (2018) 32 Ocean Yearbook 329-375.

Scheiber, Harry N., "Ocean Governance and the Marine Fisheries Crisis. Two Decades of Innovation - And Frustration" (2001) 20 Virginia Environmental Law Journal 119-138.

Scovazzi, Tullio, "Negotiating conservation and sustainable use of marine biological diversity in areas beyond national jurisdiction: prospects and challenges" (2014) 24 The Italian Yearbook of International Law 63-93.

Sebenius, James K., "Challenging conventional explanations of international cooperation: negotiation analysis and the case of epistemic communities" (1992) 46:1 International Organization 323-365.

Smouts, Marie-Claude, “The proper use of governance in international relations" (1998) 50:155 International Social Science Journal 81-89.

Sovacool, Benjamin K., "A Game of Cat and Fish: How to Restore the Balance in Sustainable Fisheries Management" (2009) 40 Ocean Development and International Law 97-125 at 98.

Spijkers, Otto \& Natalia Jevglevskaja, "Sustainable Development and High Seas Fisheries" (2013) 9:1 Utrecht Law Review 24-37.

Sumaila, U. Rashid, "How to make progress in disciplining overfishing subsidies" (2013) 70:2 ICES Journal of Marine Science 251-258.

Sumaila, U. Rashid et al, "Winners and losers in a world where the high seas is closed to fishing" (2015) 5 Scientific Reports article number 8481.

Tanaka, Yoshifumi, “The Changing Approaches to Conservation of Marine Living Resources in International Law" (2011) 71 Zeitschrift fuer Auslaendisches Oeffentliches Recht und Voelkerrecht 291-330.

Tanaka, Yoshifumi, "Reflections on the Implications of Environmental Norms for Fishing: The Link between the Regulation of Fishing and the Protection of Marine Biological Diversity" (2020) 22 International Community Law Review 389-409.

Tickler, David et al, "Far from home: Distance patterns of global fishing fleets" (2018) 4:8 Sciences Advances 1-6.

Tladi, Dire, “The Proposed Implementing Agreement: Options for Coherence and Consistency in the Establishment of Protected Areas Beyond National Jurisdiction" (2015) 30:4 International Journal of Marine and Coastal Law 654-673.

Trevisanut, Seline, "The Role of Private Actors in Offshore Energy: Shifting Models of Participation" (2014) 29:4 International Journal of Marine \& Coastal Law 645-665.

Underdal, Arild "The Concept of Regime "Effectiveness"' (1992) 27 Cooperation and Conflict 227-240.

VanderZwaag, David, "The Precautionary Principle and Marine Environmental Protection: Slippery Shores, Rough Seas, and Rising Normative Tides" (2002) 33:2 Ocean Development \& International Law 165-188.

van Hoof, Luc, "Fisheries management, the ecosystem approach, regionalisation and the elephants in the room" (2015) 60 Marine Policy 20-26. 
van Reenen, W., "Rules of Reference in the New Convention on the Law of the Sea, in particular in Connection with the Pollution of the Sea by Oil from Tankers" (1981) 3 Netherlands Yearbook of International Law 13-16.

Vidas, Davor, Jan Zalasiewicz \& Mark Williams, "What Is the Anthropocene-and Why Is It Relevant for International Law?” (2014) 25:1 Yearbook of International Environmental Law 3-23.

Vigneron, Giselle, 'The Most Recent Efforts in the International Community to Implement the 1995 United Nations Straddling Fish Stocks Agreement' (1999) 10 Colorado Journal of International Environmental Law and Policy 225-245.

Walker, Brian et al, "Resilience, Adaptability and Transformability in Social-ecological Systems" (2004) 9:2 Ecology and Society article 5.

Warner, Robin, "Strengthening Governance Frameworks for Conservation and Sustainable Use of Marine Biodiversity in Areas Beyond National Jurisdiction: Southern Hemisphere Perspectives" (2017) 32 International Journal of Marine \& Coastal Law 607-634.

Webster, D.G., "International Fisheries: Assessing the Potential for Ecosystem Management" (2013) 3:2 Journal of Environmental Studies and Sciences 169-183.

White, Crow \& Christopher Costello, "Close the High Seas to Fishing?" (2014) 12:3 PLOS Biology.

Wiersema, Annecoos, "Uncertainty, Precaution, and Adaptive Management in Wildlife Trade" (2015) 36 Michigan Journal of International Law 375-424.

Williams, Rob et al, "Impacts of Anthropogenic Noise on Marine Life: Publication Patterns, New Discoveries, and Future Directions in Research and Management" (2015) 115 Ocean and Coastal Management 17-24.

Wilson, David Sloan, Elinor Ostrom \& Michael E. Cox, "Generalizing the Core Designs Principles for the Efficacy of Groups" (2013) 90S Journal of Economic Behavior \& Organization 21-32.

Wolfrum, Rudiger \& Nele Matz, “The Interplay between UNCLOS and CBD” (2000) 4 Max Planck United Nations Yearbook 445-480.

Wright, Glen et al, "Marine spatial planning in areas beyond national jurisdiction" (2019) Marine Policy.

Young, Margaret, "Fragmentation or Interaction: the WTO, Fisheries Subsidies and International Law" (2009) 8:4 World Trade Review 477-515.

Young, Margaret A. \& Andrew Friedman, "Biodiversity Beyond National Jurisdiction: Regimes and their Interaction" (2018) 112 AJIL Unbound 123-128.

Young, Michaela, "Then and Now: Reappraising Freedom of the Seas in Modern Law of the Sea" (2016) 47:2 Ocean Development and International Law 165-185.

Young, Oran, "Building an international regime complex for the Arctic: current status and next steps" (2012) 2:2 The Polar Journal 391-407.

\section{Max Planck Encyclopedias of Public International Law}

Bothe, Michael, "Compliance" (2010) Max Planck Encyclopedias of Public International Law.

Brown Weiss, Edith \& Ahila Sornarajah, “Good Governance” (2013) Max Planck Encyclopedia of Public International Law.

Friedrich, Jürgen, "Environment, Private Standard-Setting" (2009) Max Planck Encyclopedia of Public International Law.

Koivurova, Timo, "Due diligence" (2010) Max Planck Encyclopedia of International Law.

Ladeur, Karl-Heinz, "Theory of Governance" (2010) Max Planck Encyclopedia of Public International Law.

Matz-Luck, Nele, "Treaties, Conflict Clause" (2006) Max Planck Encyclopedia of Public International Law. 
Sand, Peter H., "Endangered Species, International Protection" (2017) Max Planck Encyclopedia of Public International Law.

Schröder, Meinhard, "Precautionary Approach/Principle" (2014) Max Planck Encyclopedia of Public International Law.

Wolfrum, Rüdiger, "Legitimacy in International Law" (2006) Max Planck Encyclopedia of Public International Law.

Wolfrum, Rüdiger, "Cooperation, International Law of" (2010) Max Planck Encyclopedia of Public International Law.

Wolfrum, Rudiger, "General International Law (Principles, Rules, and Standards)" (2010) Max Planck Encyclopedia of Public International Law.

\section{Reports and other documents from intergovernmental entities and agencies}

\section{Food and Agriculture Organization (FAO)}

Ceo, Marika et al, "Performance Reviews by Regional Fishery Bodies: Introduction, summaries, synthesis and best practices, Volume I: CCAMLR, CCSBT, ICCAT, IOTC, NAFO, NASCO, NEAFC" (2012) FAO Fisheries and Aquaculture Circular No.1072, online: <http://www.fao.org/ docrep/015/i2637e/i2637e00.pdf>.

FAO, "20 years Looking Back: The Journey so Far" (2019) RSN Magazine No 18, online: <http:// www.fao.org/3/ca3925en/ca3925en.pdf>.

FAO, “4. Fisheries Management - Technical Guidelines for Responsible Fisheries” (1997), online: $<$ http://www.fao.org/3/w4230e/w4230e00.htm>.

FAO, "Deep-sea Fisheries in the High Seas. Ensuring sustainable use of marine resources and the protection of vulnerable marine ecosystems" (2009), online: <http://www.fao.org/3/i1064e/ i1064e00.pdf>.

FAO, "Fisheries Management. 2. The Ecosystem Approach to Fisheries" (2003) FAO Technical Guidelines for Responsible Fisheries No. 4 Suppl. 2, online: <http://www.fao.org/3/a-y4470e.pdf>.

FAO, "Fisheries Management. 2. The ecosystem approach to fisheries. 2.2 Human dimensions of the ecosystem approach to fisheries" (2009) FAO Technical Guidelines for Responsible Fisheries No. 4 Suppl. 2 Add. 2, online: <http://www.fao.org/docrep/012/i1146e/i1146e00.pdf>.

FAO, "Fisheries Management. 4. Marine Protected Areas and Fisheries" (2011) FAO Technical Guidelines for Responsible Fisheries, online: <http://www.fao.org/3/a-i2090e.pdf>.

FAO, "Fishing operations" (1996) FAO Technical Guidelines for Responsible Fisheries, online: $<$ http://www.fao.org/3/a-w3591e.pdf>.

FAO, "Precautionary approach to capture fisheries and species introductions" (1996) FAO Technical Guidelines for Responsible Fisheries, online: <http://www.fao.org/3/a-w3592e.pdf >.

FAO, "Report of the Expert Consultation on Flag State Performance" (2009) FAO Fisheries and Aquaculture Report No. 918, online: <http://www.fao.org/tempref/docrep/fao/012/i1249e/ i1249e00.pdf>.

FAO, "Report of the Reykjavik Conference on Responsible Fisheries in the Marine Ecosystem" (2001) FAO Fisheries Report No. 658, online: <http://www.fao.org/fishery/docs/DOCUMENT/ reykjavik/y2198t00_dec.pdf>.

FAO, "Responsible fish trade" (2009) FAO Technical Guidelines for Responsible Fisheries, online: $<$ http://www.fao.org/3/a-i0590e.pdf >

FAO, "The State of World Fisheries and Aquaculture 1996. Contributing to food security and nutrition for all" (1996) at 6, online: <http://www.fao.org/3/w3265e/W3265E.htm>.

FAO, "The State of World Fisheries and Aquaculture 2016. Contributing to food security and nutrition for all" (2016), online: <http://www.fao.org/3/a-i5555e.pdf>. 
FAO, "The State of World Fisheries and Aquaculture 2020. Sustainability in action" (2020) at vivii, online: <http://www.fao.org/state-of-fisheries-aquaculture >.

Garcia, Serge et al, "The ecosystem approach to fisheries. Issues, terminology, principles, institutional foundations, implementation and outlook" (2003) FAO Fisheries Technical Paper No 443 .

Hey, Ellen et al, "The regulation of driftnet fishing on the high seas: legal issues" (1991) FAO legislative study 47.

Munro, Gordon, Annick van Houtte \& Rolf Willmann, "The conservation and management of shared fish stocks: legal and economic aspects" (2004) FAO Fisheries Technical Paper No. 465.

Swan, Judith, "Fishing Vessels operating under open registers and the exercise of flag State responsibilities. Information and options" (2002) FAO Fisheries Circular No. 980, online: $<$ http://www.fao.org/3/y3824e/y3824e00.htm\#Contents >.

Szigeti, Péter D. \& Gail L. Lugten, “The implementation of performance review reports by regional fishery bodies, 2004-2014" (2015) FAO Fisheries and Aquaculture Circular No. 1108.

\section{Intergovernmental Oceanographic Commission of the United Nations Educational, Scientific and Cultural Organisation (UNESCO-IOC)}

Mahon, Robin et al, "Transboundary Waters Assessment Programme (TWAP) Assessment of Governance Arrangements for the Ocean. Volume 2: Areas Beyond National Jurisdiction" (2015) UNESCO-IOC Technical Series 119.

\section{Intergovernmental Panel on Climate Change (IPCC)}

IPCC, "Special Report on the Ocean and Cryosphere in a Changing Climate - Summary for Policymakers" (2019), online: <https://www.ipcc.ch/site/assets/uploads/sites/3/2019/11/03_ SROCC_SPM_FINAL.pdf>.

\section{Intergovernmental Science-Policy Platform on Biodiversity and Ecosystem Services (IPBES)}

IPBES, "Summary for Policymakers of the IPBES Global Assessment Report on Biodiversity and Ecosystem Services" (2019), para B1: online: <https://ipbes.net/sites/default/files/inline/files/ ipbes_global_assessment_report_summary_for_policymakers.pdf $>$.

\section{Organisation for Economic Co-operation and Development (OECD)}

Girard, Pierre \& Thomas Du Payrant, "An inventory of new technologies in fisheries. Challenges and opportunities in using new technologies to monitor sustainable fisheries" (2017) OECD Issue paper, online: <https://www.oecd.org/greengrowth/GGSD_2017_Issue\%20Paper_ New\%20technologies\%20in\%20Fisheries_WEB.pdf $>$.

Hutniczak, Barbara, Claire Delpeuch \& Antonia Leroy, "Closing Gaps in National Regulations Against IUU Fishing" (2019) OECD Food, Agriculture and Fisheries Papers No. 120.

OECD, "Regulatory Policies in OECD Countries: From Interventionism to Regulatory Governance" (2002) OECD Reviews of Regulatory Reform.

\section{Sargasso Sea Commission}

Sargasso Sea Commission, Work Programme Priorities (2016-2018), Doc SSC/2017/3/Doc.1, online: <http://www.sargassoseacommission.org/storage/NEW_Horta_Updated_Work_Plan_ 2016-18.pdf $>$. 


\section{United Nations Environment Programme (UNEP)}

Billé, Raphaël et al, "Regional Oceans Governance. Making Regional Seas Programmes, Regional Fishery Bodies and Large Marine Ecosystem Mechanisms Work Better Together" (2016) UNEP Regional Seas Report and Studies No 196.

Campbell, Darius et al, "Regional Seas programmes covering Areas Beyond National Jurisdictions" (2017) UNEP Regional Seas Reports and Studies No.202.

UNEP, “Realizing Integrated Regional Oceans Governance - Summary of case studies on regional cross-sectoral institutional cooperation and policy coherence" (2017) UNEP Regional Seas Reports and Studies No. 199.

\section{Reports and others documents from think tanks, non-governmental organizations, private organizations and research institutes}

Anderson, James L. et al, "Principles for Fisheries Management in Areas Beyond National Jurisdiction-the Essential Role of Incentive-Based Approaches" (2018), online: <https:// www.worldwildlife.org/publications/principles-for-fisheries-management-in-areas-beyondnational-jurisdiction-the-essential-role-of-incentive-based-approaches $>$.

Asmundsson, Stefan, "Regional Fisheries Management Organisations (RFMOs): Who are they, what is their geographic coverage on the high seas and which ones should be considered as General RFMOs, Tuna RFMOs and Specialised RFMOs?" (2016) CBD Meeting Documents, Sustainable Ocean Initiative (SOI) Global Dialogue with Regional Seas Organizations and Regional Fisheries Bodies on Accelerating Progress Towards the Aichi Biodiversity Targets, online: $<$ https://www.cbd.int/doc/meetings/mar/soiom-2016-01/other/soiom-2016-01-fao-19-en. pdf $>$.

Ardron, Jeff et al, "Advancing governance of the High Seas" (2013) IASS Policy Brief 1/2103

Battle, Jessica, “Not Undermining' is a Two-Way Street" (2019) WWF BBNJ Briefing Paper No. 3.

Cheung, William, Vicky Lan \& Collette Wabnitz, "Future scenarios and projections for fisheries on the high seas under changing climate" (2019) IIED Working Paper.

Cremers, Klaudija et al, "A preliminary analysis of the draft high seas biodiversity treaty" (2020) IDDRI Study No 01/20.

Cremers, Klaudija, Glen Wright \& Julien Rochette, "Strengthening Monitoring, Control and Surveillance in Areas Beyond National Jurisdiction” (2020) STRONG High Seas Project.

Currie, Duncan \& Mischa Davis, "Governance Principles Relevant to Marine Biodiversity in Areas Beyond National Jurisdiction. Submission to the Chair of the Third Session of the BBNJ Preparatory Committee" (25 February 2016), online: <https://www.un.org/depts/los/ biodiversity/prepcom_files/greenpeace.pdf>.

Davis, John, "Monitoring Control Surveillance and Vessel Monitoring System Requirements to Combat IUU Fishing" (2000) Document AUS:IUU/2000/14, online: <http://www.fao.org/3/ y3274e/y3274e0g.htm>.

de Haan, D. et al, "The effect of pulse stimulation on biota-Research in relation to ICES adviceProgress report on the effects on cod" (2008) IMARES Report C098/08.

Dunn, Daniel et al, "Adjacency: How legal precedent, ecological connectivity, and traditional knowledge inform our understanding of proximity" (2017) Nereus Scientific \& Technical Briefs on ABNJ series.

Durussel, Carole et al, "Strengthening Regional Ocean Governance for the High Seas: Opportunities and Challenges to Improve the Legal and Institutional Framework of the Southeast Atlantic and Southeast Pacific" (2018) STRONG High Seas Project. 
Ehler, Charles \& Fanny Douvere, "Marine spatial planning: a step-by-step approach toward ecosystem-based management" (2009) Intergovernmental Oceanographic Commission Manual and Guides No 53.

"Foreword by the Secretary-General of the United Nations" in Stephen Stec and Susan Casey-Lefkowitz in collaboration with Jerzy Jendroska (eds), The Aarhus Convention: An Implementation Guide (United Nations, New York and Geneva, 2000), online: <https://www. unece.org/fileadmin/DAM/env/pp/acig.pdf $>$.

Gianni, Matthew et al, "How Much Longer Will it Take? A ten-year review of the implementation of United Nations General Assembly Resolution 61/105, 64/72 and 66/68 on the management of bottom fisheries in areas beyond national jurisdiction" (2016) Deep Sea Conservation Coalition.

Gianni, Matthew \& Walt Simpson, "The Changing Nature of High Seas Fishing: how flags of convenience provide cover for illegal, unreported and unregulated fishing" (2005), online: $<$ http://assets.wwf.org.uk/downloads/flagsofconvenience.pdf $>$.

Gjerde, Kristina et al, "Options for Addressing Regulatory and Governance Gaps in the International Regime for the Conservation and Sustainable Use of Marine Biodiversity in Areas beyond National Jurisdiction" (2008) IUCN Environmental Policy and Law Papers.

Gjerde, Kristina et al, "Regulatory and governance gaps in the international regime for the conservation and sustainable use of marine biodiversity in areas beyond national jurisdiction" (2008) IUCN Marine Series no 1.

Gjerde, Kristina et al, "Conservation and Sustainable Use of Marine Biodiversity in Areas Beyond National Jurisdiction: Options for Underpinning a Strong Global BBNJ Agreement through Regional and Sectoral Governance" (2018) STRONG High Seas Project.

Global Ocean Commission, "Improving accountability and performance in international fisheries management" (2013) Policy Options Paper \#9.

Glowka, Lyle et al, "A Guide to the Convention on Biological Diversity" (1994) IUCNEnvironmental Policy and Law Paper No 30.

Gómez, Carlos et al, "The AQUACROSS Innovative Concept - Executive Summary. Deliverable 3.1” (2016) European Union's Horizon 2020 Framework Programme for Research and Innovation Grant Agreement No. 642317.

Greiber, Thomas, with comments from Kristina Gjerde \& Elisabeth Druel, "Paper IV: Governance Principles. An International Instrument on Conservation and Sustainable Use of Biodiversity in Marine Areas beyond National Jurisdiction. Exploring Different Elements to Consider" (2008) IUCN Policy Briefs.

Harrison, James, "The Protection of Species, Ecosystems and Biodiversity Under UNCLOS in Light of the South China Sea Arbitration: An Emergent Duty of Marine Ecosystem Restoration?" (2019) Edinburgh School of Law Research Paper No. 2019/20, online: <https://papers.ssrn.com/ sol3/papers.cfm?abstract_id=3388657 $>$.

High Seas Task Force, "Closing the Net: Stopping Illegal Fishing on the High Seas. Final Report of the Ministerially led Task Force on IUU Fishing on the High Seas" (2006), online: <https:// www.oecd.org/sd-roundtable/papersandpublications/39375276.pdf>.

I\&O Research, "Duurzaam denken is nog niet duurzaam doen" (2009), online: <https://ioresearch. nl/Home/Nieuws/duurzaam-denken-is-nog-niet-duurzaam-doen\#.XMMtxy-B0Wo >.

IASS, IDDRI \& TMG, "Marine Regions Forum 2019: Achieving a healthy ocean - regional ocean governance beyond 2020. Conference Report" (2019), online: <http://publications.iasspotsdam.de/pubman/item/escidoc:5041891:8/component/escidoc:5054888/5041891.pdf >.

IUCN, "Suggestions for elements of a draft text of an internationally legally binding instrument under UNCLOS for the conservation and sustainable use of marine biological diversity beyond areas of national jurisdiction" (2015). 
IUCN, “The ocean and climate change" (2017), online: <https://www.iucn.org/sites/dev/files/ the_ocean_and_climate_change_issues_brief-v2.pdf $>$.

Krieger, Heike \& Andrea Liese, "A Metamorphosis of International Law? Value changes in the international legal order from the perspectives of legal and political science" (2019) KFG Working Paper Series No. 27.

Mahon, Robin, Lucia Fanning \& Patrick McConney, "CLME TDA update for fisheries ecosystems: governance issues" (2011) Caribbean LME Project.

Maribus, "The Future of Fish - The Fisheries of the Future" (2013) World Ocean Review.

Ministry of Economic Affairs of the Netherlands, "Pulse Fishing. Pulse trawling as a promising alternative to beam trawling" (2017), online: <https://g8fip1kplyr33r3krz5b97d1-wpengine. netdna-ssl.com/wp-content/uploads/2018/02/Infographic-Pulse-Fishing-DEF-PRINT.pdf>.

MSC, "MSC General Certification Requirements (version 2.3)" (2018), online: <https:// www.msc.org/docs/default-source/default-document-library/for-business/programdocuments/general-certification-requirements/msc-general-certification-requirements-v2-3. pdf?sfvrsn=f055d4ac_7>.

MSC, “The MSC Fisheries Standard (version 2.01)" (2018), online: <https://www.msc.org/ docs/default-source/default-document-library/for-business/program-documents/fisheriesprogram-documents/msc-fisheries-standard-v2-01.pdf?sfvrsn=8ecb3272_11>.

PEW Charitable Trusts, "Mapping governance gaps on the high seas" (2017), online: <https:// www.pewtrusts.org/-/media/assets/2017/04/highseas_mapping_governance_gaps_on_the_ high_seas.pdf $>$.

Rayfuse, Rosemary et al, "Co-Chair's Report of Workshop on High Seas Governance for the 21st Century” (2007), online: <https://www.iucn.org/sites/dev/files/import/downloads/iucn_ workshop_co_chairs_summary_new_iucn_format.pdf $>$.

Rijnsdorp, Adriaan et al, "Pulse fishing and its effects on the marine ecosystem and fisheries. An update of the scientific knowledge" (2016) Wageningen University \& Research Report C117/16, online: <https://edepot.wur.nl/405708>.

Robinson, Nicholas A. \& Lal Kurukulasuriya, “Training Manual on International Environmental Law" (2006) Pace Law Faculty Publications.

Rogers, Alex D. et al, "The High Seas and Us: Understanding the Value of High-Seas Ecosystems" (2014) Global Ocean Commission, online: <http://www.oceanunite.org/wp-content/ uploads/2016/03/High-Seas-and-Us.FINAL_.FINAL_high_.spreads.pdf $>$.

Samarasinghe, Natalie \& Fred Carver (eds), "Sustainable development goals: from promise to practice" (2017) United Nations Association UK Report, online: <https://www.una.org.uk/ sustainable-development-goals-promise-practice>.

Shotton, Ross, "Managing the World's High-Seas Fisheries: A Proposal for a High-Seas Fisheries Trust" in Ragnar Arnason \& Birgir Runolfsson (eds), Advances in Rights Based Fishing. Extending the Role of Property in Fisheries Management (2008 RSE Research Papers, Reykjavik, Iceland) 247-290.

Stokke, Olav Schram, “The Interplay of International Regimes: Putting Effectiveness Theory to Work" (2001) Report of the Fridtjof Nansen Institute.

Sustainable Ocean Project, "Sovereignty, a shape-shifting concept in ocean governance? Report on the Expert Workshop" (2019) 2 NILOS Paper Series.

The Environmental Justice Foundation et al, "EU Regulation to combat illegal fishing. Third country carding process" (2015) Case Study \#1, online: <http://www.iuuwatch.eu/wp-content/ uploads/2015/06/Case-Study1.2pp.FIN_1.pdf>.

Treib, Olivier, Holger Bähr \& Gerda Falkner, "Modes of governance: A note towards conceptual clarification" (2005) European Governance Papers no. N-05-02. 
Underdal, Arild, "Explaining Regime Effectiveness" (2002) Jubilee Booklet of the Centre for Advanced Study at the Norwegian Academy of Science and Letters.

van Marlen, B. et al, "The effect of pulse stimulation on biota-Research in relation to ICES advice-Progress report with preliminary results" (2007) IMARES Report C098/07,

von Bieberstein, Katharina Rogalla et al, "Governance of areas beyond national jurisdiction for biodiversity conservation and sustainable use. Institutional arrangements and cross-sectoral cooperation in the Western Indian Ocean and the South East Pacific" (2017) UNEP-WCMC.

Wright, Glen et al, "High seas fisheries: what role for a new international instrument?" (2016) IDDRI Paper 3/2016.

Wright, Glen et al, "Marine spatial planning in areas beyond national jurisdiction" (2018) IDDRI Issue Brief No 08/18.

\section{Earth Negotiations Bulletin}

IISD “BBNJ IGC-3 Highlights: Wednesday, 28 August 2019” (2019) 25:216 Earth Negotiations Bulletin.

IISD, "Summary of the First Session of the Intergovernmental Conference on an International Legally Binding Instrument under the UN Convention on the Law of the Sea on the Conservation and Sustainable Use of Marine Biodiversity of Areas Beyond National Jurisdiction: 4-17 September 2018” (2018) 25:179 Earth Negotiations Bulletin.

IISD, "Summary of the First Session of the Preparatory Committee on Marine biodiversity of areas beyond National Jurisdiction: 28 March - 8 April 2016" (2016) 25:116 Earth Negotiations Bulletin.

IISD, "Summary of the Fourth Session of the Preparatory Committee on Marine biodiversity of areas beyond National Jurisdiction: 10-21 July 2017" (2017) 25:141 Earth Negotiations Bulletin.

IISD, "Summary of the ninth meeting of the working group on marine biodiversity beyond areas of national jurisdiction:20-23 January 2015" (2015) 25:94 Earth Negotiations Bulletin.

IISD, "Summary of the Organizational Meeting for the Intergovernmental Conference on an International Legally Binding Instrument under the UN Convention on the Law of the Sea on the Conservation and Sustainable Use of Marine Biological Diversity of Areas Beyond National Jurisdiction: 16-18 April 2018” (2018) Earth Negotiations Bulletin.

IISD, "Summary of the Resumed Review Conference on the Agreement for the Implementation of the Provisions of the UN Convention on the Law of the Sea (UNCLOS) 1982 Relating to the Conservation and Management of Straddling Fish Stocks and Highly Migratory Fish Stocks: 23-27 May 2016" (2016) 7:71 Earth Negotiations Bulletin.

IISD, "Summary of the Second Session of the Intergovernmental Conference on an International Legally Binding Instrument under the UN Convention on the Law of the Sea on the Conservation and Sustainable Use of Marine Biodiversity of Areas Beyond National Jurisdiction: 25 March - 5 April 2019" (2019) 25:195 Earth Negotiations Bulletin.

IISD, "Summary of the Second Session of the Preparatory Committee on Marine biodiversity of areas beyond National Jurisdiction: 26 August - 9 September 2016" (2016) 25:118 Earth Negotiations Bulletin.

IISD, "Summary of the Third Session of the Intergovernmental Conference (IGC) on the Conservation and Sustainable Use of Marine Biodiversity of Areas Beyond National Jurisdiction: 19-30 August 2019” (2019) 25:218 Earth Negotiations Bulletin.

IISD, "Summary of the Third Session of the Preparatory Committee on Marine biodiversity of areas beyond National Jurisdiction: 27 March - 7 April 2017" (2017) 25:129 Earth Negotiations Bulletin. 


\section{Presentations, addresses, remarks and workshops}

Chapman, W.S., "Seafood and World Famine - A positive Approach" (Address to the Symposium on Food from the Sea, 23 September 1969).

de Havre, Basile, "Plateforme Biodiversité 2020 - Quatrième rencontre" (Webinar hosted by IDDRI, 19 March 2020).

"Expert Workshop on Transparency in Fisheries Governance" (Organized by the University of Sydney and Utrecht University, Utrecht, 20-21 May 2019).

Gjerde, Kristina, "Underpinning a Strong Global High Seas Agreement on BBNJ through Regional and Sectoral Governance: Possible Options" (Presentation delivered at the High Level Expert Meeting "Building a Strong High Seas Treaty: What is the Role for Regional Ocean Governance?”, New York, 8 September 2018).

Guglya, Leonila, "Could the WTO Save the Oceans? An inquiry into the [accessory] role of the Organization in the future of fisheries policies" (Presentation delivered at the conference The Rule of Law for Oceans, Oslo, 4 November 2019).

Haas, Peter, "Scientific expertise, a question of legitimacy" (Presentation delivered at the IDDRI International Environmental Governance Conference, Paris 15-16 March 2004).

"Institutional Design at the Crossroads of Law, Governance and Fairness: What Institutional Architecture for an Instrument on Marine Biological Diversity beyond National Jurisdiction?" (Organized by the Utrecht University Centre for Global Challenges (UGlobe), the Netherlands Institute for the Law of the Sea (NILOS), the Copernicus Institute of Sustainable Development, and the Ethics Institute, Utrecht University, Utrecht, 27-28 June 2019).

Joyini, Thembile, "The Role of Equity in the Governance of Biological Diversity in Areas beyond National Jurisdiction" (Presentation given at the workshop "Negotiating an Agreement on the Conservation and sustainable use of marine biological diversity of areas beyond national jurisdiction", Utrecht, 12 February 2020).

Koh, Tommy T.B., "A Constitution for the Oceans" (Remarks by Tommy T.B. Koh, of Singapore, President of the Third United Nations Conference on the Law of the Sea), online $<\mathrm{https}$ ://www. un.org/Depts/los/convention_agreements/texts/koh_english.pdf >.

Kuemlangan, Blaise, "FAO and SDG 14" (Presentation delivered at the BBNJ PrepCom 4 side event “Monitor and Review SDG 14 by DOALOS”, UN Headquarters, New York, 10 July 2017).

Lodge, Michael, "Review of Factors of Unsustainability in Fisheries: Relationship to International Fisheries Instruments" (Paper prepared for the FAO Workshop on Factors of Unsustainability and Overexploitation in Fisheries, Bangkok, Thailand, 4-8 February 2002).

Marciniak, Konrad, "The notion of 'the commons' in the current negotiations concerning the New Implementing Agreement under UNCLOS" (Presentation delivered at the Interest group on the Law of the Sea of the Annual Conference of the European Society of International Law, Naples, 6 September 2017).

Rochette, Julien, Klaudija Cremers \& Glen Wright, "Les enjeux de coordination entre le futur traité haute mer et les organisations existantes" (Presentation delivered at the 16ème reunion du Groupe informel haute mer, 24 June 2020).

Stankiewicz, Monica, "The role of Regional Seas Conventions in MSP: Presenting HELCOM" (Maritime Spatial Planning Conference series: The marine environment, delivered at the Albert Borschette Conference Centre, 7 December 2015).

Trevisanut, Seline, "Unsustainable International Law" (Inaugural lecture delivered at Utrecht University, 4 April 2019).

"Utrecht informal meeting on rights and interests of coastal States (including issues relating to adjacent or subjacent maritime areas) and other States in the BBNJ Implementing Agreement - exploring scenarios and approaches" (Organized by the Netherlands Institute for the Law of 
the Sea (NILOS), Utrecht University, and the Netherlands Ministry of Foreign Affairs, Utrecht, 10-11 February 2020).

Widerberg, Oscar, "Mapping Institutions and Actors in Global Climate Governance: A Network Approach" (Presented at the General Conference of the European Consortium for Political Research, Glasgow, 3-6 September 2014).

Wills, Santiago, Chair of the WTO negotiating group on rules, "Reflections on the ongoing WTO fisheries subsidies negotiations" (Presentation given at the Session "Subsidies and IUU fishing" of the 12th International Forum on Illegal, Unreported and Unregulated Fishing, 20 May 2020).

Young, Oran, "Sugaring Off: Enduring Insights from Four Decades of Theorizing About Environmental Governance" (Lecture delivered at the Bren School of Environmental Science \& Management of the University of California, Santa Barbara, 2011), online: <https://www. youtube.com/watch?v=I0VVlk47OvI $>$.

\section{Doctoral theses}

Bohman, Brita, Transboundary Law for Social-Ecological Resilience? A Study on Eutrophication in the Baltic Sea Area (Academic dissertation for the Degree of Doctor of Laws in Environmental Law, Stockholm University, 2017).

de Souza Patu, Georgia Nogueira, Scope and evolution of ocean governance: improving crosssectoral management by the adoption of principles of international law (Doctor of Philosophy thesis, Australian National Center for Ocean Resources and Security, University of Wollongong, 2011).

\section{Online sources}

\section{Blogs}

De Lucia, Vito, "The Ecosystem Approach for Areas Beyond National Jurisdiction: Reflections on the Chair's non-paper ahead of 'PREPCOM III"' (20 March 2017) JCLOS Blog, online: $<$ http://site.uit.no/nclos/2017/03/20/the-ecosystem-approach-for-areas-beyond-nationaljurisdiction-reflections-on-the-chairs-non-paper-ahead-of-prepcom-iii/>.

De Lucia, Vito, "Reflecting on the meaning of "not undermining" ahead of IGC-2" (21 March 2019) JCLOS Blog, online: <https://site.uit.no/nclos/2019/03/21/reflecting-on-the-meaning-ofnot-undermining-ahead-of-igc-2/>.

De Lucia, Vito, "Squaring the Oceanic Circle? On Regional Approaches to the Conservation of Marine Biodiversity in Areas beyond National Jurisdiction" (9 May 2020) NCLOS Blog, online: $<$ http://site.uit.no/nclos/files/2020/05/Vito-De-Lucia-Regional-Governance-BBNJ-.pdf > .

Guggisberg, Solène, "Best Practices for Regional Fisheries Conservation and Management" (2 November 2018) Nereus Programme Blog, online: <https://nereusprogram.org/works/bestpractices-for-regional-fisheries-conservation-and-management/>.

Guggisberg, Solène, "Legal Considerations Around Japan's Announcement That it Will Leave the International Whaling Commission (IWC)" (5 February 2019) Nereus Programme Blog, online: $<$ https://nereusprogram.org/works/legal-considerations-around-japans-announcement-thatit-will-leave-the-international-whaling-commission-iwc/>.

Hubert, Anna-Maria \& Neil Craik, "Towards Normative Coherence in the International Law of the Sea for the Conservation and Sustainable Use of Marine Biological Diversity of Areas Beyond National Jurisdiction" (1 February 2018) ABlawg (originally on JCLOS Blog), online: $<$ https://ablawg.ca/wp-content/uploads/2018/02/Blog_AMH_NC_JCLOS.pdf > .

Mossop, Joanna, "Dispute Settlement in the New Treaty on Marine Biodiversity in Areas beyond National Jurisdiction" (23 December 2019) NCLOS Blog, online: <https://site.uit.no/ nclos/2019/12/23/dispute-settlement-in-the-new-treaty-on-marine-biodiversity-in-areasbeyond-national-jurisdiction/>. 
Schrerer, Laura \& Jan Boersema, "Was the EU's ban on electric fishing the right decision?" (14 February 2019), online: <https://www.universiteitleiden.nl/en/news/2019/02/was-the-eu-banon-electric-fishing-the-right-decision $>$.

Visser, Maddalena, "Assessing the role of equity in fisheries allocation decisions" (31 August 2018) JCLOS blog, online: <https://site.uit.no/nclos/2018/08/31/assessing-the-role-of-equityin-fisheries-allocation-decisions/>.

\section{News items}

Bolongaro, Kait, "The Franco-Dutch fish fight over electric pulse trawling” (14 February 2018) Politico, online: <https://www.politico.eu/article/the-franco-dutch-fish-fight-over-electricpulse-trawling/>.

CCAMLR, "CCAMLR to create world's largest Marine Protected Area" (28 October 2016), online: $<$ https://www.ccamlr.org/en/organisation/ccamlr-create-worlds-largest-marine-protectedarea $>$.

Gaffney, Owen, "Should nations close the high seas to fishing?" (3 May 2018) Re.Think, online: $<$ https://rethink.earth/should-nations-close-the-high-seas-to-fishing/>.

"Going Dark: When vessels turn off AIS broadcasts" (30 July 2016) Global Fishing Watch, online: $<$ https://globalfishingwatch.org/data/going-dark-when-vessels-turn-off-ais-broadcasts/>.

"Japan to resume whaling in Antarctic despite court ruling" (25 November 2015) BBC News, online: <https://www.bbc.com/news/world-asia-34952538>.

McGrath, Matt, "Oceans can be successfully restored by 2050, say scientists" (1 April 2020) BBC News, online: <https://www.bbc.com/news/science-environment-52122447>.

Milman, Oliver, "Captain deliberately sank illegal fishing vessel, claim Sea Shepherd rescuers" (7 April 2015) The Guardian, online: <https://www.theguardian.com/environment/2015/apr/07/ captain-deliberately-sank-illegal-fishing-vessel-claim-sea-shepherd-rescuers $>$.

"New UN high-seas treaty must close gaps in biodiversity governance" (29 August 2019) Science Daily, online: <https://www.sciencedaily.com/releases/2019/08/190829150640.htm>.

"Sea Shepherd Helps Arrest Two Illegal Fishing Vessels" (17 July 2017) The Marine Executive, online: <http://maritime-executive.com/article/sea-shepherd-aids-in-arrest-of-illegal-fishingvessels $>$.

"Talks on Antarctic marine sanctuary fail for eighth straight year" (2 November 2019) The Japan Times, online: <https://www.japantimes.co.jp/news/2019/11/02/asia-pacific/science-healthasia-pacific/talks-antarctic-marine-sanctuary-fail/\#.Xcbwyi17SL8>.

UN News, "UN court rules against Japan's whaling activities in the Antarctic" (31 March 2014), online: <https://news.un.org/en/story/2014/03/465062-un-court-rules-against-japans-whalingactivities-antarctic $>$.

"WTO members set work programme for text-based phase of fisheries subsidies talks" (21 July 2020), online: <https://www.wto.org/english/news_e/news20_e/fish_21jul20_e.htm>.

\section{Websites}

Arctic Council, "About", online: <https://arctic-council.org/index.php/en/about-us>.

Background information on the Regular Process, online: $<$ https://www.un.org/depts/los/global_ reporting/Background_to_the_Regular_Process.pdf $>$.

British Sea Fishing, "The Cod Wars”, online: <http://britishseafishing.co.uk/the-cod-wars/>.

CBD, "Aichi Biodiversity Targets", online: <https://www.cbd.int/sp/targets/default.shtml $>$.

CBD, "Clearing-house mechanism”, online: <https://www.cbd.int/chm/>.

CBD, "Cooperation and Partnerships", online: <https://www.cbd.int/cooperation/>.

CBD, "History of the Convention", online: $<\mathrm{https} / / / \mathrm{www} . c b d . i n t / h i s t o r y />$. 
CBD, "Strategic Plan for Biodiversity 2011-2020, including Aichi Biodiversity Targets", online: $<$ https://www.cbd.int/sp/default.shtml $>$.

CBD, "The Jakarta Mandate - from global consensus to global work" (2000), online: <https:// www.cbd.int/doc/publications/jm-brochure-en.pdf > .

CCAMLR, online: <https://www.ccamlr.org $>$.

CCAMLR, "Marine Protected Areas (MPAs)", online: <https://www.ccamlr.org/en/science/ marine-protected-areas-mpas>.

CITES, "Appendices I, II and III" (as of 26 November 2019), online: <https://www.cites.org/eng/ app/appendices.php>.

CMS Appendix I and II, online: <https://www.cms.int/sites/default/files/basic_page_documents/ cms_cop12_appendices_e_0.pdf $>$.

Commission on Sustainable Development, online: <https://sustainabledevelopment.un.org/ intergovernmental/csd>.

DOALOS, "Marine biological diversity beyond areas of national jurisdiction. Cooperation and coordination within the United Nations system", online: <http://www.un.org/depts/los/ biodiversityworkinggroup/webpage_cooperation\%20and\%20coordination.pdf>.

DOALOS, "Marine biological diversity of areas beyond national jurisdiction. Legal and policy framework", online: <https://www.un.org/depts/los/biodiversityworkinggroup/webpage_legal_ and_policy.pdf $>$.

DOALOS, "Meetings of States Parties to the 1982 United Nations Convention on the Law of the Sea”, online: <https://www.un.org/Depts/los/meeting_states_parties/meeting_states_parties. htm>.

DOALOS, "Review Conference on the Agreement for the Implementation of the Provisions of the United Nations Convention on the Law of the Sea of 10 December 1982 relating to the Conservation and Management of Straddling Fish Stocks and Highly Migratory Fish Stocks", online: <https://www.un.org/Depts/los/convention_agreements/review_conf_fish_stocks.htm>.

DOALOS, "Status of the United Nations Convention on the Law of the Sea, of the Agreement relating to the Implementation of Part XI of the Convention and of the Agreement for the Implementation of the Provisions of the Convention relating to the Conservation and Management of Straddling Fish Stocks and Highly Migratory Fish Stocks as at 27 June 2019”, online: <https://www.un.org/Depts/los/reference_files/status2019.pdf >.

European Commission, "Access to Waters", online: <https://ec.europa.eu/fisheries/cfp/fishing rules/access-to-waters>.

European Commission, "Fishing Effort", online: <https://ec.europa.eu/fisheries/cfp/fishing rules/fishing_effort $>$.

European Commission, "International ocean governance: an agenda for the future of our oceans", online: <https://ec.europa.eu/maritimeaffairs/policy/ocean-governance_en >.

European Commission, "Managing fisheries", online: $<$ https://ec.europa.eu/fisheries/cfp/fishing rules_en>.

European Commission, "Managing Fisheries - Fishing quotas", online: $<$ https://ec.europa.eu/ fisheries/cfp/fishing_rules/tacs_en>.

European Commission, "Regional fisheries management organisations (RFMOs)", online: $<$ https://ec.europa.eu/fisheries/cfp/international/rfmo_en $>$.

European Commission, “Technical measures", online: <https://ec.europa.eu/fisheries/cfp/ fishing_rules/technical_measures>.

European Commission, "The Barcelona Convention", online: <http://ec.europa.eu/environment/ marine/international-cooperation/regional-sea-conventions/barcelona-convention/index en.htm>. 
Eurostat, "Fisheries statistics", online <http://ec.europa.eu/eurostat/statistics-explained/index. php/Fishery_statistics\#Catches>.

FAO, "Agreement To Promote Compliance With International Conservation And Management Measures By Fishing Vessels On The High Seas - Parties to the Agreement" (2 July 2018, latest available version), online: $<$ http://www.fao.org/fileadmin/user_upload/legal/docs/012s-e.pdf $>$.

FAO, “Common Oceans - A partnership for sustainability in the ABNJ", online: <http://www.fao. org/in-action/commonoceans/en/>.

FAO, "FAO and CITES - FAO activities in relation to CITES", online: <http://www.fao.org/fishery/ topic/18145/en>.

FAO, "Fisheries and aquaculture governance", online: $<$ http://www.fao.org/fishery/governance/en $>$.

FAO, "General Fisheries Commission for the Mediterranean", online: <http://www.fao.org/gfcm/ about/legal-framework/en/>.

FAO, "Global Record of Fishing Vessels, Refrigerated Transport Vessels and Supply Vessels", online: <http://www.fao.org/global-record/en/>.

FAO, "International guidelines", online: <http://www.fao.org/fishery/code/guidelines/en $>$.

FAO, "Parties to the Agreement", online: <http://www.fao.org/fileadmin/user_upload/legal/ docs/012s-e.pdf $>$.

FAO, "Parties to the Agreement", online: <http://www.fao.org/fileadmin/user_upload/legal/ docs/037s-e.pdf>.

FAO, "Permanent Commission for the South Pacific", online: <http://www.fao.org/fishery/rfb/ cpps/en\#Org-OrgsInvolved $>$.

FAO, "Publications", online: <www.fao.org/fishery/code/publications/guidelines/en>.

FAO, "Regional fisheries management organizations and deep-sea fisheries", online: <http://www. fao.org/fishery/topic/166304/en>.

FAO, "Regional Fishery Body Secretariats Network", online: <http://www.fao.org/fishery/rsn/en>.

FAO, "Vulnerable Marine Ecosystems", online: <http://www.fao.org/in-action/vulnerablemarine-ecosystems/en/>.

FAO, "What is fisheries subsidies?", online: <http://www.fao.org/3/y4446e/y4446e 0k.htm >.

FAO Term Portal, "Maximum Sustainable Yield”, online: <http://www.fao.org/faoterm/en/>.

Fishery Progress, "Fishery Improvement Project Progress Tracking Database \& Tools", online: $<$ https://fisheryprogress.org $>$.

Global Environmental Facility, online: <https://www.thegef.org/>.

Global Fishing Watch, online: <http://globalfishingwatch.org/>.

Global Pact for the Environment, online: < https://globalpactenvironment.org/en/>.

Global Pact for the Environment, "Third and last session of the working group on the Pact in Nairobi", online: <https://globalpactenvironment.org/en/third-session-of-the-working-groupon-the-pact-in-nairobi/>.

Harmony with Nature United Nations, "Programme", online: <http://www.harmonywithnatureun. org $>$.

ICCAT, "ICCAT Record of Vessels" online: <https://www.iccat.int/en/VesselsRecord.asp >.

ICCAT, "International Commission for the Conservation of Atlantic Tunas. Basic Texts", online: $<$ https://www.iccat.int/Documents/Commission/BasicTexts.pdf $>$.

ICES, "Who we are", online: <https://www.ices.dk/explore-us/who-we-are/Pages/Who-we-are. aspx>.

IMO, "Particularly Sensitive Sea Areas", online: <http://www.imo.org/en/OurWork/Environment/ PSSAs/Pages/Default.aspx $>$. 
International Monitoring, Control and Surveillance (MCS) Network for Fisheries-related Activities, online: <imcsnet.org $>$.

IOC, "Marine Spatial Planning", online: <http://www.ioc-unesco.org/index.php?option=com_ content\&view=article\&id $=147 \&$ Itemid $=76>$.

ISA, "Biodiversity", online: <https://www.isa.org.jm/biodiversity-0 >

ISA, "Preservation Reference Zone", online: <https://www.isa.org.jm/preservation-reference-zone >.

IUCN, "International ocean governance", online: <https://www.iucn.org/theme/marine-andpolar/our-work/international-ocean-governance>.

IUCN, "When is a Marine Protected Area really a Marine Protected Area", online: <http://www. iucn.org/?uNewsID=10904>.

IUCN Shark Specialist Group, "Regional Fisheries Management Organizations (RFMOs)”, online: $<$ https://www.iucnssg.org/rfmos.html >.

IWC, online: $<$ https://iwc.int/rmp $>$.

IWC, "Statement on Government of Japan withdrawal from the IWC" (14 January 2019), online: $<$ https://iwc.int/statement-on-government-of-japan-withdrawal-from- $t$.

"Kobe II Process Recommendations. Excerpts from Reports of Kobe II Meeting and Workshops" (2009-2010), online: <http://www.tuna-org.org/Documents/TRFMO3/BackgroundInfo.pdf>.

MSC, "Marine Fisheries Standards", online: <https://www.msc.org/standards-and-certification/ fisheries-standard>.

MSC, “What does the blue MSC label mean?", online: <https://www.msc.org/what-we-are-doing/ our-approach/what-does-the-blue-msc-label-mean $>$.

NAFO, "Fishing in the NAFO Regulatory Area", online: <https://www.nafo.int/Fisheries/FishingActivity-in-the-NRA>.

NAFO, "Northwest Atlantic Fisheries Organization, online: <https://www.nafo.int/Portals/0/ PDFs/key-publications/NAFOConvention-2017.pdf>.

NEAFC, "Convention on Future Multilateral Cooperation in North-East Atlantic Fisheries", online: <https://www.neafc.org/system/files/Text-of-NEAFC-Convention-04.pdf >.

NEAFC, "NEAFC A and B Lists", online: <https://www.neafc.org/mcs/iuu>.

NEAFC, "VMEs and Closures Maps and Coordinates", online: <https://www.neafc.org/ managing_fisheries/vmec $>$.

Ocean Prosperity Roadmap, "Governance \& Marine Fisheries. Comparing across countries and stocks”, online: <https://www.oceanprosperityroadmap.org/wp-content/uploads/2015/05/5.Fisheries-Governance_survey_052715.pdf>.

OECD, "Fish landings (indicator)" (2018), online: <https://data.oecd.org/fish/fish-landings.htm >.

OECD, "Strategic Environmental Assessment and Environmental Impact Assessment", online: $<$ http://www.oecd.org/env/outreach/eapgreen-sea-and-eia.htm>.

OSPAR Commission, "Collective Arrangement", online: <https://www.ospar.org/about/ international-cooperation/collective-arrangement $>$.

Pulse Fishing, "What is pulse fishing", online: $<$ https://www.pulsefishing.eu $>$.

Regular Process, online: <https://www.un.org/regularprocess/>.

Sargasso Sea Commission, online: <http://www.sargassoseacommission.org >.

Sargasso Sea Commission, "Threats to the Sargasso Sea", online: <http://www.sargasso seacommission.org/about-the-sargasso-sea/threats-to-the-sargasso-sea>.

SEAFO, "Species summary", online: <http://www.seafo.org/Science/Species-Summary>.

SIOFA, "Monitoring, Control and Surveillance", online: $<\mathrm{http}$ //www.apsoi.org/mcs $>$.

SIOFA, "SIOFA major fish species", online: <https://www.apsoi.org/species-list>. 
SPREP, “Noumea Convention", online: <https://www.sprep.org/convention-secretariat/noumeaconvention>.

SPRFMO, "About the SPRFMO", online: <https://www.sprfmo.int/about/>.

SPRFMO, "Bottom Fishery Impact Assessment Standard", online: <https://www.sprfmo. int/assets/Meetings/Meetings-before-2013/Scientific-Working-Group/SWG-06-2008/aMiscellaneous-Documents/SPRFMO-Bottom-Fishing-Impact-Assessment-StandardagreedVanuatu-Fri23Sep2011-1140am.pdf>.

SPRFMO, "Commission Record of Vessels Authorised to Fish in the Convention Area", online: $<$ https://www.sprfmo.int/measures/record-of-vessels/>.

SPRFMO, "SPRFMO IUU List”, online: <https://www.sprfmo.int/measures/iuu-lists/\#SPRFMO>.

Stockholm Resilience Center, "Resilience dictionary", online: <https://www.stockholmresilience. org/research/resilience-dictionary.html>.

Tuna-org, online: $<$ http://www.tuna-org.org $>$.

UN, "Adopting Two Texts on Oceans, Seas, General Assembly Also Tackles Sustainable Management, Conservation of Marine Life beyond National Jurisdiction” (5 December 2017), online: <https://www.un.org/press/en/2017/ga11985.doc.htm>.

UN, "Millennium Development Goals and beyond 2015", online: <http://www.un.org/ millenniumgoals/environ.shtml>.

UN, "Table recapitulating the status of the Convention and of the related Agreements" (27 June 2019, latest available version), online: <https://www.un.org/Depts/los/reference_files/ status2019.pdf>.

UN, "United Nations Conference on Sustainable Development, Rio+20", online: <https:// sustainabledevelopment.un.org/rio20.html >.

UN, "UN Ocean Conference", online: <https://www.un.org/en/conferences/ocean2020>.

UNECE, "Background”, online: <https://www.unece.org/env/pp/ccbackground.html>.

UNECE, "Espoo Convention", online: <https://www.unece.org/environmental-policy/ conventions/environmental-assessment/about-us/espoo-convention/enveiaeia/more.html>.

UNECE, "Implementation Committee", online: <https://www.unece.org/env/eia/implementation/ implementation_committee_meetings.html >.

UNECE, “The SEA Protocol”, online: <https://www.unece.org/env/eia/sea_protocol.html>.

UNEP, online: <https://www.unenvironment.org/>.

UNEP, "Goals and principles of environmental impact assessment: decision 14/25 of the Governing Council of UNEP, of 17 June 1987”, online: <https://www.elaw.org/system/files/ unep.EIA_.guidelines.and_.principles.pdf $>$.

UNEP, "Regional seas programmes", online: <https:/www.unenvironment.org/explore-topics/ oceans-seas/what-we-do/working-regional-seas/regional-seas-programmes $>$.

UNEP, "South East Pacific", online: <https://www.unenvironment.org/explore-topics/oceansseas/what-we-do/working-regional-seas/regional-seas-programmes/south-east>.

UNEP, "Why does working with regional seas matter?", online: <https://www.unenvironment. org/explore-topics/oceans-seas/what-we-do/working-regional-seas/why-does-workingregional-seas-matter>.

UNESCAP, "What is Good Governance?" (2009), online: <http://www.unescap.org/sites/default/ files/good-governance.pdf>.

UN-Oceans, online: <http://www.unoceans.org/home/en/>.

UN Regular process, "World Ocean Assessment I", online: <https://www.un.org/regularprocess/ content/first-world-ocean-assessment $>$. 
Wageningen University \& Research, "Pulse fishing”, online: <https://www.wur.nl/en/Dossiers/ file/Pulse-fishing.htm>.

WCPFC, "WCPFC Monitoring, Control and Surveillance (MCS) and Compliance Monitoring", online: <https://www.wcpfc.int/wcpfc-monitoring-control-and-surveillance-mcs-scheme >.

World Ocean Council, "About us", online: <https://www.oceancouncil.org/>.

WTO, "Negotiations on fisheries subsidies", online: <https://www.wto.org/english/tratop_e/ rulesneg_e/fish_e/fish_e.htm>.

WTO, "Subsidies and Countervailing Measures: Overview", online: <https://www.wto.org/ english/tratop_e/scm_e/subs_e.htm>.

WTO, “The Doha Round”, online: <https://www.wto.org/english/tratop_e/dda_e/dda_e.htm>.

WTO, "The Rules Negotiations", online: <https://www.wto.org/english/tratop_e/rulesneg_e/ rulesneg_e.htm>.

WWF, “African Elephants", online: <https://wwf.panda.org/knowledge_hub/endangered_species/ elephants/african_elephants/>.

WWF, "Fishing Problems: Poor Fisheries Management", online: <https://wwf.panda.org/our_ work/oceans/problems/fisheries_management/>.

\section{Other sources}

Bankes, Nigel, "Adaptive management, Adaptive governance and the role of law: a literature review" (2018) (unpublished).

Currie, Duncan, “Talking Points: The Meaning of 'Not Undermine' and the Relationship between Negotiations for a New Legally Binding Instrument and Regional Fisheries Management Organizations" (12 July 2017).

IUCN, "Beyond the Last Frontier" (2018), online: <https://www.youtube.com/watch?v=F7x6p DVWSEg $>$.

"Preparatory Committee on Conservation and Sustainable Use of Marine Biological Diversity of Areas Beyond National Jurisdiction - New Zealand Submission" (December 2016), online: $<$ https://www.un.org/depts/los/biodiversity/prepcom_files/rolling_comp/New_Zealand.pdf $>$.

The author's personal notes from the third (March 2017) and fourth (July 2017) sessions of the BBNJ Preparatory Committee, as well as from the first session (September 2018) of the BBNJ Intergovernmental Conference 



\section{ABOUT THE AUTHOR}

Catherine Blanchard is a civil law graduate from the University of Ottawa, Canada (LL.L, summa cum laude, 2012), where she also obtained a bachelor degree in international development and globalization (B.Sc.Soc Hon DVM, summa cum laude, 2012). She also holds a common law degree from Dalhousie University, Halifax, Canada (JD, 2013). Since 2014, Catherine is a member of the Law Society of Ontario (Barrister and Solicitor, Ontario Bar Association, Canada).

After completing a clerkship at the Federal Court of Canada, Catherine obtained her master degree in Public International Law, with a specialization in the Law of the Sea and Environmental Law, at Utrecht University (LL.M., cum laude, 2015). Her master thesis, looking at the relevance of the territorial State model under current international law, using the impacts of sea-level rise on low lying islands States as a case-study, was awarded the François Prize 2016 of the Royal Netherlands Society of International Law (KNVIR). An updated version of her LLM thesis has been published in the Canadian Yearbook of International Law.

In the fall of 2015, Catherine completed an internship at the International Tribunal for the Law of the Sea in Hamburg, Germany. She also worked as a research assistant within the Netherlands Institute for the Law of the Sea (Utrecht University) from January-May 2016.

Since the beginning of her PhD research in August 2016, Catherine has presented aspects of her research in numerous international conferences and workshops. She has also authored and co-authored several academic articles and book chapters. Catherine has further joined the Dutch delegation to the third and fourth meeting of the Preparatory Committee and first meeting of the Intergovernmental Conference on the development of a legally binding instrument on the conservation and sustainable use of marine biological diversity (BBNJ) at the UN Headquarters in New York, USA. From 2017-2020, Catherine was a researcher within the multidisciplinary project "The sustainable and equitable management of the marine environment beyond national jurisdiction" from the Utrecht Center for Global Challenge, a project looking at the BBNJ process from the perspectives of the law, governance and ethics. Since August 2017, Catherine acts as manager of the Task Force on Earth System Law of the Earth System Governance Project, the largest social science research network in the area of governance and global environmental change. 
